\title{
Književnost, književnoteorijsko i postmarksistička teorija
}

\section{Glavaš, Zvonimir}

Doctoral thesis / Disertacija

2020

Degree Grantor / Ustanova koja je dodijelila akademski / stručni stupanj: University of Zagreb, University of Zagreb, Faculty of Humanities and Social Sciences / Sveučilište u Zagrebu, Filozofski fakultet

https://doi.org/10.17234/diss.2020.8406

Permanent link / Trajna poveznica: https:/urn.nsk.hr/urn:nbn:hr:131:160621

Rights / Prava: In copyright/Zaštićeno autorskim pravom.

Download date / Datum preuzimanja: 2023-04-26

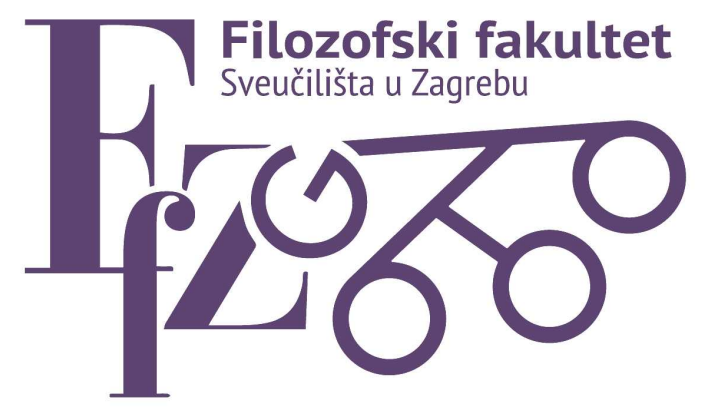

Repository / Repozitorij:

ODRAZ - open repository of the University of Zagreb Faculty of Humanities and Social Sciences
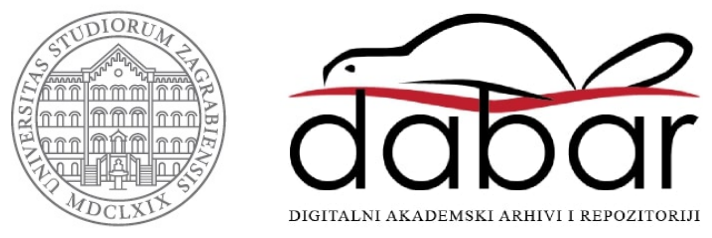


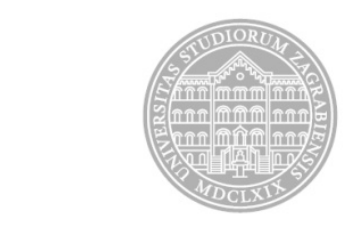

Sveučilište u Zagrebu

Filozofski fakultet

Zvonimir Glavaš

\section{Književnost, književnoteorijsko i postmarksistička teorija}

DOKTORSKI RAD

Zagreb, 2020. 
Filozofski fakultet

Zvonimir Glavaš

\title{
Književnost, književnoteorijsko i postmarksistička teorija
}

\author{
DOKTORSKI RAD \\ Mentorica: \\ doc. dr. sc. Zrinka Božić Blanuša
}

Zagreb, 2020. 




University of Zagreb

Faculty of Humanities and Social Sciences

Zvonimir Glavaš

\title{
Literature, the Literary Theory and post- Marxist Theory
}

\author{
DOCTORAL THESIS \\ Supervisor: \\ doc. dr. sc. Zrinka Božić Blanuša
}

Zagreb, 2020. 



\section{Bilješka o mentorici}

Zrinka Božić Blanuša rođena je 25. travnja 1976. godine u Rijeci. Osnovnu školu pohađala je i završila u Lovranu, a gimnaziju u Opatiji. Na zagrebačkom Filozofskom fakultetu studirala je hrvatski jezik i književnost, gdje je diplomirala 2000. godine. Iste je godine upisala poslijediplomski studij književnosti na Odsjeku za komparativnu književnost. 2002. godine pohađala je Ljetnu školu književne teorije (Europe and its Other) u organizaciji Sveučilišta u Konstanzu (Konstanz International Summer School of Literary Studies) Od 2001. godine zaposlena je na Odsjeku za kroatistiku Filozofskog fakulteta u Zagrebu, a od 2012. godine predstojnica je Katedre za teoriju književnosti. Magistrirala je 2005. temom Oblikovanje nacionalnog identiteta u hrvatskoj književnoj historiografiji, a doktorirala 2009. temom Problem smrti u suvremenoj književnoj teoriji: o francuskoj recepciji Heideggerove analize bitka ka smrti pod mentorstvom prof. dr. sc. Vladimira Bitija. Nositeljica je obaveznih kolegija na preddiplomskom studiju kroatistike Uvod u teoriju književnosti i Čitanje književnog teksta. Na diplomskom studiju izvodi izborne kolegije Ideologija i književnost i Fenomenologijska teorija čitanja: tekst - svijest - tijelo. Na Doktorskom studiju književnosti, izvedbenih umjetnosti i kulture izvodila je kolegije Književnost - politika - teorija i Književnost i revolucija. Kao znanstvena novakinja sudjelovala je u nekoliko istraživačkih projekata. Dugogodišnja je suradnica Leksikografskog zavoda Miroslav Krleža i članica Hrvatskog semiotičkog društva. Autorica je knjige Iz perspektive smrti: Heidegger i drugi (2012.). Članke, rasprave i recenzije objavljuje u domaćim i međunarodnim znanstvenim časopisima.

\section{IZBOR IZ BIBLIOGRAFIJE}

\section{Knjiga:}

Božić Blanuša, Zrinka. 2012. Iz perspektive smrti: Heidegger i drugi, Zagreb: Plejada d.o.o.,

\section{Znanstveni radovi:}

Božić Blanuša, Zrinka. 2020. Decentred Geographies: Poetics and Politics of the AvantGarde. Poznańskie Studia Slawistyczne, 18: 41-58. 
Božić Blanuša, Zrinka. 2017. Manifesting Dispossession: Politics of the Avant-Garde. U: Biti, Vladimir (ur.). Claiming the Dispossession: The Politivs of Hi/storytelling in Postimperial Europe. Leiden/Boston: Brill

Božić Blanuša, Zrinka. 2017. Touched by Disaster: Writing and the Political. U: Lugarić, Danijela; Car, Milka; Molnár, Gábor Tamás (ur.). Myth and Its Discontents: Memory and Trauma in Central and East European Literature. Wien: Praesens Verlag. 249262.

Božić Blanuša, Zrinka. 2016. The Concentration Camp on the River Sava. What Remains Afterwards? U: Heftrich, Urs ; Jacobs, Robert ; Kaibach, Bettina ; Thaidigsmann, Karoline (ur.). Images of Rupture between East and West. Heidelberg: Winter Verlag. 389-406.

Božić Blanuša, Zrinka. 2015. Tragajući za političkim: nacionalna književnost i svjetska književna republika. U: Pieniążek-Marković, Krystyna; Vuković, Tvrtko (ur.). Transmisije Kroatistike. Zagreb: Filozofski fakultet. 37-55.

Božić Blanuša, Zrinka. 2015. Obrat k estetici i politika književnosti. U: Pišković, Tatjana i Vuković, Tvrtko (ur.). Jezične, kulturne i književne politike. Zagreb: Zagrebačka slavistička škola. 81-92.

Božić Blanuša, Zrinka. 2014. Ispisivanje traga: književnost, politika i političko. Umjetnost riječi : časopis za znanost o književnosti, LVII/2: 119-137.

Božić Blanuša, Zrinka. 2014. What about the politics of deconstruction?. U: Biti, Vladimir (ur.). Reexamining the national-philological legacy: quest for a new paradigm. Amsterdam/ New York: Rodopi. 265-285. 


\section{Sažetak}

Središnji je cilj rada istražiti položaj književnosti i književnoteorijskog u postmarksističkoj teoriji te pritom povratno problematizirati kako dosadašnja istraživanja tog korpusa, tako i pojam postmarksizma.

Premda su studije koje su prethodno nastojale odrediti postmarksističku teoriju kao distinktivan teorijski korpus propustile usmjeriti pozornost na književnoteorijsku problematiku, ona se pokazuje nezaobilaznom u temeljitijem istraživanju tog polja. Ne samo da se fenomen književnosti kao objekt istraživanja gotovo beziznimno javlja u opusima teoretičara koje se dovodi $\mathrm{u}$ vezu s postmarksizmom, nego je u njihovim radovima nerazdruživo isprepleten s čimbenicima koji se izdvajaju ključnima pri tom određenju te nerijetko zadobiva privilegirano mjesto.

Stoga odgovor na pitanje o konceptualizaciji i mjestu književnosti/književnog u postmarksističkoj teoriji nije tek popunjavanje efemerne praznine u ranijim istraživanjima, nego i otvaranje puta sustavnijoj problematizaciji odlika, geneze i opsega tog teorijskog korpusa. Pritom je primarna hipoteza rada da je upravo isprepletenost i svojevrsno urušavanje granice između književno- i političkoteorijske domene - uzrokovano s jedne strane onim što smo nazvali diskurzivnom ili literarnom konceptualizacijom politike, a $\mathrm{s}$ druge konceptualizacijom književnosti kao imanentno političkog diskursa - jedna od glavnih odlika koje povezuju teoretičare koje se dovodilo u odnos s pojmom postmarksizma, otvarajući potencijal heurističkoj korisnosti tog koncepta.

Disertacija se temelji na istraživanju teorijske naravi koje svom predmetu primarno prilazi iz književnoteorijskog rakursa, no pritom se zaokupljajući dodirnim točkama književne teorije s političkom teorijom te presijecajući i druge humanističke discipline. Metodološki se oslanja na pažljivo kritičko čitanje reprezentativnih teorijskih tekstova (primarnih i sekundarnih), njihovu usporednu analizu, genealoško preispitivanje istraživanog teorijskog kretanja i temeljnih koncepata te sintezu istraživane materije.

Središnji dio rada sastoji se od triju većih dijelova podijeljenih u manja poglavlja. Prvi dio posvećen je kritičkom osvrtu na dosadašnja istraživanja o postmarksističkoj teoriji, te osim što donosi prikaz trenutne istraženosti polja, postavlja i temelje problematizaciji pojma postmarksizma. Drugi dio podijeljen je u šest poglavlja koja se bave specifičnim problemima u opusima šestorice autora - Laclaua, Rancièrea, Deleuzea, Derridaa, Foucaulta i Machereya - a povezuje ih ista struktura analize oblikovana oko triju primarnih točaka: ambivalentnosti 
odnosa prema marksističkoj tradiciji, literarnosti politike i politike književnosti. Treći dio disertacije, podijeljen u tri poglavlja, istu analitičku shemu primjenjuje na nekolicinu ranijih autora (ruski formalisti i Bahtinov krug, Bloch, Bataille) čije se djelovanje smješta unutar i u susjedstvo marksističkog korpusa mnogo prije navodne prijelomne točke nastanka postmarksizma, nastojeći tako preispitati različite kronološke i teorijsko-doktrinarne implikacije prefiksa post-.

Rad zaključuje da se trodijelni analitički model proizašao iz postavljanja pitanja o položaju književnosti i književnoteorijskog u postmarksističkoj teoriji doista dokazuje kao model koji omogućuje znatno koherentniji opis negoli ranija istraživanja, potvrđujući važnost prethodno zanemarene književnoteorijske komponente te donoseći nove uvide kako u tematiku postmarksizma, tako i u općenitija književno- i političkoteorijska pitanja postavljena u novi kontekst. No istovremeno rezultat je tog modela i mnogo snažnija problematizacija pojma postmarksizma, koja dovodi u pitanje njegovu samorazumljivost i ukazuje na proturječja o kojima valja voditi računa.

Ključne riječi: postmarksistička teorija, književnost, književna teorija, politika, literarnost 


\section{Summary}

This dissertation analyzes the position of literature and the literary in post-Marxist theory and in doing so also problematizes existing views on the concept of post-Marxism.

Even though studies which define post-Marxist theory as a distinctive theoretical corpus have failed to address issues pertaining to literary theory, a thorough investigation of this corpus cannot preclude it. Not only does the phenomenon of literature as a research object appear in the work of nearly all of the theoreticians associated with post-Marxism, it is also inextricably linked to the factors crucial for that definition and often assigned a privileged status within the theories themselves.

The answer to the question how literature/the literary is conceptualized in post-Marxist theory is therefore not a mere attempt at filling an ephemeral gap in previous research, but much rather a way of threading the path to a more systematic understanding of the features, genesis and scope of that theoretical corpus. Therefore, the main hypothesis of the dissertation is that the characteristic interweaving of the domain of literary theory with that of political theory, or even a complete subversion of the border between the two, is the distinctive trait shared by scholars associated with and discussed within the context of post-Marxism. That interweaving is primarily manifested in what the dissertation refers to as the discursive or literary conceptualization of the politic on the one hand, and by the conceptualization of literature as an inherently political discourse on the other - a chiastic feature endowing postMarxism with potential for heuristic applicability.

The dissertation is based on a theoretical research which approaches its object primarily from the perspective of literary theory. However, since it deals with the points of intersection between literary and political theory, as well as with occasional inputs from other disciplines in humanities, this study is characterized by a degree of interdisciplinarity that is long-familiar and expected in the contemporary literary theory. Methodologically, it relies on a close critical reading of representative theoretical texts (both primary and secondary), their comparative analysis, genealogical study of the explored theoretical currents and concepts, and a synthesis of the examined matter.

Apart from the introduction and conclusion, the thesis consists of three main parts, each divided into smaller chapters. The first part is dedicated to a critical overview of previous studies about the post-Marxist theory (seven books published between 1998 and 2013), together with certain studies that intersect with post-Marxist issues in various ways, 
albeit not using or discussing the post-Marxist label itself. Although the main goal of this part is to provide an insight into the state of the examined field, this part also lays the foundation for questioning of post-Marxism as a concept as well.

The second part of the dissertation is divided into six chapters, dedicated to specific research questions regarding the oeuvres of six representative authors, connected to postMarxist context in various ways: Laclau, Rancière, Deleuze, Derrida, Foucault and Macherey. The common thread running through the respective chapters is the tripartite structure of analysis shaped around three key points: ambivalent stance towards Marxism, literariness of politics, and politics of literature.

The first chapter, dedicated to Laclau's work, offers a parallax view of his oeuvre: a view primarily structured around the importance attributed to the questions of literature/literariness in this dissertation. Although in earlier studies of post-Marxism Laclau is almost unexceptionally the privileged reference point, this study differs from them in that it favors the perspective developed in his last published work, The Rhetorical Foundations of Society, and applies it to his entire oeuvre. In other words, the chapter shows that politics was from the very beginning of Laclau's theory of hegemony conceptualized as a tropological articulation and that such a perspective developed under the significant influence of contemporary literary theory. Moreover, this chapter not only re-writes the line of development in Laclau's theory in terms of its final point, but also establishes certain elements of his theoretical apparatus as analytical tools for the rest of the dissertation.

Motivated by the specific chiastic bind between literature and politic, already outlined in Laclau's analyises, the second chapter focuses on certain aspects of Rancière's oeuvre. Since Rancière was almost completely ignored in earlier studies of post-Marxism, this chapter provides an innovative inclusion of this author into the examination of post-Marxism. However, bringing Rancière into focus is not simply one of many similar variations of the scholars usually examined in previous studies with no lasting impact on the structure of the research field. On the contrary, it is a change that significantly influences the direction of further analysis. The chapter both emphasizes a largely overlooked fascinating similarity of Rancière's and Laclau's political theories, along with the relationship towards the Marxist tradition, as well as supplements the lack of direct interest for politics of literature in Laclau's work, thus closing the mentioned chiasm and preparing it for application in the following chapters.

Due to the influence he exerted on Rancière and also polemical remarks directed at him by Rancière and Laclau, the third chapter logically focuses on the works of Gilles 
Deleuze. The chosen perspective, with literariness as its focal point, enables formring analogies between Deleuze's writings on politics and literature regarding the issue of his radical immanentism, i.e. the conclusions questioning the consistency of that very immanentism. The analyzed issue, along with his extremely unorthodox stance on Marx, is what brings Deleuze in relationship with other examined authors and the main hypothesis of the dissertation.

In the fourth chapter, the same perspective is of use in order to grasp the highly important connection between literariness and politics in Derrida's works, which exceeds the mere conclusions that literature is a privileged political/emancipatory discourse and points to its essential connection with issues that Derrida finds crucial for politics, such as those of democracy, friendship, law and justice. Moreover, by broadening the scope of the analysis beyond Derrida's Spectres of Marx, which is his only work examined by previous studies of post-Marxism, the chapter disproves the notion that Specters, as well as Derrida's engagement with Marxism in general, are merely marginal detours in his oeuvre..

The fifth chapter offers an even less typical approach to the scholar it deals with than the previous one. By turning to Michel Foucault, it offers an image of him that is noticeably different not only from the one dominating in earlier studies on post-Marxism but also from the one prevailing in general. The attribute of the theorist of control is here supplemented, or even partially contested by the one of transgression, as the chapter deals with one of the least emblematic and thus rather neglected segments of Foucault's oeuvre: the one dedicated to literature. Nevertheless, this specific perspective also reveals moments within Foucault's most famous studies that testify to the important function of literariness within them, as well as to the sometimes overlooked influence of Marxist tradition, consequently modifying their usual reception.

Finally, the second part of the dissertation is concluded by an analysis of Macherey's works on literary theory, which goes against the grain of various reductive readings that either depict Macherey as an Althusserian Marxist (relying solely on his earlier works) or sharply oppose his alleged Marxist and post-Marxist phase. In contrast to such reductions, the chapter demonstrates that the lines of development of Macherey's theoretical positions testify to much less discrete borders and more heterogeneous state, which becomes even more interesting for this dissertation if we consider the fact that they intersect with quita a few of the authors from other chapters, either by direct or indirect mutual influence. Moreover, the examination of Macherey's oeuvre clearly shows what other chapters already outlined on their margins: that the borders between literature as an instrument of ideological subjection, a reflection of 
society and an emancipatory agent are not so clear-cut and self-explanatory as the binary approaches that link them to either the Marxist or post-Marxist paradigm would suggest.

The recognition of the permeability of borders of what is considered as typically Marxist or post-Marxist, as well as of the impossibility to put that distinction in a simple perspective of linear development; a recognition which shapes itself at the beginning of every chapter in order to be explicitly stated in the sixth chapter, introduces the last part of the dissertation. Consisting of three chapters, the last part turns to the past, i. e. to the other side of what is usually considered as the temporal and doctrinal border between two theoretical corpora. It is there that the same analytical structure is applied to three different theoretical nodes in different historical and geographical contexts (Russian Formalism and the Bakhtin Circle, Bloch and Bataille), which are all positioned within the Marxist corpus or in its immediate neighbourhood, and at the time regarded as an alternative to more traditional Marxist approaches to literature. Conclusions of all three chapters confirm the possibility to draw clear analogies between these scholars and the authors brought in connection with postMarxism, establishing direct or indirect anticipation where one is supposed to find firm borders and breaking points, thus seriously bringing into question various and often contradictory implications of the prefix post-.

In conclusion, the tripartite analytical model of this dissertation, derived from the perspective that examines the position of literature and literary theory within the post-Marxist theory, proves itself as a model enabling a far more coherent approach to the issue of postMarxism than previous studies do, thereby confirming the importance of a previously neglected component of literary theory, and providing new insights not only into the problem of post-Marxism but also into general literary and political theory questions framed in a new context. However, at the same time, this model results in a much stronger problematization of the post-Marxist concept itself, by bringing into question its simple and self-explanatory nature and at the same time pointing to the contradictions that should be taken into account.

Key words: post-Marxist theory, literature, literary theory, poltiic, literaryness 


\section{Sadržaj}

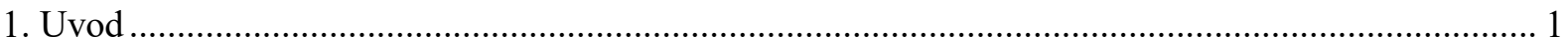

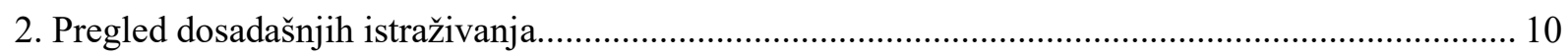

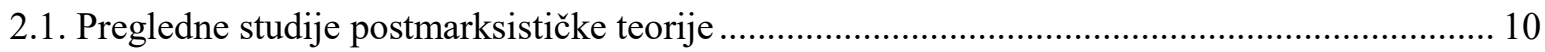

2.2. Doprinos srodnih odrednica - treba li nam pojam postmarksizma? ......................................... 31

3. Literarnost politike i politika književnosti na postmarksističkom terenu........................................ 40

3.1. Od genealogije hegemonije do političke tropologije: Ernesto Laclau iz druge perspektive ...... 40

3.2. Zoon politikon kao književna životinja: Rancière, nesuglasnost i literarnost............................ 61

3.3. Literarnost Deleuzeove politike i problem (ne)dosljednog imanentizma .................................. 80

3.4. Demokracija, pravda i književnost: Marx i Kafka u odsutnom središtu dekonstrukcije.......... 111

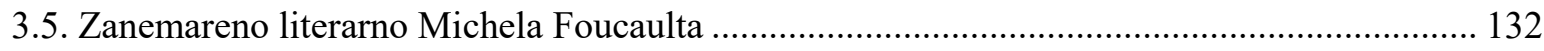

3.6. Tri odnosa književnosti i ideologije kod Pierrea Machereya .................................................. 160

4. Onkraj granice i natrag: prefiguracija i(li) problematizacija postmarksizma ................................ 177

4.1. Kontinuirana revolucionarnost revolucionarne teorije: ruski formalisti, Bahtin i marksizam. 177

4.2. Ernst Bloch i mogućnost drukčijeg marksističkog pogleda na književnost.............................. 203

4.3. Ekscesnost Batailleeva suvereniteta: Od opće ekonomije do literarnosti politike ................... 221

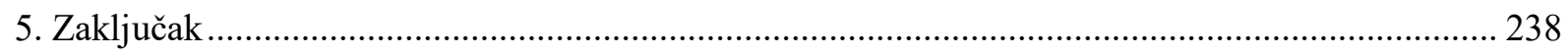

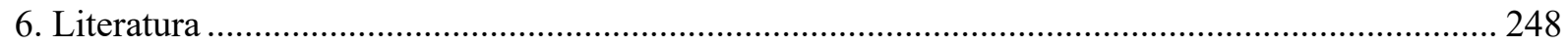

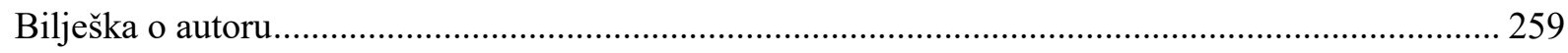


Sav svijet iz temelja se mijenja (Internacionala)

$\mathrm{Ne}$ vjerujem $\mathrm{u}$ odlučne prekide, $\mathrm{u}$ nedvosmislene „epistemološke lomove“, kako se to danas naziva. $\mathrm{Na}$ nesreću, takvi se prekidi uvijek iznova ispisuju na staroj tkanini koja se mora neprekidno i u nedogled rasplitati. Taj proces bez kraja ne može biti plod okolnosti ili slučaja; on mora biti suštinski, sustavan i teorijski. A to ni u kojem slučaju ne umanjuje nužnost i relativnu važnost određenih prijeloma, pojavljivanja i određivanja novih struktura...

(Jacques Derrida, Positions)

Književnost je nešto bitno, ili nije ništa.

(Georges Bataille, Književnost i zlo) 


\section{Uvod}

Premda se na poleđini knjige Stuarta Sima Post-Marxism: A Reader (1998), prve knjige koja postmarksizam nastoji izdvojiti kao distinktivnu teorijsku paradigmu, postmarksističku teoriju naziva već dobro utemeljenom teorijskom pozicijom ${ }^{1}$, tvrdnja je to koju nije lako braniti ni danas. Pojam postmarksističkog, čija se prva uporaba uvriježeno povezuje s Laclauom i Mouffe te njihovom studijom Hegemonija i socijalistička strategija [Hegemony and Socialist Strategy, 1985 $]^{2}$ u suvremenom teorijskom leksiku doduše nije nepoznanica, no njegov je referent daleko od određenog i čvrsto utemeljenog. U dva desetljeća od izlaska prve Simove knjige posvećene postmarksizmu objavljeno je još svega nekoliko studija autora koji pokušavaju preciznije ocrtati postmarksističku teoriju, a među njima valja izdvojiti svakako i kasniju Simovu studiju (2000), zatim Goldsteina (2005), Tormey i Townshend (2006), Bowmana (2007), Therborna (2008) te Breckmana (2013). No bez obzira na činjenicu da sve te studije dijele načelno viđenje geneze postmarksističkih teorijskih pozicija i njihovih temeljnih odlika, te uz to i brojne druge zajedničke točke, svojim se pristupima ipak nezanemarivo razlikuju pa nerijetko ulaze i u proturječja. Također, u svakoj od njih ponavlja se i varijacija ograđivanja od pretenzije na totalnu perspektivu koja bi ponudila iscrpan opis čvrsto omeđene teorijske škole, u korist ograničenog uvida u fluidno i heterogeno teorijsko strujanje.

Situacija je još manje jednoznačna uzmu li se u obzir i različita nesustavna spominjanja pojma postmarksističkog, kao i donekle srodni koncepti što se pojavljuju u knjigama koje se bave sličnom problematikom iz usporedive perspektive. No bez obzira stavimo li u fokus i tu skupinu studija ili se ograničimo samo na prvu, razlike od studije do studije uključuju različite polazne točke, razlike u popisu teoretičara koje izdvajaju kao predstavnike tog teorijskog korpusa te različite pristupe njihovoj obradi.

Osim toga, kod ranije spomenutih autora gotovo beziznimno izostaju reference na istovrsne studije koje su im u nastojanju da opišu postmarksističko polje prethodile, zbog čega potreba za makar jezgrovitim pregledom stanja, kao preduvjetom sustavnosti daljnjih

\footnotetext{
${ }^{1}$ Sim (1998: 14) slično tvrdi i unutar knjige, u uvodu odabranog odlomka Laclaua i Mouffe, gdje piše da je njihova kapitalna studija ona ključna točka „u kojoj se postmarksizam sjedinio u specifičnu teorijsku poziciju namjesto raspršenog sklopa pojedinačnih odziva.“" Istu tvrdnju ponavlja i u uvodu svoje kasnije studije o postmarksizmu; usp. Sim, 2000: 1.

${ }^{2}$ Premda je spomenuta studija Laclaua i Mouffe (2014) početna točka na koju gotovo beziznimno upućuju sve studije koje se bave postmarksističkom teorijom, ona nije prvo mjesto uporabe tog pojma u apsolutnom smislu, nego tek u smislu kakav mu je pridan u kasnijim istraživanjima. O tome više u sljedećem poglavlju.
} 
istraživanja, ostaje akutna i aktualna. Slično vrijedi i za potrebu da se odgovori na neka važna, a i dalje otvorena pitanja. Prije svega radi se o odnosu pojma postmarksizma prema onom marksizma, odnosno o višeznačnosti i ambivalentnosti prefiksa post-, koji istovremeno sugerira i (ne nužno jednostavnu i neproblematičnu) činjenicu vremenske posteriornosti, kritiku, nadilaženje i raskid, ali i nasljedovanje i reinterpretaciju, a potom i o postavljanju u suodnos s drugim bliskim teorijskim fenomenima. Pitanje je to koje su dosadašnje studije najvećim dijelom ili postavljale tek na marginama, ili potpuno zaobilazile, držeći svoja implicitna polazišta podrazumijevajućim.

No uz sve navedeno, najzanimljivija je slijepa pjega dosadašnjih istraživanja činjenica da ona gotovo $\mathrm{u}$ potpunosti propuštaju usmjeriti pozornost na književnoteorijsku problematiku u okvirima postmarksističke teorije. Čak i u slučajevima kada su autori studija po svojoj primarnoj vokaciji književni teoretičari, njihovi pregledi u prvom planu imaju pitanja iz domene političke teorije, pritom izostavljajući razmotriti poveznice s književnom teorijom bilo u smislu književnoteorijskih segmenata opusa autora koje proučavaju, bilo različitih utjecaja iz književnoteorijske domene na njihov političkoteorijski opus.

Ta bi pak odlika govorila više o konciznosti i fokusiranosti spomenutih studija, nego o njihovim nedostacima, da nije činjenice da su književno i književna teorija kontinuirano isprepleteni s materijom koju one proučavaju. Većina autora koje dosadašnja istraživanja postmarksističke teorije uzimaju za karakteristične predstavnike tog teorijskog korpusa (npr. Althusser, Foucault, Derrida, Deleuze, Macherey itd. - popis u vezi s kojim ćemo istaknuti određene zamjerke) ujedno su nezaobilazna imena $\mathrm{u}$ pregledima suvremene teorije književnosti te književnost i književnoteorijska problematika najčešće zauzimaju istaknuto mjesto u njihovim opusima. No čak i kod teoretičara koji se književnošću nisu bavili izravno primjetan je utjecaj književnoteorijskih dosega na oblikovanje njihove političke teorije. Toga je ponajbolji primjer upravo Laclau, koji implicitno oslanjanje svoje političke teorije na općesemiotičke i književnoteorijske koncepte, prisutno još od prijelomne Hegemonije $i$ socijalističke strategije, iz studije u studiju čini sve jasnijim, a potom i posve eksplicira u svojoj posljednjoj objavljenoj knjizi Retorički temelji društva [The Rhetorical Foundations of Society] (2014).

Govoreći o proučavanju književnosti, literarnosti ili naglašenoj prisutnosti drugih književnoteorijskih koncepata i problema kod teoretičara koje se u ranijim istraživanjima smatralo postmarksističkima stoga ne govorimo o efemernosti ni slučajnosti: riječ je redom o autorima u čijim se opusima problematizacija polja književnosti i politike, s pripadajućim teorijama, povezuju i nadopunjuju do razine na kojoj je između njih teško povući diskretne 
granice; autorima u čijim promišljanjima političkog privilegirano mjesto zauzima književnost, kao i obrnuto.

Imajući to u vidu, jasno je da prethodna istraživanja zanemarivši pitanje o povezanosti književnog i političkog u postmarksističkoj teoriji nisu zaobišla tek jedno od brojnih sporednih pitanja u opsežnom području koje su nastojala ocrtati. Naprotiv, riječ je o pitanju koje bi s jedne strane omogućilo da se unaprijedi razumijevanje pojedinačnih teoretičara te konceptualizacije književnosti i politike u njihovim opusima, a s druge strane i razumijevanje poveznica koje te teoretičare okupljaju pod zajedničkim nazivnikom postmarksističke teorije, što je segment u kojem postojeće studije ostavljaju mnogo prostora za nadopunu. Drugim riječima, stavljanje problematike književnosti i književnoteorijskog u središte pozornosti moglo bi biti upravo onaj čimbenik koji omogućuje da proučavanje postmarksističke teorije napravi pomak od heteroklitnog nizanja razmjerno labavo povezanih imena prema sustavnijem opisu polja oslonjenom na jasnije artikulirane značajke. Osim toga, u kombinaciji S već spomenutim propitivanjem složenosti temporaliteta i kauzaliteta prefiksa post-, takav istraživački rakurs otvara prostor ne samo reviziji popisa karakterističnih predstavnika korpusa među suvremenijim teoretičarima, kakvu je poduzimala gotovo svaka od prethodnih studija, nego i usporedbi s primjerima srodnih odnosa estetike/literarnosti i politike u ranijoj marksističkoj tradiciji ili njezinoj teorijskoj okolini, odnosno nudi potencijalno plodan način preispitivanja homogenosti s obiju strana pretpostavljene granice, kao i statusa te granice kao epistemološkog loma.

Stoga će primarni istraživački cilj disertacije biti elaboracija položaja književnog i književnosti unutar postmarksističke teorije, ali istovremeno i povratna problematizacija okvirnog pojma postmarksizma te njegovih dosadašnjih opisa. Pritom je primarna hipoteza rada da je upravo isprepletenost i svojevrsno urušavanje granice između književno- i političkoteorijske domene - uzrokovano s jedne strane povezivanjem političkog/politike s pitanjem prikazivog $\mathrm{u}$ određenom diferencijalnom poretku vidljivosti te trenucima utemeljenja i podrivanja tog poretka u korist temeljne jednakosti, a s druge strane konceptualizacijom književnosti (ili uopće umjetnosti) kao prakse koja razotkriva odsutnost temelja, kontingentnost i nestabilnost svakog takvog poretka, što je čini inherentno političkom - jedna od glavnih odlika koje povezuju postmarksističke teoretičare, stvarajući potencijal smislenosti i heurističkoj korisnosti koncepta postmarksizma, te ocrtavajući njegove granice u odnosu na druga teorijska strujanja. Drugim riječima, u središtu proučavanja naći će se ono što ćemo hijastički nazvati literarnošću politike i političnošću književnosti, za koje očekujemo da će se potvrditi kao provodna nit koja povezuje opuse pojedinih autora što su ih analizirale 
dosadašnje studije, ali i nekih koje ćemo prvi put uključiti u taj analitički kontekst. Pritom krajnje implikacije takvog povezivanja u odnosu na koncept postmarksizma tek valja utvrditi.

Disertacija se temelji na istraživanju teorijske naravi koje svom predmetu primarno prilazi iz književnoteorijskog rakursa, no pritom se zaokupljajući dodirnim točkama književne teorije s političkom teorijom te presijecajući i neke druge humanističke discipline, zbog čega će se odlikovati interdisciplinarnosti karakterističnom za suvremenu humanistiku. Metodološki će se osloniti na pažljivo kritičko čitanje reprezentativnih teorijskih tekstova (primarnih i sekundarnih), njihovu usporednu analizu, genealoško preispitivanje istraživanog teorijskog kretanja i temeljnih koncepata te sintezu istraživane materije. Rezultat koji se nadamo tako postavljenim istraživanjem postići jest elaboracija jednog do sada gotovo u potpunosti neistraženog aspekta šireg istraživačkog problema (položaj promišljanja književnog i književnosti u postmarksističkoj teoriji), čime bismo posljedično i preopisali prethodno analizirano polje. Uz to, vrijedi napomenuti da je ovo ujedno i prva studija koja se sustavno zaokuplja pojmom postmarksističke teorije u domaćoj znanosti, a u široj pak perspektivi - koliko nam je poznato - i prvo istraživanje u kojem se daje sustavan pregled dosadašnjih pokušaja da se opiše taj pojam.

Upravo je takav pogled na dosadašnja istraživanja o postmarksističkoj teoriji tema drugog dijela disertacije, podijeljenog na dva manja poglavlja. U prvom poglavlju, primjetno većeg opsega, nastojimo ponuditi sustavan pregled dosadašnjih monografskih studija o postmarksističkoj teoriji, analizirajući sedam studija objavljenih u rasponu od 1998. do 2013. Drugo se poglavlje pak zaokuplja sa šest djela koja kao predmet istraživanja nemaju postmarksističku odrednicu, no na različite načine zasijecaju analognu problematiku, ukazujući tako i iz drugih perspektiva na relevantnost postmarksističke tematike te pridonoseći njezinoj daljnjoj problematizaciji i razumijevanju. Za razliku od prve skupine, u potonjoj se bavimo i dvama domaćim autorima u čijim je radovima vidljiva anticipacija pitanja koja zaokupljaju ostatak disertacije. Nasuprot toj razlici pak, oba poglavlja drugog dijela ne zaustavljaju se tek na faktografskom pregledu, već se usporedno s njim kritički osvrću na prednosti i nedostatke svake od studija. Time istovremeno s problematizacijom prethodnih istraživanja započinju i problematizaciju samog koncepta postmarksizma, koja će se kao provodna nit nastaviti i u sljedećim dijelovima rada.

Treći, središnji dio rada čini šest poglavlja okupljenih zajedničkim nazivnikom hijazma koji je jezgra temeljnog istraživačkog pitanja ove disertacije - onog literarnosti politike i političnosti književnosti. Od poglavlja do poglavlja taj će hijastički odnos biti osovina istraživanja pojedinačnih pitanja vezanih za šestoricu autora koji se na različite 
načine povezuju s postmarksističkom problematikom, počevši s Laclauom kao privilegiranom referentnom točkom ranijih istraživanjima, preko Rancièrea kojeg su ta istraživanja odreda ostavljala po strani, pa do Deleuzea, Derridaa, Foucaulta i Machereya kojima se od studije do studije dodjeljuju oprečne pozicije. Upravo takav heterogeni tretman - pri pozicioniranju u odnosu na pojam postmarksizma, ali potom i u analitičkoj obradi - poticaj je ovom istraživanju da pokuša ujednačiti pristup spomenutim autorima te razmjerno heteroklitno nizanje zamijeniti nešto čvršćom shemom analize. Naslov trećega dijela, Literarnost politike $i$ politika književnosti na postmarksističkom terenu, osim što je parafraza čuvene tvrdnje Laclaua i Mouffe odgovorne za inicijalne pokušaje artikulacije postmarksističkog polja, ujedno ocrtava i tu temeljnu shemu. Već spomenutom hijazmu, naime, dodaje i naslovnu postmarksističku problematiku, uspostavljajući tako triangulacijske parametre što definiraju temeljne obrise svakog pojedinog poglavlja. Sva su poglavlja ovog dijela stoga u određenoj mjeri sačinjena trodijelno, s prvim dijelom posvećenim problematici (dvoznačnog, proturječnog) odnosa analiziranog autora spram marksističke tradicije, drugim literarnosti njegove koncepcije politike te trećim usmjerenim imanentnoj političnosti književnosti iz iste teorijske vizure. Pritom se ne radi o diskretno odvojenim segmentima koji bi sugerirali tri odvojena problema/polja istraživanja koja otvaramo unutar svakog od poglavlja trećega dijela rada. Upravo naprotiv, želja nam je pokazati kako se naznačena lica istog problema razmjerno nediskretno prožimaju i pretapaju jedno u drugo, odnosno čine različite pristupne točke koje vode isprepletenim nitima jedinstvene problematike koja nas ovdje zanima, baš kao što se sličan odnos uspostavlja i na razini više, među središnjim problemima pojedinih poglavlja.

Bez takve inovacije u pristupu, gotovo da bi bilo besmisleno u prvom se poglavlju trećega dijela disertacije još jednom istraživački okretati odnosu Laclauova opusa i postmarksističke teorije. Kako je već spomenuto, Laclau je u ranijim istraživanjima tog teorijskog korpusa beziznimno bio privilegirana referentna točka analiza, baš kao i primarna meta marksističkih kritičkih osvrta na istu temu, pa stoga može djelovati zalihosno otvarati još jednom isti problem. No paralaksa koju ovo istraživanje u Laclauovu slučaju čini potaknuta je njegovom u međuvremenu objavljenom posljednjom knjigom, Retoričkim temeljima društva [The Rhetorical Foundations of Society] (2014), u kojoj Laclau prethodno implicitnu tropološku dimenziju svoje teorije hegemonije eksplicitno stavlja u središte pozornosti. Stoga i poglavlje kojim počinje središnji dio disertacije čini analogan pomak: nastoji pokazati kako shvaćanje politike kao retoričke artikulacije nije novost, već je u Laclauovu opusu prisutno od ranije faze njegove političke misli, te upravo ono čini jezgru njegova odmaka od marksističkih krugova u kojima je počeo karijeru, kao i najvažniji 
segment njegovih dekonstrukcijskih čitanja marksističkih klasika. Drugim riječima, pokazat ćemo da je ono što Laclau u kasnoj fazi svog djelovanja određuje kao poopćenu literarnost ujedno i središnja tema njegovih ranijih političkoteorijskih studija.

Upravo tako shvaćena literarnost poveznica je s drugim poglavljem trećeg dijela disertacije, kojem je u središtu pozornosti teorijski opus Jacquesa Rancièrea. Dijametralno suprotno u odnosu na tretman Laclaua, Rancièreom se prethodna istraživanja postmarksističke teorije nisu bavila. Stoga uključujući ga u analizu i dodjeljujući mu u njoj važnu poziciju ovaj rad čini primjetan iskorak, istovremeno pokušavajući korigirati ranije propuste, ali i nastavljajući s otklonom od ranije perspektive započetim u prethodnom poglavlju. Razloge da se Rancièrea u kontekstu postmarksističke problematike proučava rame uz rame s Laclauom razvidnim nastoji učiniti već prvi dio poglavlja, usmjeravajući se genezi Rancièreovih političkoteorijskih gledišta u odmaku od althusserijanskih postavki, analognom Laclauovoj dekonstrukcijskom čitanju marksističkih klasika, te ukazujući pri daljnjoj analizi Rancièreove političke teorije na njezine podudarnosti s Laclauovim pogledima. Pritom u središte analitičke pozornosti dolazi Rancièreovo usko povezivanje politike $\mathrm{s}$ estetikom, ali i posebno konceptom literarnosti, koje nas u nastavku poglavlja upućuje problematici politike književnosti, kao izrazito naglašenoj temi u književnoteorijskom segmentu njegova opusa. Literarnost kakvom je poimamo u ovoj disertaciji tako ovdje, osim povezivanja sa susjednim poglavljima, zadobiva i funkciju svojevrsne zglobnice između dvaju glavnih dijelova poglavlja oko koje se oblikuje i temeljno pitanje poglavlja: ono o odnosu politike i književnosti kod Rancièrea, te odnosu njegove konceptualizacije obaju tih pojmova spram njihovih konceptualizacija u tradicijama s kojima polemizira. S jedne strane, rasvjetljavanje tog odnosa u široj će perspektivi doprinijeti odgovoru na temeljno pitanje rada u cjelini, dok će s druge strane upravo specifičan rakurs rada pritom omogućiti da se izbjegnu neka razmjerno česta pretjerana pojednostavljivanja.

Rancièreova specifična konceptualizacija politike književnosti odvest će nas $\mathrm{u}$ sljedećem, trećem poglavlju trećeg dijela disertacije autoru na čije se viđenje književnosti pri oblikovanju vlastitih pozicija Rancière nerijetko (i afirmativno i polemički) referira - Gillesu Deleuzeu. Na početku poglavlja zanimat će nas stoga naizgledno proturječje između te podudarnosti pri konceptualizaciji književnosti i neobične diskrepancije glede odnosa spram marksističke tradicije, a potom i glede promišljanja politike. Kao središnji problem poglavlja iz svih će se navedenih smjerova izbistriti Deleuzeov pokušaj izgradnje dosljedno imanentističkog i posve materijalističkog pristupa, oslonjenog na čistu razliku bez identiteta. Potaknuto među ostalim i Laclauovim te Rancièreovim podcrtavanjem problematičnosti takve 
imanentističke koncepcije, ovo poglavlje nastoji analizirajući različite faze Deleuzeovih promišljanja politike i književnosti preispitati u kojoj mjeri ona doista uspijevaju biti dosljedna deklariranom radikalnom imanentizmu, odnosno emancipaciji koja odbacuje svaki oblik utemeljenja, pri čemu je ključna nit vodilja te analize ponovno karakteristična sveza literarnosti i politike što se uočava i u Deleuzeovu opusu. Drugim riječima, zanimat će nas je li i u kojoj mjeri posljedično Deleuzeova teorija doista potpuno idiosinkrastična u svom okružju, ili pak kompatibilna $\mathrm{s}$ autorima s kojima nominalno upravo oko problematike utemeljenja i privilegiranja semiotičkog dolazi u polemičan odnos.

Četvrto će se pak poglavlje trećeg dijela disertacije okrenuti jednoj od značajnijih implicitnih meta Deleuzeove kritike među njegovim suvremenicima, ali i teoretičaru s kojim ga povezuju nezanemarive sličnosti - Jacquesu Derridau. Iako pridavanje analitičke pažnje Derridau u postmarksističkom kontekstu nije samo po sebi neobično, ovo poglavlje će nastojati i po tom pitanju učiniti stanoviti iskorak, izokrećući pritom odnos središnjeg i rubnog. Isključivo pridavanje pozornosti Derridaovoj studiji Sablasti Marxa [Spectres de Marx, 1993; usp. Derrida, 2002b] kao dvostruko rubnom fenomenu - s jedne strane neočekivanom prilogu postmarksističkom korpusu, a s druge strane Derridaovu prigodničarskom izletu izvan spektra uobičajenih tema - zamijenit će bitno izmijenjeno gledište. Odnosom marksizma i dekonstrukcije pozabavit ćemo se u perspektivi široj od pojedinačne studije u kojoj se on eksplicitno tematizira, a Sablasti Marxa potom razmatrati ne kao marginaliju Derridaova opusa, već kao jedno od sjecišta njegovih uvjetno odvojivih segmenata: ranijeg i kasnijeg, filozofskog i političkog, neknjiževnog i književnog. Takav pogled na materiju u središte će dovesti aporije pravde i demokracije, jednakosti i uspostavljanja te podrivanja zakona, koje se odreda sreću na onom mjestu na kojem, prema Derridau, nastaje književnost; na polju hegemonijskog donošenja odluka na neodlučivom terenu te poopćene literarnosti kao onoga što tako uspostavljene poretke opetovano prekoračuje i preispituje.

Transgresivna dimenzija literarnog najznačajniji je aspekt i petog poglavlja trećeg dijela disertacije, $u$ kojem $u$ fokus dolazi kao protuteža i svojevrsna druga strana novčića uobičajenoj slici još jednog Deleuzeova i Derridaova suvremenika nezaobilaznog u kontekstu suvremene teorije - Michela Foucaulta. No provodni motivi razmjerno zanemarenog segmenta Foucaultova opusa posvećenog književnosti što ga analizira ovo poglavlje ne potkopavaju uvriježenu percepciju Foucaulta kao teoretičara kontrole tek lokalno, u izdvojenom uskom tematskom pretincu. Kao što prvi dio poglavlja nastoji pokazati, distinktivna perspektiva određena tematskim čvorištima literarnosti politike i politike 
književnosti koju ova analiza zauzima u prvi plan dovodi analogne motive i u najpoznatijim Foucaultovim studijama. Ambivalentan odnos kontrole i transgresije isprepliće se pak i s ambivalentnošću Foucaultova odnosa spram marksističke tradicije, mijenjajući tako u značajnoj mjeri poziciju tog teoretičara u okvirima postmarksističke problematike što su je ocrtala prethodna istraživanja.

Stavljanje literarnosti u prvi plan uvjetovalo je konačno i interes posljednjeg poglavlja trećeg dijela ove disertacije za književnoteorijski opus Pierrea Machereya, interes koji ona dijeli s tek još jednim dosadašnjim istraživanjem o postmarksističkoj teoriji. Korjenite promjene, ali i stanovite konstante koje obilježavaju Machereyevu konceptualizaciju književnosti od najranije do kasne faze njegova opusa, oblikovane u izravnoj teorijskoj interakciji s protagonistima prethodnih poglavlja, s jedne su strane dokaz vrijednog $\mathrm{i}$ heterogenog Machereyeva doprinosa suvremenom književnoteorijskom polju, najčešće nepravedno reduciranog tek na status Althusserova učenika i povjerenika za književnost, dok su s druge strane jasan indikator jednako heterogenih kretanja i nediskretnosti granica tamo gdje se situacija naizgled čini samorazumljivom. Gravitirajući oko triju međusobno bitno različitih ključnih točaka promjena Machereyeve konceptualizacije književnosti, ovo poglavlje među ostalim nastoji pokazati da ono što se uvriježeno označava marksističkom fazom Machereyeve književne teorije već sadrži značajan iskorak iz tradicionalnih marksističkih pozicija, dok ono što se uobičajeno označava kao njezin nasuprotan, postmarksistički pol istovremeno zadržava i neke prepoznatljivo marksističke komponente. Pritom trima točkama koje poglavlje uzima za ključne momente usporedbe odgovaraju i oscilacije Machereyeva viđenja odnosa književnosti i ideologije između razotkrivanja, podjarmljivanja i podrivanja.

Evidentna nediskretnost granice između pretpostavljenog postmarksističkog korpusa i onog što se često jednako varljivo smatra homogenim korpusom marksističke teorije, na koju tako ilustrativno ukazuje analiza Machereyeva književnoteorijskog opusa, ujedno je i povod i temeljna istraživačka tema četvrtog dijela disertacije. U tom dijelu, sastavljenom od triju poglavlja, istraživačka je pozornost usmjerena kondenziranom propitivanju nekih od proturječnih aspekata prefiksa post- u pojmu postmarksizma. Prije svega, radi se o postavljanju pitanja znači li on raskid i/ili nasljedovanje, nadilaženje i/ili reinterpretaciju, ali i implicira li nužno - kako je to većina ranijih istraživanja neproblematično prihvatila određenu posteriornost $\mathrm{u}$ odnosu na marksizam te je li $\mathrm{s}$ te strane nužno vezan za točno određeni historijski kontekst i povezane teorijsko-historijske fenomene poststrukturalizma i postmodernizma. Umjesto apstraktne teorijske problematizacije tog pitanja, tri poglavlja 
posljednjeg dijela disertacije donose analize triju vremenski i prostorno odmaknutih ključnih točaka - ruskih formalista i Bahtinova kruga, Ernsta Blocha te Georgesa Bataillea teoretičara čiji opusi, u različitim historijskim kontekstima i različitom modalitetu povezanosti sa sebi suvremenim marksizmom, u značajnoj mjeri anticipiraju mnoge (nominalno) postmarksističke teorijske postavke. Tim problematiziranjem granica korpusa što smo ga netom ranije pokušali skicirati nastojat ćemo se u konačnici vratiti općenitim pitanjima koja smo postavili na početku ovog uvodnog poglavlja te, imajući konstelaciju svih pojedinačnih analiza na umu, u zaključku ponuditi odgovor i na njih. 


\section{Pregled dosadašnjih istraživanja}

\subsection{Pregledne studije postmarksističke teorije}

Iako nije sa sigurnošću utvrđeno tko je prvi uporabio pojam postmarksističkog u značenju makar približnom onom kako ga se danas razumijeva, uobičajeno se kao početna točka uzima 1985. i čuvena studija Laclaua i Mouffe Hegemonija i socijalistička strategija [Hegemony and Socialist Strategy, 1985]. No suprotno očekivanjima koje izaziva ta informacija što je u pravilu ponavljaju pregledne studije postmarksističke teorije, Laclau i Mouffe (2014: xxiv) postmarksizam ne spominju naročito naglašeno, navodeći tek u uvodu svoje knjige kako je vrijeme da sasvim jasno kažu da su ,trenutno situirani na postmarksističkom terenu“, nakon čega ublažavaju tu tvrdnju pojašnjavajući da je njihov „,intelektualni projekt u ovoj knjizi postmarksistički, ali evidentno i postmarksistički.“ (isto) Potom su se 2001. u predgovoru sljedećeg izdanja iste knjige pak otvoreno ogradili od nastojanja da tom tvrdnjom uspostave neku novu teorijsku kategoriju, premda je istovremeno nisu ni odbacili (usp. Laclau, Mouffe: 2014: ix) ${ }^{3}$.

Nesustavne uporabe postmarksističkog označitelja bilo je sasvim sigurno i kod drugih autora nakon Laclaua i Mouffe. Breckman (2013: 217), primjerice, izdvaja jednu upućujući na Žižekovo (1989: 6-7) proglašavanje Hegela prvim postmarksistom, iz vremena kad je Žižek svoj teorijski rad još uvijek držao bliskim Laclauovom ,postmarksističkom projektu“. No pokušaj da se označitelj postmarksizma uporabi sustavnije, da ga se - kako Laclau i Mouffe (2014: ix) to navode - pretvori u ,etiketu“ , odnosno da se njime imenuje određeno suvremeno teorijsko strujanje, izvorno je ipak desetljeće mlađi i inicijalno je zasluga engleskog književnog teoretičara Stuarta Sima.

Simov uvodnik u zbornik izabranih članaka naslovljen Postmarksizam: Čitanka [PostMarxism: A Reader] (Sim, 1998), zajedno s uvodima u pojedinačne članke u zborniku, prvi je tekst u kojem se nazire nastojanje sustavnijeg opisa postmarksističke teorije, budući da se postmarksizam u njemu eksplicitno imenuje ,pokretom“ (isto: 1). Doduše, odmah potom

\footnotetext{
${ }^{3}$ U predgovoru drugom izdanju knjige Laclau i Mouffe (2014: ix; [2001]) eksplicitno ističu da oni nisu ,izmislili tu etiketu - ona se tek marginalno pojavljuje (ne kao etiketa) u Uvodu naše knjige. No budući da je otada postala uvriježena u opisivanju našeg djela, možemo reći da joj se ne protivimo sve dok je valjano shvaćena...“

Osim toga, pet godina prije njih pojam postmarksističkog uporabio je i Sheridan (2005: 211 [1980]) pišući o Foucaultu, no sa značenjem tek dijelom podudarnim $s$ današnjim implikacijama tog pojma. Tom je odrednicom želio pozicionirati Foucaultovo djelo kao ono koje se razvija kronološki nakon marksizma i sa sviješću o marksističkoj teoriji (za razliku od predmarksističkog), ne implicirajući nužno snažniju povezanost s marksističkom tradicijom.
} 
slijedi i tvrdnja da on „nipošto nije homogen pokret, već u biti pokriva raspon pozicija, koje nisu nužno kompatibilne jedna s drugom“ (isto), odnosno da se radi o „nestabilnoj koaliciji interesa“ koje „na okupu održava kut intervencije“ (isto: 2). Koalicija, prema Simu (isto), okuplja „niz neprijateljskih i/ili revizionističkih reakcija prema klasičnom marksizmu iz poststrukturalističkoh/postmodernističkog/feminističkog smjera, od osoba koje su u nekom trenutku svojih života smatrale sebe marksistima, ili čije je mišljenje u značajnoj mjeri oblikovala klasična marksistička tradicija.“

Problem tako postavljenog određenja vidljiv je odmah u onome što će Breckman (2013: 95) kasnije nazvati biografskim postmarksizmom. No općeniti okviri koje Sim postavlja i utjecaji koje nabraja ostali su većim dijelom konstanta i u kasnijim studijama. Osnovna distinkcija koja se unutar tih okvira može uspostaviti jest ona između studija koje postmarksističkoj teoriji prilaze kao razmjerno širokom i heterogenom teorijskom fenomenu čiji su Laclau i Mouffe tek jedni od predstavnika (npr. dijelom Sim, 1998; Goldstein, 2005; Tormey i Townshend, 2006 i Breckman, 2013), te onih koje Laclauu i Mouffe daju status naglašeno središnjeg primjera (dijelom Sim, 2000; Bowman, 2007 te Therborn 2008). Oba pristupa imaju slabe točke: prvospomenute studije dolaze u opasnost da postmarksističku teoriju odrede toliko široko da izgubi svaku razlikovnost prema pojmu poststrukturalizma, ili da postane još i širi skup, dok se kod potonjih - premda nominalno govore o širem teorijskom kretanju - postmarksistička teorija čini ograničena tek na teorijsku produkciju Laclaua i njegovih neposrednih nasljedovatelja.

Simova prva knjiga o postmarksizmu tako naglašava da su Laclau i Mouffe „odigrali ključnu ulogu u razvoju postmarksizma, osobito svojom knjigom Hegemonija i socijalistička strategija: Prema radikalnoj demokratskoj politici (1985), koja je pomogla da se postmarksizam uspostavi kao određena samosvojna teorijska pozicija“, no istovremeno podsjeća da ta pozicija ,nije nastala s Laclauom i Mouffe, te da postoje i radovi velikog broja autora koji značajno anticipiraju postmarksizam“ (Sim, 1998: 2). Začetak postmarksističkih kretanja Sim smješta u historijski kontekst razočaranja francuskih intelektualaca tradicionalnim marksizmom i politikom PCF-a na zalasku 1968. te globalnih promjena uslijed naznaka kolapsa Sovjetskog Saveza i ekonomske preorijentacije kineskog režima, koji su doveli do „erozije političkog autoriteta marksizma“ (isto: 1). Kao primjere anticipatora navodi pak nekoliko imena: već samog Marxa, zbog navodne nesistematičnost mišljenja i otpora totalizaciji na koje ukazuje Lyotard u svojoj Libidinalnoj ekonomiji [Économie libidinale, 1974], te Lukácsa, Gramscija, Adornoa (s ostalim pripadnicima Frankfurtske škole) i 
Marcusea, zbog različitih oblika otklona od ortodoksije, ali i popularnosti među studentskim aktivistima 1968. (Sim, 1998: 3-5)

Nesustavan izbor prethodnika, doduše, nešto je manji problem od slične situacije $s$ predstavnicima postmarksističke teorije koje Sim uključuje u svoj pregled. Iako se vrlo jasno ogradio od očekivanja da se radi o teorijskoj školi kojoj bi se mogao nabrojiti konačan ili barem približno zaokružen broj pripadnika, nešto jasnija slika ne bi bila na odmet. Naime, budući da nigdje jasno ne ocrtava kako zamišlja strukturu polja niti navodi popis tipičnih predstavnika koje u njega smješta, ostaje nam rekonstruirati ih implicitno iz spominjanja $u$ uvodnom tekstu te odabira odlomaka koje u zborniku okuplja. Osim već spomenutih Laclaua i Mouffe, Sim (1998: 1, 2, 6) se tako u uvodnom poglavlju referira još i na Lyotarda, Baudrillarda i Derridaa, dok ostatak knjige strukturira trodijelno: u prvom se dijelu bavi recepcijom Laclaua i Mouffe u marksističkim krugovima, u drugom proučava „poststrukturalističke i postmodernističke intervencije“ donoseći tekstove Lyotarda, Baumana, Baudrillarda, Soya, Walkera i Derridaa, dok u trećem prostor odvaja za „feminističke intervencije“ oprimjerene tekstovima Harmann, Coward, Ramazanoglu i Walby.

„Koalicija“, kako ju je Sim (1998: 2) oslovio, pokazuje se tim izborom doista nestabilna i tek vrlo labavo povezana, budući da se radi o skupu teoretičara koji dijelom pripadaju i različitim intelektualnim tradicijama i disciplinama, a tamo gdje to nije slučaj, te se mogu supostaviti u istoj tematskoj $\mathrm{i} / \mathrm{ili}$ disciplinarnoj ravni, disparatni su pojedinim općenitijim teorijskim postavkama, ali i odnosom prema marksističkom nasljeđu koje bi im trebalo biti primarna poveznica. Postmarksizam se u tom slučaju čini manje kao heuristički korisna klasifikacijska oznaka, a više kao označitelj generacijskog sentimenta, što Sim (isto: 7) na jednom mjestu donekle i priznaje svodeći poveznicu prema marksizmu tek na „niz nekako praznih gesta, čiji je sadržaj emocionalan prije nego teorijski.“ Riječ je o nedvojbeno legitimnom stavu, no teško uskladivom s njegovom uvodnom tvrdnjom o ,određenoj samosvojnoj poziciji“ (isto: 2).

Problem s oprečnim stavovima prema Marxu i marksističkom nasljeđu teoretičara koje uključuje u studiju Sim (1998: 5) nastoji riješiti uvodeći razliku između postmarksizma i postmarksizma kao dviju struja postmarksističke misli. No premda se može činiti da se time adekvatno hvata u sraz s problemom ambivalentnosti i polisemije prefiksa post-, taj pokušaj ima nekoliko spornih strana.

Idejni impuls za tu podjelu Simu je vjerojatno bila tvrdnja Laclaua i Mouffe (2014: xxiv) da ako je njihov, ,intelektualni projekt u ovoj knjizi postmarksistički, evidentno je i 
postmarksistički ${ }^{\text {‘4 }}$. No Simova derivacija te opreke odlazi u posve suprotnom pravcu. Naime, Laclau i Mouffe odmah u nastavku pojašnjavaju kako žele reći da su upravo „razvijajući određene intuicije i diskurzivne oblike konstituirane u marksističkim okvirima, te inhibirajući ili eliminirajući druge, oblikovali [svoj] koncept hegemonije..." (isto), nastojeći time otkloniti suviše pojednostavljena tumačenja prethodne oštre kritike marksističke ortodoksije i konstatacije da se nalaze na postmarksističkom terenu, koja bi to prevela u zaključak o potpunom raskidu s marksizmom. No u svojoj reinterpretaciji, Sim naglašenu dvoznačnost potiskuje u jedan član opreke, onaj postmarksistički, dok oznaku postmarksizma zadržava za teoretičare koji su nekoć bili uvjereni marksisti, no potom su s marksizmom otvoreno i definitivno raskinuli ${ }^{5}$.

Dva su osnovna problema s takvim postavljanjem stvari. Prije svega, opravdano je pitati se čemu uopće zasebno izdvajati teoretičare koje povezuje tek činjenica marksističke prošlosti, ukoliko su s njom navodno u potpunosti raskrstili. Čak i ako možemo govoriti o nekom obliku „tjeskobe“ i „nostalgije“ (Sim, 1998: 6) zbog napuštanja marksističkog ishodišta, radi se o potencijalno suviše heterogenoj skupini, čiji bi teorijski opusi mogli imati više poveznica s teoretičarima u čijim su se pravcima odmakli od njega nego što ih imaju međusobno, budući da je jedino što ih nominalno povezuje biografska činjenica negdašnje pripadnosti marksističkoj mislí.

Drugi je problem manje uočljiv, premda je dijelom i izvorište prvog. Radi se o tome da, čak i ako s tog određenja postmarksizma pređemo na određenje postmarksizma kao kretanja „motiviranog žudnjom da uvide novih teorijskih ostvaraja poput poststrukturalističkih, postmodernističkih i feminističkih uvede u marksizam“ (Sim, 1998: 6), ostaje problem da u oba slučaja Sim marksizam prešutno smatra neproblematičnim pojmom, homogenom kategorijom koja ima definiran sadržaj i jasne granice. No Laclau i Mouffe, kako je već i spomenuto, na više mjesta naglašavaju da svoj „postmarksistički projekt“ grade u bitnoj mjeri na osvjetljavanju često previđane činjenice da to nije tako ${ }^{7}$. Utoliko bi možda bilo

\footnotetext{
${ }^{4}$ Usp. pozivanje na tu tvrdnju pri istom razgraničenju u kasnijoj Simovoj (2000: 1) studiji.

${ }^{5}$ Usp. Sim, 1998: 6-7.

${ }^{6}$ Dakako, za očekivati je da poveznice nužno nadmašuju puku biografsku podudarnost, stoga tezi o potpunom raskidu valja pristupiti sa skepsom. Sim (1998: 6) joj pak pristupa proturječno - s jedne strane kao primjer citira Lyotardovo odbacivanje čak i toga da s marksizmom raspravlja u okvirima marksističkog jezika, ili pak Baudrillardov raskid naziva „dobrodošlim otpuštanjem“, dok s druge strane eksplicitno upozorava na nostalgičnu notu u njihovim tekstovima, ali implicitno i na prepoznatljiv spektar tema i angažiran pristup njihovoj obradi, koji se može smatrati marksističkim nasljeđem. Ipak, radi opstojnosti podjele to potom dijelom zanemaruje.

${ }^{7}$ Usp. primjerice njihovu reaktualizaciju husserlijanskih pojmova sedimentacije i reaktivacije, kojom žele „pokazati izvornu kontingenciju sinteze koju su marksističke kategorije pokušale postići“ te reaktivacijskim momentima učiniti činove njezinog utemeljenja ponovno vidljivima (Laclau, Mouffe; 2014: viii; usp. i Laclau, 2014: 3) i pokazati da je ,polje marksističke teorije uvijek bilo daleko više ambivalentno i raznoliko nego
} 
primjerenije govoriti niti o teorijskom kretanju koje raskida s marksizmom, niti o onome koje „uvozi“ poststrukturalističke tendencije u marksizam konceptualiziran kao koherentan zatvoren prostor, već o teorijskom kretanju koje reaktualizira neke (najčešće neortodoksne) aspekte heterogenog marksističkog nasljeđa u kontaktu $\mathrm{s}$ drugim suvremenim teorijskim kretanjima, ponajprije poststrukturalističke provenijencije. Takvoj konceptualizaciji korisna je metafora rijeke koju kao opis svog teorijskog projekta nude Laclau i Mouffe (2014: xxv) pišući da se „,nadilaženje velike intelektualne tradicije nikada ne događa kao iznenadni kolaps, već prije poput riječnog toka, koji potječe $s$ istog izvora i širi se u različitim smjerovima ispreplićući se s tokovima koji dotiču iz drugih izvora.“ (isto: xxv)

U nastojanju da dodatno nijansira sliku suvremene marksističke ostavštine, Sim uz prefiks post- upotrebljava i drugi notorno inflatorni prefiks neo-, pa tako tvrdi da „postmarksizam valja razlikovati od fenomena kao što je neomarksizam, koji bi predstavljao znatno manje kritičnu reviziju klasičnog marksizma što uzima u obzir promjene u globalnoj politici i međunarodnim odnosima od Drugog svjetskog rata" (Sim, 1998: 2). Premda referenti te definicije ostaju prilično nejasni, a Sim u svojoj sljedećoj studiji od nje odustaje, čini nam se korisnim zadržati na umu mogućnost da se na neki način (tim označiteljem, ili nekim sretnije sročenim) vodi računa o razlici između suvremenih teorijskih fenomena koji se ipak (uvjetno rečeno) (samo)smještaju u granice marksizma od onih koji se (jednako uvjetno) smatraju postmarksističkim ${ }^{8}$.

Konačno, što se književnoga tiče, iako je Sim primarno književni teoretičar te iako je niz autora na koje se u svojoj postmarksističkoj čitanci referira neizostavan u suvremenoj književnoj teoriji, otvaranje tog pitanja gotovo je u potpunosti izostalo: niti su se položaj i uloga književnog ili književnosti u postmarksističkoj teoriji eksplicitno problematizirali u uvodnom dijelu, niti se time bavio ijedan od okupljenih tekstova, unatoč Simovoj intenciji da

monolitni transvestit kojeg marksizam-lenjinizam predstavlja kao historiju marksizma (isto: viii-ix), odnosno najavu da će „dekonstrukcijom različitih diskurzivnih površina klasičnog marksizma“ (isto: xxiii) odbaciti ideju jedinstvenog validnog diskursa $\mathrm{i}$ jedinstvenog sistema kategorija.

${ }^{8}$ Oba prefiksa, i post- i neo-, dio su iste tendencije kalemljenja prefiksa na nazive na koju upozorava Derrida (2009, [1990]) pišući o „neologizmima, novizmima, postizmima, parazitizmima i drugim malim seizmima. Derrida (isto: 10) skreće pozornost na problematičnost takve prakse imenovanja napominjući da svaka vrsta $u$ zamišljenoj tablici teorijskih pretinaca „svoj vlastiti identitet uspostavlja uključivanjem drugih identiteta: kontaminacijom, parazitiranjem, kalemljenjem, inkorporacijom itd.“ Stoga napominje da govoreći o npr. marksizmu u književnoj teoriji u jednom određenom historijskom razdoblju „,ne možemo to prepoznati a da se istoga časa ne primijete tragovi onoga što je taj marksizam integrirao - a to su koncepti, teme, pitanja, riječi i fraze koje pripadaju onome čemu se taj marksistički diskurs danas na privilegiran način suprotstavlja, primjerice strukturalizmu, psihoanalizi, neostrukturalizmu ili poststrukturalizmu.“ Zato, kada se u ovom radu koristimo spornim prefiksima i uopće kada uspostavljamo kategorije, imamo na umu to Derridaovo opažanje i ne pridajemo im nikakvu drugu vrijednost od uvjetno razlikovne za provizorno grupiranje određenih teorijskih ostvaraja i sučeljavanje s drugim teorijskim ostvarajima po pragmatičnim, ontološki nepredodređenim kriterijima. 
njima pokrije raznolika disciplinarna područja. No nekoliko rubnih opažanja ipak ukazuje u tom pravcu. Prvo je od njih Simova (1999: 4) tvrdnja da je zapadni marksizam, oprimjeren Adornom, Horkheimerom, Marcuseom i Benjaminom, „općenito odlikovao veći interes za filozofsku i estetsku tematiku nego političku i ekonomsku“ te da se već za tu promjenu može reći „da je imala postmarksističke implikacije“. Na tragu toga kao indikativnu naglašava i razliku u estetskim preferencijama između estetski vrlo tradicionalnih ortodoksnih marksista, te frankfurtovaca sklonih eksperimentima u umjetnosti. Stoga npr. za Marcuseovo stajanje u obranu modernističkih eksperimenata u umjetnosti kaže „da je indiciralo potrebu da se izađe izvan tradicionalnog korpusa marksističke misli i, zaista, osporava neke od njegovih najsvetijih pretpostavki.“ (isto) Ironična je nuspojava tih opažanja to da Sim, uočavajući poveznice koje držimo karakterističnima za postmarksizam ne kod postmarksističkih teoretičara, nego kod teoretičara koje smatra marksistima, nesvjesno pokazuje da je razdvajanje tih kategorija, problematičnije nego se to isprva čini.

Dvije godine kasnije, u preglednoj studiji naslovljenoj Postmarksizam: Povijest ideje [Post-Marxism: An Intellectual History] (2000), Sim se izazovu opisa postmarksističke teorije vraća monografskom studijom. U uvodu ponovno tvrdi kako je riječ o „dobro utemeljenoj teorijskoj poziciji koja, kao u radovima velikih teoretičara poput Ernesta Laclaua i Chantal Mouffe, nastoji spasiti aspekte marksističke misli od kolapsa marksizma (...) te ih preorijentirati zadobivanju novog značenja u kulturnoj klimi koja se rapidno mijenja." (Sim, 2000: 1). No uočljiv pomak vidi se u eksplicitnom naglašavanju heterogenosti marksizma. Sim (isto: 5) podcrtava da se u suvremenom marksizmu možda posebno u novije vrijeme događa promjena stava prema pluralizmu ( $u$ smjeru afirmacije), no da se o pluralnosti marksističke misli de facto moglo govoriti oduvijek ${ }^{9}$. Dapače, zaključuje da „,u/spon postmarksizma naznačuje odlučnost da se ta skrivena historija pluralizma dovede na površinu, da se otkrije što leži iza fasade jedinstva. “ (isto)

S tim je donekle u svezi i činjenica da je osvrt na historijski kontekst oblikovanja postmarksizma nešto uže fokusiran nego u prethodnoj studiji. Uz postističku intelektualnu klimu, koja je obeshrabrila vjerovanja u monolitne totalizirajuće teorije, te neke uobičajeno navođene prijelomnice poput raspada Sovjetskog Saveza ili pada Berlinskog zida, Sim (2000: 4-5) naglasak stavlja i na odumiranje tradicionalno shvaćene i organizirane radničke klase

\footnotetext{
${ }^{9}$ Sim kod te tvrdnje, kao i kasnije, pozornost skreće na Ryanovu studiju Marksizam i dekonstrukcija [Marxism and Deconstruction], u kojoj kritizira pokušaje (poput onog Gouldnerova, prema kojem je Breckman (2013: 83) mnogo benevolentniji) da se razgraniči određen broj „vrsta“ marksizma (u konkretnom slučaju dvije), te navodi kako bismo s pravom mogli govoriti o „tri, četiri ili čak i više 'marksizama'.“ Usp. Ryan, 1984: 236. Riječ je o zanimljivoj anticipaciji Derridaove $(2002: 14,26)$ teze o Marxovoj mnoštvenosti, kojom ćemo se pozabaviti kasnije, i to upravo u knjizi koja (desetljeće ranije) istražuje veze marksizma i dekonstrukcije.
} 
uslijed izmijenjenih ekonomskih i političkih uvjeta, koje je pridonijelo drastičnoj promjeni političke teorije i prakse.

Struktura studije velikim dijelom prati onu Simove prethodne knjige, s tim da su odabrane reprezentativne tekstove zamijenila Simova čitanja. U središtu pozornosti i dalje se nalaze Laclau i Mouffe, čiji je rad „kristalizirao postmarksizam kao specifičnu, samosvojnu teorijsku poziciju“, zaključivši razvoj koji je bio ,gotovo nužan u svjetlu rasta poststrukturalizma, postmodernizma i feminizma drugog vala (uz određenu pomoć kretanja unutar same klasične marksističke tradicije).“ (Sim, 2000: 1) Prva poglavlja potom tematiziraju raznovrsne reakcije na objavu Hegemonije $i$ socijalističke strategije Laclaua $\mathrm{i}$ Mouffe, dok sljedeći segment studije nastavlja baveći se onim što naziva „postmarksizmom prije postmarksizma“. U njemu pak usmjerava pogled dalje u povijest marksističke misli te proširuje popis „,prethodnika“ iz prošle Simove knjige: uz Lukácsa, Gramscija, Adornoa i Marcusea analizirani su i Luxemburg, Bloch, Benjamin, Brecht, Althusser, Macherey, Castoriadis i dr. ${ }^{10}$ Širenje perspektive ne odnosi se, dakako, samo na broj teoretičara; svakom od njih posvećen je po segment poglavlja s fokusom na onim aspektima njihova opusa koji se iz zadane perspektive ističu kao značajni, a ujedno predstavljaju i „tendenciju otklona“ $u$ odnosu na sebi suvremen dominantan oblik marksizma ili pak „pokušaje da se marksizam ukrsti s drugom teorijom kako bi se oblikovao 'hibridni' marksizam“, što je ,pružilo ohrabrenje kasnijim generacijama za eksperimentiranje s marksizmom.“ (Sim, 2000: 70)

Analognu situaciju šarolikom izboru ,prethodnika“ donose i sljedeća poglavlja, u kojima Sim razmatra odnose nekolicine suvremenih poststrukturalističkih i feminističkih teoretičara i teoretičarki s marksizmom, pri čemu je jasno da se ti odnosi rasprostiru duž spektra od postmarksizma do postmarksizma, poslužimo li se tom Simovom (ne osobito sretnom) podjelom, no nije razvidno smatra li sve nabrojene autore pripadnima kategoriji koju opisuje i gdje eventualno povlači granicu. Pitanje je opravdano ako imamo na umu da, primjerice, u poglavlju posvećenom poststrukturalistima - koje nam je u kontekstu ovog istraživanja značajnije - ranije zastupljenima Lyotardu, Baudrillardu, Derridau i Baumanu dodaje još i Foucaulta te Deleuzea i Guattaria. Heterogenosti je svjestan i sam Sim prvospomenutu dvojicu opisuje kao one koji su se ,progresivno udaljavali što dalje od

\footnotetext{
${ }^{10}$ Popis „prethodnika“ i ovdje nam se čini heterogen i diskutabilan, bez obzira na detaljniju elaboraciju. Uz to, vrijedi unaprijed podcrtati i razilaženje oko takvih određenja između Sima i kasnijih studija. Primjerice, Althussera Goldstein (2005) uzima kao jednu od dvije izvorišne točke korpusa koji razmatra, dok se drugi, počevši od samih Laclaua i Mouffe, takvom pogledu protive, smještajući ga s druge strane te nejasne granice. Slično je i s Machereyem i Castoriadisom; prvog predstavnikom postmarksizma smatra također Goldstein (2005), dok je drugi istaknut u Breckmanovoj (2013) studiji. Bloch i Benjamin u tom su se kontekstu slabije obrađivali, a upravo nam se oni čine vrlo zanimljivim primjerom anticipatora postmarksističkih kretanja $\mathrm{s}$ obzirom na aspekte koji su ovom radu osobito interesantni, zbog čega ćemo im kasnije posvetiti više pozornosti.
} 
marksističke orijentacije, što je rezultiralo zlobnom antimarksističkom kritikom“ (Sim, 2000: 104), dok kod Foucaulta pak nastoji profilirati poveznice s Marxom, unatoč tome što napominje da se među prvima od francuskih intelektualaca od njega udaljio (isto), u projektu Deleuzea i Guattaria vrlo benevolentno priznaje marksističke crte (isto: 113), a Derridaove Sablasti Marxa smatra izrazom ,jasne predanosti Marxovu nasljeđu“, iako ih procjenjuje i kao „karakteristično ikonoklastične“ i „nepogrešivo postmarksističke“ (isto: 115)

Širenje koncentričnih krugova Sim dovodi do kraja poglavljem u kojem odraze i učinke intelektualne klime koja je stvorila uvjete za postmarksistička strujanja traži i u suvremenim prirodnim znanostima, promatrajući razlike između npr. dosega suvremene fizike i one devetnaestostoljetne, koja je nerijetko pružala konceptualne modele klasičnom marksizmu. Izlet je to $\mathrm{u}$ povlačenje paralela koje nisu neutemeljene i irelevantne, ali nesumnjivo i same djeluju suviše mehanički. No na dugačkom putu od Laclaua i Mouffe pa do modela beskonačnog svemira, iz perspektive ovog rada važno je podcrtati dvije uočljive slijepe pjege.

Prvu bi se sasvim pojednostavljeno moglo svesti na činjenicu da u obje Simove knjige o postmarksizmu nema ni jednog jedinog spomena Jacquesa Rancièrea. I premda se ta tvrdnja isprva čini sasvim nasumičnom, Rancière u njoj može stajati i metonimijski kao (najistaknutiji) predstavnik čitave skupine mlađih (francuskih) teoretičara čiji se rad svojim značajkama lako može dovesti u vezu s odrednicama koje Sim ističe značajnima za postmarksistička gibanja, ali i kao pojedinac za kojeg to ponajviše vrijedi. Stoga je ta praznina za Simovo istraživanje i neobična i nesretna. Neobična već samim time što Sim u fokus uzima velik broj (također francuskih) teoretičara s kojima Rancière ima izravne veze, uključujući i Althussera, njegovog „učitelja“, na čijoj je kritici postavio temelje vlastitih gledišta ${ }^{11}$, kao i druge autore s kojima je eksplicitno raspravljao, poput Deleuzea ili Lyotarda. Osim toga, opuse tih teoretičara Sim odmjerava o kapitalno djelo Laclaua i Mouffe, čijoj je političkoj teoriji Rancière mnogo bliži nego ijedan od navedenih autora, što ćemo kasnije jasno i pokazati.

To izostavljanje čini se pak nesretnim po Simovo nastojanje da ocrta što jasnije poveznice među teoretičarima koje obuhvaća pojmom postmarksizma utoliko što bi Rancièreovo povezivanje estetskog i političkog, koje je u svojim radovima započeo i mnogo

\footnotetext{
${ }^{11}$ Usp. Rancièreovu (2011) studiju Althusserova lekcija [La Leçon d'Althusser, 1975] u kojoj se započinje teorijski distancirati od Althussera (na čijem je projektu čitanja Kapitala prethodno surađivao) gotovo dekonstrukcijskom kritikom njegovih postavki, postavljajući time temelje svog budućeg opusa.
} 
prije nego su slične poveznice eksplicirali Laclau i Mouffe ${ }^{12}$, potencijalno usmjerilo Sima postavljanju pitanja i o toj problematici. Ovako je ona ostala gotovo posve nedotaknuta i u njegovoj drugoj studiji, oblikujući tako i drugu slijepu pjegu ${ }^{13}$.

Sličnu situaciju na djelu imamo i kod Goldsteina, kao drugog autora koji se nakon Sima prihvatio pothvata monografskog opisa postmarksističke teorije. Pet godina nakon Sima, u studiji Postmarksistička teorija. Uvod. [Post-Marxist Theory. An Introduction], Goldstein (2005) nudi općenitu definiciju korpusa razmjerno sličnu Simovoj, no već iz nacrta sadržaja knjige razvidne su bitne razlike u zamišljenoj arhitekturi polja. Ono što na samom početku upada u oči jest tvrdnja kako teorijski korpus o kojem govori on ,izvodi iz radova Louisa Althussera i Michela Foucaulta..." (Goldstein, 2005: 2) supostavljena činjenici da se u čitavom uvodnom poglavlju, kao i cijeloj knjizi, spomen prethodnih Simovih studija može pronaći samo u jednoj fusnoti. Bilo da je naglašavanje sebe kao onog koji izvodi postmarksističku teoriju iz određenog skupa radova prisvajanje Simovih inicijalnih zasluga na tom području, ili pak implicitna referenca na Sima s podcrtavanjem razlike u odnosu na njega, odluka da se makar u uvodu studije ne progovori o sličnim istraživačkim pokušajima djeluje neobično.

Ključna razlika u odnosu na Simov pristup u tome je što Goldstein ne polazi od jednog središnjeg primjera prema rubovima kategorije, već od dviju izvorišnih točaka - Althussera ${ }^{14} \mathrm{i}$ Foucaulta - prema onome što smatra odrazima njihovog teorijskog utjecaja u raznim (pod)disciplinama. Njihov „izvanredan utjecaj“, smatra Goldstein (2005: 2), „ostvario je svoje filozofske, ekonomske, historičke, feminističke, književne i kulturne inačice“, a predstavnici kojima to potkrepljuje su, uz izvorišnu dvojicu, Laclau i Mouffe, Butler, Macherey, Bennett, Frow, donekle Derrida i dr. Kao ni Sim, Goldstein ne smatra da postmarksizam „oblikuje pokret ili školu“; riječ je o teoretičarima koji se „okreću brojnim tradicijama i metodama“, no

\footnotetext{
${ }^{12}$ Laclau eksplicitno dovodi književnoteorijsku problematiku u središte svoje političke teorije u nekoliko tekstova objavljenih u njegovoj knjizi The Rhetorical Foundations of Society (2014), dok kod Mouffe možemo pronaći pojedinačne tvrdnje o vezi estetskog i političkog, poput one da ,iz perspektive teorije hegemonije umjetničke prakse igraju ulogu u konstituciji i održavanju danog simboličkog poretka, ili u njegovom osporavanju, te zbog toga nužno imaju političku dimenziju. Političko se, sa svoje strane, tiče uspostave simboličkog poretka društvenih odnosa, i u tome počiva njegova estetička dimenzija“ (Moufee, 2013: 91).

${ }^{13}$ Pišemo „gotovo nedotaknutoj“ jer se na marginama Simove studije ipak nazire svijest o važnsoti pitanja estetskog/književnog u kontekstu koji proučava, no bez detaljnije razrade. Prvenstveno se to odnosi na segment u kojem se bavi prethodnicima postmarksističke misli, dovodeći na tren značaj estetskog u središte pažnje u odnosu na Marcusea, Adornoa, Benjamina, Brechta i Machereya (usp. Sim, 2000: 87, 95), a potom pitajući se o prostoru koji je danas ostao dostupan marksizmu za neki oblik djelovanja (usp. isto: 170).

${ }^{14}$ Smještanje Althussera „,s ove strane“ granice postmarksističkog možda je ponajveća razlika ne samo u odnosu na Sima, nego i ostale teoretičare koji su se na bilo koji način bavili postmarksizmom, osim možda Miščevića (1979), o čemu će biti riječi kasnije u poglavlju. Proturječan tretman Althussera u različitim studijama postmarksističke teorije ima svoju paralelu i u njegovom ambivalentnom tretmanu u radovima autora kojima se te studije bave, o čemu će više biti u kasnijim poglavljima.
} 
pritom „ponavljaju i ponovno utvrđuju althusserijansku i/ili foucaultovsku teoriju“ (isto). Popis predstavnika, bez obzira na relativnu šarolikost, ipak djeluje nešto koherentnije nego Simov, naročito uzmemo li u obzir interne kriterije koje Goldstein uspostavlja. Umjesto Simova pokušaja razlikovanja postmarksizma i postmarksizma, podjela koju Goldstein (2005: 21) nastoji provesti jest između onih postmarksista koji ,zadržavaju normativnu snagu frojdovske, hegelovske ili kritičke teorije te time podupiru radikalno demokratske artikulacije, prijenose ili potencijalnu hegemoniju opozicijskih ili neovisnih pokreta“ i onih koji „,naglašavaju sociohistorijski kontekst modernih diskurzivnih praksi, a ne ideale teorijske kritike, te posljedično otvaraju te prakse političkoj kritici.“15

Problemom višeznačnosti prefiksa post- i mogućnosti da se marksizam oštro razgraniči od korpusa koji naziva postmarksističkim Goldstein se pak bavi i manje od Sima. U uvodnom poglavlju usputno napominje da pojam postmarksizma smatra sinonimom/derivatom ,poststrukturalističkog marksizma“ (Goldstein, 2005: 2), iz čega bi se moglo zaključiti kako drži da se dominantno radi o kontinuitetu u odnosu na marksizam. No budući da većinu teoretičara koje u studiji obrađuje ne smatra marksistima, baš naprotiv, te budući da marksizam u znatnoj mjeri tretira kao homogen korpus, čini se da težište postavlja ipak mnogo bliže polu diskontinuiteta.

Geneza postmarksističke teorije kod Goldsteina je tako stvar konvergencije specifičnih historijskih uvjeta (kolaps Sovjetskog Saveza, otkrića mračnih strana staljinizma, ali i rastuća raznolikost i nezavisnost znanstvenih disciplina i društvenih pokreta; usp. Goldstein, 2005: 20) te unutardisciplinarnog razvoja čiji početak personificira Althusser. Značajke koje dolaze u prvi plan logična su posljedica tako postavljenih okvira: uz očekivano odbacivanje ontološke privilegiranosti klase, teleološke vizije historije te totalizirajućeg univerzalizma klasičnog marksizma, tu su još i interes za tzv. nove društvene pokrete, antihumanizam te zaokret proučavanju diskurzivnog.

Potonje je i jedna od rijetkih poveznica Goldsteinova proučavanja postmarksizma s problematikom književnog/književnoteorijskog. Implicitno se, naime, može iščitati da je autorima zastupljenim u njegovoj studiji zajedničko i to što na razna načine pomiču težište svojih radova tekstu/diskursu/diskurzivnom oblikovanju stvarnosti/kulturi, no sustavnog osvrta na vezu između te činjenice i drugih segmenata njihovog opusa kod Goldsteina nema, niti se detaljnije istražuje značaj praksi i disciplina kojima su tekst, diskurs ili kultura objekti djelovanja. Mimo toga pitanje književnosti dolazi eksplicitno u fokus u dvama poglavljima u

\footnotetext{
${ }^{15}$ Usp. i Goldstein, 2005: 110. Dvije tendencije koje ocrtava ipak nam se ne čine međusobno isključive ili čak nužno suprotstavljene.
} 
čijem su središtu Macherey te Bennett i Frow, i u njima mu se pristupa mnogo detaljnije nego kod Sima. No kao i u Simovoj studiji, izostaje poopćavanje zaključaka koje bi iskoračilo s otoka pojedinačnih primjera prema ostatku korpusa, pa tematiziranje književnosti u tako postavljenim okvirima funkcionira više kao skretanje pozornosti na jedan od brojnih sekundarnih primjera, nego kao analiza stvari od središnje važnosti.

Nekim od nabrojenih pitanja koja kod Sima i Goldsteina ostaju nedovoljno problematizirana više pak pozornosti poklanja studija Tormeya i Townshend (2006) naslovljena Središnji mislioci od kritičke teorije do postmarksizma [Key Thinkers from Critical Theory to Post-Marxism]. I oni se u uvodu referiraju na postmarksizam kao „zloglasno neuhvatljiv“ (Tormey, Townshend; 2006: 1) pojam koji se ne može proučavati poput stabilne konvencionalne škole misli, no odmah nakon toga čine ono što je Goldstein propustio: osvrću se na dotadašnje (oprečne) pokušaje konceptualizacije postmarksizma (ipak, promiče im Goldstein) te ocrtavaju tendencije koje će se nastaviti i nakon njihove studije. S jedne strane ukazuju na tendenciju da se koncept postmarksističkog ograniči samo na suradnju Laclaua i Mouffe, izdvajajući kao primjer kritike na račun tog dvojca, dok s druge strane Simu prigovaraju odlazak u drugu krajnost, tj. da ga to „nije spriječilo da opiše postmarksizam kao potpuno razvijen intelektualni 'pokret' s korijenima u nastanku zapadnog marksizma nakon marksističke bifurkacije u razdoblju Ruske revolucije i kolapsa Druge internacionale." (isto: 1-2) ${ }^{16}$

Obje krajnosti, smatraju Tormey i Townshend (2006: 2), imaju svojih mana; prva u podtekstu ima, ,i suviše olaku pretpostavku da su oblik i priroda projekta povezanog s Laclauom i Mouffe nešto unikatno ili idiosinkrastično“ te da je teorijska „etiketa validna tek kada je samosvjesno upotrijebljena kao autodeskriptivna značka“ (isto) ${ }^{17}$, dok drugoj zamjeraju neopravdanu asimilaciju teoretičara koji su nedvojbeno dokaz heterogenosti marksizma, no čiji opus nije potaknut „,vizijom iscrpljenosti marksizma koliko (...) njegovom 'renesansom' ili cvjetanjem“, budući da su „nastojali razviti i elaborirati marksizam, a ne ga zamijeniti drugim sustavom ili teorijskom polazištem.“ (isto) U široj elaboraciji tih zamjerki Tormeya i Townshend u najmanju je ruku implicitno sadržano nekoliko važnih stvari. Prvo, odbacivanjem unikatnosti Laclaua i Mouffe upućuju na nužnost da se istražuju i teorijski fenomeni srodni njihovom radu, a ne samo razvojni lanac što vodi genezi njihove pozicije. No ista tvrdnja vrijedi i šire, za čitavo postmarksističko strujanje, koje ne valja gledati kao

\footnotetext{
${ }^{16}$ Kod Sima je, podsjećamo, po tom pitanju ipak prisutno proturječje, koje Tormeyu i Townshend promiče ili ga drukčije interpretiraju.

${ }^{17}$ Tormey i Townshend (2006: 1) zanimljivo primjećuju da je postmarksizam u pravilu oznaka koja se pridaje drugome; izuzevši Laclaua i Mouffe, nitko iz iste te generacije teoretičara nije tu odrednicu primijenio na sebe.
} 
iznenadan fenomen u svjetlu čistog diskontinuiteta. Osim toga, iz drugog se dijela zamjerke, $\mathrm{u}$ obrnutom pravcu, jasno podrazumijeva $\mathrm{i}$ to da uočavanje određenog kontinuiteta ne znači da su suvremeni postmarksistički fenomeni tek otkrivanje odavno prisutne tople vode, tj. sugerira da diferenciranje postmarksizma od ranijih neortodoksnih pojava u marksističkoj teoriji ima smisla $^{18}$.

Razdjelnicu između dviju pojava Tormey i Townshend (2006: 2) iz perspektive historijskog konteksta povlače pak prilično oštro, pišući: „Ako nije predramatično izreći to tako, 1968. predstavlja početak 'kraja' i za zapadni i za istočni marksizam." Praško proljeće, nakon kojeg je nestalo nade za antiautoritarna reformna kretanja u Sovjetskom Savezu, te pariška šezdesetosmaška zbivanja, koja su razotkrila rigidnost europskih komunističkih partija, fragmentirali su europsku lijevu scenu te pomjerili težišta progresivne borbe iz uobičajenih marksističkih čvorišta prema „ulicama“, „kamenu pločnika“, „,novim društvenim pokretima: bilo gdje, činilo se, osim prema Partiji.“ (isto: 3$)^{19}$

Postmarksistički odgovor na tu krizu - prije intelektualno gibanje, nego nešto što bi se moglo nazvati pokretom (Tormey, Townshend; 2006: 4) - odlikuje nekoliko temeljnih poveznica koje se u različitom obliku i mjeri manifestiraju kod različitih predstavnika, a mogu se svesti na odbacivanje marksističke teleološke vizije historije, odbacivanje klase kao privilegiranog revolucionarnog subjekta, odbacivanje krutog ekonomskog determinizma i marginaliziranje prostora agentivnosti, odbacivanje pozitivizma, avangardizma partije i intelektualaca te naglašavanje pluralističkog momenta demokracije (usp. Tormey, Townshend; 2006: 5-6). Različitim stupnjevima aktualizacije tih obilježja doskaču Wittgensteinovim modelom kategorije obiteljske sličnosti (isto: 4$)^{20}$, no smatraju da ih sve povezuje i uvjerenje kako „nema jednostavnog 'povratka' Marxu“ (isto: 5).

Osim tvrdnje o izrazitom otporu teoretičara prema prefiksu post- (Tormey, Townshend; 2006: 4), Tormey i Townshend dotiču se problema njegove višeznačnosti razlikujući u okvirima različite realizacije temeljnih značajki postmarksističke teorije ono što nazivaju „snažnim“ i ,slabim“ postmarksizmom (isto). No ta opreka nije radikalna kao kod

\footnotetext{
${ }^{18}$ Oprez Tormeya i Townshend glede istraživanja svojevrsnih anticipacija u ranijoj marksističkoj tradiciji možda je ipak pomalo pretjeran. Opravdano kritiziraju Sima zbog anakronističke formulacije o „postmarksizmu prije postmarksizma" $i$ djelomičnom zanemarivanju historijskog konteksta, no $s$ druge strane činjenicu da je pitanje ,potonulog blaga“ marksističke heterodoksije dugo zanemarivano navode i sami Laclau i Mouffe. Usp. Laclau, Mouffe; 2014: viii; Laclau, 2014: 3.

${ }^{19}$ Nešto kasnije Tormey i Townshend (2006: 6) popisu dodaju i važnost promjene intelektualne klime, tj. ponajviše razvoja poststrukturalizma.

${ }^{20}$ Usp. Wittgenstein, 1998. Referiranje na kategoriju obiteljske sličnosti implicitno pak podrazumijeva i kasnije eksplicirano uvjerenje kako se ne radi o konačnom i sveobuhvatnom opisu (Tormey, Townshend; 2006: 10), zbog čega je taj teorijski model doista pogodan odabir za konceptualizaciju postmarksističke teorije.
} 
Sima; bez obzira na nijanse, sve postmarksističke teoretičare odlikuje s jedne strane „Zadržavanje u orbiti marksističke problematike“, a s druge „odbacivanje marksizma kao temelja obnovljene kritike“, odnosno radi se o teoretičarima koji priznaju „da je 'marksistička' ortodoksija propala, no nasuprot nje zahtijevaju promišljanje Marxova djela i nasljeđa kao temelj za rekonstituciju kritike i politički odgovor na razvijeni kapitalizam.“" (isto) Drugim riječima, radi se o onome što se, smatraju, često previđa - da je ,potreba da se zbaci ili dođe s one strane Marxa ujedno i potreba da se ponovno čita Marxa, ponovno promisli Marxa i trajno na životu drži pitanje Marxove relevantnosti..." (isto: 11)

Teoretičari čije radove Tormey i Townshend u tim okvirima detaljnije analiziraju su Castoriadis, Deleuze i Guattari, Lyotard, Laclau i Mouffe, Heller, Habermas, Derrida i dr. Kao što je vidljivo, neka od imena ponavljaju se u odnosu na prethodno analizirane preglede, druga se tako izdvojena pojavljuju prvi put, a model polaska od prototipa (Sim) ili izvorišta (Goldstein) zamijenilo je tek djelomično kronološki uvjetovano nizanje ${ }^{21}$. Uz to, napominju i da bi nesumnjivo bilo moguće napraviti „alternativnu knjigu o postmarksizmu koja bi uključila autore kao što su Andre Gorz, Jean Baudrillard, Slavoj Žižek i Claude Lefort, niz zelenih postmarksizama (John Bellamy-Foster, James O'Conner) te heterodoksne kvazimarksizme (Frederic Jameson, David Harvey, Ellen Meiksins Wood)“ (Tormey, Townshend; 2006: 11) ${ }^{22}$, povezujući ih na sličan način kao i isprva odabrane autore. Pritom napominju kako je jedino važno ,da čitatelj počne uviđati poveznice među misliocima koje se do sada nije svrstavalo u isti teorijski ili politički prostor te nastavi (ako je potrebno) otkrivati druge takve teoretičare za sebe.“ (isto)

Problematika književnosti/estetike javlja se pak ponovno tek marginalno, ali na zanimljivom mjestu: kod dvoje teoretičara koji nisu „stalna postava“ ostalih studija o postmarksizmu. Tako Tormey i Townshend (2006: 65) „,središnjost estetskog u odnosu na jezik i 'riječ', te stoga središnjost umjetnosti za strategije otpora“ prepoznaju kao ,jedinstvenu nit koja prolazi čitavim Lyotardovim opusom“, uočavajući uz to i očuđujuću, deautomatizirajuću komponentu umjetnosti. Sličnu značajku izdvajaju i u poglavlju o Heller, u kojem pišu da je već u ranim radovima „,istražila potencijal različitih, kako ih naziva, objektivacija za sebe, tvrdeći da izlaganje umjetnosti, znanosti i filozofiji može oblikovati

\footnotetext{
${ }^{21}$ Premda nema sumnje da Laclau i Mouffe i kod Tormeya i Townshend uživaju poseban status, razlozi za to nigdje se ne ekspliciraju, pa i kod njih većim dijelom imamo posla s nizanjem disperziranim obilježjima povezanih imena.

${ }^{22}$ Kovanice poput „zelenog postmarksizma“ ili „heterodoksnog kvazimarksizma“ prilično su nesretan izbor. Ne samo da umnožavanje općenitih, gotovo praznih označitelja ne pridonosi analitičkoj razgovjetnosti, nego i odrednica kvazimarksizma sugerira da postoji nekakav stvarni, istinski marksizam od kojeg se Jamesonov teorijski rad razlikuje, pri čemu ga ta razlika diskvalificira iz marksističkog kruga. Obje implikacije u suprotnosti su pak s onim što Tormey i Townshend zastupaju.
} 
kritički intelekt, a time i put što zaobilazi zagušljivu zamku buržujske ideologije.“ (isto: 143) No teško shvatljiv nedostatak ostaje činjenica da ista pitanja nisu postavljena i u odnosu na druge autore zastupljene u studiji, budući da bi iznjedrila sasvim usporedive odgovore, a time i mnogo čvršće poveznice te jasniju strukturu polja.

Najveći otklon od ostalih studija predstavlja pak Therbornova knjiga From Marxism to Post-Marxism? (2008). Iako njezin nominalni cilj, da ne bude ,intelektualna historija ili historija ideja“ već „da postavi lijevu praksu i misao dvadeset i prvog stoljeća u teren prošlog stoljeća“ te „donese sustavnu panoramu lijeve misli na Sjeveru početkom ovog novog stoljeća i usporedi je s marksizmom prošlog razdoblja“ (Therborn, 2008: ix-x) ne zvuči bitno drukčije od okvira što su ih u svojim uvodima postavljale prethodne studije, perspektiva pothvata otkriva se drukčijom. Pokazuje se naime da Therbornova (2008: x) napomena kako „ne namjerava skrivati činjenicu da je ovo djelo napisao teoretičar koji nije napustio svoje ljevičarsko uvjerenje“ identificira autora kao bliskog klasičnim marksističkim pogledima. Stoga se težište i vrijednosni naglasci njegovog proučavanja, za razliku od ostalih studija, pomjeraju u tom pravcu: radi se prvenstveno o propitivanju aktualnog položaja marksizma te pitanju kreće li se on (nužno) prema postmarksizmu.

Veći je dio studije tako posvećen drastičnoj promjeni (socioekonomske, kulturne i geopolitičke prirode) koja je nastupila kretanjima unutar marksističke teorije u poslijeratnoj Europi i približavanjem rubu stoljeća, dok se bitno manji segment bavi teorijskim preobrazbama i ostavštinom marksizma u drugim teorijskim strujanjima. Epicentrima kompleksnijih i postupnih seizmičkih pomaka koji su na prijelomu stoljeća promijenili geopolitičku i socioekonomsku sliku svijeta Therborn (2008: ix) smatra zaokret Kine prema tržišnom gospodarstvu 1978. te slom Sovjetskog Saveza 1991., dok na kulturnom planu ključnu ulogu pridaje - osjetno negativno intoniranom - postmodernizmu (u „estetskom“ i „filozofskom smislu“; usp. Therborn, 2008: 29-30) ${ }^{23}$.

Kao istaknuti akteri marksizma u njegovom poslijeratnom ruhu, prije postmoderne krize, i kod Therborna se pojavljuju pripadnici Frankfurtske škole, i to u zanimljivo ambivalentnom statusu. $\mathrm{S}$ jedne im strane pridaje gotovo metonimijski status $u$ odnosu na

\footnotetext{
${ }^{23}$ Simptomatično je da - za razliku od ostalih - Therborn kao ključnu prijelomnicu ne izdvaja 1968., što vjerojatno ima veze s njegovim stavom prema postmodernističkim kretanjima. Njih pak optužuje da su se „hranila na demoralizaciji i nesigurnosti ljevice nakon kasnih 1960-ih i ranih 1970-ih“ dok su s druge strane pridavala oskudnu pozornost usporednom usponu desnog modernizma u obliku neoliberalizma ili asertivnog kapitalizma." (Therborn, 2008: 31) Usp. i tezu da je postmodernizam sve svoje pobjede izborio na račun marksističkog dijalektičkog tretmana modernizma, a da istovremeno nije ni okrznuo desnicu (isto: 125), odnosno da nas ,postmodernistički diskurs ima čemu važnom naučiti, no da bi ga za to trebalo podvrći simptomatskom, a ne doslovnom čitanju, kao propitivanje ne-dijalektičkih koncepcija modernizma, kao simptom dezorijentiranosti (bivše) ljevice te kao oblik kratkovidnosti prema svijetu onostranom Sjevernom Atlantiku.“ (isto: 127).
} 
čitav zapadni marksizam, dok s druge strane kritički gleda na njihovu hermetičnu filozofizaciju marksizma; s jedne strane napominje da je „marksizam dvadesetog stoljeća beskonačno bogatiji i širi nego je to sićušan zapadni intelektualni kružok koji je promovirao kritičku teoriju“, a s druge navodi da je „kritička teorija Marxov unuk koji je najeksplicitnije i najustrajnije izrazio neki aspekt historijske posebnosti marksizma - njegov osvrt na dijalektičnost moderniteta.“ (Therborn, 2008: 82) No budući da ih ne smatra anticipatorima kasnijih kretanja, propušta sličnu ambivalenciju preslikati i na derivate marksističke misli u dvadeset prvom stoljeću.

Poglavlje koje posvećuje marksizmu u dvadeset i prvom stoljeću obilježava pak ambivalencija na formalnoj razini - $\mathrm{u}$ drugom dijelu Therborn pokušava minucioznom preciznosti razgraničiti različita teorijska strujanja, ne zadovoljavajući se samo kategorijom postmarksizma $^{24}$, dok u prvom nabraja različite prisutne tendencije, ne razjašnjavajući pritom smatra li pojedine teoretičare koje im pridružuje marksistima ili ne. Tako navodi da lijevu misao u Europi u novom stoljeću karakterizira svojevrstan povratak teološkog, što oprimjeruje među ostalima Badiouom i Eagletonom (Therborn, 2008: 131), dok u Sjevernoj Americi nasuprot tomu prevladavaju tendencije poput Jamesonova utopizma (isto: 134), pri čemu oboje, čini se, smatra marksističkim.

To se pak više ne može reći kada pređe na tendenciju osporavanja pojma klase, okvir u kojem prvi put spominje Laclaua i Mouffe, i to nazivajući njihovu Hegemoniju i socijalističku strategiju ,intelektualno uvjerljivo najmoćnijim doprinosom postmarksističke političke teorije“, ali i ističući da je u njihovoj političkoj filozofiji „društvena pojavnost klase postala neprepoznatljiva nakon uranjanja $\mathrm{u}$ kiselinu čiste politike“ (Therborn, 2008: 141). Neposredno nakon njih Therborn pak spominje Balibara, no u njegovu slučaju ipak se radi o „nekada Althusserovu najboljem učeniku“ koji je „ostao bliži marksističkoj tradiciji“ (isto: 142). Balibar se u kontekstu Althusserovih „bivših učenika“ spominje i u okvirima tendencije odmaka od koncepta države, u sklopu koje se u jednoj fusnoti, prvi put u nekoj studiji o postmarksističkoj teoriji, spominje i Rancière (usp. isto: 147$)^{25}$.

\footnotetext{
${ }^{24}$ Iako je svjestan problematičnosti diskretnog razgraničenja različitih kategorija (Therborn, 2008: 165), Therborn ih pokušava razdvojiti nijansiranije nego ijedan drugi autor, pa tako čak izrađuje i graf na kojem $u$ odnosu na apscisu socijalizam-kapitalizam te ordinatu marksizam-nemarksistička lijeva misao raspoređuje sljedeće pozicije: izdržljivi marksizam, neomarksizam, postmarksizam, marksologiju i znanstveni marksizam, postsocijalizam te nemarksističku ljevicu. Tako detaljna podjela ipak teško je opstojna i stoga operativno razmjerno nekorisna, premda neki njezini elementi u pojedinačnim slučajevima nisu posve za odbaciti.

${ }^{25}$ Rancièreov spomen samo je rubna referenca bez ikakve elaboracije, te bi ga jedva imalo smisla posebno izdvajati da se ne radi o prvom dovođenju u vezu s postmarksističkim strujanjima, i to zajedno s autorima koje su prethodne studije analizirale (Althusser i Balibar).
} 
Sam pojam postmarksizma, prisutan u naslovu studije, definira se tek desetak stranica prije njezinog kraja, i to kao pojam koji se „koristi u otvorenom smislu, a referira se na autore s eksplicitno marksističkom pozadinom, čiji su recentni radovi izašli iz okvira marksističke problematike i koji javno ne obznanjuju svoju marksističku privrženost.“ (Therborn, 2008: 165) Ta pozicija, smatra, „nije istovjetna bivšem marksizmu, niti uključuje denuncijaciju i odmetništvo; razvoj i nove želje, da, možda čak i razvod, no u prijateljskim uvjetima“ (isto).

Konačno, osvijestimo li si da Therborn svoju studiju objavljuje čitavo desetljeće nakon inicijalne Simove knjige o postmarksizmu, činjenica da u njoj nema nijednog spomena prethodnih pokušaja definicije i analize postmarksističke teorije čini se još neobičnijom nego je to slučaj kod Goldsteina. Stoga čak i neka od općenitijih pitanja koja su u prethodnim studijama barem donekle načeta ovdje ostaju posve nedodirnuta, a Therbornova specifična perspektiva - s težištem na marksizmu i geopolitičkim pitanjima - ne ostavlja prostor propitivanju položaja književnog u korpusu koji je analizirao. Rezultat se njegove studije stoga ne može olako nazvati podbačajem, sjetimo li se njezinih proklamiranih ciljeva, no učinak glede definicije postmarksizma jest skroman: Therborn pridonosi ocrtavanjem šireg konteksta te pojedinačnim opažanjima, no daleko je od sustavnijeg opisa kakav su nastojali ponuditi prethodni autori.

U odnosu na pokušaje tih autora neobična je i studija Paula Bowmana (2007) Postmarksizam protiv kulturalnih studija [Post-Marxism Versus Cultural Studies], koja do krajnosti dovodi pridavanje središnje uloge Laclauu i Mouffe. Naime, kao što i naslov sugerira, osnovna je Bowmanova preokupacija sučeljavanje postmarksističke teorije i kulturalnih studija, motivirana njihovim uzajamnim utjecajem i brojnim dodirnim točkama marksističkim supstratom iz kojeg su se razvili, oslanjanjem na dosege dekonstrukcije pri kritici tradicionalnog marksizma, ali i činjenici da su se profilirali ističući svoju političku i etičku odgovornost i angažiranost (Bowman, 2007: xii). No premda tako postavljena tema nije sporna, problematičnim djeluje što Bowman označitelje dvaju heterogenih korpusa reducira na njihove pojedinačne predstavnike. Kada govori o kulturalnim studijima, u vidu ima opus Stuarta Halla i njemu bliske teoretičare, dok postmarksističku teoriju još izraženije svodi samo na Laclaua (i Mouffe). Ipak, unatoč dvojbenoj opravdanosti takve redukcije, neki od uvida izrazito su korisni i za općenitije problematiziranje postmarksističke teorije.

Prije svega, iz činjenice da postmarksizam određuje kao teorijsku poziciju što proizlazi iz „dekonstrukcije marksizma, dekonstrukcije usmjerene rekonstrukciji i revitalizaciji marksizma kako bi se afirmirao novostvoreni marksizam i kako bi ga se oživjelo kao relevantnu i aktivnu silnicu unutar današnjeg 'postmodernog' ili doista 'dekonstruktivnog' 
svijeta“, odnosno kao „dekonstruiranu i dekonstruktivnu verziju marksizma“ kojoj su Laclau i Mouffe pridonijeli svojim „utjecajnim postmarksističkim radom“ (Bowman, 2007: xvi) ${ }^{26}$, razvidno je da Bowman postmarksističku teoriju smatra širim teorijskom korpusom. No unutar tog korpusa ne povlači nikakve podjele i ne izdvaja popis reprezentativnih predstavnika, niti pak eksplicitno analizira semantiku prefiksa post-, iako je njegove višeznačnosti svjestan. To se implicitno nazire u spomenutoj definiciji, a jasnije je artikulirano kada, referirajući se na Laclaua i Mouffe, navodi da termin „postmarksizam“ ukazuje na to ,da telos marksizma ostaje na svom mjestu, kao ideja vodilja, no 'post-' označava nakon, više od, drugo od marksizma“, kao i „napuštanje aksioma koje nazivaju esencijalističkim.“ (Bowman, 2007: 12) Razmjerno uska orijentacija isključuje i historijsku problematiku pa stoga izostaje i segment posvećen kontekstu oblikovanja postmarksističke teorije ${ }^{27}$, a pozornost ne zadobiva ni heterogenost marksizma, kao pozadine u odnosu na koju se određuju oba sučeljena fenomena.

U naslovnom sučeljavanju bolje pak prolaze kulturalni studiji; čitav Bowmanov pothvat, prije nego li usporedbom dvaju teorijskih fenomena, mogao bi se točnije opisati u prvom dijelu valorizacijom utjecaja koji je postmarksizam ostavio na (Hallovim) kulturalnim studijima $^{28}$, dok je drugi dio svojevrsna kritika postmarksizma (Laclaua i Mouffe) iz perspektive koju pripisuje kulturalnim studijima ${ }^{29}$. Koliko je tako postavljeno sučeljavanje opravdano, naročito s obzirom na razmjerno homogenu reprezentaciju kulturalnih studija te njihovo istovremeno izuzimanje od kritike pri pretvaranju u referentnu točku kritike Laclaua i Mouffe, pitanje je u koje ovdje nećemo ulaziti. No ostavljajući tu raspravu po strani, nekoliko je nusprodukata sučeljavanja važno našem istraživanju.

\footnotetext{
${ }^{26}$ Kasniji opis projekta Laclaua i Mouffe također može funkcionirati kao Bowmanova definicija postmarksizma u cijelosti: „Njihov remont marksističke teorije sačinjava pokušaj da 'spase' marksistički projekt - ili njegov objekt, socijalizam - od zastarijevanja, a da pritom ne napuste njegov telos, nadu za egalitarnu radikalnu demokratsku emancipaciju od svake eksploatacije i podčinjavanja, bilo onog koje se odnosi na kapitalističku proizvodnju ili nekog drugog. (...) Oni napuštaju ideju neizbježnog procesa odmatanja historijske 'nužnosti' u korist naglašavanja kontingencije društvenopolitičke organizacije i vjere u potrebu za političkom borbom za emancipaciju." (Bowman, 2007: 12)

${ }^{27}$ Bowman (2007: 2) tek kratko navodi da je zajedničko i kulturalnim studijima i postmarksizmu da su u svom nastanku bili reakcija na marksistički ekonomski redukcionizam, kao i Althusserov strukturalizam. Odmah potom ukazuje na ambivalenciju postmarksističke pozicije, rekonstruirajući njezinu vezu s marksističkom misli preko Althussera i Gramscia.

${ }^{28}$ Usp. primjerice Hallovo priznanje konstitutivnog utjecaja diskurzivne konceptualizacije društvenog kod Laclaua i Mouffe na njegovu teoriju te izjavu da se on sam stoga smatra postmarksistom i poststrukturalistom (Bowman, 2007: 24).

${ }^{29}$ Kritika se uglavnom svodi na dvije povezane stavke: da Laclau i Mouffe, primjenjujući dekonstruktivnu logiku u odnosu na političke fenomene i teoretičare koje analiziraju, propuštaju istu primijeniti i na svoj diskurs, pretvarajući ga u povlaštenu točku izmaknutu igri razlike (usp. npr. Bowman, 2007: 109), te da uvelike zanemaruju determinaciju čimbenika koje promatraju (materijalno shvaćenim) institucionalnim kontekstom (usp. npr. isto: 184, 195). Bowmanova kritika svakako nije bezrazložna, ali nije ni bez mana, budući da povremeno razmjerno plošno i pojednostavljeno shvaća Laclauove teze.
} 
Za početak, Bowman nas podsjeća na potrebu da se elaborira razgraničenje između postmarksizma te kulturalnih studija (odnosno kulturalnog materijalizma), budući da je, uz iznimku jednog Goldsteinova (2005) poglavlja, jedini koji otvara to pitanje. I dok Goldstein (2005) posredstvom Bennetta, Frowa i Millera jedan segment kulturalnih studija prikazuje gotovo odvojkom postmarksističke teorije, iz Bowmanova je izlaganja jasno da bi pogrešno bilo poopćiti takav odnos subordinacije, no isto tako i da razdvajanje dvaju polja nije jednostavno kako se isprva čini. Premda se tim pitanjem u ovom radu nećemo uspjeti detaljno pozabaviti, provizorno bismo razliku mogli tražiti u kombinaciji dviju komponenti: različitih intelektualnih tradicija u pozadini te različitim razmjerima privilegiranja diskurzivnog, odnosno izvandiskurzivnog; razlici koja je u temelju jedne od Bowmanovih osnovnih kritika Laclaua.

Nadalje, iako Bowman ne navodi koga (osim Laclaua i Mouffe) smatra predstavnicima postmarksističke teorije, i na tom polju donosi stanovit doprinos, budući da daleko više od ostalih pozornost obraća na ulogu Derridaova opusa. Naime, Bowmanova kritika Laclaua i Mouffe oslonjena je velikim dijelom na zasade dekonstrukcije, čiju odsutnu važnost za oblikovanje postmarksističke teorije opetovano naglašava. Pritom podcrtava da je upravo dekonstrukcijsko čitanje marksističkih klasika i političkih fenomena temelj teorije Laclaua i Mouffe, dok je ona istovremeno promijenila uvriježenu percepciju dekonstrukcije u

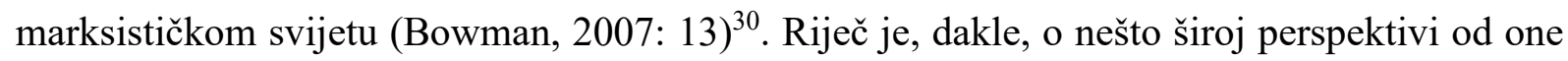
koja se uvriježila u ostalim studijama, koje vezu između Derridaa i postmarksizma reduciraju na Derridaove Sablasti Marxa (2002).

Drugi je važan pomak Bowmanova studija ostvarila dovevši (makar šturo) u svezu Laclauovu i Rancièreovu koncepciju politike. Naime, baveći se pojedinim segmentima Laclauove teorije, Bowman ih na dva mjesta - govoreći o momentu politike kao onome što izvire iz prepoznavanju nekog stanja kao „,nepravednog“ ili ,pogrešnog“ (Bowman, 2007: 23), te o politici kao onoj koja „nastupa samo pomoću i kao interupcija“ (isto: 92) - izravno povezuje s analognim tvrdnjama u Rancièreovoj Nesuglasnosti (2015). Iako se to povezivanje svodi na svega dvije bilješke u uz parafraze Laclauovih tekstova, riječ je o prvoj studiji postmarksističke teorije koja je uočila izravne podudarnosti između te dvojice teoretičara.

\footnotetext{
${ }^{30}$ Dekonstrukcija je za Bowmana (2007: 52) ključno mjesto usporedbe postmarksizma i kulturalnih studija kao ono što ih istovremeno povezuje (jer je u njihovim temeljima) i razdvaja (jer se drukčije maniifestira). Vrijedi spomenuti i njegovu parafrazu Derridaove teze da dekonstrukcija, „kao (strateški) beskonačan zahtjev za pravdom, predstavlja samo drugo ime za radikalno demokratski element postmarksističkog projekta“, uz čega dodaje i da je „,nedvojbeno vrlo bliska često prizivanoj otvorenosti drugosti kulturalnih studija.“ (isto: 40)
} 
Konačno važan je pomak i Bowmanovo (2007: 25) zapažanje da se „postmarksistička politička teorija razvila oslanjanjem na književnu teoriju i dekonstrukcijske tehnike analize teksta“, a da unatoč tomu u istraživanjima dug Laclaua i Mouffe ,teoriji teksta kako su je razvili Barthes, Derrida, Kristeva, Sollers i drugi zadobiva malo pozornosti.“ Prvi je to put da se srž Laclauove političke teorije u postmarksističkom kontekstu eksplicitno povezuje sa suvremenom književnom teorijom i njezinim shvaćanjima teksta. No iako Bowmanova tvrdnja ne ostaje tek na usputnoj opasci, već otvara raspravu o koristima i ograničenjima tekstualnog modela ${ }^{31}$, zbog uskog fokusa studije implikacije te poveznice za čitavu kategoriju ostale su nedodirnute.

Pitanju koje je izostalo kod Bowmana u nešto se drukčijem izdanju približava Breckman (2013). U njegovoj studiji Avanture simboličkog. Postmarksizam i radikalna demokracija [Adventures of the Symbolic. Post-Marxism and Radical Democracy], ujedno i posljednjoj do danas objavljenoj studiji o postmarksističkoj teoriji, u središtu doduše nije tekstualni model, već problematika simbola i reprezentacije. Za razliku od Bowmana, Breckman se vraća široj perspektivi na postmarksističku teoriju, premda napominje kako je primoran taj pojam koristiti „pomalo labavo“, odnosno da „postmarksizam u knjizi funkcionira raznoliko; kao oznaka razdoblja, samoopis, biografska činjenica te oznaka - bilo implicitnog ili eksplicitnog - kontinuiteta načina na koji se pitanja postavljaju ili čak procjenjuju kao značajna.“ (Breckman, 2013: 8) Zbog toga se pridružuje uobičajenoj ogradi da mu ,cilj nije dati iscrpan prikaz niti polja recentne francuske političke misli, niti postmarksizma.“ (isto)

Zanimljiva novost glede kontekstualizacije postmarksističke misli činjenica je da je Breckmanova studija prva koja je objavljena nakon početka ekonomske krize 2008. te stoga, uz uobičajene uvodne tvrdnje o padu značaja marksizma u široj javnosti, donosi osvrt i na svojevrsno oživljavanje njegove relevantnosti u svjetlu globalne krize. Kontekst nastanka postmarksističke teorije Breckman pak uobičajeno povezuje s kretanjima koja su dovela do konačnog sloma Istočnog bloka 80-ih i 90-ih godina, te usporednim urušavanjem marksizma kao intelektualnog sustava. Pritom ističe da se „kolaps marksizma kao dominantne paradigme progresivnih intelektualaca nigdje nije osjetio tako snažno kao u Francuskoj“, gdje je njegov izrazit prestiž trajao u kontinuitetu od Drugog svjetskog rata pa do 1968., „kada se počeo rastakati““ (Breckman, 2013: 4).

\footnotetext{
31 Bowman (2007: 28) upućuje na Mowittovo razlikovanje između tekstualne i diskurzivne paradigme, povezujući kritiku Laclaua i Mouffe zbog (navodnog) izostanka bavljenja institucionalnim kontekstom $\mathrm{s}$ tekstualnom paradigmom, nasuprot diskurzivne za koju bi bilo karakteristično obrnuto.
} 
Dramatičnosti rastakanja francuskog marksizma, smatra Breckman (2013: 5), pridodala je činjenica da se događalo usporedno s onim što naziva „širim fenomenom radikalnog skepticizma“ za koji smatra nezadovoljavajućim nazive „francuska teorija, poststrukturalizam, dekonstrukcija, postmodernizam“; fenomenom za koji je nemoguće reći je li bio uzrok ili posljedica onoga što se događalo marksizmu (isto: 6) ${ }^{32}$. Njegovo djelovanje na marksističkom je teorijskom aparatu ostavilo sljedeće učinke:

Epistemološki realizam, koji je dugo dominirao marksističkom misli, urušio se, budući da je radikalni konstruktivizam rastopio „stvarni“ referent „klase“ i „društva“ u fluidu jezika; vjerovanje u smislenu strukturu historije i modernističku metapripovijest emancipacije ustupilo je mjesto akutnoj svijesti o historijskoj kontingenciji; totalizirajuća misao popustila je pred fragmentacijom; jedinstvo pred heterogenošću; identitet pred razlikom; dijalektički razvoj pred nedeterminiranim raskidima; Hegel i Marx izgubili su tlo u korist Nietzschea i Heideggera; sama ideja emancipacije djelovala je ugroženo kritikom subjekta i ,humanizma““ koji je navodno dominirao Zapadom od samog iskona modernog doba. (Breckman, 2013: 6)

U takvom teorijskom kontekstu, Breckman postmarksističkim pojmom povezuje nekolicinu teoretičara - prije svega Castoriadisa, Leforta i Laclaua i Mouffe te donekle Gaucheta i Žižeka - za koje smatra da su zadržali kontinuitet u odnosu na marksizam pri izboru pitanja koje postavljaju i načinu na koji raspoređuju prioritete, no istovremeno su se, „namjesto Marxovu ontološkom i epistemološkom realizmu“, okrenuli „sferi reprezentacije; nasuprot Marxovu uvjerenju da simboličko pripada nadgradnji, svi oni pristaju uz osnovnu ideju da je društveni svijet konstituiran kao simbolički poredak.“ (Breckman, 2013: 10) Drugim riječima, „simbolička konstrukcija sociopolitičkog svijeta“ (isto: 11) bila je tim autorima privlačan izlaz iz marksističkog redukcionizma, no s druge je strane donijela izazov izbjegavanja drugog oblika stroge determinacije koja bi dokinula svaki oblik političke djelotvornosti, determinacije (uvijek već pretpostojećim) simboličkim poretkom umjesto ekonomskom bazom ${ }^{33}$.

\footnotetext{
${ }^{32}$ Kao primjer Breckman (2013: 5) navodi utjecaj Derridaa, Lacana, Lyotarda, Deleuzea, Nancya, LacoueLabarthea i Kristeve. Nešto kasnije Breckman (2013: 10) ocrtava i „putanju“ geneze postmarksističkog pristajanja uz simboličkog predstavljajući je kao putanju „komplicirane genealogije“ koja se proteže „od poststrukturalističkih teoretičara poput Jacquesa Derridaa, Julije Kristeve i Jeana Baudrillarda nazad preko strukturalističkih mislilaca kao što su Roland Barthes, Louis Althusser, Jacques Lacan i Claude Lévi-Strauss do međuratnih pojava poput Georgea Bataillea, Michela Leirisa, College de sociologie i nadrealista, do Marcela Maussa, Émilea Durkheima i Ferdinanda de Saussurea. Nadalje, Breckman (2013: 8) spominje i Rancièrea, i to zajedno s Badiouom i Balibarom, ali ih eksplicitno izdvaja kao primjere još nekih, alternativnih inovativnih načina promišljanja političkog, mimo linije koju je označio kao postmarksističku.

Sveukupno se može reći da je Breckmanov uvid u genealogiju postmarksističke teorije nesumnjivo najtemeljitiji, no kriteriji demarkacije stupnja uključenosti i funkcija pojedinih točaka u toj mreži nisu posve jasni ni sustavni.

${ }^{33} \mathrm{Bijeg}$ iz jedne krute determiniranosti u drugu, koji Breckman ovdje spominje, pojavio se kao tema rasprave između Butler, Laclaua i Žižeka iz koje je proizašla knjiga Kontingencija, hegemonija, univerzalnost (usp. Butler, Laclau, Žižek; 2007 [2000]. U toj je raspravi, referirajući se na Lacanov utjecaj na Laclauovu teoriju, upravo Butler izrazila zabrinutost koju ovdje dijeli i Breckman (usp. npr. isto: 19), dok je Laclaovo mišljenje kako ta zabrinutost proizlazi iz pogrešne interpretacije njegovog oslanjanja na Lacana (usp. isto: 68).
} 
Zbog toga pripovijest o različitim pojedinačnim nastojanjima postmarksista da balansiraju između marksističkih, strukturalističkih i poststrukturalističkih krajnosti Breckman (2013: 13) smatra odgovarajućim nazvati - parafrazirajući Merleau-Pontya „avanturama simboličkog“, kao protuteži dijalektičkog iz Merleau-Pontyeva naslova. „Avanture“ koje spominje prati u mnogo širem vremenskom periodu od onog u kojem su djelovali suvremeni autori; još od mladohegelovaca, preko romantičarskog socijalizma i marksizma pa do različitih faza u razdoblju koje smatra postmarksističkim.

Takva perspektiva po mnogočemu je bliska našem pitanju o položaju i ulozi književnog u postmarksističkoj teoriji, no Breckman svoje pitanje o simboličkom u konačnici ne upravlja u tom smjeru te gotovo u potpunosti ignorira književni/književnoteorijski input ${ }^{34}$ u (političkoteorijskoj) ,avanturi simboličkog“ koju opisuje. To pak nije propust samo u odnosu na potpuniju genealošku rekonstrukciju teorijskih pozicija kojima se bavi, već i u odnosu na njihovo temeljitije razumijevanje i povezivanje $\mathrm{s}$ drugim srodnim kretanjima $\mathrm{u}$ suvremenoj teoriji. Nadalje, kao slabiju stranu Breckmanove studije iz perspektive opisa postmarksističke teorije u globalu - ne u odnosu na ciljeve koje si vrlo jasno zadaje i ispunjava - mogli bismo istaknuti i razmjerno usku perspektivu na „avanturu simboličkog“ $\mathrm{i}$ njezine dodirne točke s marksizmom; teoretičari koje analizira doista čine jednu genealoški čvrsto povezanu i sasvim smislenu nit, no u njihovom teorijskom susjedstvu postoje i drugi koje bi se dalo povezati usporedivim pripovijestima.

Specifična perspektiva istraživanja zaslužna je - slično kao kod Bowmana - i za neotvaranje nekih drugih pitanja uobičajenih u ranijim studijama o postmarksističkoj teoriji ili pak njihovo presijecanje iz drugog kuta. Tako Breckman ne posvećuje zasebno pozornost marksističkoj heterodoksiji niti u njoj traži neku varijaciju Simova ,postmarksizma prije postmarksizma $^{\text {‘35 }}$, a samim se time ne zaokuplja mnogo ni problematičnošću prefiksa post-. No istovremeno na putu koji ocrtava od romantista i mladohegelovaca pa do suvremenog postmarksizma u razmatranje o ulozi simboličkog uzima i nekolicinu marksista, dapače i samog Marxa, sugerirajući pritom da je već on postavio temelje obratu simboličkom (usp.

\footnotetext{
Istovremeno, vezano za Breckmanovo dovođenje Žižeka u isti kontekst, Laclau u toj raspravi tvrdi i da Žižek u konačnici ipak ostaje pri determinaciji ekonomijom u krajnjoj instanci (usp. isto: 205).

${ }^{34}$ Iznimka je dio studije koji se bavi romantičarskim konceptualizacijama simboličkog, u koji Breckman uključuje i onodobne estetičke rasprave, te činjenica da kao utjecaje na oblikovanje postmarksističke teorije spominje nekoliko francuskih intelektualaca koji su po primarnoj vokaciji književni teoretičari (npr. Barthesa i Greimasa) ili su neizostavna imena u književnoj teoriji.

${ }^{35}$ Breckman ipak spominje Simov „postmarksizam prije postmarksizma“, i to referirajući se na to poglavlje Simove (2000) studije kao potkrepu tvrdnji da se pripovijest o krizi marksizma može protegnuti i preko čitavog dvadesetog stoljeća.
} 
Breckman, 2013: 82) ${ }^{36}$. Sve u svemu, petnaest godina nakon objave prve knjige o postmarksističkoj teoriji, Breckmanova studija možda i najkoherentnije analizira područje koje odabire kao predmet istraživanja te se pritom sustavnim praćenjem ,avanture simboličkog“ najviše približava temeljnom istraživačkom pitanju ovoga rada. S druge pak strane, ta je koherentnost plaćena cijenom ostavljanja nekih relevantnih pitanja po strani, ili barem njihovim pomjeranjem $\mathrm{u}$ domenu implicitnog, pa se - bez obzira na razmjernu zaokruženost - teško oteti dojmu da pojedini dijelovi slike i dalje nedostaju.

\subsection{Doprinos srodnih odrednica - treba li nam pojam postmarksizma?}

Uz studije koje eksplicitno upotrebljavaju označitelj postmarksizma kao klasifikacijsku oznaku određenog teorijskog korpusa, postoje i one koje na razne načine zahvaćaju (dijelom) podudarne korpuse, no koristeći se drugim pojmovima. Studija koje se uklapaju u taj opis razmjerno je mnogo i međusobno su primjetno heterogenije nego je to slučaj s pregledima postmarksističke teorije, stoga u ovom radu ne namjeravamo ponuditi njihov iscrpan pregled. Naprotiv, izdvojit ćemo tek nekoliko primjera koji se razlikuju nazivima koje upotrebljavaju, pristupom i imenima koje objedinjuju i analiziraju, pitajući se u kakvom odnosu njihovi pristupi stoje prema studijama koje smo prethodno analizirali, odnosno može li se reći da i sami ukazuju na potrebu za pojmom postmarksizma ili pridonose njegovom razumijevanju.

Kao prvi takav primjer poslužit će nam Beilharzova (1994) studija objavljena četiri godine prije inicijalne Simove knjige, naslovljena Postmoderni socijalizam: Romantizam, grad i država [Postmodern Socialism: Romanticism, City and State]. Kako se iz naslova da naslutiti, Beilharzova knjiga ne nastoji ponuditi pregled nekog konkretnog teorijskog korpusa poput postmarksističke teorije, već (marksistički) pojam socijalizma odmjerava o pojmove modernizma, postmodernizma, prosvjetiteljstva i romantizma, dovodeći ih u odnose i međusobno, te posvećujući na kraju prostor promišljanjima grada u svakom od tih okvira. No pri sučeljavanju socijalizma i postmodernizma, kao i u nekim drugim segmentima, teško je izbjeći problematiku blisku postmarksističkoj.

Tako Beilharz (1994: 1) već na samom početku upućuje na krizu marksizma koja se dogodila 70-ih i 80-ih godina dvadesetog stoljeća; istu onu koju i studije o postmarksizmu

\footnotetext{
${ }^{36}$ Marx dakako nije jedini za kojeg Breckman to tvrdi. Od imena koja su se u sličnom kontekstu spominjala i ranije tu su npr. i Lukács, Gramsci, Bloch, Benjamin, Adorno, Horkheimer, Marcuse te Sartre. Usp. Breckman, 2013: 83.
} 
prepoznaju kao pozadinu njezine geneze. Pritom kao osobito važno navodi iskustvo Althusserova marksizma, koji je ,prokrijumčario različite strane agense u suviše dogmatsku domenu kontinentalnog marksizma““ (isto: 2), ukazujući na podudaranje uvoza Freudove psihoanalize i strukturalizma u marksizam s razdobljem uspona dekonstrukcije i različitih poststrukturalističkih kretanja. Dapače, Beilharz (isto) navodi da „različiti intelektualci počinju govoriti o 'postmarksizmu'“, no da „kao i većina drugih stvari u postmodernom životu, nije jasno što bi to trebalo značiti.“

No unatoč ironijsko-rezerviranom stavu, $\mathrm{u}$ nastavku ipak pokazuje da je o tom fenomenu promišljao više nego je prethodno želio pokazati, pišući kako je „konjunkcija 'post' s 'marksizmom' otvorena dvojakoj interpretaciji“: onoj zagledanoj prema marksističkoj tradiciji, i onoj koja se usmjerava naprijed na tek dolazeće. Iako se radi o ambivalenciji prefiksa post- što je koriste i uočavaju još i Laclau i Mouffe, Beilharz se pri svom osvrtu na na njih ne referira, premda mu je Laclau poznat, što pokazuje spominjući ga kasnije u kontekstu promjena u konceptualizaciji društva (usp. Beilharz, 1994: 16) ${ }^{37}$.

Nadalje, pišući pretkraj studije o tome da aktualni problemi traže ,postmoderni socijalizam“, Beilharz (1994: 105) navodi i kakav bi on trebao biti: „diferenciran, skeptičan, pragmatičan, te onaj koji poput Benjamina nastoji uvijek govoriti o kulturi i moći zajedno.“ Spomenemo li i da tu orijentaciju kulturi prethodno adresira govoreći o kritičkoj teoriji, kao onoj koja je „Marxa izvukla iz labirinta političke ekonomije i uvela u domenu kulture“ (isto: 15), te nudeći primjer imena kao što su Adorno, Benjamin, Heller, Castoriadis, Foucault, Bataille, Habermas ili Marcuse - obrisi polja postaju još poznatiji. Konačno, kada Beilharz (isto: 114) na samom kraju studije tvrdi da nam „u modernitetu hermeneutika omogućuje da imamo Marxa, Webera ili koga drugoga koliko god ih [interpretacijski] konstruiramo“ te potom predlaže sliku Marxa koju sam želi afirmirati, udvaja čuvenu godinu dana stariju Derridaovu tezu o mnoštvenosti Marxova duha.

Razvidno je stoga da Beilharz - ne baveći se nominalno istim pitanjem kao proučavatelji postmarksističke teorije te postavljajući se skeptično prema pojmu postmarksizma - daje usporedive primjedbe o teorijskom polju koje nam je u središtu interesa te i sam uočava pitanja koja će se u kasnijim istraživanjima opetovano ponavljati. Njegovo istraživanje stoga implicitno govori u prilog potrebi za pojmom postmarksističke teorije, ma

\footnotetext{
${ }^{37}$ Laclaua Beilharz (1994: 16) problematično uparuje s Margaret Thatcher, tvrdeći da su njihove teze o nepostojanju društva analogne. No radi se o neopravdanoj banalizaciji Laclauova stava da društvo ne postoji kao objektivni totalitet, već kao dinamični diskurzivni prostor društvenog; stava koji ne dijeli tlo s thatcherovskoreganovskim otpisom društva, što mu je Laclauova politička teorija dijametralno suprotstavljena.
} 
koliko ga on izbjegavao, kao načinom da se nadiđu nekonzistentne i nepreciznije pojmovne akrobacije koje upotrebljava.

Situacija je drukčija s Marchartovom (2007) studijom Postfundacijska politička misao [Post-Foundational Political Thought] koja kao referentnu točku korpusa što ga proučava više nema Marxa, nego Heideggera ${ }^{38}$ te je stoga potreba dovođenja koncepata $u$ odnos na prvi pogled manje uočljiva. No uzmemo li $\mathrm{u}$ obzir da se na Marchartov koncept postfundacionalizma izravno referira Laclau (2014: 119), te da se kod Marcharta među predstavnicima postfundacijske političke misli može pronaći ne samo njega, nego i druge teoretičare koji su se prethodno spominjali u kontekstu postmarksizma (Leforta, Badioua, Nancya, Rancièrea, Castoriadisa itd.), nužnost kao i korist od uspostavljanja odnosa postaju vidljivije.

Pojmom postfundacijske političke misli Marchart obuhvaća one suvremene teoretičare u čijim djelima - nasuprot tradicionalnoj marksističkoj redukciji politike na stvar društvene nadgradnje ili njezinom usporedivom zatvaranju $\mathrm{u}$ distinktivnu autonomnu domenu društvenog u suvremenim političkim znanostima - dolazi do povratka političkog, a time i svojevrsne realizacije ontičko-ontološke razlike u toj domeni između političkog i politike. Nadalje, za postfundacijske teoretičare nije karakteristično samo podcrtavanje neke od inačica te razlike, nego i odsutnosti apsolutnog/konačnog temelja političkog. Kako Marchart (2007: 2) pojašnjava, to „ontološko slabljenje temelja ne vodi pretpostavci o potpunoj odsutnosti temelja, već pretpostavci o nemogućnosti konačnog temelja, koja je nešto posve drukčije, budući da implicira povećanu svijest $\mathrm{s}$ jedne strane o kontingenciji, a $\mathrm{s}$ druge strane $\mathrm{o}$ političkom kao trenutku parcijalnog i uvijek, u konačnoj instanci, neuspješnog utemeljenja.“39

Marchartova kategorija postfundacionalizma zbog drukčijeg rakursa stoga nije korpus koji bismo na istoj ravni uspoređivali s postmarksističkom teorijom, no potencijalno je korisna njezinom istraživanju postavi li se s njom u odnos shematičnog i specifičnog. Drugim riječima, svi teoretičari koje se može nazvati postfundacijskima istovremeno nisu nužno i postmarksisti, no značajno je pitanje vrijedi li obrnuto: jesu li svi postmarksistički teoretičari nužno i postfundacijski. U nastavku rada oslonit ćemo se na tu pretpostavku i preuzeti Marchartov pojam kao važnu alatku u analizi, no vrijedi napomenuti da prethodne studije nisu unisone po tom pitanju (npr. Goldstein (2005) uključuje Althussera kao zagovornika

\footnotetext{
${ }^{38}$ Točnije, Marchartova je fokalna točka uspostava varijacije ontičko-ontološke razlike između politike i političkog te konstitutivna odsutnost konačnog temelja, što nije nužno povezano s Heideggerom, ali se kod većine teoretičara kojima posvećuje zasebna poglavlja Heidegger javlja kao značajan utjecaj te Marchart (2007: 2) napominje da ih se često okuplja nazivnikom heideggerijanizma ljevice/lijevim heideggerijanizmom.

${ }^{39}$ Drugim riječima, radi se o „dekonstrukciji fundacionalizma“, a ne o „njegovoj jednostavnoj inverziji“. (Marchart, 2007: 13)
} 
determinacije u krajnjoj instanci, Sim (1998, 2000) pak Baudrillarda kao antifundacionalista). ${ }^{40}$

Iz te perspektive korisna nam je i Marchartova demarkacija između pojmova postfundacionalizma i antifundacionalizma. Potonji podrazumijeva tek puku negaciju fundacionalizma ,anything goes“ paradigmom, te tako i sam postaje neka vrsta fundacionalizma (usp. Marchart, 2007: 12-13), dok kod prvog proturječnost i kompleksnost prefiksa post- ukazuju na dekonstrukcijski tretman temelja ${ }^{41}$. Pritom je Marchart svjestan toga da postizmi ne podrazumijevaju oštar lom s nekom prethodnom paradigmom, već naglašava postfundacijsku borbu ,protiv (ili unutar) fundacionalističke paradigme kao i njezino polagano, ali sigurno izrastanje u novu samostalnu paradigmu, novi horizont razumijevanja, što bi se u historijskim terminima moglo opisati rovovskim ratom u kojem je postfundacijska paradigma tek stupnjevito zadobivala prednost.“ (isto: 32) Riječ je o procesu koji se u odnosu na problematiku postmarksizma može opisati i na marksističkom terenu.

Nadalje, Marchart čini i velik korak naprijed po pitanju povezivanja Rancièrea $s$ korpusom koji nas u ovom radu zanima. Iako ni on Rancièreu ne posvećuje posebno poglavlje, na više mjesta digresijama nemalog opsega povezuje pojedine aspekte njegove političke teorije s autorima što ih analizira, a na koncu ga studije eksplicitno navodi kao jednog od onih koje ubraja u analizirani korpus, no ne obrađuje detaljnije zbog prostornih ograničenja (usp. Marchart, 2007: 155). Time se nesumnjivo najbliže od svih autora koje smo do sada spomenuli približio tome da ga detaljnije usporedi s Laclauom.

Konačno, za naše istraživačko pitanje najvažnije je poglavlje u kojem Marchart analizira Laclauovu političku teoriju, implicitno je prikazujući kao najbližu idealnom modelu postfundacijske teorije, te potom prelazi na završne zaključke. Marchart (2007: 146) Laclauu pripisuje otkriće važnih posljedica postfundacijske konceptualizacije politike, za koje mu se „čini da ih Laclau sam oklijeva izvesti.“ Radi se o činjenici da iz Laclauove teorije proizlazi kako se između teorije diskursa, političke ontologije i opće ontologije mogu povući znakovi

\footnotetext{
${ }^{40}$ I nijanse unutar postfundacijske kategorije što ih Marchart apostrofira potencijalno su korisne istraživanju postmarksizma. Primjerice za Badioua navodi da zauzima ,,antagonističku poziciju u odnosu na većinu drugih društvenih postfundacionalista“ (Marchart, 2007: 111), parafrazirajući i Hallwarda koji u njemu vidi u francuskim okvirima najsnažniju alternativu različitim oblicima poststrukturalizma koji su preuzeli primat nakon kolapsa marksističkog projekta. Te primjedbe i kasnija elaboracija razlika mogu se uzeti kao argument u prilog ostavljanju Badioua postrani u proučavanju postmarksističke teorije, odnosno tome da ga se poveže s pojmom neomarksizma.

${ }^{41}$ Govoreći o prefiksu post- kao znaku našeg doba, Marchart (2007: 26) u nizu primjera spominje i postmarksizam, iz čega je razvidno da je upoznat s tim označiteljem, no ne pridaje mu pozornost. Otvoreno je pak nesklon terminu poststrukturalizma, smatrajući da „reducira genealogiju lijevog heideggerijanizma na znanstvenu paradigmu strukturalizma.“ (isto: 2 )
} 
jednakosti, tj. da se „teorija 'političkog označavanja'“ pokazuje kao „'politička teorija' označavanja“, koja istovremeno postaje prima philosophia ${ }^{42}$.

No ako Laclau u ranijim radovima možda doista i oklijeva eksplicirati takav zaključak, u sljedećem ćemo poglavlju pokazati kako postupno sve više naglašava, a u svojoj posljednjoj knjizi iznijet će ga i sasvim otvoreno, stavljajući povrh te jednadžbe i literarnost, kao koncept koji objedinjuje i upućuje na postfundacijska svojstva svih njezinih dijelova. Marchartov opisu ne zahvaća doduše taj zadnji korak od kojeg ovdje polazimo, no izuzme li se to njegova studija dolazi posve blizu temeljnim preokupacijama ovog rada i nudi vrlo važnu pomoć pri odgovaranju na pitanja koja on postavlja.

Jednako tako od velike koristi za ovo je istraživanje i studija Marx preko poststrukturalizma [Marx Through Post-Structuralism] Simona Choata (2010), u kojoj se autor bavi recepcijom Marxa $\mathrm{u}$ francuskom poststrukturalizmu, i to naročito u opusima autora najavljenih u podnaslovu studije: Lyotarda, Derridaa, Foucaulta i Deleuzea, omeđujući ih refleksijom u prvom i posljednjem poglavlju na ambivalentan odnos poststrukturalizma i Althusserova marksizma. Iako tako opisan sadržaj zvuči gotovo identično većini prethodnih studija o postmarksističkoj teoriji, Choat svoje istraživanje ne podvodi pod postmarksistički označitelj, i to ne jer s njim nije upoznat, nego jer ga drukčije shvaća.

Naime, Choat (2010: 5) eksplicitno napominje da su autore kojima se u svojoj studiji bavi „neki komentatori povezali s takozvanim 'postmarksizmom'“, pritom izravno upućujući na dvije Simove studije. No u neslaganju sa Simom za njega nije sporna postmarksistička kategorija, već njezine granice. Povezujući postmarksizam prvenstveno s Laclauom i Mouffe, tvrdi da ,radovi poststrukturalista zasigurno nalikuju radovima Ernesta Laclaua i Chantal Mouffe te njihovom pokušaju da se pomaknu na 'postmarksistički teren'“, no unatoč svim sličnostima koje izdvaja u konačnici smatra da je „Laclaua i Mouffe bolje gledati kao nastavljače nego kao suvremenike Derridaa i drugih“, odnosno da su postmarksisti ,proizveli radove uvelike pod utjecajem poststrukturalizma, ali drukčije od njega.“ (isto: 5-6)

U poglavljima koja slijede ovaj će rad problematizirati Choatove tvrdnje, no bez obzira na to njegova analiza odnosa autora kojima se bavio spram marksističkog naslijeđa poslužit će nam kao dragocjena pomoć, budući da je na pitanje o tom odnosu ponudio temeljitiji odgovor nego ijedna od studija o postmarksizmu. Nedostatak koji pak s njima dijeli ujedno je možda i doprinio spornome stavu o demarkaciji postmarksističkog korpusa. Choat naime teoretičarima koji su objekt njegovog proučavanja također pristupa razmjerno

\footnotetext{
${ }^{42}$ Usp. i Marchart, 2007: 149.
} 
idiosinkratično. Premda činjenica da ih smatra predstavnicima iste (poststrukturalističke) kategorije podrazumijeva stanovit broj zajedničkih točaka, Choat te poveznice ne eksplicira niti se njima (mimo marginalnih usporedbi) bavi, već autore okuplja pretežno pojedinačnim usporedbama s Marxom kao gravitacijskom točkom. Drugim riječima, bavi se tek prvim od triju temeljnih pitanja koja će se postavljati u ovom radu, a izostanak drugih dvaju potiskuje u pozadinu analogije koje se mogu uspostaviti među autorima što ih analizira, ili pak zbog postmarksizma isključuje iz analize.

Za razliku od Choatove studije, posljednja od studija koje ćemo ovdje spomenuti, Keucheyanova (2013) Lijeva hemisfera [The Left Hemisphere. Mapping Critical Theory Today] znatno će nam manje koristiti u ovom radu, a obrnutoproporcionalno se upušta u mnogo širi i ambiciozniji pothvat. U svojoj namjeri da ponudi pregledan portret kritičke teorije današnjice, Keucheyan pod današnjicom podrazumijeva prije svega razdoblje nakon pada Berlinskog zida, ali već i nakon onoga što smatra događajem „poraza“ 70-ih godina dvadesetog stoljeća ${ }^{43}$. Pojmom kritičke teorije u širem smislu obuhvaća pak gotovo čitavu lijevu misao, stavljajući naglasak u analizi na političku teoriju, no ne ograničavajući se samo na $\mathrm{nju}^{44}$.

U tako postavljenim okvirima Keucheyan pojam postmarksizma ne koristi kao označitelj neke zasebne kategorije, već govoreći o suvremenoj kritičkoj teoriji navodi da je ona u cijelosti „na neki način postmarksistička“, budući da je „marksizam bio tako dominantan u dvadesetom stoljeću da nijedna teorija nije izbjegla njegov utjecaj“, dok je s druge strane i sam „uvijek bio pluralan“, zbog čega je ,pitanje tko je danas marksist izrazito kompleksno“" (isto: 61). Kao drugu silnicu presudnu za oblikovanje suvremene kritičke teorije prepoznaje strukturalizam, uključujući i njegov postšezdesetosmaški poststrukturalistički nastavak (isto: $25,43-47$ ), a s prethodnim studijama povezuje ga i sumnjičavost prema oštrim epistemološkim lomovima (isto: 2,33 ).

Tipologija koju Keucheyan (2013: 51) predlaže razlikuje sljedeće varijacije nove kritičke teorije: konvertite, pesimiste, pružatelje otpora, inovatore, vođe i eksperte. Pritom te kategorije nisu striktno odijeljene, već se dijelom definicijama preklapaju, a i pojedini autori različitim segmentima opusa mogu pripadati različitim kategorijama, već ovisno o kutu gledišta. Postmarksistički autori u toj klasifikaciji ponajviše gravitiraju kategoriji „inovatora“,

\footnotetext{
${ }^{43}$ Keucheyan (2013: 1) piše: „Nove su kritičke teorije nove utoliko što se pojavljuju nakon pada Berlinskog zida 1989. Iako se većina njih razvila prije tog događaja, u javnoj su sferi osvanule uoči njega.“ Istovremeno pak, kada iznosi svoju tipologiju manifestacija te teorije, referentna su točka čak i više historijske promjene 70-ih nego one 90-ih godina dvadesetog stoljeća. Usp. isto: 12, 51.

${ }^{44}$ Keucheyan (2013: 2) objašnjava da pojmom teorije želi naglasiti da se ne radi samo o analizi i interpretaciji, nego i prosudbi poželjnog, dok pojmom kritičkog označava dovođenje u pitanje postojećeg društvenog poretka.
} 
koju Keucheyan dijeli na teorijske inovacije nastale hibridizacijom ranije marksističke teorije ili pak otkrivanjem novih objekata analize, no jednako tako može ih se naći i među „konvertitima“, pri čemu je konzistentnost kriterija razvrstavanja vrlo upitna.

Komparativna prednost zahvaćanja šireg teorijskog konteksta Keucheyanovoj je pak studiji ujedno i najveća mana: suvremenu lijevu teorijsku misao nastoji zahvatiti disciplinarno iznimno široko, što kao dobru posljedicu ima povezivanje teoretičara koji pripadaju različitim disciplinama, a usporedivo su pozicionirani u odnosu na referentnu prijelomnicu tipologije, no s druge strane znači i redukciju specifičnosti svakog od analiziranih teoretičara.

Drugi dio Keucheyanove studije, dajući prostor pregledu temeljnih značajki nekoliko odabranih reprezentativnih teoretičara donekle kompenzira tu redukciju, no ni sam ne ide u minucioznije analize. Za naše istraživanje osobito je zanimljivo poglavlje posvećeno Rancièreu, za kojeg navodi da mu je „opus usredotočen uglavnom na tri područja: političku teoriju, filozofiju obrazovanja i estetiku“, no da istovremeno „,narušava te kategorije i ne ostavlja nijedno područje nedodirnutim“ (isto: 170). Uz to, Keucheyan je ujedno i prvi od teoretičara što smo ih analizirali koji naglašava Rancièreov raskid s Althusserom kao početni korak oblikovanja njegove kasnije teorije, a dolazi i korak bliže našoj središnjoj pretpostavci tvrdeći da pitanje estetskog kod Rancièrea uživa primat, budući da je u podlozi bilo kojeg društvenog reda (isto: 173). No istovremeno u poglavlju o Laclauu u potpunosti ostaje pri razmjerno klasičnoj političkoteorijskoj perspektivi, zbog čega poveznica Rancièrea i Laclaua ponovno ostaje neadresirana.

Konačno, u kontekstu ovog poglavlja ostaje potrebno skrenuti pozornost i na domaću teorijsku produkciju i njezina (malobrojna) zasijecanja postmarksističkog polja. Za razliku od studija koje se eksplicitno bave određenjem postmarksističke teorije, a koje u ovdašnjem teorijskom polju do danas ne postoje, neizravno ocrtavanje tog korpusa može se uočiti na (najmanje) dva primjera vrijedna da ih spomenemo. Prvi je od njih natuknica posvećena marksističkoj kritici u Bitijevu Pojmovniku suvremene književne i kulturne teorije (2000: 297302), u kojoj Biti daje pregled heterogenog korpusa marksističkog promišljanja književnosti, dijeleći ga glavninom na dvije osnovne tendencije - humanističku i znanstvenu. Potonjom, čijim začetnikom smatra Gramscija, obuhvaća teoretičare koji su od 30-ih godina dvadesetog stoljeća naovamo oponirali lukácsevskim pogledima, obuhvaćajući imena poput Brechta, Blocha, Benjamina, Althussera, Machereya i drugih.

Nastavno na njih, o stanju marksističke kritike danas piše:

Stanovite tečevine strukturalnog marksizma, međutim, čuvaju svoju snagu. Subjekt biva deložiran s mjesta nositelja povijesnog procesa čime potonji gubi svoju teleologičnost 
razgrađujući se u stjecaj raznovremenih nizova; kulturalni se proizvodi motre kao poprišta antagonističnih praksi označavanja, kao diskurzni i žanrovski hibridi, kao indeksi raznosmjernih determinacija. Sve to otvara marksističku kritiku prema udruživanju $\mathrm{s}$ feminističkim, dekonstrukcijskim, postkolonijalnim, novohistorističkim pozicijama, s idejama filozofa i sociologa kao što su Bahtin, Lyotard, Baudrillard, de Certeau, Bourdieu ili Foucault, što istodobno stvara bojazan od gubljenja identiteta i reakcije u obliku integrativnih projekata kao što je npr. Eagletonova 'politička kritika' (1983), Jamesonova 'metapovijest' (1981) ili Habermasova revitalizacija moderne (1985). Ali od trenutka kada se stajalište totaliteta prestalo ekskluzivno vezivati uz klasu, da bi se moglo pridržati i za spol, rasu, etničku, civilizacijsku i kulturalnu pripadnost, marksistička je kritika nepovratno otvorila brešu eklekticizmu sa svim dobrim i lošim stranama koje on sobom donosi. (Biti, 2000: 302)

Premda Biti ne ulazi u detaljniju raščlambu tog prostora eklekticizma, on se u velikoj mjeri podudara s onim što možemo naći u uvodnim poglavljima studija o postmarksizmu. Pa iako bi bilo pretjerano tvrditi da se stoga u zadnjem dijelu njegove natuknice radi o određenju postmarksizma, u usporedbi s prevladavajućim izostankom ikakvog spomena tog teorijskog korpusa drugdje - Biti dolazi prilično blizu.

Nekoliko koraka bliže dolazi pak razmjerno zapostavljena Miščevićeva studija Marksizam i post-strukturalistička kretanja (1975), tim intrigantnija uzmemo li u obzir da je objavljena čitavo desetljeće prije seminalne studije Laclaua i Mouffe. Ta činjenica ujedno je i uzrok (ili jedan od uzroka $)^{45}$ da se pojam postmarksizma u njoj ne spominje, premda se radi o djelu najbližem pregledima postmarksističke teorije od svih objavljenih na ovom području. Nasuprot prevladavajućem nepoklanjanju osobite pozornosti hibridizaciji marksističke teorije u domaćoj marksističkoj literaturi ${ }^{46}$, Miščevićeva studija usredotočena je na pokušaj da se ocrta prostor prožimanja marksizma i poststrukturalizma u tada aktualnoj francuskoj teoriji, i to na primjerima Althussera, Foucaulta i Deleuzea, čije opuse detaljnije analizira.

Za razliku od Bitija, koji na promjene što su se marksističkoj teoriji dogodile od Althussera pa nadalje implicitno gleda kao na postupnu razgradnju marksističke matrice, za Miščevića su dvije odrednice u naslovu njegove studije u znatno manjem raskoraku. Iz prvih dvaju poglavlja, posvećenih Althusseru, može se iščitati da pristaje uz Althusserovu tezu kako je njegovo novo čitanje Marxa ujedno i ono „pravo“ (u najmanju ruku uvjerljivije od tradicionalnih), dok $\mathrm{s}$ druge strane $\mathrm{u}$ istom teoretičaru vidi $\mathrm{i}$ zglobnicu između

\footnotetext{
${ }^{45}$ Valja uzeti u obzir da je Miščevićeva studija rezultat jednogodišnjeg studijskog boravka u Francuskoj u sklopu stipendije Republičkog savjeta za naučni rad SR Hrvatske, kao i opći historijski kontekst u kojem je nastala. Pojam postmarksizma, čak i da je drugdje već cirkulirao, teško bi bilo očekivati u diskurzivnom okruženju u kojem je objavljena.

${ }^{46}$ Za ilustraciju može poslužiti zbornik Marx nakon sto godina (Kalanj, 1983) objavljen povodom stogodišnjice Marxove smrti - osam godina nakon Miščevićeve studije i svega dvije godine prije prijelomne studije Laclaua i Mouffe - koji je okupio tekstove domaćih i stranih marksističkih autora s temom snimanja stanja marksističke teorije u tom trenutku. Iako se u uvodniku govori o krizi marksizma, tek jedan od tekstova spominje Laclaua, a naznake prepoznavanja oblikovanja teorijskog polja koje se danas naziva postmarksističkim posve su odsutne.
} 
strukturalističkih i poststrukturalističkih gibanja. Dapače, premda je Miščević daleko od simplificirane derivacije ili subordinacije poststrukturalizma u odnosu na marksizam ${ }^{47}$, iz njegovog se izlaganja da zaključiti kako baš marksistički input u strukturalističke teorije smatra konstitutivnim rezom kojim se oblikovao poststrukturalizam.

Taj se susret, prema Miščćeviću (1975: 192), „,zbio na dvije razine, strogo različite i povezane, na razini politike i na razini teorije.“ Prva se odnosi na političku radikalizaciju koja je podijelila francusku sveučilišnu scenu, dok je potonja njezin rezultat - teorijsko okretanje Marxu i/ili marksizmu bliskoj tematici u potrazi za odgovorima na pitanja koja su se uslijed politizacije artikulirala.

Konačno, u nizu vrlo naprednih zapažanja koja anticipiraju ključna mjesta kasnijih studija o postmarksizmu, a i poststrukturalizmu uopće, za ovo je istraživanje važna Miščevićeva tvrdnja da poststrukturalizam „karakteriziraju sveze filozofije s književnošću i politikom toliko jake da se često brišu granice.“ (isto: 10) Nažalost, to zapažanje ostaje najvećim dijelom tek primjedba na način na koji teoretičari u pitanju organiziraju svoj diskurs, budući da se ne pita o uskoj svezi tog brisanja granica i sadržaja što ih izlažu. To bi ga pitanje, da je postavljeno, dovelo sustavnijem povezivanju teoretičara koje analizira, ali i nekim primjetnim razlikama među njima; razlikama koje bi se, u terminima kasnijih studija, mogle ilustrativno rasporediti na različitim pozicijama na (problematičnom) kontinuumu od marksizma do postmarksizma. No bez obzira na to, uzimajući u obzir demarkaciju polja i istraživačka pitanja koja postavlja, Miščevićeva bi se knjiga bez većih ograda mogla staviti uz bok studijama postmarksizma, dok bi s druge strane postmarksistički nazivnik u nekom drugom historijskom kontekstu nesumnjivo vrlo praktično obuhvatio ono što je njome nastojao analizirati. Na pitanja koja su kod njega izostala nastojat će pak odgovoriti poglavlja koja slijede.

\footnotetext{
${ }^{47}$ Tako Miščević (1975: 192) uspoređuje tko je od teoretičara koje smatra poststrukturalistima imao kakav odnos prema marksizmu, pokazujući široku varijabilnost odgovora na to pitanje, ali napominje i da to valja razdvojiti od utjecaja koji je marksizam imao na formaciju poststrukturalizma. Taj utjecaj pak - vidljivo je još iz uvodnog poglavlja - ne poistovjećuje s čvršćom pripadnosti određenom teorijskom korpusu, budući da smatra kako postoje poststrukturalisti za koje odnos s marksizmom nije naročito relevantan faktor.
} 


\section{Literarnost politike i politika književnosti na postmarksističkom}

\section{terenu}

\subsection{Od genealogije hegemonije do političke tropologije: Ernesto Laclau iz druge perspektive}

Argentinsko-britanski politički teoretičar Ernesto Laclau osoba je vjerojatno najzaslužnija za (frekventniju) pojavu postmarksističkog označitelja u diskurzivnom prostoru suvremene teorije. Ironično, među autorima koje se tim označiteljem uobičajeno okuplja, on je ujedno i jedan od slabije poznatih i manje utjecajnih. Laclauov se rad naime ne može nazvati nepoznatim; dapače, nedvojbeno je prepoznatljiv čimbenik suvremene europske političke teorije, napose na polju kritičke analize diskursa. Ipak, dosezi njegova utjecaja manje su disperzivno rasprostranjeni nego oni prethodne generacije (pretežno francuskih) autora koji su na njega formativno djelovali. Disciplinarno razmjerno ograničen doseg Laclauova utjecaja vjerojatno je upravo i jedan od razloga zašto pitanje o mjestu književnosti i književnoteorijske problematike u njegovu teorijskom opusu nije i ranije postavljano: s obzirom na to da se na prvi pogled nije bavio književnim temama, recepcija Laclaua među suvremenim je književnim teoretičarima nevelika ${ }^{48}$.

Kao što napominju Tormey i Townshend (2006: 88) i Breckman (2013: 186-187), ranijim Laclauovim radovima (a slično vrijedi i za Mouffe, suautoricu Hegemonije $i$ socijalisticke strategije [Hegemony and Socialist Strategy, 1985]) ${ }^{49}$ bolje bi odgovarala odrednica althusserijanskog marksizma ili pak nekog oblika neomarksizma nego postmarksizma, budući da - bez obzira na (retrospektivno) jasno vidljive naznake kasnijeg teorijskog razvoja - još uvijek nisu iskoračivali iz osnovnih marksističkih okvira. No pokušaji da novouočene probleme ${ }^{50}$ riješi unutar granica althusserijanske paradigme odveli su ga s vremenom ipak do njezinih granica, a potom $\mathrm{i}$ temeljite revizije.

\footnotetext{
${ }^{48}$ Među suvremenim domaćim studijama, a mimo istraživanja postmarksističke teorije koja mahom potpisuje autor ovog rada, na Laclaua se u književnoteorijskom kontekstu, koliko nam je poznato, detaljnije osvrnula samo Kristina Peternai Andrić (2012).

${ }^{49}$ Usp. primjerice Laclauovu studiju Politika i ideologija u marksističkoj teoriji [Politics and Ideology in Marxist Theory] (1977) te zbornik Gramsci i marksistička teorija [Gramsci and Marxist Theory] (1977) koji je uredila Mouffe.

${ }^{50}$ Riječ je prvenstveno o Laclauovu interesu za nove društvene pokrete ta za fenomen populizma, naročito u Latinskoj Americi, za čiji opis nije pronalazio adekvatne alate u marksističkoj teoriji. Te će dvije teme ostati predmet njegova interesa i kasnije, naročito potonja.
} 
Ono što je započelo kao još jedan marksistički projekt pretvorilo se tako istovremeno u projekt spašavanja jednog dijela marksističkog nasljeđa (Laclau, Mouffe; 2014: xxiv), ali i oštru borbu protiv „,monolitnog transvestita“ na koji je marksizam-lenjinizam sveo historiju marksizma (isto: ix). Ironično, to „spašavanje“ oslonjeno je pak ponajviše na poststrukturalistički teorijski input - isti onaj koji je s jedne strane, uz širi historijski kontekst, ponajviše pridonio razgradnji i opadanju prestiža marksizma na europskoj akademskoj pozornici, dok su neki od njegovih prominentnijih predstavnika naglašavali Marxov doprinos epistemološkim obratima u kojima su sudjelovali. Jednako tako, to je spašavanje istovremeno i eklektičan uvoz „vanjskih“ teorijskih postavki u marksistička polazišta, koliko i radikalizacija nekih postavki odavno prisutnih u marksističkoj tradiciji te njihovo dovođenje do krajnjih konsekvenci ${ }^{51}$.

Laclauova situiranost „na postmarksističkom terenu“ (isto: xxiv), prema njegovim vlastitim tvrdnjama kao i interpretacijama dosadašnjih studija o postmarksizmu, ponajviše se tiče odbacivanja ekonomskog determinizma u bilo kojoj instanci, svojevrsnog obrtanja odnosa marksističkih pojmova baze i nadgradnje, odnosno negiranja postojanja bilo kakvog objektivnog temelja društva, posljedičnog odbacivanja ontološke privilegiranosti klase, kao i mehanicističke, teleološke vizije povijesti. No ono što objedinjuje sve te postavke i najučinkovitije sažima Laclauov teorijski opus jest diskurzivna konceptualizacija društvenog.

Činjenica da u središte svoje političke teorije, odnosno teorije hegemonije, već u onom obliku u kojem je izlažu u Hegemoniji i socijalističkoj strategiji, kao svojoj najutjecajnijoj studiji, Laclau i Mouffe stavljaju diskurzivno oblikovanje društvenih identiteta i polja društvenog nije nikakva novost ${ }^{52}$. Na tu su činjenicu, kao značajku relevantnu za postmarksističko određenje, pozornost skretale sve studije o postmarksizmu, a bila je i

\footnotetext{
${ }^{51}$ Usp. Laclau, Mouffe; 2014: viii te Laclau, 2014: 3-4. Čitav prvi dio Hegemonije i socijalističke strategije upravo je istovremeno i genealoško istraživanje pojma hegemonije, ali i ukazivanje na proturječja u diskursima koji su ga oblikovali, no vlastite teze nisu dovodili do krajnjih konsekvenci. Ta genealoška analiza potom otvara prostor izlaganju nove teorije hegemonije $\mathrm{u}$ drugom dijelu knjige.

52 Podsjetimo, Laclau i Mouffe društvo ne smatraju skladnim, zaokruženim totalitetom s transcendentalnim uporištem koje bi logičkom nužnosti povezivalo njegove dijelove, već kontingentnom artikulacijom elemenata koja pritom modificira njihov identitet (o razlici medijacija-artikulacija usp. Laclau, Mouffe; 2014: 80), a svaki produkt takve artikulacijske prakse nazivaju pak diskursom (usp. isto: 91). Pritom je važno napomenuti da iz takve perspektive dokidaju razlikovanje između diskurzivnih i nediskurzivnih praksi (isto: 93), pri čemu se od optužbi za nekritički idealizam i autistično zatvaranje u misaone predodžbe brane ističući (1) materijalnost diskursa i neodvojivost lingvističkih i nelingvističkih elemenata (tj. riječi i djelovanja) u diskursu (usp. isto: 94, kao i Wittgenstein, 1998 \$2 na kojeg se pozivaju; istu tvrdnju opetovano naglašava Laclau i u ostalim svojim djelima; usp. npr. Laclau, 2014: 65), kao i (2) činjenicu da ne žele reći kako objekti ne postoje i izvan misli, već samo da se ne mogu konstruirati kao objekti izvan svakog diskursa. Konačno, kako bi dodatno naglasili svoju poantu - u prethodnom smo poglavlju već spominjali - odbacuju i „društvo“ (zaokruženu cjelinu utemeljenu na čvrstom principu u svojoj pozadini) kao validan objekt diskursa te umjesto njega govore o društvenom kao „polju identiteta koje se nikada ne uspijeva potpuno učvrstiti, polju nadodređenja“ (Laclau, Mouffe, 2014: 97).
} 
okosnica ranijih reakcija na njihov rad u krugovima marksističkih teoretičara ${ }^{53}$. Jednako tako neprimijećen nije ostao ni njihov dug klasicima poststrukturalističke misli po tom pitanju; Laclau i Mouffe (2014: xi) priznaju ga i sami, a nezaobilazno ga spominje i većina studija koje se njima bave. Napose to vrijedi u odnosu na dekonstrukciju, i to ne samo u smislu strategije čitanja kojom izvode svoje temeljne postavke ${ }^{54}$, nego i u širem smislu karakterističnih Derridaovih teorijskih načela. Ono što se iz toga implicitno moglo iščitati, nakon niza drugih studija ponajbolje je eksplicirao Marchart (2007: 146), i to jednadžbom koju smo prethodno spomenuli: da je Laclauova teorija diskursa u biti politička ontologija, te da tako postavljena politička ontologija postaje prima philosophia, odnosno za sebe uzima status opće ontologije ${ }^{55}$. No gdje je u toj konstelaciji mjesto književnosti i književnoteorijskom, za koje smo u uvodu postavili hipotezu da igraju odsutnu ulogu?

Kao što je u uvodu spomenuto, Laclau koncepte tropoloških pomaka, retoričkog i literarnosti u središte svoje političke teorije dovodi u tekstovima objedinjenim u svojoj posljednjoj knjizi Retorički temelji društva [The Rhetorical Foundations of Society] (2014), no ono što je tamo eksplicitno izloženo oblikovalo se iz studije u studiju još od Hegemonije $i$ socijalističke strategije, premda mu se u recepciji nije pridavala veća pozornost. Tako već u uvodu Laclau i Mouffe (2014: xxi) navode da se proliferacija raznih novih društvenih pokreta u drugoj polovici dvadesetog stoljeća, koja je motivirala njihovo istraživanje, ,predstavljala, prije svega, kao suvišak društvenog vis-à-vis racionalnih i organiziranih struktura društva - tj. društvenog poretka“, dok genealoško istraživanje hegemonije otkriva da ona izranja iz ,zijeva koji se otvorio u lancu historijske nužnosti“, odnosno „prvotne odsutnosti“ (isto: 1) koju mora nadomjestiti.

Taj zijev i odsutnost koji zahtijevaju zamjensko popunjavanje i proizvode suvišak analogni su onoj odsutnosti središta i suvišku značenja uslijed njegova suplementarnog uspostavljanja o kojima na općenitijoj razini mnogo ranije piše Derrida ${ }^{56}$ (2007: 307):

Središte se ne može odrediti, niti se totalizacija može iscrpiti, i to stoga što znak koji zamjenjuje središte, koji ga dopunjava, koji ga zastupa u njegovoj odsutnosti, taj znak se pridodaje, dolazi povrh, kao suplement. Kretanje značenja pridodaje nešto, zbog čega uvijek ima više, no to je dodavanje labilno, jer nadomješta, dopunjava nedostatak na strani označenog.

\footnotetext{
${ }^{53}$ Za jezgrovit pregled nekih od istaknutijih kritika usporediti Sim, 2000.

${ }^{54}$ Laclau i Mouffe (2014: xxiii) jasno navode da se bave „kritikom i dekonstrukcijom različitih diskurzivnih površina klasičnog marksizma.“

${ }^{55}$ Usp. Laclauovu (2014: 1) tezu da pokušava ocrtati novu političku ontologiju prikladnu postmarksističkom i poststrukturalističkom vremenu.

${ }^{56}$ Laclau i Mouffe i sami upozoravaju na tu analogiju; usp. Laclau, Mouffe; 2014: 98.
} 
A i za Derridaa, kao što je dobro poznato, „u odsutnosti središta ili podrijetla, sve postaje diskurs“. (isto: 299)

Osim što prepoznaje diskurzivnu narav polja koje proučava, studija Laclaua i Mouffe zapravo je velikim dijelom posvećena upravo zadatku koji Derrida spominje u istom tekstu da se promišlja ,zakon koji na neki način pri stvaranju strukture upravlja žudnjom prema središtu, kao i proces značenja koji propisuje dislokacije i supstitucije tom zakonu središnje prisutnosti - ali središnje prisutnosti koja nikada nije očitovala sebe, uvijek je već bila iznesena iz sebe kroz svoju zamjenu.“ (isto: 298) Upravo se tako može okarakterizirati istraživanje načina na koji nastaju hegemonijske artikulacije kao rezultati donošenja odluka na neodlučivom terenu, odnosno prošivni bodovi koji privremeno stabiliziraju određene diskurse.

No većina studija, opisujući pojedine elemente teorije hegemonije Laclaua i Mouffe, ne pridaje pozornost tome da ih oni otpočetka povezuju s pojmovima iz domene retorike, tako da naglašavaju strukturnu podudarnost između (privremenog) ovladavanja viškom značenja i njegovim raspoređivanjem $u$ polju društvenog te načina na koje funkcioniraju pojedine retoričke figure. Ipak, svjesni odsutnosti središta, u razlici spram tradicionalne retorike Laclau i Mouffe (2014: 96) jasno naglašavaju da ne vjeruju u svojevrsnu nultu razinu figuralnosti kojoj bi se pridavalo dodatno značenje: ,/s/inonimija, metonimija i metafora nisu oblici misli koji dodaju drugi smisao primarnoj, konstitutivnoj doslovnosti društvenih odnosa; naprotiv, oni su i sami dio primarnog terena na kojem se društveno utemeljuje.“ Odnosno, ,/n/e postoje dvije domene, jedna biti, a druga prikaza, budući da je nemoguće učvrstiti ultimativan doslovni smisao kojem bi simboličko bili druga i izvedena domena označavanja.“ (isto: 84$)^{57}$

Stoga će Laclau i Mouffe ekvivalencijski lanac koji povezuje različite pozicije u diskursu u odnosu na antagonistički rasjed kao njegovu (unutarnju) granicu, hegemonijski ujedinjujući zahtjeve različitih društvenih subjekata pod jedinstvenim plutajućim označiteljem i suprotstavljajući ih njegovoj antagonističkoj negaciji (npr. zahtjev za „pravdom“ - pod kojim se ujedinjuju partikularni zahtjevi različitih društvenih aktera, s premoći jednoga nasuprot onome što se označava „,nepravdom“) ${ }^{58}$, okarakterizirati kao metaforičku svezu (usp.

\footnotetext{
${ }^{57}$ Radi se o uvidu vrlo sličnom poznatom Barthesovu (1990: 9, [1973]) o odnosu konotacije i denotacije u njegovoj studiji $S / Z$, u kojoj navodi da ,denotacija nije prvi smisao, ali se prikazuje kao takva; ispod te iluzije ona je ništa drugo do li posljednja konotacija (ona za koju se čini da uspostavlja i zaključuje čitanje), nadmoćni mit pomoću kojeg se tekst pretvara kao da se vraća prirodi jezika, jeziku kao prirodi..." Utoliko vrijedi napomenuti da Coward i Ellis, baveći se francuskim strukturalizmom i njegovim odnosom prema marksizmu u svojoj studiji Jezik i materijalizam [Language and Materialism, 1977], kao ključnu prijelomnicu u Barthesovoj semiotici, ali i njegovom odnosu prema marksizmu, uzimaju upravo S/Z. Usp. Coward, Ellis; 1985.

${ }^{58}$ Detaljnije o ekvivalencijskom lancu kao jednom od osnovnih pojmova političke teorije Laclaua i Mouffe usp. u Laclau, Mouffe; 2014: 122.
} 
Laclau, Mouffe; 2014: 96, 111) ${ }^{59}$. Istovremeno, inicijalno hegemonijsko preuzimanje određene društvene uloge od subjekta kojem ona u nekom određenom poretku izvorno nije dodijeljena (npr. situacija u kojoj sindikat preuzima na sebe spektar društvenih borbi širi od borbe za bazična radnička prava) konceptualiziraju kao metonimijsko izmještanje, zbog čega će zaključiti da je „hegemonija u osnovi metonimijska.“ (isto: 128)

Ipak, ključ specifičnosti teorijske pozicije Laclaua i Mouffe naspram marksističkih klasika koje pri izvodu te pozicije dekonstrukcijski čitaju prvenstveno je u već spomenutom odbacivanju doslovnosti, odnosno uvjerenju da je doslovno značenje tek iluzija prouzrokovana (privremenom) fiksacijom i sedimentacijom određenog nezaokruženog sustava razlika. Naime, koncept hegemonije i u diskursima ruske socijaldemokracije, boljševika ili pak Gramscija - označavajući na različite načine preuzimanje uloga od strane nekog društvenog subjekta koje mu izvorno nisu predodređene, iskorak iz predviđene historijske niše - mogao bi se konceptualizirati kao metonimijski pomak. No u svim tim slučajevima pomak se čini u odnosu na historijskom nužnosti određenu objektivnu referentnu točku. Za razliku od toga, za Laclaua i Mouffe (2014: 100) odnos između nužnosti i kontingencije

ne može se zamišljati kao odnos između dvaju razgraničenih područja koja su izvanjska jedno drugome (...) budući da kontingentno postoji samo unutar nužnog. Prisutnost kontingentnog u nužnom ono je što smo ranije nazvali subverzijom i pokazuje se kao simbolizacija, metaforizacija ili paradoks što izobličuje i propituje doslovnu narav svake nužnosti. Nužnost, stoga, postoji ne kao načelo u podlozi, kao temelj, nego kao nastojanje da se učini doslovnim koje učvršćuje odnose u određenom sustavu razlika.

Privremena stabilizacija sustava razlika čvorišnim točkama ${ }^{60}$ preduvjet je funkcioniranja svakog pojedinog diskursa, kao i društvenog u (prividnoj) cjelini. No bez obzira na to što svaka nova artikulacija iznova pokušava stabilizirati mrežu elemenata ${ }^{61}$,

\footnotetext{
${ }^{59}$ Laclau i Mouffe ne povezuju s metaforom samo ekvivalencijski lanac kao rezultat određene artikulacije, nego i antagonistički odnos koji mu je preduvjet. Antagonizam, smatraju, nije ni realna opozicija ni kontradikcija, i ne može činiti tek jednu od razlika u širem tkanju razlika: „Ako je jezik sustav razlika, antagonizam je neuspjeh razlike, u smislu da se postavlja unutar granica jezika i može postojati samo kao disrupcija tog sustava, dakle, kao metafora." (Laclau, Mouffe; 2014: 111)

${ }^{60}$ Laclau i Mouffe, smatrajući da se „svaki diskurs utemeljuje kao pokušaj ovladavanja poljem diskurzivnosti, zaustavljanja tijeka razlika, uspostavljanja središta“, preuzimaju Lacanov pojam prošivnog boda te ga prilagođavaju svojoj teoriji pretvarajući ga u pojam čvorišne točke, kao „privilegirane diskurzivne točke djelomičnog učvršćivanja“ (Laclau, Mouffe; 2014: 99). Iako je inicijalno potekao od Lacana, u njihovom diskursu on mnogo više odgovara derridaovskom suplementu središta strukture.

${ }^{61}$ Element je čak i terminus technicus ranije faze Laclauove teorije; Laclau i Mouffe (2014: 91) tako nastoje razlikovati „momente“ kao „razlikovne pozicije artikulirane u diskursu“ te „elemente“ kao „razlike koje nisu diskurzivno artikulirane“. Težnja je svakog diskursa artikulacijom pretvoriti sve elemente u momente, dok heterogeno polje diskurzivnosti oko njega, preplavljujući ga polisemijom, podriva to nastojanje. U kasnijoj fazi Laclau neće isticati tu razliku, već će naglasak premjestiti na temeljnu razliku između čimbenika vezanih u nekom sustavu razlika te praznih/plutajućih označitelja.
} 
činjenica da se nijedan diskurs ne uspijeva zatvoriti u bešavnu cjelinu, kao i da ne postoji nikakav stabilan kontinuitet u podlozi različitih diskursa, znači krajnju nemogućnost da takve stabilizacije ikada budu konačne. Otvorenost svakog diskursa onome što Laclau i Mouffe (2014: 98) nazivaju ,poljem diskurzivnosti“ jamči neiskorjenjivu ,polisemiju što deartikulira diskurzivnu strukturu“ (isto: 99), zbog čega ,/d/ruštvo nikada ne uspijeva biti identično sebi, budući da se svaka čvorišna točka oblikuje unutar intertekstualnosti koja ju preplavljuje.“ (isto: 100) Time bilo kakva ideja o historijskoj nužnosti, ontološkoj privilegiranosti i objektivnosti klase ili bilo kojeg drugog društvenog subjekta ${ }^{62}$, ili pak determiniranosti totaliteta društva u krajnjoj instanci bilo kojim fenomenom, postaje s njihovim promišljanjima korjenito neuskladiva, jaz koji ih odvaja i od onih marksističkih teoretičara koji su u analizi srodnih problema došli na korak do njihova stajališta ${ }^{63}$.

Ta ključna razlika bila je, kao što smo napomenuli, jezgra postmarksističkog određenja koje su dosadašnje analize pridavale Laclauu i Mouffe. No istovremeno je u svim tim analizama u potpunosti izvan fokusa ostala činjenica da, izlažući svoju političku teoriju na ključnim mjestima, dvoje autora obilato posežu za konceptualnim aparatom karakterističnijim za književnu teoriju. Pojmovi metafore, metonimije, sinegdohe, paradoksa, intertekstualnosti itd. u Hegemoniji $i$ socijalističkoj strategiji nisu tek osebujne metafore za nešto na njih nesvodivo i pripadno drugoj domeni, već ih - ironično - odlikuje doslovnost koju negiraju diskursu. Drugim riječima, Laclau i Mouffe usvajaju pojmove tradicionalno vezane za književnu domenu ne da bi ih koristili ilustrativno, već poopćujući ih i potom prepoznajući na djelu iste te mehanizme u političkoj domeni.

No to nije jedini upliv književnog polja na njihovu prijelomnu studiju. Zapitamo li se naime koji je to diskurs kod kojeg narav diskursa kakvu konceptualiziraju Laclau i Mouffe najviše dolazi do izražaja, dok je svaki drugi diskurs u pravilu nastoji skriti (kontingencija utemeljenja, privremenost učvršćenih čvorišta, neotklonjiva polisemija te fluidnost što osporava bilo kakvu temeljnu nultu razinu figuralnog), tj. koji je to diskurs primarno usmjeren

\footnotetext{
${ }^{62}$ Govoreći o kategoriji subjekta, Laclau i Mouffe (2014: 101-102) napominju da sasvim očekivano odbacuju bilo kakvu varijantu zaokruženog izvorišnog subjekta te se zapravo uvijek referiraju na subjektne pozicije u diskursu, no istovremeno naglašavaju da esencijalizam totaliteta ne žele zamijeniti esencijalizmom elemenata; „ako je svaka subjektna pozicija diskurzivna pozicija, analiza ne može odbaciti oblike nadodređenja pojedinih pozicija drugim pozicijama“, odnosno prenaglasiti disperzivnu komponentu, zanemarujući artikulacijsku komponentu.

${ }^{63} \mathrm{U}$ iscrpnom genealoškom istraživanju hegemonije Laclau i Mouffe pokazuju kako niz marksističkih autora u različitim razdobljima dolazi na korak do njihova razumijevanja hegemonije, no potom isti autori zbog vjernosti postavkama tradicionalnog marksizma zauzdavaju krajnje implikacije svojih teorijskih izvoda i pod cijenu ulaska u proturječja s vlastitim diskursom. Ponajbolji su primjeri Luxemburg (usp. Laclau, Mouffe; 2014: 5-6), Gramsci (usp. Laclau, Mouffe; 2014: 59) i Althusser (usp. Laclau, Mouffe; 2014: 84-85).
} 
upravo transgresiji vlastitih diskurzivnih granica, čime osvješćuje o neminovnosti tog transgresivnog kretanja i na općenitijoj razini - odgovor je lako pronaći u književnosti ${ }^{64}$.

Da takva interpretacija nije tek neutemeljeno proizvoljno spajanje slučajnih podudarnosti, pokazale su Laclauove studije koje su uslijedile, a u kojima isti koncepti i dalje zauzimaju važna mjesta, sve do ogleda iz kasne faze njegove karijere u kojima se utjecaj književnih teoretičara potpuno eksplicira i tematizira. No činjenica da se o literarnom impulsu u njegovoj teoriji prethodno uglavnom nije pisalo baš stoga ne treba čuditi; Laclauov kasniji teorijski razvoj preusmjerio je pozornost i na pojedine aspekte koji su prethodno djelovali efemerno, naročito iz disciplinarne perspektive iz koje se Hegemonija $i$ socijalistička strategija uobičajeno čitala, pa je tako i ovo naše raspoređivanje naglasaka rezultat svojevrsnog anakroničnog čitanja te studije kroz prizmu kasnijih djela.

Jedanaest godina nakon objave Hegemonije i socijalisticke strategije u koautorstvu $\mathrm{s}$ Mouffe, Laclau objavljuje svoju sljedeću knjigu Emancipacije [Emancipation(s), 1996], u kojoj okuplja sedam eseja koje povezuju zajednički središnji koncepti te razmjerno široko zahvaćena tema emancipacije. Historijski kontekst nastanka tih tekstova, kako u predgovoru sam napominje (usp. Laclau, 2007: vii), pomaknuo se korak dalje u odnosu na onaj što ga opisuju dosadašnje studije o postmarksizmu ${ }^{65}$, u kojima pak reference na Emancipacije nisu česte. Činjenica da spomen Emancipacija uglavnom izostaje u ranijim istraživanjima postmarksističke teorije ne iznenađuje utoliko što je u esejima koje ta knjiga okupljaja na prvi pogled malo eksplicitne polemike s marksizmom, a upravo je ona za mnoge ekskluzivan pokazatelj postmarksizma.

No uz nekoliko sasvim izravnih polemičkih usporedbi i primjedbi na pojedine marksističke postavke, Emancipacije se ipak može i u cijelosti promatrati kao implicitnu polemiku s marksizmom, budući da Laclau većinu temeljnih problema koje razmatra - od naslovne emancipacije, preko odnosa partikularizma i univerzalizma, reprezentacije do zajednice - preuzima iz marksističke tradicije (time ne želimo reći da su ti koncepti nužno nastali u njezinim okvirima) unutar koje je nekada djelovao. Pritom koordinate razmatranja

\footnotetext{
${ }^{64}$ Tvrdnja o književnosti kao oglednom primjeru diskursa kako ga konceptualiziraju Laclau i Mouffe, dakako, ovisi i o načinu na koji konceptualiziramo književnost, budući da temeljne postavke na koje smo se referirali automatski isključuju i mogućnost čvrstog, transhistorijskog, transcendentalnog označenog pridruženog književnom označitelju. O tome kakvu koncepciju književnosti možemo iščitati iz djela Laclaua i Mouffe, više će riječi biti nešto kasnije.

${ }^{65}$ Riječ je o prvoj polovici devedesetih, u kojoj se Istočni blok već potpuno dezintegrirao, a sučeljenost dvaju velikih tabora zamijenila je s jedne strane globalizacija, a s druge unutarnja izbrazdanost društva i ,pobuna brojnih partikularizama“" (Laclau, 2007: vii). Stari spektar političkih pozicija na Zapadu uvelike se promijenio, a kao novi problemi koje Laclau adresira pojavile su se masovne migracije te novi rast populističke desnice fenomeni vrlo aktualni i danas.
} 
ostaju iste kao i u Hegemoniji i socijalističkoj strategiji te prepoznatljive iz dosadašnjih studija o postmarksizmu: svi eseji okupljeni u knjizi polemički se smještaju nasuprot i marksizma i liberalizma, te između onoga što bi se vrlo uvjetno moglo nazvati modernističkim i postmodernističkim krajnostima, krajnostima objedinjavanja i disperzije.

Za kasniji je Laclauov rad od spomenutih eseja najznačajniji tekst naslovljen „Zašto su prazni označitelji važni za politiku“ [,,Why do Empty Signifiers Matter to Politics“], u kojem detaljno elaborira povezanost odsutnosti središta diskursa s fenomenom praznih označitelja, o čemu je u prethodnoj studiji izlagao pretežno aksiomatski ${ }^{66}$. Prazni označitelji tako prema Laclauu (2006: 36) nisu naprosto ekvivokalni (povezivi s različitim označenima u različitim kontekstima) ili ambivalentni označitelji (nadodređeni tako da se ne mogu potpuno vezati za jedno označeno) ${ }^{67}$; oni „,nastaju iz strukturne nemogućnosti u označavanju kao takvom, i to samo ako se ta nemogućnost može označiti kao prekid (podrivanje, distorzija itd.) strukture znaka“, odnosno iz nemogućnosti da se označe granice određenog znakovnog sustava, koje se uslijed toga „moraju pokazati kao prekid ili slom procesa označavanja“ (isto: 37 ).

Prazan označitelj dakle nije označitelj koji nema svoje označeno (u tom slučaju ne bi bio označitelj, kako Laclau (2014: 64) kasnije napominje), već označitelj koji ukazuje na nemogućnost označavanja granica, odnosno totaliteta, punine ili središta nekog sustava, koje je istovremeno i nužno govorimo li doista o sustavu. Ta aporija nužnog i nemogućeg razlog je zašto je svaki prazni označitelj ujedno i neadekvatan (Laclau, 2006: 40), a izbor pojedinoga a ne nekog drugog presudno je političko pitanje, odnosno stvar hegemonije kao donošenja odluka na neodlučivom terenu (isto: 90). Iz iste nemogućnosti proizlazi i činjenica da se sustav nikako ne može utemeljiti na nečemu pozitivnom, odnosno nužnost da se ono što mu je onostrano „svede na čistu negativnost - to jest na čistu prijetnju koju ono što je s druge strane predstavlja sustavu (time ga utemeljujući)“ (isto: 38), što rezultira još jednom ambivalencijom: istovremenom diferencijacijom elemenata sustava među sobom, te njihovim

\footnotetext{
${ }^{66}$ Točnije rečeno, teze o odsutnosti središta i uvijek prisutnom višku značenja Laclau i Mouffe u Hegemoniji $i$ socijalističkoj strategiji (2014) najvećim su dijelom uveli kao neproblematična opća mjesta poststrukturalističke misli, referirajući se potom na paralele kod nekih drugih autora (ponajviše se oslanjajući na Derridaa; usp. Laclau, Mouffe; 2014: 98), te prebacujući tako na njih odgovornost izvoda tih teza.

${ }^{67}$ Pojam ambivalentnog označitelja Laclau (2006: 36) tu donekle izjednačuje s pojmom plutajućeg označitelja, a slijedom toga implicitno inzistira na razlikovanju praznih označitelja i plutajućih označitelja, što je razlika u odnosu na njegovu prethodnu studiju (usp. Laclau, Mouffe; 2014: 99), u kojoj se koristi samo pojmom plutajućih označitelja, no njime pokriva i ono što će kasnije nazivati praznima. Ta terminološka neodlučnost pratit će ga i u kasnijim studijama; npr. u Retoričkim temeljima društva stvari variraju od ogleda do ogleda između pokušaja da se prazni i plutajući označitelji oštro razdvoje te toga da ih se terminološki odvaja, ali se smatra da svaki prazni označitelj nadsvođivanjem lanca ekvivalencija postaje plutajući označitelj (usp. npr. Laclau, 2014: 20). Slično će i u O populističkom uтu (2007b: 131) za plutajuće označitelje reći „da im je značenje odgođeno“, ciljajući time na označitelje koji se nađu između suprotstavljenih ekvivalencijskih lanaca, tako da ih prisvajaju oba.
} 
(nikad potpunim) povezivanjem u ekvivalencijski lanac što ga predstavlja prazni označitelj, a nasuprot onoga što je sustavu onostrano.

Podsjetimo li se da su Laclau i Mouffe $(2014:$ 96, 111) i u ekvivalencijskom lancu i u antagonističkom rasjedu koji ga uzrokuje, a sam je proizvod nemogućnosti inherentne označavanju, prethodno već prepoznali metaforu, premda Laclau u Emancipacijama to nigdje ne eksplicira, jasno je da tropološka izmještanja i ovdje imaju presudnu ulogu za njegovo viđenje politike ${ }^{68}$. Katehretičan fenomen praznog označitelja postaje tako ključ razrješenja većine ostalih pitanja kojima se Laclau bavi u toj knjizi, a naročito druge velike teme koja će se pretvoriti u jednu od provodnih niti njegova kasnijeg opusa: problematike odnosa između partikularnog i univerzalnog te njegove reprezentacije. Prepoznatljivim dekonstrukcijskim zahvatom na više mjesta naime pokazuje kako je bilo koje partikularno nezamislivo bez makar implicitne reference na univerzalno, dok se neuprisutnjivo univerzalno može označiti tek (hegemonijskim) pretvaranjem neke partikularnosti u prazni označitelj koji mora označavati nešto sebi nesumjerljivo.

Takvom odnosu, u kojem možemo prepoznati klasičnu strukturu parabole ${ }^{69}$, valja još dodati Laclauovu tvrdnju da identiteti koje se reprezentira ne postoje mimo reprezentacije kao cjeloviti i stabilni, koje bi ona kao takve jednostavno odražavala. Naprotiv, kao što napominje, „odnos reprezentacije - daleko od toga da bi se referirao na potpuno izgrađene identitete - jest suplement nužan za oblikovanje tih identiteta“, koji ih još k tome ,,preoblikuje i mijenja“ (Laclau, 2006: 98) ${ }^{70}$. Nerazrješiva aporija između konstativnosti i performativnosti, koja za Laclaua tako postaje važan faktor pitanja o oblikovanju i reprezentaciji društvenih subjekata $^{71}$, fenomen je pak koji se mnogo duže primjećivao i proučavao u svezi s naravi i

\footnotetext{
${ }^{68}$ Laclau (2006: 43) eksplicitno navodi da je „prisutnost praznih označitelja (...) sam uvjet hegemonije“, a time i politike, odnosno demokracije (usp. isto: 100). Istovremeno, kada se kasnije bude referirao na esej o praznim označiteljima u ovoj studiji, tropološka će izmještanja eksplicitno imenovati metaforom, metonimijom i katahrezom (usp. Laclau, 2014).

${ }^{69}$ Parabola uvijek donosi neki partikularan slučaj koji bi odvojen od svoje partikularnosti trebao, upravo zbog tog manjka, moći stajati za nebrojeno mnogo drugih. No kao što Hillis Miller (1991: 140) napominje, temelj je parabole njezina konstativna nedjelotvornost koju nadomješta velikim performativnim potencijalom, pri čemu netransparentnost i konstativna nedjelotvornost nisu rezultat hira, nego nužnosti da se govori o onome „što u potpunosti nadilazi izravno prikazivanje“ (isto: 136). Nije potrebno posebno napominjati da Miller, kao i niz drugih suvremenih teoretičara, parabolu (ili kod drugih - alegoriju) sagledanu iz te perspektive smatra metonimijom književnog teksta, a onda i teksta uopće.

${ }^{70}$ Radi se, zapravo, o varijaciji prethodno spominjanog nepostojanja doslovnosti (usp. Laclau, Mouffe; 2014: 96, 100) zbog kojeg tropološka (metaforička, metonimijska, sinegdohska...) kretanja što se događaju u hegemonijskoj artikulaciji nisu nešto što se dodaje povrh bazičnog značenja, nego ono što u svakoj novoj artikulaciji preuspostavlja značenje na podlozi rezultata prethodne takve artikulacije.

${ }^{71}$ Političku dimenziju nerazlučivosti konstativa i performativa nije, dakako, prvi uočio Laclau; vjerojatno je najpoznatiji primjer Derridaovo čitanje američke Deklaracije nezavisnosti; usp. Derrida, 2002 [1976]: 46, a na istom nerazlikovanju svoju argumentaciju u tekstu DisemiNacija [DissemiNation: Tune, narrative and the margins of the modern nation] gradi i Bhabha (1994: 139 et passim).
} 
učincima književnog teksta, odakle je poopćavanjem dospio i u druge domene. A da ta poveznica nije posve proizvoljno učitavanje naših postavki u Laclauov tekst, svjedoči i njegova (afirmativna) parafraza Rortyjeve tvrdnje da su tijekom proteklih dvaju stoljeća dva otkrića ključna za osvješćivanje o kontingentnosti oblika zajednice, kao preduvjetu demokracije i politike: „rastuća svijest o tome da se istina proizvodi, a ne pronalazi (...) te romantičarska revolucija koja je dovela do vizije umjetnosti kao samostvaranja, a ne imitacije stvarnosti.“ (isto: 106) ${ }^{72}$

U knjizi koju je četiri godine kasnije Laclau objavio u koautorstvu s Butler i Žižekom ${ }^{73}$, naslovljenoj Kontingencija, hegemonija, univerzalnost (2007a [Contingency, Hegemony, Universality, 2000]), ujedno i jedinom njegovom djelu prevedenom na hrvatski, u fokusu se analize ponovno našao odnos između partikularnog i univerzalnog te njegova povezanost s Laclauovim konceptom hegemonije. Laclauova poglavlja u toj studiji sadržajno gledano, zapravo, jedva da donose ikakvih novosti u odnosu na izloženo u prethodne dvije knjige, no dodana vrijednost proizlazi iz konteksta rasprave sa suautorima, koji ga je naveo na dodatna pojašnjenja, obranu postavki polemičkim replikama ili pak pronalaženje dodirnih točaka u njihovim radovima. Pritom je zanimljiv pomak činjenica da se tom knjigom $u$ Laclauov diskurs vraćaju retorički pojmovi izostali u prethodnoj, i to mnogo naglašenije nego je to bio slučaj u Hegemoniji $i$ socijalističkoj strategiji.

Tako je u Laclauovu objašnjenju nužnosti praznih označitelja za politiku, hegemonijskog uzdizanja partikularnog kao univerzalnog te neizbježnosti i učinaka reprezentacije lako primijetiti promjenu pojmovnog registra u kojem se opet pojavljuju retorički termini:

Da bismo imali hegemoniju potrebno je da sektorski ciljevi neke skupine djeluju kao ime za univerzalnost koja ih transcendira - ta je sinegdoha konstitutivna za hegemonističku vezu. Ali ako je ime (označitelj) tako pričvršćen uz koncept (označenik) da nije moguće nikakvo pomicanje u odnosu između to dvoje, ne možemo imati nikakvu hegemonističku reartikulaciju. Zamisao o potpuno emancipiranom i transparentnom društvu, iz kojega bi bio uklonjen sav tropološki trenutak između njegovih konstitutivnih dijelova, uključuje kraj svakoga hegemonističkog odnosa (i također, kao što ćemo kasnije vidjeti, svih demokratskih politika). Tu imamo četvrtu dimenziju 'hegemonije': područje na kojemu se ona širi je ono

\footnotetext{
${ }^{72}$ Dakako, s takvim pogledima na književnost/umjetnost ne bi se složili neki drugi teoretičari - među njima i zagovaratelji lukačevskih ili pak socrealističkih pozicija - a stupnjevi i granice tog neslaganja, odnosno slaganja, mogli bi se dovesti u svezu s odnosom prema tradicionalnijem marksizmu na političkom planu. No za sada tek prefiguriramo tu tezu; detaljnije ćemo se njome pozabaviti kasnije.

${ }^{73}$ Riječ je o knjizi zamišljenoj poput svojevrsnog sučeljavanja troje spomenutih autora. Svaki je od njih dobio prostor za po jedan uvodni ogled te potom dva kao reakciju na eseje suraspravljača.
} 
uopćavanja odnosa predstavljanja kao uvjeta za konstituiranje društvenog poretka. (Laclau, 2007a: 61$)^{74}$

„Konstitutivna sinegdoha“, „tropološki trenutak“ te središnjost reprezentacije tu jezgrovito najavljuju Laclauovo skoro preispisivanje cijele svoje teorije iz perspektive retoričkog/tropološkog, no već u ogledima okupljenim u ovoj knjizi primjeri takve konceptualizacije mehanizama hegemonije/politike nisu ograničeni tek na pojedinačan odlomak ili usputne paralele, već se pojavljuju sustavno.

Posebno značajan korak naprijed jest Laclauovo daljnje specificiranje tih tropoloških izmještanja: povlačeći paralelu između njih i Butlerina pojma parodije, kao onoga što podriva doslovnost, odnosno značenje ustaljeno pomoću skupa institucionaliziranih praksi, on ističe da je taj ,,pokret tropologički utoliko što se pomaknuće ne vlada nužnom logikom koju diktira ono što se pomiče, kao i katahrestičan utoliko što tvorevine konstituirane putem pomaknuća nemaju nikakvo doslovno značenje izvan samih pomaknuća iz kojih proizlaze." (Laclau, 2007a: 81) Eksplicitno uvođenje katahreze u Laclauov terminološki aparat dodatno podcrtava nepostojanje doslovnosti, odnosno činjenicu da sva tropološka izmještanja koja opisuje nisu tek retorička nadgradnja na stabilan temelj, nego reartikulacija čitavog polja u kojem je takav temelj nemoguć.

Sve to zajedno Laclaua (2007a: 81) dovodi do teze da valja govoriti „o društvu organiziranom kao retorički prostor“, koju u tom trenutku doduše ne elaborira onoliko detaljno koliko će to učiniti u svojim posljednjim studijama. Konačno, prostor na kojem djeluju mehanizmi hegemonije ponovno naziva „uvijek otvorenom intertekstualnosti““ (isto: 78), a dvije osnovne logike koje na njemu djeluju - logiku razlike i logiku ekvivalencije povezuje s odnosima kombinacije i supstitucije, odnosno sintagmatskim i paradigmatskim odnosima (usp. isto: 80), što će ga u kasnijim esejima odvesti Jakobsonu.

U svojoj drugoj najpoznatijoj studiji, O populističkom umu (2007b) [On Populist Reason, 2005 $]^{75}$, Laclau nastavlja istom putanjom baveći se sve aktualnijim fenomenom populizma. Za razliku od pristupa marksističkih ili liberalnih teoretičara populizmu, koji u tom fenomenu vide eklektičku aberaciju u odnosu na „prirodnu“ političku i društvenu logiku,

\footnotetext{
${ }^{74}$ Potonji zaključak Laclau (2007: 69) ponavlja i nešto kasnije u izmijenjenoj formulaciji: „Hegemonija zahtijeva, kao što smo vidjeli, uopćavanje odnosa predstavljanja, ali na takav način da sam postupak predstavljanja stvara retroaktivno cjelinu koju treba predstaviti. Netransparentnost predstavljajućega prema predstavljenome, nesmanjiva neovisnost označitelja vis-à-vis označenika, uvjet je hegemonije koja strukturira društveno iz samoga njegova temelja i nije epifenomenalni izraz transcendentalnog označenika koji bi izvrgnuo označitelja njegovim predodređenim pokretima.“

${ }^{75}$ Radi se o svega drugoj monografskoj studiji uopće u postmarksističkom dijelu Laclauove karijere; tri preostale knjige okupljaju različite eseje povezane zajedničkim spektrom tema. No i bez obzira na to, uz Hegemoniju $i$ socijalističku strategiju, Laclau je široj teorijskoj javnosti uglavnom poznat po toj knjizi.
} 
tj. u odnosu na konzistentne ideologije koje bi određenim društvenim akterima trebale inherentno odgovarati, Laclau ga smatra fenomenom koji ponajbolje razotkriva logiku u temelju cjelokupne politike, a ta je logika - budući da artikulira heterogene elemente tropološka.

Analizirajući nekoliko različitih pristupa populizmu, Laclau pokazuje da se uglavnom slažu oko navođenja općenitih negativnih osobina - koje se mogu svesti na maglovitost $i$ neodređenost stavova i publike kojoj se populizam obraća te njegovu gotovo čistu retoričnost - no prelazeći na konkretnu razinu, ulaze u nedosljednosti i proturječja. Nasuprot toga, Laclau (2007b: 67) smatra da „(1) maglovitost i neodređenost nisu slabe strane nekog diskursa $o$ društvenoj stvarnosti, nego - u nekim uvjetima - upisane u društvenu stvarnost kao takvu, te da (2) retoričko nije epifenomenalno vis-à-vis samostalnih konceptualnih struktura, jer nijedna konceptualna struktura ne može ostvariti unutarnju koheziju bez posezanja za retoričkim sredstvima. ${ }^{\text {،76 }}$

Drugim riječima, populizam za Laclaua nije vrsta pokreta prepoznatljiva po ovoj ili onoj ideološkoj orijentaciji ili društvenoj bazi - jer „svi takvi pokušaji da se pronađe što je idiosinkratičko populizmu (...) bitno su manjkavi i uvijek završavaju preplavljeni lavinom iznimaka“ (Laclau, 2007b: 117) - populizam je sama politička logika77. Ta se logika pak odigrava na diskurzivnom terenu. Laclau (isto: 68) ponovno vrlo jezgrovito i nedvosmisleno ističe: „Diskurs je primarni teren oblikovanja objektiviteta kao takvog“, a „samo dvije vrste odnosa mogu postojati među njegovim označavajućim elementima: kombinacija i supstitucija.“ U odsutnosti središta koje bi poslužilo kao transcendentalna referentna točka supstitucijskim i kombinacijskim kretanjima središnja je uloga pak ponovno povjerena katahrezi, za koju Laclau (isto: 71) navodi da je „,više od pojedinačne figure: ona je zajednički nazivnik retoričnosti kao takve.“

Jednadžba koja iz toga slijedi važna je za kasnije segmente ovog istraživanja, naročito one koji se tiču usporedbe Laclaua i Rancièrea. Laclau, naime, političku konstrukciju naroda, kao temeljne jedinice na koju se referiraju svi ostali društveni identiteti, naziva „esencijalno katahretičkim“ (Laclau, 2007b: 72) činom, a potom i uvjetom ,sine qua non demokratskog funkcioniranja“ (isto: 169) te „paradigmatskim slučajem“ reprezentacije (isto: 163). Tako u

\footnotetext{
${ }^{76}$ Laclau (2007b: 146) tvrdnje demonstrira i na primjeru različitih „skandala“ u Marxovu sustavu, poput lumpenproletarijata, koji pokazuju da je heterogenost neiskorjenjiva, odnosno da je nemoguć čist konceptualan razvoj bez posredovanja retoričkog.

${ }^{77}$ Pojašnjavajući što misli pod političkom logikom, Laclau (2007b: 117) objašnjava da se nasuprot „društvenoj logici koja se sastoji od praćenja pravila, politička logika veže za uspostavljanje društvenog." Dakako, to uspostavljanje nije voluntarističko, već izrasta iz artikuliranih društvenih zahtjeva, no tako postavljeno još jednom potvrđuje to da Laclau izjednačuje pitanje politike/političkog s onim temeljne ontologije, dok prvo od njih pak izvodi iz retorike.
} 
radikalnom katahretičkom ulaganju objedinjuje (privremenu) stabilizaciju diskurzivnog prostora društvenog sa svim njegovim domenama i režimom reprezentacije ${ }^{78}$ te učvršćivanje referenta označitelja „narod“. No istovremeno je katehretičnost tog utemeljenja i izvor njegove kontingencije i promjenjivosti kao preduvjeta politike i demokracije.

Iz takve ambivalentnosti proizlaze i ograničenja dvjema temeljnim komponentama Laclauove hegemonijske teorije - logici diferencijacije i ekvivalencije. S jedne strane, savršeno stabilan razlikovni sustav, u kojem je logika diferencijacije došla do svoje krajnosti, nemoguć je zbog katahretičnosti utemeljenja sustava, odnosno manjka središta i viška znanja, a s druge strane - Laclau (2007b: 82) posebno upozorava - potpuno odstranjenje logike diferencijacije urušilo bi ekvivalenciju u identitet. Upravo dijalektika između logike diferencijacije i ekvivalencije po Laclauu (2007b: 231) jest ono što se uobičajeno naziva političkim.

Novost je pak u odnosu na prethodnu studiju što Laclau središnjom figurom hegemonije sada naziva sinegdohu, za koju kaže da „nije jednostavno jedno u nizu retoričkih sredstava koje taksonomski možemo dodati drugim figurama poput metafore i metonimije, već ima drukčiju ontološku funkciju.“ (isto: 72) No razlika je naprosto u širini shvaćanja metonimije - okrećući se Jakobsonu i njegovim definicijama metafore i metonimije u Retoričkim temeljima društva (2014) ponovno će to revidirati ${ }^{79}$.

U toj svojoj posljednjoj knjizi, naime, Laclau okuplja eseje koji u prvi plan dovode ono što je njegovim prethodnim studijama bilo pozadinski teorijski oslonac za bavljenje drugim, specifičnijim istraživačkim pitanjima, najavljujući ih kao „doprinose izgradnji političke ontologije koja može odgovoriti na izazove koje postavljaju postmarksistička i poststrukturalistička situacija unutar koje trenutno djelujemo.“ (Laclau, 2014: 1) Iako su spomenuti doprinosi trebali biti tek temelj budućem „sistematičnom predstavljanju takve ontologije“ (isto) ${ }^{80}$, koje nažalost nije uspio ostvariti, važnost Retoričkih temelja društva

\footnotetext{
${ }^{78}$ Kao i u prethodnim studijama, Laclau i u $O$ populističkom umu (2007b: 103) naglašava konstativnoperformativnu narav reprezentacije i njezin značaj za oblikovanje društvenih subjekata, tj. činjenicu da oni ne prethode reprezentaciji, već se u tom procesu artikuliraju. Pritom odbacuje i deskriptivizam i antideskriptivizam u teoriji imenovanja (usp. isto: 102) te kritizira niz teoretičara koji pojedince zamišljaju prethodećima društvenom i diskursima koji ga oblikuju (usp. npr. isto: 168).

${ }^{79}$ Slična je nekonzistentnost i to što Laclau (2007b: 227) na jednom mjestu ekvivalencijsku logiku poistovjećuje s metonimijom, a ne kako to obično drugdje čini s metaforom. I tu će tvrdnju korigirati (i uopće usložniti) u Retoričkim temeljima društva (2014), s tim da ni u različitim esejima u toj knjizi nije posve dosljedan glede međusobnog odnosa i primarnosti pojedinih figura.

${ }^{80}$ Laclau je sudeći po tome imao namjeru napisati zaokruženu studiju o navedenoj temi, no to se do kraja njegova života nije dogodilo. Retorički temelji društva (2014) naprotiv okupljaju devet eseja koji su nastajali u rasponu od petnaestak godina, dakle usporedno i s drugim njegovim studijama, a tek neki od njih posve su posvećeni pitanju retoričkih temelja političke ontologije, dok se drugi - kao i u ranijim slučajevima - oslanjaju na dosege na tom polju pri bavljenju drugim povezanim pitanjima. Razmjerno širok vremenski raspon nastanka
} 
ovom istraživanju obrnuto je proporcionalna njezinom neznatnom isticanju u dosadašnjim valorizacijama Laclauova opusa.

Osim sužavanja fokusa na poveznicu retorike, književnosti i političke ontologije, važna odlika ove studije koja se uočava već u njezinom uvodnom poglavlju jest i povratak odrednici postmarksizma i eksplicitnom problematiziranju toga kako se on (a time i Laclauov opus) pozicionira $\mathrm{u}$ odnosu na marksizam, što se $\mathrm{u}$ studijama nakon Hegemonije $i$ socijalističke strategije prvenstveno smještalo u implicitnu domenu. Tako Laclau (2014: 1), kao što se u gornjem citatu vidi, ponovno pozicionira svoje istraživanje u okvire postmarksističke situacije, a nešto kasnije detaljnije opisuje svoj položaj između dviju krajnosti koje uočava u suvremenoj teoriji s marksističkim zaleđem: s jedne strane „držati se čvrsto marksističkih kategorija, tako da ih se pretvori u štovanu hipostaziranu dogmu, te $\mathrm{u}$ isto vrijeme razvijati političko djelovanje tek labavo povezano s njima“, a s druge strane „svesti marksizam na sklerotičnu dogmu, nevezanu za probleme sadašnjice, te otpočeti s novom vrstom diskursa, potpuno ignorirajući polje marksističke diskurzivnosti.“ (isto: 3)

Druga značajna stvar koju čini već u uvodu jest to da se bez okolišanja hvata ukoštac s eksplicitnom definicijom političkog, izjednačujući ga - nasuprot ranije usputno dane definicije koja ga je povezala s dijalektikom logika diferencijacije i ekvivalencije (Laclau, 2007b: 231) - sa središnjim pojmom hegemonije. Političko tako postaje trenutak uvijek u izmicanju koji ne pripada nijednoj razini društvenog, nego utemeljujuće prethodi tim razinama i agensima što ih oblikuju, dok ,politiku valja konceptualizirati kao proces uspostavljanja društvenog.“ (Laclau, 2014: 7) ${ }^{81}$ Stoga kao svoju temeljnu istraživačku preokupaciju najavljuje potragu za tragovima koji ukazuju na utemeljujući trenutak političkog te rasvjetljavanje mehanizama hegemonije, ali i zadatak osobito blizak ovom istraživanju: „u isto vrijeme pokazati produktivan doprinos koji reference iz različitih konteksta mogu dati u razumijevanju političkog“ (isto: 8), pri čemu su konteksti na koje cilja prije svega „retorički, psihoanalitički, filozofski i semiotički“ (isto).

Navedene registre teško da bi imalo smisla pokušati diskretno razgraničiti $u$ suvremenoj humanistici, no u čvorištu koje Laclau opisuje nije pogrešno prepoznati čvorište

eseja i činjenica da naknadno nisu snažnije integrirani slabe su točke knjige, budući da od eseja do eseja generiraju poneku proturječnost, kao i mnogo repetitivnosti.

${ }^{81}$ Navedena se definicija ne čini kao značajna promjena, budući da hegemonijska artikulacija podrazumijeva uspostavljanje (privremene) ravnoteže između silnica diferencijacije i ekvivalencije, no prijašnja odrednica „dijalektike“ sugerirala je proces, dok Laclau u Retoričkim temeljima društva (2014) političko želi profilirati upravo kao trenutak - kao najmanji, neuhvatljivi odsječak na vremenskoj crti - dok politikom označava proces koji potom slijedi, čime se poravnava s drugim suvremenim autorima koji su počeli ponovno promišljati ontološko-ontičku razliku između političkog i politike. Kasnije će se (usp. npr. Laclau, 2014: 119) izravno referirati na Marcharta (2007), što otklanja bilo kakve dvojbe po tom pitanju. 
karakteristično za (suvremenu) književnu teoriju. Dapače, može se reći da za najvažnije tekstove u The Rhethorical Foundations of Society vrijedi da su odgovor na pitanje koje Laclau (2014: 79) postavlja na početku jednoga od njih: „Zašto bi se politički teoretičar poput mene, koji se pretežno bavi ulogom hegemonijske logike u strukturiranju političkog prostora, zanimao za djelo prominentnog književnog teoretičara kakav je Paul de Man?“ Odgovor nalazi u De Manovu podrivanju disciplinarnih granica, kao i granica između književne/retoričke i neknjiževne, strogo referencijalne/konceptualne uporabe jezika, iz čega izvodi zaključak da ,uopćena retorika (...) nadrasta regionalne granice te postaje suprotežna strukturiranju samog društvenog života. “ (isto)

Istražujući temeljne značajke tako poopćene retorike, Laclau se - uz De Mana okreće i tekstovima De Saussurea, Jakobsona i Genettea, tražeći u njihovim književnoznanstvenim i lingvističkim radovima uporište svojoj teoriji hegemonije ${ }^{82}$. Osvrćući se na poznata Genetteova i De Manova čitanja Proustova ciklusa U traganju za izgubljenim vremenom, Laclau ukazuje na to da su ta dva teoretičara u svojim tekstovima pokazala ne samo proturječnost Proustova zalaganja za metaforu kao figuru superiorniju od metonimije s činjenicom da su njegove metafore neodvojive od metonimijske okoline, nego i to da se na općenitoj razini te figure ne mogu diskretno odvojiti, budući da su kontigvitet i analogija načela koja zapadaju jedno $\mathrm{u}$ drugo, te upravo ispreplitanje tih dviju figura osigurava koherentnost Proustova teksta ${ }^{83}$. Osim toga, Laclau (2014: 57) upozorava da je uporaba pojma metafore i metonimije kod tih autora „ponešto idiosinkratička, budući da prelazi granice onoga što im kanonska retorika propisuje“, te upućuje na Genetteovu (2000: 345) tezu kako se radi „o prirodi semantičkog odnosa, a ne o obliku figure“, skupa s podsjećanjem da je tako proširene termine koristio i Proust.

U poopćenoj uporabi metafore i metonimije Laclau traži uporište temeljnoj hipotezi iz uvoda studije, pitajući se „ne bi li se označavanje moglo promatrati kao poopćena retorika.

\footnotetext{
${ }^{82}$ Usp. De Saussure, 2000 [1916], Jakobson, 2008 [1990], Genette, 2000 [1970] i De Man, 1979.

${ }^{83}$ Genette (2000: 343) već na samom početku svoga teksta piše: „Kod Prousta su vrlo rijetka ta munjevita približavanja što ih sugerira jedna jedina riječ, kojima klasična retorika isključivo daje naziv metafore. Kao da za njega analoški odnos uvijek mora biti ojačan (iako često nesvjesno) osloncem na jedan objektivniji i sigurniji odnos; odnos što ga u kontinuitetu prostora - prostora svijeta, prostora teksta - održavaju bliske stvari i povezane riječi.“ A onda potom dodaje: „Jedino presijecanje jednog s drugim može izuzeti predmet opisa, i sam opis, od 'slučajnosti vremena', to jest svake slučajnosti; samo križanje metonimijske potke i metaforičkog lanca osigurava koherentnost, 'nužnu' koherentnost teksta." (Genette, 2000: 347). Laclau će na temelju tog i sličnih Genetteovih uvida zaključiti da i na općenitoj razini samo presijecanje metaforičke i metonimijske osi može konsolidirati diskurs i pružiti dojam totaliteta (Laclau, 2014: 54-55), pridružujući to zaključku da analogija i kontigvitet nisu oprečna načela, dapače, da zapadaju jedno u drugo, odnosno da se metafora čini kao telos metonimije, i da svaka metaforička transgresija svoj početak ima u metonimijskoj (isto: 62). Preslikamo li to u registar Laclauove teorije hegemonije po ključu koji je ponudio već i u ranijim studijama - implikacije Genetteovih zaključaka kompatibilne su s njegovima.
} 
Drugim riječima, može li se 'retoričnost' promatrati ne kao povreda, nego kao ono konstitutivno (u transcendentalnom smislu) označavanja.“ (Laclau, 2014: 58) ${ }^{84}$ Ako je tako, retoričke transgresije ne bi trebale biti ograničene samo na poredak označenog (kao u Genetteovoj tezi o semantičkom odnosu), nego se protezati i još šire, na označitelje. Da to doista stoji, Laclau zaključuje okrećući se Jakobsonu. U svom poznatom tekstu „Dva aspekta jezika i dva tipa afazijskih smetnji“ [1956] Jakobson ne samo da metaforu i metonimiju također poopćene - povezuje s temeljnim osima (paradigmatskom i sintagmatskom, tj. selekcijskom i kombinacijskom) i temeljnim mehanizmima jezika, nego ta dva načela širi i na općenitije područje. Napominjući da „/n/aizmjenična prevlast jednoga ili drugog od tih dvaju procesa nije ograničena na verbalnu umjetnost“, te da se isto „osciliranje pojavljuje i u drugim, nejezičnim znakovnim sustavima“", (Jakobson, 2008: 172) kao primjere nudi pristupe u slikarstvu, filmsku montažu, ali i rad snova; redom primjere kod kojih se odnosi sličnosti i/ili bliskosti ostvaruju (i) na razini označitelja.

Uostalom, kao što Laclau primjećuje, potvrdu tome moguće je pronaći još u De Saussureovu Tečaju opće lingvistike [1916], kada opisujući asocijativne odnose u jeziku, analogne Jakobsonovoj metaforičkoj/selekcijskoj osi, piše:

Skupine koje su se oblikovale mentalnom asocijacijom ne ograničavaju se na to da približe riječi koje pokazuju nešto zajedničko; duh shvaća i prirodu odnosa koji ih u svakom pojedinom slučaju povezuje i tako stvara toliko asocijativnih nizova koliko ima različitih odnosa. (...) asocijacija može počivati i na samoj analogiji označenika (enseignement, instruction, apprentissage, éducation itd.) ili, naprotiv, samo na zajedništvu akustičkih slika (npr., enseignement i justement.) Dakle, postoji čas dvostruko zajedništvo smisla i oblika, a čas samo zajedništvo oblika ili smisla. Jedna riječ može uvijek izazvati sve ono što se s njom može povezati na jedan ili drugi način. (De Saussure, 2000: 194) $)^{85}$

Osim što dokazuju da se principi metafore i metonimije ne ograničavaju na razinu označenog, nego djeluju i na razini označitelja, ti Jakobsonovi i De Saussureovi primjeri pokazuju još jednom da su analogija i kontigvitet principi koji se preklapaju i zalaze jedan u drugi, te istovremeno podrivaju urednu diferencijalnu logiku jezičnog sistema koju svojim osima uspostavljaju. Najuočljivija je razlika što je takva transgresija kod metonimije jasno vidljiva, dok kod metafore imamo osjećaj da analogija posve ignorira strukturalne diferencijacije. Vodeći računa o njihovoj povezanosti, Laclau (2014: 62) zaključuje da bi se metafora mogla nazvati ,telosom metonimije, onim trenutkom u kojem je transgresija pravila kombinacije dostigla točku s koje više nema povratka: novi entitet je nastao koji nas navodi

\footnotetext{
${ }^{84}$ Radi se o pitanju bliskom onom o mogućnosti kontinuiteta gramatike i retorike, koje postavlja De Man u tekstu „Semiology and Rhetoric“, na koji se Laclau referira. Usp. De Man, 1979: 6.

${ }^{85}$ Isti primjer Laclau koristi ranije, uparujući ga s primjerom semantičkih zgušnjavanja i premještanja kod Freuda, na koje pak u citiranom tekstu upozorava i Jakobson; usp. Laclau, 2007b: 25-26.
} 
da zaboravimo transgresivne prakse na kojima je utemeljen. No bez tih transgresivnih praksi, koje su u biti metonimijske, novi metaforički entitet ne bi mogao nastati.“

Naposljetku, da bi završio svoj dokaz o konstitutivnosti retoričkih transgresija za označavanje kao takvo, Laclau se i u Retoričkim temeljima društva vraća svom ranijem izvodu nužnosti praznih označitelja u diskursu ${ }^{86}$ kao pokazatelju nepostojanja nulte razine figuralnosti, zbog čega smo u situaciji da „dajemo ime nečemu što je esencijalno 'bezimeno', praznom mjestu“, tj. priznamo „katahrezi njezinu središnjost.“ Drugim riječima, „budući da svako figuralno kretanje podrazumijeva da se kaže više nego se može reći doslovnim terminom, katahreza je inherentna figuralnom kao takvom - postaje zaštitni znak retoričnosti kao takve“ (Laclau, 2014: 64), a „kada se središnjost katahreze potpuno prihvati, retoričnost postaje uvjet označavanja i, posljedično, objektiviteta.“ (isto: 66) ${ }^{87}$

Vratimo li se pokretačkom impulsu cijelog istraživanja, pitanju odnosa retorike i politike/političkog, Laclau (2014: 67) naposljetku formulira sljedeću tezu: „politika je artikulacija heterogenih elemenata, a takva je artikulacija nužno tropološka, budući da pretpostavlja dvojnost između uspostavljanja i podrivanja razlikovnih pozicija, koju smatramo čimbenikom što određuje retoričku intervenciju. ${ }^{\text {"88 }}$ Odmah potom napominje da mnogo toga u društvenoj organizaciji nije političko, dapače da su trenuci većih političkih reartikulacija razmjerno rijetki, dok većinu vremena opstaje relativno stabilan razlikovni poredak za koji u ovoj studiji namjenjuje označitelj društvenog. Ipak, važno je shvatiti da ni takav poredak ne valja izjednačiti s nultom razinom figuralnosti. Husserlovskim rječnikom, ako je političko moment reaktivacije, društveno je produkt sedimentacije, no to ne znači da je usidreno u bilo kakvoj nužnosti ili izjednačivo s bilo kakvom objektivnom stvarnosti (usp. Laclau, 2014: 68).

Različite čimbenike političke artikulacije Laclau pak prevodi u retorički registar poveznicama koje smo spomenuli vezano za prethodne studije. U ekvivalencijskom lancu prepoznaje metaforički odnos, dok inicijalno prekoračenje razlikovnih pozicija i povezivanje mimo njihovih granica smatra metonimijskom transgresijom. Sukladno tome, uz manje nekonzistencije od eseja do eseja, hegemonijsku artikulaciju smatra „kretanjem od metonimije prema metafori, od 'bliskog' polazišta do njegove konsolidacije u 'analogiji'“ (Laclau, 2014: 77), odnosno ,zaustavljeno između dvije nemoguće krajnosti: prve, kod koje ne bi bilo izmještanja, bliskost bi bila samo bliskost i sve bi tropološko kretanje prestalo - to bi

\footnotetext{
${ }^{86}$ Laclau upućuje na izvod u Emancipacijama (usp. Laclau, 2006) koji smo prethodno spomenuli.

${ }^{87}$ Vrijedi napomenuti i Laclauovo zapažanje u obrnutom pravcu - da su se granice tradicionalnoretoričko shvaćenih figura preklapale s granicama klasične ontologije, tim više što zaslugu za podrivanje takvog stanja pripisuje dekonstrukciji (usp. Laclau, 2014: 88).

${ }_{88}$ Riječ je o određenju potpuno analognom onom iz O populističkom umu (Laclau, 2007b), samo izvedenom „, druge strane“.
} 
odgovaralo onome što Gramsci naziva 'korporativnom klasom'; te druge, kod koje bi metaforička totalizacija bila dovršena, te bi potpuno analoški odnosi u potpunosti zaokružili društveni prostor - u tom slučaju imali bismo 'univerzalnu klasu' klasičnog emancipacijskog diskursa.“ (isto: 91)

Konačno, vratimo li se nakon svega De Manu i onome što je Laclau, prema vlastitom priznanju, naučio od njega, ostaje nam izdvojiti još jednu važnu stvar. Govoreći o nevoljama u kojima se našla teorija ideologije danas te nastojanju da za njih nađe rješenje teorijom hegemonije, Laclau smatra da je tradicionalna definicija ideologije kao pogrešnog predstavljanja zapravo posve u redu, uz važan dodatak da je svako predstavljanje pogrešno predstavljanje, budući da ovisi o katahretičnom ulaganju, kontingentnoj čvorišnoj točki nastaloj reprezentacijom univerzalnog od strane partikularnog koje je na njega nesvodivo. Utoliko je ,ideologija dio svake reprezentacije“ (Laclau, 2014: 17), jer je svaka reprezentacija proizvod neke hegemonijske artikulacije.

$\mathrm{Na}$ tragu zaključka o iluzornosti retorički neposredovane reprezentacije te De Manova dokidanja čvrstih granica između estetske i teorijske uporabe jezika, retoričkog i konceptualnog, Laclau (isto: 79) zaključuje da „mišljena na tako visokoj razini općenitosti, literarnost književnog teksta probija granice bilo kakve specijalizirane discipline, te njezina analiza podrazumijeva nešto poput studije iskrivljujućih učinaka što ih reprezentacija ostavlja na bilo kojem referentu - učinaka koju su tako konstitutivni svakom iskustvu.“

Imamo li na umu da je reprezentacija u svim Laclauovim studijama temeljni mehanizam oblikovanja političkih aktera, kao sastavni dio hegemonijske artikulacije, ali isto tako da $\mathrm{u}$ odsutnosti središta $\mathrm{i}$ nepostojanju nulte razine figuralnog uopće nema neposredovanog pristupa nekakvoj „objektivnoj stvarnosti“, odnosno reprezentacije koja ne bi bila „iskrivljujuća“, vidimo da za Laclaua u potpunosti vrijedi jednadžba koja izjednačava političku i opću ontologiju, ali i to da im kao treći sinonimni član dodaje i literarnost. Drugim riječima, ono što - prema književnoteorijskim tradicijama koje su uvele pojam literarnosti (ili neki od srodnih pojmova) i njime se koristile - posebno dolazi do izražaja u književnom tekstu i smatra se njegovom specifičnosti, za Laclaua pripada općediskurzivnoj, a time i općeontološkoj (i političkoontološkoj) domeni. Premda se kao teoretičar Laclau nikada nije izravno bavio književnošću, svojim posljednjim studijama tako je nedvosmisleno stavlja u središte političke teorije, podrivajući svaki pokušaj da se uspostavi diskretna granica između tih dviju domena. 
Laclauovo zamagljivanje granica između političkog, retoričkog, književnog i općeontološkog ipak treba uzeti s oprezom, te vodeći računa o ontološko-ontičkoj opreci kod svakog pojedinog područja, na što i sam upozorava. Laclau piše:

Trebali bismo, u biti, izbjeći dva iskušenja. Prvo je da pretvorimo retoričke kategorije u lokus čvrste transcendentalnosti - tj. u razinu na kojoj se oblikuju sve značajne teorijske distinkcije i koja potom svodi područja njihove 'primjene' na empirijsko 'studija slučaja'. No isto bismo tako trebali izbjeći drugu krajnost, da gledamo različite razine kao potpuno zatvorene svemire čiji se međusobni odnosi mogu opisati samo u terminima potpuno vanjskih homologija. Pitanje usporedbe između regija i razina trebalo bi koncipirati tropološki: nijedna razina nema transcendentalni primat pred drugom, tako da njihovu interakciju valja promatrati kao područje izmještanja što zamagljuje granice između empirijskog i transcendentalnog. Svaka bi razina i područje trebali teorijski obogatiti razumijevanje drugih u intertekstualnosti koja nema svoje konačno sidrište. (Laclau, 2014: 67)

Pitanje koje bi se moglo postaviti jest kakva je narav veze svega do sada izloženog i pojma postmarksizma, odnosno nije li Laclauovo pristajanje uz te teorijske postavke i njihovo razvijanje $\mathrm{u}$ opisanom pravcu tek akcidentalno povezano s odrednicom postmarksizma koja mu se pridaje, tim više što se većina dosadašnjih studija o postmarksizmu manje zanimala za „unutrašnjost“ Laclauove teorije, a više za njezin polemički odnos prema marksističkim klasicima i suvremenicima.

$\mathrm{S}$ jedne strane, kao što smo u prethodnom poglavlju spomenuli, jasno je da svako usvajanje postfundacijskih postavki nije nužno i postmarksističko. Recipročno pak gledano, odgovor je potrebno dati na dvije razine. Govorimo li samo o Laclau, uvjereni smo da su postfundacijske postavke kakve on usvaja- s naglaskom na njihov izvod, središnji položaj literarnosti i zamagljivanje granica između književnog i političkog - u uskoj svezi sa svim karakterističnim odrednicama koje prema dosadašnjim studijima Laclaua određuju kao postmarksista. Jesu li isto tako i ustrajna postavka čitavog postmarksističkog korpusa, to ćemo nastojati pokazati u ostatku ovog istraživanja.

Posljednja stvar koja nam je prije toga ostala jest pitanje možemo li na temelju studija koje smo netom analizirali reći ponešto o tome kakav koncept književnosti Laclau ima u vidu kada piše o s njom povezanoj problematici. Riječ je o nezahvalnom pitanju jer, kao što smo spomenuli, Laclau nije izravno pisao o književnosti te smo stoga odgovarajući na njega primorani na razmjerno grubu rekonstrukciju. S druge strane, pitanje je to što ga je važno postaviti zbog (potencijalnih) poveznica s drugim teoretičarima kojima ćemo se u nastavku baviti.

S obzirom na opća svojstva koja Laclau u svojoj teoriji pridaje diskursima, jasno je da se ni književnost ne može promatrati esencijalistički, određena čvrstom transcendentalnom jezgrom, već odnosima s drugim diskursima i svojom pozicijom u odnosu na privremene 
stabilizacijske točke društvenog. To uostalom odgovara i pogledima čitavog niza teoretičara koji su presudno utjecali na razvoj njegovih teorijskih postavki - ne samo poststrukturalista, nego i formalista te praških strukturalista. Uzmemo li pak u obzir njegovo odbacivanje krajnjeg utemeljenja diskurzivnog u ekonomskom, ili kakvom drugom obliku „objektivne stvarnosti“, jasno je i da Laclauovim teorijskim postavkama ne može odgovarati nijedna od inačica konceptualizacije književnosti kao odraza izvanknjiževne (ekonomske, društvene) zbilje. S druge strane, ranije citiran odlomak o povezanosti i relativnoj autonomiji različitih razina i područja, kao i opetovana Laclauova podsjećanja da izvandiskurzivna stvarnost utječe na diskurzivne artikulacije, tj. na činjenicu da su one materijalne $i$ historijski kontekstualizirane ${ }^{89}$, potvrđuju da Laclauove teorijske postavke nisu kompatibilne ni s viđenjem književnosti kao apsolutno autonomne domene, potpuno indiferentne prema društvenoj stvarnosti koja je okružuje.

No mnogo je teže pitanje o naravi te neindiferentnosti, odnosno o tome je li književnost inherentno politička i inherentno emancipacijska ili ne. Podsjetimo, kada se Laclau referira na literarnost, on govori o analogiji između proučavanja literarnosti (odnosno određujućih svojstava književnosti) i proučavanja tropološkog na općenitijoj razini, odnosno o analognim mehanizmima oblikovanja značenja u tim domenama, no time ne govori nužno ništa o političnosti književnosti kao pojedinačnog tipa diskursa u nekom društvenom prostoru. Dopustimo li si pretpostavku da je po tom pitanju, kao i po mnoštvu drugih, suglasan s Mouffe $^{90}$, korisna nam je pomoć njezina teza da „iz perspektive teorije hegemonije umjetničke prakse igraju ulogu u konstituciji i održavanju danog simboličkog poretka, ili u njegovu osporavanju, te zbog toga nužno imaju političku dimenziju. Političko se, sa svoje strane, tiče uspostave simboličkog poretka društvenih odnosa, i u tome počiva njegova estetička dimenzija.“ (Mouffe, 2013: 91)

Inherentna političnost, no tek potencijalna subverzivnost ili lojalnost književnosti određenom (simboličkom) poretku, kao i tek potencijalno emancipacijsko djelovanje, ukazuju na razlike među pojmovima koji na prvi pogled djeluju sinonimni, te su donekle komplementarni i s vrlo čestim Laclauovim upozorenjima - među ostalim i njegovom

\footnotetext{
${ }^{89}$ Usp. Laclau, 2006: 43; Laclau, 2007b: 237 te Laclau, 2007a: 192, 207. Ta su Laclauova podcrtavanja vlastite svjesnosti o historijskoj situiranosti i materijalnosti diskursa te nejednakosti moći različitih diskurzivnih aktera ujedno i potencijalni odgovor na Bowmanove (2007) kritike Laclauova navodnog ignoriranja institucionalnog konteksta.

${ }^{90} \mathrm{Tu}$ pretpostavku ipak nemamo pravo uzimati zdravo za gotovo. U jednoj od svojih polemika sa Žižekom, Laclau (2014: 176) oštrom ironijom pozdravlja Žižekov uspjeh da napokon razdvoji njegove radove i tvrdnje od onih koji pripadaju Mouffe, kritizirajući (među ostalim i njegovu) navadu da ih se uvijek pripisuje oboma, bez obzira tko je autor.
} 
zamjerkom Rancièreu (usp. Laclau, 2007b: 246) ${ }^{91}$ - da politika ne znači uvijek i emancipacijsku politiku, odnosno da rezultat pojedine hegemonijske artikulacije mjeren tim kriterijima ovisi o karakteristikama radikalnog ulaganja koje je uspostavlja ${ }^{92}$.

No premda takva konstelacija atributa priziva brojna važna pitanja o odnosu književnosti i politike, dalje od ove točke Laclau nažalost nije došao, i bilo bi neozbiljno daljnjom mu rekonstrukcijom stavljati riječi u usta. Ono što pak ostaje kao valjana i produktivna mogućnost jest okrenuti se teoretičaru koji se tim odnosom izravno bavio mnogo više od Laclaua, te uspoređujući njegov i Laclauov opus proširiti odgovore na temeljna pitanja ovog rada koja smo do sada dobili. Radi se, dakako, o Jacquesu Rancièreu.

\footnotetext{
${ }^{91}$ O Laclauovoj kritici Rancièrea više ćemo govoriti u sljedećem poglavlju, no napomenimo za sada tek da se čini dijelom utemeljena, no dijelom i izazvana razlikama u pojmovnom aparatu. Politika kod Rancièrea i politika kod Laclaua naprosto nisu sinonimi.

${ }^{92}$ Ukazujući na to da nema nikakve garancije da će pojedina artikulacija biti progresivna te da određeni prazni označitelj može jednako biti iskorišten za ovaj ili onaj poredak, Laclau (2007b: 97) piše: „Rasprava oko toga hoće li pravedno društvo biti ostvareno fašističkim ili socijalističkim poretkom ne proizlazi iz logičke dedukcije koja kreće od koncepta 'pravde' što ga prihvaćaju obje strane, već se događa radikalnim ulaganjem čiji diskurzivni koraci nisu logičko-konceptualne, već atributivno-performativne sveze.“
} 


\subsection{Zoon politikon kao književna životinja: Rancière, nesuglasnost i}

\section{literarnost}

$\mathrm{Za}$ razliku od Laclaua, Jacques Rancière nikada sebe nije okarakterizirao postmarksistom, niti su mu tu oznaku pridavale dosadašnje studije o postmarksizmu. Dapače, premda se u njegovu opusu na više mjesta mogu naći eksplicitne polemike s pojedinim marksističkim postavkama, za razliku od Laclaua Rancière se u pravilu ne izjašnjava o odnosu čitavog svog opusa spram ukupnosti marksističke tradicije bilo u terminima njezina spašavanja, bilo prevladavanja. Pa ipak, sličnosti između te dvojice teoretičara brojne su i pokazuju se na više razina.

Ako je Laclauova althusserijanska faza nešto manje poznata, malo je onih kojima je nepoznato da je Rancière svoju teorijsku karijeru započeo kao Althusserov učenik i jedan od nekolicine suradnika na studiji Kako čitati Kapital (Althusser, 1975 [Lire le Capital, 1965]). No odmak od Althusserovih pozicija utoliko je bio proporcionalno oštriji; Rancièreovo nadilaženje althusserijanskog marksizma i razočaranje učiteljem rezultiralo je odličnom, no na mahove ne samo oštro polemičnom nego i zajedljivom studijom Althusserova lekcija [La Leçon d'Althusser, 1975] (usp. Rancière, 2011a). Iako je riječ o knjizi čija je primarna tema kritika Althusserova opusa koja bi se mogla sažeti na kritiku figure Platonova filozofa-kralja, odnosno činjenice da Althusserova filozofija, pod krinkom korjenite revizije marksizma, zapravo ustoličuje vlastitu ortodoksiju, gradeći privilegiranu poziciju partijskog intelektualca nasuprot bilo kakvom spontanitetu i heterogenosti masa ${ }^{93}$, već u tom djelu nazire se znatan dio budućih provodnih niti Rancièreove filozofije.

U kontekstu usporedbe s Laclauom zanimljivo je da dvojica teoretičara, osim zajedničke točke udaljavanja od marksističkih okvira, uvelike dijele i strategiju kojom to čine. Kao što sam Rancière (2011a: xxiii) napominje, njegova je polemika s Althusserom zapravo dekonstrukcijsko čitanje Althusserove filozofije, koje - umjesto polemiziranja s vanjske pozicije - upućuje na njezina proturječja i nedosljednosti, na sličan način na koji i Laclau zasniva svoju teorijsku poziciju dekonstrukcijski čitajući nekoliko marksističkih klasika. Nadalje, kao jedan od poticajnih impulsa svog propitivanja koje ga je dovelo u polemički

\footnotetext{
${ }^{93}$ Na platonovsko pozicioniranje filozofa Rancière u svojoj studiji Filozof i njegovi siromašni [Le Philosophe et ses pauvres, 1983] (usp. Rancière, 2004a) ukazuje među ostalim i u Marxovu opusu, dok s druge strane u Althusserovoj lekciji nudi sliku Marxa kao filozofa koji ,proglašava kraj ere filozofa i filantropa, dobronamjernih reformatora $\mathrm{i}$ interpretatora svijeta. Proglašava da je došlo vrijeme proučavanju stvarnog svijeta i njegovoj transformaciji, da je vrijeme zrelo za novu inteligenciju, drukčiju od one profesora" (Rancière, 2011a: 12), s kojom pak povezuje Althussera.
} 
odnos s Althusserom, Rancière (isto: xxi) navodi i „propadanje klasične ljevice“, „proliferaciju oblika pobune“ te „sve evidentniju neadekvatnost, sa strane ljevičara i lijevih partija, u pokušajima da ih izraze, kao i razvoj oblika borbi i ujedinjavanja podjednako udaljenih od marksističke teorije koliko i od klasičnog ljevičarstva u praksi.“ Riječ je o fenomenu analognom proliferaciji novih društvenih pokreta koje kao suvišak u odnosu na dotadašnje strukture spominju Laclau i Mouffe (2014: xxi).

I dok je uočavanje novih društvenih kretanja te nemogućnosti marksističkih objasnidbenih shema da ih bez grubih ostataka apsorbiraju Laclaua odvelo proučavanju uglavnom razmjerno suvremenih političkih fenomena, Rancière će svoj interes vrlo brzo okrenuti prema nešto daljoj povijesti, no oba će smjera istraživanja posve komplementarno polemizirati s klasizmom tradicionalnog marksizma i ukazati na neopravdanost ontološkog privilegiranja klase.

Taj pravac Rancière doduše započinje baveći se u Althusserovoj lekciji šezdesetosmaškim pokretom, kao primjerom „,narodne mase“ postavljene nasuprot klase, te podsjeća da je afirmacija mase maoistička novost više nego konstanta marksističkog diskursa ${ }^{94}$; pomak koji je, smatra, išao ruku pod ruku s pomakom u konceptualizaciji radničke zadaće, s kojim se „od radnika više nije očekivalo da prebaci proizvodnu normu, već da, umjesto toga, svojim jedva vidljivim gestama uspostave novi svijet.“ (Rancière, 2011a: 15) Isti lajtmotivi - znatno kompleksnija i heterogenija artikulacija radničkog identiteta nego što je zamišljao klasični marksizam te mijenjanje svijeta djelovanjem koje je prethodno bilo izvan polja vidljivosti - bitno snažnije dolaze u prvi plan već u njegovoj prvoj sljedećoj većoj studiji, kojom je zagazio mnogo dalje u prošlost.

Studija Noći proletarijata [La Nuit des prolétaires, 1981] (Rancière, 2012b) iz naznačene je perspektive značajna dvojako: i tematikom koju obrađuje, i izvorima kojima se pritom služi te načinom na koji ih predstavlja, odnosno - pojednostavimo li vrlo uvjetno - i sadržajem i formom. Što se prvoga tiče, studija je to u kojoj se Rancière bavi historijatom radničkog pokreta u razdoblju što prethodi onom koje uobičajeno naglašava marksistička historiografija ${ }^{95}$, istražujući kompleksnu genealogiju onoga što će se kasnije razmjerno neproblematično nazivati radničkom klasom i njezinom klasnom svijesti.

\footnotetext{
${ }^{94}$ Dapače, Rancière (2011a: 14) navodi da se tradicija Kautskog ,utemeljila na uvjerenju da mase ne mogu izdići svoju inteligenciju iznad onoga što je nužno da bi dobili povišicu plaće.“ Althusserovu filozofiju smatra stoga jednom u nizu varijacija takve ortodoksije, koja poručuje: „Izvan Partije, nema spasenja za mase; izvan filozofije, nema spasenja za Partiju.“" (isto: 11)

${ }^{95}$ Rancière, naime, u fokus uzima nekoliko različitih, no redom predmarksističkih radničkih strujanja i udruženja djelatnih sredinom devetnaestog stoljeća, od utopijskih socijalista pa do kršćanskih društava.
} 
Takvo istraživanje otkriva mu da bi se, namjesto čvrste objektivne jezgre koju pretpostavlja marksistički epistemološki realizam i s njim povezano ontološko privilegiranje klase, jedinom „stalnom osobinom proletarijata“ moglo nazvati njegovo „trajno bivanje u procesu oblikovanja“ (Rancière, 2012b: 29). Proces je to pozicioniran između krajnosti manjka (materijalne oskudice, ali i manjka vlastitih osobina i slobodnog vremena) i suviška (onog što je sa stanovišta buržujskog morala ocjenjivano ekscesnim, ili je pak bilo nepraktično, neodgovarajuće radniku, nekorisno $)^{96}$, te potpunog egotizma i vizije proletarijata kao univerzalne klase ${ }^{97}$.

Paradoksalan odnos manjka i suviška te partikularnog i univerzalnog nije jedina poveznica s Laclauovim uvidima o retoričnosti političkog. Rancièreovo istraživanje začetaka francuskog proletarijata na nizu različitih konkretnih primjera pokazuje ono što Laclau izvodi prvenstveno (premda ne isključivo) teorijski: bez stabilne i nepromjenjive jezgre iza sebe, objektivnog klasnog interesa kao prirodnog središta, različite radničke pokrete i identitete ne okupljaju isključivo ni materijalni interesi ni bezuvjetna emocionalna povezanost ${ }^{98}$. Oni su uvijek artikulacije što nastaju simboličkim nadsvođenjem zajedničkim označiteljem lanca heterogenih zahtjeva, pozicija i poveznica ${ }^{99}$.

No premda njegova studija prati razvoj nekoliko takvih artikulacija, više nego privremene stabilizacije različitih subjekata Rancièrea zanimaju elementi što u odnosu na njih ostaju kao suvišak i tako podrivaju njihovu stabilnost. Kao što i Laclau trenucima političkog smatra trenutke u kojima se narušava stabilnost diferencijalnog sustava prekoračenjem dodijeljenih pozicija, tako i Rancière već u toj studiji doista političkim činom ne smatra toliko

\footnotetext{
${ }^{96}$ Manjak i suvišak, kako Rancière pokazuje, stoje uvijek u dijalektičnom suodnosu, čak i kod onih fenomena koji se uobičajeno povezuju isključivo s manjkom. Tako, primjerice, navodi da se u onodobnim genealogijama kriminala kao uzrok ne pojavljuje ,potrebitost uzrokovana siromaštvom ili čak gramzljivost potaknuta prizorom bogatstva. Na početku svega ne nalazimo manjak, nego suvišak: nametnutu nemogućnost proletera da postoji u punom opsegu svojih mogućnosti i u skladu sa svojim potrebama za širenjem, koja uzrokuje mržnju što je okoliš siromaštva pretvara u grabežljivost, u pohlepu za stvarima koje posjeduju ona ljudska bića što ga sprječavaju da postoji." (Rancière, 2012b: 92)

${ }_{97}$ Proturječje između egotizma, čija prevaga rastače bilo kakav kolektivni identitet u korist partikularnih, individualnih stremljenja, te njegove potpune odsutnosti koja bi rezultirala čistom univerzalnošću, no time ponovno rastakanjem specifičnosti klase, nužno je ostalo nerazriješeno u slučajevima svih radničkih strujanja 19. st., predstavljajući njihovo krajnje ograničenje. Kako Rancière (2012b: 279) za jedno od njih piše: „Egotizam je lukav vrag, koji ostvaruje svoje najradikalnije učinke u samom srcu predanosti predanih ljudskih bića. Pojavi se i zauzme svoje mjesto u suvišku, intelektualnom i moralnom ekscesu koji je neizostavan za emancipaciju proletera.“ Također i: „Emancipacija radnika može biti samo nestanak radničke klase kao takve: to jest, suverenitet naroda.“ (isto: 266 )

${ }^{98}$ Usp. Rancière (2012b: 106) za jedan od primjera rasprava o udjelu okupljanja oko čistog materijalnog interesa te osjećaja bratstva i suosjećanja u različitim udruženjima.

${ }^{99}$ Drugdje Rancière (2011: 14) piše da je „teoretičarima koji su nastojali odvojiti realitete od reprezentacije, procese od manifestacije, ekonomske strukture, političku pozornicu i oblike ideološke svijesti (...) odgovorio da se stvarnost označena terminima 'radnik', 'narod' ili 'proleter' nikada ne može svesti bilo na pozitivne materijalne uvjete, bilo na površnu uobrazilju imaginarnog, već uvijek označava djelomičnu (u oba smisla) vezu, provizornu i polemičku, fragmenata iskustva i oblika simbolizacije - podjelu osjetilnog..."
} 
borbe radnika za poboljšanje materijalnih uvjeta ${ }^{100}$, koliko za priznanje fundamentalne jednakosti ${ }^{101}$, a onda i preraspodjelu vremena ${ }^{102}$, vidljivosti i prava na govor.

Drugim riječima,

nije znanje o eksploataciji ono što radnik treba kako bi se „uzdigao licem u lice nasuprot onoga što se sprema proždrijeti ga." Ono što mu nedostaje i što treba jest znanje o sebi koje bi mu otkrilo biće predano nečemu drugom osim eksploatacije, otkriće sebe do kojeg se dolazi zaobilazno preko tajne drugih: onih intelektualaca i buržuja s kojima, reći će kasnije, a mi ponavljamo za njim, ne želi imati ništa - posebno ne s bilo kakvom podjelom na dobre i loše među njima. (Rancière, 2012: 20)

Biti predan nečemu drugom osim eksploatacije znači „preći s druge strane platna“ (Rancière 2012b: 5), makar na tren „zamijeniti radničko oruđe za piščevo pero“ (isto: 4), kao radnik ući „u carstvo politike i kulture s kontinuiranom odanosti svojim drugarima radnicima“ (isto), i „tiče se noći, ne dana“ (isto: 20) ${ }^{103}$. Odatle i naslov Noći proletarijata: politika se za Rancièrea (2012b: 22) tiče upravo ,aproprijacije noći onih koji mogu ostati budni, jezika onih koji ne moraju prositi i izgleda onih kojima se ne mora laskati““, odnosno podrivanja „granice što odvaja one kojima je božanstvo namijenilo mišljenje od onih kojima je namijenilo da izrađuju cipele.“

Osobit značaj književnosti za (subverzivnu) aproprijaciju jezika i transgresiju granica potvrđuje se pak na dvije razine. U korpusu koji je istraživao Rancière upravo se ona pokazuje kao najpotentnija metonimija ostalih transgresivnih praksi, bilo da se radi o negativnim protuprimjerima koji su radnike trebali odgovoriti od zagrezanja u književni svijet, o primjerima radnika-pisaca koji su, okušavajući se u književnom stvaralaštvu,

\footnotetext{
${ }^{100}$ Usp. Laclauov prikaz pomaka od sasvim konkretnih materijalnih zahtjeva neke uže društvene skupine prema narodnim zahtijevanjima sve apstraktnije naravi progresivnim širenjem ekvivalencijskog lanca u Laclau, 2007: 73-76.

${ }^{101}$ Usp. u Rancière, 2012b: 35 i primjer (na prvi pogled banalnog, no politički relevantnog) zahtjeva krojačkih šegrta da majstori moraju skidati šešir po njihovu ulasku u radionicu, čime bi se ostvarila jednakost u domenama pojave i konvencija. Radi se o onome što će kasnije nazvati razdvajanjem društvenih od političko-pravnih odnosa, koje se često zaboravlja zbog utapanja politike u društveno i koncentracije na društvene nejednakosti. Društvene znanosti, smatra, dugo su se bavile mahom potvrđivanjem i ukazivanjem na (društvene) nejednakosti, pri čemu je iz fokusa ispao politički potencijal diskursa koji ističu i nastoje potvrditi fundamentalnu političkopravnu jednakost. Usp. Rancière, 2012a: 65-67.

${ }^{102}$ Rancière (2012a: 33) skreće pozornost i na aristotelijanski pojam prosodosa koji se odnosi upravo na taj nužan suvišak vremena: „Prosodos je značajna reč. Njeno prvo značenje je pristup, točka u kojoj put dotiče cilj. U političkom rečniku pristup ima precizniji smisao: to je činjenica da se predstavljate kako biste govorili pred skupštinom. Ali prosodos označava i suvišak koji omogućuje predstavljanje, stupanje na put, višak koji dopušta da se bude u skupštini: višak u odnosu na rad i na život koji rad obezbeđuje. Taj dodatak koji nedostaje nije nužno novac. To naprosto može biti vreme, slobodno vreme.“"

${ }^{103}$ Doduše, moguće je obrnuto, u ekstremnim slučajevima poput onog Louis-Mariea Pontyja, za kojeg Rancière (2012b: 77) navodi da je odabrao poslove koje može raditi noću kako bi mu dan ostao slobodan za čitanje i pisanje: „Riješio je problem učinivši noć svojim radnim danom, a dnevno doba svojom noći.“
} 
probijali uske granice koje su im nametnute, ili pak naprosto o čitanju književnosti kao sve šire dostupnom prozoru u svijet izvan tih granica ${ }^{104}$.

No osim toga tu je i već najavljeni drugi razlog zbog kojeg su nam Noći proletarijata značajne, a to je način na koji Rancière izlaže istraživanu građu. Govoreći o suvišku koji je uvijek nadilazio racionalne strukture svog vremena, te kritizirajući pokušaje teoretičara različitih provenijencija (marksiste, ali i njihove protivnike) da tim suviškom ovladaju racionalnim strukturama svoje teorije i umjesto njega trbuhozbore ${ }^{105}$, Rancière se odlučuje za pismo u kojem ne izlaže s pozicije teorijskog autoriteta, uzevši za sebe ulogu diskretnog pripovjedača te prepuštajući prostor polifoniji glasova i različitih žanrova koje u izvorima pronalazi. Ili, kao što u predgovoru engleskom izdanju navodi,

uvodi nas izravno u govor radnika u svim njegovim oblicima, od osobnih tajni i recitala dnevnih iskustava, pa do filozofskih spekulacija i programa za budućnost, iznesenih fikcionalnim pričama zapisanim u njihovim dnevnicima. Ne prihvaća nikakvu razliku statusa, nikakve hijerarhijske odnose između opisa, fikcije ili argumenta... Upravo je distribucija uloga između jezika puka i književnog jezika, stvarnosti i fikcije, dokumenta i argumenta, ono što ovi „narodni“ tekstovi osporavaju. (Rancière, 2012b: x) ) $^{106}$

Zbog takvog „odbijanja eksplanatorne distance“ (isto: xi), koje je nastojalo potkopati „poredak što drži vremena i diskurse na svom mjestu“ (isto), Rancièreov je tekst od mnogih proglašen književnim. Iako je intencija tih primjedbi prvenstveno bila nešto drugo, naime kritika žanrovske nekonvencionalnosti i dovođenje u pitanje teorijske $\mathrm{i}$ historiografske relevantnosti takvog teksta, u jednu su ruku ipak pogodile srž stvari: fundamentalna jednakost platna jezika od kojeg su iskrojeni i diskursi filozofa i učenjaka, i izumi pisaca, i proleterske priče (isto) afirmira se i ponajbolje dolazi do izražaja upravo u književnosti.

$\mathrm{Na}$ nuždu historije da „održi igru homonimije“ sadržane u svom imenu, tj. da disjunkciju između dvaju svojih lica - pripovijesti i znanosti, književnog i njegova potiskivanja - pretvori u konjunkciju Rancière (1994: 6-7) je skrenuo pozornost i na općenitijoj razini u studiji Imena historije [Les Noms de l'histoire, 1992]. Zajednički nazivnik

\footnotetext{
${ }^{104}$ Kao što u jednom od članaka na sličnu temu objavljenih u Les Révoltes logiques Rancière (2011c: 181) piše: „Radnik koji se, bez da je naučio valjano slovkati, okušao u sastavljanju stihova po popularnom ukusu bio je možda i opasniji za postojeći ideološki poredak nego onaj koji pjeva revolucionarne pjesme.“ Čestu obradu te teme u romanima devetnaestog stoljeća i kasnije analizira na više primjera. Usp. npr. čitanje Balzacova Seoskog župnika u Tijelu riječi [La chair des mots: Politiques de l'écriture, 1998] (v. Rancière, 2004b: 105) u kojem skreće pozornost na to da je „konfuzija života preusmjerenih [s namijenjenih im tokova] inzularnom moći svima dostupnih riječi, kao što znamo, bila opsesija Balzacova vremena“, nazivajući je „krimenom demokracije i knjige, njihovim simboličkim zločinom, denaturalizacijom radničke klase.“

${ }^{105}$ Usp. Rancière, 2012b: 12.

${ }_{106}$ Prethodno smo rekli da je njegov teorijski projekt započeo polemičkim obračunom sa svojevrsnom inkarnacijom platonskog mita kod Althussera; ovdje spomenuto narodno pismo Rancière (2012b: x) pak naziva protumitom tom platonskom mitu.
} 
kritike što je ta studija upravlja i marksističkoj historiografiji, zbog njezina teleološkog podređivanja događaja predeterminiranoj shemi budućnosti, i konzervativnoj empirističkoj historiografiji, zbog njezina pokušaja sidrenja u sadašnjosti (koji paradoksalno pokazuje iste manjkavosti kao i marksistička historija ${ }^{107}$ ), kao i tzv. znanstvenoj historiji, zbog njezine (potencijalne) redukcije historije na teratološku poddisciplinu društvenih znanosti ${ }^{108}$, jest nastojanje da apsorbiraju suvišak i nekim oblikom korjenitog utemeljenja ovladaju njegovom igrom.

Rancière nasuprot tomu afirmira historiju koja otvara prostor bujici lutajućeg pisma $\mathrm{i}$ višeglasju potisnutih glasova što ih je tradicionalna historija doživljavala kao opasnu buku, historiji koja izvlači na površinu latentno značenje što su ga ranije zakrivali privilegirani posrednički glasovi. Pritom naglašava da se takva historija oblikuje ne unatoč usporednim romantičarskim kretanjima, nego upravo zbog njih - zbog ,dokidanja vladavine mimetizma i preoblikovanja pravila belles lettresa u neuvjetovano književnosti“" (Rancière, 1994: 54), odnosno zahvaljujući književnoj komponenti historije i pomacima što su se - utemeljeni na fundamentalnoj jednakosti u jeziku - dogodili na književnom polju ${ }^{109}$.

No osim toga, Rancière u suvišku što su ga različite paradigme historije nastojale dokinuti prepoznaje i sam konstitutivni uvjet historije; ona postoji zbog neiskorjenjivosti anakronizama i jer „nikakav praiskonski legislator nije postavio riječ i stvari u harmoničan odnos“ (Rancière, 1994: 35). To nas pak ponovno dovodi do scene viđene i kod Laclaua: revolucionarni događaji (Francuske revolucije, u konkretnom slučaju koji uzima za primjer, ali i svake druge) što otvaraju nove političke prostore, nove stranice historije, mogu se „u potpunosti svesti na dva koncepta (...), koncepte upražnjenosti i supstitucije.“ (isto: 37) Odsutno središte, mrtav kralj, destabilizirani prošivni bod otvaraju prostor dolasku do izražaja homonimije pogubne po svaki poredak (isto: 33), višku značenja koje se potom redistribuira ${ }^{110}$.

\footnotetext{
${ }^{107}$ Za obje kritike usp. Rancière, 1994: 30.

108 Usp. isto: 41.

${ }^{109}$ Drukčije rečeno, ,/a/firmirajući se svojom apsolutnosti, svojim odjeljivanjem od mimeze i podjele žanrova, književnost omogućuje historiju kao diskurs istine." (Rancière, 1994: 51)

${ }^{110}$ Rancière (isto: 21) piše: „Za Hobbesa i tradiciju [historije] koju započinje, teorijsko i političko zlo može se identificirati ovako: proliferacija posuđenih imena, imena koja ne nalikuju nikakvoj stvarnosti te ubijaju jer su pogrešno upotrijebljena, jer ih upotrebljavaju ljudi koji njima ne bi trebali rukovati, koji su ih istrgnuli iz njihovog izvornog konteksta da bi ih upotrijebili u situaciji koja nema ništa zajedničkog s tim kontekstom. Opasnost dolazi od svih tih plutajućih imena, mnoštvenosti homonima i figura koje ne imenuju nikakvo stvarno svojstvo nego pronalaze, pri svom kretanju, načina da se inkorporiraju bilo gdje. Nered politike potpuno je identičan neredu znanja.“
} 
Drugim riječima, u podlozi svakog poretka i ovdje se otkriva ne čvrst temelj, već katahretično imenovanje ${ }^{111}$, a pridruživanje riječi stvarima nakon njega uvijek je tropološka operacija. Različiti govornici „ujedinjeni su imenima, (...) imenuju se i imenuju druge imenima koja nemaju 'nikakvu usku svezu' sa setom svojstava“" (Rancière, 1994: 35), odnosno „identitet sukobljenih strana u društvu nije izraz 'kulture' neke grupe ili podgrupe. To je izum imena kojim se zahvaća nekolicina govornih činova što afirmiraju ili osporavaju simboličku konfiguraciju odnosa između poretka diskursa i stanja stvari.“ (isto: 97) Sličnosti s Laclauovim naglašavanjem značaja (katahretičnog) imenovanja te konceptualizacijom oblikovanja identiteta političkih aktera očigledna je, naročito kada Rancière (isto) u nastavku napomene da se prije svega radi o „nijekanju isključenja uspostavljenog govorom drugoga...“

Čvrstu utemeljenost proletarijata (kao i bilo koje druge klase) u bazi, baš kao i kod Laclaua, zamjenjuje stoga osobit oblik intertekstualnosti:

Mjesta govora s kojih se projicira beskonačnost radničke 'klase' nisu tvornice ili barake, ulice ili kabarei. To su tekstovi, fraze, imena: referencijalni tekstovi - ljudska prava ili Stari zavjet koji omogućavaju artikulaciju iskustva koje je odvajanje jezika držalo u tišini; fraze i sklopovi fraza koji u nešto vidljivo i iskazivo preoblikuju ono što nije imalo svoje mjesto po kojem bi ga se moglo razlikovati i što se čulo samo kao neartikulirana buka, postavljajući u zajednički prostor nove subjekte, nove legitimacije i oblike u kojima prvi mogu raspravljati iz potonjih; riječi izdvojene iz zajedničkog jezika određenja - imena klasa koja ne određuju nikakav specifičan skup pojedinaca, nego samu disrupciju odnosa između imena i stanja stvari. (Rancière, 1994: 93) ${ }^{112}$

Prepoznatljivi momenti Rancièreova određenja politike i njezine isprepletenosti $s$ problematikom književnog vidljivi su dakle već i u njegovu bavljenju historijom, a još intenzivnije dolaze $u$ fokus $u$ onim studijama koje se prvenstveno tiču političke teorije. Jezgru svog promišljanja politike ocrtava već u esejima okupljenim u zbirci Na rubovima političkog [Aux bords du politique,1990], koja se - baš kao i prethodno spominjane studije - također izgrađuje na kritici i marksističke i liberalne paradigme kao dvaju lica iste pacifikacije politike ${ }^{113}$.

\footnotetext{
${ }^{111}$ Glede katahretičnosti, Rancière (1994: 39) piše: „Nepostojanje je stvar koju je najteže na svijetu uočiti. A nepostojanje Država je ono što Države, u mjeri u kojoj postoje, imaju zadatak prikriti. Ne radi se jednostavno o tome da 'tradicionalna fasada' još prikriva, u očima profanog, 'poredak unutar zidova'. Više o tome da su simbolički zidovi tu da skriju vlastite pukotine."

${ }^{112}$ Odnosno, za Rancièrea (1994: 92) moderni je društveni subjekt „klasa koja više nije klasa, nego 'disolucija svih klasa'“, klasa koja se oglašava „govorom bez svoga mjesta, nebrojiva kolektiviteta, nemoguća za identificirati“.

${ }^{113}$ U predgovoru drugom izdanju Rancière (2012a: 8) piše: „Postalo je, dakle, moguće ponovo misliti demokratiju, jednakost ili zajednicu, sa dvostruke distance: prema onima koji su, pokopavajući lude utopije o jednakosti i ostavljajući za sobom razdore klasnih borbi, sebi čestitali zbog novog kursa razborite demokratije; ali i prema onima koji su u tome videli ponovni dokaz lažljivosti demokratske forme i retoriku jednakosti koja
} 
Nasuprot njihovu tretmanu politike, koji je na ovaj ili onaj način podređuje društvenom, Rancière (2012a: 193) smatra da ona „svoj razlog postojanja nema ni u jednom društvenom stanju“, pridajući joj time ontološki prioritet. No to istovremeno ne znači da je primarna „aktualizacija principa, zakona, odnosno 'svojstva' neke zajednice“ (isto: 87); naprotiv, kao što smo prethodno vidjeli, „/p/olitika nema arkhe“, „/o/na je, strogo uzev, anarhična“ (isto) ${ }^{114}$. Rancière je stoga definira kao „ponovno, disenzualno oblikovanje podele čulnog, kojom dominacija nameće čulnu očiglednost svoje legitimnosti““ (isto: 13), odnosno kao scenu „na kojoj potvrda jednakosti mora da dobije formu utvrđivanja nepravde.“ (isto: 87). Njoj nasuprot postavlja pak pojam policije, kao oznaku za proces kojim se „organizuje okupljanje ljudi u zajednicu i radi se na uspostavljanju njihove saglasnosti“, a koji počiva „na hijerarhijskoj raspodeli mesta i funkcija“, odnosno koji „čini nepravdu jednakosti.“ (isto: 8687). Pojam političkog - koji u kasnijim studijama najčešće izostavlja iz jednadžbe - određuje pak kao „,ime za susret politike i policije u utvrđivanju nepravde.“ (isto: 87$)^{115}$

Kako i sam navodi, tu pojmovnu podjelu Rancière dodatno razrađuje u svojoj kapitalnoj studiji Nesuglasnost [La Mésentente, 1995], u kojoj pak politiku određuje kao aktivnost (a ne trenutak!)

koja raskida s osjetilnom konfiguracijom u kojoj se definiraju dijelovi i udjeli ili njihova odsutnost uz pomoć pretpostavke da njihovog mjesta po definiciji nema: mjesto dijela bez udjela. Taj se rascjep manifestira u nizu činova koji preobličuju prostor u kojem se definiraju dijelovi, udjeli i odsutnosti udjela. Politička aktivnost koja premješta tijelo s nekog mjesta koje mu je doznačeno ili mijenja namjenu nekog mjesta; ona čini da se vidi ono što se nije moglo, da se čuje neki diskurs koji je prije bio čut kao buka. (...) Bilo da ima obilježje spektakla ili ne, politička aktivnost uvijek označava oblik manifestacije koja rastavlja osjetilne podjele policijskog poretka tako da u djelo provodi pretpostavku koja je toj podjeli po svom načelu heterogena, pretpostavku o dijelu bez udjela koja u posljednjoj instanciji, sama po sebi manifestira kontingentnost poretka, jednakost bilo kojeg govorećeg bića s bilo kojim drugim. (Rancière 2015: 36) ${ }^{116}$

prekriva realnost klasnog izrabljivanja. Između onih koji su zadovoljni depolitizacijom i onih koje muči čežnja za razotkrivanjem političke laži, bilo je potrebno definisati treći put: kritiku vladajućih identifikacija i opozicija." Sumarno bi se pojednostavljeno moglo reći da marksističku paradigmu kritizira zbog redukcije politike na ideološku nadgradnju društvenog, dok liberalnu paradigmu kritizira zbog njezine sekluzije kao specifične djelatnosti društvenog. Riječ je, s te strane, o kritičkom pozicioniranju identičnom Laclauovu.

${ }^{114}$ Ili, kako Rancière (2015: 25) poslije piše još jasnije: „Politika postoji naprosto zato što nijedan društveni poredak nije utemeljen u prirodi, zato što nema nikakva božanskog zakona koji bi upravljao ljudskim društvima. (...) /O/naj kome se prohtje izliječiti politiku od njezinih nevolja imat će na raspolaganju samo jedno rješenje: laž koja izmišlja neku prirodu društvenog kako bi zajednici dao neki arche.

115 Približno je jednaka, podsjetimo se, situacija s analognim pojmovima kod Laclaua. On političko definira kao „moment reaktivacije“ sedimentiranog poretka, politiku kao „esencijalno tropološku artikulaciju heterogenih elemenata“ (opsegom nešto veći referent od Rancièreove politike), dok ono što Rancière naziva policijom zove sedimentiranim društvenim poretkom. Usp. Laclau, 2014: 67-68, 122.

${ }^{116} \mathrm{Na}$ prazninu i dio bez udjela, apostrofirane u citiranoj definiciji iz Rancièreove Nesuglasnosti, referira se jedna od dvije točke Laclauove kritike Rancièrea, u kojoj Laclau (2005: 246) priznaje velike podudarnosti svoje i njegove konceptualizacije politike, no tvrdi da „Rancière poistovjećuje mogućnost politike previše, vjerujem, $s$ 
Policijom pak nasuprot tomu naziva „skup procesa pomoću kojih se izvodi okupljanje i pridobivanje kolektiviteta, organizaciju moći, distribuciju mjesta i funkcija i legitimacijske sustave te distribucije." (Rancière 2015: 34)

Amblematična situacija tako definirane politike za Rancièrea je situacija nesuglasnosti što proizlazi iz već apostrofirane odsutnosti temelja, a radi se o naizgled paradoksalnoj situaciji razumijevanja i nerazumijevanja; o situaciji u kojoj sugovornici govore istu riječ, no ne mogu se sporazumijeti oko njezina značenja ${ }^{117}$. Neotklonjiv suvišak značenja, neiskorjenjiva homonimija, nepopravljivo nepodudaranje između riječi i stvari, koje smo sve već susretali u ranijim studijama, stoje tako u podlozi odnosa iz kojeg izrasta politika: spora u zajednici što se „odnosi na zbroj dijelova čak i prije nego se počne odnositi na njihova 'prava'.“ (Rancière, 2015: 20)

Personifikacije dijela bez udjela, proleter ili plebs, iz konkretnih se historijskih primjera u ranijim studijama još eksplicitnije oblikuju u šire primjenjivu teorijsku figuru, čije postojanje generira događanje politike. Rancière (2012a: 143) na jednom mjestu pojam proletera eksplicitno i naziva „metaforičkom katahrezom“, a u nizu drugih elaboriranih

mogućnošću emancipacijske politike, bez da uzima u obzir druge alternative - na primjer, da oni bez broja mogu izgraditi svoju nebrojivost ideološki nekompatibilno s onim što bismo Rancière ili ja politički zagovarali (npr. u fašističkom pravcu). “ Čini nam se da su kritiku prouzrokovale dijelom terminološke razlike, a dijelom različito postavljeni naglasci istraživanja. Politika za Rancièrea doista jest isključivo emancipacijski fenomen, no za razliku od onoga kako je definira Laclau, ona obuhvaća tek (razmjerno rijetke) aktivnosti što rastaču određeni policijski poredak, ne i rekonfiguraciju elemenata u novi poredak. Da takva rekonfiguracija nužno slijedi, Rancière se slaže, no smatra je uspostavljanjem (novog) policijskog poretka. Odatle i neke oprečne reakcije Laclauovim: dok ga Laclau očito smatra pretjerano optimističnim, autori poput Bitija (2014: 290) ili Felthama (2016: 62-63) prikazuju ga po tom pitanju pesimistom. Što se tiče naravi bilo kojeg policijskog poretka, pa tako i onog koji slijedi nakon neke političke aktivnosti, Rancière (2015:36) jasno napominje da ,/p/ostoji manje dobra i bolja policija (...) Policija se može pobrinuti za sve vrste dobara, a jedna policija može biti beskrajno poželjnija od druge. Time se ne mijenja njezina narav, a ovdje nas zanima samo ona. (...) Policija može biti blaga i ljubazna. Ali ona ne ostaje ništa manje suprotnost politike..." Jednako tako kao što policijski poredak ne ocjenjuje kao progresivan ili ne, već ga zanima samo njegova forma, ni emancipacijska dimenzija politike nije za njega emancipacijska u smislu pripadnosti nekoj velikoj emancipacijskoj pripovijesti, već naprosto svojom formom: „Politika ne posjeduje sebi svojstvene objekte i pitanja. Ni njezino jedino načelo, jednakost, nije joj vlastito i nema ništa političko po samome sebi. (...) Ono što tvori političku narav neke akcije nije objekt ili mjesto njezina prakticiranja nego isključivo njezina forma, forma koja u uspostavljeni spor, u zajednicu koja postoji samo po svojoj podjeli, upisuje potvrdu jednakosti.“ (isto: 37 )

${ }_{117}$ Rancière (2015: 11) navodi kako se dinamika nesuglasnosti smješta između krajnosti pokušaja da se svakom izrazu odredi njegovo „pravo“ značenje i potpunog rasapa komunikacije, na terenu „gdje se filozofija susreće s poezijom, politikom i mudrošću čestitih trgovaca“, u situaciji u kojoj diskursi moraju preuzimati riječi drugih kako bi i sami rekli nešto drugo, tj. terenu ispreplitanja različitih registara i diskursa, na kojem, laclauovski rečeno, nema doslovnih značenja, nulte razine figuralnog, već samo prisile na trop. U nedostatku nulte razine figuralnosti, preduvjet je bilo kakve polemike makar provizorno utemeljenje, hegemonijska artikulacija obvezujuće (kvazi)univerzalnosti. No to priznanje referentne točke „ne dopušta razdvajanje racionalnog poretka argumentacije od poetičkog poretka, ako ne i od iracionalnog, komentara i metafore." (isto: 58) S obzirom na to, razvidna je paralela između Rancièreove nesuglasnosti oko značenja te Laclauova spora oko praznog označitelja. Logiku nesuglasnosti valja dovesti u svezu i s Laclauovom teoretizacijom antagonizma kao odnosa koji nije naprosto ni proturječje ni stvarna opozicija (ni A vs. B, ni A vs. ne-A), već rasjed što ukazuje na nemogućnost društva da zaokruži i objektivizira svoj poredak; takva granica između dvaju aktera koja s pozicije jednog priječi punu realizaciju identiteta onog drugog. Usp. Laclau, 2014: 113. 
primjera pokazuje kako prisutnost dijela zajednice koji nema vlastito mjesto, svojstvo ni način za reprezentaciju, ali se baš zato izjednačava s univerzalnim, s kojim je nesumjerljiv, izaziva opetovano afirmiranje jednakosti i posljedične rekonfiguracije poretka nužne za demokratsko društvo $^{118}$. Istovremeno, naličje te demonstracije ponovno prokazuje sve političke subjekte kao rezultat tropološke artikulacije, a ne odraz nekog objektivnog svojstva ${ }^{119}$.

No pored toga što se pokazalo da je politika i kod Rancièrea stvar tropološke artikulacije ovisne o inicijalnim katehretičkim ulaganjima, makar on to ne formulira eksplicitnom retoričkom terminologijom poput Laclaua, te da su segmenti njegove političke teorije kojima smo se pozabavili velikim dijelom analogni Laclauovoj teoriji hegemonije, ostaje pitati se o drugim poveznicama književnog i političkog u Rancièreovu opusu koje proizlaze iz retoričke naravi političkog polja, premda na nju nisu ograničene.

$\mathrm{Za}$ početak, komplementarna ranije spomenutoj Laclauovoj tezi o širem značenju literarnosti (usp. Laclau, 2014: 79) pokazuje se Rancièreova tvrdnja o demokratskom iskustvu kao iskustvu estetske politike, odnosno o zoon politikonu kao literarnoj životinji. „Čovek demokratije“, piše Rancière (2012a: 73), „biće je govora, to jest, takođe poetsko biće koje je u

${ }^{118}$ Usp. navod da bi ,/d/emos mogao da ne bude ništa drugo do kretanje kojim se mnoštvo oslobađa udesa težine koji mu dodeljuje telo kao okhlos, u bezbenosti svog utelovljenja po slici celine“ (Rancière, 2012a: 51), kao i da ,/p/roleteri nisu ni manualni radnici niti radničke klase. Oni su klasa neubrojenih koja postoji samo u deklaraciji s pomoću koje se broje kao oni koji nisu brojani. Ime proleter ne definira ni nekakav skup vlastitosti (...). To ime pripada subjektivacijskom procesu koji je istovjetan procesu izlaganja onog krivog." (Rancière, 2015:42-43) Rancière na tom tragu zamjera i marksističkoj tradiciji da se zapetljala u homonimiju pojma proleter - da ga je $\mathrm{s}$ jedne strane afirmirala kao odrednicu čistog neimanja mjesta, a s druge strane pretvorila u klasu. Utoliko nam se čini promašena druga od dviju Laclauovih kritika Rancièrea, koja se tiče navodnog ,sociološkog ustupka“ (Laclau, 2005: 248) što ga Rancière čini pri definiranju radničke klase kao ne-klase. Bez obzira na jedno Rancièreovo ambivalentno apostrofiranje Marxa, na koje se Laclau poziva, iz čitavog je njegova opusa prilično jasno da na proletarijat gleda kao na deklasifirajući pojam, a ne historijski konkretnu, esencijalistički određenu klasu.

Jednako tako za njega ni ,/d/emokracija nije parlamentarni poredak niti pravna država. Ona nije ni neko društveno stanje, carstvo individualizma ili masa. Općenito gledano, demokracija je način subjektivacije politike (...). Točnije, demokracija je ime za jedinstveni prekid tog poretka raspoređivanja tijela u zajednicu koje smo pokušali konceptualizirati proširenim pojmom policije.“ (isto: 91) Odnosno: „Demokratija nije ni konsenzualna samoregulacija pluralnih strasti mnoštva individua, niti je vladavina kolektiviteta unifikovanog zakonom u senci dveju deklaracija o pravima. Demokratije u nekome društvu ima u onoj meri u kojoj demos u njemu postoji kao moć podele okhlosa." (Rancière, 2012a: 51) Utoliko je, smatra Rancière (2015: 88), liberalna ideja konsenzualne demokracije proturječje, jer se demokracija odnosi upravo na destabilizaciju konsenzusa.

${ }^{119}$ Kako Rancière (2015: 84) podcrtava, ,, /s/ubjekt u politici nije konzistentno tijelo, on je privremeni čimbenik koji ima svoje momente, mjesta, prilike i kojemu je svojstveno da izumljuje, u dvostrukom smislu, logiku i estetiku tih termina, argumente i demonstracije, kako bi ne-odnos postavio u odnos i napravio mjesto za nemjesto.“ Odnosno, kako drugdje pojašnjava, logika političke subjektivacije uvijek je logika drugosti s tri aspekta te drugosti: nužno je poricanje nekog vlastitog imena koje prišiva policija, jer je politika uvijek politika nevlastitih imena, zatim obraćanje nekome i dokazivanje u odnosu na nekoga (ali ne habermasovski konsenzus!), te konačno nemoguća identifikacija. (isto, 2012a: 92) Utoliko ,/k/lasna borba nije tajni pokretač politike ili skrivena istina iza političkih pojavnosti. Ona je politika sama, politika, uvijek već tu, s kojom se susreću oni koji zajednicu žele utemeljiti u njezinom arche. No smisao toga nije to da politika postoji zato što društvene grupe ulaze u borbu zbog svojih divergentnih interesa. Iskrivljenje zbog kojeg postoji politika također je i iskrivljenje koje uspostavlja klase kao različite od njih samih.“ (isto, 2015: 27) Usp. to s tezom Laclaua i Mouffe (2014: xixii) kako nije klasni interes ono što konstituira klasu, nego je diskurzivna artikulacija klase ono što za posljedicu ima klasni interes. 
stanju da reči odmakne od stvari, da napravi razmak koji nije opsena ili varka, već čovečnost sposobna da preuzme nerealnost predstave.“ Elementarna jednakost u jeziku, međurazumljivost nužna za dijeljenje pravila, istovremeno je i uvjet svakog poretka i ono što ga prerasta i podriva (Rancière 2015: 25); politika upisana kao nagrizajuća jednakost „u srcu policijskog poretka“ (isto: 26,37 ). Upravo to omogućuje da „/m/oderna politička životinja“ bude ,prije svega literarna životinja koja je uhvaćena u krug koji razvrgava odnose između poretka riječi i poretka tijela koji su određivali mjesto svakoga.“ (isto: 41)

Nadalje, Rancièreovi zaključci da je politika - kao pitanje položaja govorećeg tijela u zajedničkom prostoru, koji određuje ubrojivost ili neubrojivost govora - prije svega spor oko podjele osjetilnog, odnosno postojanja zajedničke scene (Rancière 2015: 33), nužno ga dovode do propitivanja povezanosti politike i estetike te tvrdnje da je ,politika estetska u svome načelu.“ (isto) Pitanje koje se potom nameće, a u izravnoj je svezi s prethodnim izjednačavanjem političke i literarne životinje, jest kakav je učinak autonomizacija moderne estetike, naročito institucionalizacija (moderne) književnosti, ostavila na politici ${ }^{120}$. Time se otvara domena istraživanja ne više samo literarnosti politike, nego i politike književnosti te međusobne povezanosti tih dviju komponenti. Radi se o pitanju do čijeg je ruba došao Laclau, no na njega nije eksplicitno odgovorio.

Rancière je to pitanje načeo već u okviru prethodno analiziranih političkoteorijskih studija, ističući još u Na rubovima političkog (2012a: 145) da je „književnost način govora koji ruši podelu između stvarnosti i fikcije, poetskog i proznog, svojstvenog i nesvojstvenog“, povezujući to s umnožavanjem mnoštva koje ruši sankcionirane poretke te dodajući da ,/z/a taj i takav način postojanja nema mesta u podeli svojstava i tela“, zbog čega književnost nužno „uvodi disenzus, unosi nemir u naše opažajno iskustvo, u odnos izrecivog i vidljivog.“ (isto: 146) ${ }^{121}$ Disenzualna narav književnosti ujedno je povezuje s demokracijom kao opetovanom afirmacijom jednakosti razdjelovljivanjem zajednice i odjeljivanjem riječi i tijela. No kakva je točnije narav te sveze, Rancière je odgovorio tek u studijama koje su uslijedile premještajući njegov interes sve naglašenije u pravcu estetike.

\footnotetext{
${ }^{120}$ Riječ je o pitanju komplementarnom onom o odnosu historije i devetnaestostoljetnih romantičarskih književnih tendencija, za koje Rancière smatra da su imale presudnu ulogu za mogućnost historije kakvu danas poznajemo, kao što smo prethodno već spomenuli. Usp. ponovno Rancière, 1994: 54.

121 Činjenica da književnost, prema Rancièreu, nužno „uvodi nemir u opažajno iskustvo“ zapravo je posljedica drugog svojstva koje joj pripisuje - toga da se ne može razlučiti od svog dokazivanja te stoga mora opetovano ponavljati to dokazivanje, činiti nešto izuzetno (usp. Rancière, 2012b: 146). Riječ je o svojstvu usporedivom $\mathrm{s}$ onim koje književnosti pridaje i Derrida; usp. Derrida, 1992: 229. Na tragu toga možemo zaključiti nešto više i o tome kakvom paradigmom književnosti barata Rancière u citiranom tekstu (pri čemu valja imati na umu da se od teksta do teksta pojavljuju razlike!), odnosno u najmanju ruku reći da takvim tvrdnjama afirmira i očuđenje kao srž književnosti.
} 
Čitavu problematiku vjerojatno najjezgrovitije sažima dobro poznata Rancièreova (2008: 7) uvodna teza studije Politika književnosti [Politique de la littérature, 2007] da politika književnosti „nije politika pisaca“, to jest da se ne odnosi na njihov osobni politički angažman, pa čak ni na pisanje o političkim strukturama i subjektima, već se pod tim izrazom „podrazumijeva da se književnost bavi politikom ostajući književnost“, i to tako što „učestvuje u preraspodeli prostora i vremena, vidljivog i nevidljivog, govora i buke“, „utiče na odnos između praksi, između oblika vidljivosti i između načina kazivanja koji deli jedan ili više zajedničkih svetova.“ (isto: 8). Pa ipak, ta poveznica između književnosti i politike, koju vrlo jasno naziva suštinskom (isto: 7), nerijetko se shvaća suviše plošno i mehanički.

Svoju disenzualnu narav književnost, u suvremenom institucionaliziranom značenju, prema Rancièreu prije svega duguje smjeni tzv. režima umjetnosti, točnije zamjeni reprezentacijskog ili poetičkog (aristotelijanskog) režima, što ga karakterizira reguliranost tema i načina dolične reprezentacije povezane s normama određene zajednice, estetičkim režimom što umjetnost oslobađa bilo kakve hijerarhije tema i oblika ${ }^{122}$. U temelju takvog dokidanja hijerarhije reprezentacije nalazi se literarnost, za koju Rancière (2008: 18) kaže da „nije nikakvo naročito svojstvo književnog jezika“, već „radikalna demokracija pisma koja je svakome na dohvat ruke“, odnosno još od Platonova Fedra poznat fenomen lutajućeg, osiročenog pisma što narušava legitiman poredak diskursa i tijela, sankcioniranu harmoniju bivanja i djelovanja u zajednici. Stoga ne iznenađuju Rancièreove tvrdnje - analogne Laclauovu (2014: 79) poopćavanju literarnosti ${ }^{123}$ - da je tako definirana literarnost upravo središnji princip opetovane preraspodjele osjetilnog što je naziva demokracijom, odnosno generičko ime za demokratski „,poremećaj“ svakog ethosa i nomosa zajednice (usp. Rancière, 2011b: 95, 2004b: 103), kao i da je nastupanje estetičkog režima umjetnosti u uskoj svezi s demokratizirajućim društvenim promjenama u svom kontekstu.

\footnotetext{
${ }^{122}$ Više o pojedinim režimima usp. u Rancière, 2006: 22 i Rancière, 2011b: 44.

${ }^{123}$ Dva poopćavanja mogu se činiti dijametralno suprotnima, budući da Laclau (2014: 79) proučavanje poopćene literarnosti naziva „studijom iskrivljujućih učinaka što ih reprezentacija ostavlja na bilo kojem referentu“, dok je kod Rancièrea u prvom planu naizgled suprotna dimenzija disrupcije nekog utvrđenog modusa reprezentacije. No ti pristupi dvije su strane iste medalje: proučavati (neizbježne) iskrivljujuće učinke u okvirima bilo kojeg diferencijalnog sustava moguće je samo uz svijest o apsolutnoj jednakosti koja prethodi tom sustavu i ostaje nepremostiva pukotina u njegovu središtu (usp. Rancière 2015: 25,37), kao što se i disruptivna narav literarnosti opaža tek na podlozi nekog prethodno uspostavljenog diferencijalnog sustava koji podriva. Tome vrijedi dodati da i Rancière (2011b: 53) primarnu ulogu u osiguravanju ekvivalencije među dijelovima jezika pridaje metafori, kao „samom principu poetičnosti“. Nešto kasnije primarnost tropa naglašava i tvrdeći da je „trop razlika između jezika i sebe, poveznica između prostora riječi i prostora onoga što one kažu.“ (isto: 146) Usporedimo li na tom tragu i Rancièreovu tezu o demokraciji kao „topografiji inzularne zajednice pisma“, koja je ,'prazan', 'apstraktan' prostor koji dijeli moć nekolicine dostupnih riječi: naroda, jednakosti, slobode itd. Također je to i kretanje kojim te riječi zarobljavaju i skreću s njihova namjeravanog puta ljude koji se nisu zanimali za bavljenje logosom ili zajednicom..." (Rancière, 2004b: 104), s oblikovanjem ekvivalencijskih lanaca nadsvođenih praznim označiteljima u Laclauovoj teoriji hegemonije, iako su razlike u stilu izlaganja prilične, sadržajna su preklapanja sasvim jasna.
} 
Ipak, ne samo da se radi o vezi koja je dvosmjerna ${ }^{124}$, nego ni njezini učinci nisu uvijek jednoznačni. Nasuprot simplificiranim viđenjima odnosa između pojedinih režima umjetnosti te između književnosti utemeljene na načelu demokracije pisma i različitih demokratskih kretanja u društvu, Rancière ističe nekoliko važnih stvari.

Kao prvo, različiti režimi umjetnosti ne smjenjuju jedni druge u potpunosti i trajno. Naprotiv, ne samo da mogu koegzistirati u istom historijskom kontekstu, nego se njihova načela mogu ispreplitati i $u$ istom književnom djelu. Rancière (2011b: 147) tako već na počecima razrade koncepta umjetničkih režima, u studiji Nijemi govor [La Parole muette, 1998], napominje da je paradoksalno upravo roman književna forma koja je s jedne strane zaoštrila kontradikcije između reprezentacijske i estetičke paradigme, dok s druge strane isti antagonizam najuspješnije i neutralizira, smatrajući da do tog pomirenja ponajbolje dolazi u naturalističkom romanu. U kasnijoj pak studiji Izgubljena nit [Le Fil perdu, 2014] kao primjer nužnosti povezivanja dviju oprečnih logika ističe Flauberta (usp. Rancière, 2017: 24); istog autora koji mu iz studije u studiju služi kao paradigmatski primjer estetičkog režima.

Nadalje, jednako je važno osvijestiti si i da opreka između estetičkog i reprezentacijskog režima umjetnosti nije analogna onoj između progresivnog i reakcionarnog/konzervativnog pokreta ili društvenog uređenja u nekom trenutku (i, dakako, iz određene perspektive). Skladno tijelo umjetničkog djela što poštuje pravila prikladnosti tema i načina reprezentacije te tako u okvirima reprezentativnog režima odražava sklad ethosa i nomosa neke zajednice može se jednako referirati, napominje Rancière (2011b: 49), na „hijerarhijski poredak monarhije kao i na egalitarni poredak republikanskih govornika.“125

S druge strane, umjetnički ostvaraji u okvirima estetičkog režima, utemeljenog na fundamentalnoj demokraciji pisma, ne samo da također nisu jednoznačno demokratični nego su i izbrazdani nekolicinom proturječja. Temeljno proturječje koje obilježava čitav režim jest

\footnotetext{
${ }^{124}$ Kao što Rancière (2004b: 10) napominje, pravila reprezentacijskog režima bila su jasno povezana $\mathrm{s}$ određenim društvenim poretkom, iz čega slijedi da i njihovo podrivanje nije događaj bez reperkusija i izvan usko shvaćenog književnog polja. No istovremeno opravdano postavlja i pitanje - nije li ,za emancipaciju lirskog subjekta u odnosu na stari poetičko-politički okvir bio nužan i novi oblik političkog iskustva“. Usp. sličnu dvojbu implicitnu i u kasnijoj Izgubljenoj niti (Rancière, 2017: 20) te nešto konkretniju raspravu o aisthesisu kao kompleksnom osjetilnom tkanju koje uključuje i sasvim materijalne čimbenike, kao i modele percepcije, režime emocija, dostupne kategorije itd., te pitanje o povezanosti svega navedenog s političkim pretpostavkama $\mathrm{i}$ ostatkom historijske pozadine u Aisthesisu (Rancière, 2013: X-XVI). Utoliko nisu u potpunosti točne kritike da Rancière potpuno izdvaja književnost iz podjele osjetilnog, poput one Bitijeve (2014: 300), no činjenica jest da se pitanjem policije književnosti ne bavi ni približno koliko njezinom politikom, što takvim kritikama daje na opravdanosti.

${ }^{125}$ Rancière (2011b: 49) ne ostaje tek na općenitoj tvrdnji, već nudi i primjer. Kako navodi, „upravo iz toga proizlazi stalna suradnja u devetnaestom stoljeću između starih vlasulja akademije i radikalnih republikanaca kako bi zaštitili taj [reprezentacijski] sustav od inovativnih littérateura, savez što ga, nasuprot Hugoove kao i Mallarméove percepcije, predstavlja ime Ponsarda, posve republikanskog autora starih tragedija.“
} 
ono između potpune indiferentnosti i apsolutizacije jezika ${ }^{126}$, pri čemu bi dovođenje do krajnosti jednog od polova te opreke, na kojima počiva specifičnost književnosti kao institucije u novom režimu umjetnosti, ujedno značilo i njezinu disoluciju, zbog čega književnost postoji samo u napetosti između njih.

Daljnja pak proturječja izlaze na površinu na mjestima susreta novog režima književnosti s drugim utjelovljenjima temeljne jednakosti u jeziku. Djela u kojima do izražaja izričito dolaze načela novog režima, naime, nerijetko nisu najpristupačnija široj populaciji koja demokratizacijom društva ulazi u krug čitatelja lutajućeg pisma. No kada se pripadnici širih slojeva i ubroje u njihove čitatelje, autori tim nuspojavama lutajućeg pisma nisu baš oduševljeni. Kako Rancière (2011b: 90-91) primjećuje, „oni što su se brinuli glede invazije [radništva, siromašnih] u hram umjetnosti nisu bili Aristotelovi vjerni sljedbenici, oni koji su zadržali uvjerenje u odvojenost žanrova i načelo prikladnosti. Naprotiv, bili su to zagovornici nove poetike - zagovornici poezije bez granica koja ujedinjuje rad nadahnutog pjesnika i pjesmu u kamenu anonimnog naroda.“ Flaubertov apsolutni stil i afirmacija potpune indiferentnosti tema i oblika dijametralno su suprotni njegovim otvoreno proklamiranim aristokratskim pogledima (usp. Rancière, 2017: 15), a Hugo i Balzac, također reprezentativni predstavnici novog umjetničkog režima, svojim su zapletima otvoreno stajali uz zlatno pravilo platonske republike da se svatko treba baviti svojim poslom (usp. Rancière, 2011b: 92).

Ipak, kao što je jedna od opsesivnih tema književnosti u estetičkom režimu postala nemogućnost voljnog racionalnog predviđanja rezultata nekog djelovanja (usp. Rancière, 2017: 19), tako se ni intencije spomenutih autora nisu uvijek preklapale s postignutim učincima. U Flaubertovim su djelima primjerice, napominje Rancière (2011b: 125), već njegovi suvremenici uočavali demokratske aberacije, premda će kasnija kritika (među ostalima i Sartre) u istim segmentima prepoznavati aristokratske impulse, dok će Rancièreove interpretacije (npr. Madame Bovary) oscilirati između naglašavanja elemenata romana što afirmiraju dehijerarhizaciju prikazivanja i ukazuju na neimanje mjesta u društvu, te onih što su rezultat zabrinutosti nepredvidivim posljedicama takve dehijerarhizacije.

Bez obzira kojoj od tih interpretacija bili bliži, odnos politike književnosti i drugih političkih fenomena očito je nemoguće zahvatiti jednostavnom formulom. Kao što Rancière u Politici književnosti (2008: 45) piše:

književna populacija predstavlja drugačiju mernu jedinicu od demokratske populacije, drugačiji oblik individualnosti koji nije više molaran već molekularan. „Ljudsku“ individualnost, definisanu kao jedinstvo tela i duše koja ga pokreće dajući čoveku opštu formu

\footnotetext{
${ }^{126}$ Usp. Rancière (2011b: 50). U više svojih studija Rancière kao prototipan primjer prvog uzima Flauberta, a potonjeg Mallarméa.
} 
i naročit način izražavanja i držanja zamenjuje „predljudska“ individualnosti koja je rezultat neujednačenog mešanja atoma, spoja vlati trave, vrtloga prašine, sjaja nokta, sunčevog zraka, koji su sastojci onoga što se u običnom životu i tradiciji predstavljanja stvari prenosi u osjećanja i mišljenje ljudi.

Ta razlika molekularnog i molarnog, na kojoj Rancière u kasnijim studijama sve više inzistira $^{127}$, ključan je razlog nemogućnosti jednostavne prevodljivosti politike književnosti u dijalektiku policijskog i političkog izvanknjiževnog. Ili, kako kasnije napominje: „Politika radi na celini, a književnost na pojedinačnim celinama“ (isto: 47), odnosno „/p/olitički disenzus se odvija u vidu procesa subjektivacije koji poistovećuje izjavu nekog kolektiva anonimnih ljudi, nekih nas, sa rekonfiguracijom polja predmeta i političkih aktera“ (isto: 49), dok književnost rastače pozicije tih aktera u „spletu percepta i afekta anonimnog života“, $u$ „dvostrukoj sceni neme reči“ - u krupnijem i sitnijem mjerilu od molarnih aktera društvenog života. Drugim riječima, „književni nesporazum teži da se udalji od služenja političkoj neslozi. On ima svoju politiku, odnosno sebi svojstvenu meta-politiku. S jedne strane književnost čita znakove napisane na telu, s druge, ona telo razrešava značenja koja hoće da mu natovare.“ (isto)

Neki kritičari, poput Bitija (2014), Felthama (2016) i Murpheta (2016) skloni su pristupe politici i književnosti u Rancièreovu opusu promatrati mnogo oštrije razgraničeno, pa tako npr. Biti (2014: 299) piše da Rancière „odvaja književnost od politike i između njihovih oblika jednakosti uspostavlja ne samo tenziju ili konflikt, kako sam tvrdi, nego i binarnu opoziciju“, a potom i da ,pažljivo odvaja sveobuhvatan modernistički umjetnički otpor podjeli osjetilnog (znan kao 'nesporazum') od ograničene političke emancipacije od te distribucije (znane kao 'neslaganje'), kako bi ih nekritički povezao pretvarajući modernistički umjetnički otpor u jedini pravi način političke emancipacije.“ (isto: 302) Slično navodi i Murphet (2016: 217), tvrdeći da je „literarni 'princip jednakosti' postavljen na razinu nesumjerljivu s razinom političke demokracije; jaz otvoren između molarnih tijela i molekularnih intenziteta u konačnici je prevelik da bi ga se premostilo“, pri čemu se kao rezultat takvog stanja stvari sugerira neefikasna, slaba mesijanska politika.

$\mathrm{S}$ obzirom na neravnomjerno raspoređene naglaske $\mathrm{u}$ Rancièreovu opusu kao i povremena proturječja, te kritike svakako nisu bez ikakvog temelja. Ipak, stajalište koje smo izložili bliže je viđenjima tog spornog odnosa npr. u tekstu Murpheta i Hellyer (2016: 13),

\footnotetext{
${ }^{127}$ Usp. npr. Rancière, 2017: 23, 57, 82, 105, 109 itd. i naglašeno ponavljanje motiva rasipanja cjeline na dijelove, raspršenosti fokalnih točaka, podrivanja granica između aktivnosti i pasivnosti, teksta i tijela, unutarnjeg i vanjskog i sl., redom vezano za desubjektivirajuće političko djelovanje književnosti. Također, na primjerima drugih umjetnosti, ali i književnosti, isti su motivi u užem fokusu i u Rancière, 2013.
} 
koji smatraju da disenzualno djelovanje umjetnosti i politike ima svojih razlika i preklapanja, tj. zajednički princip, no različit način i teren njegove aktualizacije, pri čemu su učinci jednog na polju onog drugog (naročito kad se radi o učincima književnosti na molarnopolitičkom polju) potencijalno komplementarni, ali i nepredvidivi ${ }^{128}$. Skrećući pozornost na paradoksalan odnos, prije nego čistu suprotnost, revolucionarnog molarnopolitičkog djelovanja i estetskog nedjelovanja, upućuju nas na Rancièreov navod da će tek

/b/rzopleti umovi nedvojbeno u svemu tome vidjeti nezaliječiv prijelom između estetske utopije i stvarnog političkog i revolucionarnog djelovanja. Nasuprot tomu, smatram da je to isti paradoks kao i onaj što sam ga susreo u praksama i teorijama društvene emancipacije. Emancipirani radnici nisu mogli odbaciti hijerarhijski model što je upravljao raspodjelom aktivnosti bez udaljavanja od mogućnosti djelovanja koja ih je podredila njemu te od planova djelovanja inženjera budućnosti. (Rancière, 2013: xv)

No možda je ipak manje stvar u brzopletosti, a više u različitim interpretacijama ponekad neodlučivih Rancièreovih tvrdnji, kao i promjenjivosti njegove terminologije i širine postavljenog istraživačkog fokusa. Kritike Rancièrea za potpuno odvajanje politike književnosti i „opće“ politike, ili pak za konačno podređivanje potonje prvoj (a te su kritike, paradoksalno, najčešće povezane) uglavnom se primarno oslanjaju na kasnije Rancièreove studije posvećene prvenstveno različitim fenomenima književnosti ili drugih umjetnosti realiziranih u okviru estetičkog režima, dok njegove ranije studije ostaju u pozadini. To za posljedicu ima nekoliko stvari. Kao prvo, pojam politike (pa i demokracije) upotrebljava se ponekad u mnogo širem opsegu nego što ga upotrebljava Rancière u svojim ranijim studijama, zbog čega pojedine tvrdnje o odnosu politike i emancipacije, ovisno o nejasnoj širini referenta, više ili manje stoje ${ }^{129}$. Nadalje, zaboravlja se na ranije Rancièreovo razlikovanje između literarnosti i književnosti kojim smo se ovdje prethodno pozabavili. No ponajviše, iz vida se ispušta supostojanje više različitih režima umjetnosti i njihovo međusobno prožimanje u pojedinim djelima, odnosno nehomogenost književnosti ${ }^{130}$.

\footnotetext{
${ }^{128}$ Usp. i Rockhillov predgovor engleskom izdanju Nijemog govora (Rancière, 2011b: 24) u kojem se slaže oko podudarnosti u principu jednakosti na dvama spornim poljima, no isto tako jasno navodi i da apsolutna jednakost u književnosti „,može i inhibirati demokratsku jednakost u pravom smislu te riječi.“

${ }^{129}$ Radi se o problemu analognom onom koji se pojavljuje i u Laclauovoj kritici Rancièrea, elaboriranom u jednoj od prethodnih bilježaka.

${ }_{130}$ Npr. Biti (2014: 302) tvrdi da je ,hijerarhija prethodnog reprezentativnog režima definitivno dokinuta Kantovim inzistiranjem na singularnosti umjetnosti...“, kao i da „brišući isključenje drugih vrsta književnosti iz predstavljanja 'populacije', Rancière povezuje ekskluzivnu 'estetičku' književnost, koja monopolizira univerzalnost, s inkluzivnom virtualnom zajednicom“, te da je prema Deleuzeu i Rancièreu „književnost koja ne preoblikuje unutrašnjost subjekta i ne zauzima stranu potisnutih emancipacijskih snaga, nevrijedna svog imena“ (isto: 290) Te tvrdnje čine se na mjestu ograničimo li pozornost prvenstveno na novije Rancièreove studije, u kojima se gotovo isključivo bavi estetičkim režimom umjetnosti i učinkom pojedinih djela ostvarenih u njemu, pa čak i u odnosu na činjenicu da daleko veći udio razmatranja umjetnosti u njegovom cjelokupnom opusu odlazi na tu problematiku. No kao što smo prethodno već istaknuli, Rancière ipak ne smatra starije umjetničke
} 
Pojednostavljeno rečeno, uzmemo li sve u obzir, čini se da zaključak možemo formulirati na sljedeći način: umjetnost koja nastaje u okvirima estetičkog režima nesumnjivo podriva i preoblikuje neki aktualni poredak osjetilnog, te je stoga - sukladno Rancièreovoj definiciji politike - politična, no utjecaj tog preoblikovanja ne odražava se nužno izravno i jednoznačno na razini sukoba dionika zajednice oko broja dijelova zajednice i podjele onog zajedničkog. Dapače, umjesto svrstavanja uz neku poziciju unutar spomenutog sukoba, ona često razgrađuje te pozicije; umjesto sudjelovanja $u$ subjektivaciji, $u$ pravilu djeluje desubjektivirajuće, no to desubjektivirajuće djelovanje može biti upravo ono koje otvara prostor u poretku vidljivosti za neke nove subjektivacije. S druge strane, umjetnički ostvaraji u okvirima starijih režima, s kojih Rancière u kasnijim studijama u potpunosti premješta fokus, uspostavljajući analogiju između vlastitog tijela i tijela neke zajednice osnažujuće djeluju na njezinu koherentnost. No pritom ne valja zaboraviti dvije prethodno spomenute stvari koje usložnjavaju sliku: zajednica o kojoj je riječ može biti različite naravi, a pojedini umjetnički režimi nisu monolitni i međusobno se ne isključuju.

Konačno, vratimo li se na tren na općenitiju razinu, u Izgubljenoj niti Rancière (2017: xxxiii) govoreći o pojmu fikcije jasno podcrtava kako njime zahvaća mnogo širi spektar fenomena od same književnosti te da ga uopćeno zanima kako ona „konstruira situacije, okuplja populacije, uspostavlja odnose uključenosti ili isključenosti, ocrtava ili briše granice između percepcije i djelovanja, stanja stvari i kretanja misli; uspostavlja ili dokida relacije između situacija i njihovih značenja, temporalnih supostojanja ili sljedova i lanaca kauzalnosti.“ Ništa od toga, napominje, nije ekskluzivno vezano za književnost, no književnost svojom osobitom naravi pogodno razotkriva ono što je u drugim paradigmama skriveno u pozadinu. Bilo da se radi o ,aristotelijanskim pravilima fikcije što podupiru principe koje svojataju realističko političko djelovanje, društvene znanosti i komunikacija u medijima“ (isto: xxxiv), bilo da se radi o ,remećenju tog fikcionalnog poretka kako bi se omogućilo misliti nove odnose između riječi i stvari, motrenja i djela, ponavljanja prošlosti i projekcija budućnosti, osjećaja realnog i mogućeg, nužnog i vjerodostojnog, od kojeg su oblici društvenog iskustva i političke subjektivacije izvezeni.“ (isto) ${ }^{131}$ Time Rancière

režime posve dokinutim, niti umjetničke režime općenito smatra monolitnim te, dapače, daje primjer njihova prožimanja i u nekim djelima koje itekako smatra vrijednima imena književnosti. Osim prethodno navedenog u ovom poglavlju, usp. o tome još i Murhphet, Hellyer; 2016: 4 te Rancière, 2011b: 15-16.

${ }^{131}$ U kontekstu rasprave o postmarksizmu značajno je istaknuti da kao primjer fikcije Rancière na više mjesta uzima i različite marksističke teorijske konstrukte, tim zanimljivije iz njegove perspektive s obzirom na to da se predstavljaju kao oni koji rasplinjuju fikciju. U Politici književnosti (2008: 27) piše: „Kritičari XX. veka verovali su, u ime marksističke i Frojdove teorije, sociologije i istorije ustanova i običaja, da mogu da demistifikuju književnu naivnost i iskažu njen nesvesni diskurs, pokazujući kako je ta fikcija nesvesno kodirala zakone društvene strukture, stanje borbe između klasa, tržište simboličnih dobara ili strukturu književnog polja. 
eksplicira što smo o osobitoj ulozi književnosti po pitanju činjenja manifestnim onoga što je drugdje latentno već spomenuli vezano za Laclaua.

Podvučemo li stoga naposljetku crtu pod do sada izloženo i dovedemo li još jednom sumarno u suodnos Laclaua i Rancièrea, ne samo da možemo zaključiti da se radi o nedvojbeno kompatibilnim, dapače po ključnim postavkama vrlo sličnim teorijskim pristupima, bez obzira na nezanemarive razlike u načinu izlaganja i dosadašnjoj recepciji, nego i o teoretičarima koji se izvrsno međusobno nadopunjuju. Od Laclaua smo u takvom suodnosu dobili nešto sistematičniji uvid u ono što bismo mogli nazvati literarnošću politike ili pak, njegovim riječima, retoričkim temeljima društva. Svi ključni topoi tog (središnjeg) dijela Laclauova opusa potvrđuju se, naime, i kod Rancièrea, premda nešto drukčije formulirani s obzirom na različit rakurs njihovih pristupa. No ni terminološka razlika nije potpuna; kao što smo vidjeli, u Rancièreovoj političkoj teoriji ne samo da se mogu prepoznati elementi strukturno identični Laclauovu tropološkom repertoaru, već ih povremeno eksplicitno i oslovljava retoričkim terminima, odnosno imenuje kao trope. Rezonancija s Laclauom stoga pojačava taj aspekt Rancièreove teorije i usmjerava na njega dodatnu pozornost.

S druge strane, ako za Laclaua možemo reći da doprinosi boljem razumijevanju literarnosti politike kod Rancièrea, jednako tako možemo reći da Rancièreov rad svojim uvidima o politici književnosti te o odnosima između politike književnosti i literarnosti

Međutim, isti ti kritičari koristili su eksplikativne modele same književnosti da bi rekli istinu o književnom tekstu.“ Slično u Izgubljenoj niti (2017: xxxii) kritizira pokušaj ,političkih“ interpretacija koje svode raznolike postupke Flauberta, Baudelairea, Conrada, Prousta, Woolf ili Joycea na jedan jedini uzrok - oblik robe što prikriva ljudski rad. Takvo utjecanje reifikaciji smatra „objašnjavanjem fikcije naprosto još jednom fikcijom“. Tome pak nasuprot pokazuje i kako je rana marksistička znanost - sudjelujući u trendu ,bankrota strateške akcije“, tj. „odbacivanja shema strateškog djelovanja usklađivanjem sredstava i ciljeva“, u vremenu iznicanja estetičkog režima i njegovog potkopavanja reprezentacijskog režima - ,prije nego što je povezala sredstva djelovanja s demonstracijom znanja, (...) izjednačila je revolucionarno ostvarivanje ljudske biti s dokidanjem odvojenosti sredstava i ciljeva." (isto: 20 )

Biti (2014: 301) smatra da Rancière pri tako formuliranoj kritici zadržava figu u džepu, budući da se i struktura njegovih argumenata jednako tako ,čini nepogrešivo 'romanesknom'“, što nalikuje na Bowmanovu (2007) kritiku Laclaua da dekonstrukcijski instrumentarij uperen prema drugima ne primjenjuje na vlastitu poziciju. Nešto benevolentniji prema Rancièreu po tom je pitanju Méchoulan (2016: 45), koji smatra da Rancièreovo pismo ne ide za dosezanjem istine prisutne duboko ispod pričina, već je „kretanje aktivne interpretacije, ne zamjena jednog pričina drugim kao legitimnom istinom, već nesigurna avantura čitanja u šumi znakova.“ Kojem god od ovih viđenja bili bliži, kritika da Rancière vlastitu poziciju izuzima od onoga što primjenjuje na drugima svakako je više opravdana nego druga slična Bitijeva kritika, ona da književnost (po Rancièreovu viđenju) „uzurpira slobodu isključivo za sebe, dok druge izručuje ne-slobodi.“ (Biti, 2014: 294) Kao što je iz gornjih navoda vidljivo, Rancière ipak tvrdi da su i policijska i politička kretanja karakteristična za sve fikcije, ne samo za književnost. To da je ispreplitanje tih procesa u književnosti mnogo vidljivije, rezultat je specifičnosti književnosti kao tipa diskursa, što nije ekskluzivno Rancièreov uvid, i što se teško može smatrati superiornim položajem, budući da je iste specifičnosti, kako je više puta primijetio i kako smo spomenuli, konstantno stavljaju na korak od disolucije. Doduše, kao što se također spomenulo, istina jest da Rancière - naročito u svojim kasnijim djelima - vrlo malo prostora posvećuje zapažanjima poput gornjeg, pa je unatoč njegovim ogradama lako steći dojam da u praksi književnost doista smatra privilegiranom iznimkom. 
politike izvrsno dopunjava manjkavu pokrivenost tog pitanja u Laclauovu radu. Ono što je Laclau dotaknuo tek na marginama svog istraživanja, dijelom i samo instrumentalno ili implicitno, u Rancièreovu se dugom istraživanju pokazuje nimalo marginalnom temom; dapače, čvorištem ključnih pitanja i kritičkih prijepora.

Konačno, područja podudarnosti i komplementarnosti između Laclaua i Rancièrea upravo su oni segmenti njihovih teorija koji su ključni za usmjeravanje kritičke oštrice marksističkog nasljeđa prema aktualno prevladavajućoj liberalnoj paradigmi, ali i za kritiku tog istog nasljeđa iz kojeg su ponikli. Drugim riječima, ono što tu dvojicu teoretičara povezuje, ujedno je i ono što ih čini prepoznatljivima u suvremenoj teoriji, kao i ono što $u$ njihovim očima predstavlja odmak od klasičnog marksizma, ukazujući na zajedničko historijsko iskustvo, ali i zajedničku literaturu koji su taj odmak generirali ili katalizirali.

Usmjeravajući pak pozornost na elemente koji upravo na polju proučavanja književnosti, uz spomenute konvergentne, ocrtavaju i neke divergentne linije između Laclauovih i Rancièreovih istraživanja, $\mathrm{s}$ istim ćemo temeljnim pitanjima na umu suodnosu dvojice teoretičara dodati i trećeg - Gillesa Deleuzea. 


\subsection{Literarnost Deleuzeove politike i problem (ne)dosljednog imanentizma}

Za razliku od Laclaua, čiji je teorijski interes ostao trajno vezan pretežno za procese artikulacije molarnih političkih aktera, Rancière, kako smo spomenuli, u kasnijim (književnoteorijskim/estetičkim) studijama naglasak sve više premješta na molekularnu razinu, na kretanja na njoj što podrivaju stabilnost molarnih formacija, čiste spinozističke intenzitete što umiču totalizacijama. Pod utjecajem kojeg se autora dogodio taj pomak, nije naročita tajna - Rancière bez oklijevanja izravno preuzima Deleuzeove pojmove molarnog $\mathrm{i}$ molekularnog te pojedine prepoznatljive motive njegovih analiza, otvoreno upućujući na njihov izvor. Ipak, bilo bi pogrešno smatrati da je time i općenito usvojio Deleuzeove teorijske postavke, budući da između pogleda dvaju teoretičara ostaju korjenite razlike.

Upravo zbog tih razlika, odnos prema Deleuzeu nije ni jednostavna točka razilaženja između Laclaua i Rancièrea; obojica autora o njemu s jedne strane pišu afirmativno, dok ga s druge strane podvrgavaju kritici. Baš kao i Rancière, Laclau također pronalazi dodirne točke između svojih i Deleuzeovih postavki ${ }^{132}$, no obojica su suglasna i da Deleuzeovo zagovaranje radikalnog imanentizma u određenom trenutku nužno dovodi do zida ${ }^{133}$. Ipak činjenica da Deleuzeov opus pobuđuje interes obojice tih teoretičara nije ekskluzivan ni prvenstven razlog da mu ovdje poklonimo pozornost. Riječ je o teoretičaru koji se kao nezaobilazna postaja ovog istraživanja nameće i svojim osobitim odnosom prema Marxu i marksističkom nasljeđu, kao i značajnom ulogom koju u svome opusu pridaje književnosti.

Kao što napominju Tormey i Townshend (2006: 38), i Deleuze i njegov suautor nekoliko studija Felix Guattari ${ }^{134}$ bili su aktivni, militantni dionici zbivanja 1968. te ih unatoč njihovoj nesklonosti bilo kakvim, a naročito postističkim etiketama - velik broj autora navodi kao paradigmatski primjer postmoderne intelektualne paradigme. No dok su šezdesetosmaška zbivanja, novi problematski horizonti koje su artikulirala te filozofska

\footnotetext{
${ }^{132}$ Usp. npr. Laclau, 2007: 113, gdje Laclau povlači paralele između svog i Deleuzeova viđenja odnosa dijela i cjeline.

${ }^{133}$ Usp. Laclau, 2007: 244 i Rancière, 2004: 163-164. Obje kritike mogu se u srži svesti na problem (nemogućnosti) prelaska s Deleuzeove ontologije mnoštva na neku utemeljujuću politiku zajednice, makar i potpuno egalitarne i bratske. Zanimljivo je primijetiti i da Laclau u svojoj kritici Deleuzea ne upućuje na paralele s Rancièreovom ranijom kritikom, dok je poglavlje koje nakon nje slijedi upravo ono u kojem kritizira Rancièrea, što bi moglo upućivati na razmjerno manjkavu recepciju u podlozi te potonje kritike.

${ }^{134}$ Kao što je dobro poznato, neka od najvažnijih Deleuzeovih djela kojima ćemo se i ovdje baviti nastala su u ravnopravnom i međusobno obogaćujućem suautorstvu s Guattarijem. Činjenica da ćemo se ovdje na ta djela referirati kao na Deleuzeova, na isti način kao i na ona koja Deleuze potpisuje kao jedini autor, ne implicira umanjivanje Guattarijevih zasluga niti pripisivanje dominantne uloge u autorskom dvojcu Deleuzeu. Radi se isključivo o praktičnosti. Riječ je o praksi koja nije neuobičajena u slučaju ove dvojice autora; usp. npr. Bogue, 2003: 8 ili Surin, 2000:167.
} 
gibanja što su u tom kontekstu nastajala izvršili formativan utjecaj na Laclaua i Rancièrea $u$ širem smislu oblikovanja njihovih teorijskih pozicija, ali i konkretnije glede oštrog raskida s (althusserijanskim) marksizmom, kod Deleuzea je situacija nešto drukčija.

Za početak, bez obzira na suprotnu percepciju svog opusa u marksističkim, ali i nemarksističkim krugovima, te posve obrnuto od prethodno spomenutih autora, Deleuze vlastitu filozofsku poziciju eksplicitno karakterizira marksističkom (usp. npr. Deleuze, 1995: 171). No ta marksistička afilijacija nije ograničena samo na deklarativno samoodređenje. Njezina kruna trebala je biti Deleuzeova najavljivana finalna studija Marxova veličina [La Grandeur de Marx], koju naposljetku ipak nije stigao napisati, ali i u ranijim, kapitalnim studijama mnogo je materijala koji može govoriti u prilog tomu. Uz sporadične eksplicitne reference na Marxa $\mathrm{i} / \mathrm{ili}$ istaknute marksiste u npr. Razliici $i$ ponavljanju [Différence et répétition, 1968] (v. Deleuze, 2009b) te Tisuću Platoa [Mille Plateaux, 1980] (v. Deleuze, Guattari 2013), to se ponajprije odnosi na Marxom vrlo snažno prožet L'Anti-CEdipe [1972] (v. Deleuze, Guattari 2015), ali još i više na poveznice s marksističkom paradigmom na općenitijoj i implicitnijoj razini ${ }^{135}$ : činjenicu da Deleuze svoj teorijski rad smatra korjenito materijalističkim, da se znatan njegov dio odnosi na analizu kapitalizma, njegove geneze, anatomije funkcioniranja te mogućnosti bijega/nadilaženja, kao i da središnji pojam u tom segmentu postaje (posve poopćen i u bitnoj mjeri izmijenjen) marksistički pojam proizvodnje $^{136}$.

Ipak, i tek letimično čitanje bilo kojeg Deleuzeova djela dovoljno je za zaključak kako se njegov diskurs, pa tako i njegova inačica Marxa, drastično razlikuje od ma kako širokog spektra onoga što se konvencionalno naziva marksizmom. Način na koji se oblikuje Deleuzeov Marx s jedne je strane tako vrlo sličan, a s druge oprečan onome kako pri aproprijaciji marksističke tradicije postupaju Laclau i Rancière. Laclauova maksima o „razvoju određenih intuicija i diskurzivnih oblika oblikovanih unutar marksizma“ te „,inhibiciji ili eliminaciji nekih drugih“ (Laclau, Mouffe; 2014: xxiv) potvrđuje se na djelu i kod njega, s tim da u Deleuzeovu slučaju pri tom nastojanju nemamo posla $\mathrm{s}$ dekonstrukcijskim čitanjem marksističkih klasika, već sa selektivnim izdvajanjem Marxovih (ili marksističkih) teza i citata te njihovom montažom u vlastite nove sklopove.

\footnotetext{
135 Choat (2010: 125) smatra da je, dapače, Marxov utjecaj na Deleuzea vidljiviji nego i na jednog drugog poststrukturalista, te da ukupno gledano nije bitno manji nego utjecaji Bergsona, Spinoze ili Nietzschea, premda se pored njih često previđa.

${ }^{136}$ Pojmovi proizvodnje žudnje, društvene proizvodnje, protuproizvodnje itd. protežu se velikim dijelom Deleuzeova opusa, no središnji su u Kapitalizmu $i$ shizofreniji, i to naročito u njegovu prvom dijelu, u Antiedipu (Deleuze, Guattari; 2015). No Bogue (2003: 197) napominje da središnji od tih koncepata - proizvodnja žudnje - spajajući marksistički i frojdovski pojam u bitnoj mjeri mijenja oba, šireći njihove opsege i tako ih dovodeći do preklapanja.
} 
To dakako ne znači da Deleuze falsificira Marxa ili marksizam, budući da se ne radi o monolitnim i neproturječnim fenomenima koje bi trebalo uzeti u cijelosti ili nikako, niti Deleuze igdje obećava rekonstruirati „pravog Marxa“"137, no činjenica je da ponekad, kao što primjećuje i Choat (2010: 128), ,zna biti teško uočiti što [Marxovog] odbacuje, budući da ne izdvaja vrijeme da bi kritizirao Marxa ili razotkrio njegove slabosti.“ Drugim riječima, Deleuze ne ulazi u polemiku s nekim (vlastitim) viđenjem tradicionalnog marksizma, kao što to čine Laclau i Rancière, te naglasak stavlja na dodirne točke radije nego na razlike, kako to čine njih dvojica, no konačna rezultanta, vidjet ćemo, uvelike je slična.

Ono što pak najviše razlikuje Deleuzea od dvojice prethodno analiziranih teoretičara moglo bi se značajnim dijelom svesti na odnos prema pitanjima ontologije i filozofije/teorije jezika. Ako kod potonjeg dvojca možemo govoriti o tome da ontologiju (kao prima philosophia) zamjenjuje politička teorija, koju pak u srži svode na neki oblik teorije diskursa (podsjetimo, Laclau eksplicitno negira dohvatljivost i relevantnost izvandiskurzivnog; usp. Laclau, Mouffe, 2014: 93-94 ), Deleuze nastoji upravo suprotno. Još od svojih ranijih studija, a vjerojatno najzaokruženije u Ponavljanju $i$ razlici (2009b), nastojat će udaljiti se od preferiranja jezika, karakterističnog za paradigmu koju u cjelini naziva strukturalističkom ${ }^{138}$, a koja, prema njemu, ponavlja pogreške najvećeg dijela zapadne filozofske tradicije podređujući razliku identitetu ${ }^{139}$. Oslanjanje na negativitet koje je, smatra, u temelju te filozofske tradicije, Deleuze zamjenjuje ontologijom ${ }^{140}$ čiste pozitivne razlike, bez negacije i nepodčinjene identičnom, te čistog, golog ponavljanja te razlike (usp. Deleuze, 2009b: 8), odnosno čistih intenziteta kao „formi razlike kao razloga čulnog“ (isto: 360; usp. i isto: 385, $388)$.

Odbacivanje filozofije negativiteta $u$ temelju je Deleuzeove kritike i drugih intelektualnih paradigmi - ne samo kritike hegelijanstva ${ }^{141}$, koje u velikom dijelu njegova

\footnotetext{
${ }^{137}$ Deleuzeovo posezanje za Marxom ponekad je ipak tako formulirano da implicira kako on razumije što je rečeno bolje od uobičajenih marksističkih tumačenja, ili pak kako je dosljedniji Marxovim postavkama od Marxa samog, zbog čega su ga, napominje Choat (2010: 125), pojedini autori nazivali hipermarksistom ili paramarksistom.

${ }^{138}$ Usp. Colombat, 2000: 22.

${ }^{139}$ Usp. npr. distinkciju koju Deleuze (2009b: 49) utvrđuje između razlike koja se postavlja kao vanjska u odnosu na pojam i kao takva podređuje identitetu pojma, te one koja je ,unutar Ideje“ i „razvija se kao čisto stvaralačko kretanje nekog dinamičkog prostora i nekog dinamičkog vremena koji odgovaraju ideji“; ili pak kako suprotstavljenosti i proturječja smatra „manje dubokom“ od razlike, odnosno razlikom koja je „na silu postavljena u jedan prethodan identitet, kada je stavljena na nagib identičnog koji je nužno nosi tamo gde identitet želi i dovodi do toga da se reflektuje tamo gde to identitet želi, to jest u negativnom. “ (isto: 94)

${ }^{140}$ Choat (2010: 130) naglašava da je odnos prema ontologiji ono što Deleuzea temeljito razlikuje od svih drugih teoretičara koje se naziva poststrukturalistima; on „filozofiji prilazi ne odbacujući ontologiju, već prigrlivši je.“”

${ }^{141}$ Pri kritici Hegela sa svojih vrlo osobitih stajališta, Deleuze (2009b: 335) za saveznika poziva Marxa, pa tako navodi da ,/k/omentatori Marksa koji insistiraju na temeljnoj razlici između Marksa i Hegela, s pravom podsećaju da kategorija diferencijacije u okrilju neke društvene mnoštvenosti (podela rada) zamenjuje, u
} 
opusa zauzima ulogu glavnog antagonista, nego i u temelju čuvenog kritičkog projekta shizoanalize kojim kritici izlaže kako freudovsku, tako i lacanovsku psihoanalizu ${ }^{142}$. Kada se te teorijske zasade - oponiranje negativitetu, jezično orijentiranom (post)strukturalizmu i psihoanalizi - u obzir uzmu uopćeno, djeluju kao čisti negativ kasnijih temeljnih Laclauovih postavki (a implicitno i značajnog dijela Rancièreovih), s obzirom na Laclauovo eksplicitno zagovaranje negativiteta ${ }^{143}$ te velik dug strukturalizmu u najširem smislu, a naročito Derridau i Lacanu. Ipak, spustimo li se na razinu konkretnijih problema te pozornost usmjerimo segmentima koje smo u prethodnim poglavljima smatrali primarnim otklonima od klasičnog marksizma, razlike se pokazuju bitno manjima.

Kod prethodne dvojice teoretičara vidjeli smo paradigmatske primjere odbacivanja bilo kakve objektivne društvene datosti koja bi se preklapala s marksističkim konceptom baze, a samim time i dokidanje podjele na bazu i nadgradnju te premještanje istraživačkog fokusa, ako već ne i jednoznačno davanje veće važnosti ${ }^{144}$, na one fenomene koji su u klasičnoj marksističkoj shemi pripadali nadgradnji. Drugim riječima, odbačen je bilo kakav oblik determinacije ekonomskim u krajnjoj instanci. Situacija se po tom pitanju kod Deleuzea isprva može činiti drukčijom kada piše da „/s/trogo uzev, ne postoje drugi društveni problemi do ekonomskih, premda su njihova rešenja bila juridička, politička, ideološka, i premda se

Kapitalu, Hegelove pojmove suprotstavljenosti, protivrečnosti i otuđenja - koji obrazuju samo prividno kretanje i važe samo za apstraktne učinke, odvojene od principa i pravog kretanja njihovog proizvođenja." Pritom se iza spomenutih „komentatora“, kako otkriva fusnota, kriju prvenstveno Althusser, ali i njegovi suautori na projektu čitanja Kapitala, među kojima i Rancière.

${ }^{142}$ Deleuzeova kritika psihoanalize, u koju nažalost ovdje ne možemo ulaziti podrobnije nego je to nužno za središnja istraživačka pitanja rada, raspršena je velikim brojem njegovih studija, no najsustavnije je izlaže u prvom dijelu Antiedipa, prvog sveska Kapitalizma $i$ shizofrenije (usp. Deleuze, Guattari; 2015). Kritika negativiteta tu se prvenstveno javlja kao kritika psihoanalitičkog shvaćanja žudnje prouzrokovane manjkom, nasuprot konceptu pozitivne žudnje kakvu zagovara Deleuze. Na općenitijoj razini pak, iako eksplicitno odaje priznanje i Freudu i Lacanu, psihoanalizi zamjera da - umjesto da djeluje oslobađajuće - funkcionira kao jedan od mehanizama kapitalističkog društva što opresivno djeluju na deteritorijalizirane tokove žudnje, reteritorijalizirajući ih bilo u edipovskom trokutu obitelji (u slučaju njegovog „doslovnog“ shvaćanja), bilo nekog drugog poretka Označitelja (u slučaju ,strukturnog“ shvaćanja edipovskih odnosa). Usp. naročito poglavlje Psihoanaliza i familijalizam: sveta obitelj u Deleuze, Guattari; 2015. Zanimljivo je u kontekstu postmarksističke problematike primijetiti da Deleuze (isto: 27) takvu kritiku psihoanalize nastoji osloniti o Marxa, pa tako piše da ,/k/ao što kaže Marx, ne postoji manjak, postoji samo strast kao 'prirodni i čulni objekt'. Nije žudnja poduprta potrebama, nego obratno, potrebe proizlaze iz žudnje: one su protuproizvodi u stvarnom koje žudnja proizvodi.“ Zbog toga kritizira dotadašnja slaba povezivanja marksizma i psihoanalize koja su se oslanjala na ocrtavanje analogija između tobože razdvojenih društvene proizvodne stvarnosti i proizvodnježudnje fantazme, pa zaključuje: „U zbilji, društvena proizvodnja nije drugo do proizvodnja žudnje u točno određenim uvjetima.“ (isto: 29) Deleuze (isto: 286) ocrtava i izravnu analogiju između onoga što Marx otkriva u odnosu na druge mehanizme kapitalizma te onoga što on sam tvrdi u odnosu na psihoanalizu, čime svoj projekt shizoanalize prikazuje kao potpuno komplementaran Marxovoj analizi. Ipak, vrijedi istaknuti i da se otvoreno izjašnjava protiv simplificiranog lijepljenja reakcionarne etikete Freudu, koja bi se potom preslikala i na čitavu psihoanalizu. Oboje su, smatra, mnogo složeniji od toga (isto: 110).

${ }^{143}$ Usp. poveznicu između nesvodivog negativiteta antagonizma i „neuspjele“ transcendencije što je zagovara Laclau, kritički ih suprotstavljajući imanentizmu u Laclau, 2007: 243-244.

${ }^{144}$ Podsjećamo da i Laclau i Rancière jasno ističu kako ne smatraju da se diskurzivni procesi kojima se bave događaju u vakuumu, neovisno od drugih, pa tako i ekonomskih aspekata stvarnosti. 
problemi, takođe, izražavaju u tim poljima razrešivosti“ (Deleuze, 2009b: 303). Ili pak da „/f/orma i kakvoća određenog sociusa, tijela zemlje, tijela despota, tijela kapitala-novca ovise o stanju ili stupnju intenzitetskog razvitka proizvodnih snaga utoliko što te snage definiraju čovjeka-prirodu neovisno o svim društvenim formacijama, ili bolje, čovjeka-prirodu zajedničke svima...“ (Deleuze, Guattari; 2015: 325), odnosno kada dodatno naglašava centralnost ekonomskog u kapitalizmu (isto: 236) te kritizira psihoanalizu što joj taj aspekt izmiče (isto: 337 ).

No prividno zagovaranje determinacije ekonomskim usložnjava se dodatnim pojašnjenjima, poput onog da Deleuze ekonomsko ne uzima kao „dato u pravom smislu reči“, već kao „neku diferencijalnu virtuelnost, uvek prekrivenu njenim formama aktualizacije“ (Deleuze, 2009b: 303), referirajući se tu na Althusserov koncept nadodređenja ${ }^{145}$, odnosno naglašavajući da je i sam oblik sociusa proizveden tokovima proizvodnje-žudnje u nekim uvjetima (Deleuze, Guattari; 2015: 325). Međutim, za razliku od Althussera, čije nadodređenje doista potkopava reduktivne inačice marksističke sheme baze i nadgradnje, no koji i dalje razmjerno diskretno odvaja različite segmente društva (zadržavajući i samu spomenutu shemu) te u konačnici ipak prednost daje razmjerno konvencionalno shvaćenom ekonomskom ${ }^{146}$, Deleuzeovo viđenje ekonomije teško da bi prihvatio bilo koji konvencionalni marksist. Ono obuhvaća, posve nemetaforički, interakciju najrazličitijih tokova žudnje i najrazličitijih vrsta proizvodnje (što obuhvaća i distribuciju i potrošnju; usp. isto: 7), odnosno (među)djelovanje (skupa s njegovim uvjetima) svih žudećih mašina koje presijecaju beskonačan tok materije. Zato Deleuze (isto: 32) briše isprva uspostavljenu razliku između tehničkih i žudećih mašina te između proizvodnje žudnje i društvene proizvodnje. „Postoji samo jedna proizvodnja, i to je proizvodnja stvarnog“, a ta se istovjetnost može izraziti dvojako, ovisno o perspektivi: „Možemo reći da je cjelokupna društvena proizvodnja posljedica proizvodnje žudnje u određenim uvjetima: prvi je Homo natura. Ali treba reći, točnije, i da je proizvodnja-žudnja ponajprije društvena i teži se osloboditi tek na kraju (prvi je Homo historia). (isto)

\footnotetext{
${ }^{145}$ Kao i Laclau (nešto manje Rancière), Deleuze je ambivalentan glede Althussera. Iako nikada nije bio althusserijanac, niti ima istu potrebu kritički se distancirati od njega kao dvojica autora mlađe generacije koje smo prethodno analizirali, Deleuze će ponekad eksplicitno (kao npr. u Deleuze, Guattari; 2013: 149), a mnogo češće implicitno (usp. o tome Lecercle, 2002: 200) kritizirati Althusserovu teoriju. S druge strane, nerijetko će se, kao u gornjem primjeru, sasvim afirmativno referirati na njega i prizivati ga kao svog istomišljenika (ipak, tu se vrijedi sjetiti što smo na početku poglavlja rekli o Deleuzeovim strategijama aproprijacije marksističke misli), te ga općenito ocijeniti kao autora koji je ostvario „oslobođenje Marxa od Hegela, reaproprijaciju Marxa, odgrtanje diferencijalnih i afirmativnih mehanizama kod Marxa“ (Deleuze, 2004: 145).

${ }^{146}$ Usp. kritiku toga u Laclau, Mouffe; 2014: 84-5.
} 
Drugim riječima, ono što Deleuze smatra ekonomskom problematikom obuhvaća i čitav niz fenomena koji su u tradicionalnoj marksističkoj podjeli stvar nadgradnje i tek reflektiraju (i/ili prikrivaju) stanje u bazi. Stoga se Deleuzeova analiza ekonomije tokova žudnje čini bliža Rancièreovim analizama radništva ili Laclauovim populističkih pokreta, koji djeluju i ostvaruju najrazličitija ulaganja pod posve heterogenim utjecajima, često i mimo onoga što bi klasični marksizam nazvao objektivnim klasnim interesom, nego tradicionalnoj marksističkoj ekonomskoj analizi.

Deleuze (Deleuze, Guattari; 2015: 325) zato nastoji razlikovati „nesvjesno libidno ulaganje grupe ili žudnje i predsvjesno ulaganje klase ili interesa“, pri čemu se potonje tiče „,velikih društvenih ciljeva“ i „organizama i kolektivnih organa“ (isto), dok se prvo „ne odnosi na režime društvenih sinteza, već na stupanj razvitka sila ili energija o kojima te sinteze ovise“, odnosno ne na „društvene ciljeve i sredstva, nego na puno tijelo kao socius, na oblik vladavine ili formu moći po sebi, lišenu značenja i cilja..." Reaktualizirajući stoga pitanje koje je postavio Wilhelm Reich - zašto su mase poželjele fašizam? - ili zašto uopće žele bilo koji sustav koji ih tlači, Deleuze smatra kako se ne radi o zastrtosti objektivnog interesa ideologijom, već o ekonomiji tokova žudnje.

Ako društvena dinamika nije stvar sudara pretpostojećih objektivnih interesa koji se nalaze negdje ispod vela ideologije, već međuigre molarne artikulacije interesa i molekularnih libidnih ulaganja (u čemu možemo prepoznati fenomen analogan sličnim kontingentnim artikulacijama kod Rancièrea i Laclaua), tada se ne može govoriti ni o teleološkom modelu historije u podlozi kojeg se proteže neka razlučiva kontinuirana racionalnost. Deleuze (Deleuze, Guattari; 2015: 129) to jasno podcrtava pišući: „sveopća povijest je povijest kontingencija, a ne nužnosti; prekida i granica, a ne kontinuiteta." Zanimljivo je pak da takvu viziju historije oslanja na Marxa i nastoji prikazati genuino marksističkom ${ }^{147}$, dok su npr. Laclauove kasnije teze o kontingenciji historije, izvedene iz sličnog temelja, no plasirane kao kritika marksističke sheme, u marksističkoj kritici dočekane kao magnum crimen njegova seminalnog djela ${ }^{148}$.

Iako se Deleuzeov trodijelni model opće historije svijeta ${ }^{149}$ može činiti isuviše kruto opisanim u odnosu na postavku o kontingentnosti historije, riječ je o idealnotipskom opisu

\footnotetext{
${ }^{147}$ Usp. Deleuze, Guattari; 2015: 129

148 Usp. Sim, 2000: 12 et passim.

149 Tri tipa sociusa koja Deleuze navodi su primitivni socius ili teritorijalna mašina, barbarski socius ili despotska mašina te kapitalizam. Prvi karakterizira vezanost za „megamašinu“ zemlje i čvrste kodove koji vežu plemenska društva, dakle čvrstu teritorijaliziranost i zapise koda po tijelu sociusa kao tijelu zemlje. Drugi karakterizira s jedne strane djelomično izdvajanje i dekodiranje pojedinih dijelova lanaca koda, početna deteritorijalizacija, a s druge strane cjelovito nadkodiranje čitavog sociusa tijelom despota kao glavnim označiteljem. Treći se pak
} 
koji ne priječi mogućnosti hibridizacije i istovremenog supostojanja različitih faza, kao što ne predviđa ni bilo kakav telos procesa promjena, premda je točno da ga oblikuje iz pozicije kapitalizma kao privilegirane točke gledišta, također po uzoru na Marxa ${ }^{150}$. Marksističko poimanje upravo kapitalizma kao onog sustava koji trga veo svetosti s društvenih odnosa povezuje dakle i klasični marksizam, i teoretičare poput Laclaua i Rancièrea, i Deleuzea, no u bitno drukčijim pojavnim oblicima. Klasični marksizam ispod vela pronalazi objektivnu društveno-ekonomsku stvarnost kao temelj svega, Laclau i Rancière odsutnost temelja i kontingentna kretanja suplementarnih utemeljenja, no što je s Deleuzeom?

Deleuzeova afirmacija imanentizma nasuprot svojevrsnom kvazitranscendentizmu (ili, Laclauovim (2007: 243-244) riječima, „neuspjelom“ transcendentizmu) Laclaua i Rancièrea sugerirala bi njegovo stajanje uz ono što Marchart (2007) naziva antifundacijskom nasuprot postfundacijskoj paradigmi. No kao što smo već spomenuli, upravo nastojanje da izbjegne utemeljenje u ičemu (kvazi)onostranom i Rancière (2004: 164) i Laclau (2007: 244) kritiziraju kao najveći problem njegove političke misli, utoliko što nedorečenim ostavlja prijelaz iz molekularne raspršenosti mnoštva u neki oblik egalitarne, bratske zajednice kakvu istovremeno ipak zagovara. I dok je problematika utemeljenja, ključna za literarnost politike kakvu smo opisali kod prethodnih autora, iz perspektive ukupnog Deleuzeova opusa očito nejednoznačna, za njegovu bi se shemu opće povijesti ipak moglo tvrditi da je postfundacijska.

U najjednostavnijem obliku sociusa, fazi teritorijalne mašine naime, međuodnos društvene proizvodnje i žudnje regulira „megamašina“ zemlje kao „primitivno, divlje jedinstvo žudnje i proizvodnje“; „mnogostruki i podijeljeni objekt rada“, ali i ,,jedinstven i nedjeljiv entitet, puno tijelo koje se vraća na proizvodne sile i privlašćuje ih kao prirodni ili božanski preduvjet.“ (Deleuze, Guattari; 2015: 130) Ta regulacija ostvaruje se kodiranjem proizvodnih tokova primitivnim pismom okrutnosti, tj. urezima po zemlji i po tijelu, pri čemu

odlikuje daljnjim dekodiranjem ranijih kodova, aksiomatikom koja zamjenjuje ulogu nadkodiranja i osigurava međusobnu prevodljivost različitih i uklapanje stalno novih procedura i kodova, stalnom dijalektikom dekodiranja i ponovnog kodiranja, deteritorijalizacije i reteritorijalizacije, što dovodi do stalne transgresije vlastitih granica koja osigurava ranije neviđenu dinamiku, otpornost na promjene i fleksibilnost pri aproprijaciji uvijek novih tokova žudnje. Usp. Deleuze, Guattari; 2015, naročito poglavlje Divljaci, barbari civilizirani. Striktan slijed i odvojenost tih oblika Deleuze je kasnije relativizirao. Usp. npr. Deleuze, 2006b: 310.

${ }^{150}$ „Ako je kapitalizam univerzalna istina, on je to u smislu da se pretvara u ono negativno svih društvenih formacija: on je stvar, ono neimenljivo, poopćeno dekodiranje tokova koje otkriva a contrario tajnu svih formacija, kodiranje tokova pa čak i njihovo nadkodiranje, radije nego da dopusti ičemu umaknuti kodiranju. Nisu primitivna društva izvan povijesti, već je prije kapitalizam na kraju povijesti, kao rezultat duge povijesti kontingencija i slučajnosti koji dovodi do tog kraja. Ne može se reći da prethodne formacije nisu predvidjele tu Stvar, koja je došla izvana samo tako što se pojavila iznutra, i što se njezino pojavljivanje moralo pošto-poto spriječiti. Odatle mogućnost retrospektivnog čitanja svekolike povijesti u terminima kapitalizma." (Deleuze, Guattari; 2015: 142). Usp. isto: 129-130, gdje Deleuze izvod te teze oslanja na Marxove stavove, citirajući Osnove kritike političke ekonomije. 
se pojedinačni biološki organizmi rastaču u kolektivnom tijelu sociusa, proizvodnja ,,pretvara ljude i njihove organe u dijelove i zupčanike društvene mašine.“ (isto: 134) No iako se radi o pismu koje se ne nadodaje kao reprezentant nekog govora u njegovoj odsutnosti, nego o urezima što mu prethode i djeluju izravno na tijelu zemlje ${ }^{151}$, pa Deleuze (isto: 135) zbog toga govori o ,imanentnom jedinstvu zemlje“ nasuprot „transcendentnom jedinstvu“ koje će uvesti nadkodiranje pismom, odnosno o najužoj vezi kodova i onoga što određuju, o najvećem stupnju teritorijalizacije, situacija svejedno nije statična.

Deleuze (isto: 141) naime upozorava na neizbježno „kvarenje“, odnosno „shizofreniziranje“ sustava, kao i na ono što naziva „kodnim viškom vrijednosti“, fenomen što nastaje odcjepljivanjem dijelova lanaca te proizvodi viškove i manjkove koji uzrokuju razmjene i pomake u sustavu, i to ne kao aberacije, patološke otklone inače zatvorenog stabilnog sustava, već funkcionalnu posljedicu inicijalne heterogenosti elemenata. Drugim riječima, već oblik organizacije društva što ga u Antiedipu smatra najjednostavnijim nije konstelacija koju bismo laclauovskim rječnikom mogli okarakterizirati kao nultu razinu figuralnosti, odnosno stabilan i zaokružen sustav, niti se radi naprosto o slobodnim, disperziranim, heterogenim neartikuliranim elementima ${ }^{152}$. Naprotiv, govorimo li s jedne strane o čvrstoj artikulaciji, a s druge o kontinuiranoj nestabilnosti uzrokovanoj nesvodljivom heterogenosti i neiskorjenjivim postojanjem kodnih višaka i manjaka, to znači da $u$ određenom smislu govorimo o dinamičnom sustavu što svoje privremene momente stabilnosti i okoštavanja ostvaruje nekim vidom tropološke stabilizacije.

Tropološka narav tog oblika sociusa dolazi još više do izražaja u njegovu susretu sa sljedećim, onim barbarske države, odnosno despotske mašine. Despotska mašina, smatra Deleuze (Deleuze, Guattari, 2015: 180) nastaje u pokoravanju primitivnog društva uslijed kojeg ,/d/espot pobija lateralna srodstva i proširene filijacije stare zajednice“ te „nameće nov

\footnotetext{
${ }^{151}$ Deleuze će ga drugdje nazvati i „predoznačiteljskom semiotikom“ (Deleuze, Guattari; 2013: 133). Usp. kod Rancièrea (2004: 106) s čežnjom za pismom koje bi se ispisivalo u tijelo krajolika, po samoj površini stvari, nasuprot lutajućem, nepouzdanom, varljivom pismu, povezanom s demokracijom u Balzacovom Seoskom župniku.

${ }^{152}$ To nezapadanje ni u jednu od spomenutih krajnosti, koje bi se drukčije mogle nazvati fundacijskom i antifundacijskom paradigmom, još je jače izraženo u Tisuću platoa, u dijelu u kojem revidiraju neke postavke Antiedipa. Tamo se uz uvođenje opreke između nomada/barbarskog čopora, kao disperziranih, molekularnih, deteritorijalizirajućih, „glatkih“, te države kao artikulirane, molarne, (re)teritorijalizirane, „,izbrazdane“, ipak jasno odbacuje evolucionistička paradigma po kojoj bi jedan oblik smjenjivao drugi: put doista često vodi ,'od bandi do kraljevstava'“, ali „ništa ne ukazuje na to da se radi o evoluciji, jer bande i klanovi nisu manje organizirani od kraljevstava i carstava" i konstantno supostoje (Deleuze, Guattari; 2013: 405) Naročito to dolazi do izražaja iz perspektive države, koja je po revidiranim Deleuzeovim stavovima ,oduvijek postojala, i to u vrlo savršenom, vrlo dovršenom obliku“, no i taj je Urstaat potpuno nezamisliv bez svoje vanjštine (isto). Konačno, Deleuze (isto: 434) napominje i da „potreba za najstrožijim razlikovanjem između sjedilaca, selilaca i nomada ne isključuje konkretna miješanja, naprotiv, čini ih to nužnijima." $\mathrm{S}$ obzirom na takva razmjerno eksplicitna odbacivanja oštrih binarnosti, kritike pojedinih autora na Deleuzeov račun zbog hijerarhijski postavljenog binarizma (usp. npr. Choat, 2010: 149) djeluju neopravdano.
} 
sustav srodstva i stavlja sebe u direktnu filijaciju s bogom; narod mora slijediti.“ Drugim riječima, radi se o nadkodiranju koje je, paradoksalno, „već učinkom prvoga velikog kretanja deteritorijalizacije“ (isto: 135).

Barbarska država ona je u okvirima koje se napokon javlja i pismo u klasičnom obliku kao tropološki zastupnik despotova glasa, a umjesto grafijskih znakova urezanih u tijelo (isto: 190), odnosno deteritorijalizacija „konkretnih znakova“ i njihovo pretvaranje u ,apstraktne znakove“ (isto: 184). Dominacija poretka označitelja koja se tako uspostavlja već i mnogo izravnije nalikuje kasnijim Laclauovim opisima hegemonijskog nadsvođivanja - despotovo tijelo postaje prošivni bod čitavog društva što nadsvođuje sve ranije elemente koda, uzdižući se iz svoje partikularnosti na razinu univerzalnog središta, krajnje referentne točke svakog lanca $^{153}$. Deleuze eksplicitno podcrtava i to da takvo nadsvođivanje „,nema nikakve veze sa skladnim, prirodnim i imanentnim totalitetom“, već djeluje „kao eminentno formalno jedinstvo“ (isto: 186-187) koje vlada nad heterogenim fragmentima, što dodatno naglašava njegovu tropološku narav. Također, jasno daje do znanja i da nadsvođenje uvijek nastaje nasilno: „državno nadkodiranje jest upravo to strukturno nasilje koje definira pravo“ (Deleuze, Guattari; 2013: 510), bilo da se radi o barbarskoj okupaciji u Antiedipu, bilo o policijskom nasilju u Tisuću platoa. A neodgovarajući prisilni trop što postaje izvor jezika opis je koji, vrijedi podsjetiti, odgovara katahrezi.

Konačno, disolucija despotske moći proces je što ga veže uz različita „zatajenja kodova“ (Deleuze, Guattari; 2015: 205), tj. iskrsnuća dekodiranih tokova koji izmiču zajedničkom nadkodiranju i za koje valja izmišljati pojedinačne kodove, kao što je to npr. slučaj s privatnim vlasništvom. No korijen rasapa despotskog označavanja, „razmrskavanja starog koda“, Deleuze (isto: 201) vidi u „instinktu slobode“ koji je proizašao iz svijesti o proizvoljnosti označavanja kao drugoj strani nužnosti značenja. Demokracija slova, temeljna jednakost u jeziku, odnosno literarnost, i tu se dakle, kao kod Rancièrea i Laclaua, pokazuje pukotinom u srcu policijskog poretka koja je ujedno neotklonjiv preduvjet njegova postojanja.

Kontingencija, jednakost $\mathrm{i}$ indiferentnost koje podrivaju strogu hijerarhijsku piramidu despotske mašine, oslonjenu na transcendentalno utemeljenja, ključ su uspostave posljednjeg Deleuzeova oblika sociusa, kapitalizma. U njemu država prestaje biti ,apstraktno jedinstvo koje je integriralo podskupove što su funkcionirali zasebno“, a postaje „podređena polju sila čije tokove koordinira, kao izraz njihovih autonomnih odnosa dominacije i subordinacije“

\footnotetext{
${ }^{153}$ Usp. Deleuze, Guattari; 2015: 194-196, za demonstraciju kako, unatoč (uzaludnim) usporedbama jezika sa savršeno autoreferencijalnim sustavom, referenca na neki transcendentalni označitelj (pa makar i kao prazno mjesto) ne može izostati, te kritiku De Saussurea koji to previđa.
} 
(Deleuze, Guattari, 2015: 208), odnosno „uopće više nije transcendentna paradigma natkodiranja, već imanentni model realizacije za aksiomatiku dekodiranih tokova.“ (isto, 2013: 518) Zahvaljujući tome, kapitalizam odlikuje fantastična dinamika i mogućnost iznalaženja uvijek novih aksioma kojima uvijek iznova kooptira novonastala gibanja, zbog čega Deleuze zaključuje da on „sam nema vanjsku granicu, već samo unutarnju granicu koja je sam kapital, i (...) tu granicu ne susreće nego je reproducira tako što je neprestano pomiče.“ (isto: 218 )

No iako tako predstavljen kapitalistički socius može djelovati kao prostor međuodređenja razlika koji se napokon potpuno riješio problema utemeljenja, tj. potrebe za bilo kakvim transcendentalnim označiteljem ${ }^{154}$, važna stavka Deleuzeova viđenja kapitalizma ipak je disonantna u odnosu na takvu viziju. Deleuze naime priznaje (dapače, naglašava) kako uloga države kao okvirnog regulatora dekodiranih tokova znači da se kapitalizam ni u svom najrazvijenijem obliku ne može riješiti potrebe za njom (isto: 238), odnosno da strogo gledano ne postoji krajnje liberalni kapitalizam (isto: 239). No iako više puta tvrdi da se radi o okviru koji više nema zajedničku narav s transcendentalnim nadkodiranjem, čini nam se da je opstanak iste institucije simptomatičan i ukazuje na opstanak strukturno ekvivalentnog, ma kako labavijeg principa. Pojedini proturječni momenti daju i dodatne argumente u korist tom uvjerenju.

Naročito to vrijedi za 9. plato iz Tisuću platoa, „Mikropolitika i segmentiranost“, u kojem Deleuze odbacuje oštru binarnu opreku između segmentiranosti i centraliziranosti, tvrdeći da su moderna društva sačinjena od koncentričnih, definitivno arboriziranih krugova, pri čemu ,/s/egmentiranost postaje kruta, u mjeri u kojoj sva središta rezoniraju, sve crne rupe padaju u jedno gomilište, nalik na točku presjeka negdje iza svih očiju“ (Deleuze, Guattari; 2013: 235) Dapače, u nastavku otvoreno navodi i da su „,moderna društva ili društva državnog karaktera zamijenila odumiruće kodove univočnim nadkodiranjem, a izgubljene teritorijalnosti specifičnom reteritorijalizacijom (koja se zbiva upravo u nadkodiranome geometrijskom prostoru)“ (isto: 237), pri čemu očito razlikovanje između despotske i kapitalističke države pada $\mathrm{u}$ drugi plan $\mathrm{u}$ odnosu na razlikovanje između primitivnog preddržavnog i bilo kojeg državnog sociusa. Odnosno, ,,s/vaki molarni segment ima svoje središte ili svoja središta“ kao „rezonantne komore za sve točke“ (isto: 250), svako se središte ostvaruje raspršujući se po molekularnom tkanju (nalik foucaultovskoj mikrofizici moći), pri

\footnotetext{
${ }^{154}$ Deleuze tome nalazi paralelu i u lingvistici, zagovarajući, umjesto nedosljedne saussureovske imanentnotranscendentne paradigme, Hjelmslevljevu ideju dvostruke artikulacije neovisnih tokova. Usp. Deleuze, Guattari; 2015: 229; 2013: 53.
} 
čemu ipak „nadkodirajuća linija osigurava premoć jednog segmenta nad drugim“, (...) daje određenom središtu moći relativnu rezonanciju u odnosu prema drugima (...), ističe dominantni segment kojim sama prolazi. Centralizacija je tako uvijek hijerarhijska, ali hijerarhija je uvijek segmentirana.“ (isto) Tako postavljene stvari, stoga, ne samo da govore u prilog postojanju središta, nego spomenuta hijerarhijska asimetrija ujedno snažno nalikuje na prvi pogled bitno drukčijoj Laclauovoj koncepciji hegemonijskog uspostavljanja središta i preuzimanja te univerzalizirajuće uloge od strane nekog partikularnog čimbenika.

Iz te perspektive i konstantna bi se smjena deteritorijalizacije i reteritorijalizacije, kojom kapitalistička mašina pomiče svoju unutarnju granicu ${ }^{155}$, mogla prevesti u momente laclauovske/rancièreovske rekonfiguracije i kvazitranscendentalne stabilizacije diferencijalnog poretka, potvrđujući Laclauovu tezu da već samo postojanje granice i diferencijalnog sistema podrazumijeva nužnost (kvazi)utemeljenja ${ }^{156}$.

Slično ulančavanje utemeljenja i rastemeljenja uočava se i na razini općenitijoj od opće historije; u trima sintezama vremena ${ }^{157}$ koje Deleuze izlaže u Ponavljanju i razlici. Iako je, naime, treća i finalna sinteza ona koja aktualizira Deleuzeovu inačicu ničeanskog vječnog povratka, i to tako da se „temelj prevazilazi u pravcu nekog bez-temeljnog, nekog bezdna, nekog univerzalnog rastemeljenja koje se okreće u sebi samom i dovodi do povratka samo onoga što je u-dolasku, do povratka budućnosti““ (Deleuze, 2009b: 157), njoj uvijek prethode dvije utemeljujuće (sadašnjosti i prošlosti). Nadalje, kada govori o odnosima među uspostavljenim objektima/nizovima u sustavima čistih intenziteta, želeći izbjeći ponovno

\footnotetext{
${ }^{155}$ Ta je dinamika, kako Deleuze pokazuje, vrlo često dugog roka; pojedinim se sektorima „dopušta“ prividna deteritorijalizacija u određenom momentu, da bi njezine rezultate apsorbirala prilagođena aksiomatika kasnije $u$ budućnosti. Usp. Deleuze, Guattari; 2015: 220. Dinamika deteritorijalizacije i reteritorijalizacije, paranoidne i očuđujuće mašine (isto: 19), još je češća tema u Tisuću platoa, kao dinamika između djelovanja ravni konzistencije i ravni organizacije u različitim oblastima. Usp. npr. Deleuze, Guattari; 2013: 302.

${ }^{156}$ Valja podsjetiti na Laclauov teorijski izvod praznog/plutajućeg označitelja, kao ključnog za hegemonijsko utemeljenje, koji počiva upravo na toj tezi; usp. Laclau, 2006: 36-37; 2014: 64-65. Je li granica poretka okarakterizirana kao unutarnja ili vanjska, malo je važno za problematiku u pitanju. Još je Derrida (2007: 307), na kojeg se u tom dijelu Laclauova teorija ponajviše oslanja, pokazao da je unutarnja granica (odnosno, odsutnost središta) ono što stvara nužnost suplementarnog utemeljenja i s njim povezanu dinamiku, te da je - ma koliko se središte, baš kao i u slučaju Deleuzeova opisa kapitalizma, uvijek otklanjalo i izmicalo - nemoguće misliti strukturu bez središta. Iz te perspektive čini nam se da koliko god, Deleuzeovim rječnikom, neka konkretna kapitalistička mašina naginjala rizomatičnosti, činjenica da ne govorimo o potpunoj deteritorijalizaciji (jer, koliko god se rizom opirao nadkodiranju (usp. Deleuze, Guattari; 2013: 14-15), on je ujedno ipak podložan segmentiranju te „edipovskim recidivima“ i „fašističkim skrutnućima“ (isto: 16)) znači i da njezine elemente povezuje neko suplementarno, tropološki uspostavljeno središte, rezonantna točka koju je i sam u ranijem citatu spomenuo. No bilo da ustrajemo na postfundacijskoj kritici Deleuzeove vizije kapitalizma, ili pak prihvatimo njegovu viziju podrivanja dominacije označitelja tokovima kapitalističkog sociusa, točka na kojoj na historijsku pozornicu jasno stupa literarnost politike ostaje i privilegirana točka gledišta na njezine historijske transformacije, a književnost (pa onda i ostale umjetnosti) se ponovno pokazuje privilegiranim modelom razumijevanja. Deleuze, naime, kao primjer figure koja razbija označitelj ili pak djeluje na razini višoj od njega, no u svakom mu slučaju oduzima primat (koncept preuzima od Lyotarda), navodi Mallarméove tipografske pokuse, a potom i slučajeve u drugim umjetnostima (usp. Deleuze, Guattari; 2015: 230).

${ }^{157}$ Ukratko o trima sintezama vidjeti u Miščević, 1975: 116.
} 
zapadanje u pojmove identiteta i sličnosti, Deleuze (isto: 200) taj odnos naziva „tamnim nagovještajem“ čiji identitet - a time i sličnost nizova koje dovodi u svezu - doduše postoji, ali je čista neodređenost, ono što razlikuje razlike, diferencirajuće diferencija. Takav tamni nagovještaj, smatra,

nema drugo mesto osim onoga na kojem nije, on nema drugi identitet osim onoga koji nema: on je upravo objekat $=\mathrm{x}$, onaj koji ,nije na svome mestu“, onaj koji nedostaje sopstvenom identitetu, tako da logički identitet koji mu refleksija pripisuje apstraktno, i fizička sličnost koju refleksija pripisuje nizovima koje on sakuplja, izražava samo statistički učinak njegovog funkcionisanja u celini sistema, to jest način na koji se on nužno skriva ispod sopstvenih učinaka, zato što se neprestano pomera u sebi samom i neprestano se prerušava u nizovima. Zbog toga ne možemo da smatramo da su identitet nekog trećeg i sličnost delova uslov za biće i mišljenje razlike, već samo uslov za njegovo predstavljanje koje izražava nekakvo rasprirodnjenje tog bića i tog mišljenja, kao vidljivi učinak koji bi poremetio pravi status uslova onakvog kakav je on po sebi. (Deleuze, 2009b: 200-201)

Premda se radi o ranije spomenutoj koncepciji sustava čistih intenziteta zamišljenom da zamijeni vlast označitelja, katahretična funkcija opisanog elementa strukturno nalikuje onoj plutajućeg označitelja, stvarajući tako neželjene točke usporedbe. Jednako vrijedi s druge strane za Deleuzeovu (2009b: 480) kritiku analogije kao krovnog momenta prikrivanja razlike i suštinskog elementa svijeta predodžbi, koja je pak naličje medalje Laclauova izdvajanja metafore kao tropa što artikulira i učvršćuje identitete društvenih/političkih aktera ${ }^{158}$.

Što se pak viđenja tih aktera, odnosno društvenih subjekata u Deleuzeovu opusu tiče, bez obzira na različite perspektive iz kojih u različitim studijama motri tu problematiku, radi se o pogledima koji su, unatoč nominalnom usidrenju u ekonomskom, još i udaljeniji od ontološkog privilegiranja klase nego oni Laclaua i Rancièrea. Ugrubo bi se moglo reći da,

\footnotetext{
${ }^{158}$ U Tisuću platoa Deleuze će pak naizmjence u tom smislu adresirati analogiju i metaforu. Govoreći o ravni konzistencije - koja u toj studiji donekle (iako ne u potpunosti!) zamjenjuje antiedipovski pojam tijela bez organa, te je u tom značenju pretežno sinonimna i pojmu apstraktne mašine u istoj studiji (za razliku od dvostrukog značenja apstraktne mašine u studiji o Kafki; usp. Bogue, 2003: 84), a na kojoj supostoje „krajnje disparatne stvari i znakovi“, odnosno na kojoj se u čiste intenzitete rastaču bilo kakvi molarni oblici - navodi da je ,/r/avan konzistencije dokidanje svake metafore“ (Deleuze, Guattari; 2013: 81), odnosno da je „suprotstavljena analogiji“ (isto: 284). Ravan konzistencije, odnosno apstraktna mašina, u tom značenju funkcioniraju usporedivo s poljem diskurzivnosti u Laclauovoj teoriji, iz kojeg polisemija, prolazeći kroz nikada potpuno zatvorene granice, podriva stabilnost diskursa (barem zanemarimo li da je Laclauova pozornost ograničena samo na diskurzivno, a Deleuzeova na dvostruku artikulaciju diskurzivnog i nediskurzivnog). Sličnost naročito dolazi do izražaja usporedimo li Bogueov (2003: 100) komentar na funkcioniranje apstraktne mašine u Kafkinu opusu: „Sve linije stalne varijacije jezika dijelovi su 'apstraktne mašine', koja kao komplementarne dijelove uključuje i varijabilne putanje nediskurzivnih uzoraka djelovanja koji oblikuju entitete u svijetu. Kolektivni sklopovi iskazivanja i nediskurzivni mašinski sklopovi aktualiziraju apstraktnu mašinu, a apstraktna mašina dovodi dva sklopa u međusoban odnos. Regulatorne prakse danog društvenog reda nadziru i ograničavaju varijacije, no linije stalnih varijacija ostaju imanentne unutar sklopova, omogućujući nestandardne aktualizacije koje destabiliziraju norme i pravila.“

Deleuzeov animozitet prema metafori logična je sastavnica njegova nastojanja da odbaci uvriježen koncept znaka sastavljenog od označitelja i označenog, za koji smatra da pogoduje tiraniji označitelja, te ga zamijeni konceptom ekspresije. Detaljnije o tome usp. npr. u Colombat, 2000: 16-17.
} 
nasuprot molarnim akterima - bilo individualnim ili kolektivnim - Deleuze naglasak stavlja na molekularne, parcijalne, mnoštvene, sklopove koji ignoriraju konvencionalna razgraničenja i prostiru se mimo njih, na mikro- ili makro-razinama.

$\mathrm{U}$ već spomenutom izlaganju triju sinteza vremena u Razlici i ponavljanju Deleuze (2009b: 132) tako u odnosu na prvu sintezu piše da „/i/spod jastva koje deluje postoje mala jastva koja kontempliraju i koja čine mogućim delovanje delatnog subjekta. Kažemo 'ja' samo zahvaljujući hiljadama tih svedoka koji kontempliraju u nama; uvek neko treći kaže ja.“ Kretanje od prve prema drugoj sintezi zatim je dvostruko, s jedne strane u pravcu produbljivanja molekularnih pasivnih sinteza, a s druge strane u pravcu njihova okrupnjivanja povezivanjem, na što se izravno nastavlja druga sinteza. No ako jastvo tu napokon stječe koherenciju, treća je sinteza vječnog vraćanja ponovno ona koja raspršuje identitet $u$ korist ponavljanja razlike.

Prelazeći na istraživanje mašina žudnje u Antiedipu pak, Deleuze (Deleuze, Guattari; 2015: 34-35) mašinu definira kao „sustav prekida“ u odnosu „s neprekidnim materijalnim tokom (hyle) u koji se usijeca“, pri čemu „/p/rekid ne samo da nije suprotstavljen kontinuitetu, već ga uvjetuje, uključuje ili definira ono što prekida kao idealni kontinuitet.“ Svaka mašina sačinjena je pak od „djelomičnih objekata“, a nastavlja se na točkama svojih prekida na druge mašine, s kojima čini veće sklopove te u konačnici mašinu mašine ${ }^{159}$. Primjeri koje nudi poput probave ili dojenja - jasno pokazuju da pojam mašine ne vodi računa o obrisima konvencionalno shvaćenih individualnih tijela. Subjekt priključen mašini rezultat je jedne od vrsta prekida, i to kao preostatak i sam podijeljen u dijelove što odgovaraju izdvajanjima iz toka što ih vrši mašina (Deleuze, Guattari, 2015: 38). Konkretniji oblici njegove realizacije ovise stoga o tipu sociusa i njegovoj regulaciji tokova žudnje, odnosno o modusima proizvodnje, zapisivanja i potrošnje (tj. konekcije, disjunkcije i konjunkcije) ${ }^{160}$.

Moderna molarna individua tako je produkt kapitalističkog sociusa u čijem „,pripitomljavanju“, kako Deleuze ističe u svojoj kritici, veliku ulogu ima i psihoanaliza ${ }^{161}$. No

\footnotetext{
${ }^{159}$ Bogue (2003: 68) jezgrovito sažima problematiku tvrdnjom da je „,/m/ašina ime za ono što dijelove stavlja u netotalizirajući odnos, kao i ime za ono što je stavljeno u taj odnos.“

${ }^{160}$ Teza da „subjektni prekid ne označava nikakav manjak, nego naprotiv, udio koji dopada subjektu kao dio, prihod koji mu pada u dio kao prežitak“ (Deleuze, Guattari; 2015: 39) u određenoj je mjeri kompatibilna s Rancièreovim tematiziranjem konstitutivnih dijelova zajednice prema udjelu koji u njoj imaju u Nesuglasnosti (2015). Utoliko se paralele mogu povući i između njegova dijela bez udjela koji narušava status quo zajednice te Deleuzeovih manjinskih subjekata kojima više prostora posvećuje u Tisuću platoa (2013), a kojima ćemo se uskoro opširnije pozabaviti.

${ }^{161}$ Osim što kapitalizam stalno nastoji odagnati shizofreniju kao svoju vanjsku granicu te s druge strane sam proizvodi svoje imanentne granice koje stalno prekoračuje (u već spominjanoj dinamici teritorijalizacije i reteritorijalizacije), potrebna mu je i ,pomaknuta unutarnja granica i na drugi način: upravo da bi neutralizirao ili odbio apsolutnu vanjsku granicu, shizofreničnu granicu, on je mora pounutarnjiti, ovaj put tako što će je
} 
u kontekstu odnosa prema marksizmu, kao i prema prethodnoj dvojici autora, vjerojatno nam je još i zanimljiviji njegov tretman klase ${ }^{162}$. Ne samo da Deleuze klase ne vidi esencijalno određenima nekim objektivnim svojstvom, već ih smatra rezultatom deteritorijalizacije koju uzrokuje kapitalizam: „Klase su ono negativno kasta i statusa; klase su poreci, dekodirane kaste i rangovi“ (Deleuze, Guattari; 2015: 240), odnosno rezultat onoga što smo prethodno nazivali literarnošću politike. Utoliko je i za Deleuzea čitavu historiju legitimno tumačiti kao historiju klasne borbe, no ne u smislu transhistorijske protežnosti esencijalistički određenih klasa, već „u kategorijama buržoazije kao dekodirajuće i dekodirane klase.“ (isto)

No dok odvajanje klasnog subjekta od predeterminiranosti historijskom nužnosti i od utemeljenja u ekonomskom u konvencionalnom smislu Deleuzea povezuje s Laclauom i Rancièreom, povezivanje $\mathrm{s}$ ekonomskim kako ga on shvaća proizvodi i znatne razlike. Prema Deleuzeu, naime, klasa nije ni rezultat kontingentne simboličke artikulacije, nego naprosto urušavanja starih kodova te ispunjavanja kapitalističkog polja imanencije pod djelovanjem njegove aksiomatike. Utoliko postoji tek jedna klasa, buržoazija, koja je u potpunosti dostatna da popuni to polje, dok se suprotstavljenost njoj javlja ne u vidu neke druge klase ${ }^{163}$, već „,između klase i onih koji su izvan klase“, odnosno „između dekodiranih tokova kakvi ulaze u klasnu aksiomatiku na punom tijelu kapitala i dekodiranih tokova koji se oslobađaju i od te aksiomatike i od despotskog označitelja, koji probijaju kroz taj zid $i$ taj zid zida te počinju teći po punom tijelu bez organa.“ (Deleuze, Guattari; 2015: 241)

Tako postavljene stvari s jedne su strane u čvrstoj korelaciji sa stavovima Laclaua $i$ Rancièrea $\mathrm{u}$ onoj mjeri $\mathrm{u}$ kojoj potonji politički moment $\mathrm{u}$ društvu prepoznaje ne $\mathrm{u}$ nadmetanju njegovih skladnih dijelova, već u afirmaciji dijela bez udjela, ili pak u mjeri u kojoj se kod prvog u istoj situaciji ne radi o borbi dijelova unutar društva kao zaokružene cjeline, već o antagonističkim rasjedima koji ga brazdaju međusobnim dovođenjem u pitanje

ograničiti, dovesti do toga da ne prolazi više između društvene proizvodnje i proizvodnje-žudnje, koja se odcjepljuje od društvene proizvodnje, nego unutar društvene proizvodnje, između forme društvene reprodukcije i forme obiteljske reprodukcije na koju se društvena reprodukcija svodi, između društvenog skupa i privatnog podskupa na koji se ovaj aplicira. Edip je ta pomaknuta ili pounutarnjena granica u koju se žudnja dopušta uhvatiti. Edipski trokut je intimna i privatna teritorijalnost koja odgovara svim nastojanjima društvene reteritorijalizacije svojstvene kapitalizmu.“ (Deleuze, Guattari; 2015: 252) Odnosno, ako ,/i/za svake izdaje žudnje, iza svakog prokletstva žudnje, iza svakog istrgnuća žudnje iz njenog polja imanencije stoji svećenik“, onda je „,n/ajrecentnija figura svećenika psihoanalitičar“ (Deleuze, Guattari; 2013: 174-175).

162 Premda, kao što je već rečeno, i Deleuzeova kritika psihoanalize i njezinog represivnog udjela u subjektivaciji u kapitalističkom društvu svoju pozadinu traži u marksizmu, smatrajući da iza edipovskog trokuta ne stoje obiteljske/seksualne univerzalije kao autonomna domena, već društveni odnosi koji se na njih nepravilno reduciraju. Usp. npr. Deleuze, Guattari; 2015: 250. S druge strane, seksualnost također ne treba ograničiti na obiteljske odnose, već je „sveprisutna: ona je u načinu na koji birokrat miluje svoje spise, na koji sudac vrši pravdu, na koji poslovni čovjek stavlja novac u kolanje, na koji buržoazija guzi proletarijat itd.“" (isto: 276)

${ }^{163}$ Deleuze podcrtava manjkavosti i opasnosti od tretiranja proletarijata kao klase umjesto ne-klase, povezujući to s problemima koji se nužno pojavljuju u socijalističkim pokušajima aproprijacije državnog aparata, što po njemu nužno vode nekom obliku uskrsnuća državnog kapitalizma. Usp. Deleuze, Guattari; 2015: 241-242. 
identiteta antagonističkih strana. No Deleuzeovo nastojanje da kapitalističku mašinu prikaže kao strogo imanentnu, lišenu (kvazi)utemeljenja, dovodi do stvaranja oštrih binarnih opreka: ili pripadnost jednoj klasi unutar koje je specifična pozicija u odnosu na višak vrijednosti, tokove kapitala i rada te financiranja i plaće u krajnjoj instanci irelevantna (v. Deleuze, Guattari; 2015: 240), ili apsolutna deteritorijalizacija onkraj granica bilo kakvog sociusa, pri čemu ne ostavlja prostora za to da dio bez udjela također bude rezultat neke (simboličke) artikulacije, a ne samo posvemašnje deartikulacije ${ }^{164}$.

Rezultat je toga i jednako ambivalentna (ne)kompatibilnost oko pitanja ograničenog uspjeha podrivanja nekog uspostavljenog poretka, naročito u prvom svesku Kapitalizma $i$ shizofrenije. Rancière i Laclau slažu se oko razmjerne rijetkosti i neuhvatljivosti pojave politike/rekonfiguracije diferencijalnog poretka i nužnosti da se ona ponovno pretoči u neku policiju/petrificirani diferencijalni poredak, te u perpetuiranju te dinamike ne vide tragediju, već istovremeno nužnost i priliku za kontinuiranu demokratizaciju društva. Deleuze pak kretanje deteritorijalizacije također smatra teško uhvatljivim naličjem teritorijalizacije (Deleuze, Guattari; 2015: 350), no njezin nedolazak do kraja opisuje u tonovima poraza: revolucionarne promjene na molarnoj/predsvjesnoj razini naprosto nisu dovoljne bez revolucije molekularnog/nesvjesnog ${ }^{165}$, „/p/odjarmljene grupe neprestano proizlaze iz revolucionarnih grupa-subjekata“, tj. ,/s/ve počinje s Marxom, nastavlja se s Lenjinom i završava s 'Dobrodošli gospodine Brežnjev'“ (isto: 355). S druge strane, izbjegavajući problem utemeljenja, ne uspijeva jasnije artikulirati alternativu tom poraznom povratku teritorijalizaciji.

Drugi dio Kapitalizma i shizofrenije doduše, osim što premješta naglaske u odnosu na Antiedipa, donekle i ublažava spomenute binarnosti. U različitim ,platoima“ od kojih su sastavljeni Tisuću platoa tako razlikuju relativne, negativne potpune i pozitivne potpune deteritorijalizacije (usp. npr. Deleuze, Guattari; 2013: 213). Iako su posljednje i dalje nesumnjivo najpozitivnije valorizirane, nekoliko je važnih promjena u odnosu na ranije stanje.

\footnotetext{
${ }^{164}$ Ipak, Deleuzeu se (naročito u kasnijem opusu) tu otimaju i neki proturječni momenti. Tako npr. ocjenjuje Lenjinove tekstove, konkretno onaj O parolama, kao netjelesnu pretvorbu „koja je iz masa izdvojila proletersku klasu kao sklop iskazivanja, prije nego su stvoreni uvjeti za proletarijat kao tijelo“ (Deleuze, Guattari; 2013: 95). Uzmemo li da proletarijat drugdje određuje kao ne-klasu i figuru manjine par excellence (usp. isto: 537), može se zaključiti da u toj konkretnoj historijskoj situaciji prepoznaje diskurzivno oblikovanje njegove pozicije osporavanja aktualnog poretka. Situacija je to koja posve odgovara diskurzivnoj artikulaciji analognih elemenata kod Laclaua i Rancièrea, u konkretnom slučaju s Lenjinom čak i npr. Laclauovoj figuri vođe (usp. Laclau, 2007: 59).

${ }^{165}$ Revolucionar i shizo stoga su usko povezani, ali i različiti: „Razlika između shizoa i revolucionara jest razlika između onoga koji bježi i onoga koji umije nagnati na bijeg ono od čega bježi, slamajući prljavu kanalizacijsku cijev, oslobađajući tok, presijecajući shizu. Shizo nije revolucionar, ali shizofrenični proces (kojega je shizo samo prekid ili produžetak u praznom) je potencijal za revoluciju.“ (Deleuze, Guattari; 2015: 323) No valja primijetiti da i u slučaju shizoa i u slučaju revolucionara ključan ostaje bijeg, kao suprotnost utemeljenju.
} 
Deleuze tako na više mjesta upozorava na opasnost od suviše nagle i nevaljano izvedene deteritorijalizacije, pišući primjerice: „Ako ga [tijelo bez organa] oslobodite suviše silovitom gestom, neoprezno dovedete stratume do eksplozije, bit ćete ubijeni, uvučeni u crnu rupu, pa čak i dovedeni do katastrofe umjesto da ocrtate ravan.“ (Deleuze, Guattari; 2013: 182) Ili pak: „No, i opet, potreban je velik oprez da ravan konzistencije ne bi postala čista ravan ukinuća ili smrti. Da se involucija ne bi okrenula u regresiju u nerazlučenome." (isto: 302) Iako je apsolutna deteritorijalizacija krajnji cilj svake doista emancipatorne prakse, nije dakle svejedno kako se do nje dolazi; oslobađanje od spona društva raznim nihilističkim ili suviše intenzivnim prečicama vodi u kasnije drastične reteritorijalizacije ili pak neproduktivno ukinuće.

Nadalje, Deleuze na više mjesta upozorava i na tzv. „aksiološku“ pogrešku pripisivanja apriorno pozitivne ocjene svemu molekularnom, pri čemu se zaboravlja opasnost „mikrofašizama“ i „tanane segmentacije“ (Deleuze, Guattari; 2013: 240). Na tom tragu eksplicitno podcrtava da se kod njegovih opreka poput molarnog - molekularnog, državnog nomadskog, izbrazdanog - glatkog itd. „ne radi (...) o dobrom ili lošem, već o specifičnosti“ (isto: 443), odnosno da nas naizgled afirmirani član neke od tih opreka sam po sebi neće spasiti (isto: 569$)^{166}$.

Konačno, za razliku od ranijeg razmjerno pesimističnog stava prema ičemu manjem od totalne deteritorijalizacije, Deleuze u Tisuću platoa benevolentnije gleda na relativne deteritorijalizacije te ističe kako ne smatra „da je borba na razini aksioma nevažna. Upravo suprotno, ona je odlučujuća (na najrazličitijim razinama: borba žena za pravo glasa, za pravo

\footnotetext{
${ }^{166}$ S obzirom na te ograde, donekle je diskutabilna Choatova (2010: 149) kritika da Deleuze organizira pojmove u hijerarhijske binarne opreke, koje samim time podrivaju njegovo nastojanje da odbaci svaku transcendenciju (jer bi se hijerarhija morala na neku osloniti). Situacija je slična primjerima kakve smo imali i kod Rancièreovih kritičara - Deleuze sasvim sigurno rasporedom naglasaka daje povoda takvoj kritici, no ipak se ne može zanemariti da je istovremeno anticipira i nastoji anulirati, naglašavajući na više mjesta razmjernu nepredvidljivost molarnih tokova i linija bijega te činjenicu da jednako lako mogu završiti reteritorijalizirani u fašističkim oblicima, kao i biti emancipatorni. Tako npr. piše: „Svaki rizom sadrži linije segmentiranosti prema kojima biva stratificiran, teritorijaliziran, organiziran, označen, određen itd. No sadrži i linije deteritorijalizacije duž kojih neprestano izmiče. U rizomu nastaje raskid uvijek kada se segmentirane linije rasprsnu u liniju bijega, ali linija bijega čini dio rizoma. Te se linije neprestano nanovo vezuju jedne za druge. Zbog toga nikad nije moguće utvrditi dualizam ili dihotomiju, čak ni u rudimentarnom obliku dobrog i zlog. Moguće je proizvesti raskid, ocrtati liniju bijega, no uvijek postoji opasnost da se na njoj i dalje nađu organizacije što iznova stratificiraju cjelinu, formacije koje ponovno daju moć nekom označitelju, atribucije koje nanovo uspostavljaju subjekt - što god se može zamisliti, od edipovskih recidiva do fašističkih skrutnuća." (Deleuze, Guattari; 2013: 16). Jednako tako upozorava i da je „fašizam neodjeljiv od molekularnih žarišta koja se roje i skaču s jedne točke na drugu, uvijek u interakciji, prije nego što će odjeknuti sva zajedno u nacionalsocijalističkoj državi“ (isto: 238), te stoga kritizira da je ,/s/uviše lako biti antifašist na molarnoj razini i ne primjećivati fašista u samome sebi, za kojeg se skrbi, kojeg se hrani i njeguje osobnim i kolektivnim metodama.“ (isto: 240).

Deleuzeova gesta kojom se ograđuje od toga da apsolutizira emancipacijsku komponentu uvelike je nalik Laclauovu (2007b: 97) upozorenju da nema nikakve garancije da će pojedina artikulacija biti progresivna, odnosno da će prisvajanje nekog praznog označitelja nužno biti u korist nekog demokratskog poretka.
} 
na pobačaj, za pravo na zaposlenje; borba pokrajina za autonomiju; borba trećeg svijeta; borba potlačenih masa i manjina na Istoku ili na Zapadu...). No, isto tako, uvijek postoji znak koji pokazuje da su te borbe naznake jedne druge, supostojeće borbe.“ (Deleuze, Guattari; 2013: 535) Ipak, iako ta teza nalikuje opisu povezivanja manjih, konkretnih zahtjeva simboličkim nadsvođivanjem u borbu nesumjerljivu s pojedinačnim zahtjevima kakav smo mogli vidjeti kod Laclaua i Rancièrea, Deleuze ponovno nastoji izbjeći bilo kakav oblik hegemonijske artikulacije pa s jedne strane tvrdi da maleni partikularni problemi vode prema formuliranju općenitijih rješenja, a s druge strane da se moć manjina u takvim slučajevima ne mjeri prema tome hoće li se nametnuti sustavu iznutra, ili čak preokrenuti odnos i postati nova većina, nego u potvrđivanju snage neizbrojivih skupova u odnosu na nemoći i podbačaje aksiomatike (isto: 536). Time pak ostaje u raskoraku između tropološkog povezivanja manjinskih zahtjeva i njihove nesvodive različitosti.

Te malene, ali ipak nezanemarive razlike odražavaju se i u Deleuzeovoj tezi kako se /p/ogrešno tvrdi (osobito u marksizmu) da se društvo definira svojim protuslovljima. To je istina samo u velikim razmjerima. S točke gledišta mikropolitike, društvu su svojstvene prvenstveno njegove linije bijega, koje su molekularne. Uvijek nešto teče ili bježi, izmiče binarnim organizacijama, rezonancijskom aparatu, mašini nadkodiranja: ono što se pripisuje 'promjeni vrijednosti', mladima, ženama, mentalno poremećenima itd. (Deleuze, Guattari; 2013: 241) $)^{167}$

Linija bijega nesumnjivo je stoga jedan od središnjih pojmova u Tisuću platoa, bez obzira što (intendirana) struktura te knjige nastoji izbjeći pojavu središta iz bilo kojeg aspekta i u bilo kojem smislu. No linije bijega se „nikada ne sastoje u bježanju od svijeta, već u dovođenju do bijega (...) i ne postoji društveni sustav koji ne bježi u svim smjerovima, premda se njegovi segmenti neprestano ukrućuju kako bi se blokirale linije bijega.“ (Deleuze, Guattari; 2013: 228)

Linije bijega, ukoliko ne smjeraju negativnoj deteritorijalizaciji, nisu dakle nihilističke silnice, već imaju svoj pozitivan sadržaj. To su ujedno i linije postajanja, i to postajanja drukčijim, „postajanja ženom“, „postajanja životinjom“, „postajanja neopazivim“ pa do krajnjeg rastvaranja na ravni konzistencije (usp. Deleuze, Guattari; 2013: 281, 312). No i kod tematike postajanja do izražaja dolazi Deleuzeovo bježanje od metafore. Kao što naglašava, postajanje nečim, životinjom npr., nije postajanje poput nečega, ne znači oponašanje niti identifikaciju, niti se referira na neke fiksne identitete; ono proizvodi sebe samo, nema

\footnotetext{
${ }^{167}$ Usp. varijaciju te teze i u Deleuze, Guattari; 2013: 103. Primjer što ga Deleuze nudi identičan je primjerima koji su inicirali formulaciju teorijskih pozicija Laclaua i Rancièrea - svibanj 1968. i zbivanja njemu nalik, koja se nisu dala razumjeti iz klasične makropolitičke perspektive - no otklon od te perspektive formulirao se $u$ dva vrlo slična, pa ipak ne posve kompatibilna pravca.
} 
subjekta drukčijeg od sebe niti krajnje granice te postajanjem drugim zahvaća i onog tko postaje $\mathrm{i}$ ono čime se postaje (isto: 265). No iz te je perspektive zanimljivo vratiti se „postajanju neopazivim“, koje prema Deleuzeu također nije nihilistička gesta, već se tiče pozitivne deteritorijalizacije na ravni konzistencije. Ipak, kako napominje, na toj ravni „, i samo neopazivo postaje nužno opaženo, dok istodobno opažaj postaje nužno molekularan...“ (isto: 316). Drugim riječima, političko-emancipacijski potencijal postajanja neopazivim prepoznaje upravo u rekonfiguraciji polja osjetilnog, procesu koji za politiku ključnim smatra i Rancièrea, bez obzira što prvi pod svaku cijenu nastoji izbjeći reprezentacijsku paradigmu politike, dok je potonji (u obliku kakav je opisan u prošlom poglavlju) prihvaća.

Postajanje je izravno vezano i s drugim važnim pojmom kojeg Deleuze uvodi u svom kasnijem opusu, a koji nije bio prisutan u Antiedipu - pojmom manjinskog. „Postajanje je uvijek manjinsko“ (Deleuze, Guattari; 2013: 121, usp. i isto: 325), smatra; ne postoji većinsko postajanje, većina je uvijek neko stabilno, teritorijalizirano stanje, konstanta u odnosu na koju se manjina odmjerava. No pojam manjinskog vrlo je često zbunjivao Deleuzeove čitatelje, bez obzira na njegova opetovana eksplicitna nastojanja da ga udalji od konvencionalne uporabe. Kako piše, „/m/anjina (minorité) je vrlo složen pojam, s glazbenim, književnim, lingvističkim, ali i pravnim i političkim referencijama." (isto: 121, 325) Međutim, ni u jednom od vidova taj se pojam ne ograničava (isključivo) na kvantitetu ${ }^{168}$, već na neku nekonstantnost, odstupanje od modela, potencijalnost, stvaralačko postajanje koje podriva ustaljene odnose i tako omogućuje mijenjanje većinskog (isto), odnosno na neku nebrojivost, neodređenost, nediskretnost, poziciju između (isto: 534). Istovremeno, Deleuze uvijek iznova upozorava da „ne treba pobrkati 'manjinsko' kao postajanje ili proces i 'manjinu' kao skup ili stanje“ (isto: 325), odnosno da konvencionalno shvaćen pojam manjinskog može biti osnova za snažnu reteritorijalizaciju u vidu esencijalizacije identiteta i getoizacije, dok je postajanje manjinskim subverzija svake predodžbe stabilnog identiteta, opetovana deteritorijalizacija neke većine ${ }^{169}$. U tom ključu konačno valja razumjeti i njegovu tezu o proleteru kao figuri ili

\footnotetext{
${ }^{168}$ Naprotiv, kao što Deleuze (Deleuze, Guattari; 2013: 534) napominje, kvantitativni omjer većine i manjine može biti obrnut od očekivanog. Bijeli heteroseksualni muškarac prototipan je predstavnik većine, a da u svjetskoj populaciji istovremeno može imati kvantitativno manji udio od neke druge skupine.

${ }^{169}$ Zato će Deleuze reći da ,/s/ubjekt postajanja postoji samo kao deteritorijalizirana varijabla neke većine, a medij postajanja samo kao deteritorijalizirajuća varijanta neke manjine“ (Deleuze, Guattari; 2013: 326), odnosno da je „,u neku ruku subjekt postajanja uvijek 'muškarac'“, ali samo „ulazeći u neko postajanje-manjinskim koje mu oduzima njegov većinski identitet.“ (isto: 325) Također, podcrtava i da „/k/ao što su tvrdile Crne pantere, čak i Crnci moraju postati-crnima. Čak i žene moraju postati-ženom. Čak i Židovi moraju postati-Židovom (izvjesno je da za to nije dovoljno stanje). No, ako je tako, postajanje-Židovom nužno zahvaća ne-Židova kao i Židova itd." (isto)
} 
univerzalnoj svijesti manjine (isto: 537); kao i kod prethodne dvojice analiziranih autora, dakle, umjesto univerzalne klase, kontinuirana negacija klasa ${ }^{170}$.

Pojmovi postajanja i manjinskog ključni su pojmovi i u onome što bismo (uz stanovitu rezervu) mogli nazvati Deleuzeovim viđenjem politike književnosti, budući da ta dva pojma usko veže za praksu književnosti i u studijama kojima smo se već bavili, kao i u onima koje usmjerava primarno književnim temama. No prije prelaska na tu temu, valjalo bi kratko rezimirati. Teme kojima smo se u odnosu na Deleuzea do sada bavili nedvojbeno pripadaju njegovu promišljanju politike, premda je značajno primijetiti da on politiku nigdje ne pokušava precizno definirati onako kako to čine Laclau i Rancière, odnosno da bi se njegova definicija politike istovremeno mogla svesti na rečenicu: „Ukratko, sve je politika, ali svaka je politika makropolitika i mikropolitika u isti mah.“(Deleuze, Guattari; 2013: 237)

Za razliku od prethodne dvojice autora, kod kojih se radilo o specifičnoj praksi, no na stanovit način privilegiranoj, budući da se bavi upravo utemeljenjem zajedničke scene svih ostalih praksi, pa tako i odjekuje u svim ostalima, kod Deleuzea je ona sveprisutna na drugi način: raspršena po cijelom društvenom tijelu kao tijelu ekonomije žudnje, što je pak samo drugo ime za političku ekonomiju. No koliko god se jezgre tih dviju pozicija činile disparatnima, njihova elaboracija na nešto konkretnijoj razini dovodi, vidjeli smo, do vrlo bliskih stavova, usporedivih koncepata te sličnih odmaka u odnosu i na liberalizam i na tradicionalni marksizam. Sjecište svega toga ponovno ono je što smo u prošlim poglavljima nazvali literarnošću politike. Taj se koncept naime, bez obzira na Deleuzeovo jasno odbacivanje diskurzivnih temelja politike, čini primjenjiv i na njegov opus, uzmemo li u obzir da se - uz sve nezanemarive razlike - i kod njega dinamika politike smješta između podjarmljivanja i segmentacije inicijalne polisemnosti čistih intenziteta od strane regulatornih kodova i hegemonijskog označitelja, te oslobađanja tih elemenata čiste razlike razotkrivanjem konvencionalnosti i kontingentnosti danog poretka riječi i stvari što ga postiže literarna životinja, koja je u stanju odvojiti te dvije domene, propitati im odnose i u njih unijeti disonantne tonove. Slično kao kod Rancièrea, i prema Deleuzeu u toj je praksi naročito uspješna književnost.

Kao što navode Buchanan i Marks (2000: 1), doista bi „,bilo nemoguće precijeniti važnost književnosti za Gillesa Deleuzea“. U gotovo trideset godina, od studije o Proustu iz 1964. pa do Kritičkih $i$ kliničkih eseja [Critique et clinique] iz 1993., objavio je najmanje pet

\footnotetext{
${ }^{170}$ Deleuze (Deleuze, Guattari; 2013: 121, 534) stoga kritizira i marksističke teoretičare da je njihova vizija proletarijata najčešće bila većinska, a ne manjinska, odnosno da su nastupali s pozicije „nacionalnog radnika, kvalificiranog, muškog i iznad trideset pet godina“.
} 
istaknutih studija posvećenih prvenstveno književnosti. No o važnosti književnosti u njegovu opusu još i više svjedoči činjenica da su njome intenzivno prožete $i$ sve njegove „neknjiževne“ studije, pa je tako Bogue (2003: 1) primjerice nabrojao reference na čak 75 književnika duž stranica Tisuću platoa. Istovremeno, neobična je nuspojava tog Deleuzeova širokog interesa za književnost činjenica da nikada nije razvio sistematičnu misao o književnosti; dapače, bez obzira na kontinuitet nekih temeljnih toposa, pišući o književnosti, povremeno ulazi i u proturječja. Zbog toga, unatoč zabludama na koje je moguće naići, teško da je moguće govoriti o Deleuzeovoj teoriji književnosti kao distinktivnom i konzistentnom dijelu njegova opusa.

Čak štoviše, ne bi bilo ni posve neopravdano složiti se s Crawfordom (2000: 57) kada piše da je za Deleuzea književnost primarno ,izvor za njegove filozofske koncepte i sredstvo argumentacije“, odnosno da je posve „utaknuta u veću mašinu žudnje što je naziva filozofijom“, što istovremeno ne znači da bi se valjalo složiti s njegovom ocjenom da Deleuze zbog toga ne pridonosi mnogo književnoj teoriji. Nedvojbeno je doduše da posežući za književnosti često ne uzima u obzir granice između nje i drugih diskursa (prvenstveno filozofije), da književna djela često tretira kao singularne strojeve, izdvojene iz neposrednijih književnih konteksta, zanimajući se isključivo za njihove učinke u odnosima s raznim drugim fenomenima, kao i da baveći se pojedinim autorima često zamagljuje granice između njihovog književnog rada, produkcije drugih diskursa te osobnog života ${ }^{171}$.

Zbog svega toga ovdje nećemo nastojati detaljnije izbistriti konzistentnosti i oscilacije u Deleuzeovu bavljenju književnosti, niti ćemo taj dio njegova opusa zahvatiti i izložiti u cijelosti. Naprotiv, zadovoljit ćemo se vrlo ograničenim uvidom, orijentirajući se prema problemima koje smo imali u fokusu u dosadašnjoj analizi Deleuzeova opusa, kao i kod dvojice prethodnih autora. Drugim riječima, zanimat će nas prvenstveno Deleuzeov pogled na politiku književnosti.

Takav izbor ne sužava doduše perspektivu u dovoljnoj mjeri, budući da Deleuzeovo bavljenje književnosti gotovo bez iznimke zasijeca društveno-političku problematiku. Još i prije prvih studija prvenstveno književne tematike, već u Nietzscheu i filozofiji [Nietzsche et la philosophie, 1962] (usp. Deleuze, 2002) Deleuze na Nietzscheovu primjeru razmatra jedan oblik hibridizacije književnog i filozofskog diskursa u kojem filozof zadobiva ulogu ne samo, sukladno čuvenoj ničeanskoj figuri, liječnika društva, već i umjetnika i povlaštenog tumača,

\footnotetext{
${ }^{171}$ Najbolji je primjer Deleuzeov tretman Kafke. U više referenci na Kafku u drugim studijama, no naročito u poznatoj studiji Kafka: U prilog manjinskoj književnosti [Kafka: Pour une Littérature Mineure, 1975] (usp. Deleuze, Guattari; 1986), Deleuze na istu razinu analize postavlja Kafkinu privatnu korespodenciju, kratke priče i romane, a u konačnici ih spaja i s aspektima njegovog profesionalnog i privatnog života (usp. isto: 40-41).
} 
dok se književnosti povjerava uloga interpretacije (aforizam) i valorizacije (pjesništvo) (Deleuze, 2002: 31). Motivi kritike i klinike društva u kontinuitetu će se potom protegnuti ostatkom opusa i zatvoriti puni krug postajući eponimni u posljednjoj Deleuzeovoj knjizi, no na toj se putanji ipak bitno modificirajući.

Prva studija o književnosti u kojoj Deleuze nastoji simptomatski povezati književnost sa stanjem društva jest studija Hladno i okrutno [Le Froid et le Cruel] u sklopu publikacije Predstavljanje Sacher-Masocha [Présentation de Sacher-Masoch, 1967] (usp. Deleuze, 2006a), posvećena književnom djelu Leopolda von Sacher-Masocha, ali i kritici dotadašnjeg psihoanalitičkog tretmana sadomazohizma ${ }^{172}$. Već tamo pokazuje da u takvom pothvatu književnost ne smatra pukim pasivnim indikatorom nekog stanja, već i djelatnim čimbenikom u njegovu oblikovanju. Kao što Bogue (2003: 21) napominje, za protusvjetove koje Masoch i Sade oblikuju naglašavajući određene ciljano izdvojene odnose ${ }^{173}$ Deleuze ističe da ne dijagnosticiraju samo bolesti civilizacije, nego ukazuju i na nove mogućnosti ironičkim tretmanom tih odnosa. Također, već u toj studiji pojavljuje se i motiv što će postati stalnim, dapače središnjim u njegovom kasnijem bavljenju književnosti, anticipirajući i njegovo izrazito pragmatocentrično viđenje jezika ${ }^{174}$ : ne zadržavajući se isključivo na tematskoj razini, Deleuze se zanima i za to kako književnost ,suočava jezik s njegovim vlastitim granicama, s onim što je u biti 'nejezik'“ (Deleuze, 2006a: 22), odnosno ,protujezik, što djeluje izravno na osjetila“ (isto: 37$)^{175}$.

\footnotetext{
${ }^{172}$ Politička dimenzija studije dolazi do izražaja $\mathrm{i}$ iz tog aspekta, i to dvojako - kao oponiranje jednoj od u to vrijeme najutjecajnijih epistemoloških paradigmi u Francuskoj, ali i kao kritika onoga u čemu Deleuze vidi jedan od važnih represivnih mehanizama kapitalizma. Utoliko bi se ta kritika psihoanalize mogla smatrati embrionalnom i u odnosu na projekt Antiedipa. Sacher-Masochu se u kontekstu problematike manjinskog te postajanja i ulaska u zone nerazlučivosti Deleuze vraćao i kasnije; usp. npr. Deleuze, Guattari; 1986: 66 i Deleuze, 1998: 54.

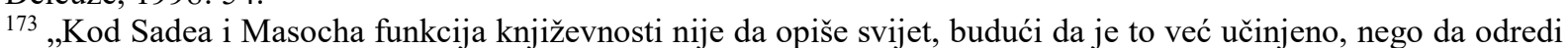
protutežu svijeta u mogućnosti da sadrži sve njegovo nasilje i suvišak.“(Deleuze, 2009b: 37).

${ }_{174}$ Jedna od posljedica toga da Deleuze na različite načine pokušava iskoračiti iz teorije jezika podređene označitelju jest i izrazita pragmatocentričnost njegova viđenja jezika. Pojava je to koja do izražaja dolazi i u njegovoj kritici psihoanalize u Antiedipu, u vidu kritike nastojanja da se odgovori na pitanje što nešto znači, a nauštrb pitanja što nešto čini, zatim i u prenošenju tako postavljenih stvari na književnost u njegovim književnim studijama, ali naročito u dva segmenta Tisuću platoa posvećena prvenstveno pitanju jezika (,Postulati lingvistike“ $\mathrm{i}$ „O raznim režimima znakova“). Tamo ističe da ,/j/ezik nije nastao da bi mu se vjerovalo, nego da bi mu se pokoravalo, te da bi nametao pozornost“" (Deleuze, Guattari; 2013: 87), odnosno da ne postoji iskaz koji ne bi reprezentirao odnos iskaza ,s implicitnim pretpostavljanjima, to jest s govornim činovima koji se izvršuju u iskazu i mogu se izvršiti samo u njemu“", tj. koji ne bi bio ono što naziva „riječju-naredbom“" (isto: 91). Isto tako, podcrtava i da ,/n/e proizlaze režimi znakova iz jezika, i nije jezik ono što samostalno konstituira strukturnu ili generativnu apstraktnu mašinu“, već upravo obrnuto, jezik proizlazi iz sklopova koji „nadilaze svaku semiologiju, svaku lingvistiku i svaku logiku.“ (isto: 168)

${ }^{175}$ Recepcija Deleuzea ponajviše je pozornosti pridala raspravi o dolaženju do/preko granica jezika u okvirima njegove studije o Kafki te Kritičkih $i$ kliničkih eseja, no značajne doprinose istoj temi dao je i npr. baveći se Lewisom i Artaudom u Logici smisla [Logique du sens, 1969]; usp. Deleuze, 1990.
} 
Nešto prije toga Deleuze se specifičnom naravi književnih znakova pozabavio u prvom dijelu studije koja je zadobila ulogu svojevrsnog mosta između ranije faze njegova opusa te one započete Antiedipom. Prvi dio studije Proust $i$ znakovi [Proust et les signes], naime, objavljen je 1964. i donosi iz kasnije perspektive vrlo neobičnu inačicu Deleuzeove misli, dok drugi dio, objavljen 1976., nastoji (s ograničenim uspjehom) ${ }^{176}$ zagladiti razlike i proturječja u odnosu na pomake koji su se u njegovim pogledima u međuvremenu dogodili te uklopiti ranije istraživanje Prousta u prepoznatljiv mašinistički diskurs kasnijeg Deleuzeova opusa.

Ipak unatoč razmjerno esencijalističkoj i herojskoj viziji književnosti u prvom dijelu studije $^{177}$, već se u njemu nalazi nekoliko elemenata relevantnih za temu politike književnosti i važnih za njezin kasniji razvoj u Deleuzeovu opusu. Kao prvo, Deleuze (2000: 94) u prvom dijelu Prousta i znakova iznimno važnom crtom Proustova projekta ocjenjuje napad „na ono što je najesencijalnije u klasičnoj filozofiji racionalističke vrste“, a to je pretpostavka tzv. dobrohotnosti mišljenja i samorazumljive usmjerenosti na istinu ${ }^{178}$. Ista će se kritika uzimanja dobrohotnosti mišljenja za prešutno polazište u klasičnoj filozofiji ponovno javiti i u Razlici $i$ ponavljanju (v. Deleuze, 2009b: 218, 220), u poglavlju Slika mišljenja koje, kako navodi Murphy (2000: 235) oslanjajući se na Deleuzeov predgovor engleskom izdanju, sam Deleuze smatra „najnužnijim i najkonkretnijim korakom u nastojanju da se oslobodi tradicionalne slike mišljenja kao 'zdravog razuma ili upošljavanja svih sposobnosti na zajedničkom objektu.'“‘

\footnotetext{
${ }^{176}$ Bogue u nekim momentima na marginama svoje analize Prousta i znakova adresira jasne razlike između dva dijela te studije (usp. npr. Bogue, 2003: 53), no u konačnici daje vrlo blagonaklonu ocjenu kako se radi prvenstveno o razlici „u stupnju i naglascima, radije nego u supstancijalnim stvarima“ (isto: 57 ). S time se ovdje ne bismo složili, budući da se dva dijela ne razlikuju tek po pokojoj drukčije posloženoj klasifikaciji ili drukčije postavljenom fokusu, već angažiraju i bitno drukčiju teorijsku aparaturu. Odnosno, drugi bi se dio mogao opisati i kao pokušaj da se prvi dovede do novouspostavljene teorijske pozicije, pri čemu taj suodnos donekle djeluje i ograničavajuće na drugi dio. No naročito se ne radi naprosto o razlici između naglaska koji se stavlja na čitatelja u prvom dijelu, odnosno autora u drugom dijelu, kako to također sugerira Bogue (isto), budući da se prvi dio tiče znakova i interpretacije čiji su subjekti različiti - od čitatelja, preko likova i pripovjedača pa do autora - dok je u fokusu drugog dijela besubjektni stroj.

${ }^{177}$ Deleuze u prvom dijelu Prousta i znakova iz Proustova ciklusa $U$ traganju za izgubljenim vremenom izdvaja četiri vrste znakova (svjetovne, ljubavne, senzualne i umjetničke) te četiri strukture vremena (izgubljeno vrijeme, vrijeme koje netko gubi/trati, vrijeme koje netko zadobiva te zadobiveno vrijeme) koje su im djelomično korespondentne, premda viša razina može uključivati i elemente odgovarajuće nižoj. Pritom razine što se odnose na umjetnost, tj. književnost (umjetnički znak i zadobiveno vrijeme) uživaju superioran status s ulogama ukazivanja na samu esenciju stvari i dolaska do vremena u njegovom čistom obliku. Iako su stvari manje banalne nego što se iz ovako reduktivnog prikaza može doimati (npr. „esencija“ o kojoj se radi nije nekakav jednostavno prisutan i objektivno utvrdiv referent znaka, niti je naprosto rezultat subjektivnih asocijativnih lanaca ili točke gledišta, već nadmašuje oboje razvijajući se u složenom razmatanju umjetničkog znaka koje u sebi pretpostavlja višeperspektivnost i rezonanciju s drugim znakovima - usp. npr. Deleuze, 2000: 37-8, 43 - radi se nedvojbeno o pogledima koje neće preuzeti njegove kasnije studije književnosti. Dapače, korigirat će ih već drugi dio studije o Proustu.

${ }^{178}$ Usp. i Deleuze, 2000: 16.
} 
Svojstvo književnosti da sebi karakterističnim znakovima podriva temelje onoga što smatra zabludama tradicionalne filozofije koje osiguravaju prevlast mišljenju identiteta, što joj ga Deleuze pridaje, samo je specifičan slučaj njezine moći da prinudi na interpretaciju. Naime, u Razlici i ponavljanju Deleuze (2009b: 232) među ostalim istražuje i fenomen sentienduma, bića osjetilnog, onog što je samo neprimjetno, no ,unosi nemir u dušu, čini je 'smetenom', to jest primorava je da postavi problem“, i kao takvo se pojavljuje u središtu kritike dobrohotnosti mišljenja, budući da tumačenje otkriva kao nešto na što smo intruzivno prisiljeni. No još ranije, u Proustu i znakovima (2000: 30), Deleuze ono što će nazvati sentiendumom prepoznaje kao istaknutu distinktivnu karakteristiku umjetnosti (a potom i konkretno književnosti) ${ }^{179}$, zaključujući da umjetnost tjera na razmišljanje i tumačenje čak i mnogo više nego filozofija, budući da je „ono što je omotano znakovima dublje nego sva eksplicitna signifikacija.“"180

Osim što je dakle književnost/umjetnost privilegirani agens destabilizacije automatizacije razumijevanja i prešutnih postavki mišljenja, što je blisko rekonfiguraciji poretka osjetilnog kod Rancièrea (odnosno, po njemu, i samoj srži politike!), ona je prema Deleuzeu (a i Proustu, kojeg citira) i privilegiran prozor do perspektive drugoga. Pritom se, kako Deleuze (2000: 42) pokazuje, ne radi naprosto o dolasku u dodir s različitim subjektivnim gledištima na objektivni izvanjski svijet, već o tome da svaki subjekt izražava apsolutno drukčiji svijet, kao rezultat unutarnje apsolutne razlike, no ipak nesvodiv na njega u onoj mjeri u kojoj je esencija nesvodiva na egzistenciju ${ }^{181}$. Iako, i prema njegovom vlastitom priznanju, takva definicija stvari ima platonistički prizvuk, važna nam je iz nekoliko perspektiva: jer skreće pozornost na postojanje nečeg „dubljeg“ i „drukčijeg reda“ od psihološkog subjekta, na činjenicu da individue ne sačinjavaju svijet, već omotani svjetovi sačinjavaju individue, što prefigurira uvide iz Razlike i ponavljanja te Antiedipa; zatim jer već tu podcrtava odsutnost monolitnog, jednostavno danog objektivnog svijeta te jer afirmira književnost kao privilegirano mjesto razumijevanja naravi intersubjektivnosti. No politička dimenzija književnosti doći će mnogo više do izražaja u drugom dijelu studije, čiji se temelj

\footnotetext{
${ }^{179}$ Usp. Murphyjev (2000) tekst u kojem autor istražuje paralele između Becketta i Deleuzea, ukazujući na to da određena Beckettova djela dramatiziraju mehanizme koje Deleuze teoretizira; prije svega sentiendum, a onda i ono što autor naziva sociendumom, loquendumom i konačno viviendumom, sa značenjem analognim sentiendumu, samo na polju svojih glagola. Važno je napomenuti da ni Murphy ni Deleuze ne smatraju književnost pukom alegorijom tih mehanizama, nego mjestom na kojem oni naglašeno dolaze do izražaja.

180 Deleuze (2000: 30-31) doduše odmah preko Prousta i kritizira one pojavne oblike književnosti koji ne pozivaju na tumačenje, već stvari izručuju suviše jasno. To pokazuje da ne smatra kako je svako književno djelo per se privilegiran nositelj sentienduma, odnosno da je to primarno slučaj s određenim tipom književnosti.

${ }^{181} \mathrm{O}$ (modernom) umjetničkom djelu kao mediju pogodnom za istraživanje razlike u činu razlikovanja usp. još i Deleuze, 2009b: 102.
} 
sažima u tezi da je „moderno umjetničko djelo mašina i funkcionira kao takva.“ (Deleuze, 2000: 145$)^{182}$

Važna odlika mašinske konceptualizacije književnosti jest daljnji pomak od konstativne prema performativnoj dimenziji književnosti; zaključak da se književnost ne svodi (tek, ili prvenstveno) na pitanje spoznaje i tumačenje znakova, nego proizvodnje neke osobite stvarnosti (Deleuze, 2000: 155; Deleuze, Guattari; 1986: x-xi). No dok je pitanje rezoniranja sa stvarnosti u drugom dijelu Prousta i znakova pretežno usredotočeno na osobne živote, studija Kafka: U korist manjinske književnosti [Kafka: Pour une Littérature Mineure, 1975] - lokus ispreplitanja ranijih Deleuzeovih promišljanja o književnosti s istraživanjima iz Antiedipa - baveći se Kafkinim opusom istražuje djelovanje jedne takve mašine u odnosu na tijelo sociusa.

Funkcija pisanja poput Kafkina prema Deleuzeovim je navodima dvojaka, iako simultana: „prevesti sve u sklopove te potom rastaviti te sklopove.“ (Deleuze, Guattari; 1986: 47) Mašine što ih sklopovi pritom oblikuju u procesima sastavljanja i rasklapanja nisu pak „,interpretacija ili društvena reprezentacija“, već „eksperiment, društveno-politička istraga.“183 (isto: 49) Jedan od rezultata takve istrage, koja eksperimentirajući jezikom potiče njegovu deteritorijalizaciju, a time i deteritorijalizaciju struktura koje na njemu počivaju, jest čuveni Deleuzeov koncept manjinske književnosti, zaslužan za općenitiji koncept manjinskog koji će, vidjeli smo, koristiti u svojim kasnijim studijama. Manjinska književnost naime, bez obzira na Kafkin status praškog Židova što piše na njemačkom ${ }^{184}$, ne stoji kao oznaka neke konkretne manjine ili specifične književnosti, već kao oznaka ,za revolucionarne uvjete svake književnosti u srcu onoga što se naziva velikom (ili etabliranom) književnosti“ (isto: 18), odnosno za književnost koju odlikuje ,deteritorijalizacija jezika, povezivanje pojedinca s političkom neposrednosti te kolektivan sklop iskaza.“ (isto)

Potonje je svojstvo izravno povezano s Deleuzeovom tezom kako je „karakteristika manjinskih književnosti to da je sve u vezi s njima političko“ (Deleuze, Guattari; 1986: 17), odnosno da im tijesan prostor koji unutar većinskog jezika za sebe prisvajaju ne omogućuje

\footnotetext{
${ }^{182}$ Valja skrenuti pozornost na atribut „moderno“, koji (premda vrlo neodređeno) ipak delimitira opseg tvrdnje, nasuprot interpretacijama koje previđaju tu delimitaciju.

${ }^{183}$ Usp. Deleuze, 2009b: 102.

${ }^{184}$ Konkretna Kafkina situacija, dakako, nije nepovezana s manjinskim statusom njegovog pisma, no Deleuze opetovano naglašava da potonji ne proizlazi nužno ni automatski iz prve. Kao svojevrstan protuprimjer može se uzeti jidiš, koji istovremeno može funkcionirati i kao (re)teritorijalizirajući jezik Židova, i kao jezik što (gramatički) deteritorijalizira njemački. Kafku, smatra, u jidišu ne fascinira jezik religijske zajednice, nego jezik pučkog kazališta (usp. Deleuze, Guattari; 1986: 25). Osim toga, ne mora ni svaki pokušaj subverzije dominantnog jezika (u ovom slučaju njemačkog) završiti uspješnom deteritorijalizacijom. Usp. isto: 19 za primjer prakse Maxa Broda i Praške škole koji Deleuze smatra pokušajem što završava reteritorijalizacijom prije negoli deteritorijalizacijom.
} 
pojedinačne brige koje se ne bi imale i političkih reperkusija. Drugim riječima, u manjinskoj književnosti „sve zadobiva kolektivnu vrijednost“ (isto) te manjinska književnost preuzimajući dužnost za kolektivno iskazivanje - postaje element kohezije manjinske zajednice, proizvođač ,aktivne solidarnosti usprkos skepticizmu“ (isto) ${ }^{185}$. Ili kako je to drugdje sročio, „ultimativni je cilj književnosti da oslobodi, u deliriju, stvaranje zdravlja ili izumljivanje naroda, tj. mogućnost života. Da se piše za narod koji nedostaje...“ (Deleuze, 1998: 4), odnosno „učiniti od odnarođenja kozmički narod, a od deteritorijalizacije kozmičku zemlju“ (Deleuze, Guattari; 2013: 389).

Riječ je o tvrdnjama koje ipak mogu zvučati kontradiktorno u odnosu na još jedno neizbježno svojstvo manjinske književnosti, a to je da njezina „književna mašina postaje zamjena za revolucionarnu mašinu koja dolazi““ (Deleuze, Guattari; 1986: 18). Sjetimo li se da je revolucija u njegovu diskursu usko povezana s linijama bijega i procesom postajanja, ne iznenađuje da Deleuze i kod Kafke krucijalan aspekt djelovanja književne mašine pronalazi u postajanjima, $\mathrm{i}$ to redom sve radikalnijim: od cijepanja subjekta iskazivanja i subjekta iskaza $\mathrm{u}$ njegovim pismima, preko postajanja životinjom u kratkim pričama ${ }^{186}$ pa do postajanja sklopom i molekularnim u romanima ${ }^{187}$.

U suočavanju s tom latentnom kontradikcijom između dvaju vidova emancipacijskopolitičkog djelovanja manjinske književnosti aktualnom nam se, dakle, ponovno pokazuju već spominjane Laclauove i Rancièreove kritike Deleuzea. Jer ukoliko je manjinska književnost $s$ jedne strane utemeljujuća za zajednicu, dok je s druge strane mašina postajanja, i to takvog koje ne završava nekim determiniranim oblikom ${ }^{188}$, dapače ako je takvo postajanje

\footnotetext{
${ }^{185}$ Deleuze glede skepticizma koji spominje čak dodaje da i sam pisac može biti „na marginama ili posve izvan svoje krhke zajednice, i tada mu ta situacija omogućuje još i više mogućnosti da izrazi druge moguće zajednice i oblikuje sredstva za drugu svijest i drugi senzibilitet..." (Deleuze, Guattari; 1986: 17). Doduše, ta primjedba ostaje razmjerno nedorečena. Jasno je da je njome želio anticipirati upravo prigovore da postoje autori na marginama manjinskih zajednica, no stavljanjem njih u središte neke buduće dolazeće zajednice zapravo potencijalno perpetuira takvo pomicanje na relaciji centar - margina do beskonačnosti.

${ }^{186}$ Problematika postajanja životinjom, uz komentar na pismo (o) ocu, dio je u kojem se u Kafki nastavlja i antiedipovski projekt kritike psihoanalize. Deleuze odbacuje ranija psihoanalitička arhetipska tumačenja Kafkinih životinja koja su, prema njemu, edipovska dijametralna suprotnost deteritorijalizirajućem djelovanju postajanja životinjom (usp. Deleuze, Guattari; 1986: 13). Za usporedbu sa situacijom glede pisma ocu, koje Deleuze također smatra deteritorijalizirajućim, vidjeti isto: 9-10.

${ }^{187}$ Usp. Deleuze, Guattari; 1986: 37, 46.

${ }^{188}$ Na primjeru komentara slikara Titorellia u Kafkinu Procesu o mogućim ishodima K-ova procesa, Deleuze pokazuje i moguće ishode žudnje koja prolazi literarnim strojem: ili naglo rješavanje, koje bi značilo smrt ili dokidanje žudnje, ili deteritorijalizaciju koja završava reteritorijalizacijom, ili pak beskonačan put deteritorijalizacije, izmicanje jednom po jednom segmentu duž linije bijega unedogled. (Deleuze, Guattari; 1986: 51-52). Tome je razmjerno komplementarna i kasnija tvrdnja da se ljudska deteritorijalizacija događa u dva koegzistirajuća stanja: $\mathrm{s}$ jedne strane stalno zarobljavana od jednog do drugog segmenta, a s druge strane nošena linijom bijega, što odgovara paranoičkom i shizoidnom zakonu (Deleuze, Guattari; 1986: 59). Tome je korespondentna i situacija s Kafkinim kratkim pričama i romanima - dok prve završavaju zaokružene, drugi su odreda nedovršeni.
} 
karakteristika književnosti uopće ${ }^{189}$, tada se nalazimo pred problemom. U postfundacijskim okvirima rješenje bi se nudilo u vidu naizmjeničnog (kvazi)utemeljenja i rastemeljenja, tropološke artikulacije (kako, na kraju krajeva, i zvuči osiguravanje kohezije zajednici i pisanje za narod koji nedostaje) i kasnije destabilizacije, no Deleuzeovo inzistiranje na korjenitoj imanenciji ${ }^{190}$, kako je Rancière primijetio, ostaje u nedomišljenom raskoraku između disruptivne i komunalne komponente ${ }^{191}$.

$\mathrm{Na}$ sličan problem nailazimo i kod još jednog izrazito važnog političkog aspekta književnosti na koji se Deleuze opetovano referira. Riječ je o već spomenutom dovođenju jezika do ili preko njegovih granica, što se kao važan čimbenik javlja još u studiji o SacherMasochu da bi u kasnijim studijama zadobio i daleko veći značaj. Naime, bez obzira na Deleuzeovo ustrajanje na tome da izvandiskurzivno ne podređuje diskurzivnom (za razliku od teoretičara koje kritizira da se nisu riješili tiranije označitelja), način na koji povezuje stvari u kasnijim studijama o književnosti stavlja taj književni zahvat na jeziku u nedvojbeno privilegiran položaj. Ako je manjinska književnost privilegirani oblik uspostavljanja manjinskog subjekta, a književnost uopće (naročito manjinska) privilegiran, dapače prototipan medij postajanja, deteritorijalizacija jezika je, prema Deleuzeu, jedan od primarnih načina na koji se ti književni fenomeni uspostavljaju.

\footnotetext{
${ }^{189}$ U Proustu i znakovima Deleuze (2000: 134-135) pokazuje kako za Prousta nijedan „dani entitet nema nego statističku vrijednost“, te da se ta činjenica često kreće u dva oprečna smjera - prema mnoštvenostima većim ili manjim od subjekta (usp. ponovno s postajanjem u Tisuću platoa!). U Tisuću platoa konstatira da ,/a/ko je pisac vrač, to je stoga što je pisanje postajanje, pisanje je izbrazdano neobičnim postajanjima koja nisu postajanjapiscem, već postajanje-štakorom, postajanje-kukcem, postajanje-vukom itd.“ (Deleuze, Guattari; 2013: 268) U tekstu „Književnost i život“ iz Kritičkih $i$ kliničkih eseja također potvrđuje da je ,,p/isanje neodvojivo od postajanja: u pisanju se postaje žena, postaje životinja ili biljka, postaje molekula sve do točke postajanja neprimjetnim“ (Deleuze, 1998: 1), pri čemu dodaje da je najbolji razlog za pisanje „sram bivanja čovjekom“ (sjetimo se da se čovjek ne postaje!), kao i da se pritom ne radi o identifikaciji/mimezi, nego o ulaženju u ,zonu bliskosti, nerazlučivosti, gdje se ne može više razlikovati od neke žene, neke životinje, neke molekule, ni neprecizne ni općenite, već one koja nije predviđena i koja ne predpostoji...“ (isto)

190 „Od sada nadalje, još je važnije odbaciti ideju transcendentnosti zakona. Ako su krajnje instance nepristupačne i ne može ih se reprezentirati, to se događa ne kao funkcija beskonačne hijerarhije kakva pripada negativnoj teologiji, nego kao funkcija kontigviteta žudnje koji uzrokuje da se, što god se događalo, događa uvijek u uredu pored. Kontigvitet ureda, segmentacija moći, zamjenjuje hijerarhiju instanci i eminenciju suverena..." (Deleuze, Guattari; 1986: 50) Usp. i s čuvenim, i u kasnijim studijama više puta ponavljanim kafkijanskim otkrićem lažne transcendentnosti zakona u isto: 45.

${ }^{191}$ Problemu bi se moglo doskočiti nekom inačicom koncepta (mesijanske) zajednice koja tek treba doći, što Deleuze na jednom mjestu implicitno i naznačuje vezano za neženju, jednu od svojih figura onoga koji bježi i navodi na bijeg, koji deteritorijalizira. Tako piše: „Mašina koja je tim više društvena i kolektivna što je više samotna, neženja, i koja je, ocrtavajući liniju bijega, u sebi jednaka zajednici čiji uvjeti još nisu ustanovljeni. Takva je objektivna definicija mašine izraza koja, kao što smo vidjeli, odgovara stvarnom stanju manjinske književnosti tamo gdje više nema 'individualnih briga'. Proizvodnja intenzivnih kvantiteta u društvenom tijelu, proliferacija i taloženje serija, polivalentne i kolektivne poveznice što ih ostvaruje agent-neženja - nema druge definicije moguće za manjinsku književnost.“ (Deleuze, Guattari; 1986: 71) No poteškoća je to što se Deleuze, kada na drugim mjestima govori o manjinskom, referira i na postojeća nevećinska mnoštva, a ne samo na mesijansku zajednicu u dolasku.
} 
Jezik već sam po sebi, smatra Deleuze (Deleuze, Guattari; 1986: 19-20), rezultat je deteritorijalizacije niza organa $\mathrm{u}$ odnosu na njihovu primarnu svrhu, no potom $\mathrm{i}$ reteritorijalizacije dvostrukom artikulacijom koja ga kroti i pretvara u instrument smisla. Kod Kafke pak u raznim neartikuliranim ili neljudskim zvukovima i nonsensnim iskazima prepoznaje ponovnu deteritorijalizaciju jezika koja „napušta smisao, svodi ga na tek implicitno; zadržava samo ljušturu smisla..." (isto: 21$)^{192}$, i to kao uvod u ono što će nazvati pokušajem da se učini da ,jezik kao takav muca“ (Deleuze, 1998: 107). Jezik u tim slučajevima „prestaje biti reprezentativan kako bi krenuo prema svojim ekstremima ili granicama“ (Deleuze, Guattari; 1986: 23), odnosno do stanja u kojem „novi jezik nije izvanjski inicijalnom jeziku, asintaktička granica nije izvanjska jeziku kao cjelini: ona je vanjština jezika, ali ne i izvan njega“; postaje „slika ili muzički komad, ali muzika riječi, slikanje riječima, tišina u riječima, kao da riječi tek sada mogu otpustiti svoj sadržaj: grandiozna vizija sublimnog zvuka.“ (Deleuze, 1998: 112-3)

No iako takvo „bivanje strancem unutar vlastitog jezika“ (Deleuze, Guattari; 1986: 26) ${ }^{193}$ koje posljedično pomjera različite jezične funkcije i centre moći te zamagljuje granice onoga što se može i ne može izreći (isto) uvelike nalikuje Rancièreovim opisima načina na koje književnost čini to isto, Rancière svejedno podvrgava dio spomenutih Deleuzeovih teza kritici. Rancière (2004b: 146, 150, 152 itd.) naime odaje priznanje Deleuzeovim antiaristotelovskim gledištima na književnost ${ }^{194}$, tj. tome kako se suprotstavlja privilegiranju zapleta i dolaska do (skrivene) spoznaje u književnosti, te kako mnoštvenost i molekularnost suprotstavlja figuralnom i mimetskom, ne krijući paralele sa svojim pristupom. Međutim, istovremeno ga kritizira da tezu kako je „književnost materijalna moć koja proizvodi materijalna tijela“ (isto: 153) potkopava neadekvatnom demonstracijom, dajući umjesto toga u interpretacijama ponovno prednost fabularnom. Priče koje Deleuze privilegira, smatra, na zanimljiv način (prividno) mire formu i sadržaj, budući da se mahom radi o pričama o transformaciji koje su ujedno transformativne i na sižejnoj razini. No Rancière (isto) upozorava da se zapravo radi o ,priči o magičnoj formuli koja preobražava svaku priču o preobrazbi u demonstraciju njezine preobrazne moći“, čime se zamagljuje granica između simbola i formule (isto), odnosno simboličko ostaje u najmanju ruku prisutno, ako ne i dalje nadređeno.

\footnotetext{
${ }^{192}$ Usp. slične primjere i u odnosu na Masocha i Melvillea u Deleuze, 1998: 107.

${ }^{193}$ Usp. i Deleuze, Guattari; 2013: 427.

194 Baugh (2000: 44) također deleuzeovski pristup književnosti naziva antipoetičkim, budući da se, kako smatra, u svemu suprotstavlja Aristotelu. Pritom ipak ne uočava proturječja koja ga vode natrag Aristotelu, koja kritizira Rancière (2004b: 154-155).
} 
Nadalje, Rancière (2004b: 153) mu zamjera da čak i u situacijama u kojima govori o jeziku koji došavši do svojih granica postaje npr. glazba, Deleuze kao primjer najčešće uzima segmente u kojima pripovjedač izvještava o različitim neartikuliranim zvukovima, a ne one u kojima tekst doista to i postaje ${ }^{195}$. Pokušavajući izbjeći opetovano vraćanje reprezentaciji i proturječje u koje time zapada, Deleuze s vremenom premješta analitički fokus na „figure operatora“ (isto: 154). No time, kako upozorava Rancière (isto: 154-155), samo ulazi u novo proturječje, vraćajući se aristotelovskom privilegiranju lika i radnje (odnosno fabulaciji nasuprot fikciji; usp. isto: 158) te dajući prednost molarnom nad molekularnim.

Rancièreova kritika Deleuzea ne samo da podcrtava razlike između njihovih pristupa, koje se analogno reflektiraju i na polju politike, već i odlično ilustrira probleme u koje Deleuze zapada u već spominjanom nastojanju da izbjegne reprezentaciju. Momenti u kojima previđa vlastite nedosljednosti pak potencijalan su razlog zašto je njegova vizija politike i književnosti „herojskija“ od Rancièreove, lišena skepse, dilema i ograničenja što su kod potonjeg prisutni ${ }^{196}$. Jednako je tako to i razlog zbog kojeg ne zamjećuje paradoks koji Rancière zamjećuje; da bi dovođenje neke od ključnih obilježja književnosti do svojih krajnjih granica ujedno značilo i njezino samodokidanje.

Ipak, ni kod Deleuzea stvari nisu posve bezrezervno crno-bijele, niti književnost ima isključivo emancipacijsko lice. Unatoč tome što svoju istraživačku fazu pretežno poklanja takvoj naravi književnosti, a na jednom mjestu piše i da „među onima koji stvaraju knjige s namjerom da budu literarne, čak i među ludima, malo je onih koji se mogu nazvati piscima“ (Deleuze, 1994: 6) - što pak daje za pravo tezama poput Bitijeve (2014: 290) da je za Deleuzea neemancipatorna književnost nevrijedna svoga imena - činjenica je kako na nekim mjestima u svom opusu jasno pokazuje da je svjestan postojanja književnosti koja se ne uklapa u emancipacijsku shemu.

Primjerice, već Antiedip istovremeno kritizira i to ,/k/ako se bijedno postavlja problem književnosti kad se polazi od ideologije koju ona pronosi ili od njezina kooptiranja od strane društvenog poretka“ umjesto da se naglašavaju njezine shizoidne crte što „pothranjuju

\footnotetext{
${ }^{195}$ Primjedba je točna glede primjera iz Kafke i Melvillea, na koje se Rancière prvenstveno i referira, no nije bez iznimki (kao npr. u slučaju Artauda).

196 Rancière (2004b: 148) napominje da se ograničenja, odnosno neki (novi) oblik heteronomije i transcendentalnog okvira, uvijek javljaju kod uspostave autonomije književnosti u odnosu na ulogu umijeća oponašanja prirode, potkrepljujući to primjerom Flaubertova apsolutnog stila. Deleuzeov (2000: 167) koncept stila koji razvija u Proustu i znakovima čini se odgovarajuć toj Rancièreovoj tezi, no Deleuze nasuprot tomu ipak inzistira da stil nije ono što daje jedinstvo, već sačinjen od beskonačno mnogo gledišta u istim rečenicama jedinstvo prima od transverzalnog povezivanja heterogenih elemenata unutar djela. Takvi odnosi stvari u Proustu i znakovima mogli bi se usporediti s pojmom sklopa u Kafki, utoliko što sklop isto tako ne ostavlja mjesto ujedinjujućem subjektu, već omogućuje još bolji uvid u prirodu i funkciju iskaza kao kotačića i dijelova literarnog sklopa (Deleuze, Guattari; 1986: 84).
} 
revolucionarnu mašinu što se pomalja na obzoru“ (Deleuze, Guattari; 2015: 124-125), te priznaje procese edipalizacije kao ,jedan od najvažnijih činitelja u svođenju književnosti na predmet konzumacije odgovarajuć utvrđenom poretku i nesposoban da ikome našteti““ (isto: 125), čime se automatski priznaje i postojanje potrošačke književnosti ${ }^{197}$.

Nadalje, čuvena je i Deleuzeova opreka između angloameričke i francuske književnosti ${ }^{198}$, kod koje je prva reprezentant književnosti kakvu uobičajeno afirmira, dok je druga njezin antipod čijeg je postojanja očito i više nego svjestan (nijedna pak nije esencijalno vezana za neku naciju). Mjestimično čak i izvan francuskog arhetipa, u drugim kontekstualnim koordinatama, Deleuze (Deleuze, Guattari; 2013: 354) se ne libi promatrati umjetnost $\mathrm{i}$ iz perspektive njezine utemeljujuće funkcije, zaključujući da bi ,/t/eritorij u tom slučaju bila posljedica umjetnosti“, dok za klasičnog umjetnika tvrdi da dolazi u ulogu boga, na zadatak da se suoči s kaosom, „raspoređuje sredine, odjeljuje ih, harmonizira, regulira njihova miješanja, prelazi s jedne na drugu.“ (isto: 379)

Konačno, upozorenje na nepredvidivost ishoda molekularnih kretanja i linija bijega u društvenoj makroperspektivi ponavlja i u odnosu na književnost, napominjući da i kod nje „postoji rizik da će bolesno stanje omesti proces ili postajanje; zdravlje i intenzivna energija susreću se s istom ambivalentnosti, stalnim rizikom da će se delirij dominacije pomiješati s mješovitim delirijem, odgurujući književnost prema larvalnom fašizmu, bolesti protiv koje se bori...“ (Deleuze, 1998: 4) Sve zajedno može se objediniti tezom izrečenom još u Razlici $i$ ponavljanju, u kojoj je književnost/poezija također privilegirani predstavnik nedokidivog suviška i naslovnih razlike i ponavljanja. No kao što Deleuze (2009b: 464) piše, ,po sebi se razume da stvarne pesme ne mogu da budu jednake sa Idejom poezije.“

Isto tako nisu posve točne ni teze po kojima korjenita emancipacija u Deleuzeovu opusu pripada isključivo domeni književnosti/umjetnosti, budući da im on na više mjesta jasno proturječi. Primjerice, u Tisuću platoa jasno se ističe da

umjetnost nikada nije cilj, već samo sredstvo da bi se povukle linije života, to jest sva ta stvarna postajanja koja se ne proizvode samo $u$ umjetnosti, svih tih djelatnih bjegova koji se ne sastoje u bježanju $u$ umjetnost, traženju utočišta u umjetnosti, te pozitivne deteritorijalizacije koje se neće reteritorijalizirati na umjetnosti, već će je odvući sa sobom, k regijama obeznačiteljskog, asubjektnog i bez-ličnog. (Deleuze, Guattari; 2013: 211)

\footnotetext{
197 Lambert (2000: 155) se također potaknut Deleuzeovim promišljanjima književnosti pita nije li institucionalizacija figure pisca isto način da se „proizvede biće koje utjelovljuje pismo“ kako bi se društvo, „koje je i samo oblikovano na i od pisma“ zaštitilo „od ludosti koje pripada njegovom vlastitom redu mogućnosti.“ Jednako problematizira i javno prisvajanje koje reteritorijalizira literarnu mašinu pridajući joj funkciju da odražava ,genij nacionalnog značaja ili duh Kulture.“ (isto: 162)

${ }^{198}$ Usp. Deleuze, Guattari; 2013: 209, 220; Deleuze, 1994: 56-57; Deleuze, 2009a: 51.
} 
Slično i Surin (2000: 176) podsjeća na Deleuzeovu tezu da „ne prolazi sve postajanje kroz pisanje, no sve što postaje jest objekt pisanja, slikanja ili muzike. Sve što postaje čista je linija koja prestaje reprezentirati što god.“

Sve u svemu, odnos književnosti i politike kod Deleuzea, baš kao ni kasnije kod Rancièrea, nije ni jednosmjeran ni jednodimenzionalan, premda je teško osporavati činjenicu da se književnost, bez obzira na heterogenost pristupa u raznim studijama, u glavnini slučajeva pojavljuje kao privilegirani nositelj emancipacijske uloge, odnosno onoga što bi Rancière nazvao politikom. Takav položaj književnosti u uskoj je pak svezi s onim što smo prethodno nazvali literarnošću politike, a u ranijem smo dijelu ovog poglavlja pokazali da je, uz stanovite razlike i ograde, primjenjivo i na Deleuzeovo viđenje društva/politike, ma kako osobito ono bilo. Štoviše, radi se ne samo o značajkama koje onda utoliko povezuju Deleuzea, Laclaua i Rancièrea, već su ujedno i one koje ih razlikuju od konvencionalne predodžbe marksizma, s tim da potonja dvojica teoretičara te značajke i sami artikuliraju kao raskid s njom, dok Deleuze (u najmanju ruku u jednom, najpoznatijem dijelu svog opusa) sebe implicitno pokušava inaugurirati kao njezin autentičan odvojak.

Razlike između tih teoretičara, koje se ne mogu proglasiti irelevantnima i zanemariti, većim su pak dijelom posljedica više puta spomenutog Deleuzeova (diskutabilno uspješnog) pokušaja odbacivanja označiteljske paradigme i onoga što Bogue (2003: 145) naziva „pantekstualizmom“. Analizirajući s tim u svezi Deleuzeovo inzistiranje na središnjem značaju vanjštine teksta kao jedan od primjera razlika između Deleuzea i (drugih) poststrukturalista, Surin (2000: 172) zaključuje kako je neimenovana meta kritike u opreci spram koje Deleuze ističe svoje viđenje teksta upravo Derrida. Čak i proširimo li razmatranje šire od pitanja unutrašnjosti/vanjštine teksta, na cijelu problematiku napuštanja označitelja, Surinova teza i dalje makar uvjetno opstaje.

Naime, iako Deleuze - u usporedbi s nekim drugim autorima s kojima polemizira ili traži poveznice - vrlo rijetko (što afirmativno, što kritički) spominje Derridaa, teoretičar je to s kojim ga povezuju mnoge postavke, dok se istovremeno u njemu doista može prepoznati i implicitna meta velikog dijela njegove polemike sa strukturalizmom i paradigmama što privilegiraju tekst/jezik. S druge strane, upravo su Derridaovi stavovi na tom polju snažno utjecali na dvojicu ranije spomenutih teoretičara, naročito Laclaua. Paralelno s tim, nasuprot Laclauu i Rancièreu, Derridaa i Deleuzea povezuje pak mesijanska dimenzija politike koja kod njih do izražaja dolazi mnogo više negoli kod dvojice teoretičara mlađe generacije. Uzmemo li u obzir još i to da je Derrida figura neizostavna u suvremenoj književnoj teoriji, kao i njegov nejednoznačan i razmjerno osobit odnos prema Marxu i marksističkom nasljeđu 
- pokazuje se nužnim priključiti ga do sada razmatranom trokutu teoretičara kao još jednu ključnu točku razmatranja. 


\section{4. . Demokracija, pravda i književnost: Marx i Kafka u odsutnom središtu dekonstrukcije}

Za razliku od Deleuzea čijem su viđenju politike označitelj mesijanskog pridavali tek pojedini kritičari (usp. npr. Biti, 2014), Derrida je autor čiji je pozni opus - u onoj mjeri u kojoj se zaokuplja pitanjem politike - velikim dijelom oblikovan oko eksplicitne razrade koncepta mesijanskog. U ovom je kontekstu osobito značajno da je jedna od prvih studija u kojoj Derrida uvodi taj koncept i podrobnije ga razmatra upravo studija Sablasti Marxa [Spectres de Marx, 1993; usp. Derrida, 2002b], knjiga koja je u dosadašnjim istraživanjima poslužila kao gotovo ekskluzivan razlog da ga se podvede pod označitelj postmarksističkog. Ovdje nam nipošto nije namjera minorizirati značaj Derridaova eksplicitnog bavljenja Marxom u Sablastima Marxa ${ }^{199}$, no s druge strane nastojat ćemo pokazati da poveznica koja se može uspostaviti između Derridaa i drugih teoretičara okupljenih pod postmarksističkim označiteljem ipak nadrasta elementarnu činjenicu autorstva jedne studije što marksističkom nasljeđu pristupa (i donekle ga prisvaja!) na neortodoksan način.

Nadalje, primarni ciljevi ovog istraživanja uvjetovat će još jednu neuobičajenost u pristupu Derridau. Dok se velik broj autora u pravilu referira na makar jednu od dvije najčešće apostrofirane razdjelnice Derridaova rada - onu između Derridaovih ranijih dekonstrukcijskih čitanja klasika zapadne filozofije i drugih humanističkih disciplina s jedne strane te njegovih kasnijih radova posvećenih političkoj problematici s druge, ili pak između njegovih dekonstrukcijskih čitanja filozofskih/znanstvenih tekstova s jedne strane, te čitanja književnih tekstova s druge, specifičnosti ovog istraživanja navest će nas da u prvi plan postavimo kontinuitet među kvadrantima tako ocrtanog koordinatnog sustava te naglasak stavimo na njihova presijecanja ${ }^{200}$.

\footnotetext{
199 Usp. npr. zbornik Ghostly Demarcations (Sprinker, 2008 [1999]), u kojem su okupljene reakcije devet uglednih suvremenih marksističkih teoretičara na Derridaove Sablasti Marxa. Veći dio priloga kritičke je naravi, a neke od kritika čak su i vrlo polemički intonirane, osporavajući Derridaovu čitanju ikakvu vezu s Marxom i marksizmom. Također, i Choatova (2010) analiza varira između naglašavanja važne uloge Sablasti Marxa u Derridaovu opusu i upućivanja na neke dodirne točke marksizma i dekonstrukcije s jedne strane, te kritike Derridaa za razmjerno proizvoljno konstruiranje inačice Marxa $\mathrm{s}$ kojom ulazi u odnos, kao i nametanje mesijanizma i drugih dekonstrukciji bliskih, a marksizmu stranih koncepata nauštrb Marxove stvarne revolucionarnosti. Vrijedi primijetiti da je Choat (2010) mnogo benevolentniji u slučaju Deleuzeove (jednako idiosinkratične) interpretacije Marxa.

${ }^{200}$ Pritom se doista ne radi ni o kakvoj značajnijoj (polemičkoj) promjeni perspektive, nego samo preraspodjeli naglasaka. Ovaj rad ne dovodi u pitanje opravdanost uobičajenih razdjelnica Derridaova opusa u slučajevima gdje su koristan analitički alat, baš kao što mnogi od autora koji za njima posežu u odnosu na njih zadržavaju i rezervu. Primjerice, Bekavac (2015), baveći se u svojoj studiji odnosom Derridaa prema književnom tekstu, podcrtava specifičnost Derridaovih čitanja književnosti (usp. naročito Bekavac, 2015: 133), pa ipak već na početku studije navodi i Derridaovo svjedočanstvo o književnom tekstu kao problemskom izvorištu čitava njegova promišljanja pisma (isto: 7). Slično i Lüdemann (2014), baveći se politikom dekonstrukcije, već u uvodu
} 
Premda su Sablasti Marxa doista prvo djelo u kojem se Derrida sustavno hvata ukoštac s Marxovim nasljeđem, njegovo promišljanje problematike koju tamo zahvaća počinje i mnogo ranije; upornim upitima i poticajima s više strana da ponudi dekonstrukcijsko čitanje Marxa prethodno je djelomično udovoljio u nekoliko navrata, uglavnom $\mathrm{u}$ formi razgovora $^{201}$. U dva na tu temu najčešće citirana intervjua, „Positions“ (intervju iz 1971.) te „Ja, ou le faux-bond“ (intervju iz 1977.) ${ }^{202}$, neki od ključnih toposa gotovo dva desetljeća kasnijih Sablasti već su prepoznatljivi. Za početak, Derrida (1992: 71) napominje da za njega ne postoji niti je postojao jedinstven historički ili dijalektički materijalizam ,na način da bi ga se moglo označiti, primjerice, određenim članom“, odnosno da marksistički korpus ne valja tretirati kao homogen korpus čija bi se istina dala rastumačiti jedinstvenom egzegetskom metodom (usp. Derrida, 1981: 63 i 1992: 73). Riječ je, dakako, o ranijoj inačici čuvene teze o pluralu sablasti što ih je uvijek više („to može značiti gomila, čak i masa, horda ili društvo...“) ili manje („u nekoj čistoj i jednostavnoj raspršenosti“ (Derrida, 2002b: 14)) od jedne, odnosno o mnoštvenosti Marxovih duhova kojih u svakom slučaju ,postoji više od jednog, mora postojati više od jednog“" (isto: 26$)^{203}$.

Afirmirajući neupitnost pluralnosti marksizma, Derrida više od bilo kojeg autora kojim smo se do sada bavili podcrtava i imperativ očuvanja Marxova nasljeđa, pišući da bi

tematsku prijelomnicu Derridaova izrazitijeg interesa za etička i politička pitanja pozicionira u kasne 1980-e (Lüdemann, 2014: xii), pa ipak nešto kasnije naglašava da se Derrida već prvim svojim djelima uhvatio ukoštac s politički relevantnim problemima, te da dekonstrukcija nikada nije bila apolitična (isto: 4). Gotovo identičnu ambivalentnost, samo s nešto kasnije pozicioniranom prijelomnicom (u 1990-e), nalazimo i kod Beardswortha (1996: xi), dok prije svih navedenih najneobičniju podjelu uspostavlja Ryan (1982), tvrdeći da su za marksističku (a samim time i političku) problematiku Derridaova djela relevantna do sredine 1970-ih, nakon čega postaju sve ezoteričnija i autoreferencijalnija (Ryan, 1982: xiv). Izlazak Sablasti Marxa dvadesetak godina nakon te prijelomnice i činjenica da se nemalo oslanjaju na neka od „ezoteričnih“ djela vjerojatno su najbolji demantij takve Ryanove teze.

Sve u svemu, još od vrlo ranog Derridaova teksta „Nasilje i metafizika“, uvrštenog u Pisanje $i$ razliku (usp. Derrida, 2007: 83 et passim), jasno je da se dekonstrukcija otpočetka zaokuplja etičkim i političkim pitanjima te da je njezin odnos prema metafizici prisutnosti sve samo ne apolitičan. Promjena se s vremenom najvećim dijelom dogodila samo na tematskom planu, izborom eksplicitnije političkih tema, dok je sa strane teorijskometodoloških zasada uglavnom riječ o kontinuitetu.

${ }^{201}$ Usp. Ryan (1982: 45-46) i Choat (2010: 72) koji ekstenzivnije pišu o intervjuima u kojima se Derrida odredio spram marksizma.

${ }^{202}$ Ovdje čitani prema engleskim prijevodima; za detaljnije bibliografske podatke usp. Derrida, 1981 i Derrida, $1995 b$.

${ }^{203}$ Vrijedi primijetiti da Derrida u Sablastima Marxa (2002b: 26) dolazak do izražaja pluralnosti Marxova duha isprva pripisuje naročito historijskom trenutku krize u kojem piše i na koji se uvodom studije referira, dok je u ranijem adresiranju te pluralnosti ustvrdio da „ono što se događa upravo danas nije izrodilo tu poteškoću [problematičnog jedinstva historijskog materijalizma], no povjerava joj hitnost kakva je, prema mom mišljenju, do sada bila nepoznata.“ (Derrida, 1992: 71) Tu ambivalentnost opsežnije će razraditi kasnije u Sablastima Marxa, ističući s jedne strane repetitivnost pripovijesti o kraju povijesti (Derrida, 2002b: 27), a s druge strane činjenicu da su suvremene pripovijesti o trijumfu liberalizma artikulirale neke nizove događaja koji se ranije $u$ tim okvirima nisu mogli predvidjeti (isto: 93). Zbog toga ne odbacuje promišljanje problematike kraja povijesti, no mimo vjerovanja u opreku stvarnog i nestvarnog te $u$ temporalnost sačinjenu od uzastopnih samoprisutnih sadašnjosti. 
propust da se bavimo Marxom, danas „kad je stroj za proizvođenje dogmi i 'marksističkih' političkih ideologija (...) u fazi nestajanja“, bio „nedostatak teorijske, filozofske i političke odgovornosti“ bez koje nema budućnosti. „Ne bez Marxa, nema budućnosti bez Marxa. Bez sjećanja na Marxa i njegovo nasljeđe, u svakom slučaju, određenog Marxa, njegova genija i barem jednog od njegovih duhova.“ (Derrida, 2002b: 26)

No unatoč kritikama koje tom iskazu odanosti Marxovu nasljeđu zamjeraju kombinaciju naknadne pameti i vrlo osebujne slike nasljeđa u odnosu na koje se poziva na odgovornost, osnovne je okvire te tvrdnje Derrida zacrtao više od desetljeća ranije, naglašavajući s jedne strane da ga ,nisu pogađale različite epizode 'marksističkih' ili pseudomarksističkih dogmatskih erupcija“" s kojima se susretao licem u lice (Derrida, 1995b: 71), ali da s druge strane jednako tako smatra „smiješnim i reakcionarnim brzinu onih koji danas misle da su napokon sletjeli na kontinent postmarksizma“, naročito kada se u oba slučaja radi o ,jednima te istima, a koga bi to iznenadilo?“ (isto: 72) ${ }^{204}$

Dapače, $u$ jednom od apostrofiranih intervjua Derrida jasno naglašava da je ( $u$ tom vremenu) smatrao kako trenutak za dekonstrukcijsko bavljenje Marxom ,još uvijek tek treba doći“ (Derrida, 1981: 62), no istovremeno izostanak takvog bavljenja priznaje kao „lakunu“ u svom opusu, ne kao namjerno izbjegavanje ili izraz neslaganja s Marxom, i to lakunu koja kao takva ima specifičan status i određenu djelotvornost. Da je doista riječ o lakuni koja je čekala svoju ispunu, a ne o sporednom dodatku kojim je udovoljavao zahtjevima vremena (premda je takva opreka u okvirima Derridaova diskursa neodrživa), potvrđuju i teze poput Choatove (2010: 70-71), da Sablasti Marxa funkcioniraju kao zglobnica što povezuje dva različita pristupa u Derridaovu opusu; $\mathrm{s}$ jedne strane dekonstrukcijske zahvate građene oko kvazikoncepata (kakva je i naslovna sablast), a s druge strane etička i politička promišljanja organizirana oko aporija i neodlučivosti, naročito vezano za koncept pravde.

No ne iznenađuje činjenica da sadržajnom stranom Marxova nasljeđa koju Derrida afirmira kao vrijednu nasljedovanja mnogi na marksističkoj teorijskoj sceni nisu bili zadovoljni onoliko koliko samim pozivom na nasljedovanje ${ }^{205}$. Derridaovu studiju o Marxu

\footnotetext{
${ }^{204}$ Derridaova uporaba postmarksističkog označitelja u sintagmi „kontinent postmarksizma“ ne referira se na tendencije koje se u ovom zahvaća tim označiteljem, već na teoretičare koji su, premda su mu nekada izražavali privrženost, s marksizmom (makar nominalno) definitivno raskinuli, zagovarajući potom odbacivanje i/ili definitivno prevladavanje marksističkog nasljeđa.

${ }^{205}$ Od devet osvrta na Sablasti Marxa koje objedinjuje već spomenuti zbornik Ghostly Demarcations (Sprinker, 2008), tek dva priloga mogli bismo odrediti kao prevladavajuće ili potpuno afirmativna u odnosu na Derridaovo čitanje Marxa (Močnikov i Hamacherov), nekoliko ih je koji naglasak podjednako stavljaju na ono što smatraju dobrim Derridaovim uvidima, kao i na ono s čime se nikako ne mogu složiti (npr. Jameson i Negri - čije primjedbe i sugestije, analogno tome, Derrida u svom završnom tekstu „Marx \& Sons“ također dijelom prihvaća, dok za dio ipak ističe da se s njima nikako ne može usuglasiti), no nekoliko ih je postavljeno u potpunosti polemično, odbacujući čitav Derridaov angažman oko Marxa kao neprihvatljiv (usp. npr. Lewisovu izjavu o
} 
teško bi se moglo nazvati marksističkom u uobičajenom smislu, ili pak ustvrditi da joj je u središtu valorizacija marksizma $\mathrm{i} / \mathrm{ili}$ uspostavljanje međusobnih odnosa između dekonstrukcije i marksizma (premda se bavi i tim), zbog čega su brojna očekivanja ostala izjalovljena. S druge strane, ona donosi nekoliko prepoznatljivih topoia koje smo susretali kod autora koje smo prethodno analizirali, što je čini nezaobilaznom u kontekstu problematizacije postmarksizma.

Prije svega Derrida, uz već spomenuto opetovano podcrtavanje pluralnosti, vrlo nedvosmisleno ističe da za njega „mesijansko ostaje jedna neizbrisiva oznaka - koju ne možemo i ne smijemo izbrisati - Marxova nasljeđa“" (Derrida, 2002b: 44), odnosno da stajanje uz marksističko nasljeđe za njega znači vjernost „onome što je od marksizma u principu i prije svega uvijek činilo radikalnu kritiku“ otvorenu ,vlastitoj transformaciji, reevaluaciji i auto-reinterpretaciji“ (isto: 114), pri čemu takva kritika uvijek mora ići ruku pod ruku s mesijanskim. Drugim riječima, Derrida piše: ,ako postoji duh marksizma od kojeg nikada ne bih bio spreman odustati, to nije samo kritička ideja ili zapitivački stav (...). To je prije određena emancipatorska i mesijanska afirmacija, određeno iskustvo obećanja koje možemo pokušati osloboditi svake dogmatike, pa čak i svake metafizičko-vjerske određenosti, svakog mesijanizma.“ (isto: 115)

Kod inzistiranja na mesijanskom kao na središnjem momentu ne radi se tek o tome da Derrida zagovara nekakav heterodoksni oblik marksizma sklon samokritici i transformaciji koji bi mogao stati rame uz rame s drugim sličnima; s obzirom na to da njegovo mesijansko podrazumijeva drugost u odnosu na bilo koju aktualnu strukturu iščekivanja ${ }^{206}$, popis odricanja opsežan je:

Taj ćemo duh razlikovati od drugih duhova marksizma, od onih koji ga pričvršćuju za tijelo marksističke doktrine, njezina navodnog sistemskog, metafizičkog ili ontološkog totaliteta (osobito u „dijalektičkoj metodi“ ili „materijalističkoj dijalektici“), za njezine temeljne

Sablastima Marxa kao napuštanju svih nada da se marksizam i dekonstrukcija povežu (Sprinker, 2008: 135) ili pak Ahmadovu tezu da Derrida ne žali za Marxom, već pokušava uzurpirati poziciju marksizma (isto: 94)), a neki su - poput Eagletona - svoje odbacivanje pritom još i vrlo agresivno i uvredljivo intonirali. Neovisno o intonaciji i strukturi, zamjerke na Derridaov račun uglavnom se tiču deontologizacije (a time i dematerijalizacije) marksizma, njegove posljedične (navodne) depolitizacije i udaljavanja od revolucionarnog potencijala, te oblikovanja „prihvatljivog“ duha marksizma od vrlo općenitih postavki koje su po ukusu dekonstrukcije, pri čemu se zanemaruju značajne, mnogo konkretnije Marxove teze koje bi s Derridaom bile nekompatibilne. Budući da za ulazak u detaljniju raspravu sa svakim od tekstova nemamo prostora, te bi to predstavljalo digresiju u odnosu na zacrtan itinerar istraživanja, tek ćemo sumarno reći da je validnost spomenutih kritika, u onom dijelu u kojem one nisu faktografski netočne i oslonjene na krivotvorenje Derridaovih navoda (a pojavljuje se i to!), nemoguće olako odbaciti bez postavljanja pitanja o teorijskom okviru unutar kojeg se one iznose. Temeljni elementi spora proizvod su sraza između postfundacijske i fundacijske paradigme, te se ne mogu razriješiti s neke treće, natkriljujuće pozicije. Uz sve to, zanimljivo je istaknuti i da jedan od Derridaovih kritičara, Lewis, taj njegov otklon od onoga što sam smatra marksizmom eksplicitno imenuje postmarksističkim te povezuje $\mathrm{s}$ Laclauom (usp. isto: 146, 148).

${ }^{206}$ Usp. Derrida, 2002b: 87-88. 
koncepte rada, načina proizvodnje, društvene klase, pa dakle i za čitavu povijest njezinih aparata (projiciranih ili stvarnih: Internacionalu radničkog pokreta, diktaturu proletarijata, jedinu partiju, državu, a naposljetku i totalitarnu monstruoznost). (Derrida, 2002b: 114)

Drugim riječima, mesijanska logika nije ahistorijska, ona pretpostavlja historiju i mesijansko kao događaj (Derrida, 2002b: 88), no njegova korjenita heterogenost i nesuvremenost onemogućuju bilo kakvu kalkulaciju i zahvaćanje nekom stabilnom, zaokruženom strukturom ${ }^{207}$. Kao i kod teoretičara koje smo prethodno analizirali, i Derridaovo prihvaćanje marksističkog nasljeđa stoga ne može uključivati nikakvu (čak ni vrlo labavo) predeterminiranu shemu historije, baš kao što istovremeno naglašava historiju emancipacijske borbe, no nužno odbacuje ontološku privilegiranost klase ili nekog drugog determiniranog historijskog aktera $^{208}$.

Nova internacionala koju Derrida opisuje (i na koju poziva), ta „veza bliskosti, patnje i nade, još uvijek diskretna veza, gotovo tajna...“, „nepravodobna veza, bez statusa, bez naslova i bez imena, jedva javna iako ne i ilegalna, bez ugovora, 'out of joint', bez koordinacije, bez stranke, bez domovine, bez nacionalne zajednice (Internacionala prije, kroz i s onu stranu svake nacionalne determinacije), bez ko-državljanstva, bez zajedničke pripadnosti klasi“ (Derrida, 2002b: 111), savez bez temelja, prilično nalik (desetljeće ranijoj!) Laclauovoj radikalnoj demokratskoj koaliciji, zamjenjuje tako tradicionalnu marksističku koncepciju proletarijata kao univerzalne klase. No dok se svrgavanje tradicionalnog koncepta proletarijata u recepciji u pravilu uočavalo i naglašavalo, nezamijećeno je ostalo to da se iz nešto drukčije perspektive nova internacionala i proletarijat izjednačuju. Naime, ne valja smetnuti s uma da Derrida novu internacionalu određuje i kao ono što osporava subjektne pozicije otvorene u suvremenom društvu; „traži se kroz te krize međunarodnog prava“, odnosno „raskrinkava granice diskursa o ljudskim pravima“ (isto: 110), čime ona preuzima ulogu proletarijata u onoj mjeri u kojoj smo kod prethodno analiziranih autora proletarijat (ili

\footnotetext{
${ }^{207}$ Derrida se u elaboraciji svog promišljanja mesijanskog nerijetko referira na Benjamina, pri čemu neskriveno upućuje na važnost njegovog utjecaja, ali ga isto tako podvrgava i kritičkom dekonstrukcijskom čitanju (usp. naročito Derrida, 2002a). No ideju marksističkog mesijanizma sustavnije je i opširnije od Benjamina duž čitavog svog opusa razradio Benjaminov suvremenik Ernst Bloch, došavši do pozicija koje nam se čine mnogo bližima netom opisanim Derridaovim od Benjaminovih. Nažalost, za razliku od Benjaminove, Blochova je recepcija u krugovima francuskih teoretičara kojima je pripadao Derrida bila slaba. Tu propuštenu priliku konvergencije dvaju promišljanja mesijanskog u marksizmu nastojat će ispraviti poglavlje posvećeno Blochu koje slijedi u nastavku rada.

${ }^{208}$ Referirajući se na navode Manifesta komunističke partije da su dominantne ideje razdoblja samo ideje dominantne klase, Derrida (2002b: 76) tako navodi kako se „/m/ože nastaviti govoriti o dominaciji na polju snaga izostavljajući ne samo referencu na taj krajnji potporanj koji će biti identitet i samoidentitet jedne društvene klase, već čak i izostavljajući povjerenje koje je dano onome što Marx naziva idejom, određenje nadgradnje kao ideje, idejno ili ideološko predstavljanje, pa čak i diskurzivni oblik tog predstavljanja.“"
} 
plebs, narod, ili razne druge bliskoznačnice) mogli vidjeti kao neklasu, negaciju svakog načela klase.

$\mathrm{Na}$ istom tragu Derrida odbacuje i bilo kakav određen telos kritičke i emancipacijske prakse $^{209}$ u smislu projekta realizaciji čijeg bi se idealnog oblika trebalo primicati (pa tako i marksistički pojam besklasnog društva). Komentirajući nepremostiv jaz između konkretnih realizacija liberalne demokracije te ideala demokracije, Derrida (2002b: 87) progovara o „konceptu demokracije kao konceptu obećanja koji se može očitovati samo u takvoj dijastemi (otklonu, neuspjehu, neadekvatnosti, rastavljenosti, neusklađenosti, u biti 'out of joint').“ $\mathrm{Na}$ tom tragu uvodi i svoj čuveni koncept demokracije koja dolazi (avenir), suprotstavljajući ga kako budućoj demokraciji (u nekom budućem prezentu), tako i kantovskoj regulativnoj ideji demokracije ili pak utopiji.

No dok je otklon od tradicionalnog marksizma te način na koji on Derridaa povezuje kako s Deleuzeom tako još i više s dvojicom autora kasnije generacije - Rancièreom i Laclauom, posve razvidan, s pravom bi se moglo postaviti pitanje donosi li s druge strane Derridaovo bavljenje Marxom poveznice s marksizmom koje bi nadrastale puku konstataciju o vrijednosti njegova nasljeđa. Iako u okvirima konvencionalnog marksizma ove odgovore zasigurno ne bi smatrali zadovoljavajućima, prvi je moguće potražiti u Derridaovoj dekonstrukcijskoj kritici trijumfalne evanđeoske pripovijesti (neo)liberalizma o kraju povijesti i uspostavljanju najboljeg mogućeg društvenog poretka, metonimijski oprimjerene ponajviše Francisom Fukuyamom. Naime, premda bi se teorijsko-metodološki Derridaova kritika Fukuyame (i paradigme kojoj pripada) teško mogla podvesti pod tipičnu marksističku raspravu, njezine temeljne točke poklapaju se s uobičajenim objektima marksističke kritike (suvremenog) kapitalističkog društva ${ }^{210}$, pri čemu u prvi plan ponovno dolaze upravo pitanja

\footnotetext{
${ }^{209}$ Važno je u tom kontekstu naglasiti Derridaovo razlikovanje eshatologije i teleologije. Dok potonju smatra usmjerenošću nekom određenom cilju, uspostavljenom u okvirima nekog znanja, i zato je u kontekstu emancipacijskog odbacuje, prvu smatra potpuno otvorenom usmjerenosti naprijed, mesijanskim očekivanjem mimo svake totalizacije i zaključivanja, mimo svakog znanja (ili neznanja). Usp. Derrida, 2002b: 53.

${ }^{210}$ Derrida prvo apostrofira nove proglase (istovremeno zabrinute i trijumfalne) o kraju marksizma kao kraju povijesti kao „pobjednički diskurs“, „,relativno homogen, najčešće dogmatski, ponekad politički dvosmislen“, a potom uzima Fukuyamu i njegovu knjigu Kraj povijesti i posljednji čovjek za najbolji primjer tog „novog evanđelja, najbučnijeg, najviše medijatiziranog, najviše 'successful' u pogledu smrti marksizma kao kraja povijesti“ (Derrida, 2002b: 76). Fukuyaminu se trijumfalnom diskursu suprotstavlja prvo dekonstrukcijski razlažući njegove unutarnje kontradikcije, poput činjenice da Fukuyama isprva proglašava aktualnost najboljeg od svih mogućih sustava da bi ga potom rascijepio na nesavršenu empiriju (u koju delegira sve probleme) i idealnu težnju (isto: 78), odnosno da se zapleo u proturječje između događaja koji se može pozitivno konstatirati te regulativnog ideala koji ostaje neutjelovljen (isto: 84), između događaja na horizontu budućnosti i događaja iz prošlosti (isto: 88-89), u kontradiktorno stapanje naturalizma i transhistorijske teleologije (isto: 90. 92), pri čemu kao referencijalnu točku svojih ideala nudi „,̌ovjeka kao Čovjeka“, koncept koji u Fukuyaminu diskursu preživljava, kako Derrida (isto: 90) ironično podcrtava, samo zbog njegovog slabog poznavanja recentnije filozofske literature (pa tako i Marxa, kojeg trijumfalno kritizira). Drugi dio Derridaove kritike suvremenog kapitalizma bliži je marksističkom duhu od prethodnog dekonstrukcijskog razlaganja proturječja, te je ponajbolje
} 
emancipacije, mesijanskog obećanja i pravde, kao poveznice $\mathrm{s}$ drugim Derridaovim studijama.

Drugi je segment Sablasti Marxa blizak marksističkoj perspektivi onaj što se nastavlja na Derridaove ranije tvrdnje da dekonstrukcija ne zanemaruje sukob materijalizma i idealizma, dapače, da se njegova „važnost ne može precijeniti“ (Derrida, 1981: 50). Ističući važnost historijskog za dekonstrukciju ${ }^{211}$, Derrida navodi da je njegova kritička analiza logocentrizma uperena i protiv idealizma, budući da idealizam to jest, no istovremeno napominje i da je logocentrizam mnogo širi i tvrdokorniji kompleks. Na tom tragu Derrida $u$ Sablastima Marxa djelomično ispunjava očekivanja ranijih pokušaja da se dekonstrukcija poveže s marksizmom, poput Ryanova ${ }^{212}$, interpretirajući Marxovu kritiku fetišizma robe u terminima svog uokvirujućeg istraživanja sablasnosti. No segment je to koji istovremeno donosi i dekonstrukcijsku kritiku Marxa, utvrđujući da je suviše naivno „mislio da se granica između utvare i efektivnosti mora prijeći, kao i sama utopija, uz pomoć realizacije, odnosno revolucije“ (Derrida, 2002b: 55), čime je porodio problematičnu tendenciju izgona sablasti koja će kasnije dominirati u marksizmu ${ }^{213}$, dok se s druge strane u njegovu diskursu granica između analitičkog izgona sablasti i ,protumagije“ koja vjeruje u njih pokazuje neopstojnom (isto: 65$)^{214}$.

koncentriran u izdvajanju deset pošasti suvremenog doba - od visoke nezaposlenosti, prekarizacije i deregulacije tržišta, preko masovne isključenosti pojedinih skupina, gomilanja vanjskih dugova pa do rasta moći nekih kapitalističkih supersila i globalnih organizacija, ali i nacionalnih država i njihovih nacionalizama (usp. isto: 105-108). U svjetlu toga zaključuje: „nikakav nam napredak ne dopušta ignorirati činjenicu da nikada, u apsolutnim brojkama, nikada na zemlji toliko muškaraca, žena i djece nije bilo potlačeno, izgladnjelo ili istrijebljeno.“ (isto: 111)

${ }^{211}$ „Dekonstrukcijska praksa koja se ne bi pozabavila 'institucionalnim aparatom i historijskim procesom' (...), koja bi se zadovoljila raditi samo na filozofemima i konceptualnim označenim, diskurzima itd., ne bi bila dekonstrukcijska; bez obzira kako bi originalna bila, samo bi reproducirala samokritičko kretanje filozofije u njezinoj unutarnjoj tradiciji.“ (Derrida, 1995b: 72)

${ }^{212}$ Ryanova Marksizam i dekonstrukcija (1982) prostor za koristan, čak nužan input dekonstrukcije u marksizam vidjela je velikim dijelom u dekonstrukcijskoj kritici idealističke, metafizičke tradicije, a time i dijalektike, dok je s druge strane smatrala da marksizam dekonstrukciji može ponuditi ono što joj, prema Ryanu, upadljivo nedostaje - jasniju refleksiju o historijsko-političkom kontekstu te vlastitoj situiranosti i učincima na njega. Ipak, Derridaova i Ryanova perspektiva na odnose između idealizma i materijalizma te metafizike prisutnosti $\mathrm{i}$ idealizma nisu posve podudarne, pa tako Choat (2001: 76) upozoravajući na njihova razilaženja podcrtava da se ona događaju već i glede Marxove teorije vrijednosti, budući da Ryan smatra kako bi dekonstrukcijski input trebao marksizmu pomoći pokazati da je heterogenost uporabne vrijednosti u kapitalizmu suprimirana (naizgled) homogenom, unificiranom razmjenskom vrijednosti, dok Derrida odlazi drugim putem, ukazujući na međusobnu kontaminaciju tih vrijednosti te tako i kritizirajući Marxa.

${ }^{213}$ Derrida (2002b: 55) piše: „Ali ni on neće prestati vjerovati, pokušati vjerovati u postojanje te granice kao stvarnog limita i konceptualne distinkcije. Ni on? Ne, netko u njemu. Tko? 'Marksist' koji je izrodio ono što će dugo dominirati pod imenom 'marksizam'. Kojeg je također proganjalo upravo ono što je pokušao isključiti.“

${ }^{214}$ Derrida to demonstrira i u odnosu na Marxovu kritiku Stirnera, kao primjer njegova obračuna s idealizmom, i u odnosu na kritiku fetišizma robe (povezujući jedno $\mathrm{s}$ drugim). U prvom slučaju, Derrida sukus vidi u problematičnom pokušaju održavanja binarne opreke između pojmova Geist (duh) i Gespenst (sablast), odnosno strukturnoj sličnosti Marxa i Stirnera koja paradoksalno postaje glavno pogonsko gorivo Marxova nastojanja da se oštro razlikovno odredi prema Stirneru i njegovoj sablasnosti, koje ga vodi do ponavljanja analognih gesta (usp. Derrida, 2002b: 175, 185 itd.). U drugom dijelu kritike Derrida demonstrira neopstojnost oštre razdjelnice 
S obzirom na dvojakost Derridaovih dekonstrukcijskih gesti prema Marxu i marksizmu, utemeljenom se čini njegova tvrdnja da dekonstrukcija ,nikad nije bila ništa više marksistička nego nemarksistička, iako vjerna određenom duhu marksizma, barem jednom od njih, jer to nećemo ponoviti dovoljno puta, postoji više od jednoga i oni su heterogeni“ (Derrida, 2002b: 100), i to jer „,dekonstrukcijska misao traga, iterabilnosti, protetičke sinteze, suplementarnosti i tako dalje“" omogućuje nadilaženje binarnosti koje podriva sablasnost, a da istovremeno ne onemogućuje kritičku analizu „fantoma, simulakruma, 'sintetičke slike', pa čak, da upotrijebimo marksistički kod, ideologema, makar se radilo o njihovim još neviđenim oblicima koje će prouzročiti tek moderna tehnologija“ (isto). Drugim riječima, ako dekonstrukcija svojim kritičkim potencijalom nadilazi zahvate klasičnog marksizma, premda su i u njemu postojale srodne tendencije koje je ortodoksija inhibirala (usp. isto: 119), ona je pak „nemoguća i nezamisliva u predmarksističkom prostoru“, čime Derrida vrlo eksplicitno Marxa stavlja uz rame nekolicini drugih mislilaca koji se uvjetno-metonimijski mogu smatrati začetnicima projekta kritičkog preispitivanja logocentrizma ${ }^{215}$, dok istovremeno ne isključuje ni mogućnost (dapače, odgovornost) povratne sprege kojom je dekonstrukcija radikalizirala marksizam $^{216}$.

Perspektiva prema kojoj pak pokušaji petrifikacije klasičnog marksizma, u svom nastojanju da ponude odgovore na ontološka pitanja koja dekonstrukcija namjerno prazni od odgovora (Derrida, 2002b: 46) predstavlja političku deradikalizaciju analogna je Laclauovim i Rancièreovim kritikama da marksističko utemeljenje politike u društvenom u potpunosti neutralizira političko, baš kao što i Derridaova teza (isto: 134) da su različiti totalitarni i autoritarni poreci uvijek nastajali kao tjeskobna ili ustrašena reakcija na sablasti, strukturno nalikuje Deleuzeovoj shemi despotskih mašina što zauzdavaju deteritorijalizirane tokove žudnje. Ukratko, ako je sablast ono što izmiče metafizici prisutnosti ${ }^{217}$, „/p/roganjanje

u binarnoj opreci uporabne i razmjenske vrijednosti, odnosno činjenicu da nema te uporabne vrijednosti koja bi bila lišena izvanuporabnog, ekscesivnog (usp. isto: 201); teza koju bismo u retoričke termine mogli prevesti kao otpisivanje nulte razine figuralnosti. Zbog toga Derrida (isto: 126-127) smatra kako genitiv iz naslova Sablasti Marxa može pokazivati u više pravaca - prema sablastima Marxa koje opsjedaju liberale, podrivajući njihov trijumfalizam, sablastima koje Marx otkriva, ali i sablastima koje ga opsjedaju i kojih se u vlastitom diskursu ne može riješiti.

${ }^{215}$ Usp. Derrida, 2007: 299, gdje tu ulogu pridaje Nietzscheu, Heideggeru i Freudu.

${ }^{216}$ Glede radikalizacije, Derrida (2002b: 119) skreće pozornost na etimološku varljivost, smatrajući da ona nipošto ne treba podrazumijevati - kako bi riječ mogla sugerirati - genealošku potragu za čistim, temeljnim i iskonskim.

${ }^{217}$ Budući da sablast nije ni duša ni tijelo, odnosno paradoksalno je oboje (Derrida, 2002b: 17), budući da je ona „,neosjetilna osjetilnost“ (isto: 19), izvan svake sinkronije i apsolutno asimetrična (isto), istovremeno apsolutno anteriorna i buduća, ni jednostavno prisutna ni odsutna itd., Derrida (isto: 22) ukazuje na potrebu formuliranja „ukletologije“ [hauntologije; hantologie], kao logike proganjanja koja „ne bi bila samo šira i snažnija od ontologije ili misli o bitku...“, već bi „u sebi pružila zaklon samoj eshatologiji i teleologiji, ali kao zaokruženim mjestima ili osobitim učincima. Ona bi ih sadržavala, ali nerazumljivo.“ 
[sablasti] pripada strukturi svake hegemonije“ (isto: 54), pri čemu Derrida iznoseći tu tvrdnju fusnotom izravno upućuje na Laclauovu teoriju hegemonije, dajući nam tako za pravo da u Derridaovoj kritici egzorcističkih praksi liberalnih i ortodoksnomarksističkih paradigmi prepoznamo Laclauove i Rancièreove kritike istih paradigmi zbog izgona političkog ${ }^{218}$.

Marxov duh čije nasljeđe Derrida afirmira nasuprot nastojanjima klasičnog makrizma da odagna sablasti i stabilizira doktrinu uvelike se, dakle, s jedne strane podudara s nekim važnim segmentima teorija prethodno analiziranih autora, dok s druge strane zadobiva važno mjesto i u ostatku Derridaova diskursa. Što se prvoga tiče, radi se o potvrdi utjecaja što ga je Derrida - na spektru od primarnog filozofskog autoriteta, kakav predstavlja za Laclaua, pa do privilegiranog takmaca, kakvim ga se, vidjeli smo, često određuje u odnosu na Deleuzea ${ }^{219}$ ostavio u odnosu na te autore, dok nas drugo usmjerava premještanju fokusa na ostale segmente Derridaova opusa.

Naime, najsnažnije profilirani elementi u Sablastima Marxa - mesijanska struktura politike, demokracija koja dolazi i, povrh svega, pravda „koja se ne može dekonstruktivirati [sic!], kao nedekonstruktibilni uvjet svake dekonstrukcije, naravno, ali uvjet koji je i sam u dekonstrukciji i ostaje, mora ostati““ (Derrida, 2002b: 43) - odreda eksplicitno određeni kao Marxovo političko nasljeđe, postali su i čvorišne točke drugih studija kasnije faze Derridaova opusa. Kao primjer možemo izdvojiti dvije najčešće spominjane (na prvu Derrida eksplicitno upućuje i u Sablastima) - tekst „Sila zakona“ [„Force of Law“, 1994; usp. Derrida, 2002a] te knjigu Politika prijateljstva [Politiques de l'amitié, 1994; usp. Derrida, 2005].

U „Sili zakona“ Derrida detaljnije razrađuje problematiku aporetičnog odnosa među silom, zakonom i pravdom te esencijalne povezanosti pravde i dekonstrukcije. U Politici prijateljstva predmet je rasprave potraga za konceptom prijateljstva koji bi izmakao fraternalističkim i uopće obiteljskim metaforama, a time i utemeljenju u prirodnom iskonu i

\footnotetext{
${ }^{218}$ U kontekstu problematizacije postmarksističkog polja, vrijedi skrenuti pozornost na još jednu podudarnost između spomenutih teoretičara i Derridaa, a to je dvojak odnos prema Althusseru. Derrida (1981: 58) naime na jednom mjestu hvali Althusserovu kritiku Hegelove koncepcije opće historije kao jedinstvenog monolitnog totaliteta i afirmaciju historija „,različitih vrstom, ritmom, načinom inkripcije...“, te napominje da u svoju analizu heterogenosti marksizma namjerava krenuti uzimajući u obzir „odlučujuć napredak što su istovremeno ostvarili Althusser i njegovi pratitelji“ (isto: 65), dok drugdje kritizira Althussera kao jednog od predstavnika marksista što su u ime Znanosti pokušali doći do pročišćenog, izvornog Marxa (isto, 2002b: 49), dok su istovremeno prezali od bilo kakve mesijanske eshatologije (isto: 116). U kontekstu tog ambivalentnog odnosa zanimljivo je da Negri u svojoj kritici Sablasti Marxa (usp. Sprinker, 2008: 5) čitavu „teorijsku klimu“ zaslužnu za nastanak dekonstrukcije povezuje upravo s Althusserom i njegovim kružokom, smatrajući da je ostavio nezanemariv utjecaj na Derridaa.

${ }^{219}$ Premda npr. Ryan (1982: 103) nasuprot uvriježenim podcrtavanjima Derridaova i Deleuzeova teorijskog suparništva nudi i drukčiju perspektivu, tvrdeći da se u Deleuzeovu opusu (baš kao i onom Kristeve i Foucaulta) osjete stanoviti konceptualni pomaci koji se mogu povezati s Derridaovom pojavom na teorijskoj sceni. Ipak, odnos Derridaa i Deleuzea, kao što smo već u prethodnom poglavlju implicirali, tema je za složeniju raspravu kojoj ovdje ne možemo pokloniti odgovarajući prostor.
} 
pripadajućoj hijerarhiji, kako bi se mogla adekvatno misliti demokracija ${ }^{220}$. U oba slučaja ključ pronalazi u otvorenosti apsolutnoj drugosti/heterogenosti što nadilazi svaku strukturu očekivanja i bilo kakvu kalkulabilnost, odnosno drugim riječima u mesijanskom ${ }^{221}$. Također, u oba slučaja Derrida dekonstrukciju gotovo poistovjećuje sa središnjim konceptom što stoji u aporijskom odnosu, istovremeno i razotkrivajući taj odnos, te je određuje nužno političkom, implicitno time vežući političnost za specifičan strukturni odnos u kojem se nalaze ključni koncepti studija 222 .

S obzirom na takvu poveznicu što je uspostavlja između mesijanskog i političkog, koja uvelike podsjeća na Deleuzea, ne bi bilo neobično očekivati da se Derrida na tom polju priklanja antifundacionalizmu, odnosno da dijeli perspektivu s teoretičarima koji pokušavaju izbjeći bilo kakav oblik utemeljenja. Ipak, on na više mjesta izriče upravo suprotan stav, ukazujući na neizbježnost kvaziutemeljenja. Zaokupljajući se tim pitanjem intenzivnije upravo u sklopu promišljanja odnosa pravde i zakona, već pri početku teksta tvrdi da ,/t/akvo preispitivanje temelja nije ni fundacionalno ni antifundacionalno“ (Derrida, 2002a: 236), demonstrirajući to već na primjeru utemeljenja zakona i pravde. Naime, kako Derrida (isto:

220 Čini nam se da bi na ovom mjestu bilo adekvatnije napisati „misliti zajednica“, i to zajednica poput Nancyjeve ,razdjelovljene“ (usp. Nancy, 2003 [1986]), kada ne bi bilo Derridaove stanovite averzije prema tom pojmu. Naime, Derrida u Politici prijateljstva pokazuje da je upoznat s raspravom o zajednici, u najmanju ruku na relaciji Bataille - Nancy - Blanchot, te je povezuje s Nietzscheovom zajednicom filozofa budućnosti, no istovremeno izražava svoje rezerve prema takvim koncepcijama za koje mu se čini da ipak ostavljaju na životu suviše fraternalističkog diskursa (usp. Derrida, 2005b: 37). Zazor još jasnije ističe na kraju studije, pišući da „riječ 'zajednica' (priznatljiva ili nepriznatljiva, razdjelovljena ili ne)“ „,nije mogao napisati, na vlastitu inicijativu i u vlastito ime, takvu kakva je“ (isto: 305 ).

${ }^{221}$ Usp. navode da ,/p/rijateljstvo nikada nije dano u sadašnjosti, ono pripada iskustvu čekanja, obećanja i angažmana. Njegov je diskurs diskurs molitve, inaugurira, no ne konstatira ništa, nije zadovoljno s onim što jest, već se kreće do mjesta na kojem odgovornost otvara budućnost“ (Derrida, 2005b: 236) te da je „demokracija uvijek u dolasku; to je njezina bit ukoliko opstaje: ne samo da će ostati beskonačno usavršiva, dakle i uvijek nezadovoljavajuće i buduća, nego, s obzirom na to da pripada vremenu obećanja, ostaje uvijek dolazeća i u svim budućim vremenima..." (isto: 306), kao i pitanje ,je li se moguće otvoriti tom 'dolaženju' određene demokracije koje više nije uvreda prijateljstvu kakvo smo nastojali misliti s onu stranu homo-fraternalnih i falologocentričnih shema.“ (isto: 306) U drugoj studiji pak npr. tezu da „,/p/aradoksalno, zbog preplavljivanja performativnim, zbog uvijek ekscesivnog napredovanja interpretacije, zbog strukturne hitnosti i taloženja pravde, potonja nema horizont očekivanja (regulativni ili mesijanski). No zbog istog razloga ima avenir, dolazeće koje se mora rigorozno razlikovati od budućnosti. Budućnost gubi svoju otvorenost, dolazak drugoga (koji dolazi), bez kojih nema pravde; i budućnost uvijek može reproducirati sadašnjost, objaviti se ili predstaviti kao buduća sadašnjost u izmijenjenom obliku sadašnjosti. Pravda ostaje dolazeća, ostaje dolazeći, mora doći, ona jest dolaženje, razvija samu dimenziju nesvodivo dolazećih događaja.“ (isto, 2002a: 256)

${ }^{222}$ Usp. tezu da se „ono što se trenutno naziva dekonstrukcijom, iako se naizgled nikada nije 'obratilo' pitanju pravde, zapravo nije bavilo ničim drugim do li tim pitanjem, iako to nije moglo izravno, nego samo na zaobilazan način" (Derrida, 2002a: 237), budući da se o pravdi i ne može govoriti izravno da je se ne izda, odnosno da je ono što omogućuje zakon ujedno i ono što omogućuje njegovu dekonstrukciju, dok ,/p/ravda u sebi, ako postoji, izvan ili preko zakona, nije dekonstruktibilna. Ništa više nego dekonstrukcija sama, ako postoji. Dekonstrukcija jest pravda.“ (isto: 243) Jednako tako Derrida tvrdi i da „nema dekonstrukcije bez demokracije, ni demokracije bez dekonstrukcije“. (isto, 2005b: 105) Bavljenjem aporijama pravde i demokracije dekonstrukcija se ne zatvara u bjelokosni toranj (isto, 2002a: 235), niti se okreće „kvazi-nihilističkoj abdikaciji pred etičko-političko-juridičkim pitanjima pravde i pred opozicijom pravednog i nepravednog“ (isto: 247), već aktivnom političkom angažmanu svojom dvostrukom gestom rastemeljenja i otvaranja prostora novom utemeljenju. 
241) razlaže, samo utemeljenje pravde i zakona implicira primjenu određene performativne sile, odnosno određenu ,,interpretativnu silu i apel na vjeru“, no ne u smislu u kojem bi bili izraz i instrument neke pretpostojeće vanjske sile (time i vanjskog temelja), već na način da podrazumijeva složen unutarnji odnos između onoga što nazivamo silom, moći i nasiljem. Isto tako to utemeljenje ne može biti ,trenutak upisan u homogeno tkivo priče ili historije, budući da je trga jednom odlukom“ (isto), no sama činjenica da se radi o utemeljenju i odluci podrazumijeva i uspostavu novog sličnog tkanja. Jaz koji se ne da zatvoriti između zakona i pravde, činjenica da se pravda ne može svesti na predvidljivo propisom, implicira da nijedno utemeljenje ne može biti konačno.

Dekonstrukcija, koju Derrrida dovodi u uzak odnos s pravdom, ona je koja ne prepuštajući se „dogmatskom drijemežu“ „suspendira vjerodostojnost aksioma“ (Derrida, 2002a: 248), potresajući tako na jedan zastrašujuć no strukturno nužan tren i vjeru u postojanje pravde uopće, te tako otvara „interval oprostorenja u kojem se događaju transformacije, čak i juridičkopolitičke revolucije“ (isto: 249). No važno je podcrtati - to suspenzivno djelovanje ,ne može biti motivirano, ne može naći svoje kretanje, svoj impuls (impuls koji se ne može suspendirati) nigdje do li u zahtjevu za povećanjem ili suplementom pravde, dakle u iskustvu neadekvatnosti ili disproporciji što se ne da izračunati.“ (isto) Rekonfiguracija određenog diferencijalnog poretka, dakle, nije motivirana nikakvim jednostavno prisutnim temeljem, već antagonizmom/nesporazumom, prevedemo li stvari u Laclauov ili Rancièreov diskurs kako bi se analogije jasnije primijetile ${ }^{223}$.

Pri uspostavi analogije s tom dvojicom autora, važno je primijetiti da Derrida (2002a: 286) pri kraju svog teksta, baveći se Benjaminovim pokušajem razdvajanja sile koja utemeljuje i koja održava poredak, Benjaminovu referencu na boga koji stoji iznad univerzalnosti zakona prevodi kao tek ništa drugo do li referencu na nesvodivu singularnost svake situacije. Upravo je koncept boga (naročito u raznim misticizmima i negativnoj teologiji) u nešto kasnijim studijama i za Laclaua postao sjajan primjer katahretičkog označitelja što preuzima funkciju reprezentacije univerzalnosti na koju je (kao i svaka druga singularnost) u krajnjoj instanci nesvodiv, odnosno kvaziuniverzalnosti, suplementa odsutnog

\footnotetext{
${ }^{223}$ Drugim riječima, ne radi se „o odsutnosti pravila i znanja, nego o reinstituciji pravila kojoj po definiciji ne prethodi nikakvo znanje niti ikakva garancija.“ (Derrida, 2002a: 255) No nemogućnost proračunatosti oslanjanjem na temelj ne podrazumijeva mogućnost odgađanja neodlučivosti do beskonačnosti, već etičku i političku nužnost, dapače hitnost odluke. Derrida (isto: 252) jasno napominje - neodlučivost nije samo oscilacija između dva proturječna pravila, već i obveza da se odluka donese. Zbog toga smatra jednako problematičnim i politički voluntarizam, naročito „u svom arhaičnom obliku logike reprezentacije i svijesti“, kao i zlouporabu différancea i neodlučivosti koja bi do beskonačnosti izbjegavala donošenje odluke na neodlučivu terenu (usp. Derrida, 1992a: 59). Podsjetimo još da Laclau (2006: 90) hegemoniju najkraće definira upravo kao donošenje odluke na neodlučivu terenu.
} 
središta $^{224}$. No baš kao što i Laclau (2014: 45, 48) povlači oštre granice između svoje postfundacijske sheme i negativne teologije, tako i Derrida (1982: 6) jasno podcrtava da différance nije negativnoteološki element; budući da potkopava uspostavu bilo kakvog apsoluta (pozitivnog i negativnog), prethodi jednako prisutnosti kao i odsutnosti.

Pitanje odnosa singularnog i univerzalnog, izravno povezano s problematikom tropološkog nadodređenja, upravo je ključno za odnos zakona i pravde: pitanje „kako pomiriti čin pravde koja se uvijek mora ticati singularnosti, pojedinaca, skupina, nezamjenjivih egzistencija, drugoga ili sebe kao drugoga, u jedinstvenoj situaciji, s pravilom, normom, vrijednosti ili imperativom pravde koji nužno ima opći oblik, čak i kada ta općenitost propisuje pojedinačnu primjenu.“ (Derrida, 2002a: 245) Ista opreka u središtu je problema i u promišljanju prijateljstva i demokracije u Politici prijateljstva, protežući se kroz veći dio zapadne misli još od Aristotela. Kako Derrida (2005b: 22) pokazuje, iz proturječja aristotelovskih zahtjeva da prijatelja ne smijemo imati prekomjeran broj, ali i da zajednica treba biti univerzalno bratstvo/prijateljstvo, slijedi aporija da „nema demokracije bez poštivanja nesvodive singularnosti ili drugosti, no nema ni demokracije bez 'zajednice prijatelja', bez kalkulacije većina, subjekata koji se mogu odrediti, stabilizirati, reprezentirati, a opet jednakih.“

Pritom nastojanje da se proturječje prikrije mobilizira dva jednako proturječna principa: utemeljenje „bratstva“ u prirodi i u simboličkoj svezi (u physisu i nomosu), što ponovno priziva nužnost tropološkog nadsvođivanja: „Takva poveznica između dvaju strukturalno heterogenih veza uvijek ostaje opskurna, mistična, esencijalno strana racionalnosti - što ne znači jednostavno iracionalna, $u$ jednako modernom smislu termina. Ona će uvijek ostati izložena, u najmanju ruku, 'sofistikacijama', mistifikacijama i perverzijama retorike“ (Derrida, 2005b: 99), koje svoj vrhunac efikasnosti doživljavaju u raznim oblicima nacionalizama i ksenofobije. U kontekstu tih retoričkih operacija, izrazito je ilustrativan Kantov primjer. Naime, pokazujući da bratska/familijarna koncepcija prijateljstva uvijek implicira hijerarhijsku strukturu, Derrida upućuje na Kanta koji svoj koncept prijatelja čovjeka te ideju univerzalne jednakosti svih ljudi ilustrira slikom oca i braće - „Podložne i jednake braće. Ljudi su braća, a otac nije čovjek: 'svi ljudi predstavljaju se ovdje kao da su braća pod jednim ocem što im svima želi sreću.“ (isto: 261) Drugim riječima, katahretično

\footnotetext{
${ }^{224}$ Usp. tekst „O imenima boga“ [„On the Names of God“] u Laclau, 2014. Nešto kasnije u svom tekstu Derrida (2002a: 293) Benjaminov koncept boga povezuje i s apsolutno i nepredvidivo drugim kao „apsolutnom metonimijom", što je također usporedivo s Laclauovom retoričkom shemom sjetimo li se da je hegemoniju određivao kao metonimijski odnos, koji potom učvršćivanjem metonimijskog prekoračenja prelazi u metaforu/katahrezu.
} 
hegemonijsko nadsvođivanje (Benjaminovim) bogom, (Kantovim) ocem ili nekim drugim kvazitranscendentalnim označiteljem ostaje nužan most između univerzalnog i singularnog čak i kod tobože posve fraternalističkih i univerzalističkih shema, a politika se ponovno potvrđuje usko povezanom s retorikom. Dapače, i konceptualno zahvaćanje demokracije koja dolazi jednako se tako pokazuje ovisno o tropološkom prijenosu. Derrida naime u knjizi Razbojnici: dva eseja o razumu [Voyous: Deux essais sur la raison, 2003] demokraciju koja dolazi dovodi u svezu sa svojim shvaćanjem antičkog koncepta khôre (Derrida, 2005a: 82), kao onog što zauzima određeno mjesto ostajući neodređeno; kao zauzetog mjesta, ali ne i onog što ga zauzima. No kako Lüdemann (2014: 99) podsjeća upućujući na Platona, još od njegova Timeja khôra je nešto neuhvatljivo, što se ne da opisati do li analogijama i slikama na koje nije svediva i koje joj nisu vlastite. Ponovno se, dakle, nalazimo na terenu katahreze.

Binarna opreka physisa i nomosa što se uvijek u novim likovima pojavljuje u podlozi čitave te problematike, kako Derrida podsjeća u „Sili zakona“ (2002a: 235), bila je jedna od prvih predmeta kojima se bavila dekonstrukcija. Tom Derridaovu podsjetniku vrijedi dodati da je u najpoznatija dva slučaja (u čitanju Lévi-Straussa u Pisanju $i$ razlici [1968] te Rousseaua u O gramatologiji [1968]) došla do čuvenih zaključaka da „u odsutnosti središta ili podrijetla sve postaje diskurs“ (Derrida, 2007: 299), odnosno da „izvan teksta ne postoji ništa“ (Derrida, 1976: 207, 212) ${ }^{225}$. No jednako tako, isti tekstovi pokazuju i da se ,zapravo i ne može zamisliti neorganizirana struktura“ (Derrida, 2007: 297), kao i da valja ,promišljati zakon koji na neki način pri stvaranju strukture upravlja žudnjom prema središtu“ (isto: 298) i njegovim različitim metaforama i metonimijama $u$ historiji metafizike (isto), odnosno promišljati „Zakone simboličke misli“ što raspodjeljuju „višak značenja“ (isto: 308) nastao odsutnošću središta i njegovim opetovanim suplementarnim nadomještanjem.

Drugim riječima, Derridaovoj tvrdnji da je već od ranijih radova poklanjao pozornost problematici koja će jače doći do izražaja u kasnijem bavljenju političkom tematikom možemo pridodati i tvrdnju da su već tada pojedini aspekti kritike metafizike prisutnosti vrlo

\footnotetext{
${ }^{225}$ Iskaz je to koji se široko prihvatio kao zloglasno krivo tumačeno geslo dekonstrukcije, zbog čega je Derrida morao intervenirati objašnjavajući da „tvrditi da nema apsolutne vanjštine teksta ne znači pretpostavljati nekakvu idealnu unutrašnjost, neprestanu obnovu odnosa pisma prema samome sebi. To što je u pitanju nije više idealistička ili teološka operacija koja, u hegelijanskoj maniri, suspendira i izdiže ono što je izvan diskursa, logos, koncept, ideju. Tekst afirmira izvanjskost, označava granice te spekulativne operacije, dekonstruira i reducira na status 'učinaka' sve predikate pomoću kojih spekulacija aproprira vanjštinu. Ako nema ničega izvan teksta, to implicira, zajedno s transformacijom koncepta teksta uopće, da tekst više nije sigurna hermetički zatvorena unutrašnjost ili identitet za sebe (...) već različito postavljanje učinaka otvaranja i zatvaranja.“ (Derrida, 2016: 28 [1972]) Drugim riječima, reći da nema ničega izvan teksta za Derridaa znači „ništa drugo nego li da nema ništa izvan konteksta“, budući da je ,jedna od definicija onoga što se naziva dekonstrukcijom upravo nastojanje da se bezgranični kontekst uzme u obzir, da se najoštrija i najšira pažnja pokloni kontekstu, a time i neprestanom kretanju rekontekstualizacije." (Derrida, 1988: 136)
} 
jasno implicirali da posljedično politiku konceptualizira diskurzivno i postfundacijsko, stavljajući u prvi plan njezinu tropološku narav. Kao eksplicitniji primjer povezivanja kvaziutemeljenja s tropima, posve nalik desetljećima kasnijem Laclauovom, može nam poslužiti i Derridaov tekst „Bijela mitologija“ [La mythologie blanche, 1972], česta referentna točka u književnoj teoriji upravo zbog preispitivanja metafore i metaforičkog diskursa.

Ukazujući na nemogućnost filozofije da se oslobodi metafore i tako utvrdi granice i privilegiranu poziciju svog diskursa, nemogućnost prouzročenu činjenicom da su i temeljni koncepti filozofije (uključujući i koncept i metaforu) metafore ${ }^{226}$, Derrida (1982: 228) zaključuje kako bi ovladavanje metaforom ,pretpostavljalo rješenje važnih problema, i to primarno problema koji ustanovljuju čitavu filozofiju u njezinoj historiji“, odnosno da je „metaforologija derivativna u odnosu na diskurse kojima navodno dominira“ (isto). Pitanje „mogu li se ti određujući tropi, što prethodne svoj filozofskoj retorici i proizvode filozofeme još zvati metaforama“ (isto: 255) Derridaa odvodi tradicionalnim određenjima katahreze kao „nasilnog, prisilnog, zloupotrebljujućeg upisa znaka, nametanja znaka značenju koje još nije imalo vlastiti znak u jeziku.“ (isto) No osim što se katahreza pokazuje nazivom za „utemeljenje čitavog tropološkog sustava“, u kojem čista denotacija/nulta razina figuralnosti postaje nemoguća ${ }^{227}$, Derrida podcrtava i činjenicu da raniji opisi kretanje značenja koje proizvodi katahrezu smještaju negdje između (fundamentalne) opreke između doslovnog i figurativnog značenja:

Ono što nam je ovdje naročito zanimljivo stoga je proizvodnja doslovnog značenja, nove vrste doslovnog značenja, pomoću nasilja katahreze čiji posrednički status izmiče opoziciji doslovnog i figurativnog, postavljajući se između njih kao „sredina“. Ako pak sredina opreke nije prolaz posredovanja, po svemu se čini da opreka nije odgovarajuća. Posljedice su bezgranične. (Derrida, 1982: 256)

Drugim riječima, katahreza dolazi u usku svezu s différance, svezu koju će potvrditi i sljedeći tekst iz Margina filozofije [Marges de la philosophie, 1972], „Qual quelle: Valéryjevi izvori“ [Qual quelle. les sources de Valéry]. Tamo naime Derrida (1982: 283), govoreći o

\footnotetext{
${ }^{226}$ Usp. npr. Derrida, 1982: 224-225. Zanimljivo je primijetiti da u tekstovima koji u Marginama filozofije prethode „Bijeloj metafori“ Derrida ukazuje na slične zaključke kod Nietzschea (odbacuje validnost pojma istine i demonstrira da sve počiva na metafori, usp. isto: 178) i Heideggera (zaključuje da se bitak, koji nije biće, ne može sebe izreći nikako drukčije do li ontičkom metaforom, usp. isto: 131), dok u samoj „Bijeloj metafori“ apostrofira i Marxovu kritiku (Stirnerova) etimologizma i koncepta vlastitog/doslovnog, pokazujući tako da je i kritičko istraživanje pozicije metafore koje poduzima, baš kao i čitava kritika metafizike prisutnosti kojega je ono dio, počelo i mnogo ranije.

${ }^{227}$ Kao što Derrida (1982: 244) pokazuje na primjeru sunca (ističući uz to da su heliotropi zapravo tropi par excellence, usp. isto: 250), činjenica da taj označitelj stoji u relaciji s mnoštvom katahreza, što su primijetili već i tradicionalni retoričari, ne znači da se radi o „vlastitom imenu unikatne stvari koje bi metafore preuzele“, već nas upućuje na to da je ono uvijek „,već počelo izražavati mnoštveno, podijeljeno porijeklo“ svih riječi s kojima dijeli mrežu metaforičke povezanosti.
} 
Valéryjevoj konceptualizaciji jastva i njegove nemogućnosti da se vrati sebi, da ostvari samoprisutnost, da se vrati točki izvora namjesto raspršenosti bez povratka, navodi kako takvo jastvo ne može postati objekt doslovne ili figurativne definicije, čak ni zahvaćanja tropom, osim možda „nasiljem katahreza“. Uska sveza katahreze kao kvaziutemeljujućeg momenta sustava te kretanja karakterističnog za différance razlog je dakle da sustav ne može biti zaokružen i stabilan. Sličnosti s Laclauovom konceptualizacijom društvenog očigledne su; premda se Laclau nigdje ne referira na ove i kasnije Derridaove tekstove o tropima, to značajno preklapanje jasno svjedoči o snazi utjecaja koji je Derrida na njega ostvario te istovremeno potvrđuje Derridaovu tezu da je sve navedeno embrionalno sadržano već u njegovim najranijim tekstovima, iz kojih je Laclau pak obilno crpio.

Još jedna poveznica između autora kojima smo se pozabavili u prethodnim poglavljima te Derridaa dovodi nas pak na korak do pitanja o statusu književnosti. Radi se naime o literarnosti, konceptu za koji smo vidjeli da se ne odnosi ekskluzivno na književnost, već na višoj razini općenitosti označava temeljnu jednakost slova i razotkrivanje figuralnog inputa svakog sustava reprezentacije, odnosno privremenosti i izvedenosti svakog diferencijalnog poretka.

Jednako tako ni za Derridaa „,ne postoje tekstovi koji su literarni po sebi“, zbog čega zaključuje da ,/l/iterarnost nije prirodna bit, intrinzično svojstvo teksta. Ona je korelativ intencionalne relacije prema tekstu, intencionalne relacije što u sebi integrira, kao komponentu ili intencionalni sloj, više ili manje implicitnu svijest o pravilima koja su konvencionalna ili institucionalna - društvena u svakom slučaju.“ (Derrida, 1992: 44) Drukčije rečeno, „o 'literarnosti' se zasigurno ne može govoriti kao onome što pripada književnosti, što uključuje fenomen ili objekt, čak i djelo, u neko polje, domenu ili regiju čije bi granice bile čiste i čiji bi naslovi bili nedjeljivi.“ (isto: 215) Naprotiv, literarno „,ne pripada polju, nego preoblikuje polje“ (isto) i to upravo (makar implicitnim) razotkrivanjem prešutnih konvencija koje nekim poljem dominiraju. ${ }^{228}$

Važno je podcrtati da se takva poopćena formulacija literarnosti, kao što zamjećuju i Bekavac (2015: 274) i Beardsworth (1996: 37), u svom najpoznatijem izdanju javlja upravo u sklopu problematizacije naravi zakona te aporetičnog odnosa singularnog i univerzalnog u

\footnotetext{
${ }^{228}$ Takvo poopćenje literarnosti, kao i znatan dio svoje konceptualizacije književnosti, Derrida duguje utjecaju nekolicine autora koji su na njega ostavili snažan utisak: Heideggerovu konceptu Dichtunga te Levinasovu dovođenju u suodnos književnosti i drugosti, no prije svega Mauriceu Blanchotu, autoru na čije se promišljanje (književnog) pisma Derrida uvelike nadogradio. Kako napominje Clark (1992: 65) istražujući poveznice među spomenutim autorima, upravo se „kod Blanchota prvo put može primijetiti kako je literarno, u posljednja dva stoljeća, postalo kvazi-transcendentalni prostor, 'iskazivanje bitka'.“ Odnosno, kako je jedino pozitivno određenje literarnog postala neobičnost njegova pristupa: „Ono ne postoji, no njegova je ustrajnost... neotklonjiva.“ (isto: 2 )
} 
Derridaovu istoimenu čitanju Kafkine novele „Pred zakonom“ [„,Devant la loi, 1985/1987]. Na taj svoj tekst Derrida upućuje i u „Sili zakona“, smatrajući da iskustvo koje tematizira Kafkina novela odgovara onom „trenutku neizvjesnosti, toj epokhe, tom utemeljujućem ili revolucionarnom trenutku zakona koji je, u zakonu, instanca ne-zakona. No istovremeno je to i čitava historija zakona. Taj se trenutak uvijek događa i nikad se ne događa u prisutnosti.“ (Derrida, 2002a: 269) Trenutak u kojem se zakon suspendira da bi se ponovno uspostavio, trenutak koji otkriva katehretičnu narav utemeljenja i istovremeno je prikriva, taj kratak, istovremeno revolucionaran i tjeskoban tren, ono je na što ukazuje literarnost.

Trenutak kvaziutemeljenja, politički trenutak par excellence, koji „/z/ahtijeva i negira priču, taj kvazidogađaj nosi trag fiktivne pripovjedivosti (fikcije pripovijedanja kao i fikcije kao pripovijedanja: fiktivnog pripovijedanja kao simulakruma pripovijedanja i to ne samo kao pripovijedanja imaginarne historije). To je $\mathrm{u}$ isto vrijeme izvor književnosti kao i zakona...“229 (Derrida, 1992: 199), zbog čega nije neobično da i kod Derridaa književnost stoji u povlaštenom odnosu spram politike. Dapače, trenutak u kojem ,ne znamo ni tko ni što je zakon“, smatra Derrida (isto: 207), „trenutak je u kojem počinje književnost“. Njoj nasuprot, „filozofski, znanstveni ili historijski tekst, tekst znanja ili informacije, ne bi napustili ime u korist stanja neznanja, ili bi u najmanju ruku to učinili tek slučajno, ne $u$ esencijalnom ili konstitutivnom smislu.“ (isto)

Književnost je, za razliku od tih diskursa, diskurs koji upućuje na odsutnost temelja, zlatne jezgre, „svetinje svetinja“ (Derrida, 1992: 208), koji demonstrira uskratu izvora i središta stalnim izmicanjem u igri différancea (isto: 202), nedodirljivost koja proizlazi upravo iz čitljivosti (isto: 197), istinu biti zakona koja kaže da biti nema (isto: 205), književnost je baš kao i zakon - tekst „koji govori samo o sebi, to jest o svom ne-identitetu sa sobom.“ (isto: 211) Ono što je na djelu u „Pred zakonom“, noveli koja u tom slučaju funkcionira i kao metonimija književnog teksta uopće, za Derridaa je „esencijalno održavanje veze s igrom uokvirivanja i paradoksalnom logikom granica, što uvodi neku vrstu pertubacija u 'normalan' sustav referencije, istovremeno razotkrivajući esencijalnu strukturu referencijalnosti. Radi se

\footnotetext{
${ }^{229}$ Usp. Clark (1992: 86) o sličnoj paradoksalnoj spirali odnosa kauzalnosti između pripovijesti (récit) i događaja o kojem pripovijeda, odnosno stvarnosti koju pripovijest opisuje i stvarnosti pripovijesti kod Blanchota, pri čemu se također opetovano podriva bilo kakva privilegirana točka utemeljenja. Ili kako Blanchot (2009: 343 [1949]) drugdje piše ocrtavajući još jedan vid dinamike između utemeljenja i podrivanja utemeljenja: nema simbola bez zahtjeva za negacijom ,i taj mu zahtjev, djelujući iza svakog pokreta pripovijedanja, priječi, svojom neprestano djelatnom negacijom, da dobije neki određeni smisao, da postane samo nositeljem značenja.“
} 
o opskurnom otkrivenju referencijalnosti koja se ne referira, koja ne proizvodi referenciju, ništa više nego što je događajnost događaja po sebi događaj.“ (isto: 213$)^{230}$

Smatrajući da se književnost, baš kao i zakon, gradi na raskrižju univerzalnog i singularnog, na paradoksalnoj opetovanoj idiomatičnosti onoga što se predstavlja kao da bi trebalo biti stalno i univerzalno ${ }^{231}$, Derrida (1992: 213) za protagonista Kafkine novele koji je imao poteškoća s razumijevanjem naravi zakona kaže da je „imao poteškoća s književnosti““, pridajući tako i posve eksplicitno književnosti svojstvo razotkrivanja onoga što stabilan poredak nastoji držati skrivenim u odnosu na narav zakona ${ }^{232}$. Dapače, književnost ne samo da ukazuje na kvaziutemeljiteljsku narav zakona nego je, u svom modernom obliku, i privilegiran prostor razotkrivanja opće validnosti tog principa. Naime, kako Derrida ističe u intervjuu naslovljenom „Neobična institucija zvana književnost““ [1989], „književno pismo u modernom vremenu mnogo je više od tek jednog u nizu primjera [opće tekstualnosti], ono je privilegirana nit vodilja za pristup općoj strukturi tekstualnosti.“ (isto: 71)

No osim što suočava s odsutnosti središta i posljedičnom diseminacijom značenja, odnosno upravo zbog toga, književnost je i „čudesna“ institucija koja „omogućuje da se kaže sve“ (Derrida, 1992: 36). Budući da je prostor književnosti istovremeno ,institucionalizirana fikcija kao i fikcionalna institucija“, činjenica da može izreći sve znači „nedvojbeno da okuplja, prevodeći, sve figure jednu u drugu, da totalizira formalizirajući, no isto tako reći sve znači i osloboditi se zabrana. (...) Zakon književnosti nastoji, u principu, ne poštovati ili dokinuti zakon.“ (isto) Zbog toga Derrida institucionalizaciju književnosti (u modernom smislu) smatra povezanom s mogućnosti da se kaže sve i s temeljnom jednakosti u jeziku (segment vrlo naglašen u kasnijem Rancièreovu opusu), odnosno nerazdvojivom od „dolaska do moderne ideje demokracije“, i to „ne u smislu da ovisi o demokraciji, nego se čini

\footnotetext{
${ }^{230} \mathrm{Na}$ drugom mjestu Derrida (1992: 48) proširuje tu tezu, nazivajući književnost privilegiranim mjestom na kojem se osjeti problem koji imamo sa samom srži jezika, s istinom i biti, odnosno s jezikom biti uopće. Utoliko je točna Clarkova (1992: 9) tvrdnja da za Derridaa, za razliku od američkih dekonstruktivista, književnost nije privilegirano mjesto problematizacije interpretacije ili epistemologije, već i same ontologije.

Usp. također i tvrdnju izrečenu u intervjuu iz 1967. da se „u određenom sektoru i određenom karakterističnom obliku 'literarne' prakse“ „subverzija logocentrizma pokazuje bolje nego igdje“ (Derrida, 1981: 11), pri čemu navodnike koje stavlja na literarno tumači kao naglasak na historijsku specifičnost te prakse, odnosno činjenicu da pod njom ne podrazumijeva transhistorično shvaćenu književnost, već književnost kao relativno modernu instituciju, čime naznačuje prijelomnicu koju je kao važnu uvijek isticao i Rancière.

${ }^{231}$ Odnos sa zakonom koji nalaže i zabranjuje, smatra Derrida (1992: 192), traži od nas da se ponašamo kao da taj zakon nema historiju i kao da nije ovisan o historiji svog predstavljanja. S druge strane, uvijek nas stavlja u kušnju domišljanja i istraživanja te historije ne-historije, porijekla ne-porijekla.

${ }^{232}$ Premda Derrida (1992: 202) napominje da zabrana pristupa zakonu u Kafkinoj noveli nije imperativna uskrata pristupa nekom stabilnom mjestu, nego izmicanje différancea, jednako tako skreće pozornost na čuvare zakona koji priječe njegovu prezentaciju (usp. isto: 201). Ili, kako navodi: „Zakon se daje uskraćujući se, ne odajući svoje porijeklo i mjesto. Tišina i diskontinuitet konstituiraju fenomen zakona.“ (isto: 192) Književnost, nasuprot tomu, uvijek poziva na tumačenje (isto: 45) te po tom pitanju nadilazi juridički diskurs odbacujući teološke note koje on još donekle zadržava (isto: 72).
} 
nerazdvojiva od onoga što priziva demokraciju, u najotvorenijem (i dolazećem) smislu demokracije.“ (isto: 37$)^{233}$

Činjenica da je demokracija za Derridaa uvijek nesamoprisutna dolazeća demokracija slaže se s karakteristikom koju pridaje književnosti da nužno nadilazi sebe: „Što bi bila književnost koja bi bila tek ono što jest, književnost? U tom slučaju, bivajući ono što jest, ona ne bi bila ono što jest.“ (Derrida, 1992: 215) No ni kod njega ta nužnost stalne (auto)transgresije nije postavljena tek plošno, nedomišljeno i nekritički. Moći reći sve, ili pak osporavati zakone koji određuju što se može reći, kako Derrida (isto: 50) naglašava, često je snažnije djelatno na formalnoj nego sadržajnoj razini2 ${ }^{234}$; ,preispitivanje je ponekad mnogo efikasnije pomoću konkretne prakse pisanja, postavljanja, kompozicije, ophođenja s jezikom, retorike, nego li pomoću spekulativnih argumenata.“ Drugim riječima, ,iskustvo, strast jezika i pisma (...), mogu prožimati diskurse koji su tematski 'reakcionarni' ili 'konzervativni' i pridati im moć provokacije, transgresije ili destabilizacije veću od one što je imaju takozvani revolucionarni tekstovi (na ljevici ili desnici) koji se mirno razvijaju u neoakademskim ili neoklasničnim formama.“ (isto: 50-51) ${ }^{235}$

Pritom ipak ostaju neki ograničavajući momenti. Za početak, bez obzira na svoj razmjerno ekskluzivistički književni ukus ${ }^{236}$, Derrida politiku književnosti ne poistovjećuje s književnim avangardizmom, pišući:

Ne vjerujem da je dovoljno, s obzirom na stanje stvari, tvrdoglavo ustrajati na krijumčarenju superrafiniranih avangardnih proizvoda bez borbe za masivnu preobrazbu aparata [književnog polja]. No nije ni beskorisno. Ipak, vjerovati da je dovoljno nahraniti dominantne aparate sa što više avangardističkih napravica: a to je upravo ono što trebaju na svojim marginama, za koje vežu avangardnu produkciju. Pa ipak, vjerovati da je to beskorisno svodi se na

\footnotetext{
${ }^{233}$ Derrida (1992: 38) ipak podcrtava da to ne znači pridavanje nekog oblika „kritičke funkcije“ književnosti, odnosno pretvaranje njezine diskurzivne specifičnosti koja ima visok emancipatorni potencijal u svojevrsnu regulativnu ideju, program ili krajnje značenje, budući da bi upravo to bilo književnosti strano.

${ }^{234}$ Pojmove formalnog i sadržajnog ovdje upotrebljavamo tek priručno, uz ogradu, budući da ih Derrida eksplicitno ocjenjuje neodgovarajućima da zahvate ono što čini događaj književnog teksta te navodi da je svojim čitanjima književnih djela među ostalim želio i skrenuti pozornost na neadekvatnost te opreke i njoj sličnih opreka. Usp. Derrida, 1992: 51.

${ }^{235} \mathrm{Na}$ drugom mjestu Derrida (1995b: 57) piše: „Ono što se čini najrevolucionarnijim ili najsubverzivnijim sadržajem (bilo čina ili diskursa) često se savršeno dobro prihvaća, neutralizira i asimilira u sustavu kojem se ti sadržaji navodno protive dokle god se poštuju određena pravila formalne doličnosti. A doličnost često može uzeti oblik kanonske i samozadovoljne nedoličnosti (mnogo je primjera toga). Dovoljno je da ta doličnost zna poštovati stvari za koje dominantan poredak zabranjuje da se s njima poigrava i voila. I obrnuto, čak i bez da se ima revoluciju na svojim usnama i bez da je se nosi na rukavu, dovoljno je okrznuti formalno površinu bilo čega od onog što čuvari forme doista čuvaju, i cenzorski će se stroj uključiti.“

${ }^{236}$ O Derridaovu književnom ukusu dalo bi se suditi već i prema književnim djelima kojima se u svojim tekstovima bavio, a radi se odreda o modernističkim autorima te ponekom klasiku svjetske književnosti. No i u ranije citiranom intervjuu otvoreno je priznao da ne uživa mnogo u prozi koja naglasak stavlja na identifikaciju, već preferira književna djela što se poigravaju kapacitetima jezika i mogućnostima simulakruma (usp. Derrida, 1992: 39).
} 
ograničavanje preobrazbe unaprijed na mlaku reformističku revnost. Stoga je nužno (...) djelovati u više smjerova i više ritmova. Monoritmičnost i monokodnost uvijek završavaju s trenutnom aproprijacijom. (Derrida, 1995b: 58)

Nadalje, bez obzira na privilegiranu emancipacijsku ulogu koju pripisuje književnosti, Derrida (1995b: 56) izražava sumnjičavost prema pripisivanju herojske uloge pojedinačnim autorima i djelima u smislu pridavanja voljne/intencionalne pozadine preobrazbama koje književnost donosi i njihovu povezivanju s pojedinačnim ostvarajima ${ }^{237}$. Kako napominje, „preobrazbe zahtijevaju mnoštvo očito heterogenih gesti. Jednako grupnih i individualnih gesti. Štoviše, često se događaju bez gesti i bez znanja.“

Upravo jer je opetovana inventivnost koja odlikuje književnost ukorijenjena u kolektivnim, dijelom i nesvjesnim kodovima, mogućnost invencije nailazi na ograničenja i uvijek joj izmiče apsolut. Premda je književno djelo iz njegove vizure možda i najbliže utjelovljenju koncepta singularnosti, apsolutna singularnost ostaje nemoguća jer bi kao takva bila nečitljiva. „Da bi [djelo] postalo čitljivo, mora biti dijeljeno, mora sudjelovati i pripadati.“ (Derrida, 1992: 68) Ili kako Derrida pokazuje, baveći se konceptom invencije u studiji Psyche: Invencija drugoga [Psyche: Invention de l'autre, 1987], svaka invencija mora $\mathrm{s}$ jedne strane imati strukturu singularnog, posve novog inauguralnog događaja, dok s druge da bi kao takva bila prihvaćena, njezina socijalizacija mora biti „zaštićena sustavom konvencija koje će osigurati njezino upisivanje u zajedničku historiju, pripadnost kulturi: nasljeđu, lozi, pedagoškoj tradiciji, disciplini, lancu generacija. Invencija počinje podložnošću ponavljanju, eksploataciji i reinskripciji.“ (Derrida, 1992: 316) Odnosno, invencija nije teološko stvaranje ex nihilo, pa tako Derrida i za pjesmu Francisa Pongea što je u spomenutom radu analizira navodi da ona „,ne stvara ništa u teološkom smislu riječi, (...) ona izumljuje samo okrećući se leksiku i sintaktičkim pravilima, prevladavajućem kodu, konvencijama kojima se na određeni način također i podlaže.“ (isto: 338)

U toj paradoksalnoj situaciji dosljednog poštivanja pravila, ali na takav način da se ona izvijaju kako bi se „omogućilo da drugi dođe ili najavi svoj dolazak“, Derrida (1992: 340) prepoznaje paralelu između (Pongeova) književnog teksta i dekonstrukcijskog čitanja, zaključujući potom na istom tragu da je ,jedina moguća invencija invencija nemogućega“ (isto: 341). Time književnost zapravo dolazi u (aporetičnu) poziciju otvaranja i pripremanja mjesta apsolutno drugom, onom čiji se dolazak ne može izmisliti i izvesti iz neke postojeće

\footnotetext{
${ }^{237}$ Usp. Clarkovu (1992: 86) tezu o kontinuitetu takve geste osporavanja autorskog značaja još od Blanchota i Heideggera.
} 
strukture $^{238}$, koji nije podložan kalkulacijama i pripremi, čime - makar neimenovan - s njom u izravnu svezu dolazi koncept mesijanskog ${ }^{239}$.

Ipak, važno je istaknuti ni da za Derridaa, baš kao ni za Rancièrea i Deleuzea, nije sva književnost automatski mesijanska, niti je odnose koji se uspostavljaju oko te problematike iz bilo kojeg rakursa moguće učiniti crno-bijelima. Književnost kao ,protuinstitucionalna institucija može biti i subverzivna i konzervativna. Može biti konzervativna time što je institucionalna, no može jednako tako biti i konzervativna kao antiinstitucionalna, tako da bude 'anarhična', u onoj maniri u kojoj i određene vrste anarhizma mogu biti konzervativne.“ (Derrida, 1992a: 58) Ta (potencijalna) ambivalentnost možda najviše do izražaja dolazi u tvrdnji koju Derrida formulira baveći se Celanovim pjesništvom u tekstu Shibboleth [Schibboleth: Pour Paul Celan, 1986]. Tamo naime skreće pozornost na to da shibboleth, kao riječ koja se u Celanovoj pjesmi višestruko ponavlja, a istovremeno je singularna lozinka, može funkcionirati među ostalim i kao „lozinka ili poziv na okupljanje, pravo pristupa ili znak članstva u svim političkim situacijama duž historijskih granica koje se spajaju u konfiguraciji pjesme“ (isto: 403). No shibboleth može postati i lozinka koja čuva prijelaz granice neke zajednice, njezina se vrijednost tako „može uvijek, i tragično, izokrenuti. (...) Lozinka u borbi protiv opresije, isključenja, fašizma i rasizma može i iskvariti njezinu diferencijalnu vrijednost, koja je uvjet saveza i pjesme, pretvarajući je u diskriminatornu granicu, rešetku policije, normalizacije i metoda pokoravanja.“ (isto: 409) Riječ je dakle o upozorenju vrlo

\footnotetext{
${ }^{238}$ Privilegiranje književnosti kao prostora drugosti karakteristično je i za Levinasa i za Blanchota, no Derrida je u odnosu s tom dvojicom teoretičara ponovno bliži Blanchotu, koji za razliku od Levinasa Drugog ne pretvara u transcendentalnu instancu, nego ga povezuje sa svojom diferencirajućom koncepcijom pisma. Usp. o tome Clark (1992: 100, 105). Utoliko takva problematizacija odnosa između jezika/pisma i Drugog Blanchotovu (baš kao i Derridaovu) koncepciju književnosti čini oprečnom i konceptualizacijama kakve susrećemo u različitim inačicama teorije odraza, i strogo imanentističkim koncepcijama: „Drugi se ne da misliti ni u terminima transcendencije ni u terminima imanencije. Iskustvo je za koje ne možemo biti zadovoljni reći da jezik samo izražava ili odražava, budući da se pojavljuje samo u prostoru i vremenu jezika.“ (Blanchot, 1992: [1969])

${ }^{239} \mathrm{Na}$ sličnu ambivalenciju, samo iz drugog rakursa, upućuje jednim svojim dijelom i Derridaov tekst Arhivska groznica [Archive Fever/Mal d' archive, 1995], upozoravajući da arhiv, s obzirom na dvoznačnost riječi arkhe, u sebi uvijek objedinjuje i „sekvencijalno“ i ,jusivno načelo“ (Derrida, 1995a: 9), načelo „prirodnog“ slijeda i načelo poretka. Međusobnu kontaminaciju te još jedne od inačica binarne opreke između physisa i nomosa, zajedno sa svim paradoksima koji izviru iz njezine neopstojnosti, arhiv uvijek nastoji prikriti, no ona se svejedno reflektira u svakom segmentu problematike arhiva koji Derrida uzima u fokus. Svaki arhiv, pa i onaj književni, tako se s jedne strane predstavlja kao mjesto (jednostavnog) sjećanja, pohrane, dok s druge strane implicira i aparaturu klasifikacije, unifikacije, identifikacije i uopće koordinacije korpusa, što Derrida označava konceptom konsignacije (isto: 10). Arhiv je tako privilegirano mjesto (proturječnog) križanja singularnosti svakog pojedinog zapisa i (kvazi)univerzalnosti zakona koji omogućuje njegov izbor i pohranu (usp. isto). Pitanje politike arhiva tako postaje pitanje politike par excellence (isto: 11), budući da $\mathrm{s}$ jedne strane njegova struktura determinira strukturu onoga što se uopće može smatrati događajem (isto: 18), dok s druge strane ima odgovornost prema budućnosti, s kojom ga veže odnos mesijanskog obećanja (isto: 28) i koja uvijek ima strukturu nepredvidivog, nespoznatljivog, nesvodivo drugog (isto: 47). Premda polje književnosti u Arhivskoj groznici nije pojedinačno apostrofirano, promišljanja o politici arhiva zbog svega se navedenog mogu čitati među ostalim i kao Derridaovo promišljanje o politici književnosti iz perspektive drukčije od uobičajene, one - rancièreovski rečeno - policije književnosti.
} 
sličnom Deleuzeovu na ono što je nazvao mikrofašizmima, odnosno na nužnost da se molekularnom per se ne pridaje pozitivna aksiološka ocjena i emancipatorna nota.

No činjenica da Derrida poklanja pozornost i ograničavajućim čimbenicima onoga što nazivamo političnošću književnosti ne umanjuje po tom pitanju poseban status književnosti u njegovu opusu, već svjedoči o nepovršnom promišljanju sposobnom preduhitriti eventualne prigovore na račun nekritičkog pridavanja herojske uloge i oblikovanja nove metafizičke binarne opreke na temeljima onih koje je prethodno dekonstruirao. Bez obzira na to, književnost je za Derridaa nedvojbeno iz te perspektive privilegiran diskurs koji na osobit način u prvi plan stavlja problematiku mesijanskog obećanja, iskustva radikalne drugosti, rastemeljujućeg rada diffërancea te uvijek već dolazeće jednakosti. Riječ je redom o tematskim čvorištima ključnim za promišljanje političkog u kasnijoj fazi Derridaova opusa, no dovedena na književnom polju u izravnu svezu s problematikom pisma, ona se pokazuju i kao neraskidive poveznice između njegovih ranijih i kasnijih radova.

Jednako tako, mesijansko obećanje emancipacije, iskustvo radikalne drugosti, aporična neodlučivost vakuuma između rastemeljenja i utemeljenja te demokracija što dolazi odreda su i temeljni topoi Sablasti Marxa, te kao takvi glavne točke onog dijela Marxova nasljeđa što ga Derrida afirmira. Presjek književnosti i politike, zona u kojoj do izražaja dolazi literarnost politike i političnost književnosti, za Derridaa dakle ujedno obuhvaća i oris Marxova duha, ,jednog od njegovih duhova“, jer „postoji više od jednog, mora postojati više od jednog.“ (Derrida, 2002b: 26) Tvrditi da je čitavo ispreplitanje literarnog i političkog u Derridaovu opusu dug tom duhu, izvedeno iz Marxova djela, bilo bi dakako ne samo suviše reduktivno nego i gruba faktografska pogreška. Ipak, određeni dug Derridaovih viđenja književnosti i politike prema Marxu nesumnjivo postoji, baš kao što se i poveznica između Derridaove razrade Marxove ostavštine te književnosti očito ne zaustavlja tek na sablasti Hamletova oca čije javljanje započinje provodnu nit Sablasti Marxa.

No dok sve autore kojima smo se do sada bavili povezuje - kako međusobno, tako i u odnosu na marksizam - afirmacija te emancipacijske dimenzije književnosti i Marxova nasljeđa, u nastavku ćemo se usredotočiti na teoretičara uz kojeg se ona glavninom ne veže kao prevladavajuća asocijacija - Michela Foucaulta. 


\subsection{Zanemareno literarno Michela Foucaulta}

Iako Goldstein (2005) u svojoj studiji o postmarksizmu Foucaulta (razmjerno nekritički) stavlja na povlašteno mjesto jednog od dvaju ,izvorišta“ tog teorijskog korpusa, a u postmarksistički kontekst smještaju ga i neki drugi autori, takvo određenje čini se teže opravdati u njegovu slučaju nego kod ranije razmatranih teoretičara. Svaki od njih, vidjeli smo, na Marxa i njegovo nasljeđe referira se (polemički, afirmativno ili, ponajviše, ambivalentno) kao na elemente utkane u svoj teorijski opus konstitutivnije nego je to slučaj kod Foucaulta, koji Marxa nigdje ne određuje presudnom referencijalnom točkom u izgradnji svoje teorijske pozicije. Nadalje, druga je primjetna razlika činjenica da je Foucault, nasuprot četvorici prethodnih autora koje se uvriježeno percipira kao mislioce emancipacije, u široj percepciji ostao zapamćen prvenstveno kao mislilac kontrole; teoretičar čiji je opus najvećim dijelom posvećen regulatornim shemama i mehanizmima što uvjetuju reprodukciju diskursa, znanja i moći u različitim historijskim fazama Zapada.

Uključujući Foucaulta i u ovo problematiziranje postmarksističkog korpusa, u poglavlju što slijedi pokušat ćemo dovesti u pitanje te razlike, i to iz više aspekata. Ne samo da ćemo, poput ranijih studija o postmarksizmu, nastojati ukazati na njegove veze s Marxom i marksističkim nasljeđem, već odmjeravajući Foucaultov opus o pitanja koja smo postavili i u odnosu na prethodne autore namjeravamo premostiti i drugospomenutu komponentu razlike. Pritom, kao i ranije, cilj neće biti nekritička redukcija singularnosti svakog od teoretičara, već praćenje određenih provodnih niti koje vežu različite teoretičare i mimo kategorija u koje su uobičajeno smještani, osvjetljujući tako i neke manje primjećivane poveznice i aspekte njihova rada. $\mathrm{S}$ obzirom na njegov golem utjecaj u različitim društvenim i humanističkim disciplinama, koji nadmašuje doseg pojedinačnog utjecaja bilo kojeg od prethodno analiziranih teoretičara, u slučaju Foucaulta to se tkanje poveznica još i manje nego u ranijim poglavljima zaustavlja samo na autoru kao pojedincu i njegovu opusu, šireći se metonimijski raznovrsnim diskurzivnim poljima. Konačno, veliku ulogu u pomaku perspektive odigrat će upravo - u recepciji Foucaulta pretežno zanemarivana - književnost.

U motu prvog poglavlja svoje monografske studije o Foucaultu Merquior (1985: 11) bilježi njegovu izjavu: „Nikada nisam bio frojdovac, nikada nisam bio marksist i nikada nisam bio strukturalist.“ Premda bi se o svakom od segmenata te ograde moglo raspravljati, $u$ ovom trenutku primarno nam je $u$ fokusu drugi. Smatrao on retrospektivno svoju poziciju $u$ 
danom trenutku doista marksističkom ili ne ${ }^{240}$, Foucaulta se u najranijem stadiju njegove karijere unatoč toj tvrdnji ipak nedvojbeno imalo zbog čega povezivati s marksističkim supstratom, premda je riječ o vezama koje nisu mnogo potrajale. Osim akademskih poveznica s Althusserom ${ }^{241}$ i kratkotrajnog članstva u francuskoj komunističkoj partiji, Choat (2010: 94) podcrtava da se i Foucaultova rana studija Duševne bolesti i osobnost [Maladie mentale et personnalité, 1954.] obilno oslanjala na marksistički konceptualni aparat, „naglašavajući važnost ekonomskih proturječja i klasne borbe ${ }^{\text {‘242. }}$. U drugom izdanju studija je objavljena prerađena, s uklonjenim marksističkim referencama, baš kao što se i njegova politička podrška partiji s vremenom posve slomila u raspravi o pitanju gulaga (usp. Foucault, 1980: $134)^{243}$

No najeksplicitniji polemički istup u odnosu na Marxa na teorijskom je polju Foucault učinio u Riječima i stvarima [Les mots et les choses, 1966]; upravo se ta referenca najčešće izvlači kao potkrjepa njegove sukobljenosti s marksizmom ${ }^{244}$. U toj studiji, naime, ključan doprinos oblikovanju političke ekonomije - koju smatra jednom od triju glavnih sastavnica moderne episteme nastale krajem osamnaestog stoljeća - pripisuje Ricardu, dok za marksizam tvrdi da ,/n/a dubokoj razini zapadnoga znanja (...) nije uveo nikakav zbiljski prekid“. Drugim riječima, marksizam je po njemu ,u misli XIX. stoljeća kao riba u vodi, odnosno on na svakomu drugom mjestu prestaje disati“, a sudare marksističke i buržujske ekonomske misli XIX. stoljeća naziva „olujama u bazenima za djecu“ (Foucault, 2002: 285).

\footnotetext{
${ }^{240}$ Choat (2010: 101) o toj temi piše: „Kao prvo, Foucault sebe ne želi označiti marksistom ili nemarksistom, te tako tretirati Marxovo djelo kao nekakav veliki sistem s kojim je nužno slagati se ili ga odbaciti. Naprotiv, Marxa tretira kao proizvođača kutije alatki koje će se pokazati korisnima samo ako njegovo 'teorijsko jedinstvo na neki način stavimo u stanje neizvjesnosti, ili barem ograničimo, podijelimo, zbacimo, karikiramo, učinimo teatralnim ili kako već želite...'“ Cjelovit citat koji Choat navodi usp. u Foucault, 1980: 81, a tiče se - zanimljivo je primijetiti - ne samo Marxa, nego i Freuda. U svakom slučaju, iz više je Foucaultovih intervjua razvidno da Sheridan (1980: 4), čiji citat preuzima i Sim (2000: 105) nije u pravu dajući općenitu ocjenu da je Foucault Marxa uzimao prvenstveno kao historijsku ličnost zatvorenu u svoje vrijeme i njegovu epistemu, implicirajući time izostanak njegove relevantnosti za suvremenu teoriju.

Choat (2010: 113) zanimljivo napominje da se Foucaultva poveznica s Marxom objavljuje između redaka, vrlo rijetko u izravnim citatima, no istovremeno daje sliku mnogo bližu marksističkoj nego kod drugih bliskih autora. Time bi Foucault zapravo što se odnosa prema Marxu tiče bio čista inverzija svog suvremenika i prijatelja Deleuzea koji, vidjeli smo, u jednoj fazi svog rada Marxa obilno citira, no pritom te citate i parafraze ugrađuje u teorijski kontekst vrlo dalek od tradicionalnog marksizma.

${ }^{241}$ U jednom intervjuu Foucualt izjavljuje: „Budući da sam bio Althusserov student i da mu mnogo dugujem, moguće je da imam tendenciju pripisivati mu u zaslugu i stvari koje bi on sam preispitivao..." (Foucault, 1998: 281)

${ }^{242}$ Usp. i During, 1992: 26.

${ }^{243}$ Usp. na sličnom tragu i citat koji donosi Choat (2010: 100/186), u kojem Foucault (2005: 185) razdvaja i pozitivno vrednuje marksističku misao, dok kritizira političke sustave koji su iz nje proizašli: „Drugo je bolno iskustvo ono koje nije nastalo između filozofa i buržujskog društva, već između revolucionarnih mislilaca i socijalističkih država kakve danas poznajemo. Iz Marxovih vizija, vizija socijalista, iz njihovih misli i analiza, koje su među najobjektivnijim, najracionalnijim i naizgled najpreciznijim mislima i analizama, izrasli su u sadašnjosti politički sistemi, društvene organizacije i ekonomski mehanizmi koji se danas osuđuju i valja ih odbaciti.“

${ }^{244}$ Usp. npr. Sim, 2000: 106.
} 
Ipak, Foucault u studijama koje su uslijedile bitno revidira takav stav prema Marxovim historijsko-epistemološkim dosezima. Već Arheologija znanja [ $L^{\prime}$ Archéologie du Savoir, 1969] na istu temu odmjerava isti par teoretičara, Ricarda i Marxa, no u ovom slučaju Foucault (2010a: 176) dvojac koristi kao primjer promjene koja nastaje „,među diskurzivnim formacijama koje su vrlo bliske i povezane mnogim vezama“, označavajući tako Marxa kao predstavnika važne diskurzivne prekretnice. U poznatom predavanju Što je autor? [Qu'est-ce qu'un auteur?, 1969], koje je održao iste godine, Marxova je prijelomna uloga dodatno naglašena i elaborirana time što mu Foucault dodjeljuje ulogu začetnika diskurzivnosti, onoga koji proizvodi mnogo više od vlastitih djela, koji stvara „mogućnosti i pravila za formaciju drugih tekstova“, odnosno „utemeljuje beskonačnu mogućnost diskursa.“ (Foucault, 1998: 217) Na sličnom ga je tragu još ranije u kratkom tekstu Nietzsche, Freud, Marx [1964], uz drugu dvojicu naslovnih autora, označio ključnim predstavnikom radikalnog preoblikovanja moderne hermeneutike: „devetnaesto stoljeće, točnije pojedinačno Marx, Nietzsche i Freud dovode nas ponovno do prisutnosti novih mogućnosti interpretacije. Utemeljuju iznova mogućnost hermeneutike.“ (Foucault, 1990: 61) ${ }^{245}$

U studijama što su uslijedile pak Foucaultov dijalog s marksizmom najvećim se dijelom tiče odnosa diskursa i njegove nediskurzivne okoline (za koju mu raste interes u tzv. genealoškoj fazi), šireg historijskog konteksta, poprima implicitnu narav te postaje ambivalentan. Navedimo tek neke primjere iz najpoznatijih studija. Već pri početku Arheologije znanja Foucault (2010a: 43), bez izravnog imenovanja referenata u suprotnosti s kojima afirmira svoju metodu, ukazuje na podjednaku nedostatnost objašnjenja povremenih pojava novih objekata znanja (u npr. 19. st.) i u okvirima tradicionalne historije ideja i u marksističkoj paradigmi. Za prvu smatra karakterističnim uvjerenje da su ideje rezultat ulančavanja novih otkrića i njihovog analoškog uklapanja u postojeće sheme znanja, a za potonju različitih izvanjskih promjena bilo u bazi ili nadgradnji društva u istom historijskom momentu. Istovremeno Foucault (isto: 67-68) ističe da je jedna od važnih odrednica teorijskih izbora koji se ostvare u nekom diskursu „funkcija koju diskurs što ga proučavamo mora obavljati u polju nediskurzivne prakse“, baš kao i „pravila i procesi prisvajanja diskursa“ (isto: 68).

U kasnijem predavanju naslovljenom Poredak diskursa [L' ordre du discours, 1971] Foucault problematiziranju društvenog prisvajanja diskursa daje dodatnu, otvoreniju

\footnotetext{
${ }^{245}$ Usp. s tezom iz Arheologije znanja da su konzervativne silnice, zalažući se za tendencije kontinuiteta, kroz devetnaesto stoljeće nastojale očuvati antropologiju i humanizam nasuprot decentrirajućeg djelovanja koje metonimijski oprimjeruje upravo Marxom i Nietzscheom (v. Foucault, 2010: 12-13).
} 
marksističku komponentu upozoravajući da društveno prisvajanje diskursa rascjepima „u svojoj distribuciji, u onome što dopušta i u onome što sprečava, slijedi pravce koji su označeni socijalnim distancama, suprotnostima i borbama. Cijeli je sistem obrazovanja politički način da se zadrži ili promijeni prisvajanje diskursa, zajedno sa znanjima i moćima što ih oni sa sobom nose.“ (Foucault, 1994: 129) Vrijedi pritom imati na umu da je to predavanje jedno od ranijih poprišta usmjeravanja njegova interesa prema odnosima između moći i diskursa, glede kojih vrlo eksplicitno naglašava da diskurs ne smatra onim „što izražava borbe i sisteme vladavine“, već onim „zbog čega i pomoću čega se vodi borba, moć koje se valja dočepati.“ (isto: 117)

Vrlo slično već i u Arheologiji znanja, kako bi izbjegao simplifikacije tog međuodnosa u pravcu mehaničkog preslikavanja, vrlo jasno upozorava da se različite diskurzivne strategije, izbori i jedinstva ili transformacije elemenata ne mogu promatrati kao puki ,izraz nekog svjetonazora skovan u oblik riječi“, ili ,licemjerni prijevod nekog interesa što se skriva iza maske teorijskog preteksta“" (Foucault, 2010a: 69), da ne izrastaju iz neke pretpostojeće pozitivnosti kao iz sjemenke (isto: 70), odnosno da arheološka analiza kakvu sugerira „suspendira teme izraza i refleksije, odbija u diskursu gledati površinu simboličke projekcije događaja ili procesa koji su situirani negdje drugdje“. No ona to čini ne da bi takvu perspektivu zamijenila bilo kontinuiranom sekvencom koja povezuje „neko otkriće i događaj, ili koncept i društvenu strukturu“, niti da bi „garantirala suverenu, samotnu nezavisnost diskursa“, već da bi „otkrila domenu postojanja i funkcioniranja diskurzivne prakse“; „cjelovitu domenu institucija, ekonomskih procesa i društvenih relacija na kojima se diskurzivna formacija može artikulirati““, s naglaskom na to da njezina autonomija i specifičnost nikada ne postaju čista idealnost i potpuna neovisnost o historiji (isto: 164).

Konačno, analizirajući različite pragove pozitiviteta koje određena diskurzivna formacija može proći, Foucault (2010a: 185) naglašava da se pitanje odnosa znanosti i ideologije, osobito važno iz marksističke perspektive, može postaviti „tamo gdje se znanost artikulira na temelju znanja“, a ne na razini neke idealne strukture, tehničke uporabe u društvu ili svijesti subjekta, kritizirajući time - iako i dalje posve implicitno - Althusserovu opreku (marksističke) znanosti i ideologije, odnosno proširujući svoju kritiku marksizma na epistemološkom polju s grubog mehaničkog ekonomizma kakav mu se stereotipno pripisuje i na njegovu althusserijansku varijantu. Kako pojašnjava:

Općenito govoreći, i ostavljajući po strani sva posredovanja i specifičnosti, može se reći da politička ekonomija (...) služi interesu buržujske klase, da je napravljena od te klase i za tu klasu te da u svojoj logičkoj arhitekturi i konceptima nosi trag tog porijekla; no bilo kakav 
precizniji opis odnosa između epistemološke strukture političke ekonomije i ideološke funkcije mora u obzir uzeti analizu diskurzivnog oblikovanja koje je omogućilo dolazak do nje, te grupu objekata, koncepata i teorijskih izbora koje je bilo nužno razviti i sistematizirati; također nužno je pokazati kako je diskurzivna praksa koja je stvorila takvu pozitivnost funkcionirala među drugim praksama koje mogu biti diskurzivnog, ali i političkog ili ekonomskog reda. (Foucault, 2010a: 186)

Implementirajući te općenite postavke u kasnijim konkretnim genealoškim studijama, Foucault konstantno oscilira između dva pola. Primarno se, naime, uvijek bavi genealoškim istraživanjem diskursa, no kako ono uključuje i odnose prema izvandiskurzivnoj okolini, s jedne strane opetovano podcrtava tu činjenicu, nastojeći preduhitriti prigovore za idealizam i autistični pantekstualizam, dok se s druge strane kritički ograđuje od reduktivnodeterminističkog pristupa i usidravanja svega u ekonomskoj bazi i pripovijesti o klasnoj borbi.

Tako primjerice u Nadzoru i kazni [Surveiller et Punir: Naissance de la prison, 1975] već na početku studije započinje razrađivati svoj specifičan koncept moći odmjeravajući ga o (ponovno neimenovanu) marksističku pozadinu, navodeći da se „moć upotrebljava, a ne posjeduje; nije 'privilegija', stečena ili sačuvana, dominantne klase, nego sveukupni učinak njezinih strateških pozicija - učinak koji se manifestira i ponekad širi pozicijom onih koji su podložni.“ (Foucault, 1995: 26) Zbog toga ti odnosi sežu „u dubine društva“, umjesto da se zaustavljaju na „odnosima između građana i države“ ili „na granici između klasa“ (isto), te nisu analoške ili homološke projekcije s viših razina na niže, niti jednoznačni sukobi dvaju tabora. S druge strane, nakon takvog određenja moći koje točku po točku polemizira s pojedinim marksističkim postavkama, Foucault se ne libi ni podcrtati uvide koji se čine karakterističnim za marksističku perspektivu, zapažajući povezanost transformacije pravnog aparata $\mathrm{s}$ transformacijom oblika vlasništva i kapitala (isto: 86), klasnu pozadinu diskriminacije različitih ilegaliteta te različitog tretiranja prijestupa koji se tiču vlasništva i prijestupa koji se tiču prava (isto: 87), povezanost discipline tijela i njegove povećane ekonomske efikasnosti (isto: 138, 218) i brže akumulacije kapitala (isto: 220), klasno profiliranje zločina pri oblikovanju delinkvencije i korpusa znanja o njoj (isto: 275), kao i korelaciju nadzora kao središnjeg elementa disciplinarne moći s nadzorom kao ključnim ekonomskim operatorom u novom tipu proizvodnje (pri čemu čak i izravno citira Marxa; usp. isto: 175).

Aporija kauzaliteta, situacija kokoši i jajeta, javlja se tako na sličan način kao i dva desetljeća kasnije kod Rancièrea u slučaju njegova međuuvjetovanja estetičkog režima umjetnosti i društvenih fenomena u njegovoj pozadini. Ekonomski uzlet Zapada, posljedična akumulacija kapitala, akumulacija ljudi i tehnike efikasnog upravljanja i osiguravanja 
podložnosti međuovisni su faktori među kojim Foucault ne izdvaja središnju točku: „svaki čini druge mogućima i nužnima; svaki osigurava model drugima.“ (Foucault, 1995: 221) No konkretna proučavana artikulacija ipak je posve kontingentna; ,rast kapitalističke ekonomije omogućio je nastanak specifičnih modaliteta disciplinarne moći, čije su opće formule, tehnike činjenja podložnim sila i tijela, ukratko 'politička anatomija', mogli djelovati u najrazličitijim političkim režimima, aparatima ili institucijama.“ (isto: 221)

Slične dvojnosti lako je uočiti i u prvom svesku Povijesti seksualnosti [Histoire de la sexualité, 1976] u kojem Foucault nastavlja s elaboracijom odnosa između znanja i moći te razvojem svojih promišljanja o kapilarnosti moći i biopolitici, započetih u prethodnim studijama. Poznato opovrgavanje onoga što naziva „represivnom hipotezom“ (Foucault, 2013: 14) - da je buržujsko društvo od osamnaestog do polovice dvadesetog stoljeća potiskivalo diskurs o seksualnosti - primjetnim dijelom gradi na implicitnoj raspravi s marksističkom perspektivom na tu problematiku. Kako tvrdi, diskurs što povezuje represiju seksa s razvojem kapitalizma dobro se drži „,b/ez sumnje i zato jer ga je lako držati“ (isto: 11), budući da povijest seksa ,pretvara u uštogljenu povijest proizvodnih oblika; nestaje njegova beskorisnost“ (isto), dok njegovu emancipaciju legitimno „nadovezuje na časni politički probitak: i seks je također dio budućnosti.“ (isto)

$\mathrm{Na}$ tragu te sumnjičavosti prema suviše jednostavnim objašnjenjima (faktografski upitne) represije, pretežno oslonjenim na vid mehaničkog preslikavanja i usidrenja u fenomene ekonomske baze, Foucault odbacuje teze o seksualnoj represiji kao posljedici „općeg i intenzivnog uvođenja u radni odnos“ (Foucault, 2013: 11) zbog kojeg je trebalo ograničiti neproduktivne užitke, ili pak o tome da je izbacivala oblike „seksualnosti koji nisu podređeni strogoj ekonomiji razmnožavanja“ (isto: 35 ) radi što efikasnije reprodukcije radne snage. Jednako tako odbacuje i tezu o svođenju seksualnosti u promatranom razdoblju na „monogamnu i bračnu ćeliju“ (isto: 43) obitelji 19. st., upozoravajući na složene mehanizme odjeljivanja i klasifikacije u tadašnjem dispozitivu seksualnosti koji tome proturječe. Zaključujući sveukupno da se „hipoteza o represivnoj moći, koju bi naše društvo vršilo nad seksom i zbog ekonomije, čini vrlo tanka“" (isto: 64), Foucault u pozadini nje polemizira s Engelsovim tezama još iz Porijekla porodice, privatnog vlasništva $i$ države, a potom i s ostatkom marksističkih interpretacija na njegovu tragu. No istovremeno zaključujući da umjesto preuveličavanja represivnih mehanizama valja istraživanje usmjeriti historijskom istraživanju pozitivnih mehanizama; „fine mreže diskursa, znanja, zadovoljstava, moći“, procesa koji seks „,raspršuju po površini stvari i tijela, nadražuju ga, očituju ga i navode da govori, usađuju u zbilju i nalažu mu da kaže istinu“ (isto), taj istraživački put naziva 
osnutkom „'političke ekonomije' volje za znanjem“ (isto: 65), izravno time aludirajući na Marxa.

Ipak, iako Foucault (2013: 111) ironično poziva neka mu „oproste oni za koje buržoazija označava zaobilaženje tijela i potiskivanje seksualnosti, oni za koje klasna borba podrazumijeva bitku za uklanjanje tog potiskivanja“, dodajući da ,'spontana filozofija' buržoazije nije međutim tako idealistična ni kastracijska“, istodobno pak ne negira da je organizacija dispozitiva seksualnosti povezana s ekonomskom dimenzijom. Tako npr. različite stupnjeve postupne hegemonijske univerzalizacije buržujske seksualnosti dovodi u izravnu svezu s relacijama prema onodobnom proletarijatu i promjenama uvjeta u kojima je živio (pri čemu se ponovno referira i na Marxa; usp. isto: 112), kao što i dvije različite inačice tog dispozitiva veže s razlikama između društvenih, primarno ekonomskih, karakteristika ranog i kasnog kapitalizma (isto: 101-102). Zaključak je stoga ponovno ambivalentna međuodređenost: „,bio-moć“ izgrađena na dispozitivu seksualnosti bila je jedan od najvažnijih elemenata za razvoj kapitalizma (Foucault, 2013: 123) utoliko što je omogućila kontrolirano uključivanje tijela u proizvodni aparat te njihovu prilagodbu ekonomskim procesima, ali se i sama razvila u njihovim okvirima ${ }^{246}$, isprepletena u međusobnom rastu i jačanju.

Razlog zbog kojeg smo ovoj problematici posvetili toliko prostora jest činjenica da se upravo u Foucaultovu minucioznom historiziranju često tražila poveznica s Marxom drukčija od one apostrofirane kod njegovih suvremenika ili pak sljedeće generacije bivših Althusserovih učenika. Dobar je primjer Miščevićeva (1975: 182) teza da u Foucaultovu arheološkom istraživanju, u opreci spram ranijih teorija izraza ili uvjetovanja zastupljenih u marksizmu, valja prepoznati postupak koji je „u mnogome prekretnica u konstruiranju materijalističke teorije diskursa“. Identična je i Choatova (2010: 102) tvrdnja da Foucaultova kritika svojim genealoškim pristupom nije htjela „potkopati Marxa, već odvesti njegov materijalizam još dalje“, a Foucaultov opis vlastitog historijskog istraživanja smatra potpuno primjenjivim i na Marxovo djelo (isto: 94).

Tome svako treba pridružiti i Foucaultovu valorizaciju Marxova značaja za istraživanje historije, prikladno sublimiranu u njegovoj konstataciji da ,je moguće zapitati se koje razlike uopće može biti između bivanja historičarom i bivanja marksistom“ (Foucault, 1980: 53), odnosno da je termin „marksistički historičar“ pleonaza. Tu tvrdnju doduše odmah

\footnotetext{
${ }^{246}$ Foucault (2013: 123) jasno naglašava da se povezivanje dviju temeljnih komponenti onoga što smatra biomoći koja prevladava od devetnaestog stoljeća - discipline te kontrole populacije - nije dogodilo „na razini spekulativnog diskursa, nego u obliku konkretnih ustrojstava koji će tvoriti veliku tehnologiju vlasti u XIX. stoljeću“, naglašavajući materijalnost diskursa te „opipljivost“ mjesta susreta diskurzivnih i nediskurzivnih praksi.
} 
potom modificira pozivom na polemiku s marksistima unutar tako postavljenog horizonta, budući da „oni igraju igru čija pravila nisu marksistička, nego komunističkološka, koje postavljaju komunističke partije određujući kako se morate koristiti Marxom da bi vas proglasili marksistom.“ (isto: 53) Unatoč toj ogradi na drugom mjestu Foucault (1998: 281) ne ostaje na pohvali tek Marxovu promišljanju historije, već je širi i na jednog konkretnog marksista, hvaleći „doista izvanrednu kritiku i analizu koncepta historije što je razvija Louis Althusser na početku svog Kako čitati Kapital“. Time se ambivalencija odnosa prema marksizmu potvrđuje i na prijmjeru Althussera: s jedne strane imamo kritički odnos prema njegovoj teoriji ideologije i determinaciji ekonomskim u krajnjoj instanci, a s druge strane iznimnu valorizaciju ideje besubjektne historije.

No takvoj perspektivi valja dodati napomenu da Foucaultova opetovana ambivalentnost pri historijskoj kontekstualizaciji i uspostavljanju (prije svega kauzalnohijerarhijskih) odnosa između diskursa koje proučava i izvandiskurzivne stvarnosti istovremeno funkcionira i kao poveznica s prethodno analiziranim autorima, a ne samo kao razlikovni element. Možda se radi o oprečnim omjerima raspoređivanja istraživačkih naglasaka, ili dvjema stranama novčića, no nastojanje da se s jedne strane ne zapadne u autistični tekstni imanentizam, a s druge izbjegne ekonomski determinizam i vulgarni historizam nesumnjivo im je zajedničko. Drugim riječima, ako je osobita pozornost prema povezanosti diskursa s fenomenima što ih tradicionalna marksistička shema društva smješta $u$ bazu ono što Foucaulta povezuje s marksizmom, uočavanje ograničenja tih odnosa i njihovo višesmjerno usložnjavanje te priznavanje relativne autonomije različitih domena ono je što ga na istom mjestu razlikuje od klasičnog marksizma i približava uobičajenim odrednicama postmarksističkog korpusa.

U konačnici, iako se može činiti samorazumljivim, vrijedi podsjetiti, kako to čine Brlek i Koludrović (2015: 2), da se Foucault primarno ,zanima diskurzivnim praksama kažnjavanja, zatvaranja, mučenja, liječenja, ispovijedanja, parezije, pisanja, čitanja, hranjenja, spolnog općenja i drugih pojava povijesne svakodnevnice - a ne samim tim pojavama. Zanimao ga je, da ponešto pojednostavimo, tekst kojim se uspostavlja kontekst a ne kontekst kojim se uspostavlja tekst. “247

Dapače, ne samo da se Foucault (primarno) bavio diskurzivnim praksama, nego i u trenucima u kojima progovara o izvandiskurzivnim fenomenima, možemo zapaziti kako ih

\footnotetext{
${ }^{247}$ Usp. iz te perspektive Faubionovu (1998: xxxvii) primjedbu na kasnije Foucaultovo zanimanje za i afirmaciju Veyneova historiografskog nominalizma što također govori u prilog „tekstualnijoj“ verziji Foucaulta: „Pomalo je neobično da je Foucault, koji je tako zajedljivo prigovarao Jacquesu Derridau na ekscesivnoj 'tekstualizaciji diskurzivne prakse', mogao svim srcem prihvatiti Veyneov vlastiti tekstualni tretman historijske činjenice.“
} 
opisuje u terminima gotovo identičnim onima kojima opisuje diskurse. Primjerice, govoreći u Nadzoru i kazni o tijelima u domeni panopticizma kao dijametralnoj inverziji nekadašnjeg tijela suverena, navodi da je prvospomenuta ,područje nepravilnih tijela, s njihovim detaljima, mnogostrukim kretanjima, heterogenim silama, prostornim odnosima“, zbog čega proučavatelj treba „mehanizme koji analiziraju distribuciju, praznine, serije, kombinacije te upotrebljavaju instrumente koji čine vidljivima, bilježe, diferenciraju i uspoređuju: fiziku relacijske i mnogostruke moći, koja svoj maksimum intenziteta ne postiže u osobi kralja, nego tijelima koja se mogu individualizirati tim odnosima.“" (Foucault, 1995: 208) Slično tako u Povijesti seksualnosti odbacuje "izostavljanje tijela, anatomije, biološkog, funkcionalnog" iz analize seksualnosti kao „političkog dispozitiva“, te poziva na analizu u kojoj to dvoje čini nediskretni splet: analizu „u kojoj biološko i povijesno ne bi dolazilo jedno za drugim, kao u evolucionizmu starijih sociologa, nego bi se povezivali prema rastućoj složenosti srazmjerno razvoju modernih tehnologija vlasti koje za predmet uzimaju život.“ (isto, 2013: 132) U ranijoj Arheologiji znanja Foucault (2010a: 76) pak podcrtava i kako valja shvatiti preddiskurzivno: „U pozadini zaokruženih sustava analiza diskurzivnih formacija ne otkriva bujajuće izvore života samog, život u još neuhvaćenom stanju; ona pronalazi neizmjernu gustoću sistematičnosti, zbijen skup mnogostrukih odnosa. Nadalje, iako ti odnosi ne pripadaju samoj mreži teksta - oni svojom prirodom nisu ni strani diskursu. Zasigurno bi se mogli okarakterizirati kao 'preddiskurzivni', no samo ako se prizna da je to preddiskurzivno još uvijek diskurzivno“, a ne neka prisutnost koja se a posteriori transkribira u diskurs. ${ }^{248}$

Ako je pak izvandiskurzivno (makar $\mathrm{u}$ istraživačkom zahvaćanju) ustrojeno poput diskursa, te ako ispod diskursa pronalazimo samo mjesta presijecanja drugih diskursa, tada Foucaultov pristup u svakom slučaju nije tako oštro suprotstavljen teorijskim pozicijama koje u primarnom fokusu imaju neki oblik tkanja opće tekstualnosti, kako se to isprva može činiti, te bi se također mogao okarakterizirati postfundacijskim, budući da - prisjetimo se - „u odsutnosti središta ili podrijetla, sve postaje diskurs“ (Derrida, 2007: 299) i obrnuto. A velik dio Foucaultova opusa ne samo da karakterizira odbacivanje središta, već se ono nerijetko događa $\mathrm{u}$ ambivalentnom odnosu prema nasuprotno pozicioniranim doktrinama tradicionalnog marksizma (poput ekonomizma ili klasizma).

\footnotetext{
${ }^{248} \mathrm{~S}$ te strane čini se u potpunosti opravdanom primjedba Laclaua i Mouffe (2014: 93) da je Foucaultov pokušaj razlikovanja diskurzivnog i nediskurzivnog i/ili preddiskurzivnog diskutabilan i u najmanju ruku nekonzistentan. Također, valja opaziti sličnosti između preddiskurzivnog kako je definirano u Arheologiji znanja te polja diskurzivnosti kod Laclaua i Mouffe (usp. Laclau, Mouffe; 2014: 98), što ga povezuje i s problematikom neiskorjenjivog viška značenja.
} 
Već u Riječima i stvarima tema odsutnosti središta javlja se s Foucaultovom analizom moderne episteme, u koju smješta i marksizam, te u čiju poznu fazu stavlja svoje/naše doba, i upravo toj tematici pripada i vjerojatno najpoznatija pojedinačna teza te studije - o čovjeku kao recentnom izumu koji se već bliži svome kraju (usp. Foucault, 2002: 333). Čovjek je, namjesto klasicističke tablice reprezentacije, onaj koji u modernoj epistemi koordinira $\mathrm{i}$ organizira različite discipline. No pritom je u paradoksalnom položaju i subjekta i objekta, položaju koji se s vremenom pokazuje preprekom što se ne može nadići, koja središte čini neuhvatljivim i dovodi do toga da se, u korist otvorenosti mišljenja, antropološki poredak „pred našim očima uporno razbija budući da u njemu u isto vrijeme počinjemo prepoznavati, na neki kritički način optuživati, i zaborav otvora koji ga je učinio mogućim i tvrdoglavu prepreku koja se uporno suprotstavlja sljedećoj misli.““ (isto: 368)

Zaborav i otvor, „praznina nestalog čovjeka“ (Foucault, 2002: 368), nisu jedine sličnosti s različitim figurama odsutnog središta i njihovim tretmanom kod ranije analiziranih teoretičara. Foucault naime izdvaja historiju i nesvjesno kao dva lica, ali i dva ograničenja dovršenosti (isto: 398) što su se ispriječila pred svakom od disciplina što ih naziva humanističkim znanostima ${ }^{249}$, te na tom tragu i dvije povlaštene ,protudiscipline“ psihoanalizu u odnosu na nesvjesno i etnologiju u odnosu na historijske kulturne kodove. „O objema bismo mogli reći“, smatra Foucault (isto), „ono što je Lévi-Strauss govorio o etnologiji: one uništavaju čovjeka. Ne zato što se radi o tome da se pronađe bolji čovjek, čistiji i kao oslobođen, već zato što se one vraćaju onome što podbada njegovu pozitivnost.“ Na okomito sjecište psihoanalize i etnologije, značenjskog lanca za artikulaciju singularnog iskustva pojedinca i formalnog sustava za konstituciju značenja kulture, Foucault (isto: 407) pak smješta lingvistiku, kao ,znanost koja je savršeno utemeljena u poretku pozitivnosti koje su izvanjske čovjeku (budući da se radi o čistom jeziku)“ i koja će osigurati zatvaranje pitanja dovršenosti.

Ostavimo li po strani Foucaultovo nastojanje da zatvori uredne i zaokružene strukture karakteristično za njegovu (uvjetno rečeno) strukturalističku fazu, što će je polako napuštati nakon Riječi i stvari, u citiranom se odlomku može primijetiti anticipacija i stanovita paralela kasnijeg Laclauova pozicioniranja analize diskursa na usporedivo raskrižje. No dok je Laclauova analiza diskursa potom desetljećima kasnije okarakterizirana kao retorika, Foucault

${ }^{249}$ Za bolji uvid u to što Foucualt smatra humanističkim znanostima usp. Foucault, 2002: 370 et passim. 
je u svojoj ranijoj fazi još smatra „neutralnom“ općom lingvistikom, prije negoli u kasnijim studijama fokus prebaci na dinamičnije konstelacije diskursa i moći ${ }^{250}$.

U poopćenoj teoretizaciji analize diskursa koju donosi Arheologija znanja Foucault je glede odsutnosti izvora/središta još jasniji. Već pri samom početku navodi da svako traganje za „tajnim iskonom - toliko trajnim i fundamentalnim da ga se nikada ne može uhvatiti po sebi“ vodi kroz „naivnost kronologija prema točki što se uvijek povlači i nikada nije prisutna ni u jednoj historiji; točki koja je samo vlastita praznina; i počevši od nje nijedan početak ne može biti ništa drugo do li ponovno započinjanje ili prikrivanje ( $i$ jedno $i$ drugo u istoj gesti).“ (Foucault, 2010a: 25) Pravila oblikovanja diskursa kojima se studija bavi ne počivaju koncentrirana u takvoj jednoj bezvremenoj točki iskona „na temelju koje se događaji stvarne historije trebaju samo odviti u nužnom pravcu“, no jednako tako nisu sadržana ni u nekom drugom izvanjskom temelju; ljudskim mislima ili određenju na razini institucija ili društvenih i ekonomskih odnosa (isto: 74).

Izravna je posljedica toga i dobro poznato Foucaultovo strogo relacijsko određenje diskursa te orijentacija na tvrdnju kao njegovu temeljnu jedinicu, čijom analizom „ne nastoji ponovno otkriti izgubljeni totalitet ili oživjeti, ma kako bi to mnogi nostalgično željeli učiniti, obilje živog govora, bogatstvo Riječi, duboko jedinstvo Logosa“ (Foucault, 2010a: 108), niti se ta analiza može svesti na ,jedinstva opisana gramatikom ili logikom“ kao dubokim generativnim principom, već na „određenje uvjeta u kojima funkcija koja seriji znakova (...) osigurava postojanje može djelovati.“ (isto) Drugim riječima:

Opisati skupinu tvrdnji ne kao zatvoren, punokrvan totalitet značenja, već kao nedovršenu, fragmentiranu figuru; opisati skupinu tvrdnji ne referirajući se na interioritet intencije, misao ili subjekt, već u skladu s disperzijom eksterioriteta; opisati skupinu tvrdnji ne kako bi se otkrilo trenutak ili trag njihovog iskona, već specifične oblike akumulacije, sasvim sigurno ne znači ponuditi neku interpretaciju, otkriti neki temelj ili osloboditi neke konstitutivne činove, niti to znači odlučiti se za neku racionalnost ili prihvatiti neku teleologiju. (Foucault, 2010a: 125)

Pritom primjetan pomak u odnosu na situaciju u Riječima i stvarima predstavlja činjenica da Foucault više pozornosti posvećuje konfliktima i proturječjima unutar diskursa.

\footnotetext{
${ }^{250}$ Druga poveznica koju je zanimljivo uočiti jest i ona koja preko etnologije i Lévi-Straussa vodi do Derridaa $\mathrm{i}$ njegova teksta Struktura, znak i igra u diskursu humanističkih znanosti, već više puta citiranog u ovom radu. U tom tekstu, nastalom u gotovo isto vrijeme, i Derrida etnologiji, s Lévi-Straussom kao predstavnikom, povjerava privilegiranu ulogu discipline na poseban način povezane s otkrivanjem odsutnosti središta (usp. Derrida, 2007: 300), te podsjeća na Lévi-Straussovu tvrdnju da bi raspodjelu viška značenja nastalog uslijed odsutnosti središta trebali proučavati etnolozi i lingvisti (isto: 308). Psihoanalizu pak u vezu s istom problematikom dovodi nešto ranije u tekstu, navodeći Freuda kao jednog od reprezentativnih „uništavatelja“ metafizike prisutnosti (isto: 300).
} 
Kako navodi, „diskurzivna formacija nije (...) idealan, kontinuiran, glatki tekst što teče ispod mnoštva kontradikcija i razrješava ih u mirnom jedinstvu koherentne misli; niti je površina na kojoj se na tisuću različitih načina odražava jedno proturječje koje uvijek izmiče, ali je svugdje dominantno. To je prije prostor brojnih nesporazuma; set različitih opozicija čije se razine i uloge moraju opisati.“ (Foucault, 2010a: 155) Utoliko odbacuje i koncept jedinstvenih prijelomnih točaka i jedinstvenu dinamiku razvoja i transformacija svih diskurzivnih formacija u nekom razdoblju u korist višeglasnije i dinamičnije slike (isto: 175), što je pak u izravnoj svezi s napuštanjem ideje konzistentne i zaokružene episteme iz Riječi $i$ stvari u korist bitno drukčijeg historijskog a priorija. Nasuprot tradicionalne figure formalnog $a$ priorija, historijski je a priori čisto empirijska figura, kojoj Foucault povjerava razjašnjavanje pojava i nestanaka različitih formalnih struktura u različitim diskursima u nekom historijskom trenutku. Pritom se ponovno ne radi o jednostavnoj mehaničkoj kauzalnosti (psihološkoj ili društvenoj determinaciji), već o tome da on „omogućuje shvatiti kako ti formalni a prioriji u historiji nalaze dodirne točke, mjesta unosa, provala, pojavljivanja te domena ili prilika djelovanja, kao i razumjeti kako ta historija nije kontingencija potpuno izvanjska formi, kao ni nužnost forme što razvija vlastitu dijalektiku, već specifična pravilnost.“ (isto: 128) ${ }^{251}$

Problematizacija antagonizama i nesuglasnosti unutar diskurzivnih formacija, nesvodivih na jednostavna dijalektički razrješiva proturječja, kao i historijski dinamičnog, polja mogućnosti formulacije elemenata tih formacija, ne samo da već u toj Foucaultovoj studiji povezuju razmatranje decentriranog diskursa što se ne da svesti na puku ekspresiju nekog ujedinjujućeg principa u svojoj pozadini s pitanjima odnosa diskursa i moći, odnosno s hegemonijskom dimenzijom kontingentnih i privremenih fiksacija diskursa, već i snažno evociraju druge agonističke koncepte vezane za diskurs, poput bitno kasnijih Laclauova antagonizma i Rancièreove nesuglasnosti, kao i s time povezane problematike polja vidljivog/osjetilnog.

Studije koje su uslijedile nastavit će s razvojem te tendencije u pravcima pojedinačnih objekata svoga istraživanja u najmanju ruku sve do posljednje faze Foucaultova stvaralaštva, često zvane etičko-estetičkom. Zadržavajući se pak i dalje na općenitijoj razini, korak dalje od Arheologije znanja u pravcu odnosa diskursa i moći napravit će, spomenuto je, predavanje Poredak diskursa, u kojem su obje stvari koje smo prethodno razmatrali vrlo jasno istaknute.

\footnotetext{
${ }^{251}$ Kako Foucault (2010: 128) primjećuje, „ništa ne bi bilo ugodnije, no i nepreciznije od zamišljanja historijskog a priorija kao formalnog a priorija koji je uz to još obdaren vlastitom historijom: velika, nepomična, prazna figura koja je jedan dan nastala na površini vremena, prakticirala tiraniju nad ljudskom misli kojoj nitko nije mogao umaknuti, i koja je potom iznenada nestala u potpuno neočekivanom zamračenju bez presedana: transcendentalno sinkopiranje, igra isprekidanih oblika.“
} 
Ocrtavajući dvije temeljne skupine analiza što ih $\mathrm{u}$ daljnjem radu namjerava provoditi, Foucault (1994: 135) u tom predavanju čitavu jednu skupinu - onu „kritičkih“ analiza posvećuje upravo neposrednom odnosu diskursa i moći, odnosno iznalaženju oblika „,isključivanja, ograničavanja i prisvajanja“ diskursa te tome „kako su se oni oblikovali, kojim su potrebama morali udovoljiti, kako su se mijenjali i premještali, koju su prisilu zbiljski vršili, u kojoj su mjeri bili izokrenuti.“ Nasuprot tome, ,unutarnje“ preispitivanje oblikovanja diskursa i njihovih uvjeta mogućnosti, kojim su se prvenstveno bavile prethodne studije, svrstava u ,genealošku“ skupinu.

Nadalje, izlažući metodološka pravila za analizu diskursa, Foucault (1994: 132) na prvom mjestu podcrtava pravilo obrata, koje sugerira da ,tamo gdje se tradicionalno smatra da se raspoznaje izvor diskursa, njegovo bujanje i kontinuitet, u likovima koji naizgled igraju pozitivnu ulogu, kao što je lik autora, discipline, volje za istinom, valja radije raspoznati negativnu igru sječe i razvodnjavanja diskursa“, čime ne samo da još jednom odbacuje favoriziranje nekog oblika iskona, nego i usmjerava naglasak analize i prema represivnom aspektu međuodnosa diskursa i moći. Odbacivanje različitih figura središta prožima i ostala tri principa - princip eksteriornosti u potpunosti je i posvećen njemu, budući da nalaže da „ne treba ići od diskursa prema njegovoj unutrašnjoj i skrivenoj jezgri, prema središtu misli ili značenja koji bi se u njemu očitovali“ (isto: 133), dok principi diskontinuiteta i specifičnosti to implicitno sadrže u svom odbacivanju ideje sveprotežnog općeg diskursa u podlozi pojedinačnih diskursa, te poimanja diskursa kao pukog čitanja već upisanih značenja u stvarima (isto: 132). Potonji princip Foucault pojašnjava i tvrdnjom da „/d/iskurs valja pojmiti kao naše nasilje nad stvarima, u svakom slučaju kao praksu koju im namećemo“ (isto), što dodatno eksplicira katahretičnu narav povezivanja diskursa i stvari.

U Nadzoru $i$ kazni pak tema odsutnosti središta javlja se prvenstveno u analizi mikrofizike moderne disciplinarne moći. Tim terminom Foucault označava specifičnu kombinaciju znanja i institucionalnih praksi kojima se oblikuju moderni subjekti kao „korisna sila“, dakle „produktivno i podložno tijelo“ (Foucault, 1995: 26). Pritom se ,podlaganje ne postiže samo instrumentima nasilja ili ideologije“ (isto): ono može biti i izrazito tjelesno, a opet nenasilno; suptilno, a opet posve fizičko. No ono što ga važno karakterizira jest da počiva na vještinama i znanjima o tijelu koji nisu puka znanost o njegovu funkcioniranju, spletu različitih diskursa koji se presijecaju u tom djelovanju, te da nije lokalizirano u nekom tipu institucije ili državnog aparata, već sveprisutno i višesmjerno u odnosima među akterima 
u društvu. Osim prešutne kritike Althussera ${ }^{252}$, implikacije takvog povezivanja produktivne međuuvjetovanosti znanja i moći, kao dviju strana istog novčića, te isključivo relacijske, dakle diskurzivne naravi moći, sežu izvan kaznenopravne domene i do određene se mjere povezuju s drugim postfundacijskim, diskurzivnim koncepcijama političkog kojima smo se do sada bavili ${ }^{253}$.

Figura koja se u Nadzoru i kazni javlja kao najefektivnija metonimija disciplinarne moći, Benthamov panoptikon, kao mehanizam koji „automatizira i deindividualizira moć“, tj. osigurava da ,/m/oć nema svoje utemeljenje toliko u osobi koliko u određenoj koncentriranoj distribuciji tijela, površina, osvjetljenja, pogleda; u aranžmanu čiji unutarnji mehanizmi stvaraju odnose u koje su pojedinci uhvaćeni“ (Foucault, 1995: 202), spaja mikrofiziku moći s onim što danas, desetljećima kasnije percipiramo kao tipično rancièreovsku temu raspodjele vidljivosti. Mjera vidljivosti, izloženosti pogledu, na isti način kao i mjera zastupljenosti u diskurzivnoj produkciji na kaznenopravnom polju, u izravnoj je relaciji sa subjektivacijom i zahvaćenosti moći, samo je perspektiva dijametralno suprotna u odnosu na Rancièreovu. Dok kod njega u primarnom fokusu imamo politiku kao rekonfiguraciju polja vidljivosti i transgresiju danog sustava, Foucaultov istraživački interes prvenstveno je - barem u tom segmentu opusa - vezan za policijsku stranu medalje, dinamiku raspoređivanja tijela, subjektnih pozicija i odnosa moći u okvirima određenog sustava. To pak ne dovodi u pitanje činjenicu da je Foucaultovo viđenje moći prije svega produktivno, a ne restriktivno, te da izlaže kritici svaki oblik njezina čvrstog utemeljenja.

Istovremeno, uspostavljanje poveznice $s$ Rancièreovim policijskim poretkom ne znači da disciplinsku moć kako je Foucault vidi valja poistovjećivati sa službenim, eksplicitno kodiranim pravnim poretkom nekog sustava, što bi koncept mikrofizike moći pretvorilo u nacrt neobično efikasne, distopijske totalitarne države. Naprotiv, Foucault (1995: 222) jasno navodi da državnopravni poreci počivaju na „tim malenim, svakodnevnim, fizičkim

\footnotetext{
${ }^{252}$ Foucaultova implicitna kritika Althusserova koncepta subjektivacije opovrgava pak teze koje su na temelju površinskih sličnosti povezivale dvojicu autora upravo s obzirom na problematiku institucionalnog konstruiranja subjekta, ne vodeći računa o važnim razlikama. Usp. npr. Goldstein, 2005: 38.

${ }^{253}$ Kritičari takve interpretacije mogli bi upozoriti na grubo zanemarivanje specifičnosti Foucaultovih predmetnih zapažanja, budući da se ona tiču određenog diskurzivnog područja (kaznenopravnog) te određenog historijskog konteksta (europskog moderniteta), pa bi njihovo nekritičko poopćavanje moglo biti neopravdano. No oba segmenta potencijalne primjedbe u ovom se slučaju mogu odbaciti. Naime, istina jest da se konkretno Foucaultovo istraživanje u Nadzoru i kazni tiče specifičnog diskurzivnog područja, no osim što je to područje izrazito važno za ustrojstvo društva, teze koje on oblikuje (o npr. oblikovanju tijela, proizvodnji subjekata, kapilarnosti moći...) mnogo su šireg dosega te se ponavljaju u drugim njegovim studijama što komplementarno nadopunjuju ovu. Nadalje, ako disciplinarna moć jest specifično obilježje određenog historijskog perioda, njezinim istraživanjem Foucault dolazi i do spoznaja o općoj naravi moći što u tom kontingentnom historijskom poretku najbolje dolaze do izražaja, što se potvrđuje u njegovim kasnijim radovima na temu moći. Drugim riječima, Nadzor i kazna dakako nije političkoontološka studija, no određene se političkoontološke postavke iz nje mogu deducirati.
} 
mehanizmima, svim tim sistemima mikromoći koji su esencijalno ne-egalitarni i asimetrični a koje zovemo disciplinama.“ Neiskorjenjiva asimetrija i dinamičnost odnosa u podlozi naizgled stabilnih i egalitarnih državnopravnih sistema ukazuju na to da Foucault i u studijama posvećenim mehanizmima kontrole zadržava agonistički moment na mjestu odsutnog temelja društva.

U prvom svesku Povijesti seksualnosti Foucault pak zaokružuje elaboraciju svog viđenja moći, podcrtavajući sve ključne aspekte kojima smo se do sada bavili, no stavljajući i dodatan naglasak na posljednje spomenuti: pitanje asimetrije, mikrodinamike moći te otpora. U sklopu već spomenutog odbacivanja tzv. represivne hipoteze, jednim pojmom - pravne koncepcije moći (Foucault, 2013: 77) - istovremeno ponovno kritički zahvaća i navadu da se djelovanje moći percipira samo kao zabrana (čemu suprotstavlja svoju produktivnu koncepciju moći), kao i da je se ograničava samo na pravni poredak. Kako ponovno naglašava:

Pod vlašću ${ }^{254}$ ja ne podrazumijevam ni oblik pokoravanja, koji bi, za razliku od nasilja, bio u obliku pravila. Konačno, ne podrazumijevam neki opći sustav premoći što ga ostvaruje jedan element ili jedna skupina na drugu, i čije bi posljedice, uzastopnim izvođenjem iz jednih u druge, u potpunosti prožimale društveno tijelo. Analiza, u pojmovima vlasti, ne smije kao početne datosti postaviti suverenost države, oblik zakona ili ukupno jedinstvo neke premoći; sve su to više tek njezine završne forme. Čini mi se prije svega da pod vlašću treba razumjeti mnogostrukost odnosa snaga imanentnih području na kojem se oni ostvaruju i sastavni su dio njihove organizacije; igru koja ih putem neprestanih borbi i sukobljavanja mijenja, pojačava, obrće; oslonce što ih ti odnosi snaga nalaze jedni u drugima, tako da stvaraju lanac ili sustav, ili, s druge strane, pomaci, proturječnosti što ih odvajaju jedne od drugih; konačno, strategije $u$ kojima oni stupaju na snagu i čiji se opći model, ili institucionalna kristalizacija utjelovljuju u državnim aparatima, u utvrđivanju zakona, u društvenim prevlastima." (Foucault, 2013: 83)

Taj podulji navod Foucault (2013: 84) je odmah potom sažeo u svojoj poznatoj maksimi o sveprisutnosti moći koja se često navodi kao definicija njezine mikrofizike: „Vlast je posvuda; ne stoga jer sve obuhvaća, nego jer dolazi odasvud.“ No unatoč efektnosti te fraze, nekoliko stvari koje se u njoj potencijalno gube potrebno je dodatno naglasiti. Kao prvo, ističući ponovno da uvjet mogućnosti moći i točku s koje je se može valjano zahvatiti i razumjeti ,ne treba tražiti u početnom postojanju neke središnje točke, u jedinstvenom žarištu suvereniteta iz kojeg bi se širili izvedeni i niži oblici“‘255, Foucault dodaje da je to prije

\footnotetext{
${ }^{254}$ U prijevodu Zlatka Wurzberga kojim smo se koristili (v. Foucault, 2013) pojmom „,vlast“ prevodi se Foucaultov pojam pouvoir, koji se u domaćoj teorijskoj tradiciji inače prevodio kao „moć“. Stoga će i ovaj rad ostati pri uporabi termina „moćc“, a „vlast“ će se pojavljivati samo u citatima iz gornjeg izdanja.

${ }^{255}$ Kako Foucault (2013: 86) kasnije dodaje, relacijskom koncepcijom moći koja izbjegava jedinstvena žarišta napokon možemo „,izbjeći sustav Suverena-Zakona koji je tako dugo opčinjavao političku misao. I, ako je točno da je Machiavelli bio jedan od rijetkih - a u tom je bio nesumnjivo skandal njegovog 'cinizma' - koji je vladarevu vlast mislio u pojmovima odnosa snaga, onda je možda potrebno krenuti korak dalje, odreći se osobe
} 
„pomična podloga odnosa snaga koje neprestano, svojom nejednakošću, dovode do stanja moći, ali uvijek ograničenih i nepostojanih.“ (isto) Time mnogo eksplicitnije nego prije konstatira ne samo relacijsku narav moći, nego i to da diferencijalni sustav u kojem ona egzistira nije stabilan i zaokružen sustav kakvog bi zamišljali strukturalisti, već sustav nesvodivih nejednakosti koje posljedično uzrokuju nepostojanost pojedinačnih artikulacija moći.

Nadalje, nejednakosti inherentne moći nisu prolazne prepreke, niti je moć neka zasebna društvena domena ili pripadna samo jednoj od domena; moć je, smatra Foucault (2013: 84), imanentna svim društvenim domenama upravo kao posljedica podjela i nejednakosti u njima, a potonje su preduvjet razlikovanja različitih domena i njihovih unutrašnjih odnosa. Drugim riječima, različiti i uvijek promjenjivi oblici agonističkih/antagonističkih situacija ono su što istovremeno omogućuje postojanje moći i definira strukturu diskursa, što nas dovodi do još jedne od inačica izjednačavanja između teorije diskursa, političke teorije i opće ontologije. S obzirom na takvo određenje moći, jasno je da Foucault (isto: 85) isključuje mogućnost postojanja racionalnog subjekta u pozadini veza moći, no istovremeno ih paradoksalno naziva intencionalnima, time želeći naglasiti da su one u potpunosti strateške, da „nema vlasti koja se ostvaruje bez neke serije težnji i ciljeva“, no da s druge strane ne proizlaze iz odluke jedinstvenog subjekta - pojedinačne osobe, klike, klase ili nekog drugog kolektivnog subjekta.

Detronizirajući tako subjekte koje se percipiralo kao tradicionalne „nositelje“ moći, i nastavljajući se na teze o stalnoj dinamici odnosa moći i njihovoj prisutnosti u svim društvenim domenama, Foucault (2013: 85) odbacuje i fiksnu binarnu opreku između vladajućih i potlačenih koja bi prošla čitavim društvenim tijelom, što i njegov diskurs čini nekompatibilnim s tradicionalnim marksističkim klasizmom, ali i bilo kojim drugim binarnim esencijalizmom. Nasuprot tome, predlaže

pretpostaviti da višestruki odnosi snaga koji se stvaraju i odvijaju u proizvodnim aparatima, obiteljima, užim skupinama, institucijama, služe kao oslonac širokim učincima raslojavanja što cijepaju društveno tijelo u cjelini. Ovi posljednji tada tvore jednu opću silnicu koja prolazi

\footnotetext{
vladara, i raščlanjivati mehanizme vlasti s polazištem u strategiji imanentnoj odnosima snaga." Foucaultova referenca na Machiavellija jasno pokazuje što smo i ranije naglasili - da relacijska narav moći koju je otkrio i opisao istražujući moderni disciplinarni poredak moći nije ograničena samo na taj poredak, već je njezina narav općenita. Drugim riječima, kada Foucault (1995: 208) u Nadzoru i kazni piše da je panopticizam inverzija kraljevske moći, gledano retrospektivno iz perspektive ovog odlomka o Machiavelliju možemo zaključiti da on ne smatra kako je moć u predmodernom razdoblju doista imala svoju fiksnu točku porijekla/središte, već da je suveren služio kao vrlo izraženo metaforičko/hegemonijsko čvorište odnosa moći, kao označitelj što nadkodira njezinu diferencijalnu strukturu, povučemo li usporedbu s Deleuzeovim drugim oblikom sociusa. Usp. kao analognu interpretaciju Laclauovo (2007b: 59, 100) viđenje funkcije vođe u populizmu.
} 
kroz lokalna sukobljavanja i povezuje ih; naravno, za uzvrat oni nad njima vrše preraspodjele, poravnavanja, homogeniziranja, serijska planiranja, usklađivanja. Velike premoći posljedice su prevlasti što ih stalno podupire intenzitet svih tih sukobljavanja. (Foucault, 2013: 85)

Time Foucault namjesto esencijalističkog klasizma zapravo na nešto drukčiji način formulira istu poziciju kakvu smo vidjeli najdetaljnije artikuliranu nešto kasnije kod Laclaua: odbacivanje ontološke privilegiranosti i fiksne datosti klase u korist njezine hegemonijske artikulacije analoškim povezivanjem pozicija iz više različitih lokalnih diskursa.

Konačno, iako je svemoćnost i sveprisutnost moći i ranije bila ograničena negiranjem njezine homogenosti i isticanjem različitih rasjeda, asimetrija i konflikata, Foucault (2013: 8586) tek u ovoj studiji eksplicitno uvodi pojam otpora, tvrdeći da „ondje gdje postoji vlast, postoji i otpor, a da ipak, ili upravo stoga, taj otpor nikada nije u izvanjskom položaju u odnosu na vlast. (...) Ne postoji dakle u odnosu na vlast jedno mjesto velikog Odbijanja duša pobune, žarište svih otpora, čisti zakon revolucionarnog. Nego više otpora koji su posebni slučajevi (...); po definiciji oni mogu postojati jedino u strateškom polju veza vlasti.“

Ipak, unatoč tome što anticipirajući kritike tvrdi da tako formuliran otpor nije tek binarno negativno naličje moći koje bi se s njom u konačnici pasivno neutraliziralo, činjenica jest da tako binarno formuliran odnos, imamo li na umu način na koji je neposredno prije određena moć, donosi problem referentne točke imenovanja i razgraničenja moći i otpora ${ }^{256}$. Neovisno o tome važno je istaknuti Foucaultovo podcrtavanje nepravilne disperzije čvorišta otpora, koja rijetkošću čini velike radikalne prijelome, proizvodeći umjesto njih sitnije pukotine, cijepanja, trenja, pomake i transformacije manjih dimenzija što presijecaju različite društvene slojeve i pojedinačne cjeline. Kao i kod moći, tako i kod otpora to otvara prostor hegemonijskoj artikulaciji: „nedvojbeno je da upravo strateško kodiranje tih točaka otpora čini mogućom neku revoluciju, donekle kao što država počiva na institucionalnom objedinjavanju odnosa vlasti.“" (Foucault, 2013: 86)

No još jedno pitanje koje se nameće prilikom ocrtavanja poveznica između Foucaulta i autora kojima smo se do sada bavili tiče se njegova odnosa prema politici/političkom ukupno, a u usporedbi s njihovom eksplicitnom ili implicitnom tematizacijom te razlike i naglaskom koji pritom stavljaju na emancipatorne prakse. Drugim riječima, pitanje je to je li Foucault - u

\footnotetext{
${ }^{256}$ Osobito je diskutabilno Foucaultovo razmatranje odnosa moći i otpora na primjeru određenja biopolitike. Kako piše, „trebalo bi govoriti o 'bio-politici' da se označi ono čime se život i njegovi mehanizmi uvode u područje izričitih proračuna i što od vlasti-znanja čini čimbenika promjene ljudskog života; život nipošto nije potpuno uklopljen u tehnike koje dominiraju i vladaju njime; neprestano im izmiče.“ (Foucault, 2013: 125) Postavlja se pitanje ukazuje li ta neuhvatljivost života naprosto na nemogućnost potpune i zaokružene simbolizacije i apsolutne kalkulabilnosti, ili pak otvara prostor vitalističkim čitanjima života i tijela koja su se Foucaultu u nekim polemikama pripisivala.
} 
razlici spram njih - doista tek teoretičar mehanizama kontrole, kompleksa znanja-moći koji postavlja okvire oblikovanju subjekata i njihove društvene okoline te je li njegov interes za emancipacijsko doista ograničen tek na prethodno spomenutu koncepciju otpora, nerazdvojnu od moći unutar neke društvene konfiguracije, te na prakse samooblikovanja i javnog govorenja istine, kojima se prvenstveno bavio u svojoj zadnjoj istraživačkoj fazi ${ }^{257}$.

Upravo takvo viđenje Foucaultova opusa razmjerno je često, pa tako i Goldstein (2005: 21) u svojoj podjeli, podsjetimo, Foucaulta smatra glavnim predstavnikom onih postmarksističkih teoretičara koji su izgubili vjeru u snagu teorijske kritike pa „naglašavaju sociohistorijski kontekst modernih diskurzivnih praksi, a ne ideale teorijske kritike, te posljedično otvaraju te prakse političkoj kritici.“ No pitanje je isključuje li jedno doista drugo, te ne podrazumijeva li zadnji dio opisa ipak neki oblik teorijske kritike.

Teško bi, doduše, bilo tvrditi da Foucault mjestimično ne daje za pravo upravo takvoj perspektivi. U njegovim radovima politika se spominje često, no taj pojam najčešće rabi razmjerno kolokvijalno, u kontekstu govora o aktualnim oblicima i odnosima moći u nekom historijskom trenutku, bez da oblikuje nešto što bismo u uobičajenom smislu mogli nazvati Foucaultovom političkom teorijom. Dapače, na jednom od mjesta gdje usputno nudi nekakvo određenje politike (doduše ponovno u određenim historijskim okvirima), ona je za Foucaulta „tehnika unutarnjeg mira i poretka“, odnosno bliža onome što bi Rancière nazvao policijom. Osim toga, Foucault (2010b: 146) u kasnijim radovima i eksplicitno kritizira uvođenje distinkcije između politike i političkog kod svojih suvremenika, referirajući se u konkretnom slučaju na Leforta, tvrdeći da "u mnogo suvremenih analiza služi maskiranju problema i cjeline specifičnih problema politike, dunasteja, vršenja političke igre i političke igre kao iskustvenog polja sa svojim pravilima i svojom normativnošću, kao iskustva onoliko koliko je ta politička igra usklađena s istinitim govorenjem i onoliko koliko od onih koji u njoj igraju ulogu podrazumijeva odnos sa samim sobom i s drugima.“

No unatoč toj kritici, kod Foucaulta se još od ranijih studija koje smo razmatrali može uočiti svojevrsna ontičko-ontološka opreke kakvu u njoj polemički zahvaća, bez obzira što je eksplicitno ne promišlja kao takvu. Tako još na samom početku Riječi i stvari kao izvorište svog promišljanja epistema navodi Borghesovu novelu koja na površinu iznosi problem kategorizacije kao ono što „uzdrmava svako uobičajeno mišljenje“, „dovodeći do kolebanja svih uređenih površina i svih planova koji za nas smiruju bujanje bića“, te tako ukazuje na „granicu naše [misli]: ogoljelu nemogućnost da to mislimo“ (Foucault, 2002: 9). Potaknut

\footnotetext{
${ }^{257}$ Kao paradigmatski primjer usp. skup predavanja naslovljen Vladanje sobom i drugima [2008] (Foucault, 2010b), u kojem se bavi konceptom parezije i parezijskog govora.
} 
time, uočava da između temeljnih kodova kulture koji određuju empirijske poretke s kojima se čovjek u nekom historijskom trenutku susreće na jednoj strani, te znanstvenih/filozofskih interpretacija poretka uopće, postoji posredničko područje „konfuznije, mračnije i nesumnjivo teže za analizu“" u kojem dolazi do suptilnog odvajanja kulture i poretka, kritike kodova jezika, percepcije, prakse i njihovog djelomičnog označavanja nevaljanim; međupodručje koje se, „u mjeri u kojoj iskazuje načine postojanja poretka, može dati kao najtemeljnije“ jer prethodi riječima, gestama, teorijama i filozofskim temeljima (isto: 15). Drugim riječima, Foucault od samog početka svoj arheološki pothvat vidi kao istraživanje ne samo aktualnih poredaka znanja-moći, njihove dinamike i mijene, nego i kretanja utemeljenja i rastemeljenja koja ih omogućuju ${ }^{258}$.

U Arheologiji znanja tome će dodati i eksplicitan nacrt toga kako bi mogla izgledati arheologija političkog znanja, kao odgovor na pitanje ,jesu li politička ponašanja nekog društva, skupine ili klase prožeta osobitom, opisivom diskurzivnom praksom“, pri čemu se takva analiza „ne bi podudarala ni s političkim teorijama tog razdoblja, ni s ekonomskim određenjima“" (Foucault, 2010: 194). Naprotiv, ona bi određivala ,što u politici može postati objekt iskazivanja te oblike koje to iskazivanje može poprimiti, koncepte koji se u njemu koriste i strateške izbore koji se čine“, no ne krećući se prema epistemi koja se tako oblikuje (što isto smatra legitimnim putem istraživanja), već prema ponašanju, borbama, sukobima, odlukama i taktikama“, te otkrivajući tako polje artikulacije političkih praksi i teorije mimo kolektivnih i pojedinačnih svijesti (isto). Tako zamišljena ,arheologija političkog znanja“ u velikoj mjeri anticipira zadatke političkoteorijskih istraživanja koje si postavljaju neki od prethodno analiziranih autora - naročito Laclau i Rancière - a političnost arheologije za Foucaulta, kao ni za njih, nije ograničena samo na arheologiju jednog polja. Dapače, kako Foucault (isto: 210) tvrdi u samom zaključku te studije, svako ispitivanje materijalnosti i netransparentnosti diskursa, svako propitivanje njegovih granica, uznemirujuće je u odnosu na umirujuće predodžbe kontinuiteta, transparentnosti i intencionalnosti koje smo prethodno posjedovali, dakle političko ${ }^{259}$.

\footnotetext{
258 During (1992: 17), parafrazirajući Saida, navodi da Foucault „pokušava sekularizirati, posvjetoviti poststrukturalističku ontologiju ispisujući historije institucija koje su omogućile zaborav riskantnog, 'beznačajnog' Bitka“. Takvo uspostavljanje poveznice nije posve netočno, a istovremeno je slikovito i pojednostavljeno. No vidimo da (kvazi)ontološka istraživanja ipak nisu bila strana ni Foucaultu.

${ }^{259}$ Kako pišu Brlek i Koludrović (2015: 2) „Stoga, ne: Foucault nije tražio znanje. On ga je upravo htio prekoračiti, pomaknuti se onkraj granica institucionalnih formacija znanja, kako bi pokazao, možda prokazao, a svakako postavio pitanje proizvodnje znanja. Njegovom bi se terminologijom moglo reći kako je želio izigrati vlastitu epistemu, shvaćenu kao poredak autoritarnih diskurzivnih praksi, podmećući joj umjesto indikativa kondicional (...) kao trajno propitivanje uvjeta mogućnosti vlastitog postojanja.“
} 
No, ako i jest imanentno političko, u kakvom je odnosu takvo uznemiravanje granica prema Marxu i marksizmu? Imajući sve do sada izloženo na umu, jasno je da bi Foucaultov opus, već ovisno koji njegov segment konzultiramo, mogao ponuditi nekoliko proturječnih odgovora. No jedan zanimljiv nudi nam se još i prije Riječi $i$ stvari, u već spomenutom predavanju Nietzsche, Freud, Marx [1964]. U njemu Foucault po tom pitanju razdvaja marksizam i Marxa (kao što je, vidjeli smo, i drugdje činio) tvrdeći da je marksizam nakon Marxa „hermeneutika koja se obavija oko semiologije, vjerujući u apsolutno postojanje znakova, odričući se nasilja, nedovršnosti i beskonačnosti interpretacije kako bi stvorila vlast terora u kojoj oznaka vlada i sumnjiči jezik“. (Foucault, 1990: 67) S druge strane Marxa smatra jednim od trojice najznačajnijih začetnika suprotne hermeneutičke tendencije; one koja odbacuje robinzonovske potrage za izvorima (isto: 63), shvaćajući da je interpretacija proces koji ne ide prema konačnom rješenju, izvoru ili svrsi, već mjestu na kojem se približava vlastitom iščeznuću. Iz perspektive takve hermeneutike ne postoji nikakav ,interpretandum koji već ne bi bio interpretans“, stoga se u interpretaciji „utemeljuje odnos nasilja koliko i rasvjetljavanja“ (isto: 64) ${ }^{260}$. Svaka nova interpretacija mora „nasilno zauzeti interpretaciju koja je već tamo, koju mora izokrenuti, vratiti, razbiti udarima čekića“ (isto), a suvišak značenja u tom slučaju postaje temelj jezika, odnosno ono što mu prethodi, a ne naknadan dodatak, „ne ono što se podvlači pod riječi naknadno kako bi ih izmjestilo i učinilo da vibriraju, već ono što rađa riječi, što ih čini da sjaje sjajem koji nikada nije čvrsto vezan.“ (isto: 65)

Opisana katahretičnost jezika te agonistička/antagonistička narav označavanja Foucaulta (1990: 67) vode od Marxa (kao i Freuda i Nietzschea) prema hermeneutici „koja oko sebe obavija posredničko područje ludila i čistog jezika te ulazi u domenu jezika koji se ne prestaju miješati.“ Riječ je o konstelacija koju u tom predavanju pripisuje označavanju uopće i smatra poželjnom za svaku hermeneutiku, pa ipak pitanje ludila i čistog jezika, kao i ranije naznačeno pitanje granica - odreda politička pitanja par excellence - skupa će izrazito doći do izražaja u Foucaultovu bavljenju jednim specifičnim diskurzivnim područjem: onim književnosti. Usmjeravanje interesa prema segmentu Foucaultova opusa posvećenom književnosti stoga nam se na dvojak način nameće kao logičan nastavak istraživanja. S jedne strane, nakon što smo potvrdili podudarnost Foucaultovih teorijskih stajališta s onim ostatka autora kojima smo se bavili i po pitanju ambivalentnog odnosa prema Marxu i marksističkom

\footnotetext{
${ }^{260} \mathrm{Tu}$ općenitu značajku Foucault (1990: 66) kod Marxa prepoznaje na konkretnom primjeru tretmana novca u Kritici političke ekonomije te prvom svesku Kapitala, gdje se radi o znakovima koji su zapravo interpretacije što se pokušavaju opravdati, a ne obrnuto.
} 
nasljeđu, i glede svojstva koje smo prethodno nazivali literarnošću politike (odnosno njezinom diskurzivnom koncepcijom), ostaje nam istražiti i treći segment profiliran u ovom istraživanju. No jednako tako, kako nam do sada rečeno pokazuje, Foucaultovi radovi o književnosti nisu tek efemeran segment njegovog opusa ili kuriozitet koji s ostatkom njegovih radova jedva da ima snažnije veze (kako bi se mogao steći dojam na temelju dijela istraživanja o Foucaultu), a koji bi tek specifičan interes ovog rada logikom posve izvanjskom Foucaultovu djelu nametnuo kao relevantnu temu istraživanja. Naprotiv, pitanje književnosti kod Foucaulta pokazuje se kao raskrižje na kojem se susreću teme kojima smo se do sada bavili analizirajući njegov daleko poznatiji dio opusa, a postmarksistička optika koja nas je spajanju tih problemskih žarišta usmjerila na površinu izvlači poveznice što su često ostajale u pozadini, rezultirajući slikom tog autora koja donekle odudara od tipične udžbeničke.

Upravo Foucaultovi radovi o književnosti, naime, intenzivnije nego ijedan drugi segment njegova opusa $u$ fokus dovode problematiku ispitivanja granica znanja, diskursa $i$ moći, kao i opetovanog prelaska tih granica, čineći tako svojevrsno (posve komplementarno) naličje njegovoj uvriježenoj percepciji. Samim time u kontekstu ovoga istraživanja pokazuju se i kao odlična zglobnica između autora kojima su se bavila prethodna poglavlja te Foucaulta ${ }^{261}$. Razlog zbog kojeg je ta poveznica u dosadašnjim istraživanjima postmarksizma, ali i velikom broju drugih, čak i književnoteorijskih bavljenja Foucaultom ostajala neprepoznata leži u činjenici da je, kako primjećuju Brlek i Koludrović (2015: 1), recepcija njegovih radova posvećenih književnosti razmjerno skromna ${ }^{262}$.

Osobinu što povezuje Foucaultove radove o književnosti (najvećim dijelom nastale tijekom šezdesetih godina) ${ }^{263} \mathrm{~s}$ jedne strane s ostatkom njegova opusa, te $\mathrm{s}$ druge strane $\mathrm{s}$ političkom konceptualizacijom književnosti kod ranije razmatranih autora (kako Derridaa i

\footnotetext{
${ }^{261}$ Dajući svojevrstan pregled temeljnih značajki Foucaultova bavljenja književnošću, Brlek i Koludrović (2015: 2) smatraju da je obilježeno trima temeljnim pojmovima za koje bismo mogli reći da se gradacijski kreću od neuobičajenije slike Foucaulta prema onoj uvrježenijoj: transgresija, iskusutvo jezika i funkcija autora.

${ }^{262}$ Ukazujući na disproporciju između činjenice da je Foucault s jedne strane neizbježno ime u većini pregleda suvremene književne teorije, dok s druge strane u njima jedva da ikada ima referenci na njegove književne studije, Brlek i Koludrović (2015: 1) kao osobito paradoksalan primjer ističu Duringovu knjigu Foucault and Literature: Towards a Genealogy of Writing u kojoj, naslovu unatoč, autor književnosti posvećuje tek jedno poglavlje (usp. During, 1992: 68-91). During (isto: 10) pak u spornoj studiji i sam primjećuje zapostavljenost Foucaultovih tekstova o književnosti, no tome kao drugu slijepu pjegu dodaje i politiku.

Konačno, vrijedi dodati i neobičnu činjenicu koju u svom predgovoru jednom od svezaka Foucaultovih sabranih djela podcrtava Faubion (1998: xiv), da ni Foucault sam u svom retrospektivnom eseju naslovljenom Foucault, napisanom pod pseudonimom Maurice Florence za francuski Rječnik filozofa, ni jednom riječju ne spominje svoja istraživanja književnosti i uopće avangardne umjetnosti.

${ }^{263}$ Osim monografske studije o Raymondu Rousselu (usp. Foucault, 2004 [1963]) ovdje smo u fokus uzeli većinom objavljena predavanja i/ili pojedinačne članke što su prikupljeni na dvama mjestima: u zbirci naslovljenoj Velika strankinja [La grande Étrangére, 2013] (usp. Foucualt, 2018) te drugom svesku Foucaultovih sabranih članaka i kraćih radova posvećenom estetici, metodologiji i epistemologiji (usp. Foucault, 1998).
} 
Deleuzea, kao Foucaultovih suvremenika, tako i mlađe generacije), Faubion (1998: xv) dobro sažima tvrdnjom da Foucault u tim tekstovima ,nije bio u potrazi za ljepotom: nije bio estetičar, već proučavatelj onoga što bi stari Grci nazvali aisthesisom, 'osjećajem', 'iskustvom', 'proživljenim iskustvom'.“ No problematika aisthesisa, koji će se godinama kasnije naći u naslovu Rancièreove zbirke eseja slične tematike, kao i transformativna uloga književnosti u odnosu na tu ukupnost poretka osjetilnog nisu jedine poveznice koje se pak mogu uspostaviti na toj relaciji; još jedna važna stvar koja ih veže jest i historijska kontekstualizacija, tako značajna u ostatku Foucaultova opusa.

Kao i autori kojima smo se prethodno bavili, Foucault naime ne barata transcendentalnom, ahistorijskom idejom književnosti, već opetovano podcrtava važnost historijskog konteksta njezine institucionalizacije u odnosu na njezina svojstva koja smatra ključnima. Razdoblje u kojemu se književnost osamostaljuje kao institucija - isto ono koje je kasnije detaljnije zaokupljalo Rancièrea, obilježeno približno istim autorima i ključnim mjestima $^{264}$ - velikim se dijelom poklapa s onim koje je Foucault u poznatijem segmentu svog opusa označio razdobljem smjene dviju epistema - klasične i moderne, kao i razdobljem uspona disciplinarne moći. U tom vremenu, od kraja osamnaestog pa nadalje tijekom devetnaestog stoljeća, Foucault (2018: 92) uočava otvaranje treće točke u odnosu između jezika i djela kao jezičnog artefakta, što taj odnos pretvara u trokut s književnosti kao povlaštenom točkom. Nasuprot ,pasivnom odnosu znanja i memorije“ (isto) karakterističnom za klasicizam, javlja se tada ,aktivan, praktičan, a samim tim nejasan i dubok odnos između djela [u trenutku nastajanja, i samoga jezika; ili pak između jezika u trenutku preobražaja i djela u koje se taj jezik pretvarao (uglata zagrada u izvornom tekstu)]“ (isto); nasuprot „,intrigentnom odnosu staroga i novoga koji je propitivala cijela klasična književnosti“ javlja se „sasvim posebna vrsta povjesnosti“ koja „,p/odrazumijeva odbacivanje same književnosti“ kroz „veoma složeni splet negacija.“ (isto: 98)

Zbog toga Foucault (2018: 101) dvjema temeljnim, iako proturječnim figurama književnosti smatra transgresiju i ponavljanje biblioteke, određujući je time kao diskurs koji se ,pokorava kodu u kojemu je smješten, ali koji čim počne i svakom riječju koju izgovara kompromitira taj kod u kojemu je smještena i shvaćena“ (isto: 130), te apostrofirajući tako onaj isti proturječni odnos između stalne inovacije i ukorijenjenosti u tradiciju koji je u

\footnotetext{
${ }^{264} \mathrm{Ta}$ i druga preklapanja između Foucaulta i Rancièrea glede objekata analize bi bilo možda nepravedno u potpunosti nazvati Foucaultovom prefiguracijom budućih Rancièreovih analiza, odnosno utjecaju prvog na potonjeg, budući da se radi o kanonskim djelima i autorima, no određeni stupanj utjecaja - posrednog ili neposrednog - svakako ne bi valjalo isključiti.
} 
približno isto vrijeme elaborirao i Derrida ${ }^{265}$. Čitava književnost stoga bi se, smatra Foucault (isto: 89) mogla smjestiti u praznom prostoru koji u njoj otvara pitanje „Što je književnost?““, postavljeno ne izvana, kao pitanje kritičara, povjesničara i sociologa, već kao pitanje koje svoje ishodište nalazi u njoj samoj. No pitanje je to na koje bi „mogla odgovoriti samo jedno, a to je da ne postoji bitak književnosti; postoji samo simulakrum, simulakrum koji je cijeli bitak književnosti.“ (isto: 108)

Struktura simulakruma u izravnoj je svezi pak s drugom važnom historijskom i formalnom prekretnicom koju Foucault opetovano ističe kao ključnu. Riječ je o gubitku središta, odnosno o raznim inačicama smrti boga. U tekstu Očevo „,ne“ Foucault (1998: 19) piše: „Osim što je bila događaj koji je jednostavno pogodio naše osjećaje i proizveo strah od ništavnosti, smrt boga duboko je utjecala na naš jezik; na izvorište jezika postavila je tišinu koju nikakav rad, osim čistog brbljanja, ne može prikriti.“ Jezik je tako postao suveren, dolazeći ni od kuda, s mjesta koje je neizgovorivo, i preoblikujući se u djelo ukazujući na tu odsutnost središta ${ }^{266}$. Slično i u predavanju Književnost i jezik; Foucault (2018: 119) navodi da književnost počinje „onog dana kada je prostor retorike zamijenilo ono što bismo mogli nazvati volumenom knjige“, pri čemu retoriku shvaća kao igru figura koje su u klasičnoj episteme imale približiti „ono što je izrekla priroda ili Bog“ (isto: 118). U predgovoru Batailleevoj Transgresiji (iz koje je i preuzeo dotični pojam) istaknut će pak da nas „smrt boga ne vraća u neki ograničeni, pozitivistički svijet, već u svijet izložen iskustvu granice ${ }^{267}$, stvaran i rastvaran onim suviškom koji je prelazi“ (Foucault, 1998: 72), povezujući tako odsutnost središta s obje književne figure - transgresijom i bibliotekom tradicije, katahretičkim utemeljenjem i rastemeljenjem ${ }^{268}$.

\footnotetext{
${ }^{265}$ Zbog toga Foucault (2018: 129) odbacuje Jakobsonovu ideju da književnu kritiku definira kao metajezik u odnosu na književni kod, ističući da pojam metajezika podrazumijeva mogućnost zahvaćanja stabilnog, zaokruženog koda.

Glede aporijskog odnosa tradicije i inovacije, koda i njegove povrede, važno je napomenuti i da on nije ograničen tek na književnu historiju zatvorenu u sebe; sasvim očekivano, Foucault (isto: 140) podcrtava važnost toga da znamo „gdje se [književnost] smješta u svijetu znakova nekoga društva“, kritizirajući da su takva istraživanja u odnosu na suvremena društva mahom izostala. No pritom treba imati na umu da je historizacija i tu prvenstveno diskurzivna; riječ je o odnosima među diskursima, ne o odnosu s nekakvom neposrednom, nepatvorenom stvarnosti.

${ }^{266}$ Pritom je ta „eshatologija“ što je ugrađena u svako književno djelo (Foucault, 1998: 19) ipak bitno različita od misticizma i negativne teologije, koji ipak - čak i u svom negativitetu - tragaju za nekim pozitivnim sadržajem, otvaraju „nekakav zaklon u kojem iskustvo može počivati“ (isto: 166). Usp. s desetljećima kasnijom Laclauovom kritikom negativne teologije u Laclau, 2014.

${ }^{267}$ Usp. i Foucault, 1998: 94.

${ }^{268}$ Pišući o Flaubertovim Kušnjama sv. Antuna te Bouvardu i Pechuchetu, Foucault (1998: 100) pak dodatno modificira figuru biblioteke, suprotstavljajući je figuri retorike kao neprestanom prijevodu apsolutnog, samoprisutnog, punog govora koji se u raznim figurama obavlja za smrtna, konačna bića. Nasuprot toga, biblioteka podrazumijeva beskonačnost fragmentiranih jezika i zapisa koji smjenjuju dvostruki, kontinuirani lanac retorike. Tako i u prijelazu između dva spomenuta Flaubertova romana prepoznaje razliku u odnosu prema tradiciji, odnosno prijelaz s Knjige na knjižaru, s objedinjavanja sveg pisma na proliferaciju fragmenata u tisku.
} 
Jedna od tema koje Foucault razmjerno rano i na više mjesta dovodi u odnos $\mathrm{s}$ transgresivnom naravi književnosti jest i ludilo. No suprotno uvriježenim predodžbama o vezi između književnosti i diskursa „luđaka“, jasno podcrtava da pritom pod svaku cijenu želi izbjeći psihološki biografizam, odnosno ,pitanje što ga postavlja nekonceptualni eklekticizam, izvedena iz 'kliničke' psihologije“ (Foucault, 1998: 7), pitanje što cilja usidriti označiteljske lance književnog djela u život pojedinačnog autora. Kako napominje, ,/s/vaki diskurs koji nastoji dostići temeljne dimenzije djela mora makar implicitno istraživati njegove veze s ludilom“, no ne zbog tematske podudarnosti ili izomorfnosti iskustva, već jer „djelo postavlja i prelazi granice koje ga stvaraju, prijete mu i dovršavaju ga.“ (isto: 14) Drugim riječima, „ne znači da svaki jezik ludila ima književno značenje, a ne znači ni da je književnost danas fascinirana ili opsjednuta ludilom“, već da je „naše vrijeme otkrilo - i to gotovo istodobno - da je književnost zapravo jezična činjenica i da je ludilo značenjska pojava“, da se „oboje poigravaju znakovima, da se igraju onim znakovima koji se poigravaju s nama.“ (Foucault, 2017: 82) S te strane, „,̌ak i da su svi ljudi na svijetu razumni, i dalje bi, uvijek bi postojala mogućnost da se izvrne svijet naših znakova, svijet naših riječi, našeg jezika, da se pomuti njihov najpoznatiji smisao i da se samim čudesnim naviranjem nekoliko riječi koje se međusobno sudaraju svijet iskrivi.“ (isto: 64)

Ono što pak takvo mišljenje transgresije ipak čini postfundacijskim jest Foucaultovo jasno isticanje međuovisnosti granice i transgresije. Kao što piše u predgovoru Batailleevoj Transgresiji, u kojem razmatranje transgresije započinje u odnosu na pojmove seksualnosti i erotizma (što je poveznica s kasnijim Foucaultovim studijama), ,granica ne bi mogla postojati ako bi bila apsolutno neprekoračiva $i$, recipročno, transgresija bi bila besmislena kada bi prelazila tek granicu sačinjenu od iluzija i sjena.“ (Foucault, 1998: 73) Utoliko je odnos transgresije i granice nemoguće misliti crno-bijelo, „kao zabranjeno naspram zakonitog, vanjštinu naspram unutrašnjosti, otvoren prostor naspram zatvorenog. Njihov odnos poprima oblik spirale koju nikakav jednostavan lom ne može iscrpiti.“ (isto: 74) Upravo zbog toga, transgresiju se ne može promišljati ni kao „nasilje u podijeljenom svijetu“, ni kao „pobjedu nad granicom (u dijalektičkom ili revolucionarnom svijetu)“, već kao čisto afirmaciju

\footnotetext{
Vrijedi podsjetiti da su ista dva romana kasnije zaokupljala i Rancièreove analize, kao da i kod njega možemo pratiti slično povlačenje razlike između tretmana jezika kao skladnog tijela u klasičnoj retorici, u okvirima poetičkog/reprezentativnog režima, te kao proliferacije pisma u estetičkom režimu. Konačno, kao što su i Rancièreove smjene prikazivačkih režima vezane za društveno-političke mijene, kao što je i kod Derridaa književnost kao mogućnost da se kaže sve bila vezana s političkom idejom demokracije, tako i kod Foucaulta smrt boga valja promatrati kao decentriranje na više razina, uključujući i društveno-političku. Usp. o tome Foucault, 2002: 410-411.
} 
neograničenosti u koju svaki put zakoračuje prekoračujući granicu; afirmaciju koja pak ne sadrži nikakav pozitivitet na temelju kojeg bi je se omeđilo i odredilo (isto).

Sličnosti između tako koncipirane transgresije i koncepcija politike književnosti, odnosno njezine mesijanske uloge - kao opetovanog prekoračenja danih struktura ne u korist nekih drugih, nego u korist otvorenosti mimo svake strukture očekivanja - dodatno dolazi do izražaja kada Foucault (1998: 75) u istom tekstu Batailleevu konceptu transgresije doda i Blanchotov koncept osporavanja kao ne-pozitivne afirmacije, onoga što nije jednostavna negacija, već afirmacija ničega. Osporavanje nije ,proces misli što niječe postojanja ili vrijednosti“, nije suprotstavljanje pozitivnih sadržaja, već „čin koji ih odvodi do njihovih granica, i od tamo do Granice na kojoj ontološka odluka doseže svoj kraj; osporavati znači nastaviti dok se ne dođe do prazne jezgre kao mjesta gdje biće dostiže svoju granicu i gdje granica određuje biće.“ (isto)

Transgresivni jezik, karakterističan za književnost, tako za Foucaulta svojim kretanjem predstavlja suprotnost tradicionalnom jeziku zapadne filozofije na više načina: umjesto vanjskom referentu spoznaje, u istraživanju granice okrenut je vlastitoj unutrašnjosti ${ }^{269}$, raspršuje subjekt umjesto da ga okuplja (Foucault, 1998: 80) ${ }^{270}$, ekonomsku logiku koristi i potrebe zamjenjuje suviškom (isto: 84-85), a kastracijsko djelovanje antikastracijskim (Foucault, 2018: 212). Transgresija je, kako pišu Brlek i Koludrović

prelaženje granica koje smo uspostavili mi sami; stoga se svakim našim transgresivnim činom neizbježno uspostavljaju nove granice. Neumitna snaga granice leži u njezinoj konstitutivnoj moći, da stvori dojam vlastite samodostatnosti, da figuraciju diskursa prikaže kao konfiguraciju izvanjskosti. Drugim riječima, prikrivajući vlastitu prirodu granice, ona strukturu epistemoloških obrazaca predstavlja kao ontološku strukturu zbilje: izvanjskost se objavljuje u vidu bitne unutrašnjosti i na temelju toga autoriteta određuje protokole istine. (Brlek, Koludrović, 2015: 5)

Utoliko transgresivni jezik zahtijeva preobrazbu refleksivnog jezika, preorijentaciju od „središnjih, nepokolebljivih izvjesnosti“ prema granici „,na kojoj je prisiljen samoosporavati se“ (Foucault, 1998: 152); izvanjski referenti ne nude mu se više kao „,pozitivna prisutnost kao nešto iznutra osvijetljeno sigurnošću vlastitog postojanja“, već kao „odsutnost koja odguruje od sebe što je dalje moguće, nestajući u znakovima koje čini kako bi privlačila, kao da ju je moguće dosegnuti.“ (isto: 155) Takvu protutežu spoznajnom jeziku, jezik što ukazuje

\footnotetext{
${ }^{269}$ Istovremeno, paradoksalno, u toj okrenutosti vlastitoj unutrašnjosti, potragu za dovršenosti ne aktualizira tragajući za točkom središta, nego za rubom mogućnosti, što je dijametralno suprotno u odnosu na konkretizacije figure dovršenosti koje su se razvile u znanstvenim disciplinama moderne episteme. Usp. i Foucault, 2002: 409.

${ }^{270}$ Usp. i Foucaultovo (1998: 149) suprotstavljanje kartezijanskog ,ja mislim“, usmjerenog prema unutra u potrazi za sigurnim temeljem subjekta, s rečenicom ,ja govorim“, koja otvara vrata disperziji jezika i subjektnih pozicija.
} 
na vlastitu netransparentnost i granice mimetičkih prijenosa, Foucault (isto: 133) ilustrira primjerima Bataillea, Blanchota i Klossowskog ${ }^{271}$, što ne znači da transgresivnost jezika i odsutnost središta kao svojstva ograničava na avangardnu književnost. Potonju tek smatra diskurzivnom praksom što (ponajbolje) razotkriva neka opća svojstva ${ }^{272}$.

Upravo zato Foucault se suprotstavlja onome što naziva uvriježenim mišljenjem da autoreferencijalno udvostručenje, koje je odlikuje, modernoj književnosti „omogućuje da se interiorizira do krajnosti (do stanja ničega drugoga do li sebe)“, tvrdeći da je ona „samo površinski interiorizacija“, a zapravo „daleko više stvar prolaska do 'vanjskoga': jezik što izbjegava modus bivanja diskursom - dinastiju reprezentacije..." (Foucault, 1998: 148) 273 Drugim riječima, književnost je diskurs koji ne odlikuje autistična zatvorenost u sebe, već činjenica da zahvaljujući vlastitom autoreferencijalnom pregibanju, transgresivnom istraživanju granica, razotkriva kontingenciju kako eksplicitnih, tako još i više implicitnih ograničenja $^{274}$ što ih svi pojedinačni diskursi nameću bezgraničnom jeziku. Odnosno, u podlozi uspostavljenih diskursa ona razotkriva literarnost kao temeljnu demokraciju pisma, jednakost u jeziku.

No ako su Foucaultovi radovi o književnosti, kako smo već napomenuli, svojom perspektivom bitan komplementaran čimbenik ostatku njegova opusa, jednako bi se tako za pojedina kratka tematiziranja književnosti u njegovim ne-književnim studijama moglo ustvrditi da su minimalan, iako koristan dodatak književnim studijama. Naime, i kod autora koje smo prethodno analizirali slika književnosti ipak se u konačnici nije pokazala crnobijelom, tj. jasno se pokazalo da su, bez obzira što se prevladavajuće fokusiraju na mesijansku dimenziju književnosti odreda svjesni kompleksnosti odnosa koje književnost u određenim

\footnotetext{
${ }^{271}$ U konkretnom tekstu Foucault (1998: 133) se referira na poigravanje simulakrumima kod Klossowskog, Batailleevu desakralizaciju, odnosno profanaciju, te Blanchotovo zaokupljanje adresiranjem smrti. Tome bi se mogao dodati i primjer Sadea te gotičkih romana koji koristi u drugom kontekstu, govoreći o njima kao prijelomnici u nastanku književnosti (isto, 94-95, 97), pri čemu su oba primjera ponovno suprotnost tipičnom mimetičkom jeziku - prvi utoliko što bjesomučnim ponavljanjem iscrpljuje jezik i pomiče granice izgovorivog nastojeći imenovati ono što se ne može imenovati, a drugi obrnuto, utoliko što osiromašuju jezik nastojeći ga ogoliti do čiste emocije; straha, užasa, suosjećanja. Čitavu je problematiku moguće povezati sa sličnim primjerima koji su usporedno zaokupljali i Deleuzeove analize književnosti što odustaje od opisa i nastoji iskazati suvišak ili otići s druge strane granice jezika.

${ }^{272}$ U Arheologiji znanja npr. eksplicitno komentira da književnost, kod koje smo već stekli naviku odvajati subjekt iskaza od raznih izvanjskih figura izvora, prvenstveno autora - po tom pitanju nije aberacija, nego samo dobar primjer situacije koja vrijedi i za ostale diskurse. V. Foucault, 2010: 93-94. Usp. također i Duringovu (1992: 116) tvrdnju da je književnost ono što omogućuje arheologiju, no istovremeno joj i izmiče.

${ }^{273} \mathrm{O}$ razlici između konačnog diskursa - ma kako difuznog, te beskonačnog jezika usp. Brlek, Koludrović; 2015: 3 .

${ }^{274}$ Foucault (1998: 157) napominje da je nemoguće „poznavati zakon i doista ga iskusiti“, „natjerati ga da izađe na vidjelo, da jasno pokaže svoju moć“ bez da ga se „provocira, proganja do povlačenja, bez da se rezolutno ide i dalje u vanjštinu u koju se on uvijek povlači“, drugim riječima bez transgresije. Foucault dakle i tu uočava implicitnost i neopazivost određenog (diferencijalnog) poretka sve do trenutka u kojem je doveden u pitanje.
} 
historijskim trenucima može uspostavljati, uključujući i one suprotne emancipatornim. Slično tako i kod Foucaulta, često na marginama studija posvećenih drugim temama, nailazimo na određene korektive i ograničenja transgresivne dimenzije književnosti.

Najpoznatiji primjer koji se uvelike tiče književnosti, a bavi se ne njezinom transgresivnom stranom, već onom ,policijskom“, nije rubna opaska u nekoj od drugih studija, nego Foucaultovo poznato i prethodno već spominjano predavanje Što je autor?. U njemu jasno ističe osobitu povezanost autora-funkcije kakvog opisuje s institucijom književnosti u modernom društvu (nasuprot stanju prije; usp. Foucault, 1998: 212), te kritici izlaže navodnu smrt autora u korist koncepta pisma, kao onog što ,,samo premješta empirijske karakteristike autora u transcendentalnu anonimnost.“ (isto: 208) Nasuprot takvoj transcendentalizaciji izvora autor-funkcija, kao način klasifikacije i osiguravanja koherentnosti diskursa $\mathrm{u}$ konkretnoj historijskoj situaciji, za Foucaulta je put povratka historijskom, ne-idealnom i ne-esencijalističkom proučavanju diskursa (isto: 220), no u svakom se slučaju istovremeno radi o perspektivi suprotnoj onoj koja je u svom fokusu zadržavala prvenstveno transgresiju.

No Foucault je očito svjestan i činjenice da književnost, bez obzira na to što očuđujućim djelovanjem potkopava vlastitu mimetičku dimenziju, jednako tako može i omogućivati, pa čak i poticati prepoznavanje i poistovjećivanje, odnosno ona može osim kao poprište raspršivanja subjekta poslužiti i kao mehanizam subjektivacije. Tako u Nadzoru $i$ kazni ističe da je književnost, sa svojim ambivalentnim učincima na tom polju, bila svojevrsno bojno polje u oblikovanju te difamaciji ili glorifikaciji kriminalnog subjekta (usp. Foucault, 1995: 57). U prvom svesku Povijesti seksualnosti pozornost pak skreće na međuodnos priznanja kao temelja buduće scientie sexualis i na nju oslonjene biomoći te određenih preobrazbi u književnosti koje su je „od zadovoljstva u pripovijedanju i slušanju koje je usredišteno na junačkoj ili čarobnoj pripovijesti o neustrašivim ili svetačkim 'kušnjama'“ usmjerile prema „,beskrajnoj zadaći da se iz dubine samoga sebe, između riječi, izvuče istina, koju sama forma priznanja prikazuje kao nedostižnu“ (Foucault, 2013: 54), što je u svakom slučaju pridonijelo etabliranju i rasprostranjenju te forme. Konačno, vrijedi skrenuti pozornost i na ulogu romana u subjektivaciji u okvirima pastoralne moći kojom se Foucault bavio u kasnom razdoblju svog stvaralaštva; naročito određenih romana (sentimentalnih, npr.) u tvorbi određenih subjekata (građanskih ženskih, npr.), kako to podcrtava During (1992: 174).

Jedna perspektiva dakako ne isključuje drugu, niti se pak radi o dvije oštro razdvojene vrste književnosti, pri čemu bi jedna bila emancipatorna i ukazivala na kontingenciju poretka i 
granica diskursa, a druga upregnuta u podlaganje kompleksu diskursa-moći. Riječ je, naprotiv, o dvama (potencijalno različito naglašenim) aspektima složenog odnosa koje svako djelo uvijek iznova uspostavlja sa svojom historijskom okolinom - neposrednom unutardiskurzivnom, kao i onom širom. A upravo istraživanje tog međuodnosa općenito, vidjeli smo, ovisno o kutu gledišta može se prepoznati i kao ono što Foucaulta čini teoretičarom kontrole, i kao ono što ga čini teoretičarom emancipacije; odnosno i kao ono što povezuje njegov istraživački rad s marksističkim nasljeđem, i kao ono što ga povezuje s postavkama koje se pridružuju nazivniku postmarksizma (pri čemu te dvije opreke ne treba uzeti sinonimno!). No pritom se ni tu ne radi o diskretno odvojenim binarnim oprekama, već složenom sustavu presjeka i odmaka $u$ odnosu na koje se par politike i književnosti/literarnosti još jednom pokazao prikladnom zglobnicom i središnjom niti opisa. Takvo pozicioniranje književnosti između emancipacije i kontrole, između mehanizama subjektivacije te njihova razotkrivanja, kao i mreža odnosa što smo je skicirali među autorima kojima smo se prethodno pozabavili, sugeriraju nam ujedno i smjer u kojem valja nastaviti ovu analizu. 


\subsection{Tri odnosa književnosti i ideologije kod Pierrea Machereya}

Samo jedna od dosadašnjih studija o postmarksističkoj teoriji, ona Goldsteinova (2005), u svoj je fokus uzela i Pierra Machereya. To da je njegov opus ostao nezapažen u ostalim studijama moglo bi biti rezultat prvenstveno dvaju faktora. S jedne strane radi se o činjenici da su se Machereyeva kasnija djela slabije prevodila i da je stoga ne-francuskoj akademskoj javnosti uglavnom poznat po svojoj studiji Teorija knjževne proizvodnje (1979) [Pour une théorie de la production littéraire, 1966], koja se svojim postavkama nije uklapala $\mathrm{u}$ kriterije kojima se vodila većina ranijih istraživanja. S druge strane tu je i već spominjano zanemarivanje književne/književnoteorijske problematike u korist političke teorije: iako je u Machereyevu opusu moguće prepoznati nekoliko tematskih žarišta ${ }^{275}$, književna je teorija nesumnjivo jedno od značajnijih, dok se političkom teorijom u užem smislu nije izravno bavio. U ovom ćemo poglavlju stoga učiniti svojevrstan zaokret u odnosu na prethodna: umjesto polaska od političke teorije prema književnoj teoriji, tj. od literarnosti/diskurzivnosti politike prema političnosti književnosti, izvrnut ćemo perspektivu i poći od potonjega.

Kada se analiza započne tematikom književnosti, potreba da se Macherey uključi u istraživanje postmarksističke teorije postaje očiglednija, no pitanja i izazovi što proizlaze iz heterogenosti njegovog opusa time nisu anulirani. I sam Macherey u retrospektivnom tekstu Soutenance iz 1991. za vlastiti opus kaže kako ga se na prvu može okarakterizirati „zbrkom divergentnih radova“" (Macherey, 1998: 17) te da ta divergencija „doista svjedoči o načinu na koji se proces istraživanja odvijao, akumulacijom incidenata prije nego u duhu kontinuiteta“, bez nekog zadanog dogmatskog nacrta ili krajnjeg telosa, no istovremeno ipak smatrajući da se u podlozi disparatnosti retrospektivno može prepoznati određena nužnost i skriveni red. Prihvatimo li taj oris skrivenog reda što ga sam nudi, ulogu značajnog sjecišta divergentnih pravaca nesumnjivo zauzima Machereyevo istraživanje književnosti. U turbulentnim kretanjima koja gore opisuje može se pak, možda i jasnije nego u genealogiji pozicija autora iz prethodnih poglavlja, pratiti pomak od pozicije koja se uobičajeno smatra marksističkom do one koja se smatra postmarksističkom. Odnosno, ona jasno svjedoče o notornoj nediskretnosti granice između tih dviju domena i problematičnosti pokušaja da se ona diskretno povuče.

Macherey je naime akademsku karijeru započeo pod Althusserovim mentorstvom, kao jedan od njegovih bliskih suradnika na projektu Kako čitati Kapital (na kojem je radio i mladi Rancière) te član kružoka Althusserovih „učenika“" kojem je povjereno bavljenje pitanjem

\footnotetext{
${ }^{275}$ Macherey (1998: 18) izdvaja tri žarišta svog opusa: „spinozizam“, odnos književnosti i filozofije te historiju filozofije u Francuskoj.
} 
književnosti ${ }^{276}$. Kapitalni proizvod tog bavljenja, uz nekoliko kraćih pojedinačnih rasprava, spomenuta je Machereyeva studija Teorija knjževne proizvodnje, koja već samim okolnostima nastanka dobila etiketu paradigmatskog primjera althusserijanske teorije književnosti. Tako i Goldstein (2005) u poglavlju posvećenom Machereyu prikaz drastične transformacije njegovih teorijskih stajališta oslanja na dvije ključne točke: Teoriju književne proizvodnje kao još uvijek prilično marksističku studiju, te gotovo četvrt stoljeća kasniju $O$ čemu misli književnost [A quoi pense la littérature, 1990] $]^{277}$ kao primjer tipične postmarksističke studije. No premda se za prikaze Machereyeva opusa kroz takvu binarnu opreku ne može reći da su posve pogrešni, oni su u najmanju ruku suviše pojednostavljeni, budući da zanemaruju nekoliko relevantnih čimbenika.

Kao prvo, kako bi se naglasila oštrina navodnog kopernikanskog zaokreta, velikim dijelom izvan fokusa ostaju nezanemarive poveznice koje postoje između dviju spomenutih studija. Nadalje, takva perspektiva izostavlja najmanje još jedan „,međukorak“ u razvoju Machereyeve konceptualizacije književnosti, kao i diskurzivnu okolinu svake od ključnih točaka, budući da bi u protivnom njezina binarna struktura postala narušena. Konačno, suzimo li pogled na prvu od studija, u sjeni naglašavanja althusserijanskog konteksta nastanka Teorije književne proizvodnje vrlo često ostaju i oni njezini aspekti koji nedvojbeno odudaraju od althusserijanskih postavki, ili pak pripadaju onim njihovim segmentima koji i sami prekoračuju granice tradicionalnih marksističkih okvira. No prije negoli krenemo u razmatranje tih stavki obrnutim redoslijedom, od potonje prema prvoj, na trenutak ćemo skrenuti pozornost prema Althusserovu razmatranju književnosti i općenito umjetnosti koje je bilo polazište Machereyeve analize, kako bismo je bolje razumjeli.

Althusserovo viđenje umjetnosti i književnosti moguće je izvesti iz triju njegovih manje poznatih studija: „Piccolo Teatro “: Bertolazzi i Brecht $[1962]^{278}$, Pismo o umjetnosti [1966] te Cremonini, slikar apstraktnog $[1966]^{279}$. No premda ta tri teksta tvore razmjerno koherentnu perspektivu, istovremeno su u djelomičnom proturječju s kasnijim, a vjerojatno pojedinačno najpoznatijim Althusserovim tekstom - Ideologijom i državnim ideološkim aparatom. U tom tekstu Althusser (2001: 96) naime književnost i općenito umjetnost navodi kao segmente jednog od državnih ideoloških aparata, onog kulturnog. Nasuprot tomu, u ranijem će Pismu o umjetnosti od umjetnosti učiniti iznimku u odnosu na ostale elemente

\footnotetext{
${ }^{276}$ Usp. Macherey, 1998: 3 i Goldstein, 2005: 82.

${ }^{277}$ Studiju smo ovdje čitali u engleskom prijevodu koji je objavljen pod nešto drukčijim naslovom, The Object of Literature. Vidjeti Macherey, 1995.

${ }^{278}$ Usp. Althusser, 1996.

${ }^{279}$ Usp. Althusser, 2001.
} 
ideološke nadgradnje eksplicitno tvrdeći: „Ne ubrajam pravu umjetnost u ideologiju, premda umjetnost doista ima vrlo osobit i određen odnos s ideologijom." (Althusser, 2001: 151) Rješenje naizgledne kontradikcije možda je u atributu „prava“, tj. u činjenici da Althusser kao i autori kojima smo se prethodno bavili - očito ne izuzima od funkcije reprodukcije vladajuće ideologije svu književnu, likovnu i inu produkciju po sebi, već samo one njezine segmente koje smatra „autentičnom umjetnosti“ (nasuprot „djelima prosječne ili osrednje razine“, usp. isto: 152). Kao što u još ranijoj studiji o Brechtu i Bertolazziju piše, „i u kazališnom svijetu, kao i u estetičkom svijetu općenito, ideologija je u biti uvijek mjesto natjecanja i borbe u kojoj krik i bijes političkih i društvenih borbi čovječanstva odjekuje jedva ili oštro“ (Althusser, 1996: 149), što bi impliciralo da ni učinak po pitanju raskrinkavanja ili reprodukcije ideologije očito nije uvijek isti.

No ostavimo li po strani to potencijalno problematično pitanje i usredotočimo li se na tri ranije spomenute studije, ono što im je nesumnjivo zajedničko jest kritika i „estetike konzumacije“ i „estetike stvaranja“ (Althusser, 2001: 158) kao različitih strana istog novčića, tj. tumačenja i vrednovanja umjetnosti bilo sa stanovišta recepcije i potrošnje, bilo sa stanovišta romantičarskog privilegiranja stvaralačkog čina, a u korist umjetnosti kao artefakta što mimo izvorišne autorske intencije apstrahira i razotkriva življene odnose u određenom trenutku historije. Drugim riječima, umjetničko djelo „čini vidljivim stvarnost postojeće ideologije (bilo kojeg od njezinih oblika), uspostavljajući distancu u odnosu na nju“ (isto: 166), odnosno „osobitost je umjetnosti da nas 'navodi da vidimo', 'navodi da percipiramo', 'navodi da osjetimo' nešto što izmiče stvarnosti“, a to nešto je ,ideologija iz koje se [umjetnost] rađa, u kojoj se kupa, iz koje se izdvaja kao umjetnost te kojoj izmiče.“ (isto: 152)

Ipak, raskrinkavanje ideologije koje omogućuje umjetnost nije ekvivalentno onome koje omogućuje znanost; ,umjetnost (...) ne zamjenjuje znanje u užem smislu, dakle ne zamjenjuje znanje (u modernom smislu: znanstveno znanje), no ono što nam ona pruža ipak održava specifičan odnos sa znanjem.“ (Althusser, 2001: 152) Tom tezom Althusser definira tripartitan odnos među znanosti, ideologijom i umjetnosti u kojem umjetnost zauzima svojevrsnu posredničku ulogu između ostalih oblika ideologije te herojski oslikane marksističke znanosti: iako i sama oblik ideologije i uronjena u ideologiju, u stanju je zauzeti

\footnotetext{
${ }^{280}$ Pritom za opsežniju elaboraciju tog odnosa Althusser (2001: 151) čitatelja upućuje na Machereyev članak o Lenjinu i Tolstoju.
} 
distancu spram nje i tako pružiti pomoću osjećaja uvid u stvarne historijske odnose ${ }^{281}$, no ne i preraditi ideološki materijal u konceptualno znanje kako je to u stanju marksistička znanost.

Takvu tripartitnu podjelu među ideologijom, književnosti i znanosti, baš kao i relacijsko, historijsko određenje književnosti, prihvatio je potom u razradi svoje ranije teorije književnosti i Macherey, no već zarana kritizirajući pojedine Althusserove postavke. Primarne mete njegove kritike, $\mathrm{u}$ suprotnosti spram kojih gradi argumentaciju Teorije književne proizvodnje, glavninom su pak dva naizgled dijametralno suprotna teorijska strujanja - s jedne strane različite inačice teorije odraza, odnosno mehaničke determinacije književnosti historijskim kontekstom, a s druge strukturalistička imanentna kritika.

Analizirajući različite pristupe određenju i analizi književnog djela, Macherey (1979: 39) zaključuje da su „transcendentna kritika i imanentna kritika“ jednako „uzaludne“, budući da „i jedna i druga teže da rastoče objašnjenje stvarne kompleksnosti djela“, odnosno da je „strukturalizam bliži nego što se misli mehaničkoj teoriji odraza“ (isto: 47) utoliko što oba pristupa reduciraju književno djelo na jedinstveno središte. Tomu nasuprot, za Machereya (isto: 48 ), ,s/poznati uvjete neke proizvodnje ne znači svesti proces te proizvodnje na puki razvoj klice u kojoj bi cijelo kretanje mogućeg bilo jednom za svagda anticipirano, u genezi koja je samo obrnuta slika analize.“ Drugim riječima, „knjiga se ne gradi kao produžetak jednog smisla, već polazi od inkompatibilnosti više smislova, što joj je i najčvršća veza s realitetom u zategnutom i uvijek obnavljanom sučeljenju.“ (isto: 73)

Upravo na tom tragu Macherey kritizira i Althussera, i to - kako navodi Montag (usp. Macherey, 1998: 7) - isprva u privatnoj korespondenciji, u kojoj je Althusser kritiku svog učenika primio s uvažavanjem, a potom preselivši kritička zapažanja u vlastite studije o književnosti. U potonjem slučaju radi se prvenstveno o Althusserovoj uporabi koncepta latentne strukture djela u analizi Bertolazzija i Brechta (Althusser, 1996: 141-142), koja je u konfliktu s četiri godine kasnijom Machereyevom kritikom strukturalističke koncepcije strukture uopće, u kojoj Macherey tvrdi da

/a/ko postoji struktura, ona nije u knjizi, duboka ili skrivena: knjiga joj pripada ne sadržavajući je. Činjenica da djelo može biti svedeno na strukturu ne implicira da je ono samo jedinstveno; struktura utoliko bolje drži djelo ukoliko je djelo raznoliko, raspršeno, nepravilno: vidjeti strukturu znači vidjeti tu nepravilnost. (Macherey, 1979: 133)

Machereyeva kritika usidrene strukture, odnosno usidrenja djela pomoću strukture, značajna je i izvan konkretnog konteksta rasprave o književnosti utoliko što se u raspravi s

\footnotetext{
${ }^{281}$ Nasuprot stvarnih odnosa u pozadini do kojih jedino može doprijeti marksistička znanost, ideologiju u toj fazi svog opusa Althusser (1996: 233-234) definira kao življeni odnos prema svijetu, odnosno kao nadodređenje stvarnog imaginarnim i imaginarnog stvarnim.
} 
Althusserom poziva na znatno općenitije uvide Spinoze i Deleuzea (usp. Macherey, 1996: 7), kao i jer kritika Althusserova koncepta latentne strukture nije ograničena samo na književnoteorijsku domenu, budući da je isti koncept vrlo važan i za Althusserovu analizu u Kako čitati Kapital (1975, usp. naročito 188-205).

Vratimo li se pak književnosti, Macherey (1979: 81) namjesto kretanja od središta, kao mjesta „gdje [djelo] pretendira da postiže svoju puninu“, ali jednako tako i namjesto kretanja od nekog drugog, izvanjskog mjesta, sugerira kako valja ,pretpostaviti da djelo ima svoje margine, ono što u njemu još nije potpuno takvo, u čemu se može vidjeti njegov nastanak, njegova proizvodnja.“ Drugim riječima, tvrdi da ,/s/misao nije u djelu, već pored njega: na njegovim rubovima, na onoj granici gdje djelo prestaje biti ono što hoće biti, jer je tu ono upućeno na uvjete svoje mogućnosti. Ono tada nije više konstituirano varljivom nužnošću (proizvodom namjere, svjesne ili nesvjesne).“ (isto: 136) Traženje uzroka - u vidu osobne intencije ili neosobne strukture u podlozi djela - tako bi se, smatra, zamijenilo traženjem zakona njegove proizvodnje.

Izmještanje određujućeg čimbenika djela iz neke od varijacija središta u produktivni rad oko njega, tj. koncepcija strukture kao onoga „što izvana lišava djelo njegove pogrešne interiornosti (...) i uspijeva predočiti tu temeljnu grešku bez koje ono ne bi postojalo“ (Macherey, 1979: 136), očigledno se dakle udaljava od udžbeničkih inačica i marksizma i strukturalizma, kao odrednicama koje se uobičajeno vezuju uz tu Machereyevu fazu (najčešće i u kombinaciji - kao strukturalistički marksizam), a anticipira klasike poststrukturalističke misli, poput onih kojima smo se bavili u prošlim poglavljima. Slično je i s pozicioniranjem u odnosu na opreku konceptualizacije književnosti kao autonomne prakse ili kao determinirane bazom. Macherey (isto: 51) napominje da „ne treba brkati autonomiju i nezavisnost“; djelo bi bez relacije s okolinom bilo nečitljivo i neshvatljivo, no istovremeno je u toj relaciji relativno autonomno.

Ipak, nalik proturječju između Althusserovih principa nadodređenja te determinacije bazom u krajnjoj instanci, i Machereyeva oscilacija između autonomije i determiniranosti književnosti, odnosno afirmacija margine nasuprot unutrašnjeg ili vanjskog određenja u konačnici često otkliže prema determinaciji ekonomskim. Tako u svojoj kritici Šklovskog Macherey (1979: 40) odbacuje „zaustavljanje na postupku“ kao ni iz čega izabranoj formi, zahtijevajući da se umjesto toga ide do pravog rada koji se obavlja na materijalu što se preuzima iz povijesnog svijeta i koji je kao takav ograničen ulogama koje može preuzeti i značenjima koje može proizvesti. Premda istovremeno inzistira da su ti elementi međusobno proturječni jer dolaze iz različitih konteksta, te da im djelo ne osigurava nikakvo više 
jedinstvo, svojevrstan Aufhebung, već naprotiv ukazuje na proturječja, određenje izvanjskim nedvojbeno ipak dolazi u prednost. Još jasnije to naglašava kasnije u studiji, raspravljajući o „nesvjesnom djela“ (isto: 82-83) koje se kao koncept razlikuje od (psihoanalitičkog) autorova nesvjesnog, te koje je analogno „odnosu na koji ukazuje Marx kad zahtijeva da se iza svakog ideološkog fenomena sagledaju materijalni fenomeni koji proizlaze iz baze društva“. Unatoč tome što se i tu nastoji ograditi od mehaničke refleksije ističući da to ne znači da bi se pojava nekog ideološkog fenomena trebala objasniti ,jednostavnom emanacijom iz baze, što bi se svodilo na konstataciju da je ideološko u stvari ekonomsko u drugom obliku“, „debatu“ o ekonomskim kretanjima ipak naziva „debatom debate“ (isto: 83), konačnom točkom analize svakog ideološkog fenomena, pa tako i književnosti.

Ograničenja tako čvrstog usidrenja književnog djela u njegov izvorišni historijski kontekst, kao i poteškoće da se pritom diferencira od potonuća u tek nešto sofisticiraniju teoriju odraza, naročito su dobro vidljivi kada Machereyeva analiza dođe do teme učinaka (konkretnih) književnih djela, odnosno do ranije ocrtane tripartitne sheme ideologije, književnosti i znanosti. Naime, pronalazeći u autoreferencijalnosti književnog diskursa konstitutivnu značajku književnosti istovremeno zaslužnu za njezinu (relativnu) autonomiju, ali i povezanost s drugim diskursima i stvarima (usp. (Macherey, 1979: 43-44; 57), Macherey takav književni diskurs smješta u naročit parodijski odnos spram ideološkog i znanstvenog diskursa:

Svojom snagom i svojom slabošću taj diskurs oponaša teorijski izraz, čiju čvrstu liniju ponavlja, iako je točno ne reproducira. Ali svojom evokativnom funkcijom, koja mu omogućava da označi specifičnu realnost, on također imitira svakodnevni jezik, koji je jezik ideologije. Mogla bi se predložiti privremena definicija književnosti karakterizirajući je tom parodičkom funkcijom. Miješajući stvarne upotrebe jezika ona završava tako što, pomoću tog neprekidnog sučeljavanja, pokazuje njihovu istinu. Eksperimentirajući na jeziku, iako ga ne izumljuje, književno je djelo istovremeno analogno spoznaji i karikatura obične ideologije. (Macherey, 1979: 57)

Koncepcija književnosti kao jezičnog eksperimenta, istraživanja granica jezika, čiji je izravan učinak oduzimanje „prividne spontanosti“ (Macherey, 1979: 57) ideološkom diskursu velikim je dijelom analogna koncepcijama koje smo analizirali u prethodnim poglavljima, doima se kao njihova anticipacija te na prvi pogled podjednako sretno balansira između binarnih krajnosti koje smo ranije istaknuli. No ono što ih značajno razlikuje nije samo Machereyevo inzistiranje na razlici između književnosti i znanosti u njihovim odnosima spram ideologije, te inferiornosti prve u odnosu na drugu ${ }^{282}$, nego i veći stupanj zatvorenosti

\footnotetext{
${ }^{282}$ Macherey (1979: 61) piše: „Treba još dodati da ona ne može zauzeti mjesto spoznaje. Međutim, postavljena u neadekvatno, ona nalazi sredstvo da u njemu počne kretanje, da preobrazi odnos prema ideologiji: ne da
} 
distancirajućeg i očuđujućeg učinka književnosti u historijske okvire nastanka djela u Machereyevim analizama konkretnih primjera.

Primjerice, kao ilustracija ranijeg Machereyeva pristupa književnosti najčešće se navodi njegovo čitanje romana Julesa Vernea. U njemu Macherey provodi dva koraka koja smatra ključnima za svaku književnu analizu - rekonstrukciju, ponovno sabiranje i prepoznavanje konstitutivnih elemenata nekog djela, a potom njegovo upisivanje u ideološku historiju (Macherey, 1979: 83), tj. analitički zahvaća dvostruku artikulaciju djela - na razini sekvenci/fabule i tema/figura koja daje iluziju reda, i kojom se prema njemu većinom bave različite estetske teorije, te na razini artikulacije odnosom s određenom ideološkom stvarnosti (isto: 137). Analiza Verneove figuracije i fabulacije pripovjednog materijala (usp. isto 162163) otkriva pak proturječja poput onog između sadržaja pripovijesti o pravocrtnom napretku te konkretne pripovjedne realizacije koja taj napredak pokazuje samo kao prolazak putem kojim se uvijek već kročilo i povratak na stare pozicije ${ }^{283}$; proturječje za koje Macherey (isto: 167) smatra da je „doslovce odraz protuslovlja u ideološkom planu.“

Potencija analitički svakako zanimljive divergencije sadržaja i forme djela tako se, bez obzira na Machereyevu upornu kritiku mehanicizma teorije odraza, ipak naziva odrazom, te većim dijelom zatvara u ograničen historijski kontekst: to nas literarno proturječje, prema Machereyu, tek osvješćuje (osjećajem/viđenjem, ne znanstvenom spoznajom) o proturječju između življenog odnosa prema stvarnosti i istinskih odnosa u stvarnosti određenog razdoblja - u konkretnom slučaju široko zahvaćenog kapitalizma. Premda je kapitalistička pripovijest o napretku prostorno-vremenski već izrazito protežna, pa isto vrijedi i za trajnost učinaka Verneovih pripovijesti, one su ipak svedene na slikovito razotkrivanje proturječja ideologije $i$ stvarnosti u vremenu svog nastanka i u tome se njihovo djelovanje iscrpljuje.

Još izrazitiji primjer obaju problema Machereyeva je analiza Lenjinova čitanja Tolstoja, u kojem Macherey pribjegava elaboriranim verbalnim akrobacijama kako bi ublažio naglašenu uporabu metafore zrcala u Lenjinovu čitanju i tako izbjegao etiketu teorije odraza. Tako izrijekom inzistira na tome da ,/k/njiga ne može neposredno doprijeti do povijesne zbilje: između nje i povijesne zbilje postoji niz posrednika. (...) Knjiga nije neposredan odraz stvarnosti i nema, dakle, spontanosti značenja...“ (Macherey, 1979: 105) Zato ni Lenjinovo

\footnotetext{
preobrazi ideologiju samu, što je nemoguće (ideologija koja se, po prirodi, uvijek nalazi drugdje ne zauzima nikakvo pravo mjesto; ona se, dakle, ne može doista reducirati). Zato što je lažna, fikcija nas zloupotrebljava; ali ta varka nije početna, jer se i sama odnosi na jednu korjenitiju lažnost, koju pokazuje i odaje, pridonoseći tako da se nje oslobodimo. (...)Treba, dakle, razlikovati tri oblika što ga jeziku daju tri različite upotrebe: iluziju, fikciju, teoriju. Gotovo iste riječi tvore ta tri diskursa. Ali između tih riječi uspostavljaju se neusporedivi odnosi, toliko odvojeni da je nemoguće bez raskida prijeći s jednog na drugi.“

${ }^{283}$ Usp. Macherey, 1979: 204 za opsežniju rekapitulaciju analize Vernea.
} 
zrcalo ne može biti tek obično zrcalo: „Ogledalo je, dakle, ogledalo tek prividno; bar se zrcali na način koji pripada samo njemu. Nije riječ o bilo kojoj površini koja odražava. Više nego na laku ideju jedne deformacije, Lenjin misli na ideju fragmentacije slike. Nije li ogledalo razbijeno ogledalo?“ (isto: 107) No bez obzira na to, Macherey se ne uspijeva distancirati od teze da Tolstojevo djelo odražava, makar na kompleksan i neizravan način, uvjete u kojima je nastalo i ideologiju tog doba (isto: 103), a pritom je njegov uvid nepotpun, jer kad bi Tolstoj dao potpun (dakle znanstven) uvid, „,ne bi više bio pisac, nego bi se odredio novim odnosom prema znanju i povijesti.“ (isto: 100)

Sve u svemu, Machereyeva ranija teorija književnosti po mnogočemu je daleko od neproblematičnog smještanja u tradicionalno shvaćenu marksističku domenu i oštrog odvajanja od autora kojima smo se bavili u prošlim poglavljima, no istovremeno je od njihovih pogleda razlikuje manja djelatna ovlast koju dodjeljuje književnosti, odnosno činjenica da je doživljava više kao razotkrivajuću prizmu čiji emancipatorni učinci ovise o čitanju protiv struje koje provodi neki marksistički znanstvenik, svojevrsnoj varijaciji Althusserova simptomatskog čitanja ${ }^{284}$, nego imanentno politički fenomen koji aktivno mijenja uspostavljene odnose. U pozadini te razlike nesumnjivo je najvažniji faktor još uvijek nedovoljno prevladan ekonomski determinizam, a očita je posljedica otklizavanje prema teoriji odraza koju je, vidjeli smo, istovremeno podvrgnuo valjanoj teorijskoj kritici.

Sljedeća značajna točka Machereyeva teorijskog razvoja kojom ćemo se ovdje kratko pozabaviti dodijelila je književnosti pak u puno većoj mjeri ulogu agensa, no istovremeno je posve izmjestivši iz domene emancipacijskog. U tekstu Književnost kao ideološki oblik. Nekoliko marksističkih hipoteza [Sur la littérature comme forme idéologique. Quelques hypothèses marxistes, 1974], koji je Macherey objavio u suautorstvu s Etienneom Balibarom (usp. Macherey, Balibar; 2012), dogodio se naime kopernikanski obrat njegova pogleda na književnost koji se teško može apsorbirati u dosadašnje sheme prikaza njegova opusa, pa je iako intrigantan - vjerojatno dobrim dijelom zbog toga ostao izvan analitičkog fokusa ${ }^{285}$.

Oslanjajući se s jedne strane na Althusserovu teoriju o državnim ideološkim aparatima, a s druge na istraživanja francuskog školskog sistema koja su provodili Renée Balibar i suradnici, Macherey je naime književnosti $u$ tom tekstu namjesto uloge

\footnotetext{
${ }^{284}$ Takva koncepcija, jasno je, rezultira dolaskom analitičara, tj. marksističkog znanstvenika, u superioran položaj, što odgovara teorijskoj poziciji koju je kao tipičnu za Althussera kasnije kritizirao Rancière (usp. Rancière, 2011a).

${ }^{285}$ Goldstein (2005: 85) u svojoj studiji Književnost kao ideološki oblik ukratko tretira kao poveznicu između prve i druge faze Machereyeva rada koje ocrtava, no pritom naglašavajući tobožnju kritičko-refleksivnu dimenziju književnosti koja ostaje prisutna i u tom tekstu, što je prilično u suprotnosti sa stvarnim rasporedom naglasaka u njemu. Bennett ga (1979: 12-13) pak spominje tek na jednom mjestu kao primjer kritike tradicionalnog esteticizma u prethodnoj marksističkoj književnoteorijskoj produkciji.
} 
raskrinkavanja ideologije dodijelio ulogu izrazito važnog „agensa reprodukcije ideologije“ (Macherey, Balibar; 2012: 12). Iako je pritom nove zaključke pokušao dovesti u kontinuitet s Teorijom književne proizvodnje (usp. isto: 8), te iako određene poveznice između dviju studija i dviju faza konceptualizacije književnosti doista nedvojbeno postoje, jaz između njih ipak je nemoguće zanemariti.

Ono što dvjema studijama jest zajedničko inzistiranje je na specifičnosti i autonomiji književnosti kao fenomena nadgradnje, koji se ni u Književnosti kao ideološkom obliku ne može svesti na „moral, religiju, politiku itd.“ (Macherey, Balibar; 2012: 12) Nadalje, i u potonjoj studiji književnost je konstitutivno određena svojim odnosom „unutarnje kontradikcije“" s historijom, kako ga Macherey (isto: 6) naziva, odnosno njezinim ideološkim prelamanjem. No za razliku od Teorije književne proizvodnje, u njoj se taj odnos ne ostvaruje primarno kao raskrinkavanje ideologije, nego kao njezina reprodukcija funkcionalnom upregnutošću u državne ideološke aparate (isto). Nadalje, Macherey jednako tako više ne zauzima ni kritičku distancu spram teorije odraza per se, nego samo upućuje na njezino često iskrivljavanje i banalizaciju te slijedom toga potrebu za rekonceptualizacijom (isto: 5).

No u takvom zaokretu osobito je zanimljiv detalj činjenica da Macherey sada jezgrovito i eksplicitno - nakon implicitnog određenja koje se moglo izlučiti iz dulje rasprave o književnoj činjenici u prethodnoj studiji - definira literarnost, i to na način koji je paradoksalno blizak i odmaknut od autora kojima smo se prethodno bavili. „Literarnost je“, smatra, „ono što je prepoznato kao takvo, a prepoznato je kao takvo točno u onom trenutku i opsegu u kojem aktivira interpretacije, kritiku i 'čitanja'.“" (Macherey, Balibar, 2012: 11) Iza (i neposredno oko) takve definicije nalazi se zapravo odbacivanje različitih estetičkih pristupa književnoj činjenici i esencijalističkih definicija literarnosti, odnosno relacijsko određenje nalik onima s kakvim smo se i prethodno susreli, u kojem literarnost nije neko osobito svojstvo književnog teksta, nego naprosto jednakost riječi naglašena uporabom jezika koja je izvučena izvan diskurzivnih normativnih okvira ${ }^{286}$.

Velika je razlika, doduše, to što promišljanje koje takav začuđujući efekt pobuđuje za Machereya u ovoj fazi više ne služi oduzimanju ,prividne spontanosti“ (Macherey, 1979: 57), već „izazivanju drugih ideoloških diskursa koji se ponekad mogu prepoznati kao literarni, no koji su uglavnom samo estetički, moralni, politički ili religiozni diskursi u kojima se ostvaruje

\footnotetext{
${ }^{286}$ Hibridizacija obilježja različitih diskursa, koja je u Teoriji književne proizvodnje označena kao „parodička funkcija književnosti“ (Macherey, 1979: 57) važna je stavka i u Književnosti kao ideološkom obliku (Macherey, Balibar, 2012: 10), samo joj je, umjesto podrivanja spontanosti ideologije, sada pridružena funkcija naročite efikasnosti u njezinu širenju. No zanimljivo je primijetiti da se u oba slučaja - koncentrirali se na emancipatoran ili podjarmljujuć učinak - radi o transgresiji načela doličnosti nalik onom koje desetljećima kasnije određuje Rancièreov poetički/reprezentativni režim.
} 
dominantna ideologija.“ (Macherey, Balibar, 2012: 12) To otvaranje prostora drugim ideološkim diskursima, uz vrlo efikasno interpelativno djelovanje literarne identifikacije (isto: 10) te stvaranje prividnog sklada, lažnih izmirenja i rješenja što prikrivaju ideološke kontradikcije (isto: 8), označeni su tako kao temeljne funkcije književnosti (u njezinoj uporabi u državnim ideološkim aparatima, prije svega u obrazovanju), slijedom čega Macherey (isto: 12) zaključuje: „Pod tim uvjetima, estetski je učinak također neizbježno i učinak dominacije: podlaganja pojedinaca dominantnoj ideologiji, dominaciji ideologije vladajuće klase.“

Ipak, unatoč tome što se takva koncepcija književnosti unutar Machereyeva opusa pokazala tek privremenom fazom, gotovo neobičnim izletom, ona nije istraživački u potpunosti slijepa ulica. Iz perspektive ovog istraživanja značajna je činjenica da je Macherey najviše od svih autora kojima se u ovom istraživanju bavimo podcrtao i „policijsku“ stranu književnosti, koja nedvojbeno jest važan faktor. Iz šire perspektive njegovog opusa pak kao jasan pomak u odnosu na Teoriju književne proizvodnje opstala je koncepcija književnosti s većom djelatnom ovlasti te premještanje fokusa na njezine učinke na širu populaciju u procesu koji će kasnije nazvati reprodukcijom, namjesto mnogo pasivnije uloge čiji je emancipatorni efekt ovisio o znalačkom čitanju marksističkog znanstvenika.

Pomicanje težišta s produkcije na reprodukciju teksta, započeto u Književnosti kao ideološkom obliku, Macherey je nastavio i u kasnijim tekstovima, o čemu svjedoči i Za teoriju književne reprodukcije [For a Theory of Literary Reproduction, 1998], kratak tekst čiji je naslov očita varijacija na raniju Teoriju književne proizvodnje. U njemu Macherey, oslanjajući se uvelike na Foucaultovu raspravu o autoru, još jednom odbacuje romantičarske koncepcije autorstva i vezanje književnog teksta za bilo kakav oblik središta/izvorišta, no decentriranje ovaj put nije u korist šireg historijskog konteksta proizvodnje djela, nego (prvenstveno) diskurzivnog konteksta njegove reprodukcije. Kao i u Teoriji književne proizvodnje, dakle, ključne ostaju margine djela, no konceptualizacija margina te referentna točka u odnosu na koju se određuju doživjeli su promjenu.

„Djelo“, tvrdi Macherey (1998: 47), „,s učinkom značenja koje mu je pridruženo, nije strogo gledano samo rezultat proizvodnje, nego reprodukcije, pri čemu potonja počiva na aleatoričkom događaju diskursa koji ga podupire." Pritom,

/o/sim u snu, nitko ne piše po posve praznoj stranici: izvedba teksta nužno se oslanja na reprodukciju ranijih tekstova, na koje se implicitno ili eksplicitno referira. Svaka knjiga u sebi sadrži labirint knjiženice. S tog gledišta, književnost bi se, u svojoj cijelosti, mogla smatrati jedinstvenim tekstom, beskonačno variranim, moduliranim i preobraženim, bez ijednog od njezinih stanja koje bi se bi se moglo jednom za svagda izdvojiti i fiksirati. (Macherey, 1998: 49) 
Dapače, trenutak poslije zaoštrit će tezu tvrdnjom da „književnost ni ne postoji kao takva, osim kao historijska fikcija stvorena literarnim žanrom kritike“ (isto: 50), utoliko što ne postoji nijedno jedinstveno distinktivno svojstvo koje bi je kao takvu odlikovalo, niti je zaokružen korpus djela, već fluidan skup tekstova koji se preispisuju jedni u drugima. No ono što postoji, smatra, jest „literarno“, kao fenomen koji „,oblikuje korpus u stanju permanentnog prevrednovanja“ (isto), odnosno skup procesa što dinamično međuodređuju pisanje i reprodukciju, neovisno o normativnim idealima koji pokušavaju nametnuti nekakvu instancu stabilizacije. Tako definirano literarno analogno je literarnosti u prethodno analiziranoj studiji - riječ je ponovno o (manifestaciji) jednakosti pisma mimo stabilizirajuće instance, koja otvara prostor složenoj rezonanciji među tekstovima, samo što se u ovom slučaju ne radi o reprodukciji ideologije, kako je to Macherey prethodno tvrdio, nego konstantnoj reevaluaciji što priječi trajnu stabilizaciju. Drugim riječima, slici još bližoj literarnosti kako su je definirali autori kojima smo se prethodno bavili, a s kojima Macherey u ovoj fazi svog rada očito ulazi $\mathrm{u}$ intenzivniju komunikaciju.

Ako je pak literarnost/literarno ono što za svoj nusproizvod ima promišljanje, budući da izglobljuje iz uvriježenih i sankcioniranih odnosa, onda je riječ i o fenomenu zaslužnom za središnju temu proučavanja u drugoj velikoj Machereyevoj književnoj studiji kojom ćemo se ovdje pozabaviti, knjizi $O$ čemu misli književnost. U njoj se naime Macherey usredotočuje na pomalo maglovito definiran pojam literarne filozofije kao onaj vid ispreplitanja književnog i filozofskog koji se ne bi sveo na tradicionalne hermeneutičke zahvate u kojima filozofija pronalazi nereflektirane istine u pozadini književnog teksta (usp. Macherey, 1995: 2), već na istraživanje čimbenika književnosti koji potiču mišljenje, viđenje, spoznaju određenih odnosa i ostvarivanje određenih učinaka u historiji, pri čemu se ispreplitanja filozofije i književnosti ne stabiliziraju ni u kakvom predodređenom hijerarhijskom odnosu ili doktrinarnom obliku (isto: 7).

Iako je takav koncept literarne filozofije sam po sebi u najmanju ruku diskutabilan i djeluje kao pomalo nejasno protetsko pomagalo za zaobilaženje onoga što je u Machereyevim analizama prethodno bio odnos književnosti i ideologije, ovdje nećemo ulaziti u detaljniju diskusiju o njemu. Unatoč suprotnim Machereyevim tvrdnjama naime, čini nam se neesencijalnim za funkcioniranje njegove knjige kao skupa intrigantnih književnih studija, pa ćemo stoga u prvi plan staviti upravo koncepciju književnosti kakva u njoj prevladava te njezine učinke na poredak osjetilnog.

Koncepcija književnosti koju možemo izvesti iz različitih studija okupljenih u $O$ čemu misli književnost na određeni je način spoj pojedinih aspekata prošlih dviju ključnih točaka - 
subverzije uvriježenih obrazaca mišljenja i percipiranja svijeta iz Teorije književne proizvodnje te djelotvornije vizije književnosti i interesa za njezinu diskurzivnu okolinu iz doba suradnje s Balibarom. Drastičnom otklonu od Althussera i priklanjanju njegovim drugim bivšim učenicima i poklonicima pridonijelo je pak nekoliko čimbenika, od daljnjeg razvoja Machereyeva već $u$ althusserijanskoj fazi naglašeno prisutnog interesa za spinozističku filozofiju koji ga je približio Deleuzeu, preko interesa za Foucaultova arheološka istraživanja pa do opće intelektualna klime tog vremena. No nesumnjivo je relevantna poveznica i promjena lektire kojoj je Macherey posvetio svoj interes.

Nasuprot ranijih teza o književnosti kao mjestu (fragmentarnog) zrcaljenja ideoloških proturječja i historijskih uvjeta vlastite proizvodnje, već u prvoj analizi u $O$ čemu misli književnost Macherey (1995: 14) pokazuje da će ga zanimati književnost pripadajuća estetskom režimu što ga naziva „estetikom singulariteta“, koji je, „za razliku od modela nasljeđenih iz klasicizma, odbacio princip imitacije“, a tu tendenciju u predlošcima kojima se bavio pratila je i njegova teorija. Početke književnosti kakva ga zaokuplja u suglasju s Foucaultom (1998: 94-95, 97) povezuje s De Sadeom i gotičkim romanom (Macherey, 1995: 86), dok nam je ostatak popisa autora kojima se u knjizi bavi također dobro poznat i iz studija koje smo analizirali u prošlim poglavljima: od Hugoa, Flauberta i Mallarméa pa do Bataillea, Celinea, Roussela i drugih. No neovisno o pojedinačnim specifičnostima od predloška do predloška, književnost za Machereya postaje heterogen i decentriran korpus pisma što „slama sve sisteme misli“ te „u njih uvodi kolektivnu, dijeljenu polifonijsku refleksiju što potiče od slobodne cirkulacije slika i shema pripovijedanja i iskazivanja više nego od nekog striktno organiziranog deduktivnog uređenja.“ (isto: 233)

Premda Althusserov trokut između ideologije, književnosti i znanosti tako definitivno ostaje stvar prošlosti, neke nijanse razlike među analizama u knjizi mogu se uočiti. Primjerice, u studiji posvećenoj Hugou i metafori dubine, kao figuri što se istovremeno javlja i kao književni i kao epistemološki instrument, studiji koja tako spaja Hugoa i Marxa te je od svih u knjizi tematikom najbliža tradicionalnim marksističkim žarištima interesa, književnost se doduše već pridje veća djelatna ovlast nego u Teoriji književne proizvodnje, no motiv zrcaljenja još je prisutan. Tako Macherey (1995: 109) napominje da usporedbama Marxovih i Tocquevilleovih tekstova s Hugoovim ne želi nijekati njihovu autonomiju i literarizirati ih, nego ,pokazati kako fikcionalni tekstovi na svoj način mogu ne samo prenositi nego i proizvesti oblike spekulacije koji izravno izražavaju određenu historijsku stvarnost.“ Ili pak nešto drukčije rečeno: 
Pisci su odigrali veliku ulogu u oblikovanju te figure misli [metafore dubine]: oni su izumili njezine konkretne oblike izlaganja davši im pojavni oblik svoje fikcije. No 'ispod' i 'iza' te fikcije moramo prepoznati znanje koje ju je izvorno oblikovalo i u njoj se utjelovilo: literarnu filozofiju te ere, onakvu kakva je utjelovljena u historijskoj mitologiji čovjeka dna. (Macherey, 1995: 111)

No istovremeno ista analiza Hugoa donosi i gotovo rancièreovske tvrdnje o formalnim značajkama Hugoova romana koje su bile nužne da bi se ,pokazalo, ili radije sugeriralo, nešto što po svojoj prirodi pripada sjeni““ (Macherey, 1995: 99), odnosno da je takav korpus pisma „prepoznao ispod uobičajene buke onoga što se događalo na površini (rada vlade i njezinih kotačića) prigušeno gunđanje neopazivih preobrazbi koje su se događale u tajnoj historiji svakodnevnog života.“ (isto: 101) Moć književne figure izvrće čak i raniji odnos između znanosti i književnosti: premda začetak oblikovanja figure dubine traži u literarnoj filozofiji tog historijskog razdoblja, Macherey (isto: 104) suspendira svoje nekadašnje privilegiranje marksističke znanstvene spoznaje i tvrdi: „Tajna podudarnost uspostavljena je između teorijska analize i poetske vizije: kao da je, prije nego što se ikakva planirana refleksija dogodila, logika slika (...) nametnula svoje stereotipe diskursima o masama.“287

Pomak s ranijih klasika na djela u kojima su modernistički postupci i eksperimenti s jezikom znatno izraženiji dodatno pak pomiče i Machereyevu koncepciju književnosti prema aktivnoj transformaciji poretka osjetilnog. Osim toga, analize mu postaju i primjetno usredotočenije na formu i uporabu konkretnih književnih postupaka, umjesto zaustavljanja na tematskom sloju i uposlenim figurama. Takav pomak analitičkog interesa vodi ga do zaključaka poput onog koji veže uz Roussela i prethodno Foucaultovo čitanje njegovog djela ${ }^{288}$ : da Rousselovi deautomatizirajući eksperimenti s jezikom „izvrću spontanu koncepciju koju o jeziku oblikujemo bez da o njemu razmišljamo, kao njegovi korisnici“ (Macherey, 1995: 217), te da njegovo pismo, ,zahvaljujući rigoroznom radu na oblicima jezika, rezultira preispitivanjem poretka stvari.“ (isto: 218$)^{289}$

\footnotetext{
${ }^{287} \mathrm{U}$ usporedbi s Laclauovim opisom artikulacije ,naroda“ metaforičkim nadsvođivanjem lanca ekvivalencija označiteljem koji se tada nalazi u nesvodivom raskoraku između partikularnog i univerzalnog, kao i sličnim Rancièreovim primjerima, značajno je primijetiti još jedan primjer „podudarnosti teorijske analize i poetske vizije“ (Macherey, 1995: 104) u Machereyevoj analizi razapetosti Jeana Valjeana između partikularnog i univerzalnog, između toga da biva nitko i čitav svijet (kao i svijet za sebe), pojedinačna sudbina i metafora naroda itd. Usp. isto: 93.

${ }^{288}$ Glede ranijeg pitanja o utjecajima koji su oblikovali teorijsku poziciju Machereyeva kasnijeg opusa, kao i uspostavljanja poveznica među autorima kojima smo se do sada bavili, vrijedi primijetiti Machereyevo (1995: 215) podcrtavanje Deleuzeova značaja za afirmaciju Foucaultova djela o Rousselu kao još jedan signal pomnog čitanja te dvojice autora, razvidnog već iz njegovih analiza.

${ }^{289}$ Drugim riječima, Rousselovo djelo kao reprezentant određene vizije književnosti ,izvrćući naš odnos s jezikom, a time i sa svijetom, otkriva njegovu drugu stranu, prokazuje nerazum našeg rezoniranja ukazujući na cijenu koju moramo platiti želimo li govoriti 'razumno' o stvarima.“ (Macherey, 1995: 215)
} 
Uska povezanost poretka riječi i poretka stvari i za Machereya je, kao i za autore kojima smo se prethodno bavili, nešto na čega osobito upućuje književnost kao „isprazna vladavina slika“ (Macherey, 1995: 196) što iza sebe ne otkriva čvrst referent, nego ,prazninu u kojoj se one pretaču i stapaju.“ Budući da iza jezika „više nema još jednog jezika, jezika prije jezika, koji bi postavio konačnu granicu kretanju interpretacije“ (isto: 222), Macherey također primjećuje da (u slučaju autora koje analizira, ali i na općenitoj razini) stilistika postaje zamjena za metafiziku (isto: 132), odnosno da se analize poput Foucaultova bavljenja Rousselom, a onda samim time i Machereyevih studija, „više tiču polja prve filozofije [tj. ontologije] nego li polja poetike“ (isto: 219). Time i u odnosu na njegove analize postaje moguće potvrditi Marchartovu (2007) poznatu jednadžbu o poravnavanju ontologije, teorije politike i teorije diskursa u postfundacijskoj misli.

Iako se, kao što smo napomenuli, Macherey nije bavio političkom teorijom na način na koji su to činili autori kojima smo se prethodno bavili te je ta problematika izvan primarnog fokusa ovog poglavlja, u prilog tezi da nije riječ tek o marginalnoj opasci, nego doista postfundacijskom pogledu u njezinoj pozadini, mogle bi govoriti i kasnije Machereyeve studije o Spinozi. Primjerice, u tekstu Spinoza, kraj povijesti i lukavstvo uma [Spinoza: études sur la doctrine et l'histoire du spinozisme, 1992], Macherey (1998: 148) ukazuje na - ali se i implicitno svrstava uz - Spinozinu viziju historije u kojoj je sve konačno i ništa novo, no opet se konstantnim novim intervencijama oblikuje u nove konjunkture, što odgovara shemi konačne strukture čija konačnost ne leži u vanjskoj granici, nego unutarnjoj odsutnosti središta. Nadalje, Macherey (isto: 157) tvrdi da po Spinozi ,,ako politički red ovisi o prirodnim uvjetima, to je zato što je poredak prirode, u najopćenitijem smislu, politički“", što je tvrdnja gotovo potpuno podudarna Marchartovoj gorespomenutoj jednadžbi.

Vratimo li se nazad problemu književne forme, Machereyevo naglašavanje njezine važnosti do kraja knjige postaje toliko korjenito da i svoj pojam literarne filozofije izjednačava s njom, tvrdeći da „literarnu filozofiju trebamo tražiti unutar literarnih formi, a ne u podlozi onoga što nam se čini da one govore; literarna je filozofija misao koju književnost proizvodi, a ne oblik misli koji manje ili više nesvjesno proizvodi književnost.“ (Macherey, 1995: 231-232) Posljedica je toga da je eponimni objekt mišljenja književnosti uvijek na neki način rezultat „neprijanjanja jezika uz jezik, jaza koji konstantno dijeli ono što govorimo od što govorimo o tome i što mislimo o tome“ (isto: 234), rascijepa između označitelja i označenog koji se zbog odsutnosti transcendentalnog uporišta ne da premostiti. Stoga 
Macherey (isto: 234) sada govori o ,ironijskom odnosu prema istini“, koji zahtjeva interpretacije što uvjeravaju, odnosno o „esencijalno kritičkom“ (isto: 233) odnosu prema istini koji se „podudara s proizvodnjom stanovitog Verfremdungseffekta što, u trenutku u kojem književnost promišlja o vlastitim diskursima, u njezino promišljanje uvodi unutrašnji odmak. “'290

Macherey tim pomakom prema postfundacijskoj poziciji doduše neće napustiti stav da je odnos književnosti i istine važno pitanje u proučavanju književnosti, no istinu neće tretirati kao podudaranje iskaza i referenta, odnosno književnosti i historijske stvarnosti, već spinozistički, iz perspektive ostvarenog učinka. Književni tekst tako više nije inferioran oblik dolaska do istine, smješten između ideologije i herojske znanosti, već postaje privilegiran instrument raskrivanja ideologije. Pa ipak, kada pri kraju $O$ čemu misli književnost tvrdi da je književni tekst „filozofska savjest historijskog perioda“, odnosno ono što nam ,govori što određeni period misli o sebi.“ (Macherey, 1995: 234), Macherey kao da se djelomično opet približava pozicijama iz Teorije književne proizvodnje. Tvrdnja da se „književna retorika, pod uvjetom da je rigorozna, povezuje s ideologijom razdoblja utoliko što je dovodi u konflikt samu sa sobom, rastavlja je od sebe, iznosi na vidjelo njezine unutrašnje konflikte i tako je kritizira“, tj. da se „od Sadea do Célinea doima kako se književnost posvetila otkrivanju onoga što nije trebalo biti rečeno“ (isto: 237), ponovno naime u prvi plan stavlja razotkrivanje ideološkog momenta neke historijske stvarnosti, dok učinci književnosti na polju aktivnog oblikovanja nove stvarnosti ostaju u domeni implicitnog. Riječ je o razlici u perspektivi koja jest malena, no u kontekstu ovog istraživanja ne i posve irelevantna.

Ambivalentnosti na koje smo ukazali u dvjema ključnim Machereyevim književnim studijama, kao i u odnosu s trećom koja se smjestila između njih te ih kao neobičan otklon povezuje, jasno nam dakle pokazuju da je gruba podjela njegovog opusa na tobožnji marksistički i postmarksistički pol reduktivna perspektiva što zanemaruje pojedine aspekte svake od studija, i to aspekte koji nisu efemerni. Situacija je to koja se skladno uklapa u provodnu nit sličnih ambivalencija u prethodnim poglavljima. Ipak, možda nam Machereyev slučaj još izraženije od prethodnih daje zaključiti kako se ne radi o tome da bismo mogli reći da je njegov marksizam već pomalo postmarksistički, odnosno da je njegov postmarksizam još uvijek pomalo marksistički. Naprotiv, potvrđuje nam da se te dvije kategorije nisu toliko diskretno odvojeni korpusi koliko bi heuristička upotreba tih pojmova mogla sugerirati. Radi

\footnotetext{
${ }^{290}$ Usp. i tezu da se „misao koja prati sva književna djela ne može svesti na neku izvanjsku svijest pomoću čijim se posredovanjem književnost odriče svojih tajni istovremeno priznajući da je tajne posjeduju više nego što je ona u posjedu tajni. Ona se, naprotiv, podudara sa stalnom autorefleksijom koju književnost poduzima dok proizvodi svoje tekstove.“ (Macherey, 1995: 231)
} 
se prije o ispreplitanju i međusobnoj rezonanciji čitavih snopova utjecaja koji se iz perspektive bilo kakve ortodoksije ili udžbeničkog modela moraju doimati uvijek već kontaminirano, odnosno, kako nam Machereyeva (1998: 17) samoocjena sugerira - o teorijskim putanjama koje se, ovisno o perspektivi, čine kao divergentno vrludanje i otkrivaju skriveni red.

Slična ambivalentnost na djelu je i kod Machereyeva stava o marksizmu. Dok je još blisko surađivao s Althusserom, Macherey je bio pod izrazitim utjecajem Spinozine filozofije koja se teško može pomiriti s klasičnim marksizmom (no paradoksalno se ispreplitala s althusserijanskom pretenzijom na ortodoksnost). Napuštajući Althusserovo okružje, velikim je dijelom napustio i marksistički teorijski aparat, a svoj raskid s prethodnim pozicijama nije prikazao ni kao ni polemički raskid, ni kao vjerno nasljedovanje, već kao okretanje novim temama. No kao što smo vidjeli, ni u tim temama interes za problematiku tipičnu za marksizam nije jenjao. Dapače, bez obzira na Machereyevu želju da ga se pola stoljeća kasnije ne povezuje isključivo s Teorijom književne proizvodnje (Goldstein, 2005: 81), na pitanje smatra li se marksistom daje ambivalentan odgovor, potencirajući shvaćanje marksizma ne kao zaokruženog doktrinarnog aparata, već kao problematičkog čvorišta, te sugerirajući da je točno uz takvu konceptualizaciju oduvijek pristajao (usp. detaljnije Macherey, 1998: 18)

Za razliku od svojih suvremenika, čijim se teorijskim pozicijama u kasnijoj fazi svog rada izrazito približio, Macherey je pak znatno manje ambivalentan u retrospektivnoj procjeni svog nekadašnjeg učitelja Althussera. Na kraju svog retrospektivnog eseja Macherey (1998: 27) izriče zahvalu Althusseru za kojeg kaže da je ,onim što mnogi možda nazivaju sljepilom, no ja bih ga nazvao neustrašivošću, otvorio tolike brojne puteve, od kojih su se neki pokazali jedva razmotrivi, dok su drugi zadržali neiscrpnu plodnost.“ Althusserov kružok možda dakle jest bio pokušaj da se uspostavi novi bastion marksističke ortodoksije, no sudeći po Machereyu bio je i inkubator ispreplitanja heterogenih utjecaja koji su rezultirali uspjelim opusima nekolicine međusobno vrlo različitih teoretičara, uvelike zaslužan za ono što ih spaja. $^{291}$

Machereyevom zahvalom Althusseru ocrtali smo u ovom radu potencijalno dvije figure. S jedne strane, moguće je to promatrati kao svojevrsno zatvaranje kruga, od autora poput Laclaua i Rancièrea koji su svoje pozicije oblikovali na najeksplicitnijoj i polemičkoj

\footnotetext{
${ }^{291} \mathrm{Na}$ tragu Machereyeve zahvale jest i nešto elaboriranija Montagova ocjena iz uvodnika zbirci Machereyevih tekstova, u kojem Althusserovu kružoku pripisuje učinak radikalne izmjene teorijskog terena na kojem je nastao, odnosno posredno i inicijatorski impuls oblikovanju teorijskih silnica kojima se primarno zaokuplja ovaj rad. Usp. Macherey, 1998: 12.
} 
kritici Althussera, preko nešto ambivalentnijih ocjena njegovog značenja, pa do konačnog povratka Althusseru povezivanjem ključnih zajedničkih značajki. S druge strane, moguće je u tom kretanju prepoznati i retrospektivno povučenu liniju što se od Althussera nepovratno udaljuje nekim novim teorijskim kretanjima. No postavkama korpusa kojim se bavimo više od kruga ili ravne linije odgovarala bi figura nastala njihovim spajanjem - ona spirale. Utoliko ne samo da sugeriramo da do sada ocrtano kretanje valja promatrati upravo u tom ključu, već ćemo na sličan način i nastaviti.

Budući da smo došli do zaključka o problematičnosti povlačenja čvrste granice između marksizma i postmarksizma, odnosno najmanje se s jedne strane te (pretpostavljene) granice uvjerili u njezinu fluidnosti i ambivalentnost prefiksa post-, za očekivati je da ćemo određena ponavljanja s otklonom/razlikom sličnih teorijskih obrazaca pronaći i u ranijoj tradiciji marksističke misli i njezinoj neposrednoj teorijskoj okolini, u najmanju ruku u nečemu što bismo mogli nazvati njezinim heterodoksnim pojavnim oblicima.

Stoga ćemo u nastavku usmjeriti pozornost na nekoliko vremenski i prostorno diskontinuiranih, ali teorijskim postavkama ipak povezanih (iako ne identičnih) fenomena koji su se javili u historiji ili historijskoj okolini marksizma, nastojeći sumnju u radikalne epistemološke lomove te rezolutnost i univočnost prefiksa post-prenijeti i s druge strane navodne granice. 


\section{Onkraj granice i natrag: prefiguracija i(li) problematizacija postmarksizma}

\subsection{Kontinuirana revolucionarnost revolucionarne teorije: ruski formalisti, Bahtin i marksizam}

Suočeni s pitanjem kojim bi smjerom valjalo nastaviti ovo istraživanje nakon svojevrsnog povratka $\mathrm{s}$ pomakom Althusseru i njegovom krugu, točnije njihovoj konceptualizaciji književnosti i utjecaju na znatan dio suvremenog teorijskog korpusa kojim smo se pozabavili, odgovor ćemo potražiti prateći i dalje te linije utjecaja koje na općenitoj razini nisu nepoznate, no kontekstu su istraživanja postmarksizma velikim dijelom ostajale u pozadini. Pritom doduše nećemo ulaziti u temeljito genealoško proučavanje postmarksističkog polja. Ono bi bilo preopsežan zadatak čak i za drukčije postavljenu studiju; s obzirom na heterogenost predmetnog korpusa, bez obzira na to što se prominentniji i recentniji utjecaji na njega mogu razmjerno neproblematično izdvojiti, iscrtavanje detaljne mape intelektualnih tradicija i pojedinačnih opusa koji su oblikovali pozicije pojedinih teoretičara otkrilo bi vrlo divergentnu sliku i zahtijevalo posezanje u daleku prošlost. Ono što ćemo umjesto toga na sljedećim stranicama nastojati jest, zadržavajući se unutar dvadesetog stoljeća, ponuditi uvid u tri prostorno i vremenski odvojena, a teorijski ipak razmjerno bliska žarišta mišljenja zaokupljenog sličnom problematikom kao i kod teoretičara kojima smo se pozabavili u prethodnim poglavljima, te pozicionirana usporedivo ambivalentno u odnosu na klasični marksizam desetljećima prije točaka koje se uzimaju prijelomnima za oblikovanje postmarksističke teorije. Pritom će u središte pozornosti, kao i u prethodnom dijelu rada, doći odnos prema književnosti, koji bi se i ovdje mogao pokazati kohezivnim faktorom razmatranja.

Odnosno, premda ne pretendiramo na zaokružen genealoški prikaz, pomicanje naglaska na konceptualizaciju književnosti rezultirat će s jedne strane dolaskom $u$ fokus nekih imena koja se u ranijim istraživanjima nisu pojavljivala, a s druge strane povezati izdvojene pozicije u nešto koherentniji narativ, što će ih izravno dovesti u vezu s teoretičarima kojima smo se bavili u prethodnim poglavljima te dodatno staviti pod upitnik granice između prefiksa post- i onoga što za njim slijedi u postmarksizmu. $U$ toj analizi zadržat ćemo se ipak na nešto površnijoj razini nego u prethodnim poglavljima, zadovoljavajući se skiciranjem poveznica koje bi vrijedilo detaljnije rasvijetliti u budućim istraživanjima. 
Imajući to na umu, dobar smjerokaz za nastavak moguće je pronaći u nekoliko knjiga koje su se u desetljeću nakon objave njihovih studija o književnosti osvrnule na djelovanje Althusserova kruga ${ }^{292}$. Povezivanje specifičnosti Althusserova marksizma s uplivom strukturalističke misli, naime, postalo je već razmjerno neproblematično opće mjesto historije marksizma, no suočavanje tog odnosa s poststrukturalizmom rezultira s dvama mogućim oprečnim tumačenjima. Teoretičari poput Mišćevića (1975) u poststrukturalističkim kretanjima što se na određeni način naslanjaju na althusserijansku problematiku tako vide logičan i posve skladan daljnji razvoj tendencija koje je započeo Althusserov kružok, dok s druge strane autori poput npr. Coward i Ellisa (1985 [1977]) u poststrukturalističkom bavljenju temama jezika, književnosti i ideologije (u konkretnom slučaju teze demonstriraju na opusu Kristeve) vide korekciju nedostataka koji podjednako obilježavaju i Althussera i strukturalizam ${ }^{293}$. No ako je dakle dodir sa strukturalizmom na ovaj ili onaj način nedvojbeno značajan za pravce kojima su se stvari razvile iz Althusserova kruga, posezanje iz iste perspektive u pretpovijest strukturalizma čini se kao valjan istraživački put i za razmatranje pretpovijesti postmarksizma. Utoliko nam je osobito intrigantna Bennettova studija Formalizam i marksizam [Formalism and Marxism, 1979], koja za razliku od dvije prethodno spomenute svoju perspektivu ne usmjerava od strukturalizma unaprijed, nego unazad.

Iako su od objave Bennettove studije prošla četiri desetljeća, njezina recepcija bila je razmjerno ograničena ( $u$ dosadašnjem istraživanju postmarksizma, primjerice, prošla je nezamijećeno), te je $u$ istraživanju poveznice iz svog naslova najvećim dijelom ostala prilično usamljena. Veza između strukturalizma i ruskog formalizma, posredstvom Jakobsona i njegove suradnje s Lévi-Straussom, danas je naime vrlo dobro poznata, pa su stoga udžbenički pregledi suvremene književne teorije koji pri svojim počecima ne sadrže poglavlje posvećeno formalistima rijetki. No isti uvriježeni prikazi formalista uobičajeno ih u najmanju ruku odvajaju od marksizma, a često prikazuju i njegovim antipodima, što je najvjerojatniji uzrok tomu da im pozornost nisu poklonila ni prethodna istraživanja postmarksističke teorije. Razlozi tomu, sugerira Bennettova studija, leže u historiji recepcije formalizma na Zapadu.

Inicijalna zakašnjelost recepcije ruskog formalizma na Zapadu još više dolazi do izražaja kada se fokus suzi na tzv. zapadni marksizam, čija su vrata za formaliste, kao i

\footnotetext{
${ }^{292}$ Vrijedi podsjetiti da određene smjerokaze nude i ranije studije o postmarksizmu u dijelovima u kojima se bave svojevrsnim „protopostmarksistima“, tj. različitim teorijskim fenomenima koje smatraju anticipatorima razvoja postmarksističkih tendencija (usp. prvenstveno Sim, 2000 i Breckman, 2013), odnosno korektno priznati da nije riječ o pitanju koje se u ovom istraživanju postavlja u potpunosti prvi put. No s gledištima ranijih studija već smo polemizirali u prvom poglavlju, stoga se toj problematici nećemo ponovno vraćati.

${ }^{293}$ Prije svega se radi o kritici nastojanja da se iz razmatranja posve ukloni subjekt, koje rezultira time da se on s druge strane neprimjetno vraća u igru u svom zaokruženom, nefragmentiranom obliku. Usp. Coward, Ellis; 1985: 97, 100 itd.
} 
pripadnike skupine teoretičara koja se najčešće naziva Bahtinovim krugom, a s formalistima dijeli brojna obilježja ${ }^{294}$, dugo bila zatvorena. Razlozi tomu prema Bennettu (1979: 38) velikim dijelom leže u dugoj dominaciji teorije odraza i drugih lukácsevsko/hegelijanskih paradigmi u podlozi pokušaja da se uspostavi marksistička književna teorija (o kojoj u smislu jednoznačne koherentne teorijske konstrukcije teško da je moguće govoriti), ali jednako tako i u predrasudama o apolitičnosti i/ili reakcionarnosti koje su formaliste pratile još iz Sovjetskog Saveza ${ }^{295}$. No činjenica da se europska akademska javnost $\mathrm{s}$ formalizmom upoznala posredovanjem strukturalizma također nije bila od pomoći; brojni europski marksisti, kako podsjeća Bennett (1979: 27), strukturalizam su smatrali i buržujsko-reakcionarnim i glavnim teorijskim konkurentom ${ }^{296}$.

Bennettova studija $\mathrm{u}$ zadatak si je uzela temeljito reartikulirati tu kanoniziranu perspektivu na odnose marksizma i formalizma, suprotstavljajući se onome što smatra zanemarivanjem i potiskivanjem istinskog materijalističkog pristupa koji je marksističko promišljanje o književnosti moglo pronaći u formalizmu. Nastupajući s još uvijek pretežno althusserijanskih pozicija, iako zauzimajući i kritičku distancu spram Althussera, Bennett (1979: 3) naime tvrdi da su „mnoge teškoće u kojima se marksistička književna teorija danas nalazi rezultat činjenice da se nikada nije adekvatno raspetljala od tradicionalne estetike“. Kritizirajući pritom ono što smatra buržujskom dimenzijom marksističke književne teorije te afirmirajući althusserijanski pristup kao poželjnu alternativu, neočekivane saveznike pronalazi upravo u ruskim formalistima i Bahtinovu krugu.

Kao referentne točke (tada) recentnije marksističke produkcije u usporedbi $\mathrm{s}$ teoretičarima formalističkih kružoka te Bahtinovim krugom Bennett uzima upravo Althusserove oglede o književnosti (usp. Althusser, 1996 i 2001) te naročito Machereyevu Teoriju književne proizvodnje (1979). Sličnosti između dviju strana pronalazi, ugrubo rečeno,

\footnotetext{
${ }^{294}$ Važno je podsjetiti da teoretičari okupljeni nazivom ruskog formalizma nikada doista nisu činili jedinstvenu teorijsku školu, već su bili članovi dvaju različitih te (doktrinarno) razmjerno labavih istraživačkih kružoka: Moskovskog lingvističkog kruga i OPOJAZ-a (Občestvo izučenija poètičeskogo jazyka) u Petrogradu/Lenjingradu. O razlikama između i unutar kružoka usp. Erlich (1980: 63 [1955]), Ambrogio (1977: 22 [1968]), Striedter (1989: 18) i Biti (2000: 146-147). Također, svjesni smo razlika između formalista i Bahtinova kruga, kao i činjenice da su članovi potonjeg skovali i rabili termin formalizma kao pogrdu. Ipak, vjerujemo da ih naglasak koji stavljaju na formu te smjer u kojem su se njihove teorije razvijale povezuje dovoljno da ih u ovom kontekstu analiziramo zajedno, te mnogo više nego što su oni sami bili skloni priznati, o čemu više u nastavku rada.

${ }^{295}$ Detaljnije o odnosima između formalizma i marksizma unutar SSSR-a usp. Glavaš, 2017. Što se tiče navodne apolitičnosti formalista, zanimljivo je da na početku svoje studije i Bennett $(1979: 19,27)$ na nekoliko mjesta daje naslutiti da se slaže s ocjenom o apolitičnosti njihove teorije, dok je s druge strane znatan dio njegove studije posvećen upravo političkim učincima koje književnosti pripisuje ta ista teorija.

${ }^{296}$ Bennett (1979: 27) piše: „Uz iznimku kratkog flerta u ranim 1960-im, marksisti su strukturalizam smatrali novim idealizmom, doista novim 'formalizmom', što je rezultiralo time da je [ruski] formalizam često bio proglašavan krivim već samom asocijacijom.“
} 
na četiri razine: (1) formalne sličnosti u oblikovanju i određenju objekta njihova proučavanja, (2) slično stavljanje naglaska na očuđujuću narav književnosti, (3) slični postupci analize književnog djela koji naglasak stavljaju na upotrijebljene književne postupke, te (4) slične teorijske putanje koje su započele zanimanjem za književnost kao takvu, kao autonoman fenomen, a potom se polako kretale prema pitanjima proizvodnje i recepcije (usp. Bennett, 1979: 98).

Kratak pogled na svaku od navedenih razina sličnosti otkriva njihovu logičku povezanost i međuuvjetovanost. Prva se, pojednostavljeno rečeno, odnosi na činjenicu da ni formalisti ni Macherey književnost ne percipiraju kao transcendentalnu danost, već je promatraju kao relacijski određen historijski fenomen ${ }^{297}$. Drugoj razini Bennettove usporedbe ključna je pak referentna točka Šklovskij i njegov koncept očuđenja (ostranenie) kao postupka „koji povećava teškoću i dužinu percepcije, jer je perceptivni proces u umjetnosti sam sebi svrha“ (Šklovskij, 1999: 126), te koji tako omogućuje „osjet stvari kao viđenje, a ne kao prepoznavanje“ (isto: 125). Bennett poopćava koncept Šklovskog (što nije neuobičajena praksa) pa očuđenje u njegovoj analizi postaje metonimija sličnih pojmova i učinaka što se pripisuju književnosti, uključujući i razotkrivanja ideologije kakvo smo u prošlom poglavlju vidjeli kod Machereya. No pri tom poopćenju iz fokusa ispušta i neke nezanemarive razlike između odnosa između književnosti i ideologije kod ranog Machereya te očuđenja kod Šklovskog, čemu ćemo se vratiti kasnije u tekstu. Trećom razinom sličnosti Bennett pak smatra činjenicu da književne analize obiju strana naglašavaju formalnu dimenziju

\footnotetext{
${ }^{297}$ S tim je u svezi Machereyeva (1979: 51) primjedba elaborirana u prošlom poglavlju kako „,ne treba brkati


reputaciju teoretičara naklonjenih apsolutnoj autonomiji književnosti. No ta je reputacija u velikoj mjeri rezultat ranih proglasa koji su temeljitost žrtvovali u korist efektivnosti (usp. npr. Erlich, 1980: 77-78 te Striedter, 1989: 12-14), a onda i zlonamjernih protivničkih interpretacija i potenciranja upravo tog segmenta formalističke produkcije uz potpuno zanemarivanje njihovog teorijskog razvoja. O toj problematici u svojoj je analizi stanja u ranom formalizmu pisao još i Ėjhenbaum (1975: 25, [1925]) tvrdeći: „Govoreći o formalnom metodu i njegovoj evoluciji, mora se neprestano imati u vidu da su mnogi principi koje su istakli formalisti u godinama ogorčene borbe sa protivnicima imali značaj ne toliko naučnih principa koliko parola koje su se paradoksalno zaoštravale radi ciljeva propagande. Ne uzimati u obzir tu činjenicu i odnositi se prema radovima Opojaza 1916-1921 kao prema radovima akademskog karaktera znači ignorisati istoriju.“"

Ipak, neovisno o stavu spram problematike razvoja i kompleksnosti formalističke teorije, nemoguće je zanemariti činjenicu da je već u prvom značajnijem tekstu - Umjetnosti kao postupku [Iskusstvo kak priem, 1917.] Viktora Šklovskog - književnost opisana kao „govor konstrukcija“ (Šklovskij, 1999: 30) određen u razlici spram svakodnevnog, instrumentalnog govora te u odnosu na svoju diskurzivnu i historijsku okolinu. Nadalje, pitanje književne evolucije kao mjesto potencijalnog dodira s marksizmom sugerirao je i Ėjhenbaum još 1924. (usp. Erlich, 1980: 108). U kasnijoj fazi, naročito u radovima Jakobsona i Tinjanova o književnoj činjenici i književnoj evoluciji, ta će dimenzija dodatno doći do izražaja, pa tako dvojica teoretičara tvrde da je povijest književnosti „povezana s drugim povijesnim nizovima“, no da je - kao i druge nizove - obilježava „složen kompleks osobitih strukturalnih zakona“ (Tinjanov, 1998: 89) bez čijeg pojašnjenja nije moguće preći na pojašnjavanje odnosa između različitih nizova. Istovremeno, upoznavanje imanentnih zakona književne evolucije „ostavlja, doduše, mogućnost ograničenog broja rješenja, ali nikako samo jednoga“, budući da su oni „neodređena jednadžba“ (isto.: 92), stoga se puna slika dobiva tek proučavanjem suodnosa sustava, odnosno „sustava sustava“.
} 
analiziranih djela, posebno se zanimajući za upotrijebljene književne postupke i time premještajući fokus, a stoga i važnost koju im pripisuju, s različitih oblika tematske analize na varijacije razlika između fabule i sižea/priče i diskursa ${ }^{298}$. Konačno, posljednju razinu usporedbe nije potrebno posebno objašnjavati, no vrijedi napomenuti da se postupno kretanje od analize književne činjenice za sebe prema problematici proizvodnje i recepcije što ga Bennett opisuje na dvjema stranama usporedbe ne događa na istoj razini: u Machereyevu slučaju ono je smješteno unutar Teorije književne proizvodnje, dok kod formalista približno odgovara razlici u istraživačkom interesu ranijeg i kasnijeg formalizma (kojem Bennett onda pridružuje još i Bahtinov krug).

Premda se Bennett (1979: 42), govoreći o navedenim sličnostima, eksplicitno ograđuje od pretjeranog pojednostavljivanja stvari, jasno tvrdeći da ,između dviju pozicija postoje i jednako važne razlike“, to ga ne sprječava da formalizam prikaže kao svojevrsno marksističko izgubljeno nasljeđe (kako glasi jedan od podnaslova studije, usp. isto: 95), tj. književnoteorijsku paradigmu mnogo bližu temeljnim principima marksizma nego što je to ijedan od nominalno marksističkih pristupa književnosti, osim althusserijanskog. Prema njemu, baveći se temom književnosti u okvirima strukturalnog marksizma, pripadnici Althusserova kruga - ponajviše Macherey - istovremeno su nastavili prethodno naprasno prekinutu liniju istraživanja, čiji su vrhunac bili radovi Jakobsona i Tinjanova te pripadnika Bahtinova kruga, no čiji su temeljni postulati postavljeni već u ranim radovima Šklovskog ${ }^{299}$. No u kontekstu istraživanja postmarksizma zanimljivo je podsjetiti da je Macherey - kojeg Bennett smatra ponajboljim primjerom doista marksističke teorije književnosti i dostojnim nastavljačem formalističke tradicije kao njezinog navodnog ,potonulog blaga“ - ujedno i autor čija je konceptualizacija književnosti, vidjeli smo u prethodnom poglavlju, od samih početaka pokazivala kritičke otklone od prevladavajućih marksističkih postavki.

Ostavljajući za sada to zapažanje po strani, zajedno s kritikom pojedinih spornih dijelova Bennettove usporedbe, za početak moramo reći kako ona nije posve neutemeljena.

\footnotetext{
${ }^{298}$ Bennett (1979: 144) doduše priznaje da „na tehničkoj razini istraživanja formalista o toj problematici ostaju znatno naprednija ne samo od onih koja predlaže Althusser, već i od onih osvjedočenih u detaljnijim radovima Pierrea Machereya i Terryja Eagletona. Na toj razini, radovi althusserijanaca ostaju parazitski spram dosega formalista."

${ }^{299}$ Naime, iako Bennett Jakobsona i Tinjanova smatra najboljim izdancima formalističke misli te pojedine njihove radove izdvaja kao primjere prijelaza formalizma u zrelu fazu (usp. Bennett, 1979: 34-35), njegovo inzistiranje na očuđenju kao središnjem i najpotentnijem elementu formalističke književne teorije (isto: 20), kao i glavnom čimbeniku usporedbe s Machereyem i Althusserom, nužno upućuje sve skupa natrag na Šklovskog. No Bennett nije ni približno jedini koji Šklovskom dodjeljuje privilegiranu sinegdohsku ulogu. Primjerice, iako se Erlich (1980: 70) eksplicitno protivi simplificiranim konstruktima što predstavljaju čitav ruski formalizam kao invenciju Šklovskog, otvoreno priznaje da je Šklovskij od početaka bio među najglasnijim i najutjecajnijim formalistima te ga opisuje kao „briljantnog, osebujnog, svestranog“ i ,enfant terribleom ruskog formalizma“ (isto: 67).
} 
Pripovijest o posvemašnjoj nekompatibilnosti i oštroj suprotstavljenosti marksizma i formalizma, baš kao i onaj o njegovoj reduktivnosti i rigidnosti - a oba su postala dio uvriježene slike tog teorijskog korpusa - znatnim je dijelom konstrukcija sovjetskih (ortodoksno)marksističkih teoretičara oblikovana u godinama njihovih oštrih polemika $\mathrm{s}$ formalistima; polemika koje su, osim teorijskih neslaganja, u svom podtekstu imale i borbu za status teorije koja bi odgovarala duhu Oktobarske revolucije. Već su i ranija temeljita istraživanja ruskog formalizma pokazala znatnu skepsu u odnosu na tako simplificirano postavljanje stvari.

Erlich, primjerice, napominje da razlozi tih rasprava svojom kompleksnošću nadilaze pitanje političkog primata i nasljeđa revolucije, no činjenica jest da marksističko-lenjinistički teoretičari tijekom revolucionarnih godina formalizmu nisu poklanjali toliko pozornosti, dok u godinama formalističkog uspona polemika uzima maha. Stoga piše:

Sovjetski marksistički književni teoretičari teško su si mogli priuštiti da mirno stoje suočeni s onim što je jedan od njih opisao „trijumfalnim usponom“ formalističke škole u godinama između 1921. i 1925. Rastuća popularnost Opojaza među mladim ruskim filolozima i studentima književnosti predstavljala je opasan izazov nadmoći „historijskog materijalizma“, koju su službeni sovjetski teoretičari zagovarali kao jedini legitiman pristup književnosti i jedinu doktrinu vrijednu revolucionarne ere. (Erlich, 1980: 99)

Opća mjesta tradicionalnomarksističke kritike formalizma ponajbolje na jednom mjestu ilustrira ogled o formalistima u zbirci rasprava Književnost i revolucija [Literatura $i$ revolyutsiya 1923] Lava Trockog. Trockij (1971: 117-118) naime priznaje korisnost većeg dijela formalističkog istraživačkog rada, no smatra da tu korisnost ograničava njihova (navodna) reakcionarnost te nesklonost da priznaju „sitničavi, skicozni uslužno-pripremni karakter“ (isto) svog djela, odnosno da svedu „metodološke postupke formalizma“ u „zakonite granice“ (isto). Propisivanje zakonitih granica, dakako, pripalo bi pak istomišljenicima Trockog, s čime se formalisti, kako pokazuje nastavak njegova eseja, nisu htjeli pomiriti. Analogna argumentacija prisutna je i kod drugih marksističkih autora koji tih godina kritiziraju formaliste, poput Lunačarskog, Buharina, Kogana, ali i Majakovskog (usp. Ambrogio 1977: 175-176; Erlich 1980: 104-105), a sve ih povezuje i karikaturalna verzija formalizma koju ocrtavaju tako što teze formalista posve reduciraju stavljanjem naglaska na radikalnije istupe ranog formalizma.

Magnum crimen formalista iz te perspektive navodna je apsolutizacija forme te odbacivanje referencijalne funkcije umjetnosti u korist njezine potpune autonomije. Premda te 
zamjerke nisu nastale ni iz čega te uporište imaju u radovima ranijeg razdoblja ${ }^{300}$, one teško opstaju kada se promotri kasniji razvoj formalističke teorije. No unatoč radikalnim stavovima u tekstovima ranijeg Šklovskog, već i Umjetnost kao postupak daje dovoljno materijala za sumnju u beziznimnu točnost marksističkih kritika.

Deautomatizacija percepcije, odnosno pružanje osjeta umjesto viđenja, kao sama srž fenomena očuđenja, vezana je za referencijalnu dimenziju književnog djela, doduše shvaćenu drukčije od mehaničkog upućivanja na konkretan historijski referent. Bez obzira na tvrdnju da je ,perceptivni proces u umjetnosti sam sebi svrha“ (Šklovskij, 199: 126), Šklovskij najveći dio elaboracije očuđenja odvaja za primjere koji se tiču učinaka kojima Tolstojevi romani podrivaju konvencionalan odnos prema svakodnevnici, politički potentno preispitujući institucije kao što su tjelesna kazna, privatno vlasništvo, građanski teatar ili religija (isto: 126129). Činjenica da očuđenje, osim na materijalnost označitelja, usmjerava percepciju i na njegov (poli)semantički potencijal, jer se „stvar ne opaža u svojim prostornim odnosima, nego, da tako kažem, u svojoj neprekidnosti“ (isto: 130), za posljedicu nužno ima preispitivanje konvencija - kulturnih, povijesnih, ali i političkih.

Stvari podjednako ambivalentno stoje i kada se u obzir uzme problematika autonomije književnosti: činjenica jest da su formalisti na njoj relativno dugo inzistirali, nastojeći podcrtati zahtjev za specifikacijom književne činjenice te obraniti svoj teorijsko-metodološki pristup od podređivanja nekoj od tada raširenih socioloških metoda. No nužnost da se iskorak iz posve sinkronijskog pristupa prema problemu književne evolucije napravi vodeći računa o širem historijskom kontekstu nije primijećena tek u ranije spomenutim Tinjanovljevim (1998) radovima, već je također, makar u embrionalnoj fazi, vidljiva još u Umjetnosti kao postupku. Šklovskij piše o životu umjetničkog djela koji se kreće „od viđenja prema spoznaji, od poezije prema prozi, od konkretnog prema općem, od Don Quijotea - skolastika i siromašnog plemića koji polusvjesno podnosi poniženje na dvoru vojvodinu - do Turgenjevljeva Don Quijotea: širokog ali praznog, od Karla Velikog do imena 'kralja'..." (1999: 126), a potom pri kraju teksta skreće pozornost i na historijski promjenjive načine na koje se ostvaruje „,cudno“ u poetskom jeziku (isto: 130).

\footnotetext{
${ }^{300}$ U vezi s prvom zamjerkom usp. primjerice Ambrogio (1977: 157), o kritici kojoj Žirmunskij podvrgava teze ranih formalista, napose Šklovskog, o tome da se u pjesništvu riječi koriste neovisno o njihovu značenju, ili pak Ambrogio (ibid.: 184-185), o davanju apsolutnog primata umjetničkom postupku (priem) kod ranih formalista. Vezano za apsolutnu autonomiju, najpoznatije su teze Šklovskog da je ,umjetnost uvijek bila slobodna od života“ te da "njezine boje nikada nisu odražavale boju zastava koje su se vile iznad gradskih utvrda“" (Šklovskij, prema Erlich 1980: 77), odnosno da umjetnost valja proučavati „imajući u vidu samo tehničko 'tkanje', a ne vodeći pritom nimalo računa o 'tržištu pamuka' i 'politici trustova'“ (parafraza u: Ambrogio 1977: 220). Na sličnom je tragu teza Jakobsona da bi ,inkriminacija pjesnika zbog ideja i osjećaja bila jednako apsurdna kao i ponašanje srednjovjekovne publike koja premlaćuje glumca što glumi Judu“(Jakobson, prema Erlich 1980: 77).
} 
Usporedimo li sve to $\mathrm{s}$ Machereyevim, pa čak i Althusserovim pogledima na književnost kojima smo se pozabavili u prethodnom poglavlju, Bennettove teze o kontinuitetu između formalista i potonje dvojice autora nisu neobične. No s druge strane, paradoksalno jednako tako nimalo ne čudi ni činjenica da su formalistički pogledi bili neprihvatljivi marksističkim teorijskim grupacijama koje su u postrevolucionarnom Sovjetskom Savezu izborile monopol na marksistički označitelj na polju književne teorije. Formalistička teorija dakle čak ni u povojima nije bila apolitična ni ahistorična, no isto tako nije ni (nastojala biti) marksističko-lenjinistička. Je li to zapreka valjanosti Bennettove tvrdnje da je formalizam mogao osigurati književnu teoriju primjereniju jezgrenim marksističkim postavkama?

Odgovor na to pitanje nužno je ambivalentan upravo jer se jezgra marksizma (i) na ovom primjeru potvrđuje kao katehretičan označitelj; ne kao pretpostojeći element u podlozi diferencijalne konstelacije, nego kao izvedena projekcija što je objedinjuje. Odnosno, slikovitije rečeno, metaforom koju Erlich (1980: 116) posuđuje od Kazina, onodobna marksistička ortodoksija dala je tek okvirno objašnjenje ovisnosti ideoloških fenomena o ekonomskim procesima, otvarajući u njegovu sklopu prostor za teorije pojedinačnih oblasti; marksizam je percipiran kao „,prostrana kartoteka čiji pojedinačni odjeljci čekaju da ih se popuni prikladnim proučavanjima“, i s te strane nije bilo nužnih prepreka, kao ni garancija, da popuna bude formalistička. Ambrogio (1977: 177) naime napominje da i onodobna književnoteorijska kretanja koja su sebe, za razliku od formalista, nazivala marksističkim pokazuju ,veliku heterogenost pogleda i stavova, takvu zamršenost i isprepletenost utjecaja i prijelaznih nijansi i takav eklekticizam...", a i sam Trockij (1971) u neposrednim postrevolucionarnim previranjima izgradnju odgovarajuće marksističke teorije književnosti smatra zadatkom koji tek predstoji.

Razdoblje trajanja i neposredno nakon završetka Oktobarske revolucije nesumnjivo je bilo vrijeme u kojem je do izraza dolazila heterogenost na svim društvenim razinama, vrijeme aktivacije prethodno sedimentiranih slojeva te njihove aktivne reartikulacije, stoga podjednako kao ni dinamična slika teorijskih kretanja ne čudi ni raznolikost i povremeno proturječje stava pojedinih teoretičara, pa tako i formalista, spram marksizma te angažmana $u$ revolucionarnim kretanjima ${ }^{301}$. No razvoj ruskog formalizma usko je povezan s fenomenom

\footnotetext{
${ }^{301}$ Primjerice, Erlich (1980: 79) skreće pozornost na to da su pojedini formalisti, poput Brika i Jakubinskog, bili aktivno uključeni u revolucionarnim političkim tijelima, dok je s druge strane Šklovskij prošao djelomično proturječan put od pobornika socijalnih revolucionara (SR-a) pa do boljševičkog angažmana. Jednako tako možemo suprotstaviti i kapriciozno-ironične odgovore Šklovskog da formalisti nisu marksisti, ali „budu li se ikada našli u potrebi za njihovim alatima, (...) neće jesti rukama iz čistog inata“ (Šklovskij, prema Erlich, 1980: 109) tvrdnjama Brika kako bi „Opojaz trebalo smatrati 'najboljim odgajateljem mladih proleterskih pisaca'“ (isto: 81).
} 
Oktobarske revolucije u širem smislu. Pored zajedničkih teorijskih stavova, kako navodi Èjhenbaum (1975: 8-9), okupljala ih je i ,parola oslobađanja pesničke reči od okova filozofskih i religioznih tendencija“ u ime koje su ,svi kompromisi morali biti odstranjeni“, s jasnom željom za društvenim reperkusijama tog oslobođenja.

Sve u svemu, konfrontacija formalizma i marksizma, u svoj svojoj kompleksnosti i sa svim približavanjima i udaljavanjima, po Striedterovom (1989: 76) je mišljenju „mogla enormno doprinijeti razrješavanju pitanja poveznice između književnosti i društva, a samim time i poveznice između književne evolucije i opće historije“. Riječ je dakle o stavkama koje uvelike anticipiraju problematiku koja se na sličan način aktualizirala i više od pola stoljeća kasnije, a kao preduvjet njezinom ranijem razrješavanju činila se „obostrano stimulirajuća konfrontacija“ te „volja da se kritički raspravlja o temeljima obiju metodologija“. Unatoč oštrim tonovima rasprava, takva je volja postojala do sredine dvadesetih godina dvadesetog stoljeća, da bi je okoštavanjem diferencijalne strukture postrevolucionarnog društva zamijenila dogmatična antiformalistička kampanja ${ }^{302}$ koja je djelovanje formalista $u$ sovjetskom savezu privela kraju ${ }^{303}$. Ironično, taj se proces završio u trenutku u kojem su formalizam i srodna kretanja došli na pozicije mnogo bliže njihovim lenjinističkomarksističkim kritičarima nego na svojim počecima.

Upravo svojevrsnim mostom između formalizma i marksizma aktualnim $u$ istom tom razdoblju dvadesetih godina dvadesetog stoljeća često se smatra i drugi teorijski kružok koji smo prethodno spomenuli, tzv. Bahtinov $\mathrm{krug}^{304}$. U isto vrijeme, riječ je i o kružoku čija se teorijska produkcija, već ovisno o krugovima recepcije, interpretirala kao anticipacija kasnijeg

\footnotetext{
${ }^{302}$ Spomenuta sedimentacija pak nije bila stvar jedinstvenog trenutka, već hegemonijskog procesa kojim je boljševička partija nastojala usmjerivati i ovladavati revolucionarnim kretanjima. Kako napominje Erlich (1980: 82), boljševička je partija nastojala zauzdati teorijsku produkciju i usmjeravati je prema definiranju ortodoksije, no zadržavajući privid neutralnosti. Otud i česte kontradikcije poput iskaza Trockog da (1977: 158, 160) ,/p/odručje umjetnosti nije takvo u kome je partija pozvana da komandira“, tj. da „u svakom slučaju partija ne može i neće stati na poziciju literarnog kružoka, koji se bori s drugim literarnim kružocima“, no da istovremeno to ne znači ni apsolutnu slobodu: „Ako revolucija ima pravo da ruši mostove i umjetničke spomenike kad je to potrebno, ona se neće zaustaviti ni pred tim da svoju ruku stavi na bilo koji umjetnički pravac, koji, uza sva svoja formalna dostignuća, prijeti unošenjem razdora u revolucionarnu sredinu, ili se neprijateljski suprotstavlja unutrašnjim snagama revolucije.“. Sličnu „obranu revolucije od revolucije“ možemo vidjeti i kod Lunačarskog (1967: 140 [1924, 1964]), koji se nominalno zalaže za slobodu umjetničkog izraza pišući da se „/n/e smiju zatvarati usta onima koji govore“, no dodajući na to i da „to ne znači da govorim u prilog liberalnoj slobodi riječi. Mi moramo pratiti čak i umjetnost. Umjetnost je snaga (...) Ne može se dopustiti da se koriste umjetnošću i uopće riječju s ciljem da truju svijest još uvijek kolebljivih masa“. Unatoč tomu, Erlich (1980: 82) naglašava da bi teško bilo naći oštriji kontrast u odnosu na uniformnost kasnije sovjetske teorijske scene od onoga $\mathrm{s}$ proliferacijom teorijskih i umjetničkih škola u razdoblju Revolucije, Građanskog rata i NEP-a.

${ }^{303}$ Kao što se Umjetnost kao postupak Šklovskog sinegdohski uzima za početnu točku formalističke teorije, tako se i njegova izjava da je formalizam stvar prošlosti sredinom dvadesetih, a potom i gorljiva samokritika tridesetih smatra znakom njegova kraja. (usp. Erlich, 1980: 137)

${ }^{304}$ Riječ je o kružoku kojem su, uz Bahtina, pripadali Vološinov, Medvedev, Kagan, Pumpijanski, Solertinskij i dr., no ovdje ćemo pozornost najvećim dijelom ograničiti na Bahtina, Medvedeva i Vološinova. Kružok se vjerojatno oblikovao u Nevelu i nastavio djelovati šireći krug suradnika u Vitebsku. Usp. Hirschkop, 1999: 146.
} 
razvoja marksizma, anticipacija poststrukturalizma ili pak specifična sovjetska inačica suvremenog liberalizma ili različitih oblika suvremenog kršćanskog misticizma. Ovdje će nas zanimati prvenstveno prve dvije stavke, no raspon pionirskih uloga što im se pripisuju već dovoljno svjedoči o kompleksnosti i heterogenosti produkcije tog teorijskog kružoka.

Već i sam Bahtinov opus, unatoč različitim simplifikacijama, zahtjevan je zadatak za proučavanje. Nije to slučaj samo zato što se njegovi osebujni radovi opiru zatvaranju u uredne pretince, nego i zbog nepovoljnih okolnosti njihovog nastanka koje su rekonstrukciju cjelokupnog opusa učinile pravom filološkom poteškoćom ${ }^{305}$. Ipak, uz već spomenuto pozicioniranje (zajedno s ostatkom kružoka) između marksizma i formalizma, njegovi se radovi ugrubo mogu podijeliti na fenomenološku i (uvjetno rečeno) marksističku/društvenu fazu. Pritom svako od tih određenja otvara i prostor zamjerkama.

U studiji Mihail Bahtin između fenomenologije i marksizma [Mikhail Bakhtin between phenomenology and Marxism] Bernard-Donals (1994: 1) najzaslužnijima za inzistiranje na vezi između Bahtina i formalista u Bahtinovoj recepciji na Zapadu smatra Clark, Hoquista, Erlicha i Bennetta. No ta je veza, kako upozorava Hirschkop (1999: 118), potencirana još i mnogo ranije u Sovjetskom Savezu, kao dio Ivanovljeve semiotizacije Bahtina. Jednako je tako već tada i osporavana u izrazio antiformalističkim interpretacijama pojedinih Bahtinovih redaktora (isto: 120). I Kristeva, kao najzaslužnija za Bahtinovu veliku popularnost u poststrukturalističkim krugovima, 1966. Bahtina je prvi put kontekstualizirala kao formalista (usp. Lesic-Thomas 2005: 4), dok je godinu kasnije na ovim prostorima Flaker (1967: 366) konstatirao da je Bahtin ,/p/o svojim metodama bio blizak 'formalnoj' školi, ali ih je razvijao prema istraživanju socioloških aspekata i idejnoga svijeta književnoga djela i njegova autora“.

Sličnosti s formalizmom, baš kao i polemično isticane razlike, ne podudaraju se pak $\mathrm{s}$ podjelom na fenomenološki i marksistički/socijalni pol. Dodirne točke s formalizmom većina autora tražila je upravo u naglašenije semiotičkim, jeziku orijentiranim djelima Bahtinova kružoka, budući da ona analitički naglasak stavljaju na materijalnost jezika, formu verbalnih

\footnotetext{
${ }^{305}$ Najpoznatiji je segment problema rekonstrukcija Bahtinova opusa tzv. kontroverza oko autorstva pojedinih knjiga, prije svega Marksizma i filozofije jezika [1927] objavljenog pod Vološinovljevim imenom, te Formalni metod u nauci o književnosti [1928] objavljenog pod imenom Medvedeva. Za detaljniji prikaz rasprave o autorstvu tih studija ovdje nemamo prostora, stoga ćemo se držati ili kompromisnog označitelja „Bahtinov krug“ ili pojedinačnog imena autora pod čijim je imenom tekst inicijalno objavljen, dok ćemo reference stavljati na imena pod kojim je objavljeno pojedino. Ipak napominjemo da dionici Kruga nisu uvijek bili suglasni oko svih pitanja, zbog čega ni kompromisno rješenje s „Krugom“, koje monologizira i homogenizira izrazito dijalogičan i heterogen kružok, nije bez mana. Citirajući MacCannell, ,da 'Medvedev' i 'Vološinov' nisu postojali, Bahtin bi ih morao izmisliti da bi pisao“" (MacCannell 1992: 57).

No kontroverze glede autorstva spomenutih studija nisu jedine filološke poteškoće. Kao što je u svom pokušaju rekonstrukcije kronologije i uvjeta nastanka Bahtinovih djela pokazao Hirschkop (1999), one uključuju i probleme slijeda nastanka pojedinih studija, njihovih kasnijih revizija, rekonstrukcije neobjavljenih predavanja, fragmentarnosti te nestalih ili nikada doista napisanih spisa.
} 
artefakata, konkretne uporabljene iskazivačke postupke i njihove učinke te pritom analizom nemalo nalikuju formalističkim analizama. No i Bermard-Donals (1994: 3) i Hirschkop (1999: 142) skreću pozornost na neokantovske elemente formalističke teorije kao snažnu poveznicu s Bahtinovim jednako neokantovski obojenim fenomenološkim radovima, oboje kao produkt utjecaja neokantovske filozofije na lenjingradske intelektualne krugove neposredno uoči Revolucije.

S druge strane, zasigurno najpoznatija kritika formalizma iz pera pripadnika Bahtinova kruga, Medvedevljev Formalni metod u nauci o književnosti (usp. Medvedev, 1976), pripada upravo marksistički obojenoj fazi djelovanja Kružoka. No kritike formalista ne manjka ni u fenomenološki intoniranim djelima, pa tako Bahtin (1991: 205) u studiji Autor i junak u estetskoj aktivnosti [Avtor i geroy v esteticheskoy deyatel'nosti, 1979] formalistima zamjera nerazlikovanje forme i materijala djela, odnosno toga da je „forma uslovljena datom sadržinom, s jedne, i osobinama materijala, s druge strane“, a samim time i poistovjećivanje drugorazrednog odnosa prema materijalu s ključnim odnosom prema formi.

No Bahtinovu krugu, kao i formalisima, svojstven je ambivalentan odnos prema marksizmu na svim razinama, od osobnog angažmana članova do teorijskih postavki. ${ }^{306}$ Primjerice, iako s obzirom na historijat recepcije Bahtinova kružoka na Zapadu njegovo povezivanje s marksizmom i dalje može djelovati neobično, ono nije novost, pa ćemo tako npr. kod Erlicha (1980: 114), Ambrogia (1977: 28) ili Bennetta (1979: 75) autore Bahtinova kruga pronaći označene marksistima. S druge strane, i otpor marksističkoj oznaci ima svoju povijest, naročito među Bahtinovim američkim interpretatorima liberalne i ruskim religioznomističke provenijencije. Hirschkop (1999: 130, 137) čak i dio kontroverze o autorstvu spornih Vološinovljevih i Medvedevljevih tekstova pripisuje takvim tendencijama, skrećući pozornost na to da je Bahtinu autorstvo odricano dijelom i radi udaljavanja njegova imena od marksističke intonacije spornih studija. Odnosno, kako tvrdi, u pojedinim je slučajevima „stvarni cilj rasprave o autorstvu ne uspostavljanje Bahtinovih prava na djela drugih, nego

\footnotetext{
${ }^{306}$ Primjerice, premda za razliku od formalista Bahtin nije izravno sudjelovao u revolucionarnim zbivanjima, dapače Todorov (1997: 190-191) tvrdi da ih se nastojao kloniti pod svaku cijenu, te premda se u najmanje dvama razgovorima eksplicitno ogradio od bivanja marksistom (usp. Hirschkop, 1999: 132), to ne vrijedi i za druge članove Kružoka. Vološinov i Medvedev bili su daleko angažiranjiji u sovjetskom kulturnom i uopće društvenom životu nego je to bio Bahtin, dok je Kagan bio i aktivan član boljševičke partije (isto: 135) Razlika u intenzitetu javnog angažmana odrazila se i na njegove posljedice. Hirschkop (1999: 136) navodi: „Oni koji su skloni prikazivati Bahtina kao tragičnu figuru među njima [dionicima Kružoka], ili zaboravljaju ili ignoriraju činjenicu da je Bahtin umro u krevetu, dok je Medvedev bio onaj kojeg su streljali nedugo nakon uhićenja.“ Medvedev nije bio jedini koji je po tom pitanju prošao tragično; Vološinov je umro od tuberkuloze 1936. te tako izbjegao čistke koje su netom počinjale, dok je Kagan umro godinu nakon njega i godinu prije nego je streljan Medvedev, od srčanog udara prouzrokovanog uvjerenjem da mu se i samom sprema streljanje. Ipak, ni Bahtinov angažman nije prošao bez posljedica u vidu uhićenja, izgona u provinciju, života u neimaštini i jedno vrijeme u ilegali, te u konačnici kronične bolesti. Usp. isto: 176.
} 
uspostavljanje načina čitanja koji bi omogućio asimilaciju Bahtinovih vlastitih djela filozofskom modelu njegove karijere.“ (isto: 137)

Marksističke konotacije spornih Vološinovljevih i Medvedevljevih tekstova doista jest teško zanemariti, pogotovo uzme li se u obzir naslov kapitalnog djela što ga potpisuje Vološinov - Marksizam i filozofija jezika, ili pak činjenica da Medvedev u uvodnom poglavlju svoje studije progovara o ,predmetu i zadacima marksističke nauke o književnosti““. Bahtin se, s druge strane, nigdje eksplicitno ne referira i ne oslanja na marksizam. No kako napominje Hirschkop (1999: 132), čak i ukoliko bismo sporne tekstove izolirali, ostalo bi problema u kasnijim Bahtinovim djelima s kojima bi se trebao nositi, budući da je $\mathrm{u}$ pojedinim fazama istraživanja o romanu Bahtin ,militantniji od ičega što se može pronaći kod Vološinova i Medvedeva“.

Međutim, suprotno onome što bi se iz te ironične kritike Bahtinovih antimarksističkih interpretatora moglo zaključiti, Hirschkop ne tvrdi da je Bahtin marksist, no jednako tako ne tvrdi ni da on to nije. Skrećući pozornost na spomenutu heterogenost sovjetskog marksizma (Hirschkop, 1999: 131), zaključuje da u djelima Bahtinova kružuka „ništa izravno ne proturječi marksističkim argumentima, baš kao što ni za što nisu ni apsolutno nužni.“ (isto) ${ }^{307}$ Slično tako i Bernard-Donals (1994: 2), bez obzira na činjenicu da u naslovu vlastite studije Bahtinov krug smješta ,između fenomenologije i marksizma“, za marksističku fazu njihova stvaralaštva smatra da bi je možda bilo bolje nazivati sociološkom, budući da je ,daleko od bilo kojeg prepoznatljivog ortodoksnog oblika marksističke teorije“, odnosno da baš poput njegove fenomenološke faze, koja odudara od fenomenoloških teorija na koje se oslanjao, ni njegov „materijalizam i koncept društvene promjene ne poklapaju se s verzijama historijskog materijalizma koje ovdje razmatramo.“ (isto: 105) Osnovne su točke odudaranja od klasičnog marksizma koje Bernard-Donals (1994) na više mjesta u svojoj studiji ističe izostanak scijentizma karakterističnog za historijski materijalizam te dovođenje u pitanje determinacije ekonomskim.

Naime, čak i u ranijim radovima fenomenološke faze Bahtin vidljivo nastoji pronaći put između zatvaranja književnosti/umjetnosti u samodovoljnu cjelinu te njezinog potpunog razlaganja u „svijetu“. Već u vrlo kratkom eseju Umjetnost i odgovornost [1919.] nastalom za

\footnotetext{
${ }^{307}$ Hirschkop (1999: 130) sličan zaključak izriče i glede korespondencije između Pasternaka i Medvedeva u kojoj je prvi zapazio i komentirao netradicionalnost marksizma Formalnog metoda potonjeg te neokantovski utjecaj u djelima Bahtinova kruga. No odmah potom Hirschkop dodaje i da taj neokantovski moment također nije nužno isključujuć u odnosu na marksizam, ukazujući na primjer Lukácsevih neokantovskih elemenata te tvrdeći da su se „Bahtin i Lukács, kao i čitava generacija europskih intelektualaca, čvrsto oslanjali na neokantovsku filozofiju društva u vlastitoj društvenoj kritici, bez obzira na njihove lokalne političke afilijacije. Ta činjenica ne čini Bahtina ništa više marksistom nego što čini Lukácsa antimarksistom..." (isto: 132)
} 
trajanja Revolucije Bahtin (1990: 2) inzistira na tome da „/u/mjetnost i život nisu jedno, no nužno se ujedinjuju u meni - u jedinstvu moje odgovornosti.“ Nešto kasnije u Autoru i junaku $u$ estetskoj aktivnosti izrazito kritizira „objašnjavanje određenog dela biografijom“ (Bahtin, 1991: 10) kao i nerazlikovanje autora kao osobe od autora kao „principa viđenja“ (isto: 220). Nadalje, premda jasno razdvaja estetsku domenu od ostalih područja života, tvrdeći da „estetska objektivnost ide u drugom pravcu u odnosu na spoznajnu i etičku“ (isto: 14), Bahtin dvjema jednako nepoželjnim krajnostima smatra i otklizavanje prema etičkom kojim bi se izgubila estetička posebnost (isto: 218) i autistično zatvaranje u čisti esteticizam (isto: 219).

No kada u sljedećoj fazi svog stvaralaštva sva trojica najistaknutijih autora Bahtinova kruga od dijaloškog subjekta kao izvorišta jezične produkcije pozornost pomaknu prema dijaloškom subjektu oblikovanom jezikom ${ }^{308}$, ambivalencija će postati još naglašenija. Naime, primarna meta kapitalnih studija Vološinova i Medvedeva nisu samo reduktivni psihologistički i biologistički pristupi, u koje su ubrajali i formalizam, nego i mehanički determinizam karakterističan za dio onodobnog sovjetskog marksizma ${ }^{309}$.

Uzmimo za primjer Vološinova, koji na slučaju tzv. suvišnog čovjeka u ruskoj književnosti odbacuje njegov mehanički izvod iz historijske situacije propadanja plemstva, ali istodobno ne prihvaća ni da se suvišni čovjek može promatrati samo kao unutarknjiževni mehanizam, naglašavajući „da od ekonomskih promena u privredi do pojave 'suvišnog čoveka' u romanu vodi veoma dug put koji prolazi kroz niz kvalitativno različitih sfera, od kojih svaka ima svoju specifičnu zakonitost i samosvojnost" (Bahtin 1980: 19). No iako opisuje prolazak kroz te sfere - od reorganizacije romana, preko sustava književnosti pa do ekonomske baze - u konačnici ne daje konkretan primjer tretmana suvišnog čovjeka koji ne bi gravitirao jednoj od krajnosti ili mehaničke refleksije tradicionalnog marksizma ili nedovoljne analize društvenih problema u formalizmu, niti bitno odmiče od kasnog formalizma.

Na drugom pak mjestu Vološinov (2012: 151-152), raspravljajući sa Sakulinom i njegovim povezivanjem sociološke metode s imanentnom kritikom, gotovo da raspravlja i s kasnim formalističkim postavkama, te odbacujući dvojnost gibanja koja utječu na književnu evoluciju ističe da se takve pretpostavke kose s monističkom prirodom marksizma. Tvrdeći da sociološka metoda mora moći objasniti i „unutarnje“ i „vanjske“ silnice, ipak ne odgovara na

\footnotetext{
${ }^{308}$ Zasluge/odgovornost za prelazak kružoka u izraženije semiotičku, više materijalističku pa i potencijalno marksističku fazu stvaralaštva najvjerojatnije pripadaju Vološinovu. Usp. Hirschkop, 1999: 166 i BernardDonals, 1994: 87.

${ }^{309}$ Usp. Vološinovljevu (Bahtin, 1980: 18-20; Vološinov, 2012: 151-153 [1927] ) i Medvedevljevu (1976: 5-7; 23) kritiku tradicionalnih marksističkih postavki u uvodima studija, kao i teze da marksizam nije razvio specifične teorije pojedinačnih oblasti nadgradnje, pa ni valjanu teoriju ideologije. Potonja je zamjerka vrlo nalik onoj kojom će svoj ogled o državnim ideološkim aparatima započeti Althusser (usp. Althusser, 2001).
} 
pitanje „kako?“, a istovremeno priznaje da je ta metoda do sada potpuno zanemarila takozvane imanentne strukture.

Slično je i s Medvedevom, koji usložnjava pitanje relativne autonomije književnosti pišući sljedeće:

Književnost je samostalni deo ideološke sredine i zauzima u njoj posebno mesto kao skup verbalnih tvorevina organizovanih na određen način, sa specifičnom, samo njima svojstvenom strukturom. Ova struktura, kao i svaka ideološka struktura, prelama društveno-ekonomsko biće koje postaje; prelama ga na svoj način. Ali, u isti mah, književnost odražava i prelama u svom sadržaju prelamanja i odraze drugih ideoloških sfera (etike, saznanja, političkih učenja, religije), tj. književnost u svom „sadržaju“ odražava ceo ideološki horizon, čiji je i ona sama deo. (Medvedev 1976: 24-25) $)^{310}$

Takvo viđenje Medvedev suprotstavlja čak i kasnom formalizmu ${ }^{311}$, za koji smatra da pati od nepreciznosti i proizvoljnosti kada se bavi književnom evolucijom (usp. Medvedev 1976: 247-8), no istovremeno se - kako je Erlich (1980: 115) primijetio - i sam rijetko spušta $\mathrm{S}$ visoke razine apstraktnosti.

Nekolicina teoretičara ipak smatra da Bahtinove studije pokazuju razvojnu tendenciju prema konkretnije elaboriranoj determinaciji materijalnim. Tako Bennett (1979: 96) u odnosu na studiju o Rabelaisu ${ }^{312}$ tvrdi da „u potpunosti oprimjeruje kako bi marksistički - to jest, historički i materijalistički - pristup proučavanju književnog teksta trebao izgledati.“ DeJean (1992: 68) pak na primjeru karnevala i karnevalizirane književnosti upozorava na razliku u odnosu historije i književnosti u Bahtinovim studijama o Rabelaisu i o Dostojevskom ${ }^{313}$, tvrdeći da se „/d/jelo o Rabelaisu manje bavi književnim, a više sociokulturnim razvojem. Dostojevski, sa svojim daleko isključivije književnim fokusom, izgrađuje razrađeniji terminološki sistem." Odnosno, studije prema tome gravitiraju različitim polovima opozicije sociologizam-formalizam: prva zaokupljena književnim i kulturnim fenomenima čvrsto usidrenim u određen historijski kronotop, dok druga tek rubno obrađujući historijski kontekst, fokusirajući se na književnu historiju i formalnu analizu, zbog čega DeJean (isto: 71) zaključuje da ,postoje nerješivi problemi koji osuđuju na neuspjeh svaki pokušaj da se ta dva Bahtinova glavna djela čitaju kao homologna.“

\footnotetext{
${ }^{310}$ Usp. s Vološinovljevim tvrdnjama: „Druge ideološke sfere, naročito uključujući i sociopolitički poredak te ekonomiju, imaju određujući učinak na verbalnu umjetnost ne samo izvana, nego i izravno djelujući na njezine intrinzične strukturne elemente. I obrnuto, umjetnička interakcija autora, slušatelja i junaka može ostvariti utjecaj na druge domene društvenog međudjelovanja“ (2012: 194).

${ }^{311}$ Glavne točke Medvedevljeve kritike formalizma odnose se ipak prvenstveno na raniji formalizam te prema njemu, iako nedvojbeno dobro teorijski argumentirane, nisu naročito benevolentne, već prvenstveno ciljaju na njegove mane.

312 Usp. Bahtin, 1978 [1965].

${ }^{313}$ Usp. Bahtin, 1967 [1963].
} 
Premda razlike od studije do studije nesumnjivo postoje, dvojbeno je opisati ih kao kontinuiran linearan razvoj jedinstvene tendencije ${ }^{314}$. Primjerice, u Problemima poetike Dostojevskog Bahtin (1967: 71-72) razmjerno rano u studiji afirmira Kausovu tezu da je specifična struktura romana Dostojevskog rezultat promjena izazvanih kapitalizmom, i to „upravo u Rusiji, gdje je kapitalizam nastupio kao katastrofa“ (isto: 72), no odmah potom zamjera mu da previđa da je ,'duh kapitalizma' ovdje izražen jezikom umjetnosti, i to jezikom jednog posebnog vida romana“, te da bi stoga prije svega bilo „neophodno otkriti specifičnosti konstrukcije tog višeplanskog romana“, namjesto mehaničkog prelaska na vanjski svijet. Veći dio studije potom je posvećen tom zadatku, i time se ona doista donekle razlikuje od historijskim kontekstom zaokupljenijeg Stvaralaštva Fransoa Rablea i narodne kulture srednjega veka i renesanse. No jednako tako stoji i činjenica da u takvom Stvaralaštvu Fransoa Rablea koncepti karnevala i karnevalesknosti na općenitijoj razini ipak nisu tek poopćenja kasnijih Bahtinovih interpretatora, nego je tom poopćenju temelj jasno položen već u njegovoj studiji. Slična je i situacija i s Bahtinovim tekstovima okupljenim pod naslovom Pitanja iz književnosti $i$ estetike [Voprosy literatury i estetiki, 1975], na ovim prostorima objavljenim pod naslovom $O$ romanu (1989). Naime, dok poznata studija Oblici vremena $i$ hronotopa u romanu nastoji ponuditi svojevrsnu historijsku studiju geneze i razvoja romana, studije poput Reči u romanu ili Ep i roman $^{315}$ ne samo da (gotovo transhistorijski) poopćavaju koncepte romana i romanesknog, nego i pojmom dijalogizma upućuju na jezik u cijelosti ${ }^{316}$.

Hirschkop (1999: 81) stoga kritički podcrtava da kod Bahtina u konačnici nije jasno je li historija uzrok višeglasja ili je višeglasje uzrok historije. Pritom utječući se „cirkuskim arenama, vašarskim binama, uličnim pesmama i anegdotama“ (Bahtin, 1989: 166) kao mjestu rođenja društveno tipičnih glasova određenih ljudi, nasuprot uopćenog bezličnog jezika, Bahtin više zaobilazi pitanje nego što daje odgovor ${ }^{317}$. Otuda i na prvi pogled proturječna Bernard-Donalsova ocjena da se s jedne strane potencijal Bahtinova kruga glede usložnjavanja odnosa između baze i nadgradnje zaustavlja na (makar nominalnom)

\footnotetext{
${ }^{314}$ Dapače, Hirschkop (1999: 53) na općenitijoj razini tvrdi da različita Bahtinova djela prije sugeriraju stalno preispisivanje s promjenama nego li stvarnu evoluciju ideja.

${ }^{315}$ Sve spomenute studije usp. u Bahtin, 1989.

${ }^{316}$ Hirschkop (1999: 22) kritički napominje da se kod Bahtina u nizu slučajeva „posljedice historijskog razvoja postupno zakopaju u koncepte diskursa samog, te prateći ih dolazimo do modela intersubjektivnog dijaloga koji takoreći u sebi ima ugrađenu modernost." Kao jedan od primjera nudi Bahtinov koncept višeglasja (poliglosije) određenog kao „unutrašnja raslojenost svakog jezika u svakom datom trenutku njegovog istorijskog postojanja“ što je kao takvo „nužna pretpostavka romanesknog žanra“ (Bahtin, 1989: 16). Pritom se, kao posljedica poopćavanja pojma, iz vida postupno gube historijski okvir u kojem je inicijalno definirano višeglasje nastajalo, kao i eventualne historijske razlike u njegovom funkcioniranju.

${ }^{317}$ To sugerira i Vološinovljeva (2012: 194) tvrdnja da se „tehnička pitanja mogu odvojiti od socioloških pitanja forme samo u apstrakcijama“, odnosno da je nemoguće realno odvojiti formalno-lingvističku stranu nekog diskurzivnog postupka od njezinih ekstraverbalnih učinaka.
} 
pribjegavanju određenju društvenim okružjem u krajnjoj instanci (usp. Bernard-Donals, 1994: 102), te s druge strane da je za Bahtina zapravo ipak jezik ono što određuje u krajnjoj instanci, budući da se izvanjezična stvarnost može spoznati i intersubjektivno priznati jedino unutar jezika (isto: 111)

Nestanak čvrste objektivne datosti koja ne bi bila podložna određenju pozicioniranošću bilo u jeziku, bilo u fenomenološkom trokutu ja-drugi-autorska pozicija, bez obzira na povremeno utjecanje Bahtinovih analiza nekom vidu stabilizacijskog faktora, $\mathrm{u}$ izravnoj je svezi s nemogućnošću herojske marksističke znanosti i istine koju ona spoznaje. Utoliko, pozicija Bahtinova kruga možda nije nužno ne-marksistička, no u konačnici ne samo da se, kako je spomenuto, nije mogla izmiriti s pozicijama prevladavajućeg strujanja sovjetskih marksističkih krugova svoga vremena, nego to ne može ni s mnogo kasnijom Althusserovom, s kojom je pokušava povezati Bennett (1979). No ta je specifična nekompatibilnost, baš kao i ona formalista, ujedno anticipacija desetljećima kasnijih teorijskih kretanja što smo ih analizirali u prethodnom dijelu rada; i to anticipacija koja ne počiva na pukoj slučajnosti, već na recepciji isprepletenih niti različitih teorijskih tradicija.

Proturječnošću glede determinacije umjetničkog djela historijskim kontekstom postavke Bahtinova kruga pokazuju se u biti kao svojevrsna druga strana medalje kasnoformalističkih stavova - ambivalentnost je jednaka, analitički fokus sličan, tek je pol kojem se nominalno daje prednost suprotan. No dok se formalisti nisu teorijski bavili političkim pitanjima, Bahtinov je opus započeo na polju etike, da bi se ubrzo potom naizgled predominantno okrenuo pitanjima estetike. Ipak, dvije komponente ostale su zapravo cijelo vrijeme nerazdvojne. Stoga ne čudi da se književnost i u ovom slučaju našla na privilegiranom mjestu svojevrsnog modela za razumijevanje funkcioniranja političkog/društvenog, ali i učinkovitog sredstva za intervenciju u njemu. Upravo je takvo pozicioniranje književnosti ono što možda $i$ ponajviše navodi na usporedbu $s$ postmarksističkim kontekstom.

Premda ni formalistički kružoci ni Bahtinov krug nisu bili zastupljeni u dosadašnjim istraživanjima postmarksizma, radi se o teoretičarima koji nisu bili posve recepcijski zanemareni $\mathrm{u}$ trenucima kad je intenzivnije ispreplitanje (althusserijanskog) marksizma i poststrukturalističkih kretanja započelo na europskoj sceni. Doduše, recepcija je bila oprečna - dok se Bahtin u njoj pretvorio u svojevrsnog protopoststrukturalističkog junaka ${ }^{318}$,

\footnotetext{
${ }^{318}$ Usp. Lesic-Thomas (2005) o inicijalnom oblikovanju protopoststrukturalističkog Bahtina kod Kristeve.
} Također, u golemoj bibliografiji o Bahtinu zadnjih desetljeća, zbornik Bahtin i drugi (Biti, 1992) jedan je od 
formalistima protostrukturalistička etiketa nije donijela prednost ni među marksistima, ni među poststrukturalistima ${ }^{319}$. No da je takvo oštro odvajanje i dijametralno suprotno pozicioniranje rezultat interpretativnih zabluda prije nego stvarnog obilježja dvaju teorijskih fenomen vrlo dobro pokazuje Lesic-Thomas, analizirajući najznačajniju ulaznu točku Bahtinova kruga na europsku teorijsku scenu - Kristevinu recepciju Bahtina.

Naime, kako zanimljivo primjećuje Lesic-Thomas (2005), Kristeva je svoj pojam intertekstualnosti, danas jedan od frekventnijih teorijskih koncepata, šezdesetih godina doista izgradila na Bahtinovu pojmu dijaloga, istovremeno se time „uspostavljajući kao prepoznatljiv glas u francuskim strukturalističkim krugovima, kao i upoznajući te krugove sa svijetom bahtinovske misli“ (isto: 1). No osim što je u tom procesu Bahtinov tekst transformacijama prilagođen čitanju u suodnosu s poststrukturalističkim idejama što su intenzivno nastajale (isto: 6), interpretacija ključnih pojmova na trenutke je bliža stajalištima ruskih formalista nego Bahtinu: „Kristeva se možda referira na Bahtina, no mnogo preciznije parafrazira Tinjanova“" (isto: 13).

Višeslojno shvaćanje dijaloga svedeno na međuigru neutjelovljenih glasova, vidljivo izbjegavanje koncepta subjekta u korist desubjektiviranog teksta (ili teksta kao subjekta), pa i čuvena definicija intertekstualnosti kao sveprisutne međuigre mozaika citata, odnosno opetovane apsorpcije i preoblikovanja drugih tekstova, više su nalik Tinjanovljevim opisima književne činjenice, sustava i parodije ${ }^{320}$, nego Bahtinovu dijalogu. Stoga, premda je utjecaj pojedinih Bahtinovih koncepata nedvojbeno od presudne važnosti za Kristevinu intertekstualnost, fenomen intertekstualnosti i veze formalista s kontekstom u kojem Kristeva adaptira Bahtina zaslužni su da intertekstualnost „duguje jednako mnogo (ako ne i više) idejama Šklovskog, Jakobsona i Tinjanova, koliko i onima Bahtina“ (isto: 3).

Spomen Šklovskog ovdje je vrlo zanimljiv jer Lesic-Thomas (2005) ne staje na Jakobsonu i Tinjanovu, nego - poput Benneta (1979) - korijen kasnoformalističkog viđenja književnih sustava i evolucije vidi u konceptu očuđenja, odnosno u Umjetnosti kao postupku Šklovskog, a s njime povezuje i revolucionarnost Kristevina koncepta. Stoga piše: „Uloga očuđenja Šklovskog mnogo je više revolucionarna: ono izaziva potpunu perceptivnu reviziju, čineći nas osjetljivijima na neobičnost i senzualnost svijeta. Bahtin nije bio revolucionar u smislu u kojem ga Kristeva čita; Šklovskij, s druge strane, zajedno s većinom ostalih formalista, jest" (Lesic-Thomas 2005: 17).

\footnotetext{
zornih pokazatelja tendencije da se Bahtina i Bahtinov krug odmjerava o imena i koncepte poststrukturalističke teorije te da se iz te perspektive progovara o njegovoj aktualnosti.

$319 \mathrm{O}$ balastu protostrukturalističke etikete pridavane formalistima usp. Striedter, 1989: 12-13.

${ }^{320}$ Usp. Tinjanov, 1998.
} 
Iako je odricanje revolucionarnosti Bahtinu diskutabilno, te za početak ovisi i o određenju značenja tog nimalo samorazumljivog pojma, primjedba Lesic-Tomas o značaju formalističkog nasljeđa i profiliranje očuđenja kao učinka potpune perceptivne revizije izrazito su vrijedni. Upravo tako shvaćeno očuđenje stoga može poslužiti i kao temeljna okosnica usporedbi formalista s autorima kojima smo se bavili ranije u radu, a koji $\mathrm{s}$ Kristevom dijele kontekst djelovanja i mnoge od temeljnih teorijskih postavki.

Naime, iako je i Bennett (1979: 98) upravo učinak očuđenja izdvojio kao jednu od središnjih točaka svoje usporedbe formalističke teorije s konceptualizacijom književnosti kod Althussera i ranog Machereya, ta je jezgra formalističke teorije ujedno i nezanemariv razlikovni element spram navedene dvojice teoretičara. Kao što smo pokazali, za Althussera i ranog Machereya književnost se - pojednostavljeno rečeno - smješta negdje na pola puta između marksističke znanosti i ideologije, te s te pozicije razotkriva proturječja ideologije i ukazuje prema istini, no ne može osigurati njezinu spoznaju onako kako to čini znanost. Drugim riječima, iz perspektive teorije ideologije književnost je inferioran oblik spoznaje u odnosu na marksističku znanost te gravitira pasivnom zrcaljenju (iako ne u smislu mehaničkog odraza, već razotkrivajućeg prelamanja) prije negoli djelatnom podrivanju ideoloških konstrukta.

Formalističko očuđenje nije pak upravljeno otkrivanju istine, nego, kako LesicThomas (2005: 17) formulira, potpunoj perceptivnoj reviziji, te samim time nije pasivan instrument prelamanja što razotkriva ideološko iskrivljenje, već aktivan postupak što rekonfigurira sliku. Razlika se može činiti minimalnom, no u kontekstu dosadašnjih razmatranja značajna je utoliko što formaliste pozicionira bliže autorima koji književnost u pravilu perpcipiraju imanentno političkim diskursom što aktivno rekonfigurira poredak osjetilnog, odnosno - u obrnutom pravcu - omogućuje da poopćenim konceptom očuđenja ujedinimo njihove konceptualizacije učinaka književnosti, neovisno o pojedinačnim razlikama

Dapače, iz usporedbe nije nužno isključiti ni Laclaua, bez obzira na to što se on sa svoje strane nije izravno istraživački bavio književnosti, dok se formalisti s druge strane nisu izravno bavili političkom teorijom. Laclauovo (2014) pozivanje na Jakobsona (s čijim je radom očito dobro upoznat) te Jakobsonovo (2008: 172) izdizanje tropa na višu razinu općenitosti, nije naime jedino mjesto dodira Laclauove tropološke teorije društva i gotovo stoljeće ranijeg formalističkog bavljenja tropima. $U$ formalističkoj se teoriji naime problematika tropa našla u središtu polemike s Potebnjinom školom. Premda su polemizirali s Potebnjinim naglašavanjem slike-tropa kao biti umjetničkog, Ambrogio (1977: 129) primjećuje kako ni sami ne uspijevaju umaknuti afirmaciji tropa, pa tako i Šklovskij koncept 
očuđenja gradi na tropološkom principu, kao ono što čini da se „stvar ne opaža u svojim prostornim odnosima, nego, da tako kažem, u svojoj neprekidnosti““ (Šklovskij, 1999: 130), odnosno ono što trga predmet iz „niza uobičajenih asocijacija u koje je uklopljen“ (Šklovskij, prema Ambrogio 1977: 129). Drugim riječima, ,/i/ očuđenje i metafora dovode do 'specifičnog semantičkog pomaka' i time do potpuno novog 'viđenja stvari'; čupajući je iz semantičke serije u kojoj se nalazi oni je prebacuju u novi perceptivni niz“ (isto). Iz toga proizlazi i da je Laclauova definicija literarnosti - u kojoj se doduše nigdje ne poziva na formaliste, ali koju donosi $\mathrm{u}$ tekstu oslonjenom na pojedine Jakobsonove izvode komplementarna definicijama mehanizma očuđenja, uzmemo li da očuđenje, kao srž književnog za Šklovskog, razotkriva „iskrivljujuće učinke“ (Laclau 2014: 79) određenog režima reprezentacije ${ }^{321}$.

Nadalje, putanja što je Laclau (2014: 67) opisuje od sedimentiranog društvenog poretka, preko njegove reaktivacije pa do ponovne sedimentacije analogna je putu „od viđenja prema spoznaji, od poezije prema prozi“ (Šklovskij, 1999: 126), odnosno od automatizacije preko očuđenja do ponovne automatizacije. Ono što je za formaliste srž umjetničkog, te istovremeno i političnosti umjetnosti, za Laclaua je na višoj razini općenitosti, ne bez razmjerno kasno no ipak otvoreno priznatog duga formalističkoj teoriji, ključan moment politike.

No i sam Šklovskij u jednoj situaciji trope promatra nalik Laclauu kao mehanizme političke artikulacije. Baveći se člancima formalističkih autora objavljenim o Lenjinu neposredno nakon njegove smrti, Eisen (1996: 69) poseban naglasak stavlja na Šklovskog i njegovo izjednačavanje modusa Lenjinova djelovanja s djelovanjem umjetnosti: “'Lenjin kao

\footnotetext{
${ }^{321}$ Govoreći o literarnosti, u priču svakako valja uključiti i Rancièrea. O kompatibilnosti Laclauova i Rancièreova koncepta literarnosti iz političke perspektive već je bilo riječi, a na analognost Rancièreove i formalističke (prije svega Jakobsonove) definicije literarnosti ranije je upozorio Brlek (2015), ispravljajući tako prethodne pogrešne interpretacije u kojima je sudjelovao i sam Rancière. Naime, Brlek (2015: 148) piše: „Iako poprilično jednoznačno izložena, Jakobsonova će teza [o literarnosti kao projekciji načela ekvivalentnosti s osi selekcije na os kombinacije] gotovo bez iznimke biti pogrešno tumačena, kao zagovaranje specifičnosti književnog (pjesničkog) jezika, koja bi imala tekstu pribaviti status literature. Takva pogrešna tumačenja očito ima na umu Jacques Rancière kada daje svoju definiciju literarnosti, pri čemu ne spominje Jakobsona iako je jasno da na njega misli (...) suprotstavljajući je 'strukturalističkoj viziji'. No razlike između te dvije literarnosti nema, to jest Rancièreova je Jakobsonova, ispravno shvaćena." Utoliko je na temelju Brlekove analize moguće ustvrditi da se Rancière na formalističko nasljeđe naslanja i u većoj mjeri nego Laclau, no toga je manje svjestan od njega. Za razliku od Laclaua, koji se na Jakobsona referira izravno i afirmativno (doduše tek u kasnijim radovima), Rancière polemizira s ponešto iskrivljenim predodžbama o formalističkim postavkama (usp. npr. i Rancière, 2011b: 153). No neovisno o tome, uzmemo li u obzir da je literarnost, kao jednakost slova, temeljna jednakost u jeziku koja je nepremostiva pukotina politike u srcu svakog policijskog poretka, važan segment Rancièreove političke teorije, povratne implikacije u odnosu na formalističku literarnost jasne su: „Ozloglašena autonomija književnosti nije, prema tome, nikakav društveno-povijesni autizam, nego upravo suprotno, krajnje izoštrena svijest o svim diskurzivnim - kako književnim tako i neknjiževnim - konstelacijama u koje se tekst nastankom i recepcijom upisuje, a koje samim svojim postojanjem nepovratno mijenja." (isto: 151)
} 
dekanonizator' izrazito je sugerirao da je Lenjinova moć, kao i moć umjetnosti, izvedena iz njegove sposobnosti da ironizira, da se odmakne od ograničenja ideologije i dogme te djeluje na neinhibiran način“. Nadalje, kako navodi Šklovskij, „,esencija Lenjinove moći nije se oslanjala ni na kakvu ideološku shemu, nego je bila vidljiva u slobodi da se po volji pokreće i redefinira svoju poziciju, ili poziciju protivnika“ (isto: 74), što je ostvarivao efektivnom uporabom jezika. Šklovski naročito važnim smatra Lenjinove polemičke taktike oslonjene na činove imenovanja, kojima je Lenjin proizvodio nove pozicije u određenom diskurzivnom prostoru (najčešće da bi odijelio protivnike i konsolidirao redove), te konstantnu reviziju terminologije sukladno potrebi određenog trenutka. Prisjetimo li se Laclauova viđenja katahreze kao srži političkog, baš kao i katahretične funkcije vođe koju opisuje u $O$ populističkom umu (Laclau, 2007b: 100), zaključci Šklovskog djeluju kao fascinantna anticipacija Laclauovih, što i s te strane potvrđuje važnost njegove (makar ograničene i posredne) komunikacije s formalističkom tradicijom.

Katahretičnost svakog diferencijalnog poretka ujedno je, podsjetimo se, i razlog postojanju onoga što Laclau naziva praznim označiteljima te borbe za njihovo zaposjedanje. Impresivno sličan prikaz borbe oko stabilizacije značenja nekog znaka nalazimo i u radovima jeziku orijentirane faze Bahtinova kruga, najjezgrovitije izražen u Vološinovljevom Marksizmu i filozofiji jezika. Vološinovljeva potpuna semiotizacija ideologije i politike tezom da je ideološko jednako znakovnom (usp. Bahtin 1980: 12) te njegovo razumijevanje odnosa između različitih oblasti ideologije i subjekata, svih skupa uronjenih u znakove, impresivno prefigurira Laclauove postavke društvenog ${ }^{322}$, a ta veza ponajbolje dolazi do izražaja u opisu društvenog antagonizma realiziranog unutar jezika.

Vološinov primjećuje da se društvene klase ne podudaraju sa znakovnim kolektivom, stoga se „/u/sled toga u svakom ideološkom znaku ukrštaju različiti akcenti“, koji su nosioci vrijednosne evaluacije znaka, a ,/z/nak postaje arena klasne borbe“ (Bahtin, 1980: 25). ${ }^{323}$ Primjetna je razlika ipak u tome što je kod Vološinova borba nužno klasna (premda taj aspekt

\footnotetext{
${ }^{322}$ Kao što smo već natuknuli, važna, no ne posve dorečena razlika jest odnos prema ekonomskoj bazi. Vološinov smatra da su različite ideološke oblasti relativno autonomne, no istodobno i da one na svoj način prelamaju stvarnost (Bahtin 1980: 12), tj. da su njome u konačnici determinirane (premda je ta determinacija specifično realizirana u svakoj oblasti). Laclau i Mouffe (2014: 69, 84-85), djelujući u izmijenjenom teorijskom i historijskom kontekstu više od pola stoljeća kasnije, prednost daju diskurzivnom odbacujući determiniranost bazom u krajnjoj instanci, no ipak ne smatraju da ekonomski faktori ne igraju ulogu u diskurzivnim borbama.

${ }^{323}$ Kao i Laclau nakon njega, Vološinov sukob različitih aktera oko ispune znaka smatra preduvjetom njegove živosti: „Socijalna poliakcentnost veoma je važan momenat ideološkog znaka; u stvari, znak je živ i pokretljiv i sposoban za razvoj samo zahvaljujući tom ukrštanju akcenata. Izvađen iz napete društvene borbe, znak će se naći s one strane borbe klasa i neizbežno će zamreti, pretvoriće se u alegoriju, postaće objekt filološkog ali ne i živog socijalnog razumevanja“ (Bahtin 1980: 25)
} 
nije šire elaboriran pa ne možemo sa sigurnošću tvrditi radi li se o predeterminiranim klasama ili ne). Kod Medvedeva isti primjer nalazimo bez klasne odrednice:

Uzmimo ovakav slučaj. Dve neprijateljske društvene grupe raspolažu lingvistički istim jezičkim materijalom - potpuno istim rečnikom, istim morfološkim i sintaksičkim mogućnostima i sl.

U tom slučaju, ako su razlike između te dve grupe uslovljene bitnim društveno-ekonomskim pretpostavkama njihovog bića, iste reči biće veoma različito intonirane; u istim gramatičkim konstrukcijama reči će ulaziti u smislovne i stilske kombinacije koje se dosta razlikuju jedna od druge. Iste reči zauzimaće potpuno drukčije hijerarhijsko mesto u celokupnom iskazivanju kao društvenom činu. (1976: 185)

No bez obzira na tu razliku, riječ je o dimenziji jezične produkcije koja je za teoretičare Bahtinova kruga od prvoklasne važnosti ${ }^{324}$. „Jezik se stvara, formira i neprekidno postaje u granicama određenog horizonta vrednosti““, navodi Medvedev (1976: 185), baš kao što Vološinov (2012: 167) podcrtava da vrijednosna evaluacija „određuje samu selekciju verbalnog materijala i formu verbalne cjeline."

Činjenicu da je znak u društvu uvijek višestruko naglašen (tzv. društvenu poliakcentnost) vladajuća skupina uvijek nastoji prikriti, težeći da značenje prikaže bezvremenim, da ,stabilizuje prethodni momenat dijalektičkog toka socijalnog postajanja, da istinu jučerašnjeg dana akcentuje kao današnju istinu.“ (Bahtin, 1980: 26) Situacija znaka kao arene (klasne) borbe, odnosno ukrštenih vrijednosnih naglasaka, analogna je dakle onome što se kasnije pojavljuje kao antagonistički rasjed kod Laclaua ili pak nesporazum, odnosno nesuglasnost kod Rancièrea, te utoliko nije ishodište i determinanta samo jezične produkcije, nego i politike uopće. No kao i kod dvojice netom spomenutih autora, i za Vološinova (isto) su takvi momenti izrazito rijetki: ,unutrašnja dijalektičnost znaka ispoljava se do kraja samo u epohama socijalnih kriza i revolucionarnih preokreta. U običnim uslovima socijalnog života, ova protivrečnost (...) ne može se do kraja ispoljiti...“

Baš kao i kod autora kojima smo se bavili u prethodnim poglavljima, u situacijama sedimentacije aktualnog diskurzivnog poretka, prema autorima Bahtinova kruga, izrazitu političku potenciju pokazuje književnost. Naime, tamo gdje iskaz u svojoj podlozi ima općeprihvaćen vrijednosni sud, taj se sud podrazumijeva i ne iskazuje posebno (Vološinov, 2012: 166). S druge strane, kada god se vrednovanje posebno verbalizira, ono je izdvojeno iz svoje prirodne okoline te izloženo preispitivanju. Budući da u književnosti vrijednosna

\footnotetext{
${ }^{324}$ Dapače, ta prvoklasna važnost vrijednosnog naglaska nije se pojavila tek u kasnijoj fazi djelovanja Bahtinova kruga, nego je prisutna još i u fenomenološkim radovima. Primjerice, u Autoru i junaku u estetskoj aktivnosti Bahtin (1991: 200) navodi da „momenat ocene ili, tačnije, vrednosna orijentacija svesti ima mesto ne samo u postupku u pravom smislu, nego i u svakom preživljavanju, čak i u najjednostavnijem osećaju: živeti - znači zauzimati vrednosnu poziciju u svakom momentu života, vrednosno se orijentisati.“ Razlika se doduše može uočiti u naglašenije individualnoj/kolektivnoj dimenziji vrednovanja, no ni vrednovanje u Bahtinovoj fenomenološkoj shemi nipošto nije čisto individualan čin.
} 
intonacija mora biti inkorporirana drukčije no u živom dijalogu, Vološinov smatra da je ona „moćan kondenzator neartikuliranih društvenih evaluacija - svaka je riječ natopljena njima. Upravo te društvene evaluacije oblikuju formu kao njihov izravni izraz“ (isto: 178).

Naglašena vrijednosna intonacija u književnosti kod autora Bahtinova kruga tako preuzima ulogu gotovo $\mathrm{u}$ potpunosti usporedivu s onom očuđenja kod formalista. No $\mathrm{s}$ obzirom na drukčije raspoređene naglaske njihovih teorija, politički učinci preustroja poretka osjetilnog očekivano više do izražaja dolaze u Bahtinovim nego formalističkim studijama, a temeljni prostor takvog preustroja za Bahtina je postao roman. Zbog nedostatka prostora za temeljitu analizu, skrenut ćemo pozornost tek na neke aspekte.

Već po osnovnoj definiciji koju nudi, roman je za Bahtina (1989: 16) „umetnički organizovana društvena govorna raznolikost, ponekad višejezičnost, i individualna disonanca“, odnosno prostor raslojavanja jedinstvenog hegemonijski stabiliziranog jezika ,na društvene dijalekte, manire grupa, profesionalne žargone, jezike žanrova, jezike generacija i uzrasta, jezike pravaca, jezike autoriteta, jezike grupa i prolaznih moda, jezike društvenopolitičkih dana pa čak i časova...“", pa samim time i rezonator društvene poliakcentnosti što podriva normativnu stabilizaciju. No ta imanentna dijalogičnost romana nije stvar, kako Bahtin pojašnjava, ma kako tragičnih individualnih nesporazuma i proturječja, već

svojim korenima prodire duboko u suštinsku društveno-jezičku govornu raznolikost i višejezičnost. Istina, i u romanu govorna raznolikost je uglavnom uvek personifikovana, otelotvorena $\mathrm{u}$ individualnim likovima ljudi sa individualizovanim raznoglasjem i protivurečnostima. Ali ovde su te protivurečnosti individualnih sloboda i umova zaronjene u društvenu govornu raznolikost i preosmišljene njome. Ovde su protivurečnosti individua samo uzdignuti hrbati stigije društvene govorne raznolikosti, stihije koja se razigrava i despotski ih čini protivurečnim, ispunjava njihovu svest i njihove reči svojom suštinskom govornom raznolikošću. (Bahtin, 1989: 86)

Pojedinačni antagonizmi u romanu dakle, poslužimo li se kasnijim Laclauovim rječnikom, situacijske su tropološke artikulacije heterogenog i vrlo dinamičnog polja društvenih proturječja; tropološki artikulirane pozicije privremeno stabilizirane društvene slike. Artikulacija unutar romana je pak, kako upozorava i Hirschkop (1999: 78), za Bahtina velikim dijelom zasluga autora koji glasove u romanu kondenzira iz „fluidnog i kaotičnog materijala“ (što je motiv koji se provlači još od Autora i junaka u estetskoj aktivnosti, s tim da se tamo radilo o oblikovanju junaka, ne glasa-kao-junaka) ${ }^{325}$, što dovodi do pojave

\footnotetext{
${ }^{325} \mathrm{~S}$ obzirom na to da je u Autoru i junaku u estetskoj aktivnosti (Bahtin, 1991) jedna od temeljnih funkcija bila prevladavanje ograničenja horizonta junaka estetskim zaokruživanjem iz perspektive drugoga, analoški bi se moglo tvrditi da autorski angažman u kondenzaciji glas(ov)a i u kasnijem Bahtinovu stvaralaštvu podrazumijeva izdizanje iznad ograničenog horizonta te slijevanje više pojedinačnih zaokupljenosti u jedinstven kolektivni glas. To bi značilo još jednu analogiju s tropološkim oblikovanjem društvenih aktera i njihovih glasova/zahtjeva kod autora u drugoj polovici dvadesetog stoljeća, prvenstveno Laclaua i Rancièrea.
} 
karakteristične romaneskne dvoglasnosti, kod koje svaki iskaz zapravo sadrži unutarnji dijalog dvaju glasova - izravne intencije lika i neizravne „autorske“ (usp. Bahtin, 1989: $85)^{326}$. No borba za romaneskno izdvajanje iz kaosa neartikulirane buke najrazličitijih postojećih glasova, baš kao i kasnije kod Rancièrea (2015: 36), borba je za priznanje postojanja u historiji, uzimanja udjela u zajednici.

Kako Hirschkop (1999: 229) prenosi iz Bahtinove studije o Flaubertu, iz njegove je perspektive bit valjanog pripovijedanja pripovijedati ,ne o promjenama unutar granica danog života (njegovog napredovanja ili propasti), nego o mogućnostima života koji je u temelju drukčiji, s drukčijim mjerilima i dimenzijama“. Takvo pripovijedanje gotovo je nužno zaokupljeno ekscesivnim u odnosu na neku normu, kako bi svojom transgresijom granice pokazalo kontingenciju granica, to da „svaka rutina i norma, svaka institucija i zakon, ukratko, simboličke strukture čitavog života ili društvenog svijeta, nemaju druge supstance do li značenja i vrijednosti, niti ikakve snage jednom kad se više ne čine opravdanima.“ (isto)

Analogije koje Bahtin uspostavlja između pripovjedivosti te posjedovanja (osobne i kolektivne) historije, odnosno između romana i javnog/političkog prostora, nužno nas vode prema istim postfundacijskim impulsima kao i krajnje implikacije Vološinovljeve semiotizacije društvenog (zanemarimo li nedorečeno sidrenje u ekonomskom), tj. zamjenjivanje objektivne utemeljenosti društva borbom za značenje poliakcentnih znakova. To izmicanje temelja, kao što je spomenuto, prisutno je već i u Bahtinovoj fenomenološkoj fazi, no dok je tamošnja perspektiva autora nudila neki oblik zaokruženja, a analogije s religijskom figurom Kristova otkupljenja (Bahtin, 1991: 62) i usidrenje tog zaokruženja u (mistično) transcendentno, kasnija heteroglosija romana, u kojoj autorski glas postaje tek jedan od glasova u nezavršivom dijalogu, dovela je konačno u pitanje svaki pojavni oblik središta.

U Problemima poetike Dostojevskog Bahtin u nastojanju da izbjegne nekom obliku počela ili telosa afirmira vremenski razmjerno statičnu sliku romana, tvrdeći da ,/o/snovna kategorija umetničke vizije Dostojevskog nije bilo postojanje, već koegzistencija i uzajamno delovanje. On je video i zamišljao svoj svet prvenstveno u prostoru, a ne u vremenu“ (Bahtin, 1967: 82), fokusirajući tako polifone sudare proturječnih pozicija radije nego genezu

\footnotetext{
${ }^{326}$ Nije nevažno ni primijetiti, kako to Hirschkop (1999: 82) čini, da je reprezentacija/personifikacija glasa za Bahtina uvijek vezana za neki vid utjelovljenja, u doslovnom smislu osiguravanja materijalnog tijela (ako ne ljudskog, tada jezičnog). To rekonfiguraciji poretka vidljivosti i artikulaciji novih aktera na njoj daje materijalističku dimenziju, koja dakle nije potpuna novost kod autora kojima smo se bavili u ranijim poglavljima. Dovoljno je a usporedbu podsjetiti na sinonimičnost između političke aktivnosti kao mogućnosti „da se čuje neki diskurs koji je prije bio čut kao buka“ te kao onoga što ,premješta tijelo s nekog mjesta koje mu je doznačeno ili mijenja namjenu nekog mjesta“ kod Rancièrea (2015: 36).
} 
pojedinačne pozicije i njezin dijalektički razvoj prema nekom afirmiranom cilju. No u kasnijoj studiji o bildungsromanu (usp. Bahtin, 1986) središnji pojam postaje upravo postajanje kao protezanje bića historijom, s tim da determinirani cilj zamjenjuje otvorenost budućnosti i povratna autoreferencijalna petlja. Hirschkop (1999: 178) stoga smatra da je upravo studija o bildungsromanu ona $\mathrm{u}$ kojoj se Bahtin uspio riješiti i zadnjih natruha religiozne terminologije, ali i potrebe za njom: „za heroja modernog kronotopa život postaje značajan samo na jedan mogući način, kao stalno revidirana samoprocjena budućnosti i njezinih mogućnosti. Kada pripovijest razvije tu razinu autorefleksivnosti, estetika napokon može preuzeti jaram smislene historije bez ikakve pomoći religije.“327

Romaneskno odbacivanje te(le)ološke/fundacionalne perspektive kasniji će Bahtinov tekst Ep i roman povezati s književnim vrstama iz naslova. Ako je roman onaj koji je iz sebe prognao sakralne momente i stvorio prostor višeglasju i otvorenom postajanju, ep je za Bahtina (1989: 5) paradigmatski primjer poetičkih žanrova, autoritarnih diskursa što potiskuju višeglasje u korist statičnog svijeta i unificiranog jezika ${ }^{328}$. Hirschkop (1999: 70) inicijalno skreće pozornost na Bahtinovo historijsko razdvajanje prevlasti romaneskne i poetičke književnosti delegiranjem potonje u „klasičnu i srednjovjekovnu kulturu koja je zloupotrijebila svoju dobrodošlicu“ te povezivanjem prve s „modernosti samom“. No kasniji segmenti njegove studije, kao i one Neubauerove (1996), otkrivaju nam da se i ep u Bahtinovu diskursu mjestimično poopćava i ahistorizira, te funkcionira kao metonimija autoritarnog diskursa, označavajući unificirajuću, represivnu, centripetalnu tendenciju čak i u slučajevima suvremenih društvenih ustrojstava ${ }^{329}$.

\footnotetext{
${ }^{327}$ Hirschkop (1999: 73) upozorava i na dvostruku narav oslobođenja romanesknog od bilo kakve figure otkupljenja: dezintegracija transcendentnog oslonca oslobađajuća je, no i zastrašujuća, „možda jest uzbudljiva, no ne ostavlja li ništa pozitivno na svom mjestu, označava kaos prije nego progres. “ Upravo u odnosu na taj problem važno je podsjetiti na razliku između postfundacijske $\mathrm{i}$ antifundacijske pozicije, kao $\mathrm{i}$ na to da neodlučivost ne podrazumijeva oslobođenost svake odgovornosti, nego upravo poziv na odgovornost.

$\mathrm{S}$ tim u svezi valja istaknuti i paralelu s mesijanskim motivima kod kasnijih autora kojima smo se bavili u prošlim poglavljima, na koju upućuje Hirschkopova (1999: 237) napomena da „Bahtin s pravom vidi da svaka eshatologija ili anticipacija kraja vremena devalvira etičku supstancu sadašnjosti, no istovremeno oblikuje alternativu kao drugi oblik vjere prije nego skeptičko odbacivanje vjere. 'Ne vjeru (u smislu konačne vjere u pravoslavlju, vjere u progres, čovjeka, revoluciju itd.), nego osjećaja vjere, tj. integralnog odnosa (čitave osobe) spram više i ultimativne vrijednosti.““ Odnosno, „trajno uvjerenje da je kretanje historije utemeljeno u neotkupljivoj anticipaciji otkupljenja.“ Anticipirajuća sličnost ponovno nije rezultat slučajnosti, nego posredne povezanosti. Već smo spomenuli da je, primjerice, Derrida motiv mesijanskog preuzeo pod utjecajem Benjamina, a Benjamin i Bahtin, posredstvom Lukácsa, preuzimaju ga iz neokantovske tradicije. O tome će više riječi biti u sljedećem poglavlju.

${ }^{328}$ Neubauer (1996) ukazuje na to da je opreku roman - ep Bahtin naslijedio od Lukácsa (on pak od Hegela), no interpretirajući je dijametralno suprotno upravo kao tihu polemiku s njim.

${ }^{329}$ Opreka poetičkih i romanesknih diskursa te dvojba treba li ih uzimati strogo historijski kontekstualizirano ili poopćeno također se aktualizirala u više navrata u desetljećima koja su slijedila, sve do analogne Rancièreove opreke između poetičkog/reprezentativnog i estetičkog režima umjetnosti.
} 
Za razliku od romanesknog društva, izgrađenog na višeglasju i posljedično orijentiranog otvorenoj budućnosti ${ }^{330}$, ,/s/vet epa je nacionalna junačka prošlost, svet 'početaka' i 'vrhova' nacionalne istorije, svet predaka i rodonačelnika, svet 'prvih' i 'najboljih'“ (Bahtin, 1989: 445), izrazito monološki dominiran autorskim glasom.“ Epska je prošlost apsolutna vrednujuća prošlost lišena svake relativnosti (isto: 448), „za suvremenost (...) suvremenost se oblikuje u mramoru i bronci“ (isto: 451), a „vrijednosni akcenat nije na budućnosti, zasluge nisu za nju i ne služe joj (...), ali služe budućem sećanju na prošlost, služe širenju sveta apsolutne prošlosti..." (isto) Ep tako postaje reprezentant književnog utjelovljenja autoritarnog diskursa kakvog opisuje Reč u romanu (Bahtin, 1989: 105 et passim.), diskursa što ,zahteva bezuslovno prihvatanje, a nikako slobodno usvajanje i asimilaciju s našom sopstvenom reči“ (isto), riječi što je „neraskidivo srasla s autoritetom političkom vlašću, ustanovom, licem“ (isto), odnosno „organski je povezana sa hijerarhijskom prošlošću“ (isto: 104) kao riječ predaka i antipodna je romanesknom diskursu. Neubauer (1996: 541) Bahtinovu inspiraciju za takvo poopćavanje mitskog/epskog diskursa nalazi u modernim autoritarnim državama, a s njim se slaže i Hirschkop (1999: 288), opažajući tijesnu povezanost između unificirajućeg centripetalnog autoritarnog diskursa te projekata hegemonističke artikulacije „naroda“, u kojoj vidi ne transcendenciju individualnih okvira prema mnoštvu, nego uvećavanje principa individualnosti ${ }^{331}$.

Neizbježno asociranje te epsko-autoritarne diskurzivne operacije izgradnje naroda $\mathrm{s}$ populističkim diskursom dovodi Hirschkopa (1999: 297) do kritike Laclaua i njegova poopćavanja pojma populizma, kao i implicitne sugestije da je Bahtinova afirmacija romanesknog upravo suprotna Laclauovu interesu za populizam. Čini nam se ipak da je takva kritika rezultat manjkave interpretacije Laclauovih teza, budući da je u Bahtinovoj opreci između romanesknog i epskog te pripadajućim centrifugalnim i centripetalnim kretanjima lako prepoznati fenomene što anticipiraju Laclauovu tropološku hegemonijsku artikulaciju, ali i njezino nužno rastakanje. U tom smislu mnogo smo bliži paraleli koju između određenih aspekata ranije teorije Laclaua i Mouffe, naročito glede diskurzivne tvorbe subjekta i njegovog višestrukog i nerijetko proturječnog pozicioniranja u različitim diskursima, povlači Bernard-Donals (1994: 129), a podjednako afirmativno o toj svezi, samo u odnosu na druge

\footnotetext{
${ }^{330}$ Usp. primjedbu Bernard-Donalsa (1994: 126) da preustrojavanje odnosa u dijaloškom momentu nije nužno otvoreno napretku dijalogizma, nego može završiti i monologizacijom. Riječ je o upozorenju sličnom onom koji smo već imali priliku vidjeti kod Laclaua, Rancièrea, Deleuzea i dr., da trenuci rekonfiguracije poretka ne završavaju nužno nekim progresivnijim poretkom, tj. da deteritorijalizacije mogu završiti još represivnijom reteritorijalizacijom.

${ }^{331}$ Usp. i tezu izrečenu glede studije o Rabelaisu, da ,u Bahtinovim analizama apsolutistička država predstavlja ne alternativan kolektivni princip, nego apoteozu samog individualizma.“(Hirschkop, 1999: 183)
} 
poveznice, progovara i Koczanowic (2015). Njegova studija, naime, s jedne strane nastoji pomiriti pozicije Bahtinova ranog fenomenološkog etičkog djela Ka filosofiji postupka [K filosofii postupka, 1986] (usp. Bahtin, 2010) s kasnijom semiotičkom fazom Bahtinova kruga ${ }^{332}$, dok $\mathrm{s}$ druge strane $\mathrm{u}$ takvoj sintezi traži sretan spoj liberalnih i antagonističkih/agonističkih teorija zajednice. Bahtinov dijalogizam iznimno je pogodna točka presjeka tih teorija zajednice, budući da obuhvaća i sporazumijevanje, i (među)djelovanje, ali i borbu za značenje i međusobno (pre)oblikovanje u procesu iste.

Istraživanja Bahtinova djela na tom tragu stoga su potencijalno najbolji demant teze Bernarda-Donalsa (1994: 133) da je ,problem optimističnog pogleda na dijalogizam i analizu ideologije poput onog kakvog se čini da Bahtin nudi to što oslanjanje na literarne modele (...) ne sugerira doista praktične načine kojima bi se mogao koncipirati globalniji pogled na


su se opusi u znatnoj mjeri oblikovali i u svjetlu ponovnog otkrića Bahtina na Zapadu, oslanjanje na literarne modele u političkoj misli nije romantičarska slijepa ulica želje da se iznađe svjež način promišljanja emancipatorne politike, nego tendencija koja je već neko vrijeme prisutna $u$ jednom dijelu suvremene političke teorije, filozofije i uopće humanistike. Bahtinov pokušaj u Sovjetskom Savezu, doduše, baš kao i onaj formalistički, završio je slijepom ulicom okoštavanja teorija i političkih struktura što nisu bile sklone višeglasju i očuđenju, no riječ je o idejama koje nisu ostale lišene recepcije i izvan vremena i prostora svog nastanka, te nisu ostale bez bliskomišljenika u kasnijim trenucima dezintegracije okamenjenih paradigmi. Dva takva momenta - revolucionarna kretanja inicirana 1917. i 1968., ne bez posrednika između tih ključnih točaka, iznjedrila su teorijska kretanja slično ambivalentnih stavova prema marksističkoj ortodoksiji te usporediva promišljanja politike književnosti i literarnosti politike čije bi daljnje detaljnije usporedno istraživanje nesumnjivo rezultiralo zanimljivim uvidima.

\footnotetext{
${ }^{332}$ Riječ je o spoju za koji Bernard-Donals (1994: 2) tvrdi da nije nemoguć per se, no da ga istovremeno nasuprot uvjerenjima nekih ranijih njegovih kritičara - Bahtin nikada nije učinio.

${ }^{333}$ Primjedba Bernard-Donalsa točna je samo u onom dijelu u kojem se tiče činjenice da Bahtin doista ne nudi alternativnu teoriju društva. Kao što primjećuje i Hirschkop (1999: 286) govoreći o Bahtinovoj studiji o Rabelaisu, karnevalesknost koja je u njoj prikazana dovodi u pitanje institucije, no ne reformulira ih. No dok Hirschkop tu činjenicu karakterizira kao promjenu lišenu politike, rječnikom pojedinih suvremenijih teoretičara mogli bismo je jednako nazvati i politikom bez policije ili demokracijom avenir. Drugim riječima, jednako bi se legitimno moglo istaknuti da se ne radi o omašci i slaboj točki Bahtinova sustava, već o značajki određene tradicije mišljenja politike koja se dosljedno potvrđuje zasigurno i mnogo ranije, no u najmanju ruku od Bahtinova kružoka pa do određenih suvremenih autora, kako smo to pokazali u prethodnim poglavljima.
} 


\subsection{Ernst Bloch i mogućnost drukčijeg marksističkog pogleda na književnost}

Neubauerovo (1996) podcrtavanje značajnog utjecaja što ga je Lukács ostvario na Bahtina i njegove suvremenike te interpretacija segmenata Bahtinova opusa kao prešutne polemike s Lukácsem dobar su smjerokaz daljnjem pomicanju fokusa ovog istraživanja kako u prostoru, tako i u vremenu. No u tom kretanju od početka prema sredini dvadesetog stoljeća Lukács se u odnosu na dosadašnje referentne točke ovog istraživanja pokazuje ambivalentnom figurom. S jedne strane, Neubauer ga u kontekstu sovjetske književne teorije gotovo dijametralno suprotstavlja Bahtinu, kao ime što predstavlja etablirani književnoteorijski autoritet u Sovjetskom Savezu (nasuprot opozicijski intoniranim formalistima i Bahtinu), misao zaokruženosti i totaliteta (nasuprot Bahtinova rastvaranja i stalnog postajanja) te teoriju odraza što se nastoji uklopiti u marksističku ortodoksiju (nasuprot Bahtinove opetovane kritike teorije odraza te nedvojbene neortodoksnosti). No s druge strane u sjeni takve, zasigurno poznatije Lukácseve slike ostaje Lukács koji je i sam pretrpio političke poraze, sankcije i prisile, čija je teorija odraza bila sofisticirana protuteža vulgarnom mehaničkom sociologizmu rasprostranjenom u onovremenim marksističkim krugovima te čije je ranije djelovanje odigralo ključnu formativnu ulogu u odnosu na mnoge nedvojbeno manje tradicionalne marksiste.

Osobito potonja činjenica mnogo više dolazi do izražaja kada se pogled sa sovjetske usmjeri prema njemačkoj književnoteorijskoj sceni, prema krugu njemačkih međuratnih teoretičara čiji su ugled i recepcija u suvremenoj teoriji većinom značajni, no veza $\mathrm{s}$ Lukácsem pritom je rijetko u žarištu pozornosti, pa tako njezino adresiranje izostaje i u kontekstu rasprava o postmarksizmu ${ }^{334}$. Riječ je o autorima kao što su Bloch, Benjamin te generacijski nešto mlađi Adorno.

Umjesto usporednih čitanja spomenutih autora međusobno i u odnosu prema Lukacsu, zadatka koji ostaje za neka buduća istraživanja ${ }^{335}$, ovdje ćemo se zadovoljiti time da

\footnotetext{
${ }^{334} \operatorname{Sim}$ (1998: 3-4, 2000: 74-78) doduše u svojim studijama posvećuje određenu pozornost Lukácsu, a u drugoj čak apostrofira i odnos Lukácsa, Benjamina, Blocha i Adorna, no čini to jednodimenzionalno i razmjerno površno. U prilog Lukácseve netradicionalnosti podcrtava samo njegovo uvjerenje da je marksizam prije metodologija nego zaokružena doktrina te antideterminističko stajalište, dok odnos s trojicom drugih spomenutih teoretičara kratko spominje samo glede rasprave o ekspresionizmu, u kojoj su se našli na suprotstavljenim stranama, zanemarujući njihove prethodne dodirne točke te Lukácsev razvojni put.

${ }^{335}$ Dijelovi te usporedbe već su, doduše, obavljeni u nekoliko izvrsnih studija, kao što je Tihanovljeva Gospodar i rob: Lukács, Bahtin i ideje njihovog vremena (2000) [The Master and the Slave: Lukács, Bakhtin, and the Ideas of their Time] ili pak Boldyrevljeva Ernst Bloch i njegovi suvremenici (2014) [Ernst Bloch and His Contemporaries].
} 
istraživačkim fokusom zahvatimo samo jedno od navedenih imena, šireći tek povremenim usporedbama perspektivu na ostatak konstelacije. Odabir je stoga pao na Ernsta Blocha, autora čiji je opus u odnosu na prethodno spomenuti dvojac ipak mnogo rjeđe predmetom analiza u ovakvom teorijskom kontekstu. Taj nam se izbor zato čini dvostruko korisnim - kao mogućnost da analiza s jedne strane postane skromno proširenje Blochova tipičnog kruga recepcije, dok bi s druge strane, s obzirom na brojne dodirne točke između Blocha i njegovih prethodno spomenutih suvremenika, mogla biti primjenjiva i šire.

Čvorište koje - posredstvom Lukácsa - povezuje Blocha s teoretičarima kojima smo se pozabavili u prošlom poglavlju, te je ujedno i najčešće polje referenci na njega u književnoj teoriji, jest avangardna umjetnost. Naime, usporavanje revolucionarnih gibanja te okoštavanje autoritarnog političkog poretka u Sovjetskom Savezu stajalo je u korelaciji sa zamiranjem sovjetske avangardne umjetnosti, u njoj zastupljenih modela zajednice te s njom povezanih teorijskih pravaca ${ }^{336}$, a u korist različitih oblika socrealističke umjetnosti. Premda je Lukács i sam bio protivnik vulgarnog socrealizma, prikazi koji ga dovode u izravan kontrast $\mathrm{s}$ revolucionarnim sovjetskim teoretičarima, poput Neubauerova (1996), često ga implicitno pretvaraju u personifikaciju posljedica petrifikacije sovjetskog političkog prostora na književnoteorijskom planu. Tome međutim nesumnjivo pridonosi Lukácsev poznati angažman protiv njemačkih avangardnih kretanja, u kojem mu se s druge strane najistaknutije suprotstavio upravo Bloch.

Naime, u takozvanoj drugoj ili marksističkoj (nakon nacionalsocijalističke) raspravi o ekspresionizmu u njemačkoj umjetnosti (tzv. Expressionismusdebatte), koja se većim dijelom odvila na stranicama moskovskog časopisa za njemačku literarnu emigraciju Das Wort, Lukács je ekspresionistička kretanja prozvao i odbacio ocjenama sličnim onima koje je boljševička kritika pridavala ruskom futurizmu ${ }^{337}$. Pozivajući se u svom članku Radi se o realizmu [Es geht um den Realismus, 1938] eskplicitno na „postupno, ali neumoljivo“

\footnotetext{
${ }^{336}$ Ruski futuristi svoj su pokret oblikovali kao „Zahtjev za stvaranjem novih ljudskih odnosa, potpuno novih moralnih vrednota i nove civilizacije“ (Ambrogio 1977: 98), a formalistička teorija - premda valja izbjeći nekritička izjednačavanja formalizma i futurizma - dijeleći s futurizmom neke svoje protagoniste te značajne elemente pogleda na umjetnost, nesumnjivo je na sebe gledala kao na novu znanost namijenjenu novom društvu, te je u njegovom stvaranju namjeravala sudjelovati. Bahtinov je krug pak u svojim književnoteorijskim analizama u usporedbi s formalistima pokazivao manje afiniteta prema avangardnoj umjetnosti, no teorijska vizija dijaloške zajednice, kao i pokušaj njezine realizacije unutar Kruga, te u konačnici suživot i su-djelovanje s pojedinim avangardnim umjetnicima značajne su dodirne točke između dvaju teorijskih strujanja po tom pitanju. Usp. npr. White i Peters (2017), koji istražuju dosege međudjelovanja Bahtinova kruga i avangardnih umjetnika promatrajući njihov suživot $\mathrm{s}$ Chagallovom umjetničkom akademijom te Malevičevim kružokom u revolucionarnom Vitebsku.

337 Primjerice, Trockij (1971: 90) futurizam diskreditira kao „okuku buržoaske umjetnosti“, tvrdeći da „/r/adnička revolucija u Rusiji izbija prije nego što se futurizam uspio osloboditi svojih djetinjarija“ (isto: 91), optužujući futuriste za „utopijsko sektaštvo“ i ,anarhizam“ (isto: 95) te zaključujući da se tu ne radi o proleterskoj, komunističkoj umjetnosti (isto: 113).
} 
potiskivanje avangarde u Sovjetskom Savezu od „rastuće samouvjerene realističke škole“ kao simptom „konsolidacije pobjede proletarijata u Sovjetskom Savezu“ te „sve šireg i šireg prihvaćanja kulturne revolucije među radničkim masama“ (Lukács, 2007: 52), Lukács smatra poraz i iščezavanje njemačkog ekspresionizma izravnom posljedicom ,zrelosti revolucionarnih masa“, a njegova temeljna obilježja duboko problematičnima.

Prigovarajući mu prije svega nezrelost i subjektivizam, samozaokupljeno potenciranje forme nauštrb bilo kakvog sadržaja, te odvajanje od izvantekstovne stvarnosti, Lukács (2007: 33) subverzivne tendencije ekspresionizma smatra tek površinskim fenomenom, a čitavo ekspresionističko kretanje uspoređuje s promašenom politikom USPD-a ${ }^{338}$, nazivajući ekspresioniste ideolozima koji su posredovali stajališta tog političkog strujanja masama te tako u svojoj konfuznosti i nezrelosti nastojali fiksirati ono što je bila samo prijelazna revolucionarna faza (usp. isto: 51). Tomu nasuprot Lukács (isto: 48) tvrdi da doista avangardni mogu biti samo ,veliki realisti“, smatrajući da njihovi romani u suprotnosti spram subjektivističke fragmentacije stvarnosti valjano zahvaćaju totalitet epohe, umjetnički zaodijevajući odnose što ih apstrakcijom izvlače iz stvarnosti te tako transcendirajući subjektivizam i čistu apstrakciju (isto: 39$)^{339}$.

Bloch pak u svom prilogu raspravi, naslovljenom Rasprava o ekspresionizmu [Diskussion über Expressionismus, 1938], odbacuje koncept zaokruženog totaliteta u korist fragmentarnosti i montaže kao tipičnih odlika ekspresionizma, kritizirajući Lukácsa da njegov koherentan, bešavno zaokruženi totalitet odaje „koncepciju stvarnosti koja se nije uspjela osloboditi klasičnog sistema“ (Bloch, 2007: 22) te tako reproducira određene obrasce prikaza

\footnotetext{
${ }^{338}$ Radi se o kratici naziva Nezavisne socijaldemokratske partije Njemačke [Unabhängige Sozialdemokratische Partei Deutschlands], nastale raskolom od Socijaldemokratske partije 1917.; iz prvobitnog članstva USPD-a oblikovala se i Komunistička partija Njemačke (KPD), da bi potom 1920. znatan dio USPD-a pristupio KPD-u, dok je ostatak postojao pod starim imenom do 1931. Za Lukácsa i ostale sudionike rasprave USPD je metonimija srednjestrujaške ljevice, koja nije izjednačiva s omraženim socijaldemokratima, no nije ni komunistička, već ostaje ukorijenjena u onome što su smatrali buržujskim zabludama. Pri takvoj Lukácsevoj usporedbi ekspresionisti su dobro i prošli u odnosu na Zieglerov članak Sada je s tim nasljeđem gotovo [Nun ist dies Erbe Zuende..., 1937] kojim je rasprava započela, a u kojem Ziegler prirodan nastavak ekspresionizma vidi u nacizmu. Usp. Bloch, 2007: 16. Lukács je, za razliku od Zieglera, svoj tekst općenito pisao manje agresivnim no podcjenjujućim tonom, pa tako na samom kraju članka ne otpisuje intelektualce koji se ne slažu s njime glede ekspresionizma, implicitno ciljajući na Blocha, već tvrdi da će prije ili kasnije sazrijeti i nadoći na pravi stav. Usp. Lukács, 2007: 59.

${ }^{339}$ Lukácsevo uvjerenje da realizam, ostvarajući uvide u tipičnosti neke epohe i njezin totalitet, doista uspijeva nešto što ne uspijeva nijedan drugi pristup od naturalizma do avangardnih strujanja (usp. Lukács, 2007: 36) u izravnoj je suprotnosti s formalističkim raskrinkavanjem svih stilskih formacija kao tek drukčijih modusa prikazivanja ovisnih o vlastitim konvencijama i njihovom odnosu prema automatiziranoj diskurzivnoj okolini, ne o podudarnosti s vanjskom stvarnosti. Upravo taj formalistički uvid, izdvajajući kao ponajbolji primjer Jakobsonovo pisanje o realizmu, Bennett (1979: 34, 53 et passim) smatra važnim elementom u formalističkom nastojanju da se ponudi rješenje problema evolucije književnosti, tj. osigura put između mehaničkog historizma i u sebe zatvorenog larpurlartizma. Podsjetimo, Bennett je upravo ta dostignuća smatrao „više marksističkim“ od nominalnog književnoteorijskog marksizma.
} 
koji nisu nužno objektivni. Dapače, postavljajući retoričko pitanje ,što ako je autentična stvarnost također diskontinuitet?““ (isto), priprema temelj za jednostavnu inverziju koja bi namjesto Lukácseva realizma ustoličila ekspresionizam kao autentičniji izraz stvarnosti, narodnog duha, humanizma, politike narodne fronte i drugih poželjnih pojmova diskursa $u$ čijim se tonovima vodila rasprava. No znatan dio Blochova teksta ipak ekspresionizam ne opisuje u terminima tako simplificirane inverzije, već mu pripisuje narušavanje neoklasičnog diskurzivnog režima: „Svakome tko je imao uši da čuje teško je mogao promaknuti revolucionarni element koji su njihovi [ekspresionistički] pokliči sadržavali, čak i ako su bili nedisciplinirani i neobuzdani, i koji je rasuo znatnu količinu 'klasičnog nasljeđa' - ili onoga što se tada nazivalo klasičnom starudijom“ (isto: 20)

Taj revolucionarni element što ,potkopava shematske rutine i akademizme na koje je 'vrijednost umjetnosti' svedena“ (Bloch, 2007: 23) bivajući „,avangarda dekadencije“ umjesto da se „,igra liječnika uz bolesničku postelju kapitalizma“ (isto) po Blochu je od središnje važnosti za ekspresionističku umjetnost, no podrivačko-razotkrivačka dimenzija ipak nije jedina prisutna. Za razliku od onoga što naziva Lukácsevom neoklasicističkom perspektivom, u kojoj afirmacija normativnog modela umjetničkog djela uzrokuje to da ,anticipatorna kretanja u nadgradnji ne mogu posjedovati nikakvu istinu“ (isto: 20), Bloch u ekspresionističkoj umjetnosti prepoznaje i utopijski nagovještaj drukčijeg, pitajući se „moraju li konfuzija, nezrelost i nerazumljivost uvijek i u svakom slučaju biti kategorizirane kao buržujska dekadencija“ ili bi ,jednako - u suprotnosti spram tog simpliciranog i zasigurno nerevolucionarnog pogleda - mogli biti dio prijelaza iz starog svijeta prema novom.“ (isto: $23)^{340}$

Utopijski nagovještaj novog i boljeg kakav Bloch $\mathrm{u}$ raspravi o ekspresionizmu prepoznaje u ekspresionističkoj umjetnosti tek je poseban slučaj općenitijeg fenomena utopijskog nagovještaja koji Blochovu filozofiju obilježava još od njezinih početaka u ranim tekstovima krajem Prvog svjetskog rata te prvoj većoj studiji Duh utopije [Geist der Utopie, 1923] (usp. Bloch, 1982). No u vrijeme oblikovanja Blochove rane utopijske filozofije, on i Lukács nisu se sučeljavali u polemikama dijametralno suprotnih mišljenja, nisu bili (decidirani) marksisti te su uzajamno poticajno utjecali na razvoj svojih opusa. Kako navodi Zipes (2019: 2), Bloch je Lukácsa upoznao već u prvom desetljeću dvadesetog stoljeća, pohađajući između 1908. i 1911. seminare kod Simmela u Berlinu, gdje mu je Lukács ubrzo

\footnotetext{
${ }^{340}$ Tome nasuprot, viziju književnosti kakvu afirmiraju Lukács i Ziegler upravo zbog odsutnosti anticipacije nečeg drukčijeg te iscrpljivanja u zrcaljenju navodnog totaliteta Bloch (2007: 21) smatra mehaničkom prije nego dijalektičkom, a petrificirani socrealistički model naziva „trećerazrednim klasicizmom“ (isto: 25) koji je svojim obilježjima bliži nacizmu nego ijedna varijanta ekspresionizma.
} 
postao veliki prijatelj, da bi se kasnije preobrazio u njegovog „najistaknutijeg filozofskog antagonista“. Prema Boldyrevljevoj (2014: 45) ocjeni, presudan utjecaj na rano oblikovanje Blochove mesijanske misli izvršila je već Lukácseva studija Metafizika tragedije [Metaphysik der Tragödie, 1911.], a još izravnije značajne analogije, osobito glede odnosa pojedinca i historije te mesijanskih motiva, lako je uočiti usporedbom Blochova Duha utopije i Lukácseve Teorije romana [Die Theorie des Romans, 1916/1963.] (usp. Boldyrev, 2014: 52). Sukob između dvojice autora nije pak nastao tek tridesetih godina $\mathrm{s}$ raspravom $\mathrm{o}$ ekspresionizmu, nego već krajem Prvog svjetskog rata, no jedan od kamena spoticanja jest bio stav o avangardi (usp. isto: 40).

Ipak, kao što Boldyrev (2014: 48) napominje, sukob Blocha i Lukácsa nije se oblikovao samo oko estetike, već i oko ontologije. Odnosno, ta bi se teza mogla modificirati tvrdnjom da se oblikovao oko pitanja što po Blochu čine zonu preklapanja estetike i ontologije. Odnos između društva, politike i umjetnosti za Lukácsa je, naime, kontinuirano bio privilegirana tema istraživanja, no pritom je već zarana uspostavio razmjerno jasnu demarkaciju i hijerarhizaciju oblasti: umjetnost je odraz društvenih fenomena, dočim su politika i estetika odvojene domene. Ako je pak tvrdnja da kod Blocha stvari stoje dijametralno suprotno i pretjerana (isto: 49), sigurno je da su one u najmanju ruku mnogo ambivalentnije postavljene.

Nadalje, Boldyrev (2014: 57) upozorava na važnu razliku između dvojice teoretičara čak i kada govorimo o motivima mesijanskog/utopijskog u njihovim ranijim djelima. $\mathrm{Na}$ početku Lukácseve Teorije romana stoji:

Srećna su vremena za koja je zvjezdano nebo zemljopisna karta prohodnih i prolazećih putova i čije putove osvjetljava svjetlost zvijezda. Za njih je sve novo, a ipak blisko, pustolovno, a ipak posjed. Svijet je prostran, a ipak kao vlastita kuća jer vatra koja gori u duši iste je prirode kao i zvijezde; svijet i Ja, svjetlost i vatra strogo se razdvajaju, a ipak nikada ne postaju jedno drugom zauvijek tuđi jer vatra je duša svake svjetlosti i svaka se vatra zaodijeva svjetlošću. (Lukács, 1990: 21)

Blochovo utopijsko, s druge strane, orijentirano je uvijek prema neodređenoj budućnosti što je tek sugeriraju indicije u sadašnjosti, pa tako nasuprot Lukácsevoj nostalgiji za zlatnim dobom na početku svog Duha utopije piše: „Ja sam. Mi smo. To je dovoljno. Sada treba da započnemo. U našim rukama je život. (...) Ono što je do sada bilo svakako će se brzo zaboraviti.“(Bloch, 1982: 41) $)^{341}$

\footnotetext{
${ }^{341} \mathrm{Tu}$ razliku usmjerenja utopijskog kod Blocha i Lukácsa može se prispodobiti razlici u prikazu nebesa kod Dantea i Goethea na koju pozornost skreće Bloch (1981: 227): kod Dantea je to vječna prošlost koja postaje savršeno zaokružena i konzistentna bezvremenost i besprostornost, dok se kod Goethea radi o stalnom
} 
S tim je u svezi i najveća razlika što se od njihovih ranih djela mogla zapaziti između dvojice teoretičara, djelatna i u raspravi o ekspresionizmu, a tiče se (ne)pristajanja uz zaokružene forme i koncepte totaliteta. Bloch je, kako je to sročio Boldyrev (2014: 50), „filozofski uvijek bio buntovnik, dok se Lukács razmjerno brzo mirio sa stvarnosti, i u političkoj i u estetskoj domeni.“ Odnosno, kako je Bloch izjavio u jednom intervjuu, Lukács je za razliku od njega „bio opsjednut strašću za redom i ravnim linijama“ (isto), što ga je, prema njemu, poguralo prihvaćanju (neo)klasicizma, ali i staljinističke estetike.

U svakom slučaju, zadnja značajna obostrano formativna točka preklapanja između dvojice autora bila je Lukácseva Povijest i klasna svijest [Geschichte und Klassenbewusstsein, 1923] (usp. Lukács, 1970), koju Boldyrev (2014: 59) opisuje kao „posljednje Lukácsevo djelo u kojem se Blochov utjecaj može precizno ocrtati“, ciljajući među ostalim i na mesijansku djelatnu dimenziju proletarijata u toj studiji, dok s druge strane tvrdi da je upravo izdavanje te knjige prijelomnica nakon koje se Bloch odlučnije približio marksizmu, preispisujući svoju dotadašnju filozofiju kao marksistički projekt (isto: 65$)^{342}$. No u vrijeme rasprave o ekspresionizmu, revidirajući svoje stare stavove uslijed dodatnog približavanja marksističkoj

transcendiranju, zametku potencijalnosti koji se konstantno širi i izmiče. Ipak, vrijedi na umu imati da u slučaju te opreke Bloch idealnom smatra sintezu dviju suprotstavljenih strana.

No osim u odnosu na ono ranog Lukácsa, Blochovo mišljenje utopijskog/mesijanskog razlikuje se i u odnosu na Benjaminovo: dok je za Blocha utopija svojevrsni (nepredeterminirani, nespoznatljivi) telos historije, za Benjamina je ona potpuno izvan historije, nešto što ne pripada domeni politike, već samo teologije (usp. Boldyrev, 2014: 119).

Za razliku od th nepodudarnosti, Boldyrev (isto: 57) upozorava na zanimljivu podudarnost Blochova koncepta ne-još-bitka s istoimenim konceptom kod ranog Bahtina, u Autoru i junaku u estetskoj aktivnosti, a onda $\mathrm{i}$ povezanim idejama ,metafizike tamnog trenutka, teorije subjektiviteta netransparentnog samome sebi, što u sebi nosi utopijski višak koji se ne može racionalizirati...", tvrdeći da istoimeni pojmovi i preklapanja nisu rezultat međusobne recepcije, već neokantovskog supstrata koji im je svima zajednički. No vrijedi primijetiti i to da Boldyrev (isto: 53) nešto ranije upućuje na znatan utjecaj Dostojevskog na utopijske ideje Blocha i Lukácsa, a s obzirom na dobro poznat značaj Dostojevskog za Bahtinov opus - čini se kako popisu zajedničkih utjecaja možemo pridodati i tog autora.

Dodamo li tome i druge paralele između Blochova i Bahtinova ranijeg opusa koje Boldyrev ne spominje, poput nužne upućenosti čovjeka na put izvan sebe kako bi povratno poznao sebe (usp. Bloch, 1982: 18 i 1973: 33), jasno je da bi se Prohićeva teza da je Blochov Duhu utopije, ,jedinstven pokušaj marksističkog zasnivanja teorije intersubjektiviteta“ (isto: 17) mogla revidirati u najmanju ruku dodavanjem Bahtina i njegovih suradnika.

${ }^{342}$ Boldyrev (2014: 87) doduše priznaje diskutabilnost tako oštrog razgraničenja, upućujući na neslaganja autora kao što su Zudeick (1980), Schiller (1982) i Ujma (1995), koji Blochovo konačno pristajanje uz marksizam pozicioniraju kasnije, prvi u vrijeme nakon nacističkog prisvajanja vlasti, potonja pak na sam početak tridesetih godina. Posve precizno pozicioniranje te modifikacije Blochova odnosa prema marksizmu nije presudno, no važno je imati na umu da se ona ipak zbila, tj. da je perspektiva poput Prohićeve u predgovoru domaćem izdanju Duha utopije (usp. Bloch, 1982: 17 et passim), koja već tu studiju, kao i najranije Blochovo djelovanje, tretira nesporno marksističkim nije neproblematična. Činjenica je da je Bloch od svojih najranijih djela Marxu pridavao značajnu ulogu, no jednako tako i da svoj filozofski projekt ispočetka nije predstavljao integralnim dijelom marksističke filozofije, te je tek takav okvir njegovu utopijsku misao pretvorio iz slogana u revolucionarni historijski projekt. S druge pak strane, Prohić nije u krivu kada kaže da je, figurativno rečeno, Duh utopije u određenom smislu i početak i kraj Blochove filozofije jer je sve što je kasnije razradio već prisutno u toj knjizi (usp. isto: 10), stoga ta prijelomnica u svakom slučaju nije ni tako oštra. 
ortodoksiji, Lukács (2007: 49-50) se kao reakcionarnih zabluda odrekao obaju svojih velikih djela što ga povezuju s Blochom - i Teorije romana i Povijesti i klasne svijesti.

Bilo bi, čak i unatoč tom Lukácsevu kasnijem autorevizionizmu, ipak suviše pojednostavljeno zaoštriti binarnu opreku između Lukácsa i Blocha te potom iz suvremene perspektive prvog pohraniti u pretinac klasičnog marksizma, a drugog tretirati kao anakronog postmarksista. Odnos između njih dvojice evidentno je jednako složen kao i odnos svakog od njih prema ostatku marksističkog korpusa i historijskim varijacijama hegemonijskih oblika marksizma. No razlike između Lukácsa i Blocha koje su od tog razdoblja trajno ostale aktualne nesumnjivo ipak upućuju na Blochovu kontinuiranu buntovnost i nekonvencionalnost, koje je moguće pratiti i analizirati na više razina - od njegovog političkog djelovanja, preko forme izlaganja vlastite filozofske misli pa do njezina sadržaja.

Već pogled na Blochovo političko djelovanje zorno oslikava te ambivalentnosti što podrivaju pokušaje simplifikacije. Naime, dok smo u prošlom poglavlju u slučaju formalista i pripadnika Bahtinova kruga još i mogli govoriti o poziciji trajne (latentne ili vrlo konkretne) političke marginalnosti i disidentske pozicioniranosti koja se može postaviti u analogiju spram jednake pozicije njihove teorije $u$ onodobnom institucionalnom kontekstu, te bi se takva konstelacija doista mogla oštro suprotstaviti Lukácsevu nastojanju da bude što bliže centrima političke moći, s Blochom je situacija nešto složenija. Iako ga dio kritičara opisuje kao dosljednog političkog marginalca ${ }^{343}$ - što Bloch i jest bio uzmemo li u obzir njegovu u odnosu na Lukácsa svakako marginalnu pozicioniranost u marksističkim krugovima prije i za vrijeme Drugog svjetskog rata, a onda i revizionističke etikete koje je zaradio kasnih 50 -ih u DDR-u te potom potisnutost na rub filozofske scene BRD-a - ta marginalnost nije uvijek sinonim i za progresivnost. Naime, osim što romantičnu sliku filozofa-buntovnika narušava činjenica da je Bloch u jednom (ma kako kratkom) razdoblju ipak bio percipiran kao svojevrstan „službeni“ državni filozof, te je i nakon što je emigrirao i stekao status disidenta uživao položaj za sveučilišnom katedrom, mnogo je sporniji segment njegovog javnog djelovanja ambivalentan odnos prema staljinizmu, što ga dobro ilustrira podrška koju je kao intelektualac s margine 30-ih godina uputio Staljinovim čistkama i Moskovskom procesu ${ }^{344}$. Aporiji revolucionara i čuvara revolucije, dakle, i u njegovu je slučaju teško umaknuti.

\footnotetext{
${ }^{343}$ Usp. npr. Zipesovu (2019: vii) ocjenu da je Bloch uvijek bio „loš plesač s vremenom“, „u raskoraku“ s dominantnim strujanjima, ili već spominjanu Boldyrevljevu (2014: 50) o Blochu kao buntovniku.

${ }^{344}$ Pojedini Blochovi čitatelji nastojali su racionalizirati taj njegov u konkretnom kontekstu neobičan čin (usp. Livingstone, Anderson i Mulhern; 2004 te Zipes, 2019: 11), no da on nije naišao na odobravanje kolega i suvremenika pokazuje već i onovremena Adornova oštra kritika (usp. Boldyrev, 2014: 169). S druge strane i Adorno, koji se etablirao kao dio akademskog establišmenta već za izgnanstva u SAD-u, te koji je s te pozicije
} 
Što se pak ocjena o nekonvencionalnosti forme Blochova izlaganja tiče, one su pak znatno manje obilježene ambivalencijom i u potpunosti rezultat prodora literarnog u njegovo filozofsko pismo. Tvrdnje kako se radi o filozofu koji je nesklon sustavnoj misli i klasičnom filozofskom diskursu u različitoj su mjeri primjenjive na različite knjige - od literarnih fragmenata u Tragovima [Spuren, 1930/1969; usp. Bloch, 2006] ili mješavine takvih minijatura i fragmenata te kratkih eseja u Nasljeđu ovoga vremena [Erbschaft dieser Zeit, 1935/1962; usp. Bloch, 1991] pa do pokušaja izgradnje čitavih filozofskih sustava u kasnijim Tübingenskom uvodu u filozofiju [Tübinger Einleitung in die Philosophie, 1963; usp. Bloch, 1973] i Experimentum mundiju [1975; usp. Bloch, 1980] $]^{345}$ - ali čak i u potonjim primjerima zadržala se otvorenost utopijskom kao provodna nit na idejnoj razini, koju pak i dalje prati žanrovska hibridnost, nazočnost literarnih/anegdotalnih fragmenata te stilska nekonvencionalnost izraza.

No Blochov tretman književnosti još u ranim međuratnim djelima u mnogočemu je prethodnik njezina tretmana u djelima poslijeratnih teoretičara kojima smo se bavili u prvom dijelu rada, utoliko što književnost u njegovom opusu nije (samo) arhiv pogodnih alegorija i stilskih sredstava za hibridizaciju/subverziju konvencionalnog filozofskog diskursa, već je uz ostale umjetnosti - od izrazite važnosti za konceptualizaciju i djelovanje utopijskog kao središnjeg predmeta Blochova filozofskog interesa, odnosno nezaobilazna je u njegovu viđenju politike i ontologije. A upravo su osobita politika i ontologija utopije ono što Blocha najsnažnije udaljava od tradicionalnog marksizma, razvijajući postupno značajke koje će postati prepoznatljivi motivi suvremene teorije.

Boldyrev (2014: 26) taj očiti jaz tumači tvrdeći da je Bloch „ne samo favorizirao marksizam, nego se i smatrao marksistom“, premda pitanje ostaje „uklapaju li se njegovi tekstovi u klasičan marksistički kanon“. Nasuprot tomu, sigurno je da „Bloch nije doista bio ni nasljednik ni interpretator marksističke filozofije.“ (isto) Iako takva formulacija, koja s jedne strane Blocha s marksizmom povezuje autodeklaracijom i političkim pristajanjem, dok ga $\mathrm{s}$ druge strane tretira kao idiosinkratički filozofski projekt koji ne dijeli primarnu

\footnotetext{
ambivalentno gledao na šezdesetosmaška zbivanja, zbog čega ga je Bloch smatrao licemjerom i defetistom (isto: 167), također nije naročito sretna referentna točka za ocjenu nečijeg „disidentstva“.

${ }^{345}$ Prohić, primjerice, žanrovsko-stilsku raznolikost Blochova djela zahvaća trima kategorijama, tvrdeći da se „,ipak, jasno uočava gdje je Bloch filozofski minijaturist, gdje kultivira posebnu vrstu filozofske feljtonistike i putopisa (...), a gdje je vođen težnjom da na najširem problematskom nivou ostvari misaonu sintezu." (Bloch, 1982: 8) No učestale tvrdnje o tome da se Bloch kontinuirano držao istog temeljnog istraživačkog interesa u čitavu opusu, tj. da je osnovne crte svog filozofskog projekta skicirane u ranim djelima kasnije samo proširivao i dorađivao (usp. npr. Bloch, 1982: 10-11 ili Boldyrev, 2014: 7) utoliko su primjenjive i na ovu tematiku, pa možemo reći da su njegove „minijature“ ili „,feljtonistički“" tekstovi vrlo uspješno integrirani u kasnije studije što su ciljale „misaonim sintezama“, a da su pritom zadržali značajnu mjeru samostalnosti.
} 
preokupaciju s ostatkom marksističkog korpusa, može djelovati kao efektan kompromis, ona je istovremeno proturječna u odnosu na kasniju Boldyrevljevu (isto: 75) tvrdnju o Blochovu preuzimanju „hegelijanskog marksizma“ kao „revolucionarnog fermenta“ bez kojeg bi „utopijska misao ostala puki slogan, fraza bez posljedica“. Ako su usvajanje marksističkih kategorija i reformulacija vlastite filozofije u njihovim terminima konstitutivni za Blochovu filozofiju kakva nam je danas poznata, tada njegov odnos s marksizmom ne može biti sveden tek na sentiment i političku podršku. S druge strane, podcrtana diskrepancija u odnosu na marksistički kanon neosporna je činjenica. Riječ je dakle ponovno o proturječjima s kakvima smo se imali priliku susresti u ranijim poglavljima, samo ovaj put s „druge“ strane onoga što se uobičajeno uzima granicom marksističkog korpusa.

Prepoznatljiva tema što stvara supstrat iz kojeg izrastaju takve ambivalencije i kod Blocha je kritika marksističkog ekonomskog determinizma te krajnje simplifikacije odnosa između baze i nadgradnje. Bloch u više navrata kao personifikaciju krajnjeg ekonomizma uzima Kautskog, kritizirajući ga da afirmira potpunu vulgarnomaterijalističku negaciju (Bloch, 1973: 49), čime „svojom građanski preuzetom parcijalnošću (...) gubi iz vida snagu ideologijskih isprepletanja, čak i u samom načinu privrede; filozofijskoj ekonomiji je to isprepletanje socijalno-materijalna stvar sama.“ (isto, 1981: 78) ${ }^{346} \mathrm{Za}$ razliku od vulgarnomaterijalističke perspektive, marksizam stvari uvijek mora uzimati relacijski i u naizmjeničnom djelovanju (isto: 82), pa tako ,područja umjetnosti, religije, nazora na svijet (...) za marksističku analizu nisu u cjelini izvodljivi pravocrtno ili napola neposredno iz podgradnje. [sic!]“ (isto: 83) Odnosno, „Marxovo naglašavanje ovog vanjskog [determinacije svijesti društvenim bitkom] nema ništa zajedničko s pasivističkom teorijom milieua, upravo $\mathrm{s}$ obzirom na ovo pasivno, budući da ovdje čak sama svijest sudjeluje u društvenom bitku, koji je nosi i uvjetuje, tako da ga i sama uvjetuje.“ (isto, 1973: 59)

No zaplićući se u elaboraciju međuodnosa što bismo ih danas althusserijanskim rječnikom nazvali nadodređenošću, koji ukidaju prividnu autarkiju baze i/ili nadgradnje (Bloch, 1973: 199), Bloch u trenutku kada konačno treba presjeći nit elaboracije međudjelovanja i time ostati u okvirima temeljnih marksističkih poučaka dolazi do istog problema kao i Althusser mnogo poslije njega. Determinacija u krajnjoj instanci ipak pripada bazi: „Materijalni procesi u bazi koji rastu ljudima upravo preko glave, kao i proturječja između načina proizvodnje i proizvodnih odnosa, bez sumnje daju krajnji odlučujući

\footnotetext{
${ }^{346}$ Etiketom preuzete „građanske parcijalnosti““ Bloch (1981: 78) želi podcrtati to da tvrdnju Kautskog da „,reformacija nije 'ništa drugo do ideologijski izraz dubokih promjena na evropskom tržištu vune'“ smatra jednakim ,uštogljeno-izoliranim besmislom poput idealističke uznosite govorancije da reformacija potječe isključivo iz germanske ćudi.“ (isto)
} 
društveni poticaj. - To ostaje istina - ekonomskog-kauzalnog priusa.“ (isto) Pa ipak, odmah potom $\mathrm{u}$ istom tekstu nastoji ublažiti rezolutnost te tvrdnje, dodajući da ,ekonomski disponirani duh u nadgradnji nije samo odraz nego štaviše može biti s njom u tako snažnom uzajamnom djelovanju da čak aktivira nadgradnju“ (isto), te nudeći primjere prosvjetiteljstva koje je prethodilo francuskoj revoluciji, dakle promjeni proizvodnih odnosa, te ideološkog importa marksizma koji je prethodio potpunoj promjeni sovjetske ekonomske baze (i proizvodnim odnosima, ali dijelom i načinu proizvodnje).

Proturječnost pokušaja da se istovremeno drži tradicionalnog marksističkog poučka o determinaciji bazom u krajnjoj instanci te nastojanja da podcrta nepravedno zapostavljen značaj nadgradnje dolaze do izražaja još više u onim dijelovima Blochova istraživanja u kojima to pitanje nije u prvom planu. No budući da mu se istraživački fokus najvećim dijelom pomiče od općeontoloških pitanja do pitanja nadgradnje (ideologije, umjetnosti, religije), pri čemu ekonomskim temama ne posvećuje mnogo prostora, takvi dijelovi uvjerljivo pretežu. Naime, unatoč nominalnom utemeljenju u ekonomskom u krajnjoj instanci, Blochovo promišljanje utopijskog gotovo se u potpunosti pokazuje kritički nastrojeno prema konceptu temelja. Dapače, značajni koncepti različitih faza njegove utopijske misli kao što su privid [Schein], nagovještaj [Vor-Schein], ne-još-bitak [Noch-Nicht-Sein] i druge bliskoznačnice, odreda se suprotstavljaju čvrstom utemeljenju u danom te otvaraju vremenski jaz prema budućnosti.

Temu anakronosti, ključnu za svoj koncept utopije, Bloch je artukulirao upravo istražujući kompleksnost odnosa nadgradnje prema bazi, zanemarenu u velikom dijelu marksističke teorije. U Nasljeđu ovog vremena Bloch (1991: 37 et passim) u nekoliko eseja na historijskim primjerima prvi put pokazuje ono što će kasnije i teorijski elaborirati: fenomen neistovremenosti, heterogenost vremenskih tokova uslijed koje se javlja svojevrsno „zaostajanje“ u odnosu na dominantne tendencije nekog vremena, kaskanje i zapinjanje pojedinih elemenata pretežno nadiđenih paradigmi, često ograničeno na specifične društvene skupine koje pogađa nejednak društveni razvoj (usp. primjer provincije ili specifičnih zanimanja u Bloch, 1973: 104-105). To ga pak, uz rastuću skepsu prema pojmu napretka, vodi zaključku da ,proizvodne snage kao i proizvodni odnosi mogu pokazivati napredak koji nadgradnja ne samo što ne slijedi nego mu je dapače ponekad suprotstavljena s naročitim kulturnim gubitkom.“ (isto: 131) No društvena neistovremenost ima i svoju pozitivnu stranu one društvene skupine i pojedince koji ostvaruju prestizavanje, hodajući ukorak s vremenom, ali anticipirajući i naznake onkraj sadašnjeg trenutka, doživljavajući stvari „ne onakve kakve 
one jesu, već onako kako idu, ili kako bi realno mogle ići; dakle u njihovoj tendenciji.“ (isto: 105)

Da bi pak zapažanje tendencije bilo moguće, nužna je druga razina neistovremenosti koju Bloch uočava spuštajući se od društvenih skupina preko pojedinca prema uodsutnjenom temelju. Naime, on se opetovano zaokuplja problemom nesinkroniciteta iskustva koje se živi i svijesti o tom iskustvu te posljedične nužnosti za perspektivom drugog (usp. npr. Bloch, 1973: 33, 49), kao i neuhvatljivosti iskustva pojedinačnog trenutka. Fenomenologiju tog trenutka istovremeno smatra temeljem fenomenologije svakog drugog iskustva, ali temelj što se izmiče, budući da je iskustvo trenutka odsutnost bilo kakvog konkretnog iskustva (Bloch, 1995: 287 et passim) ${ }^{347}$. Slijedom toga Bloch razvija ontologiju ne-još-bitka, što svoj fokus premješta $s$ otkrivanja nekog latentnog statično prisutnog bitka na istraživanje njegove tendencije koja se $u$ potpunosti otkriva i ispunjava tek u utopijskoj budućnosti ${ }^{348}$.

$\mathrm{U}$ jednom od nastojanja da usustavi svoju utopijsku misao $\mathrm{u}$ Tübingenskom uvodu $u$ filozofiju Bloch do ontološke dimenzije utopijskog dolazi pak započinjući od pojedinca te krećući se prema općeontološkoj razini. Tako s jedne strane anticipira shemu inicijalnog manjka koji posljedično izaziva suvišak, što obilježava i kasnije inačice mesijanske politike koje u godinama koje su uslijedile započinju s oblikovanjem, dok s druge strane apstrakciju takvog odnosa dopunjuje zaodijevajući je marksističkom intonacijom ukorijenjenosti u materijalni život svakodnevnice. Bloch piše:

Da oskudijevamo, to nam ponajprije dolazi do svijesti. Svi ostali nagoni zasnivaju se na gladi; svaki nagon proizlazi odatle i oko toga da bi na gladi odmjerio što i nešto - izvan sebe e- da utaži. Što znači; sve što živi mora biti prema nečemu upućeno ili se mora kretati i usput nešto biti. Nemirna praznina stišava vani svoju vlastitu potrebu koja je muči. Time se potreba može zakratko zadovoljiti, kao da potražnja i nije bila u pitanju. No zadovoljstvo ne traje nikada dugo, nužda se ponovno javlja, i na nju treba brižno misliti, prije svega zbog toga da bi mogla nestati. (1973: 34)

Potom opisuje vrlo sažete pomake koji su ljudski rod uslijed neotklonive oskudice dovele od lova i sakupljanja do moderne civilizacije, ostavljajući i dalje utopijske čežnje na obzoru. Utopijski ciljevi nisu pak određujući samo za razvoj čovjeka, već i za ono što omogućuje

\footnotetext{
${ }^{347}$ Premda ćemo ovdje izostaviti detaljniju elaboraciju ove usporedbe, vrijedi upozoriti na intrigantnu sličnost Blochove metafizike (mračnog) trenutka, koja se javlja već u Principu nada, s kasnijim Deleuzeovim (čak i nazivom vrlo sličnim) konceptom mračnog nagovještaja te Derridaovim différanceom, kao usporedivim osnovnim jedinicama (uz svu svijest o paradoksalnosti te sintagme u danom kontekstu) njihovih kritika metafizike prisutnosti. Ta sličnost zasigurno nije rezultat izravnog utjecaja, no mogla bi sugerirati stanovitu posrednu komunikaciju.

${ }^{348}$ Usp. tezu da „puni bitak, ontos on, nije zbilja, nego tek realno-mogući utopikum.“ (Bloch, 1981: 35)
} 
historiju, pa i bilo kakav doživljaj vremena koji ne bi bio posve amorfan; smatrajući da je, nasuprot vulgarnomaterijalističkom mehanicizmu te buržujskom klasicizmu zatvorenih formi, takva utopijska perspektiva istinska marksistička perspektiva ${ }^{349}$, Bloch (1973: 154) ce stoga tvrditi da „,ne postoji nikakva marksistička antropologija bez marksističke kozmologije.“

Dapače, tu krilaticu bez mnogo ustručavanja možemo proširiti i na opću ontologiju, s obzirom na Blochovu (1973: 114) tezu da „supstancija svijeta, svjetska materija i sama još nije zaključena, već se nalazi u još utopijski otvorenom stanju, tj. u stanju koje se još ne pokazuje kao identično samom sebi“, odnosno da je utopijska narav same materije temeljni preduvjet svih ostalih procesa u društvu i prirodi. Kako piše:

Čovjek i mogućnost, ta građa pjesništva, filozofije, politike, koja se tek sada pojavila, njegovo Possibile, kako je ono moguće ? Jedino u svjetskom supstratu otvorenih, raspoloživih latentnih osobina. Ni sam proces ne bi bio moguć bez materije koja ima takva utopijska obilježja. (Bloch, 1973: 207) $)^{350}$

Posljedična kontinuirana dijalektika između geneze i strukture - unutar koje se „u gotovoj strukturi ono bivajuće oblikuje ali se ne zaključuje“ (Bloch, 1973: 234) - tako poopćenu procesualnu materiju čini svojevrsnim diskurzivnim tkanjem. Naime, ako vrijedi teza da su iz perspektive utopijske filozofije entiteti uvijek decentrirani te se ,/n/išta ne pojavljuje samo na onom mjestu gdje stoji“ ${ }^{\prime}$, odnosno,$/ \mathrm{j} /$ edno se na ovaj ili onaj način dade izraziti pomoću drugog“ (isto: 237), tada oni uspostavljaju neku vrstu tkanja opće tekstualnosti nalik onom kakvo je zaokupljalo mnogo kasnije postfundacijske mislioce. Pomalo anakrona perspektiva iz koje jednim dijelom pristupamo Blochu, služeći se konceptualnim aparatom koji se razvio kasnije te koji je njegov opus jednim dijelom i fascinantno anticipirao, navodi nas stoga da u mreži međusobno zamjenjivih i suodređenih diferencijalnih elemenata, organiziranih u sustave polupropusnih i nezaokruženih granica, prepoznamo poopćenu diskurzivnost (ili literarnost) izjednačenu s prvom filozofijom.

\footnotetext{
${ }^{349}$ Govoreći o perspektivi u estetici, ali i općenitije, Bloch (1981: 57-58) navodi kako „temeljna crta (...) građanski-klasicističke estetike nije nada (i od nje uzbuđena volja), nego promatranje (i od njega umirujući užitak)“, te kako „/t/akva pojmovna navlaka pukog, na sve primjenjivanog i jednoobraznog promatranja, ugrožava čak i podosta marksističkih pokušaja estetike“. Autentična marksistička perspektiva, nasuprot tomu, ne bi se trebala zadovoljiti statičnim promatranjem danog, već aktivnim posezanjem prema utopijskom.

${ }^{350}$ Pojam materije Bloch zadržava kao krajnju razinu općenitosti koju doseže analiza, dakako, upravo kako bi ostao u marksističkom ključu i unaprijed doskočio potencijalnim optužbama za idealistička zastranjenja svoje filozofije utopije. Usporedno s tim ponovno kritizira i ono što smatra vulgarnim materijalizmom dijela tradicionalnog marksizma, tvrdeći da se u odnosu na utopijske zahtjeve ,pokazuje preuskim samo pogrešni pojam mehanički dovršene, statičke materije, ali nipošto pojam povijesne, procesualne materije.“ (Bloch, 1973: 207)

Legitimirajuća utemeljenost u materijalnom Blochu (isto: 206) je važna i kod podcrtavanja razlike između pukog apstraktnoutopijskog „wishful thinking koje nije posredovano sa svijetom i precesom“ pa tako ni „,s materijom“, te „konkretne utopije“" koja je ,posredovana s povijesnim indeksom historijski-procesualne materije.“
} 
Odemo li iz te perspektive korak dalje, možemo zaključiti da Blochu ne izmiče, makar na rubovima njegovih zapažanja, ni tropološka narav takve mreže. Prateći međusobno odražavanje stvari od konvencionalnih usporedbi, preko metafora koje počivaju na mitu i zaokruženosti simbola ${ }^{351}$, Bloch (1973: 241) dolazi i do ,prave metafore kao jeke otvorenih značenja u kojima je sadržan početak novog života - Incipit vita nova.“ Prava pak metafora u gornju jednadžbu ontologije i diskurzivnog uvodi i politiku, u agonističkoj figuri sraza perspektiva, zaokružujući time prepoznatljivu postfundacijsku tročlanu konstelaciju: ,genuina metafora pokazuje utakmicu vidnih polja, slike odraza i u borbenom, istraživačkom smislu, i to upravo nedovršenu utakmicu." (isto)

Decentriranost struktura te izmještenost i odgođenost značenja prema Blochu ne vode potpunom relativizmu i odbacivanju utemeljenja. „Totalna sumnja (...) je dakako još veći neprijatelj mišljenja od masivne predrasude“, „/n/jeno je stanovište uvijek veoma ugodno, naime, par excellence defetističko“ (Bloch, 1973: 43). Stav koji naziva „totalnim apsurdom“ Bloch smatra tek drugom stranom novčića „totalnog panlogizma““ (isto: 170), a obje su te perspektive „u svom nastupu i u svom sadržaju tako reći antidatirane, predodređene“ (isto), odvraćene od djelovanja, za razliku od utopijske perspektive koja na njega obvezuje. Kako Bloch zaključuje:

...svijet nije automatski zatvoren u željezne okove, a još je manje golemo anarhično hazardiranje. Nego je svjetski tok jednako determiniran dosadašnjim zbivanjem kao što je i otvoren prema naprijed. On se, dakle, može nanovo determinirati pomoću aktivne upotrebe (revolucionarnog posluha) onih zakona koji i dalje djeluju, kao i nadasve onih koji novo nastaju. I to - protiv svih postvarenih otpora - u susretljivoj struji u smjeru plivanja procesa koji ne da da se zaboravi da su svi zakoni zakoni razvoja, te da se stoga s novim uvjetima i oni sami mijenjaju. (Bloch, 1973: 224)

Pritom utopijski cilj spomenutog razvoja prema Blochu nije nešto nestvarno, no istovremeno odbacuje i da se u taj „Optimum Marximum“ smjesti ,jedna već 'prezentna' eshatologija“"(Bloch, 1973: 185) ${ }^{352}$.

Kako bi naznaka onoga što upućuje utopijskom mimo aktualne strukture postala vidljiva, potrebna je promjena perspektive, određeni vid očuđenja. U kratkoj crtici što je prvi

\footnotetext{
${ }^{351}$ Zakruženost i metafizička usidrenost simbola kod Blocha se, baš kao i u poznatijem slučaju kod Benjamina, javljaju kao suprotnost diseminaciji alegorije. Usp. Bloch, 1973: 182, 242.

${ }^{352}$ Boldyrev (2014: 25) napominje da Blochovi ontološki i estetski utopijski konstrukti nužno stječu i etičku dimenziju; nada obvezuje na preoblikovanje statusa quo, ne-još-bitak uvijek ukazuje na mogućnost boljeg svijeta. Nešto kasnije pak skreće pozornost i na paralele s Derridaom, napomenuvši da Blochova formula transcendencije bez transcendentnog podsjeća na Derridaov mesijanizam bez mesijanskog ili anticipaciju bez anticipiranog (isto: 111). Analognost eshatologije mimo strukture svakog očekivanja nije jedina sličnost između dvojice teoretičara. Isto vrijedi i za neodlučivost koja u domeni mesijanske politike ne znači paralizu djelovanja, već upravo suprotno - etičku obvezu da se djeluje. Sličnosti ne iznenađuju, s obzirom na već spomenut utjecaj Benjamina na oblikovanje Derridaova viđenja mesijanskog te poveznicu između Blocha i Benjamina.
} 
put donosi u Tragovima (usp. Bloch, 2006: 82), a kasnije potvrđuje koliko je smatra važnom ponavljajući je i u Tübingenskom uvodu (isto, 1973: 41), Bloch ovisnost onoga što zapažamo o poznatim modelima i određenoj konfiguraciji polja perceptivnog pokazuje anegdotom o domorocima koji su zapažali kolonizatorske čamce, no ne i njihove goleme brodove, budući da su im potonji bili nepoznati. Slična je i anegdota o pruskim osvajačima Pariza i nemogućnosti da pljačkajući pronađu Monalizu, ne jer nije bila prisutna u prostoru u kojem su je tražili, nego jer im je pogled bio preusmjeren na manifestno, dok se ona nalazila izvan horizonta očekivanja (usp. isto, 2006: 83). No kako ostvariti pomak perspektive i umaknuti zadržavanju na površinskom?

Kao što smo prethodno spomenuli, izrazito značajnu ulogu u zadatku otkrivanja i artikuliranja utopijskog Bloch pripisuje upravo umjetnosti, veliku pozornost pritom posvećujući književnosti. Primjeri djetinjeg i umjetničkog čuđenja malim svakodnevnim stvarima, kakvima se Bloch rado okreće (usp. npr. 1973: 37-38) ${ }^{353}$, suprotstavljeni njihovom instrumentalnom prihvaćanju u većine ljudi, slikovit su odgovor na pitanje zašto je tome tako. Pojašnajvajući vrijednost prekida i očuđenja za utopiju, Bloch (isto: 209) podcrtava kako je ona „predugo nailazila na refrain koji je bio i odviše približan da bi bio istinit“, ispaštajući zbog tog ponavljanja, no da istovremeno zahtijeva paradoksalan ,lom koji povezuje, prekid koji uzduž i popreko spaja“ (isto), jer bi se u protivnom svela na potpuno singularno, neupotrebljivo iskustvo. A upravo te značajke na drugom je mjestu prepoznao imanentnima umjetnosti.

Izlažući naime kriterije onoga što naziva umjetničkom istinom, Bloch (1973: 179) navodi kako umjetnost $\mathrm{s}$ jedne strane odlikuje upravo to ,,s/pasavanje posebnog $i$ u njemu artikuliranje nečega bitnog što se nalazi u oblikovanju (ili tipičnog da ne kažemo cum grano salis)“, što rješava problem aporije prekida i kontinuiteta, odnosno singularnog i općeg. ${ }^{354} \mathrm{~S}$ druge strane, upravo zahvaljujući tome ona „osobe, situacije i sudbine tjera do posljednje konzekvencije, to jest njihovoj biti“, i to „u mediju privida kao virtualno oblikovanog nagovještaja izrođenih imanentno dovršenih entelehija.“ (isto: 180) Zbog toga je umjetnost za

\footnotetext{
${ }^{353}$ Svojevrsan lajtmotiv Tragova upravo je misao da bi „trebalo promatrati male baš male stvari te ići za njima.“ (Bloch, 2006: 5)

${ }^{354}$ Posredovanjem posebnog i bitnog/tipičnog Blochova koncepcija na određen način posreduje i između Bahtinova naglaska u jednoj fazi stvaralaštva na književnosti kao prostoru mogućnosti singularnog te Lukácseva naglašavanja apstrakcije i umjetničkog zaodijevanja tipičnog. Blochovo pozicioniranje između dvojice svojih suvremenika tako ga stavlja i najbliže kasnijim autorima čije je mišljenje književnosti obilježila ista aporija singularnog i univerzalnog (najizraženije se u prethodnim poglavljima to moglo primijetiti kod Derridaa). On sam pak poveznice proteže na drugu stranu, prema prošlosti, sve do Aristotela, prepoznajući u Aristotelovu razlikovanju historije i pjesništva prefiguraciju svoje vizije književnosti, također oslonjene na bitno (kao poveznicu singularnog i općeg) te moguće (utopijski pred-sjaj). Usp. Bloch, 1981: 213.
} 
Blocha privilegirano mjesto na kojem do izražaja dolazi pred-sjaj [Vor-Schein], nagovještaj utopijskog u predmetu koji uzima u fokus. ${ }^{355}$ A s obzirom na to da prikazuje ,tendencije $i$ latentnosti svojih predmeta (...) na način do kraja tjeranog pred-sjaja“ (Bloch, 1981: 58), umjetnosti „nema druge nego da bude nezaključenom.“ (isto) ${ }^{356}$

Nužna „nezaključenost“ umjetnosti Blocha odvodi do svojevrsnog kompromisnog rješenja u dilemi između umjetnosti kao (raskrinkavajućeg) odraza neke ideologije te aktivnog agensa promjene; dilemi koja je nakon njega mučila i Althusserov krug. Velika književna djela, smatra, podrazumijevaju i veliku količinu nagovještaja (pred-sjaja) i utopijskog značenja (Bloch, 1973: 113), odnosno velik su spremnik onoga što naziva „kulturnim viškom“ (usp. Bloch, 1973: 113 i Bloch, 1981: 89). On pak s jedne strane osigurava preživljavanje djela i nakon raspada baze i nadgradnje kojima je izvorno pripadalo (isto, 1973: 113), a s druge strane „višak koji kultura predstavlja nad golom ideologijom“ (isto, 1981: 89), tj. to da ,/u/mjetnost nipošto nije samo ideologija vladajuće klase, niti pak njena sluškinja za propagandu.“ (isto, 1973: 113)

Drugim riječima, ako ,/i/deologija u velikom djelu zrcali i opravdava svoje vrijeme, utopija u njemu cijepa vrijeme i privodi ga svrsi, privodi ga onoj svrsi u kojoj više ne bi bilo puke prošlosti i njene ideologije, već bi se moglo pokazati: tua propria vera res agitur.“ (Bloch, 1981: 92) Nastojeći pronaći sintezu između zrcaljenja vremena s jedne strane te cijepanja i utopijskog nagoviještanja s druge strane, Bloch (1981: 214) tvrdi da „značajni pjesnik unosi u svijest svijeta pospješujuću struju djelovanja, razjašnjavajući budni san onog bitnog“, što će se zbog toga promijeniti, a istina na koju tako ukazuje ,nije odražavanje fakata, već procesa“, „najzad pokazivanje tendencije i latencije toga što još nije postalo i treba svoje izvršioce.“ To je kompromisno rješenje u igri ostavilo odražavanje dominantne ideologije i historijskih okolnosti nekog vremena, kao prepoznatljiv aspekt marksističke analize, no istovremeno utopijskim pred-sjajem nadilazeći tradicionalnomarksistički ekonomski determinizam. Potonji je Bloch (isto: 84) ocijenio kao „ekonomistički shematizam“ od kojeg „ništa nije neprimjerenije“, optuživši ga da je svim autorima samo lijepio ekonomske naljepnice te se „na taj način lišio svojih velikih pjesnika.“

Uskogrudnost perspektive na književnost u klasičnom marksizmu zaslužna je i za afirmaciju socrealizma koji Bloch (1973: 177) naziva „najneistinitijim kičem“, kritizirajući pritom sovjetsku postrevolucionarnu umjetnost da je ostvarila „religiozno raščinjavanje“ i u

\footnotetext{
${ }^{355} \mathrm{O}$ odnosu umjetničke istine i pred-sjaja usp. još i Bloch, 1995: 214-215.

${ }^{356}$ Upravo zbog toga Bloch umjetnost u već spomenutoj opreci alegorija - simbol uparuje s alegorijom, dok za npr. religiju zadržava simbol. Usp. npr. Bloch, 1973: 182.
} 
isti mah „prevaru s draperijama“, odnosno ocjenjujući je „ispod svakog nivoa (za razliku od sovjetske umjetnosti dvadesetih godina)“ (isto: 178). Takvu orijentaciju, koju odlikuje „dugotrajno veličanje klasicističkog, čak primjereno receptu kastriranog realizma kao jedino realističkog“ smatra „marksističkom uskogrudnom i diletantskom anomalijom“ (Bloch, 1981: 211), suštom suprotnosti onoga što bi marksizam trebao biti. Marksizam, smatra Bloch (isto: 212), ,rastjerava (...) fantaste, no ponajmanje egzaktnu fantaziju“, te stoga ne zaslužuje stanje u kojem je dalji od eksperimentalnog pjesništva nego građanska kritika, i u kojem se čini „da je dozvoljena samo reportaža ili ono lošije: ljudi i djelovanje prema plitkim, utvrđenim klišejima." (isto: 210$)^{357}$

Kada se njegovo čuveno sudjelovanje u raspravi o ekspresionizmu upari sa činjenicom da Bloch razlikuje pjesništvo privida od pravog velikog pjesništva (usp. Bloch, 1981: 215) te u potonjem vidi prevladavanje ideološke laži u korist konkretne utopije, odjeljivanje privida od mogućeg estetskog pred-sjaja, lako je nadoći na zaključak da i on, baš poput kasnijih generacija teoretičara kojima smo se u ovom radu bavili, pokazuje pristranost prema modernističkim klasicima i avangardnoj književnosti. No premda im se popisi kanonskih referenci uvelike poklapaju, te premda se Bloch $u$ polemikama što ih je vodio $s$ konkurentskim marksističkim viđenjima književnosti uvelike oslanjao upravo na historijsku avangardu, prije svega ekspresionizam i nadrealizam, koja je s druge strane ostavila snažan formativni učinak na njegovu filozofiju, u njegovu je slučaju nemoguće govoriti o jednostavnom odbacivanju ,trivijalne“ književnosti i popularne kulture. Naprotiv, baš kao i Bahtin usporedno s njim, Bloch pokazuje interes za potonju, te utopijsku dimenziju književnosti ne ograničava samo na tzv. visoku književnost, već je analizama pokazuje u šarolikom spektru žanrova, od anegdota i minijaturističkih crtica (omiljen žanr u Tragovima; usp. Bloch, 2006), preko (narodnih i umjetničkih) bajki i fantastične književnosti (Bloch, 1973: 107; Zipes, 2019: 105 et passim) pa do detektivskih romana (Bloch, 1981: 241 et passim).

\footnotetext{
${ }^{357}$ Bloch (1981: 211) kritiku ipak završava optimistično, tvrdeći da ,,p/rolaze vremena u kojima je svaka umjetnost izmišljavanja bila sumnjiva i glava s mislima gotovo da se trudila da ih više nema“, ,/u/ kojima je fantazija bila gotovo stvar za kažnjavanje, u kojima je ona unaprijed bivala prezirana kao idealistička, kao da tu ne bi bio dan subjektivni faktor", te opisujući postupan dolazak na svoje onoga što smatra autentičnom marksističkom kritikom. No nejasno je radi li se tu o anticipaciji pro-eksperimentalnog, pro-avangardnog odnosa prema umjetnosti u onome što se često naziva kasnim marksizmom te postmarksizmom, ili pak samo o frazama koje su trebale biti optimistična protuteža razmjerno hrabrom pesimističknom kritičkom oslikavanju socrealističke doktrine. U tom kritičkom obračunu sa socrealizmom Bloch (isto: 215) čak zadržava i termin realističkog kao poželjan označitelj kojeg valja kooptirati, pa tako tvrdi da je marksizam ,potpuno realistički, no jasno ne u smislu banalnog, čak shematskog klišeja; naprotiv, njegova realnost se naziva: zbilja plus budućnost u njoj.“
} 
No tretman književnosti kao privilegiranog prostora pojave pred-sjaja utopijskog ipak ni kod Blocha nije lišeno zadrške bez koje bi završilo u krajnjoj romantizaciji. Na posve općenitoj razini Bloch (1973: 180) upozorava na opasnost prepuštanja zavodljivoj strani književnosti koje bi u korist uživalačkog prepoznavanja i poistovjećivanja s preobrazbama u književnosti imanentnom zaboravilo na njezinu relacijsku narav. „Opasnost od takve ljepote i njenog ipak samo virtuelnog nagovještaja sastoji se u tome da ostane samo nagovještaj i da naspram besmislenog bitka postavi samo obezbitni smisao.“

Vratimo li se pak s te općenitije razine natrag na opreku između ,visoke“ i „popularne“ književnosti, Blochov stav o opasnosti od negativnih nuspojava tu je dvojak. Kako pokazuje Zipes (2019: 89-90), s jedne strane svijest o tome da je književni kanon rezultat ne isključivo izvrsnosti, već i političke selekcije dominantne društvene skupine navela je Blocha da pokuša ,,povratiti zanemarena i potonula značenja popularne kulture koja su dala materijal razvoju visoke kulture, istovremeno osiguravajući i impetus promjene.“ No s druge strane, takav tip popularne kulture nije uvijek jednostavno odvojiti od onoga što naziva „kičem“, kao tipom kulturne produkcije na koji, prema njegovim riječima, „nasjeda“ sve veći dio naroda, i koji umjesto pred-sjaja donosi obmanu i daljnje potpadanje pod malograđanštinu (usp. isto: 90).

Razvidno je dakle da se u odnosu na ključne točke koje su strukturirale prethodne segmente ovog istraživanja Blochova perspektiva pokazuje uvelike anticipatornom, potvrđujući relevantnost i svježinu njegove misli čak i kad je se odmjerava s autorima koji su se na teorijskoj sceni pojavili u poznim godinama njegova života. Ne samo da i Bloch književnost smatra privilegiranim prostorom politike, odnosno estetsko i političko esencijalno povezanim poljima; ne samo da razmjenjujući polemičke tonove s dominantnim strujama marksizma svog vremena gaji podvojen odnos prema tradicionalnim marksističkim postavkama, afirmirajući emancipacijsku i decentrirajuću dimenziju marksističkog nasljeđa, nego u pozadini Blochove utopijske filozofije možemo prepoznati i ono što smo nazvali literarnošću politike/ontologije.

No za razliku od prethodnih poglavlja, u kojima smo se bavili autorima što su na razne načine bili usko povezani s marksističkim poljem, no ipak su oko njega gravitirali s vanjske strane granice kojom se konvencionalno omeđuje marksizam, s Blochom smo se našli s druge strane granice, budući da se radi o filozofu kojeg se, bez obzira na opetovana upozorenja na njegovu buntovnost i nekonvencionalnost, gotovo beziznimno nalazi atribuiranog kao marksističkog filozofa. Taj nam razmjerno gladak prelazak onoga što se obično konceptualiziralo kao tvrda i diskretna granica potvrđuje hipotezu artikuliranu na početku 
ovog istraživanja - da je diskretno omeđivanje postmarksizma bilo vremenskom odrednicom izrazito suvremenog (ili „postmodernog“) fenomena, bilo relacijski u suprotnosti spram marksizma problematično, budući da se značajke koje se pokazuju kao određujuće za njega protežu i onkraj tih granica.

Osim toga, ovo i prethodno poglavlje dokazali su nam ne samo problematičnost jasnog omeđenja postmarksističke teorije, nego i iscrpnog popisivanja mozaika utjecaja ključnih za njezino oblikovanje. Naime, i u slučaju sovjetskih teoretičara koje smo analizirali, kao i kod njemačkih heterodoksnih marksista poput Blocha i Benjamina, teško je ne primijetiti značajan formativni utjecaj neokantovske filozofije - korpusa kojemu se u dosadašnjim studijama o postmarksizmu nije posvetila značajnija pozornost, premda je ostavio posve razvidan trag i na određenim nekonvencionalnijim inačicama suvremenog marksizma, kao što je to primjerice Jamesonova misao. S obzirom na svježinu i relevantnost Blochovih uvida u kontekstu suvremene teorije, slični tragovi zasigurno bi se mogli otkriti utkani i u pozadini uobičajenih geneaoloških pripovijesti o autorima koje se uvriježeno vezalo uz postmarksistički kontekst. 


\subsection{Ekscesnost Batailleeva suvereniteta: Od opće ekonomije do literarnosti politike}

Tek desetljeće mlađi od Ernsta Blocha, no gotovo dva desetljeća kraće prisutan na javnoj sceni, francuski intelektualac George Bataille najveći je dio svoje popularnosti u književnoznanstvenim i širim humanističkim krugovima stekao nakon svoje smrti. Propulzivan rast Batailleeve recepcije ponajviše je posljedica interesa koji su za njegove radove pokazali francuski poststrukturalisti te posljedične reputacije protopoststrukturalista ili preteče poststrukturalizma koju je zadobio u radovima što su se bavili njegovim slavni(ji)m čitateljima ${ }^{358}$. No premda je Batailleevo ime tako postalo gotovo nezaobilazna referenca pri bavljenju velikim brojem autora kojima smo se bavili i u ovom tekstu, ono se ipak nije pojavilo u dosadašnjim istraživanjima postmarksističke teorije niti se često spominjalo $u$ kontekstu povezanosti s Blochom. U korekciji prvospomenute stavke poći ćemo stoga, pomalo neočekivanim putem, od potonje.

Naime iako poveznice između njih na prvi pogled i nisu upadljive, Bataille i Bloch nedvojbeno dijele nezanemarive dodirne točke. Premda su obojica autora svoje opuse započeli ranije, društveno-politička klima kasnog međuraća, tj. tridesetih godina dvadesetog stoljeća kod obojice je generirala formativne prijelomnice. Dapače, u oba slučaja te su prijelomnice usko povezane s dvjema stvarima: uočavanjem društvene nesinkronosti te analitičkom zaokupljenosti i rastućom zabrinutosti spram jačanja fašizma ${ }^{359}$. Nadalje, razvoj i

\footnotetext{
${ }^{358}$ Usp. Noys $(2000: 1,16)$ i Hegarty (2000: 12) za širi prikaz recepcije Bataillea kao preteče poststrukturalizma. No situacija je ipak složenija od jednostavnog pridavanja tog atributa. Primjerice, Noys (2000: 17) i Koludrović (2014: 206) s pravom upozoravaju i na dijametralno suprotnu pojavu prešućivanja Bataillea u brojnim inačicama historije poststrukturalizma, pri čemu Noys kao jedan od uzroka navodi činjenicu da ga je teško uglaviti u okvire pojedinačnih disciplina u fokusu različitih preglednih studija. Hegarty (2000: 87) čak ističe i primjere u kojima se čitavi sklopovi Batailleeve teorije pripisuju autorima koji su se njime u pojedinim tekstovima bavili (u konkretnom Hegartyjevu primjeru to je Derrida), a da se pritom Bataillea ne spominje. Međutim, jednako je problematično i dijametralno suprotno izvrtanje takve prakse koje, oponirajući dugotrajnom zanemarivanju, nastoji Batailleev utjecaj naglasiti do te mjere da se čini kao da je čitav poststrukturalizam izrastao iz njegove kabanice. Stoga se dobrim čini Noysov (2000: 16) savjet da Bataillea valja čitati „,između gesti odbacivanja i aproprijacije“, ne asimilirajući ga kasnijim autorima, no zadržavajući svijest o njegovoj „anakronosti“, u suodnosu koji može obogatiti i razumijevanje njegova djela, ali i to kako razumijemo poststrukturalističke autore.

${ }^{359}$ Slično kao što Blochovi eseji u Nasljeđu ovoga vremena donose njegova prva zapažanja o nesinkronicitetu povezana s kritičkim osvrtom na uspon fašizma, tako i Batailleev esej Psihološka struktura fašizma [La structure psychologique du fascisme, 1933] (usp. Bataille, 1985: 137 et passim) povezuje njegovu analizu uspona fašizma s ranim razmatranjima o homogenim i heterogenim elementima u društvu, u čemu Boldyrev (2014: 27) prepoznaje poveznicu između dvojice autora. Toj poveznici valja dodati i činjenicu da je u oba slučaja komponenta analize i kritika neodgovarajućih reakcija marksizma/politike komunističke partije na fenomene u pitanju. No za razliku od Blocha, uz Bataillea se vežu i optužbe suvremenika za afinitet pojedinih njegovih suradnika, ali i elemenata njegove teorije (naročito teorije zajednice) spram fašizma (usp. Noys, 2000: 8, 43), bez obzira na njegovo razmjerno jasno distanciranje i kritiku istoga. Među optužbama ističu se i one Frankfurtske škole, konkretno i Benjamina, kao još jedne poveznice Blocha i Bataillea, za „predfašističku estetiku“
} 
Blochova i Batailleeva opusa našao se u međudjelovanju s avangardnim književnim krugovima: za Blocha je značajan bio kontakt s ekspresionizmom, dok se u Batailleevu slučaju radilo o nadrealizmu ${ }^{360}$. Konačno, obojica autora gajila su snažnu antipatiju prema zaokruženim cjelinama i konceptu totaliteta, odmičući se od hegelijanske paradigme prema inačicama dijalektičkog kretanja bez pozitivnog početnog uporišta i krajnjeg Aufhebunga ${ }^{361}$. Posljedično, obojica su proizvela misao uz koju se do danas u najmanju ruku vežu atributi heterodoksnog, a često i mističnog i ezoteričnog ${ }^{362}$.

No dok se za heterodoksnost Blochova opusa, kako smo vidjeli, kao referentnu točku uobičajeno uzima marksističke okvire unutar kojih je se konvencionalno i smješta, Bataille se, pozicioniran na marginama sveukupne teorijske scene svoga vremena, u marksističkom kontekstu razmjerno rijetko spominje. To je paradoksalno stoga što Batailleev opus znatno veći naglasak stavlja na pitanja zajednice, a još i više stoga što, za razliku od Blocha, uokvirujuću ulogu (ako je o njoj i uz stanovitu rezervu moguće govoriti) dodjeljuje ekonomiji. Ipak, premda se naizgled radi o nekim od ključnih topoia tradicionalne marksističke teorije, činjenice da je riječ o atipičnoj koncepciji zajednice te onome što Bataille - nasuprot ograničene - naziva općom ekonomijom, kao i da prethodna dva tematska čvorišta njegove teorije povezuje koncept transgresije, ipak govore $u$ prilog njegovu izostavljanju iz marksističke domene. Jesu li onda u krivu autori poput Koludrovića (2014: 206) koji ga naziva „heterodoksnim marksistom“ ili Hegarty (2000: 32) kada kaže da Bataille nastupa s „kvazi-marksističke“ pozicije? Odgovor na to pitanje, dakako, ne može biti jednoznačan, no nesumnjivo je značajno drukčiji iz perspektive zaokupljenosti problematikom postmarksizma

Batailleevih krugova. No Noys (isto: 44) smatra da su dotične prvenstveno potaknute međusobnim polemikama. Uostalom, Benjaminova poveznica sa Schmittom dovodi u pitanje legitimnost pozicije izricanja takvih optužbi.

${ }^{360}$ Batailleev međuodnos s nadrealizmom obilježio je doduše i sukob s njegovim vodećim figurama, prije svega s Bretonom, i to zbog Batailleevih stavova koji su ponovno bliski onima što ih je i Bloch zagovarao u svojim raspravama o umjetnosti. Naime, Bataille nadrealistima zamjera „Ikarov kompleks“ (Bataille, 1986: 37) zagledanosti u visine i ignoriranja niskog u shemi prostornih metafora kroz koje se prelama društvena stvarnost, odnosno idealizam i ,potpuno nezdravu želju da se okrenu višim spiritualnim područjima“ (isto: 41) u potrazi za superiornom stvarnosti, ali i za Bataillea ontološki problematično uvjerenje u mogućnost oslobađanja ,stvarnog sebstva“. Ne čudi stoga pomalo paradoksalna zamjerka na koju se, prema Hegartyju (2000: 5-6), daju svesti Bretonove optužbe - to da je Bataille nadrealizam odgurao suviše daleko.

${ }^{361}$ Batailleev komentar o vlastitom odnosu prema Hegelu vidjeti u Bataille, 1993: 370. Taj odnos središnja je tema i čuvenog Derridaovog čitanja Bataillea; usp. Derrida, 2007: 267 et passim.

${ }^{362}$ Usp. Hegartyjevo (2000: 9) povezivanje Bretonovih polemika s Batailleem sa Sartreovim optužbama da se radi o autoru koji treba pomoć jer je opsjednut fatalnim i opasnim stvarima te mistiku bez čvrstog sustava misli. O (ne)sustavnosti Batailleeve misli više ćemo reći u nastavku teksta, no glede misticizma valja reći da je takve usporedbe poticao i sam Bataille vrlo čestim referencama na različite mističke prakse. Ipak, ono što ga u konačnici najvažnije razlikuje od različitih tradicija misticizma činjenica je koju podcrtava Derrida (2007: 290): „Bataille je ponajmanje novi mistik. Ono što se pokazuje kao unutarnje iskustvo nije iskustvo, budući da se ne odnosi ni na koju prezenciju, ni na koju punoću, nego jedino na ono nemoguće što ga iskustvo 'doživljava' u muci." 
u ovom radu nego iz klasične marksističke perspektive ili uobičajene perspektive istraživanja Bataillea kao preteče poststrukturalizma.

Anticipirajući prigovore poststrukturalista na koje je formativno utjecao, ali jednako tako i dijeleći ih sa svojim (djelomičnim) suvremenicima poput Blocha i Bahtina, Bataille (1985: 137) marksizmu zamjera da, nakon što je ,utvrdio da baza društva u konačnici određuje ili uvjetuje nadgradnju“, nije „proveo nikakvo općenito istraživanje modaliteta osobitih za formaciju religijskog ili političkog društva“. Pritom pokazuje da je svjestan da „marksizam jest priznao mogućnost odgovora nadgradnje“, no tvrdi da se unatoč tome „nije pomakao daleko od puke tvrdnje prema znanstvenoj analizi.“ Svoju Psihološku strukturu fašizma Bataille stoga vidi kao skicu jednog takvog istraživanja koje se ne bi zaustavilo na pukoj analizi homogenih elemenata (uredno strukturiranih, uklopljenih u diferencijalni sustav kako društva, tako i znanosti koje ih proučavaju), već bi proučavalo i domenu heterogenog (neapsorbiranog viška u odnosu na racionalnu strukturu društva/znanja) te utjecaj koji ono pomoću fenomena nadgradnje ostvaruje na društvo, a koji se ne može svesti na jednostavnu determinaciju ekonomskom bazom kako ju shvaća marksizam.

Skica istraživanja koje bi ,utvrdilo ograničenja inherentnih tendencija znanosti te konstituiralo poznavanje neobjašnjivih razlika“ (Bataille, 1985: 141) zapravo je skica onoga što se uskoro potom pretvorilo u istraživanje opće ekonomije; projekt koji u raznim oblicima prožima cjelokupan Batailleev opus. Uz stanovito pojednostavljivanje moguće je stoga zaključiti da se znatan dio Batailleeva teorijskog stvaralaštva razvio kao (elaboriran i postupno sve udaljeniji) odgovor na ono što je smatrao deficitom perspektive tradicionalnog marksizma. Da to nije pretjerana ocjena, pokazuje i članak Pojam trošenja [La notion de dépense, 1933.], Batailleev tekst objavljen iste godine kao i Psihološka struktura fašizma, u kojem je inicijalno artikulirao ideju opće ekonomije, koja je svoju temeljitu razradu doživjela u poslijeratnom Prokletom dijelu [La Part maudite, 1949].

U Pojmu trošenja, naime, Bataille svoj koncept opće ekonomije - ekonomije što se ne zadržava samo u terminima proizvodnje i korisnosti, već nastoji zahvatiti ukupne tokove energije u biosferi, uključujući i one procese koji se iz perspektive tzv. ograničene ekonomije, odnosno ,racionalne“ proizvodnje i akumulacije, označavaju kao neproduktivno trošenje ${ }^{363}$ elaborira još uvijek značajnim dijelom iz marksističkog rakursa. Tako uspostavu buržujskog

\footnotetext{
${ }^{363}$ Krajnjim poopćavanjem pojma ekonomije Bataille prefigurira sličan postupak niza kasnijih autora; mogli smo to dobro vidjeti na primjeru Derridaa i Foucaulta, no možda i ponajviše kod Deleuzea. Njegovo je širenje pojma proizvodnje, a onda i s njim povezanog ekonomskog leksika, na najrazličitije procese na molarnoj i molekularnoj razini vrlo blisko Batailleevu, dok je, s druge strane, jasno koliko je ta perspektiva divergentna u odnosu na tradicionalno marksističko poimanje ekonomskog.
} 
društva prepoznaje kao historijski najznačajniju prijelomnicu u ustoličenju ograničene ekonomije, budući da su buržuji prvi vladajući sloj koji je počeo trošiti samo za sebe, istovremeno proklamirajući odbojnost prema rastrošnosti i racionalno gospodarenje koje je omogućivalo transformaciju ranijeg feudalnog društva potrošnje u moderno društvo akumulacije (Bataille, 2012: 20-21). No ako su proizvodnja i korisnost temeljni stupovi onoga što i na općenitijoj razini naziva homogenim društvom, specifičnost modernog buržujskog društva koju Bataille (1985: 138) naglašava jest činjenica da u njemu homogenost utemeljuje vlasnik proizvodnih sredstava, a ne proizvođač, u čemu je lako prepoznati tipičnu marksističku pripovijest o otuđenju od proizvoda vlastitog rada.

Batailleev opis geneze klasne borbe u buržujskom društvu tako je razmjerno komplementaran s marksističkim, premda razlika u perspektivi između opće i ograničene ekonomije, odnosno naglašavanja akumulacije i potrošnje, korisnosti i rasipanja nije za zanemariti. To se pokazuje i širenjem historijskog fokusa $s$ buržujskog društva na ranije civilizacije, pri čemu tvrdi da su

/s/astavnice klasne borbe prisutne u procesu trošenja još od arhaičkog razdoblja. U potlatchu bogat čovjek razdjeljuje proizvode koje mu pribavljaju drugi, siromašni ljudi. Pokušava se uzdignuti iznad nekog takmaca koji je bogat kao i on, ali svrha najvišeg stupnja uzdizanja kojemu teži jest što veća udaljenost od siromašnih. (...) Bogat čovjek troši gubitak siromašnoga uspostavljajući za nj kategoriju gubitnika i poniženog koja otvara vrata ropstvu. (Bataille, 2012: 22)

Proletarijat u modernom buržujskom društvu, u jedinstvenom kontinuiranom narativu obespravljenosti, preuzima dakle funkciju robova u arhaičnom društvu (Bataille, 2012: 22) i iz perspektive potrošnje, no važna razlika spram marksističke perspektive jest to što ga $u$ Batailleevoj teoriji ne određuje ništa pozitivno: u anticipaciji onog što se kod kasnijih autora naglašavalo kao odbacivanje marksističkog ontološkog privilegiranja klase, suočeni smo s proletarijatom kao ne-klasom, heterogenim društvenim elementom određenim time što ne može sudjelovati u potrošnji niti se posve apsorbirati u homogene strukture društva (usp. i isto, 1985: 138) $)^{364}$. Jednako tako i klasna borba ostaje na pijedestalu kao ,glavni oblik društvenog trošenja“ (isto, 2012: 24), a revolucija se uspoređuje sa suncem koje „društvo prisiljava da međusobno isključivanje klasa iskoristi za ostvarenje načina trošenja koji će biti koliko god je moguće tragičan i slobodan, istodobno uvodeći posvećene forme, toliko ljudske da će tradicionalni oblici u usporedbi s njima biti prezira dostojni.“ (isto: 26-27) No takvo

\footnotetext{
${ }^{364}$ U drugom dijelu Prokletog dijela Bataille (1993: 334) ukazuje i na stratifikaciju klasa s obzirom na stupanj ljudskosti koji im se pridaje, a u odnosu na ideal koji uspostavlja dominantna skupina. Nasuprot tomu ističe komunizam kao jedini društveni okvir u kojem je vrijednost čovjek kao takav, nikakva kulturna verzija tog čovjeka; drugim riječima ponovno pripadnik ne-klase, bez određujućih svojstava.
} 
općeekonomsko određenje u dvojakom je odnosu spram klasne borbe i revolucije kakvom ih konceptualizira marksistička teorija.

U poslijeratnom se prvom svesku Prokletog dijela udio prepoznatljivog marksističkog leksika pak bitno smanjio, no unatoč tome teško bi bilo tvrditi da se Bataille potpuno odrekao Marxa. Kako Hegarty (2000: 148) primjećuje, „Batailleeva je priča vrlo slična Marxovoj, no u Batailleevim je tekstovima toliko elemenata u nesuglasju s Marxom da se možemo pitati što je od potonjeg ostalo kod prvog“. Ipak, kako navodi, iako se Bataille „nije deklarirao kao komunist, zbog nepovjerenja prema političkim partijama, zasigurno se smatrao više ili manje marksistom.“ (isto) ${ }^{365}$ Takvu Batailleevu poziciju spram marksizma i Hegarty i Noys prepoznaju kao analognu onome što će se iz kasnije perspektive oslovljavati „ultraljevičarstvom“ (Hegarty, 2000: 153), odnosno „ni lenjinistom, ni trockistom“, već jednostavno „ljevičarom [gauchiste]“ (Noys, 2000: 8). No činjenica da teorijski i ideološki nije ni na lenjinističkoj ni na trockističkoj, a kamoli staljinističkoj liniji, nije Bataillea spriječila da u Prokletom dijelu - nalik ranije spomenutom kontroverznom Blochovu potezu u određenim momentima čak i stane u obranu Staljina i staljinizma u SSSR-u ${ }^{366}$.

Unatoč svemu tome Hegarty (2000: 155) ipak zaključuje kako Bataille u poslijeratnoj karijeri politiku više ne doživljava sferom vrijednom intervencije te sav svoj interes premješta na polje opće ekonomije. No taj je zaključak u najmanju ruku dvojben, odnosno može se smatrati opravdanim samo ima li se na umu vrlo usko i tradicionalno definirana politika. U protivnom, iskorak prema promišljanju opće ekonomije ujedno je i iskorak prema fundamentalnijem proučavanju politike.

Na početku drugog, za njegovog života neobjavljenog dijela Prokletog dijela [1976] Bataille (1993: 21) se naime vraća problematici heterogenosti i nesinkronosti društva, tvrdeći da ,često govorimo o svijetu, o čovječanstvu kao da imaju neko jedinstvo. U stvarnosti pak čovječanstvo oblikuje svjetove, naizgled povezane, ali zapravo međusobno strane“. Dapače, pojašnjavajući da ti svjetovi „,isključuju i ignoriraju jedan drugoga“ (isto), te prefigurirajući

\footnotetext{
${ }^{365}$ Bataille (1993: 262-263) u jednom od svojih osvrta na „komunističku doktrinu“, pri čemu taj pojam koristi gotovo sinonimno marksizmu, nastoji zapravo pokazati da se tu i ne radi o gotovoj zaokruženoj doktrini, već dinamičkom tijelu kojem je prije svega funkcija da djeluje. Kako navodi, samo pitanje „razumijevanja komunizma“ jest „postrevolucionarno pitanje“ - ,/d/anas, dok je sudbina revolucije na kocki, 'poanta nije razumjeti svijet, nego ga mijenjati.'“

${ }^{366}$ Iako mu se za razliku od Blocha na teret ne može staviti nekritička glorifikacija SSSR-a te sudjelovanje u razmjerno mračnim staljinističkim političkim epizodama - dapače, na više ga mjesta u svom opusu eksplicitno kritizira - Bataille istovremeno ipak ostavlja prostora ekskulpaciji tvrdeći da je Staljin bio jedini u određenom historijskom kontekstu koji je mogao i imao snage preuzeti određeni historijski zadatak (Bataille, 2012: 205) te kritizirajući antistaljinističke komuniste da ih njihova kritika Staljina, potaknuta tjeskobom prevladavanja pojedinca, često odvlači u buržujski tabor (isto: 186-188).
} 
tako inačice antagonizma poput onih u središtu Laclauove i Rancièreove političke teorije, dodaje da je osobito zanimljiva pojava to što se „ta inkompatibilnost također koncentrira i u pojedincima“" (isto). Umjesto objektivnog danog svijeta, imamo dakle posla s nerijetko proturječnom nadodređenosti. Da pritom nije pretjerano reći kako se radi o diskurzivnoj koncepciji svijeta, pokazuje i Batailleeva (1993: 237) tvrdnja da nam je svijet stvari ${ }^{367}$ dan kao mreža pojava koje kauzalno ovise jedna o drugoj, sa suverenim subjektom kao istovremeno rupturom te mreže i prošivnim bodom koji u njoj uspostavlja hijerarhijske odnose $^{368}$.

$\mathrm{S}$ obzirom na to da je suverenitet prema Batailleu izjednačiv $\mathrm{s}$ neproduktivnim trošenjem, životom onkraj potrebe i koristi (Bataille, 1993: 198), odnosno onim što se ostvaruje prekoračenjem zabrana koje konstituiraju diferencijalni sustav stvari ${ }^{369}$, nije neobično da ,ljudski svijet“" određuje kao

ništa drugo nego hibrid transgresije i zabrane, tako da riječ čovjek uvijek označava sustav proturječnih impulsa, od kojih neki ovise o onima koje neutraliziraju, no nikada potpuno ne eliminiraju, dok drugi donose nasilje pomiješano s izvjesnosti mira koji će uslijediti. Stoga ni riječ čovjek nikada ne označava, kako prostodušni ljudi zamišljaju, stabiliziranu poziciju, već očito prekaran ekvilibrij koji odlikuje ljudska svojstva. (Bataille, 1993: 342) 370 $^{37}$

Pritom je trajna dijalektika granice i prijestupa, odnosno činjenica da je svaki prijestup ovisan o uspostavljenoj granici i da je svaki poredak ovisan o mogućnosti prijestupa ma kako provizorne granice ili uspostavljene pozicije bile, za Batailleevu ideju opće ekonomije toliko važna da na nju opetovano upućuje u svojoj studiji ${ }^{371}$. Riječ je ujedno i o segmentu njegove

${ }^{367}$ „Stvar“ u Batailleevu leksiku nije ograničena na neživo, već je općeniti pojam za element uhvaćen u odnos korisnosti, kauzalni odnos, usporediv npr. s kasnijim Laclauovim elementom artikuliranog diskursa, tj. nešto što bismo mogli i jednostavno nazvati objektom. Nasuprot njoj nalazi se suvereni čimbenik, odnosno subjekt.

${ }^{368}$ Usporedba s jezikom/diskursom nameće se kada se Bataille dotakne te tematike, upozoravajući primjerice na kontradikciju nužnog uzročno-posljedičnog ulančavanja segmenata jezika koji pretpostavljaju određeno konačan uzrok/svrhu, ali i paradoksalne nemogućnosti da se tom ulančavanju stane na kraj apsolutno suverenom točkom (usp. Bataille, 1993: 316), ili pak na to da je jezik (pri čemu naglašava „diskurzivni, a ne poetični jezik“ (isto: 382)) sustav oznaka koje značenje zadobivaju upućujući jedna na drugu, i to tako da se sustav može zatvoriti samo „sakralnim“ označiteljem ispražnjenim od bilo kakvog konkretnog značenja, no uz paradoks da upotreba tog označitelja kao garanta značenja ostalih elemenata uzrokuje i to da on zadobiva njihovo značenje (usp. isto: $382)$.

${ }^{369}$ Noys (2000: 60) upozorava na neuhvatljivost i nedefiniranost Batailleeva koncepta suvereniteta, skrećući pozornost na to da on ,izražava napetosti između slobodnog postojanja i društvene hijerarhije, između nesređenog iskustva i uređenog koncepta“, nazivajući ga „crtom rasjeda“ što prolazi Batailleevim opusom, „ocrtavajući nemogućnost koja se ne može pomiriti sa stabilnim sustavom.“

${ }^{370}$ Usp. i tezu da je život „destabilizacija ekvilibrija bez koje ga ne bi bilo“ (Bataille, 1988a: 16), odnosno da u prirodi i čovjeku postoji ,jedan poriv“ koji ,stalno prekoračuje granice“ $\mathrm{i}$ „,može se samo delimično obuzdati“ (Bataille, 1980: 45), no ne i izraziti.

${ }^{371}$ Bataille na taj odnos upućuje na primjerima razgraničavanja ljudskog i animalnog u erotizmu (Bataille, 1993: 48), erotskih tabua i devijacija u odnosu na brak (isto: 57), odnosa prirode i konvencije (isto: 78), festivalske transgresije društvenih pravila (isto: 90) itd. Slični primjeri ponavljat će se i u drugim njegovim studijama, a zaokupljenost iskustvom granice i njezina prekoračenja na posve fundamentalnoj razini središnji je element i 
teorije koji je ostavio najupečatljiviji utjecaj na kasnije autore, o čemu svjedoči i činjenica da se ta dijalektika transgresije i uspostavljanja granice, kao što smo mogli vidjeti, pojavljuje i kao središnji element Foucaultova, Machereyeva te Derridaova teksta o Batailleu te posljedično oblikuje i njihove teorijske postavke. No i šire od toga, u njoj se može prepoznati gotovo paradigmatski primjer postfundacijske dinamike provizornog utemeljenja, odnosno konstantne dijalektike (kvazi)utemeljenja i rastemeljenja koju je Marchart (2007) u slučajevima kasnijih autora pripisao heideggerijanskom antihegelijanskom impulsu, no očito nedvojbeno važna komponenta u spletu utjecaja jest i Batailleeva vrlo specifična recepcija Hegela.

Aporična pozicija Batailleeva suvereniteta ,između slobodnog postojanja i društvene hijerarhije“ (Noys, 2000: 60) ipak onemogućuje jednostavan mehanički prijevod tog koncepta na terminologiju koju uspostavljaju kasniji autori, jer njegova uloga može biti i disrupcija kao i uspostavljanje određenog poretka, budući da je neproduktivno trošenje s kojim je suverenitet usko povezan, „prokleti dio“ iz naslova studije, kod Bataillea bilo koji suvišak u odnosu na međuzamjenjivost stvari u paradigmi korisnosti. No stanovite paralele svejedno je moguće povući.

Tako je u ulozi tradicionalnog suverena što ga Bataille povezuje s razdobljem od arhaičnih društava pa do kraja feudalizma (s naglaskom na potonji) lako prepoznati anticipaciju (u prvom slučaju izravniju, u drugom posrednu) Deleuzeova nadkodiranja čitavog sustava despotskim tijelom u barbarskim državama/despotskoj mašini, odnosno katahretičkog hegemonijskog nadsvođenja što ga utjelovljuje vođa nad ekvivalencijskim lancem kod Laclaua. Radi se o tome, naime, da je ,/t/radicionalni suverenitet razmetljiv. To je subjekt iznimke (samo jedan subjekt među svim ostalima ima prerogative svih subjekata kao cjeline).“ (Bataille, 1993: 239) Odnosno, „pojedinac iz mnoštva“, radeći za suverena, „prepoznaje sebe u suverenu“ (isto: 240); to je čovjek koji „u očima svakog člana zajednice preuzima vrijednost ostalih (...) utoliko što označava subjektivitet svih ostalih“ (isto 243). Ta mu pozicija pak osigurava mogućnost neproduktivnog trošenja onoga što drugi proizvode, transgresiju granica koje za druge uspostavlja, odnosno prijelaz iz onoga što Bataille naziva domenom profanog u domenu svetog.

Bunt protiv takvog modela tropološkog prijenosa suvereniteta, smatra Bataille (1993: 251) počinje postupnim uočavanjem neegalitarnosti među suverenovim podanicima, no prava

njegova Unutarnjeg iskustva [L'expérience intérieure, 1943.] (koje nije u uobičajenom smislu ni unutrašnje ni pravo iskustvo; riječ je tek o tome da nije iskustvo nekog vanjskog objekta, već nemoguće iskustvo same granice i njezina prekoračenja. Usp. Bataille, 1988b). 
pobuna „kreće tek u trenutku kada je osoba kralja dovedena u pitanje, kada se čovjek mnoštva odluči da više neće prenositi na drugoga, tko god to bio, udio suvereniteta koji mu pripada.“ Razdoblje nakon smrti suverena, dok je sustav tradicionalnog suvereniteta još aktualan, otvara prostor privremenom karnevalesknom prekoračenju svih granica (isto: 89-90), rasipanju diferencijalnog poretka do njegovog ponovnog uspostavljanja. No kada je prijenos suvereniteta trajno doveden u pitanje, struktura se društva profanizira, suverenitet zamjenjuje postvarenje s dva moguća modela: buržujskim i komunističkim ${ }^{372}$.

I buržujsko društvo koje se razvija izravno iz ruševina feudalnog, i staljinističko što nastaje iz njega revolucijom u nepovoljnim okolnostima, prema Batailleu dijele istu temeljnu odliku: oba su naime društva akumulacije, a ne potrošnje (Bataille, 1993: 310), odnosno društva stvari, a ne društva subjekata (isto: 345). No premda im je zajednička temeljna orijentacija akumulaciji, dva društvena modela ipak se razlikuju: u buržujskom je društvu ultimativnu referencu na suverena zamijenila „nemilosrdna bitka svih protiv sviju“ (isto: 349 ), dok komunističko društvo Bataille naziva „strojem za uklanjanje razlika među ljudima“ (isto: 350). Opširnije rečeno, iščezavanje suvereniteta u buržujskim društvima ne uklanja apsolutno suverenu potrošnju, već ona raspršena po društvenom tkivu ostaje osiguravati društveni rang (Bataille, 2012: 18) i klasno raslojavanje (isto, 1993: 334), oblikujući nešto nalik kasnijoj Deleuzeovoj viziji kapitalističkog društva u kojem jedinstveno nadkodiranje despota zamjenjuje mnoštvo dinamičnih aksioma. Komunističko društvo s druge strane odlikuje zatvorenija, zaokruženija struktura, u kojoj suverenu potrošnju zamjenjuje težnja egalitarnoj potrošnji. Ipak, premda je tradicionalni oblik suvereniteta utoliko potpuno odstranjen ${ }^{373}$, određena stratifikacija postoji i Bataille $(1993: 352,356)$ je - u razlici spram suverene vlasti naziva moći, smatrajući da proizlazi isključivo iz odricanja od suvereniteta te funkcije koju pojedinac na taj način zauzima u sustavu.

U oba slučaja dakle potpuno odstranjenje nekog oblika artikulacijskih prošivnih bodova i posljedične stratifikacije diferencijalnog sustava izostaje, bilo da se radi o pretežno metaforičkoj artikulaciji u staljinističkom sustavu ili metonimijskoj u buržujskom

\footnotetext{
372 Bataille (1993: 279) piše „Ne mogu si pomoći nego inzistirati na ovim aspektima: želim naglasiti, nasuprot i klasičnom i suvremenom marksizmu, vezu svih velikih modernih revolucija, od engleske do francuske i nadalje, s raspadom feudalnog poretka. Nije bilo nijedne velike revolucije koja je porušila uspostavljenu buržujsku dominaciju. Sve one koje su zbacile neki režim počele su revoltom motiviranim suverenitetom koji se podrazumijeva u feudalnom društvu." Time zauzima identičnu poziciju kao desetljećima kasnije Laclau i Rancièree, kada privilegiraju Francusku revoluciju kao moment rađanja moderne političke stvarnosti skidanjem maske sakralnog s društvenih odnosa.

${ }^{373}$ Bataille (1993: 353, 356) stoga tvrdi da - suprotno uvriježenim predodžbama - Staljinov autoriten ne počiva na suverenitetu, već na golemoj moći, dok su s druge strane buržujski političari negdje između suverena i moćnika.
} 
kapitalizmu. Idealna situacija kakvom je Bataille vidi pak strukturno je načelo tih sustava odvedeno do njegovih krajnjih implikacija, postvarenje dovedeno do ekstrema koje ukida vlastiti otuđujući učinak: „Odsutnost diferencijacije kao cilj ne mora imati samo negativno značenje dokidanja suverenih vrijednosti. (...) Ako je svakom čovjeku namijenjena sudbina potpune nediferencijacije, on u sebi ukida otuđenje. Prestaje biti stvar. Ili bolje rečeno, ostvaruje bivanje stvari toliko potpuno da više nije stvar.“(Bataille, 1993: 301). Na tom tragu Bataille tvrdi:

Dakako, suverenitet (...) ne može biti postavljen kao cilj historije. Čak tvrdim upravo suprotno: ako historija ima neki cilj, suverenitet ne može biti taj cilj, i nadalje, suverenitet ne može imati ništa s tim ciljem, osim što bi se od njega razlikovao. Taj cilj je možda, baš naprotiv, besklasno društvo; besklasno je društvo u najmanju ruku smjer kojim je historija krenula u naše vrijeme. (...) Očito je točka kojoj se približavamo, privučeni gravitacijom analognom toku vode, neizdiferencirano čovječanstvo." (Bataille, 1993: 281)

Prenesemo li to Batailleevo viđenje (pomalo nasilno, no nipošto neopravdano) $u$ semiotičku terminologiju, radi se dakle o diferencijalnom sustavu „stvari“ iz kojeg bi se otklonili svi antagonistički rasjedi i artikulacijska čvorišta, sva posljedična tropološka izmještanja, i koji bi tako trajno stabiliziran paradoksalno prešao iz diferencijalnog sustava $u$ savršen, neomeđen (unutarnjim ili vanjskim granicama) lanac ekvivalencije, dakle apsolutiziran tropološki prijenos. Paradoksi koji iz takve situacije izviru podrivaju Batailleev utopijski projekt: kao što su mnogo kasnije pokazala Rancièreova istraživanja - apsolutizacija ekvivalencije, kao principa koji inače podriva policijski poredak u korist politike, u potpunosti bi eliminirala politiku u korist stabilnog policijskog poretka. Odnosno, kako smo vidjeli na primjeru književnosti - apsolutizacija literarnosti, kao drugog imena za ekvivalenciju, paradoksalno bi dokinula književnost.

Bataille je toga, čini se, unatoč takvim nacrtima utopijskog cilja u najmanju ruku implicitno svjestan. S jedne strane upozorava na opasnost koja prijeti komunističkom društvu da se, zauzdavajući bilo kakvu neproduktivnu potrošnju unutar svojih granica (koje očito uvijek moraju postojati), nađe u situaciji prinude na potrošnju izvan granica te se pretvori u ratnu mašinu (Bataille, 1993: 359) ${ }^{374}$. S druge strane, pišući o Nietzscheu i pritom se poistovjećujući s njim ${ }^{375}$, Bataille (isto: 367 ) navodi: „Komunisti se protive onome što im se

\footnotetext{
${ }^{374}$ Kao moguće rješenje Bataille (1993: 425) predlaže egalitarnu potrošnju, no ono ponovno otvara spiralu paradoksa pitanjima o mogućnosti apsolutne egalitarnosti, odnosno oksimoronu u sintagmi egalitarne potrošnje, ukoliko je potrošnja definicijom povezana sa suverenitetom. Problemi su to kojih je svjestan i sam, stoga zadržava rezervu prema vlastitom prijedlogu.

${ }^{375}$ Poglavlje započinje sljedećom rečenicom: „Jesam li ja jedini koji sebe smatra ne komentatorom Nietzschea, već istim kao on. Ne radi se o tome da je moja misao uvijek vjerna njegovoj: često se udaljava od nje, pogotovo
} 
čini suverenim. Ali za Nietzschea svijet lišen onoga što nazivam suverenim ne bi više bio izdrživ.“ U nastavku pak tvrdi da bi se i Nietzsche protivio „tradicionalnom suverenitetu“ (isto) kakav na meti imaju komunisti, uvodeći tako implicitno razliku između „tradicionalnog“ poimanja suvereniteta, koje očito ne favorizira, te ničeanskog koje „ne prihvaća svijet u kojem bi čovjek - u kojem svaki čovjek - bio tek sredstvo, a ne i cilj nekog zajedničkog pothvata“ (isto), uz koje pristaje. No teško je oteti se dojmu da se tu već i sam Bataille pomalo zapliće u svom proturječnom poimanju suvereniteta.

$\mathrm{U}$ svakom slučaju, istinski suveren moment $\mathrm{u}$ emancipatornom smislu ostaju transgresije koje su Bataillea i potakle na istraživanje, no koje nisu ograničene samo na iznimne i nesvakidašnje pojave poput žrtvovanja, orgija ili karnevala - podjednako je to i radnička čaša vina, izmaknuta iz bilo kakvih odnosa korisnosti, s kojom radnik „ulazi u čudesni element naslade koja je upravo bit suvereniteta“ (Bataille, 1993: 199), odnosno sotonski non serviam koji odbija svođenje na tek alatku u svijetu (isto: 134). Odreda su to motivi koji prefiguriraju rancièreovske noćne aktivnosti proletarijata, predstavljajući i za Bataillea očuđujuće momente u kojima se narušava uvriježen tijek stvari i aktualan poredak vidljivosti, otkrivajući iza naizgledne stabilnosti i neprozirnosti stvarnosti njezinu kontingenciju. No imajući to na umu, kada Bataille (isto: 261-262) piše da je „komunizam protupokret, posljedica koja je vukla snagu iz suvereniteta samo kako bi ga zbacila“, ali i da je „komunizam prostrani svijet u kojem suvereno mora ponovno oživjeti, možda u novim oblicima, ali možda i u najobičnijim oblicima“, čini se da se Batailleevu emancipatornom idealu komunizma najbliže može prići u opetovanom dijalektičkom podrivanju uspostavljenih suverena emancipatornim prodorima suvereniteta, odnosno kratkim i rijetkim trenucima političkog između razdoblja policijskog, prije nego idealnim utopijskim projektom ${ }^{376}$.

uzme li se u obzir razvoj teorije do detalja. No ta je misao pozicionirana u istim uvjetima kao što je bila $\mathrm{i}$ njegova." (Bataille, 1993: 367)

${ }^{376}$ Na sličan problem nailazi i Batailleevo čuveno promišljanje zajednice. Još od Unutarnjeg isksutva Bataille naglašava moment prekoračenja/suvereniteta kao imanentno komunitaran moment, iskustvo ,u kojem više nema ograničenog postojanja“ (Bataille, 1988: 27), tek iskustva granica i njihove transgresije. Kako Derrida (2007: 281) napominje, za razliku od tradicionalnog poimanja tih pojmova, komunikacija, kontinuum i trenutak tu su tek provizorno stabilizirane skretnice tijeka razlike; pojmovi što se naizgled poistovjećuju s ostvarenjem prisutnosti zapravo potvrđuju i izoštravaju razliku. No konkretni primjeri ipak dovode do problema kod izazova odstranjivanja privilegiranog suverena u tim dijeljenim trenucima suvereniteta. Žrtvovanje, koje je Batailleev vrlo čest primjer intenzivne transgresije što povezuje zajednicu i privilegirano utjelovljenje prokletog dijela (usp. npr. Bataille, 2012: 90), donosi dobru ilustraciju tih teškoća. Poznate su, naime, anegdote prema kojima je Batailleev kružok Acéphale namjeravao provesti jedan takav eksperiment transgresije prinoseći ljudsku žrtvu, no dok pronalazak dobrovoljaca za žrtvu nije bio problem, nitko nije želio preuzeti privilegiranu suverenu poziciju žrtvovatelja (usp. Noys, 2000: 9). Sličan problem ostaje neriješen i na općenitijoj razini, čak i u slučajevima tzv. elektivnih i transgresiji usmjerenih zajednica, a kamoli s drugim oblicima. Na tom je tragu i Nancyjeva (2003) kritika Batailleeva promišljanja zajednice, na koje se Nancy uvelike oslanja, da mu se potkradaju momenti nereflektirane samoprisutnosti i esencijalističkih pretpostavki. 
Iz te perspektive točnom bi se pokazala Noysova (2000: 134) tvrdnja da „Batailleevo djelo nije isključivo destruktivno“ te „da smo vidjeli kako konstantno nastoji razviti nove modele političke prakse, novu etiku i nove načine da živimo zajedno“, no da istovremeno Bataille „nije voljan umanjiti učinke razlike kako bi se postilgi ti ciljevi, ili živjeti u nijekanju činjenice da je 'heterogena stvarnost stvarnost sile ili šoka.'“ Ipak, budući da Batailleevo djelo, kako smo mogli vidjeti, pokazuje proturječne momente ne samo od studije do studije nego i unutar pojedinih studija, ono zasigurno pruža uporišta i osporavanju te naše interpretacije ${ }^{377}$.

Nedvojbeno je pak da Batailleeva opća ekonomija u prokletom dijelu kao svom primarnom objektu proučavanja na intrigantan način pokušava posredovati odnos između moći i emancipacije, utemeljenja i rastemeljenja koji je problematski obilježio opuse autora koji su se na njega ugledali, ali i odnos između onoga što marksistička teorija naziva bazom i nadgradnjom, koji je ostao trajna nedorečenost te kamen spoticanja kako u tradicionalnim marksističkim okvirima, tako i u onome što se naziva postmarksističkom teorijom ${ }^{378}$. Također, općom ekonomijim Bataille na način koji će se zadržati kao prepoznatljiv motiv i kod kasnijih autora objedinjuje problematiku ekonomije i politike diskurzivnim modelom društvene stvarnosti, ili barem modelom koji se bez suviše disonancije podaje takvom prijevodu $^{379}$. Ostaje nam stoga još zapitati se kakva je veza književnosti s tako shvaćenim prokletim dijelom i općom ekonomijom.

Odgovor na to pitanje disperziran je cijelim Batailleevim opusom, koji gusto prožimaju književne reference. Ipak prvenstveno ćemo ga potražiti u zbirci ogleda o književnosti Književnost i zlo [La littérature et le Mal, 1957], čija je provodna nit upravo problematika odnosa onog što drugdje naziva prokletim dijelom te književnosti. Osnovni motiv na koji bi se uvelike dala apstrahirati jezgra svih tamošnjih ogleda prisutan je pak i u segmentu drugog dijela Prokletog dijela posvećenom tematici umjetnosti, a mogli bismo ga u formalističkoj maniri nazvati očuđenjem. Uspoređujući književnost i uopće umjetnost $\mathrm{s}$ prethodno spomenutom radničkom čašom vina, Bataille (1993: 200) se naime pita što bi joj

\footnotetext{
${ }^{377}$ Bataille je svjestan svoje mjestimične proturječnosti koja proizlazi iz potrebe da se sustavno promišlja ono što prekoračuje sustav (Bataille, 2012: 36), odnosno nastojanja da se prikaže užas sustava u kojima je sve upregnuto u korist, koje tada i ono nekorisno pretvara u korisnost (Bataille, 1993: 16).

378 Opća ekonomija zamišljena je kao nadilaženje te binarne opreke, no na jednom mjestu u drugom dijelu Prokletog dijela Bataille (1993: 311) ipak razmišlja u njezinim terminima, suočavajući se odmah s aporijom nemogućnosti određivanja primarnog člana: objašnjavajući da prevladavajuće vrijednosti u društvu utječu na proizvodnju, dodaje i da „,nema sumnje kako su te prevladavajuće vrijednosti i same određene; one su određene, čini se, ekonomskim faktorima ..."

${ }^{379}$ Povezivanje Batailleeve opće ekonomije s općim pismom/općom tekstualnosti nije novost; najpoznatije čitanje te vrste upravo je ono Derridaovo (2007). No takva su čitanja doživljavala i kritike, pa tako Hegarty (2000: 84) veze što ih Derrida uspostavlja s pismom smatra pomalo nategnutima i aproprijacijsko-reduktivnima u odnosu na heterogenost Batailleevih istraživanja. Ipak čini se da bi se prije moglo Hegartyju prigovoriti da Derridaove koncepte shvaća suviše reduktivno.
} 
moglo biti značenje „do li anticipacija jednog takvog odgođenog, zapanjujućeg, čudesnog trenutka" suvereniteta. S druge pak strane, ono što književnosti omogućuje prevođenje te anticipacije u konkretne učinke jest njezina unikatna mogućnost upisivanja singularnih trenutaka suvereniteta u općenito tkanje historije (usp. isto: 164).

U pojedinim segmentima istog istraživanja književnosti će doduše naizgled povjeriti nalik Freudu - posve sekundarnu funkciju poligona zamjenskih iskustava što u kontroliranom okružju omogućuju dodir s doživljajima gubitka, užasa ili strasti, koje u regularnim uvjetima rijetko imamo priliku iskusiti, odnosno negaciju našeg uobičajenog otklona od tih iskustava i suvereno prekoračenje njihove granice (usp. Bataille, 2012: 12; 1993: 106-107). No liminalno-posrednički položaj koji joj mnogo češće dodjeljuje, između s jedne strane singularnog i neprevodivog suvereniteta, a s druge općenitosti pisma i historije, čini književnost mnogo važnijim fenomenom od pukog simulacijskog prostora, dapače pretvara je u jedan od povlaštenih agenata i prostora suvereniteta.

U uvodu Književnosti $i$ zla Bataille (1977: 6) stoga jezgrovito i eksplicitno tvrdi: „Književnost je nešto bitno, ili nije ništa“, odstranjujući time eventualne zaostale dvojbe. Odmah uz to upućuje i na historijski kontekst iz kojeg je izraslo takvo poimanje književnosti, uvelike sličan onom koji je otprilike u isto vrijeme ocrtao i Bloch. Radi se o razdoblju nemira koji se ,/p/ojavio u književnom životu u vreme nadrealističkih bura“, „u godinama posle prvog svetskog rata, prožet osećanjem koje se nije dalo obuzdati. Književnost se gušila u svojim granicama. Činilo se da ona u sebi nosi revoluciju.“ (isto: 5) Poslijeratno razdoblje donijelo je pak pomake analogne onima u promišljanju opće ekonomije: od osluškivanja revolucionarne bure koja se prelijevala preko granica književnosti, do književnosti koja možda više ne nudi modele za političke revolucije, no zato revolucionarno preispituje granice politike.

Moderna je književnost, ističe Bataille (1977: 20-21) u određenju koje snažno evocira ona kod Rancièrea, Derridaa i Foucaulta, ,slobodna i neorganska književnost“, a s obzirom na to i „neodgovorna. Ništa na njoj ne počiva. Ona može reći sve.“ To svojstvo neutemeljenosti i nevezanosti diskurzivnim pravilima pretvara je stoga u privilegirano utjelovljenje transgresije i disruptivni element drugih diskursa: „Samo književnost može da razgoliti kršenje zakona bez koga zakon ne bi imao svrhe - nezavisno od stvaranja novog reda." (isto)

Kao takva, književnost kakvom je Bataille vidi trajno je granično pozicionirana, pa tako i u slučaju opreke između angažirane i autonomne književnosti, koja je u to vrijeme bila 
u središtu diskusija na književnom polju ${ }^{380}$. Kako Bataille (1977: 154) pokazuje čitajući Kafku, književnost se ne može izmaknuti od svijeta onako kako su to i zagovornici i oponenti njezine autonomije zamišljali: „Bekstvo o kome je reč bitno se razlikuje od onoga što pod tim podrazumevaju književni podlisci: to je neuspelo bekstvo. Štaviše, to je bekstvo koje mora, koje teži tome da ne uspe.“ Tako i „Kafka nije doista želeo da pobegne“ iz svijeta svoga oca; ,/h/teo je upravo da živi u tom svetu - i da se oseća isključenim iz njega.“ Istovremeno, ta isključenost unutar jednog svijeta ne može biti temelj uspostavljanja drugog svijeta: „Ako borac protiv stega pobedi, on sa svoje strane postaje, kako za sebe tako i za druge, sličan onima koje je pobedio, na koje prelazi stega. Detinjasti život, suvereni hir, hir bez računa, ne mogu da nadžive svoju pobedu.“" (isto: 157 )

$\mathrm{U}$ isto vrijeme to ne znači da je književnost, ako je imanentno politična, ujedno i isključivo destruktivna. Pišući o Baudelaireovoj poeziji, kojoj se taj atribut pridavao, Bataille (1977: 42) nudi još jednu varijaciju opisa procesa disruptivno-očuđujućeg djelovanja književnosti pišući da ,/p/oezija u prvom trenutku razara predmete kojih se laća i (...) uključuje ih u neuhvatljivu fluidnost pesničkog življenja“, da bi potom pokušala tim predmetima i ovladati te pritom nužno doživjela neuspjeh - „sve što ona može je da ovladane stvari skučenog života zameni oslobađanjem: ona ne može da izbegne da oslobađanje stvari zauzme mesto stvari.“ (isto) No pritom jasno ističe i to da je ,/n/eodvojiva od poezije obveza da se nezadovoljstvu da vid očvrsle stvari.“ (isto) Materijalizacija nezadovoljstva, društvenog antagonizma, neodvojiva je dakle od prokazivanja kontingencije određenog poretka i njegove transgresije. Dapače, otpor poretku korisnosti utoliko je stvaralački što „čini da se, u svetu čiji se svaki sastojak žrtvuje da bi doprineo veličini celine, javi jedinstvenost, to jest otpor jednog odlomka, jednog delića. Na taj način nastalo je nešto čega ranije nije bilo, što ništa ne može izbrisati i što ni na koji način nije nagoveštavalo strogo ustrojstvo sveta..." (isto: 32)

Zadržavanje suverene pozicije na granici poredaka uvjetuje i drukčiju usmjerenost književnosti nego je to slučaj sa svakodnevnim govorom. Obično viđenje stvari, podcrtava Bataille (1977: 37), uvijek je takvo da je „sadašnjost određena budućnošću“ i pritom „zaboravlja sebe“. Nasuprot tomu, pjesnička riječ opisana je kao ona koja produljuje sadašnjost te upućuje na svijest o sebi. Takvo decidirano odbacivanje referenci na budućnost može se činiti stavom posve oprečnim od Blochova, no u pitanju nije odbacivanje budućnosti kao utopijskog faktora, nego kao definiranog telosa kojem podređujemo sadašnje djelovanje u

\footnotetext{
${ }^{380}$ Jedan od glavnih proponenata angažirane književnosti u to je vrijeme bio upravo Sartre, koji istovremeno duž gotovo cijele Književnosti i zla (Bataille, 1977) funkcionira kao meta Batailleevih polemičkih primjedbi.
} 
paradigmi korisnosti ${ }^{381}$. S druge strane, Batailleevo naglašavanje autoreferencijalnog luka anticipira čitav niz teoretičara koji su isti prepoznali kao ključan određujući faktor književnosti, kao što ga i diskurzivna zaobilaznica kojom bolje stječemo uvid u vlastitu poziciju te „usporavanje“ percepcije namjesto algebriziranog govora koji reducira označitelj radi što bržeg prelaska označenom naglašeno povezuju s nešto ranijim zapažanjima formalista i Bahtinova kruga.

Autoreferencijalna komponenta što je Bataille naglašava ujedno je i čimbenik na temelju kojeg otpisuje relevantnost teorije odraza za razumijevanje književnosti. Književnost po njemu nije ni tek mehanički odraz historijske stvarnosti, niti subjektivna perspektiva na nju; ona je pokušaj dokidanja granica između subjekta i objekta, pokušaj jedinstva svijesti i odraza. No ,/i/stina je da poezija, tražeći jedinstvo odraza stvari i svesti što ih odražava, traži nemogućno. Ali nije li doista jedini način da ne budemo svedeni na odraz stvari u tome da tražimo nemogućno.“ (Bataille, 1977: 42) To istovremeno ne znači i potpunu izolaciju književnosti od drugih historijskih procesa; Bataille (1977: 52) jasno inzistira na povezanosti poezije, ekonomije i morala u procesima opće ekonomije, te pišući o Baudelaireu tvrdi da „puni smisao jedne Bodlerove pesme nije dat u njegovim zabludama, već u historijski - na opštem planu uslovljenom očekivanju na koje su te 'zablude' odgovorile. Po svoj prilici, izbori jednaki onome koji je, prema Sartru, Bodler učinio, bili su mogućni u drugim vremenima. Ali iz njih, u drugim vremenima, nisu proistekle pesme slične Cveću zla.“ (isto)

Sasvim očekivano s obzirom na svijest o široj historijskoj perspektivi, ni Bataille ipak ne barata isključivo herojskom vizijom književnosti, tj. ne pripisuje književnosti per se odlike suvereniteta niti je uzima kao ahistorijski fenomen. Radi se naprosto o tome da termin književnosti najčešće upotrebljava metonimijski, zahvaćajući njime mahom modernistički kanon koji, prema njemu, posjeduje odlike suverenosti. No osvrćući se ukratko na historijat odnosa umjetnosti i suvereniteta, u Prokletom dijelu napominje kako je primjerice ,/a/rhaično društvo samo u biti isključivalo mogućnost suverenog pisca ili umjetnika“; ,pisac ili umjetnik nije mogao biti suveren u tom društvu“ budući da je umjetnost bila podređena reprezentaciji suvereniteta suverena ili zajednice (Bataille, 1993: 412). Lako je u tome prepoznati analogiju Bahtinova epskog, što se suprotstavlja romanesknom, odnosno prefiguraciju Rancièreova poetičkog/reprezentacijskog režima umjetnosti, u kojem je umjetnost također bila vezana funkcijom prikladne reprezentacije tijela zajednice.

\footnotetext{
${ }^{381}$ Utoliko kod Bataillea nemamo ni romantičarski odnos prema prošlosti kakav je Bloch, kao antipod svojoj utopijskoj budućnosti, zamjerao Lukácsu. O tome usp. Bataille, 1977: 40-41.
} 
Baš kao u oba spomenuta modela prije i poslije Batailleeva, i u njegovom do promjene situacije dolazi profanizacijom društvenih odnosa, $t \mathrm{j}$. odumiranjem tradicionalnog suvereniteta usponom buržujskog društva. Pritom i Batailleev model upozorava na određene prepreke koje onemogućuju jednostavnu jednadžbu između odumiranja feudalnog društva i rađanja suverene umjetnosti. Društva stvari, kako ih naziva, nisu ništa više prijateljsko okružje za suvremenu umjetnost nego su to bila arhaična društva, samo se njezina uloga mijenja. Sovjetsko društvo, smatra, „posve je prognalo suverenog pisca ili umjetnika“ te upregnulo umjetnost ,u službu vođa koji nisu suvereni, kao što sam rekao, osim u odbacivanju suvereniteta.“ Rezultat je toga neobičan fenomen da sovjetsko društvo „više ne dopušta ništa do li umjetnost i književnost prošlosti.“ (Bataille, 1993: 411) S druge strane, „buržujski svijet, koji je u osnovi još više zatvoren nego komunistički pozitivnom suverenitetu, pozdravlja suverenog pisca ili umjetnika sve dotle dok nije prepoznat kao takav“ (isto). Drugim riječima, u oba „postvarena svijeta“ suverena je umjetnost upregnuta $u$ paradigmu korisnosti, s razlikom koju smo već vidjeli između dvaju sustava - s jedne strane manje dinamičnosti i otvorenosti, s druge strane nominalnog poticanja dinamičnosti dok god je ona u službi tržišta, odnosno ograničene ekonomije.

Potonjoj skupini fenomena vjerojatno pripada i ono što Bataille (1977: 193) kritički naziva izazovom zavodljivosti što je ,podređena želji da se postigne spoljašnji uspeh, opredeljenju za opsene koje brže deluju. U takvom traganju za uspehom i pisac i čitaoci potčinjeni su na isti način. Svako sa svoje strane, autor i čitalac, izbegavaju razdiranje, uništenje, to jest suvereno opštenje, i jedan i drugi ograničavaju se na čari uspeha. “ Nasuprot tomu stoji ona zavodljivost koju Bataille (1993: 257) preporučuje umjetniku u svijetu stvari, kao modus operandi spram glasnogovornika tog svijeta, a u suprotnosti spram iluzornog vjerovanja da njegov suverenitet može, bez da ga preda, imati utjecaj na svijet stvari. $\mathrm{Ne}$ uspije li zavodljivost, smatra, ne valja ni žaliti za onim vremenima „kada se suverenost podredila stvarima pokušavajući podrediti stvari““ (isto).

No poželjnom alternativom podređivanju stvarima, važno je istaknuti, Bataille (1993: 419) ne smatra ni larpurlartizam, za koji priznaje da je bio logičan odgovor na feudalno podjarmljivanje umjetnosti, no da njegov ,puki bijeg od društvenih preokupacija kao cilj nema ništa s čistim suverenitetom“, dapače, da se radi o ciljevima koji „u konačnici nisu ništa drukčiji od osnovnih ciljeva sovjetskog društva." Suprotno tomu, književnost koju smatra doista suverenom remetilački je faktor i buržujskog i staljinističkog društva, odnosno bilo kojeg petrificiranog društvenog poretka. Zbog toga Bataille (1977: 148) pitanje jednog poratnog komunističkog časopisa o tome treba li spaliti Kafkina djela smatra jednako 
logičnim kao i animozitet između tih djela i buržujskog društva. Citirajući Carrougesa, piše: „Kafkin stav bio je mrzak mnogim revolucionarima, ne zbog toga što on ne postavlja izričito problem buržoaske birokratije i pravde, oni su se tu lako mogli naći, već zato što on postavlja problem svake birokratije i svake lažne pravde.“ (Carrouges, prema Bataille, 1977: 165)

Imanentna političnost (suvrmene) književnosti dakle i kod Bataillea upotpunjuje drugo krilo hijazma što ga započinje literarnost politike, pozicionirajući se kritički u odnosu i na buržujsko-liberalnu i na tradicionalnomarksističku perspektivu, pritom se naslanjajući na emancipacijsko-revolucionarnu baštinu obiju kao vlastiti preduvjet. Hijazam je to na samoj granici baze i nadgradnje, krajnje poopćenih ekonomije i semiotike, kritike marksizma i marksističke kritike, koji već poslovično dovodi u pitanje opstojnost tih binarnih opreka. U takvim odnosima lako je uočiti analogiju s temeljnim sadržajem jednog po jednog prethodnog poglavlja, sve do vrlo načelnih određenja postmarksističke teorije na samom početku rada. To pak ne samo da potvrđuje ranije teze o impresivnom opsegu Batailleeva intelektualnog utjecaja, već nas vodi zaključku da smo, da parafraziramo Laclaua i Mouffe (2014: xxiv), već na postmarksističkom terenu, a da pritom nismo sigurni kad smo tu granicu točno prešli. No gledano iz obrnute perspektive, jednako tako posve legitimno možemo zaključiti da su čak i Laclau i Mouffe znatan dio svoje teorije gradili na marksističkom terenu, ili barem na heterogenom teorijskom terenu koji je marksizmu suvremen i njime intenzivno prožet, unatoč tome što su im pojedine interpretacije zajedno s prefiksom post- pripisivale i temeljito okretanje nove stranice.

Prethodna su tri poglavlja tako - pomacima od jednog do drugog teorijskog konteksta i pojedinačnog teoretičara, ali i unutar opusa pojedinih autora - demonstrirala intrigantnu lakoću kretanja kojom se prelazi preko onoga što bi nominalno trebala biti razmjerno tvrda i diskretna granica koja iza sebe ostavlja jedno razdoblje i jedno prevladano teorijsko nasljeđe, kakvom je ocrtavaju ranija historijska određenja postmarksizma te kakvom je osobito naglašava prefiks post-. Ta lakoća kretanja nedvojbeno upozorava na nužnost kritičkog tretmana uobičajenih okvira postmarksizma na koje smo se implicitno oslonili i u većem dijelu ovoga rada. No kako bi se, s obzirom na to, onda trebalo postaviti prema granici u pitanju? Treba li je suziti i pojačati, radi dodatne preciznosti? Proširiti na širi spektar teorijskih fenomena? Pomaknuti unazad u povijest? Ili povući posve prema suvremenosti? Ili $\mathrm{u}$ nedostatku valjanog odgovora na ta pitanja preostaje jedino zaključak da takva granica uopće nema smisla?

Možda Batailleev opus daje ponajbolji odgovor na ta pitanja pokazujući da su premda je granica uvijek kontingenta - njezino postojanje i mogućnost transgresivnog 
kretanja dva neodvojiva konstitutivna čimbenika u odnosu na ono što njome provizorno omeđujemo, odnosno ono što joj je onostrano. Dapače, provodni motiv koji se opetovano pojavljuje u Batailleevu opusu upravo je paradoks da granica, ali i njezina transgresija prethode uspostavi odvojenih entiteta, kao i da ih beziznimno podrivaju i kontaminiraju. Klasični marksizam kao paradigma zaokruženosti i totaliteta nije mogao prihvatiti takvu perspektivu, pa tako iz svog rakursa - kao što smo već pri početku rada spomenuli - nije mogao zamisliti ni da bi moglo postojati nešto što bi se zvalo postmarksističkim ${ }^{382}$. Utoliko je postmarksistička odrednica doista produkt (prvenstveno, no ne isključivo) jednog vremena u kojem se marksistička pretenzija na zahvaćanje totaliteta pokazala iluzornom. No jednom konstituirana, ne ostaje nužno fiksirana za jedinstveni historijski okvir. Bataillevim rječnikom bi se tako, umjesto postističke etikete, moglo govoriti i o stanovitoj heterogenosti naspram homogenizacijskih tendencija klasičnog marksizma. No za ozbiljniji kritički pristup, koji odolijeva kompartmentizaciji kakvoj su skloni shematizirajući udžbenički pregledi, svakako bi i prefiks post- trebao podrazumijevati stanoviti asinkronicitet te podvojenost između nasljedovanja i podrivanja, karakteristične za Batailleevo heterogeno.

Stoga se i ovaj istraživački pokušaj našao u nevolji sličnoj Batailleevoj, pred izazovom homogenog opisa heterogenosti što je određuje odmak od homogenog sustava; upravo jednog od onih koje i sam Bataille uzima za paradigmatske primjere homogenosti. Možda je stoga i prikladno zaključiti ga na ovom mjestu, poglavljem posvećenim njemu, premda (ili upravo zbog toga što, po Batailleevoj mjeri i mjeri drugih autora kojima smo se bavili) opis koji smo ponudili zasigurno ne daje iscrpan uvid u zatvoreni totalitet, ne rezultira slikom zaokruženog korpusa niti trajno i temeljito rješava pitanje granice. Ipak, provodne niti koje smo pratili isprva unutar provizorno uspostavljenih granica, a potom i prekoračujući ih, u najmanju su ruku čvršće povezale taj ektopični korpus, omogućile bolju komunikaciju po njegovoj površini, skrenule pozornost na neke nove aspekte istraživanja te popunile ranije praznine. Naročito onu najveću, koja se odnosila na književnost - čudesnu instituciju koja je ili nešto bitno, ili nije ništa.

\footnotetext{
${ }^{382}$ Usp. Sheridan, 2005: 211.
} 


\section{Zaključak}

Svojevrsno spiralno kretanje kojim smo od Laclaua i Rancièrea, preko Deleuzea, Derridaa i Foucaulta stigli do Machereya i Althussera, a potom u još jednom zavrtaju od sovjetskih (post)revolucionarnih teoretičara (formalista i Bahtinova kruga), preko njemačke međuratne teorijske scene (prvenstveno Blocha) do Bataillea i nazad prema suvremenijoj francuskoj teoriji, ocrtalo je konzistentnu provodnu nit prepoznatljivih obilježja što razdaljinu od točke do točke povezuje čvrstom logikom čija je elaboracija ispunila prošle stranice. No činjenica da je ta logika čvrsta, ne znači istovremeno da je isključiva; nit što smo je ocrtali tek je jedan od mogućih itinerara kojim se može izbrazdati površina skiciranog teorijskog korpusa i s te strane ona ostavlja prostora sugestijama dopuna i alternativnih puteva. Baš kao i sva ostala ranija istraživanja postmarksističke problematike, ni ovo nije obećalo iscrpan opis kategorije, stoga ne smatramo da je oris što smo ga ponudili nepodložan dopuni ili reviziji. Ipak, čini nam se da je, sukladno inicijalnoj najavi, uspio u namjeri da bude sustavniji od većine ponuđenih u prethodnim sličnim studijama, budući da su poveznice među autorima $\mathrm{i}$ problemima kojima smo se bavili podignute na višu razinu konkretnosti (namjesto ranijih vrlo općenitih opisa postmarksističke klime), odnosno ranije je pretežno heteroklitno nizanje primjera zamijenjeno trodijelnom analitičkom shemom kakvu smo najavili već u uvodu.

Činjenica da se ta shema pokazala primjerenim analitičkim pristupom opusu nekolicine autora čije su teorijske pozicije nedvojbeno povezane, no ipak razmjerno različite, ujedno implicira i potvrdu uvodne hipoteze o tome da - uz opetovano naglašavanje ambivalentnog odnosa prema marksističkoj tradiciji - teoretičare koje smo na tragu zaključaka i implikacija prethodnih istraživanja odabrali za analizu u ovom radu odreda povezuje i specifična, diskurzivna konceptualizacija politike te konceptualizacija književnosti kao imanentno političkog diskursa, ali i izrazita povezanost tih dviju stavki. Pritom je prva odlika uvijek neki od pojavnih oblika derivata ideje o odsutnom središtu i posljedičnoj nesvodivoj višeznačnosti, odnosno o nemogućnosti konačnog utemeljenja i paradoksalnoj nužnosti nekog oblika kvaziutemeljenja (samim tim i ontološko-ontičke razlike politike i političkog, koja se doduše ne mora nužno formulirati u tim terminima). Potonja je pak odlika uvijek rezultat toga da je književnost diskurs koji se specifično odlikuje upravo ukazivanjem na tu činjenicu, odnosno da je riječ o praksi koja je distinktivno određena upravo time što razotkriva odsutnost temelja, kontingentnost i nestabilnost svakog poretka. 
Štoviše, u našem se istraživanju kao naročito značajan izbistrio koncept literarnosti, bitno poopćen u odnosu na njegovo uobičajeno značenje unutar književne teorije, kao oznake za fenomen temeljne jednakosti u jeziku (i svakom drugom diferencijalnom sustavu koji konceptualiziramo po tom modelu) koja je paradoksalno i temelj i nesavladiva prepreka svakog poretka, te oznaka onoga što razotkriva kontingenciju privremene suspenzije takve jednakosti tropološkim artikulacijama. Pritom smo pokazali da je takvo određenje literarnosti, koje je šire od nekog specifičnog obilježja književnog diskursa, a izravno povezano s njegovim političkim učincima, kod dijela autora kojima smo se bavili čak i posve eksplicitno prisutno, dok se kod drugih na tom tragu može deducirati. Riječ je dakle i o potvrdi da hijazam koji smo uporabili u uvodu - literarnosti politike i političnosti književnosti - nije tek stilska akrobacija, već jezgrovit način da se opiše vrlo značajan aspekt teorijskih pogleda autora kojima smo se pozabavili.

Stavljanje književnosti u središte istraživanja pokazalo se tako valjanim istraživačkim izborom ne samo zato što je omogućilo ovom radu da u novom kontekstu preispita i proširi neke ranije književnoteorijske spoznaje te problematiku postmarksizma poveže $\mathrm{s}$ književnoteorijskim poljem, što je prethodno većinom izostalo, nego i zato što je upravo takav izbor žarišta primarno uvjetovao strukturu ovog rada te omogućio i drugu polovicu gore spomenutog zaključka.

Naime, upravo je odluka da se pođe od književne problematike uvjetovala to da $\mathrm{u}$ središnjem dijelu disertacije s jedne strane baš kao i prethodna istraživanja u analizu pođemo od Laclaua, ali da se, s druge strane, taj polazak usmjeri bitno drukčije postavljenim problemom. Rezultat takve promjene perspektive, koju je sugerirao analogan Laclauov potez u njegovoj posljednjoj knjizi, bio je s jedne strane dokazivanje kontinuiteta retoričkog shvaćanja politike u njegovu opusu, a s druge strane preopis tog opusa u terminima koji su nam analitički poslužili i onkraj poglavlja, dapače u većini disertacije.

Nadalje, stavljanje književne problematike $\mathrm{u}$ fokus te njezino povezivanje $\mathrm{s}$ političkoteorijskim poljem odluka je koja nas je uputila na potrebu da u razmatranje uključimo i Rancièreov opus, pri čemu se ne radi tek o jednoj od brojnih varijacija autora kojima se poklanja analitička pozornost bez većeg utjecaja na temeljne postavke analize, a takve su varijacije bile uobičajene i za ranije studije, već o promjeni koja je u bitnoj mjeri usmjerila ovu analizu. Kako zaključci tog poglavlja pokazuju, ono ne samo da je podcrtalo zapanjujuću bliskost Rancièreova i Laclauova političkoteorijskog opusa te odnosa spram marksističke tradicije, o čemu se do sada nedostatno pisalo, već je svojim drugim dijelom dopunilo i (uvjetno rečeno) manjak izravnog proučavanja politike književnosti kod Laclaua te 
tako dovršilo ranije spomenuti hijazam i pripremilo njegovu primjenu u ostatku istraživanja. Tome svakako vrijedi dodati i da nam je baš konvergencija Laclauova i Rancièreova tretmana tog pojma omogućila uspostavljanje koncepta literarnosti u onom smislu i opsegu u kojem smo ga nešto ranije opisali i odredili izrazito važnim za ovo istraživanje.

Jednako je tako upravo stavljanje književnosti u analitički fokus, zajedno s prethodno pobrojanim zaključcima, bilo ključno i za artikulaciju specifičnih istraživačkih problema u dvama sljedećim poglavljima, te njihovo povezivanje sa središnjim istraživačkim pitanjima disertacije. Odabrana perspektiva, s literarnosti kao fokalnom točkom, omogućila je uočavanje analogije između Deleuzeova bavljenja književnošću i politikom vezane za problematiku njegova pokušaja radikalnog imanentizma, odnosno zaključke koji dosljednost tog imanentizma dovode u pitanje. Ta je problematika pak, s obzirom na uvodne hipoteze, od velikog značaja za njegovo povezivanje s ostatkom analiziranih autora. Jednako nas je tako ista perspektiva odvela i uočavanju izrazito važne veze između literarnosti i politike kod Derridaa koja, kako smo pokazali, nadrasta zaključke o književnosti kao tek privilegirano političkom/emancipacijskom diskursu te upućuje na njezinu bitnu vezu s problemima koje Derrida smatra ključnima za politiku, poput onih demokracije, pravde i zakona.

Naglasak na književnosti presudan je i za pogled koji smo ponudili na opus Michela Foucaulta, a koji se bitno razlikuje ne samo od onih ponuđenih u prethodnim studijama o postmarksizmu, nego i od uvriježenih predodžbi o njegovu djelu općenito, postavljajući nasuprot uobičajene odrednice teoretičara kontrole i onu transgresije. Kao što su pokazali zaključci tog poglavlja, ono nije u prvi plan stavilo samo jedan razmjerno atipičan segment Foucaultovih radova koji se često posve zanemaruje, a posvećen je književnosti, nego je i unutar njegovih najpoznatijih studija skrenulo pozornost na ulogu poopćene literarnosti i tako ostvarilo određen pomak u odnosu na njihovu prevladavajuću recepciju.

Također, upravo je perspektiva koja se gradi polazeći od propitivanja položaja književnosti u postmarksističkom teorijskom kontekstu primarno zaslužna da je analiza na samom kraju središnjeg dijela disertacije obuhvatila i Machereyev književnoteorijski opus, a on nam je pokazao dvije komplementarne općenito značajne stvari. Nasuprot bilo reduktivnim pogledima na Machereya koji ga prepoznaju isključivo kao althusserijanca, bilo binarnim pogledima koji oštro suprotstavljaju njegovu marksističku i postmarksističku fazu, pokazali smo da razvojna linija njegovih teorijskih pozicija ukazuje na mnogo heterogenije stanje i mnogo nediskretnije granice, tim zanimljivije što ta razvojna linija međusobnim izravnim ili posrednim utjecajem zasijeca i velik broj teoretičara kojima se bave ostala poglavlja. Jednako tako, istraživanje Machereyeva opusa - u kontekstu rasprave o privilegirano emancipacijskoj 
ulozi književnosti - pokazalo nam je najzornije ono na što su na svojim rubovima upozoravala i ostala poglavlja: da granice između književnosti kao sredstva ideološke subjektivacije, kao odraza društva te kao emancipacijskog agensa nisu tako jasne i samorazumljive kako binarne opreke koje ih pridružuju (navodnim) marksističkoj i postmarksističkoj paradigmi često smatraju.

Konačno, upravo ta spoznaja o nediskretnosti granica i nemogućnosti da odnos onoga što se u određenim slučajevima uzima tipično marksističkim i tipično postmarksističkim stavimo u jednostavnu perspektivu linearnog razvoja - spoznaja koja se oblikovala $\mathrm{u}$ početnim dijelovima svakog poglavlja, a potom se naročito eksplicirala u posljednjem poglavlju trećeg dijela rada - povela nas je u četvrtom dijelu disertacije prema prošlosti, na drugu stranu onoga što se uvriježeno uzimalo vremenskom i teorijsko-doktrinarnom granicom između tih dvaju teorijskih korpusa. Strukturu tog iskoraka ponovno je primarno odredilo pitanje književnosti: na više mjesta spomenuta činjenica da su se pokušaji razvoja zaokružene i koherentne marksističke doktrine možda i ponajviše mučili s problemom razvoja odgovarajuće književne teorije (što je vrlo indikativno), navela nas je da problematizaciji granice pristupimo analizirajući tri različita vremenski i prostorno udaljena književnoteorijska čvorišta unutar marksističkog korpusa ili u njegovoj neposrednoj blizini (ruski formalizam i Bahtinov krug, Bloch, Bataille), koja su slovila kao alternativa tradicionalnomarksističkim pristupima književnosti u svom kontekstu. Zaključci svih triju poglavlja jasno su potvrdili analogije koje se daju uspostaviti između tih čvorišta i kasnijih teoretičara koje smo analizirali u odnosu na sve tri temeljne točke analize - ambivalentan odnos prema marksističkoj tradiciji, literarnost politike i političnost književnosti - svjedočeći o jasnoj anticipaciji koju ponegdje valja zahvaliti izravnom utjecaju, a ponegdje nešto složenijoj mreži poveznica.

No neovisno o izravnosti ili neizravnosti anticipacije, činjenica da smo držeći se temeljne analitičke sheme ovog rada neopazice i velikom lakoćom prešli navodno razmjerno tvrdu i diskretnu granicu nedvojbeno je dovodi u pitanje. Upravo stoga četvrti dio ove disertacije nije tek dometak koji donosi uvid u pojedine kuriozitetne podudarnosti, već se pokazao kao segment rada bitan za ispunjavanje zadanih istraživačkih ciljeva: ne samo opisa položaja književnosti i književnoteorijskog u postmarksističkoj teoriji, nego i povratne problematizacije koncepta postmarksizma.

Zahvaljujući posljednjem dijelu rada, također, dodatno se istakao intrigantno proturječan (ništa manje i nije bilo za očekivati) status zbroja svih navedenih pojedinačnih doprinosa književnocentričnog pogleda odgovoru na temeljna istraživačka pitanja disertacije. Naime, s jedne smo strane već ustvrdili da je takav pogled uspio u namjeri da osigura nešto 
koherentniji opis, nasuprot ranijem znatno manjem stupnju koherentnosti koji je dovodio u pitanje potrebu za pojmom postmarksizma. S druge strane, veća koherentnost opisa plaćena je problematizacijom tog pojma iz drugog ugla.

Prije svega, činjenica da je stavljanje književnosti u središte opisa postmarksističke teorije izrazito bitno za njegovu koherenciju navodi na pitanje o potencijalnom paradoksu: nije li glavnina ranijih studija, iako je sadržajno propustila posvetiti značajniju pozornost književnoteorijskoj problematici, strukturno njome određena? Već smo, naime, u uvodu spomenuli da su autori koje ranija istraživanja postmarksističke problematike uzimaju za karakteristične predstavnike tog teorijskog korpusa mahom ujedno i nezaobilazna imena u pregledima suvremene teorije književnosti. Odnosno, preciznije rečeno, radi se velikim dijelom o (pretežno europskim, konkretnije francuskim) filozofima i teoretičarima čiji opusi presijecaju različita disciplinarna polja, ali je njihova golema međunarodna popularnost značajnim dijelom rezultat recepcije na književnim katedrama američkih sveučilišta ${ }^{383}$. Stoga nije pretjerano tvrditi da je književnoteorijski čimbenik i u odsutnosti (i prilično neosviješteno) bio ključan pri pokušajima oblikovanja postmarksističke kategorije. Tome u prilog govori i vidljiv otklon Simovih (1998) ranijih nastojanja da u čitavu priču uključi i autore iz nešto udaljenijih disciplinarnih područja, od kojih se kasnije odustalo, a još i više izrazita ektopija Therbornove (2008) studije, koja s književnom teorijom nema dodirnih točaka. Spornom pak u odnosu na takve zaključke može djelovati već višestruko ponavljana činjenica da je referentna točka gotovo svih studija bio Laclau, budući da se radi o političkom teoretičaru koji se također nije bavio književnom teorijom. No odgovor se krije u Laclauovu značajnom dugu klasicima suvremene književne teorije, na koji upućuje i sam, a koji je potom determinirao strukturu pokušaja da se opiše kategorija za koju je poslužio kao polazište.

$\mathrm{Za}$ prekooceansku, a potom i globalnu recepciju gorespomenutih teoretičara karakteristično je i ono što Derrida (2009) u svom istoimenom tekstu, na koji smo se već referirali u drugom dijelu rada, naziva sklonošću „neologizmima, njuizmima, postizmima, parazitizmima i ostalim malim seizmima“. Nema sumnje da je za odabir postmarksizma kao kategorijalnog nazivnika zaslužna upravo ta sklonost. No dok se u potpunosti slažemo s Derridaom da je posljedica takve tendencije u pravilu ono što naziva razvojem teorijskih gatova u međusobnom zapasavanju i nadmetanju (isto: 9), odnosno vrtuljka etiketa što se međusobno smjenjuju, prikrivajući usporedno s tim međusobnu kontaminiranost i isprepletenost polja što ih nastoje zapasati, jednako nam tako u slučaju određenih pojmova

\footnotetext{
${ }^{383} \mathrm{O}$ tome usp. npr. Cusset, 2008.
} 
koji su se nametnuli dosadašnjom uporabom ne djeluje nužno neprihvatljivo zadržati ih brikolerski, neesencijalistički kao heurističko sredstvo, uz stanoviti kritički oprez koji ne dozvoljava odviše samorazumljivosti.

No čak i prihvatimo li pojam postmarksizma kao dovoljno uvriježen da bismo mu s te strane tražili opravdanje uporabi, što je otvoreno diskusiji jer rasprostranjenost te etikete ipak još nije na razini frekventnijih postističkih pojmova kao što su poststrukturalizam i postkolonijalno, zaključci prethodnih poglavlja pokazali su da pritom svakako treba imati na umu sljedeće stvari. Za početak, prefiks post- nikako se ne može shvatiti kao jednostavna oznaka vremenske posteriornosti koja bi postmarksizam pozicionirala na vremenskom pravcu nakon marksizma, tj. nakon određene prijelomne točke kojom prevlast jedne paradigme završava, a druge započinje. Kao što je drugi dio ove disertacije pokazao, u ranijim je istraživanjima nekoliko uobičajenih kandidata za takvu prijelomnu točku, većinu kojih je moguće metonimijski okupiti šezdesetosmaškim promjenama ili padom Berlinskog zida. No konvergencija trećeg i četvrtog dijela rada jasno pokazuje kako se odlike koje su se prepoznavale ključnima kod teorijskih fenomena nakon šezdesetosmaških gibanja i Berlinskog zida jednako tako mogu pronaći i prije tih povijesnih razdjelnica, dapače između njih se mogu rekonstruirati i izravne linije utjecaja, a ne oštri prekidi. Odnosno, ne dovodeći u pitanje prekretničko značenje spomenutih historijskih događaja, čini nam se kako historijske odsječke koje odjeljuju ne valja doživljavati suviše homogeno niti preokrete s drugih razina tek tako jednostavno preslikavati na teorijsku, premda stanovita povezanost između njih nedvojbeno postoji.

Naime, iz perspektive analogija koje uspostavljaju treći i četvrti dio rada, plauzibilnijom se čini pretpostavka kako se radi ne toliko o prijelomnim točkama između dvaju homogenih korpusa, koliko o točkama krize koje pogoduju - da se poslužimo rječnikom i interpretacijom koju smo posudili od Bataillea te njezinu primjenu nagovijestili u tom poglavlju - dolasku do izražaja heterogenih fenomena, inače apsorbiranih ili potisnutih u pozadini homogenog. Trenuci u kojima se razotkrivanjem kontingencije u njegovoj podlozi dovodi u pitanje određeni prethodno stabilan diferencijalni poredak svakako pogoduju i teorijskim fenomenima koji se bave takvim trenucima, te i sami participiraju u takvom djelovanju. Razdoblja krize pojedinih paradigmi, dakako, nisu isključiva razdoblja u kojima se takva teorijska gibanja pojavljuju i egzistiraju, no u njima svakako najznačajnije dolaze do izražaja - što objašnjava analogije na koje smo ukazali među korpusima povezanim s prekretnicama Oktobarske revolucije, krize tridesetih i šezdesetosmaških zbivanja. U takvu sliku logično se uklapa i privilegiranje literarnog, podsjetimo li se na poopćenu definiciju 
literarnosti, dok je s druge strane paradoksalno da postmarksistička odrednica u određenoj mjeri nastoji post festum homogenizirati takvu heterogenu pojavu.

Za razliku od vremenskog značenja prefiksa post- koje nisu eksplicitnije problematizirale, na ispreplitanje proturječnih značenja raskida i nasljedovanja neke su od prethodnih studija upozorile na različite načine, o čemu je više rečeno u drugom dijelu disertacije. U tom se dijelu već upozorilo na činjenicu da ne primjećuje svaka studija tu temu, da spoznaja o ambivalentnosti postizma ne raste progresivno (dapače, prisutnija je na početku kod Sima (1998) negoli kod nekih kasnijih autora), te da se često formulira nesustavno. No dio problema posebno se istakao u svjetlu kasnijih dijelova ovog rada. Naime, čak i uz uočavanje spomenute ambivalentnosti raskida i nasljedovanja, ranije su studije u pravilu u tom odnosu i marksizam i postmarksizam tretirale kao zaokružene distinktivne korpuse, a tragove nasljedovanja prvog kod potonjeg kao nekolicinu starih prepoznatljivih elemenata raspoređenih na njima inače stranom, posve oprečnom tijelu. Različite varijacije tvrdnje nekolicine autora da sebe smatraju marksistima ili autentičnim nastavljačima određene Marxove ideje s jedne su se strane pritom koristile kao argument, ali s druge implicitno tretirale kao nevjerodostojno pretjerivanje. Rječnikom dviju djelomično proturječnih Laclauovih tvrdnji rečeno, prednost se davala tome da se nalazimo na postmarksističkom terenu (Laclau, Mouffe; 2014: xxiv) prije negoli tome da se tamo gdje jesmo nalazimo specifičnim čitanjem marksističke teorije; takvim koje odbacuje ideju jedinstvenog validnog marksističkog diskursa i sistema kategorija (Laclau, 2015: xxiii).

Početkom trećeg dijela disertacije i ova je analiza svojim rakursom u oscilaciji između tih dviju neobično, a bitno povezanih teza bila nešto bliža prvoj, naglašavajući odmak teoretičara kao što su Laclau i Rancière od marksističkog supstrata na kojem su započeli karijeru prema nečemu što je djelovalo bitno drukčije. No pomak prema kraju trećeg te četvrtom dijelu disertacije dao nam je zaključiti kako se struktura tog kretanja ne mora nužno podudarati s prelaskom iz marksističkog u neki ne-marksistički okvir. Ako su sumnju u to nedovoljno izazvala preostala poglavlja trećeg dijela disertacije, ukazujući na mnogo čvršću vezu s različitim aspektima marksističke tradicije onih teorijskih impulsa prema kojima su se dvojica gorespomenutih autora okrenula navodno napuštajući marksistički supstrat, četvrti je dio rada problematizaciju neizbježno stavio na dnevni red. U njemu se naime jasno pokazalo ne samo da se analogne teorijske postavke mogu uočiti i u ranijim razdobljima, na što smo se osvrnuli maločas, već da ih tamo pronalazimo i različito pozicionirane $\mathrm{u}$ odnosu na marksistički korpus. Isprva kao konkurenciju u kretanjima u kojima se tek oblikovala, da se ponovno poslužimo tom metaforom, popuna marksističke teorijske kartoteke, potom $u$ 
raspravama među nekim od slavnijih marksističkih filozofa i estetičara svoga vremena, te naposljetku u novom (ali nikad potpunom) odmaku od dominantnih marksističkih kretanja, koji je izravno anticipirao i kasniji navodno radikalni prekid.

Time pak ne želimo sugerirati da kovanicu treba naprosto obrnuti na njezino drugo lice i zaključiti da su svi teoretičari koje se pokušalo obuhvatiti postmarksističkim nazivnikom zapravo marksisti. Naprotiv, radi se o tome da uvidimo kako je riječ o složenim ispreplitanjima pogleda, utjecaja i tradicija što ne staju na nekoj zamišljenoj granici između marksizma i postmarksizma, gdje god je pokušali ucrtati. Doprinos da se to ako ne posve previdi, a onda barem zadrži daleko u drugom planu, u ranijim je studijama svakako dala i već spomenuta kompartmentalistički strukturirana recepcija teoretičara u pitanju, koja je velikim dijelom previđala kako heterogenost marksističke teorije (na koju je Laclau - kao njihova primarna referentna točka - konstantno upozoravao, pa makar ponekad bivajući i proturječan!), tako i činjenicu da su Marx i marksizam u akademskom kontekstu koji smo analitički obuhvatili bili neizbježne reference brojnih kanonskih teoretičara koje se uobičajeno smatra klasicima drugih škola misli, a ne marksizma (npr. fenomenologije ili strukturalizma). Imajući to na umu, nije pak nužno ni opravdano posve otpisati semantičku komponentu odbacivanja iz prefiksa post-, tek je preciznije kontekstualizirati, no ni tako se ne možemo riješiti njoj proturječne komponente nasljedovanja. Naime, odbacivanje i prevladavanje u konkretnom slučaju ne treba gledati u odnosu na marksizam per se, već određene historijske varijante marksističke teorije i interpretacije marksističke tradicije - prvenstveno u odnosu na dva onodobna pretendenta na status ortodoksije: sovjetski i Althusserov. No jednako tako, kao što su sva poglavlja trećeg dijela odreda pokazala, ta gesta ubijanja oca, prepoznatljiva u oštrom udaljavanju Althusserovih bivših učenika od njegova nasljeđa, ruku pod ruku sa sobom nosi i prihvaćanje nekih aspekata njegovog teorijskog nasljeđa.

Sve u svemu, važan je doprinos preispitivanja pojma postmarksističkog, u nekim slučajevima možda i njegova neplanirana nuspojava, dolazak do spoznaje da se ne smije zanemariti golem utjecaj Marxa i marksističke misli na teoretičare u čijim se uvriježenim prikazima on uobičajeno zanemarivao. Dapače, jasno smo pokazali kako ni u jednom od analiziranih slučajeva referiranje na marksizam nije tek ukrasna figura, poza ili danak zahtjevima vremena, već je u nezanemarivoj svezi s ključnim postavkama pojedinih teoretičara. S druge strane, jednako je tako nužno izbjeći potpunu marksocentričnost u koju je s postmarksističkom perspektivom lako posrnuti: promatrati dane autore samo u odnosu na Marxa i marksizam te njihov čitav teorijski rad na ovaj ili onaj način izvoditi iz marksizma, kao nasljedovanje ili otpor. Čineći tu pogrešku, postmarksistička perspektiva potencijalno 
zapada u još jedan paradoks: nastojeći ukazati na propast dogmatski konceptualiziranog marksizma, kao i općenito velikih homogenih zaokruženih doktrinarnih sistema, i sama apsolutizira Marxa.

Sve nas to konačno dovodi do pitanja kako se postaviti prema pojmu postmarksizma u uporabi, odnosno je li ta uporaba doista opravdana? Jednostavan i jednoznačan odgovor na to pitanje teško je dati. Iz svega što smo do sada izložili lako je deducirati da se radi o problematičnom pojmu koji nipošto ne bi valjalo prigrliti olako i samorazumljivo bez svih ograda koje smo do sada apostrofirali. Dapače, čini se teškim zamisliti bilo kakvu upotrebu tog pojma koja sa sobom ne bi nosila makar implicitne navodne znakove ili ogradu u vidu atributa „takozvani“. No ako je tako, zašto posve ne otpisati taj pojam i nije li riječ tek o štetnom primjeru inflatornog pojavljivanja novih postističkih kovanica? Prije svega, vrijedi uzeti u obzir da bi se sve rečeno jednako tako moglo primijeniti i na najpoznatiju postističku kovanicu - onu poststrukturalizma. Štoviše, stanovito ograđivanje pri uporabi tog u humanistici već sveprisutnog pojma, ili čak tendencija njegova izbjegavanja, postala je u dijelu znanstvene zajednice gotovo opće mjesto. Pa ipak, ne samo da je rasprostranjenost upotrebe tog pojma nemoguće tek tako stornirati sviješću o njegovoj problematičnosti, nego i unatoč toj problematičnosti postoje neke situacije u kojima je iz praktičnih, pragmatičnih razloga teško zamjenjiv: npr. situacije kakve su stvorili udžbenički pregledi potrebiti poopćavanja visokog stupnja, koji u pripovijestima o razvoju teorije najčešće uzimaju strukturalizam kao referentnu točku. Na sličan način bi, ukoliko praksa tako pokaže, u uporabi mogao opstati i postmarksistički nazivnik, kao prečica za ukazivanje na složen i proturječan (a često zanemaren) odnos pojedinih suvremenih teoretičara prema marksističkoj tradiciji. No pritom bi bilo dobro nastojati da on u svakoj situaciji bude čim više alat problematizacije, a što manje etiketa koja se stavlja na čvrsto omeđene ladice.

Jednako su tako i istraživanja što se zaokupljaju problematizacijom postmarksističkog pojma, čini nam se, korisna i potrebna upravo u onoj mjeri u kojoj na tom tragu potiču rekonfiguraciju određenih uspostavljenih shema vidljivosti i dodijeljenih diferencijalnih pozicija u aktualnoj epistemi, a ne u mjeri u kojoj uspostavljaju nove zaokružene kategorije. Naročito to vrijedi za književnoteorijski kontekst, s obzirom na distinktivna svojstva književnosti kao diskursa koja su imala izrazito važnu ulogu u ovoj našoj studiji, ali i za općenitiju razinu, sudeći po zaključcima koji ta svojstva projiciraju i na druge razine i diskurse. Izazov sustavnog opisa fenomena koji se odupire sustavnosti pritom je uvijek nemali izazov koji u pravilu ne uspijeva ponuditi posve zadovoljavajuće rezultate, ostajući podvojen između vjernosti oprečnim zahtjevima metodičnosti i fenomena kojim se bavi. 
Nesumnjivo je sličan problem, od uvodnih hipoteza preko kritičke analize ranijih studija pa do dvaju temeljnih analitičkih dijelova, obilježio i ovu disertaciju, budući da je takav raskorak nazočan već u dvama temeljnim zadacima koje si je zadala - opisati ulogu književnosti i književnoteorijskog u postmarksističkoj teoriji kao potencijalni put prema sustavnijem razumijevanju te teorijske odrednice, ali i posljedično preispitati pojam postmarksizma. Odgovori koje je ponudila, uvjereni smo, ipak su rezultirali pojedinim novim spoznajama na različitim razinama - u odnosu na specifičnu problematiku postmarksizma, ali i neka od općenitih pitanja književne i političke teorije postavljena u novi kontekst. Ako je uz taj doprinos homogenom, strukturiranom znanju uspjela zadržati i ponešto heterogenog; odgovarajuću dijalektiku ponavljanja i razlike bez konačnog Aufhebunga, mesijansku komponentu otvorenosti, odnosno utopijske usmjerenosti što nadilazi strukture očekivanja kako bi i dolikovalo studiji čije su temeljne teme književnost i politika - tada bi se mogla smatrati valjanim zalogom za buduća istraživanja. 


\section{Literatura}

1. Adorno, Theodor i dr. 2007. Aesthetics and Politics. London/New York: Verso.

2. Althusser, Louis (i dr.). 1975. Kako čitati Kapital [1965]. (prev. Rade Kalanj i Ljerka Šifler). Zagreb: Centar za kulturnu djelatnost Saveza socijalističke omladine.

3. Althusser, Louis. 1996. For Marx [1965]. (prev. Ben Brewster). London: Verso.

4. Althusser, Louis. 2001. Lenin and Philosophy [1969]. (prev. Ben Brewster). New York: Monthly Review Press.

5. Ambrogio, Ignazio. 1977 [1968]. Formalizam i avangarda u Rusiji. (Prev. Vera Frangeš). Zagreb: Stvarnost.

6. Anderson, Perry. 1987. Considerations on Western Marxism [1976]. London: Verso.

7. Bahtin, Mihail Mihajlovič. 1967. Problemi poetike Dostojevskog [1963]. (Prev. Milica Nikolić). Beograd: Nolit.

8. Bahtin, Mihail Mihajlovič. 1978. Stvaralaštvo Fransoa Rablea [1965]. (Prev. Ivan Šop i Tihomir Vučković). Beograd: Nolit.

9. Bahtin, Mihail Mihajlovič. 1980. Marksizam i filozofija jezika [1929]. (Prev. Radovan Matijašević). Beograd: Nolit.

10. Bahtin, Mihail Mihajlovič. 1989. O romanu [1975]. (prev. Aleksandar Badnjarević). Beograd: Nolit.

11. Bahtin, Mihail Mihajlovič. 1990. Art and Answerability [1919.] (prev. Vadim Liapunov). Austin: University of Texas Press.

12. Bahtin, Mihail Mihajlovič. 2010. Ka filosofiji postupka [1986]. (prev. Rušan Radunović). Beograd: Službeni glasnik.

13. Bahtin, Mihail Mihajlovič. 1991. Autor i junak u estetskoj aktivnosti [1979]. (prev. Aleksandar Badnjarević). Novi Sad: Bratstvo-jedinstvo.

14. Barthes, Roland. 1990. S/Z [1973]. (prev. Richard Miler). Blackwell.

15. Bataille, Georges. 1977. Književnost i zlo [1957]. (prev. Ivan Čolović). Beograd: Beogradski izdavačko-grafički zavod.

16. Bataille, Georges. 1980. Erotizam [1957]. (prev. Ivan Čolović). Beograd: Beogradski izdavačko-grafički zavod.

17. Bataille, Georges. 1986. Visions of Excess. Selected Writings 1927-1939. (prev. Allan Stoekl). Minneapolis: University of Minnesota Press. 
18. Bataille, Georges. 1988a. Guilty [1944]. (prev. Bruce Boone). Venice: The Lapis Press.

19. Bataille, Georges. 1988b. Inner Experience [1954]. (prev. Leslie Anne Boldt). New York: State University of New York Press.

20. Bataille, Georges. 1993. The Accursed Share. An Essay on General Economy. Vol. 2\&3. (prev. Robert Hurley). New York: Zone Books.

21. Bataille, Georges. 2012. Prokleti dio [1949]. (prev. Daniel Bučan). Zagreb: Litteris.

22. Baugh, Bruce. 2000. „How Deleuze can help us make Literature work“, u: Buchanan, Ian; Marks, John (ur.). 2000. Deleuze and Literature. Edinburgh: Edinburgh University Press. 34-57.

23. Beardsworth, Richard. 1996. Derrida \& the political. London/New York: Routledge.

24. Beilharz, Peter. 1994. Postmodern Socialism. Romanticism, City and State. Melbourne: Melbourne University Press.

25. Bennett, Tony. 1979. Formalism and Marxism. London/New York: Methuen \& Co.

26. Bekavac, Luka. 2015. Prema singularnosti. Derrida i književni tekst. Zagreb: Disput.

27. Bernard-Donals, Michael F. 1994. Mikhail Bakhtin: Between Phenomenology and Marxism. Cambridge/New York: Cambridge University Press.

28. Biti, Vladimir. 2000. Pojmovnik suvremene književne i kulturalne teorije. Zagreb: Matica hrvatska.

29. Biti, Vladimir. 2014. „Disaggregating Territories: Literature, Emancipation, and Resistance“. U: Umjetnost riječi, LVIII/3-4: 277-308.

30. Bhabha, Hommi K. 1994. The Location of Culture. London/New York: Routledge.

31. Blanchot, Maurice. 1992. The Infinite Conversation [1969]. (prev. Susan Hanson). Minneapolis: University of Minnesota Press.

32. Blanchot, Maurice. 2009. Jezik fikcije [1949]. (prev. Marko Gegorić). U: Brlek, Tomislav (ur.). 2009. Praksa teorije. Quorum, XXV/5-6: 337-351.

33. Bloch, Ernst. 1973. Tübingenski uvod u filozofiju [1963]. (prev. Davor Rodin). Beograd: Nolit.

34. Bloch, Ernst. 1980. Experimentum mundi [1975]. (prev. Olga Kostrešević). Beograd: Nolit.

35. Bloch, Ernst. 1981. O umjetnosti. Izabrani tekstovi. (prev. Nadežda ČačinovićPuhovski i dr.). Zagreb: Školska knjiga.

36. Bloch, Ernst. 1982. Duh utopije [1923]. (prev. Milan Tabaković). Beograd: Beogradski izdavačko-grafički zavod. 
37. Bloch, Ernst. 1991. Heritage of our Times [1935/1962]. (prev. Nevile i Steven Plaice). Berkley/Los Angeles: University of California Press.

38. Bloch, Ernst. 1995. Principle of Hope. Volume 1 [1959]. (prev. Neville Plaice, Steven Plaice, Paul Knight). Cambridge: MIT Press.

39. Bloch, Ernst. 2006. Traces [1930/1969]. (prev. Anthony A. Nassar). Stanford: Stanford University Press.

40. Bloch, Ernst. 2007. Discussing Expressionism [1938]. U: Adorno, Theodor i dr. 2007. Aesthetics and Politics. London/New York: Verso. 16-27.

41. Bowman, Paul. 2007. Post-Marxism Versus Cultural Studies. Theory, Politics and Intervention. Edinburgh: Edinburgh University Press.

42. Bogue, Ronald. 2003. Deleuze on Literature. New York/London: Routledge.

43. Boldyrev, Ivan. 2014. Ernst Bloch and His Contemporaries. London/New York: Bloomsbury.

44. Breckmann, Warren. 2013. The Adventures of the Symbolic. Post-Marxism and Radical Democracy. New York: Columbia Press.

45. Brlek, Tomislav. 2015. Lekcije. Studije o modernoj književnosti. Zagreb: Školska knjiga.

46. Brlek, Tomislav; Koludrović, Bernard. 2015. Foucault i književnost. U: CASCA, časopis za društvene nauke, kulturu i umetnost. 4: 1-14.

47. Buchanan, Ian; Marks, John. 2000. „Introduction: Deleuze and Literature“, u: Buchanan, Ian; Marks, John (ur.). 2000. Deleuze and Literature. Edinburgh: Edinburgh University Press. 1-14.

48. Choat, Simon. 2010. Marx Through Post-Structuralism. Lyotard, Derrida, Foucault, Deleuze. London/New York: Continuum.

49. Clark, Timothy. 1992. Derrida, Heidegger, Blanchot. Sources of Derrida's notion and practice of literature. Cambridge: Cambridge University Press.

50. Colombat, André Pierre. 2000. „Deleuze and Signs“, u: Buchanan, Ian; Marks, John (ur.). 2000. Deleuze and Literature. Edinburgh: Edinburgh University Press. 14-34.

51. Coward, Rosalind; Ellis, John. 1985. Jezik i materijalizam [1977]. (prev. Ranka Gregurić). Zagreb: Školska knjiga.

52. Crawford, T. Hugh. 2000. „The Paterson Plateau: deleuze, Guattari and William Carlos Williams“. u: Buchanan, Ian; Marks, John (ur.). 2000. Deleuze and Literature. Edinburgh: Edinburgh University Press. 57-80. 
53. Cusset, Francois. 2008. French Theory. How Foucault, Derrida, Deleuze \& Co. Transformed the Intelectual Life of the United States [2003]. (prev. Jeff Fort). London/Minneapolis: University of Minnesota Press.

54. De Man, Paul. 1979. Allegories of Reading. New Haven/London: Yale University Press.

55. De Saussure, Ferdinand. 2000. Tečaj opće lingvistike [1916]. (prev. Vojmir Vinja), Zagreb: ArTresor naklada, Institut za hrvatski jezik i jezikoslovlje.

56. DeJean, Joan. 1992. Bahtin i povijest/Bahtin u povijesti. (Prev. Borislav Knežević). U: Biti, Vladimir (ur.). Bahtin i drugi. Zagreb: Naklada MD. 61-79.

57. Deleuze, Gilles. 1990. The Logic of Sense [1969]. (prev. Mark Lester). London: The Athlone Press.

58. Deleuze, Gilles. 1995. Negotiations [1990]. New York: Columbia University Press.

59. Deleuze, Gilles. 1998. Essays Critical and Clinical [1993]. (prev. Daniel W. Smith, Michael A. Greco). London/New York: Verso.

60. Deleuze, Gilles. 2000. Proust and Signs [1964, 1976.]. (prev. Richard Howard). Minneapolis: University of Minnesota Press.

61. Deleuze, Gilles. 2002. Nietzsche and Philosophy [1962]. (prev. Hugh Tomlinson). London/New York: Continuum.

62. Deleuze, Gilles. 2004. Desert Islands and Other Texts (1953-1974) [2002]. Los Angeles/New York: Semiotext(e).

63. Deleuze, Gilles. 2006a. „Coldness and Cruelty“, u: Deleuze, Gilles. 2006. Masochism. (prev. Jean McNeil). New York: Zone Books. 9-143.

64. Deleuze, Gilles. 2006b. Two Regimes of Madness: Texts and Interviews 1975.-1995. Los Angeles/New York: Semiotext(e).

65. Deleuze, Gilles. 2009a. Dijalozi [1996]. (prev. Olja Petronić). Beograd: Fedon.

66. Deleuze, Gilles. 2009b. Razlika i ponavljanje [1968]. (prev. Ivan Milenković). Beograd: Fedon.

67. Deleuze, Gilles; Guattari, Felix. 1986. Kafka: Toward a Minor Literature [1975]. (prev. Dana Polan). London/Minneapolis: University of Minnesota Press.

68. Deleuze, Gilles; Guattari, Felix. 2013. Kapitalizam i shizofrenija 2. Tisuću platoa [1980]. (prev. Marko Gregorić). Zagreb: Sandorf/Mizantrop.

69. Deleuze, Gilles; Guattari, Felix. 2015. Kapitalizam i shizofrenija 1. Antiedip [1972]. (prev. Marko Gregorić). Zagreb: Sandorf/Mizantrop. 
70. Derrida, Jacques. 1976. O gramatologiji [1967]. (prev. Ljerka Šifler-Premec). Sarajevo: Veselin Masleša.

71. Derrida, Jacques. 1981. Positions [1972]. (prev. Alan Bass). Chicago: The University of Chicago Press.

72. Derrida, Jacques. 1982. Margins of Philosophy [1972]. (prev. Alan Bass). Chicago: The University of Chicago Press.

73. Derrida, Jacques. 1988 Limited Inc. (prev. Samuel Weber i Jeffrey Mehlman), Evanston: Northwestern University Press.

74. Derrida, Jacques. 1992. Acts of Literature. London/New York: Routledge.

75. Derrida, Jacques. 1995a. „Archive Fever“. (prev. Eric Prenowitz), u: Diacritics, 25/2: $9-63$.

76. Derrida, Jacques. 1995b. Points [1992]. (prev. Peggy Kamuf i dr.), Stanford: Stanford University Press.

77. Derrida, Jacques. 2002a. „Force of Law“ [1990/1994/2001], u: Derrida, Jacques. 2002. Acts of Religion. New York/London: Routledge. 228-299.

78. Derrida, Jacques. 2002b. Sablasti Marxa [1993]. (prev. Srđan Rahelić). Zagreb: Hrvatska sveučilišna naklada.

79. Derrida, Jacques. 2005a. Rogues: Two Essays on Reason [2003]. (prev. Pascale-Anne Brault, Michael Naas), Stanford: Stanford University Press.

80. Derrida. Jacques. 2005b. The Politics of Friendship [1994]. (prev. George Collins). London/New York: Verso.

81. Derrida, Jacques. 2007. Pisanje i razlika [1967]. (prev. Vanda Mikšić), Sarajevo: Šahinpašić.

82. Derrida, Jacques. 2009. Some statements and Truisms about Neologisms, Newisms, Postisms, Parasitisms, and other Small Seisms [1990]. (prev. Tomislav Brlek). U: Brlek, Tomislav (ur.). Praksa teorije. Quorum, XXV/5-6: 7-41.

83. Derrida, Jacques. 2016. Dissemination [1972]. (prev. Barbara Johnson). London/New York: Bloomsbury.

84. During, Simon. 1992. Foucault and Literature. London/New York: Routledge.

85. Eisen, Samuel D. 1996. Whose Lenin is it Anyway? Viktor Shklovsky, Boris Eikhenbaum and the Formalist-Marxist Debate in Soviet Cultural Politics (A View from the Twenties). U: The Russian Review. 551/1: 65-79.

86. Ejhenbaum, Boris. 1972 [1925]. Teorija „formalnog metoda“. U: Ejhenbaum, Boris. Književnost. (Prev. Marina Bojić). Beograd: Nolit. 
87. Erlich, Victor. 1980 [1955]. Russian Formalism. History - Doctrine. Paris/New York/The Hague: Mouton Publishers.

88. Faubion, James D. 1998. Introduction. U: Foucault, Michel. 1998. Aesthetics, Method, and Epistemology. Essential Works of Foucault. Volume Two [1994]. (prev. Robert Hurley i dr.). New York: The New Press. xiii-xlv.

89. Feltham, Oliver. 2016. „Rancière and Tragedy“, u: Hellyer, Grace; Murphet, Julian (ur.). 2016. Rancière and Literature. Edinburgh: Edinburgh University Press. 58-76.

90. Flaker, Aleksandar (ur.). Sovjetska književnost 1917-1932. Zagreb: Naprijed.

91. Foucault, Michel. 1980. Power/Knowledge. Selected Interviews and Other Writings 1972-1977. New York: Pantheon Books.

92. Foucault, Michel. 1990. Nietzsche, Freud, Marx [1964]. U: Ormiston, Gayle L.; Schrift, Alan D. (ur) 1990. Transforming the Hermeneutic Context. From Nietzsche to Nancy. New York: State University of New York Press.

93. Foucault, Michel. 1994. Znanje i moć. (ur. Rade Kalanj, Hotimir Burger; prev. Rade Kalanj). Zagreb: Globus.

94. Foucault, Michel. 1995. Discipline and Punish: The Birth of the Prison [1975]. (prev. Alan Sheridan). New York: Vintage Books.

95. Foucault, Michel. 1998. Aesthetics, Method, and Epistemology. Essential Works of Foucault. Volume Two [1994]. (prev. Robert Hurley i dr.). New York: The New Press.

96. Foucault, Michel. 2002. Riječi i stvari [1966]. (prev. Srđan Rahelić). Zagreb: Golden marketing.

97. Foucault, Michel. 2004. Death and the Labyrinth. The World of Raymond Roussel [1963]. (prev. Charles Ruas). London/New York: Continuum.

98. Foucault, Michel. 2010a. The Archaeology of Knowledge [1969]. New York: Vintage Books.

99. Foucault, Michel. 2010b. Vladanje sobom i drugima [2008]. (prev. Zlatko Wurzberg). Zagreb: Antibarbarus.

100. Foucault, Michel. 2013. Povijest seksualnosti 1. Volja za znanjem [1976]. (prev. Zlatko Wurzberg). Zagreb: Domino.

101. Foucault, Michel. 2018. Velika strankinja [2013]. (prev. Vanda Mikšić). Zagreb: Meandarmedia.

102. Genette, Gérard. 2000. „Metonimija kod Prousta ili rođenje pripovijesti“ [1970]. (prev. Zlatko Wurzberg), Europski glasnik, 5/5: 343-350. 
103. Glavaš, Zvonimir. 2017. Stotinu godina Umjetnosti kao postupka: je li (i danas) revolucionarna revolucionarna teorija. Književna smotra, 49/185: 27-44.

104. Goldstein, Philip. 2005. Post-Marxist Theory. An Introduction. Albany: State University of New York Press.

105. Hegarty, Paul. 2000. Georges Bataille. Core Cultural Theorist. London: Sage Publications.

106. Hillis Miller, Joseph. 1991. Tropes, Parables, Performatives: Essays on TwentiethCentury Literature. Durham: Duke University Press.

107. Hirschkop, Ken. 1999. Mikhail Bakhtin: An Aesthetic for Democracy. Oxford: Oxford University Press.

108. Jakobson, Roman. 2008. O jeziku [1990]. (ur. Linda R. Waugh, Monique Monville-Burston; prev. Damjan Lalović), Zagreb: Disput.

109. Kalanj, Rade (ur.). 1983. Marx nakon 100 godina. Zagreb: Globus.

110. Keucheyan, Razmig. 2013. The Left Hemisphere. Mapping Critical Theory Today. (prev. Gregory Elliott). London/New York: Verso.

111. Koczanowicz, Leszek. 2015. Politics of Dialogue : Non-Consensual Democracy and Critical Community. Edinburgh: Edinburgh University Press.

112. Koludrović, Bernard. 2015. Političnost književnosti, literarnost politike i transgresivnost: Georges Bataille. U: Umjetnost riječi, 58/2: 205-224.

113. Kristeva, Julia. 1984. Revolution in Poetic Language. (prev. Margaret Walter). New York: Columbia University Press.

114. Kristeva, Julia. 1989. Moći užasa: ogled o zazornosti [1980]. Zagreb: Naprijed.

115. Laclau, Ernest. 1977. Politics and Ideology in Marxist Theory. Capitalism Fascism - Populism. London: NLB.

116. Laclau, Ernesto. 1996. Emancipation(s). London/New York: Verso.

117. Laclau, Ernesto. 2007a. „Identitet i hegemonija: Uloga univerzalnosti u konstituiranju političke logike“; „Struktura, historija i političko“; „Konstruiranje univerzalnosti““, u: Butler, Judith; Laclau, Ernesto; Žižek, Slavoj. 2007. Kontingencija, hegemonija, univerzalnost. Zagreb: Jesenski i Turk.

118. Laclau, Ernesto. 2007b. On Populist Reason [2005]. London/New York: Verso.

119. Laclau, Ernesto. 2014. The Rhetorical Foundations of Society. London/New York: Verso. 
120. Laclau, Ernesto. Mouffe, Chantal. 2014. Hegemony and Socialist Strategy. Towards a Radical Democratic Politics [1985]. London/New York: Verso.

121. Lambert, Gregg. 2000. „On the Uses and Abuses of Literature for Life“, u: Buchanan, Ian; Marks, John (ur.). 2000. Deleuze and Literature. Edinburgh: Edinburgh University Press. 135-167.

122. Livingstone, Rodney; Anderson, Perry; Mulhern, Francis. 2004. Presentation I. U: Adorno, Theodor i dr. 2007. Aesthetics and Politics. London/New York: Verso. 915.

123. Lecercle, Jean-Jacques. 2002. Deleuze and Language. Hampshire/New York: Palgrave Macmillan.

124. Lesic-Thomas, Andrea. 2005. Behind Bakhtin: Russian Formalism and Kristeva's Intertextuality. U: Paragraph. 28/3: 1-20.

125. Lüdemann, Susane. 2014. Politics of Deconstruction. Stanford: Stanford University Press.

126. Lukács, Georg. 1970. Povijest i klasna svijest [1923]. (prev. Milan Kangrga, Danilo Pejović). Zagreb: Naprijed.

127. Lukács, Georg. 1990. Teorija romana [1916/1963] (prev. Kasim Prohić) Sarajevo: Veselin Masleša/Svjetlost.

128. Lukács, Georg. 2007. Realism int he Balance [1938]. U: Adorno, Theodor i dr. 2007. Aesthetics and Politics. London/New York: Verso. 28-60.

129. MacCannell, Juliet Flower. 1992. Temporalnost tekstualnosti. (Prev. Mladen Kožul). U: Biti, Vladimir (ur.). Bahtin i drugi. Zagreb: Naklada MD. 39-61.

130. Lunačarski, Anatolij. 1967 [1924, 1964]. Marksisti i književnost. (Prev. Aleksandar Flaker). U: Flaker, Aleksandar (ur.). Sovjetska književnost 1917-1932. Zagreb: Naprijed. 139-144.

131. Lyotard, Jean-Francois. 1993. Libidinal Economy [1974]. (prev. Iain Hamilton Grant). Bloomington/Indianapolis: Indiana University Press.

132. Macherey, Pierre. 1979. Teorija književne proizvodnje [1966]. (prev. Rade Kalanj, Mihaela Vekarić). Zagreb: Školska knjiga.

133. Macherey, Pierre. 1995. The Object of Literature. (prev. David Macey). Cambridge/New York: Cambridge University Press.

134. Macherey, Pierre. 1998. In a Materialist Way. (prev. Ted Stolze). London: Verso. 
135. Macherey, Pierre; Balibar, Etienne. 2012. Literature as an Ideological Form. U: Oxford Literary Review, 3/1: 4-12.

136. Marchart, Oliver. 2007. Post-Foundational Political Thought. Edinburgh: Edinburgh University Press.

137. Méchoulan, Eric. 2016. „Jacques Rancière int he Forest of Signs: Indiscipline, Figurality and Translation“, u: Hellyer, Grace; Murphet, Julian (ur.). 2016. Rancière and Literature. Edinburgh: Edinburgh University Press. 42-58.

138. Medvedev, Pavel. 1976 [1928]. Formalni metoda u nauci o književnosti. Kritički uvod u sociološku poetiku. (Prev. Đorđije Vuković). Beograd: Nolit.

139. Merquior, José Guilherme. 1985. Foucault. Berkley: University of California Press.

140. Miščević, Nenad. 1975. Marksizam i post-strukturalistička kretanja: Althusser, Deleuze, Foucault. Rijeka: Marksistički centar, Centar za društvenu i uslužnu djelatnost mladih.

141. Mouffe, Chantal (ur). 1977. Gramsci and Marxist Theory. London: Routledge. 142. Mouffe, Chantal. 2013. Agonistics. London/New York: Verso.

143. Murphet, Julian. 2016. „Ineluctable Modality of the Sensible: Poverty and Form in Ulysses“, u: Hellyer, Grace; Murphet, Julian (ur.). 2016. Rancière and Literature. Edinburgh: Edinburgh University Press. 207-226.

144. Murphet, Julian; Hellyer Grace. 2016. „Introduction: Rancière and Literature“, u: Hellyer, Grace; Murphet, Julian (ur.). 2016. Rancière and Literature. Edinburgh: Edinburgh University Press. 1-25.

145. Murphy, Tymothy S. 2000. „Only Intensities Subsist: Samuel Beckett's Nohow On“،, u: Buchanan, Ian; Marks, John (ur.). 2000. Deleuze and Literature. Edinburgh: Edinburgh University Press. 229-251.

146. Nancy, Jean-Luc. 2003. „Razdjelovljena zajednica“ [1986], u: Nancy, JeanLuc. 2003. Dva ogleda. (prev. Tomislav Medak), Zagreb: Multimedijalni institut, Arkzin.

147. Neubauer, John. 1996. Bakhtin versus Lukács: Inscriptions of Homelessness in Theories of the Novel. U: Poetics Today, 17/4: 531-546.

148. Noys, Benjamin. 2000. Georges Bataille. A Critical Introduction. London: Pluto Press.

149. Peternai Andrić, Kristina. 2012. Ime i identitet u književnoj teoriji. Zagreb: Antibarbarus. 
150. Rancière, Jacques. 1994. The names of history: on poetics of knowledge [1992]. (prev. Hassan Melehy). Minneapolis: University of Minnesota Press.

151. Rancière, Jacques. 2004a. Philosopher and His Poor [1983]. (prev. John

Drury, Corinne Oster, Andrew Parker). Durham/London: Duke University Press.

152. Rancière, Jacques. 2004b. The flesh of words: the politics of writing [1998].

(prev. Charlotte Mandell). Stanford: Stanford University Press.

153. Rancière, Jacques. 2006. The politics of aesthetics: the distribution of the sensible [2000]. (prev. Gabriel Rockhill). London/New York: Continuum.

154. Rancière, Jacques. 2008 [2007]. Politika književnosti. (Prev. Marko Drča). Novi Sad: Adresa.

155. Rancière, Jacques. 2011a. Althusser's Lesson [1974]. (prev. Emiliano Battista). London/New York: Continuum.

156. Rancière, Jacques. 2011b. Mute speech: literature, critical theory, and politics [1998]. (prev. James Swenson), New York: Columbia University Press.

157. Rancière, Jacques. 2011c. Staging the People. Volume 1. The proletarian and his double. (prev. David Fernbach). London/New York: Verso.

158. Rancière, Jacques. 2012a. Na rubovima političkog [1990]. (prev. Ivan Milenković). Beograd: Fedon.

159. Rancière, Jacques. 2012b. Proletarian nights: the workers' dream in nineteenth-century France [1981]. (prev. John Drury). London/New York: Verso.

160. Rancière, Jacques. 2013. Aisthesis [2011]. (prev. Zakir Paul). London/New York: Verso.

161. Rancière, Jacques. 2015. Nesuglasnost [1995]. (prev. Leonardo Kovačević), Zagreb: Fakultet političkih znanosti sveučilišta u Zagrebu.

162. Rancière, Jacques. 2017. The lost thread: the democracy of modern fiction [2014]. (prev. Steven Corcoran). London: Bloomsbury Academic.

163. Ryan, Michael. 1982. Marxism and Deconstruction. Baltimore/London: The John Hopkins University Press.

164. Sheridan, Alan. 1980. Michel Foucault: The Will to Truth. London/New York: Tavistock.

165. Sim, Stuart. 1998. Post-Marxism. A Reader. Edinburgh: Edinburgh University Press.

166. Sim, Stuart. 2000. Post-Marxism. An Intellectual History. London/New York: Routledge. 
167. Sprinker, Michael (ur.) i dr. 2008. Ghostly Demarcations [1999]. London/New York: Verso.

168. Striedter, Jurij. 1989. Literary Structure, Evolution, and Value. Russian Formalism and Czech Structuralism Reconsidered. Cambridge/London: Hardvard University Press.

169. Surin, Kenneth. 2000. „'A Question o fan Axiomatic of Desires': The Deleuzian Imagination of Geoliterature“, u: Buchanan, Ian; Marks, John (ur.). 2000. Deleuze and Literature. Edinburgh: Edinburgh University Press. 167-194.

170. Šklovskij, Viktor. 1999 [1917]. Umjetnost kao postupak. U: Suvremene književne teorije. (ur. Miroslav Beker). Zagreb: Matica hrvatska. 121-131.

171. Therborn, Göran. 2008. From Marxism to Post-Marxism?. London/New York: Verso.

172. Tihanov, Galin. 2000. The Master and the Slave. Lukács, Bakhtin, and the Ideas of their Time. Oxford: Oxford University Press.

173. Tinjanov, Jurij. 1998 [1929, 1967, 1972] Pitanja književne povijesti. (Prev. Dean Duda). Zagreb: Matica hrvatska.

174. Todorov, Tzvetan. 1997. Zašto se Jakobson i Bahtin nikad nisu sreli. U: Treći program Radio Beograd. 109-110: 173-200.

175. Tormey, Simon; Townshend, Jules. 2006. Key Thinkers from Critical Theory to Post-Marxism. London: Sage.

176. Trocki, Lav. 1971 [1923] Književnost i revolucija. (Prev. Tatjana Korač) Rijeka: Otokar Keršovani.

177. Vološinov, Valentin. 2012. Freudianism. A Marxist Critique [1927]. (Prev. I. R. Titunik). London/New York: Verso.

178. Wittgenstein, Ludwig. 1998. Filozofijska istraživanja [1953]. Zagreb: NZ Globus.

179. White, E. Jayne; Peters, Michael A. 2017. Bakhtin and the Russian Avant Garde in Vitebsk: Creative Understanding And the Collective Dialogue. U: Educational Philosophy and Theory. 49/9: 922-939.

180. Zipes, Jack. 2019. Ernst Bloch. The Pugnacious Philosopher of Hope. Minneapolis: Palgrave MacMillan.

181. Žižek, Slavoj. 1989. The Sublime Object of Ideology. New York: Verso. 


\section{Bilješka o autoru}

Zvonimir Glavaš rođen je 25. kolovoza 1989. u Osijeku, gdje je pohađao osnovnu i srednju školu. Na osječkom Filozofskom fakultetu završio je dvopredmetni preddiplomski te diplomski studij Hrvatskog jezika i književnosti i Povijesti, diplomiravši 2013. godine. Odmah potom na Filozofskom fakultetu Sveučilišta u Zagrebu upisuje Poslijediplomski doktorski studij književnosti, izvedbenih umjetnosti, filma i kulture, u okviru kojeg je nastala i ova disertacija.

Od prosinca 2013. do listopada 2014. radio je kao asistent na Odsjeku za filologiju Učiteljskog fakulteta u Osijeku, a od listopada 2014. godine zaposlen je na Odsjeku za kroatistiku Filozofskog fakulteta Sveučilišta u Zagrebu, na Katedri za teoriju književnosti. Trenutno izvodi nastavu u okvirima dvaju obveznih kolegija (Uvod u teoriju književnosti, Čitanje književnog teksta), izlaže na domaćim i stranim znanstvenim skupovima te znanstvene radove objavljuje u zemlji i inozemstvu. Suradnik je istraživačkog projekta Književne revolucije (2018-2022) koji podupire Hrvatska zaklada za znanost.

Primarno mu je područje znanstvenog interesa suvremena književna i kulturalna teorija.

\section{Izbor iz bibliografije:}

Glavaš, Zvonimir. 2019. Metonimije 1918. Politika tropa u Krležinu Hrvatskom bogu Marsu. U: Giger, Markus ; Kosáková, Hana ; Přihoda, Marek (ur.). Střední, jižní a východní Evropa a rok 1918: Společenské a mezinárodní souvislosti. Prag: Pavel Mervart. 3752.

Glavaš, Zvonimir. 2019. Katahretičnost politike ili o tropima postmarksizma. Govor: časopis za fonetiku. 36/1: 79-101.

Glavaš, Zvonimir. 2017. Möbiusovom vrpcom između cvrčaka i bubnjeva:

Autoreferencijalnost u Samotnom životu tvom Ranka Marinkovića. U: Umjetnost riječi, LXI/3-4: 221-261.

Glavaš, Zvonimir. 2017. Stotinu godina Umjetnosti kao postupka: je li (i danas) revolucionarna revolucionarna teorija. U: Književna smotra, 49/185: 27-44.

Ćuti, Davorin; Glavaš, Zvonimir; Krivak, Marijan; Peić, Luka (ur.). 2017. Michel Foucault: moć ideja. Osijek: Filozofski fakultet Osijek.

Glavaš, Zvonimir. 2016. Loveći vampira od Jadrana do Karpata: Balkanizam, vampiri i rod u 
romanu Povjesničarka Elizabeth Kostove. U: Romanoslavica, LII/2: 52-69

Glavaš, Zvonimir. 2016. Podjela i raščlamba naslova na mrežnim portalima. U: Rišner, Vlasta (ur.) Jezik medija nekada $i$ sada. Zagreb/Osijek: Hrvatska sveučilišna naklada/Filozofski fakultet Osijek. 127-147.

Glavaš, Zvonimir. 2015. Povraci filologiji između igre i komentara. Croatica. 39/59: 19-32. 